4 norden 



\section{Intake of caffeine and other methylxanthines during pregnancy and risk for adverse effects in pregnant women and their foetuses}

Andersson, H. C., Hallström, H. and Kihlman, B.A 
Intake of caffeine and other methylxanthines during pregnancy and risk for adverse effects in pregnant women and their foetuses

TemaNord 2004:565

(C) Nordic Council of Ministers, Copenhagen 2005

ISBN 92-893-1098-7

Print: Ekspressen Tryk \& Kopicenter

Copies: 350

This publication may be purchased from any of our sales agents listed on www.norden.org/order. Other Nordic publications are available at www.norden.oeg/publications

Printed in Denmark

Nordic Council of Ministers

Store Strandstræde 18

DK-1255 Copenhagen K

Phone (+45) 33960200

Fax (+45) 33960202

www.norden.org

\author{
Nordic Council \\ Store Strandstræde 18 \\ DK-1255 Copenhagen K \\ Phone (+45) 33960400 \\ Fax $(+45) 33111870$
}

\section{The Nordic Food Policy Co-operation}

The Nordic Committee of Senior Officials for Food Issues is concerned with basic Food Policy issues relating to food and nutrition, food toxicology and food microbiology, risk evaluation, food control and food legislation. The co-operation aims at protection of the health of the consumer, common utilisation of professional and administrative resources and at Nordic and international developments in this field.

\section{Nordic co-operation}

Nordic co-operation, one of the oldest and most wide-ranging regional partnerships in the world, involves Denmark, Finland, Iceland, Norway, Sweden, the Faroe Islands, Greenland and Åland. Cooperation reinforces the sense of Nordic community while respecting national differences and similarities, makes it possible to uphold Nordic interests in the world at large and promotes positive relations between neighbouring peoples.

Co-operation was formalised in 1952 when the Nordic Council was set up as a forum for parliamentarians and governments. The Helsinki Treaty of 1962 has formed the framework for Nordic partnership ever since. The Nordic Council of Ministers was set up in 1971 as the formal forum for cooperation between the governments of the Nordic countries and the political leadership of the autonomous areas, i.e. the Faroe Islands, Greenland and Åland. 


\section{Table of Contents}

Preface

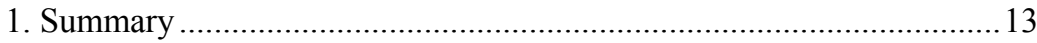

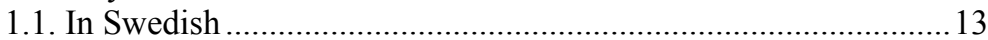

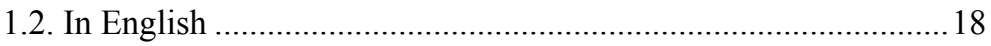

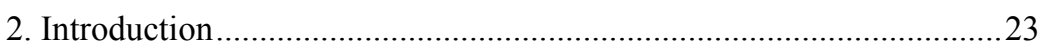

3. Discovery of caffeine and related compounds .................................25

3.1. The discovery of caffeine and related compounds .....................25

3.2. The development of the structural formulae of caffeine and related compounds ................................................2 26

3.3. Nomenclature of methylxanthines...........................................2 27

3.4. Physical and chemical properties of methylxanthines ............... 27

3.5. Chemical analysis of methylxanthines ......................................28

4. Plants containing methylxanthines .............................................. 31

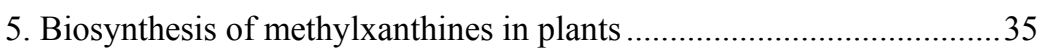

6. Occurrence of methylxanthines in food plants, beverages

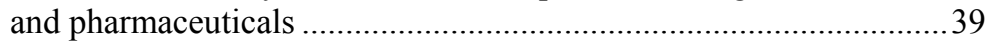

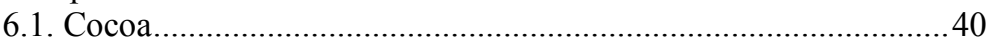

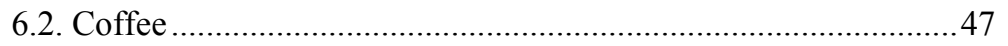

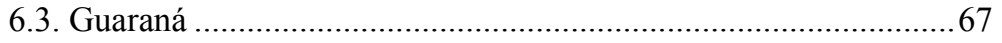

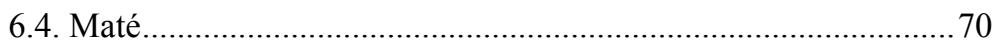

6.5. Tea 71

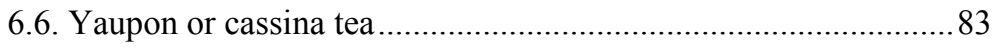

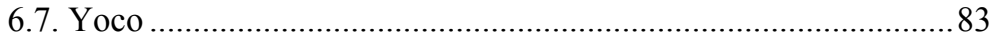

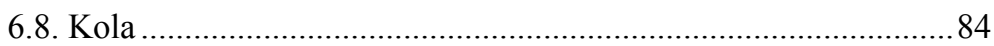

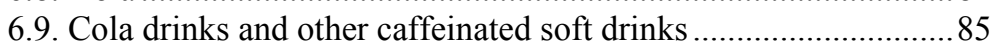

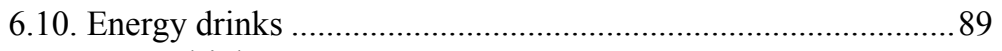

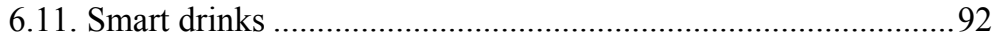

6.12. Caffeinated water ............................................................. 93

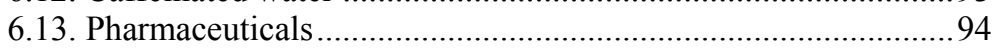

6.14. Conclusion on occurrence of methylxanthines in food plants, beverages and pharmaceuticals........................................97

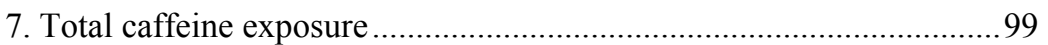

7.1. Caffeine intake among pregnant women ................................ 104

7.2. Caffeine intake and lifestyle ............................................... 105

7.3. Methods and problems to estimating caffeine intake ................ 108

7.4. Total intake of theobromine and theophylline ........................... 111

8. Pharmacokinetics of methylxanthines........................................... 113

8.1. Absorption and distribution in man ......................................... 113

8.2. Metabolism in the adult human being ...................................... 116 
8.3. Methylxanthines during pregnancy, in the foetus, and in the newborn .................................................... 122

8.4. Absorption and distribution in experimental animals .............. 127

8.5. Metabolism in experimental animals ..................................... 128

9. Pharmacological and toxicological actions of methylxanthines

- a short overview ................................................................... 133

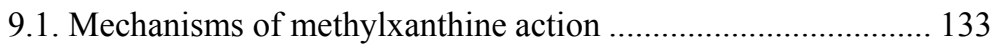

9.2. Pharmacological effects of the metylxanthines......................... 137

9.3 Toxicological effects of the methylxanthines ........................... 141

Evaluation of epidemiological studies............................................ 147

10. The epidemiological instrument with special reference to nutritional

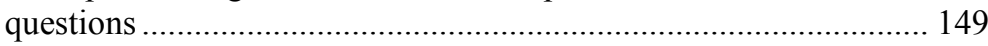

10.1. Types of epidemiological studies.......................................... 149

10.2. Methodology for studying dietary habits.............................. 153

11. Caffeine intake and fertility ........................................................ 161

11.1. Caffeine intake and time to conception/pregnancy, alternatively Caffeine intake and fecundability............... 162

11.2. Caffeine intake and pregnancy rate after induced abortion..... 185

11.3. Caffeine and menstrual function ........................................... 185

11.4. Caffeine and sperm activity ................................................. 186

11.5. Caffeine intake and in vitro fertilisation and embryo transfer 188

11.6. Caffeine intake and insemination........................................ 189

11.7. Consumption of caffeine-containing beverages and adverse pregnancy outcomes................................................... 189

11.8 Summary of caffeine intake and fertility ............................... 190

12. Caffeine intake and spontaneous abortions ................................. 195

12.1. Caffeine intake and early spontaneous abortions................... 196

12.2. Caffeine intake and late spontaneous abortions ...................... 208

12.3. Caffeine intake and stillbirth................................................. 221

12.4. Summary of caffeine and spontaneous abortion .................... 221

13. Caffeine intake and congenital malformations ................................ 227

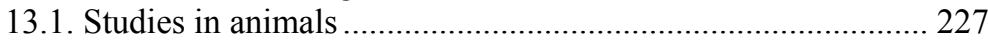

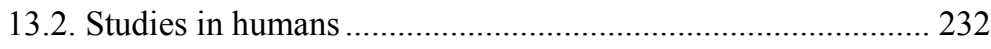

14. Caffeine and pre-term delivery ...................................................... 243

14.1. Pre-term delivery and caffeine exposure .............................. 244

14.2. Pre-term delivery and intake of caffeine-containing beverages.................................................................... 252

14. 3. Summary of caffeine and pre-term delivery ........................ 260

15. Caffeine and foetal growth retardation ....................................... 263

15.1 Foetal growth retardation in relation to intake of caffeine ....... 265

15.2. Foetal growth retardation in relation to intake of caffeine-containing beverages.......................................... 283

15.3 Meta-analysis of foetal growth retardation in relation to intake of caffeine/caffeine-containing beverages.............. 294

15.4 Summary of results of studies devoted to the relationship between exposure to caffeine/caffeine-containing beverages and foetal growth retardation 
15.5 Discussion

16. Caffeine intake and effects on foetuses in utero ...............................301

16.1. In vitro studies on caffeine exposure of foetal organs/tissues .301

16.2. Clinical studies on the effect of maternal caffeine intake

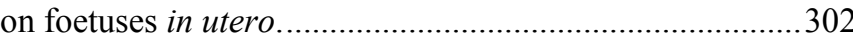

16.3. Summary of caffeine intake and effects on foetuses.

17. Maternal intake of caffeine and effects on neonates, infants and older children.

17.1. Effects of chronic caffeine consumption by the mother on neonates, infants and older children....

17.2. Effects of chronic consumption of caffeine-containing beverages by the mother on neonates, infants, and older children

17.3. Results of studies regarding caffeine/caffeine-containing beverages and effects on children including neonates and infants

18. Summary of the results in epidemiological studies on the relationship between caffeine intake, or intake of caffeine-containing beverages and foods, and adverse effects on the pregnancy or the foetus

18.1. Summary of the critical assessment of epidemiological studies and their results

19. Concluding discussion

20. References

21. Abbreviations used in this report 



\section{Preface}

The Nordic Committee of Senior Officials for Food Issues is an advisory body of the Nordic Council of Ministers which co-ordinates Nordic work in the field of food and nutrition. The Nordic Working Group on Food Toxicology and Risk Evaluation (NNT) has been given the responsibility by the Committee to promote co-operation and co-ordination among Nordic countries in matters relating to food toxicology and risk assessment.

Assessment of health risks connected with naturally occurring toxicants in foodstuffs has become an important area for NNT. The series of published Nordic reports based on the work performed by the Nordic project group on inherent natural toxicants in food plants and mushrooms include:

Gry, J. and Pilegaard, K. (1991) Hydrazines in the Cultivated Mushroom (Agaricus bisporus). Vår Föda 43;Supplement 1.

Uggla, A. and Busk, L. (1992) Ethyl carbamate (urethane) in alcoholic beverages and foodstuffs - A Nordic View. Nordiske Seminar- og Arbejdsrapporter 1992:570.

Størmer, F.C., Reistad, R. and Alexander, J. (1993) Adverse health effects of glycyrrhizic acid in licorice. A risk assessment. Nordiske Seminar- og Arbejdsrapporter 1993:526.

Andersson, C., Slanina, P. And Koponen, A. (1995) Hydrazones in the false morel. TemaNord 1995:561.

Søborg, I., Andersson, C. and Gry, J. (1996) Furocoumarins in Plant Food - exposure, biological properties, risk assessment and recommendations. TemaNord 1996:600.

Gry, J. and Andersson, H.C. (1998) Nordic seminar on phenylhydrazines in the Cultivated Mushroom (Agaricus bisporus). TemaNord 1998:539.

Andersson, C. (1999) Glycoalkaloids in tomatoes, eggplants, pepper and two Solanum species growing wild in the Nordic countries. TemaNord 1999:599.

Andersson, C. (2002) Calystegine alkaloids in Solanaceous food plants. TemaNord 2002:513.

Andersson, C., Wennström, P. and Gry, J. (2003) Nicotine in Solanaceous food plants. TemaNord, 2003:531.

Andersson, H.C. and Gry, J. (2004) Pheylhydrazines in the cultivated mushroom (Agaricus bisporus) - occurrence, biological properties, risk assessment and recommendations. TemaNord 2004:558. 
In 1980 the American Food and Drug Administration (FDA) issued recommendations to women to limit their intake of caffeine-containing beverages during pregnancy. This recommendation was based on results from studies on experimental animals, which had shown teratogenic effects of caffeine at very high doses. Since then, many epidemiological studies have been conducted in order to investigate whether intake of caffeine could affect pregnancy outcome. These studies have predominantly been performed in the US and Canada, but there are also some Europeans studies. The cultural affiliation is important, as the average caffeine intake in North America is substantially lower than in Europe. As the mean consumption of caffeine is very high in the Nordic countries, the Working Group on Food Toxicology and Risk Evaluation (NNT) within the Nordic Council of Ministers commissioned an expert group of Nordic food toxicologists to evaluate available epidemiological data concerning the relationship between maternal exposure to caffeine and adverse effects on pregnancy, the foetus, and young children.

The Project Group consisted of the following members:

$\begin{array}{ll}\begin{array}{l}\text { Christer Andersson } \\ \text { (Co-ordinator) }\end{array} & \begin{array}{l}\text { National Food Administration, } \\ \text { Sweden } \\ \text { Helena Hallström }\end{array} \\ \text { Nitional Food Administration, } \\ \text { Sweden } \\ \text { Department of Genetics, Uppsala } \\ \text { University, Sweden } \\ \text { Dørn Gry } \\ \text { Danish Veterinary and Food Ad- } \\ \text { ministration, Denmark } \\ \text { National Institute of Public Health, } \\ \text { Norway } \\ \text { Risto Juvonen } & \begin{array}{l}\text { Department of Pharmacology and } \\ \text { Toxicology, University of Kuopio, } \\ \text { Finland }\end{array} \\ \text { Torkell Johannesson } & \text { Department of Pharmacology, } \\ & \text { University of Iceland, Iceland }\end{array}$

Prof. Björn Isaksson, Ljungskile, was consulted by the Project Group to supply additional nutritional expertise on questions related to the critical evaluation of the epidemiological literature. The Project group is very much indebted to Prof. Isaksson for contributing chapter 10 to the report. We are also indebted to Marianne Lindblom, Kraft Food Sweden, for supplying additional information on methylxanthines in chocolate products.

The literature reviewed in this report had been found in searches on Medline, Toxline and FSTA (all up to March 2002), and in the reference lists of the publications found in the searches. 
The Nordic Project Group on 'Methylated oxypurines, pregnant women and their foetuses' produced the present report, which was accepted by NNT in September 2003. NNT formulated the following text, related to risk management, to be printed on the back-cover of the report:

"This report characterizes the health hazards to the human foetus associated with intake of caffeine and related methylxanthines during pregnancy. The conclusion of the report demonstrates the need for restrictions of caffeine exposure during pregnancy. NNT recognizes that human exposure to caffeine and related compounds causes a spectrum of pharmacological effects, for instance cardiovascular, renal, neurological and behavioural effects. The increasing use of caffeine and related methylxanthines in various foods and beverages consumed by children and adolescents cause concern.

NNT recommends that a full hazard characterization of caffeine and related methylxanthines should be performed, with the aim to reach a conclusion about the upper safe level of intake of the compounds." 



\section{Summary}

\subsection{In Swedish}

Den här rapporten sammanfattar tillgänglig epidemiologisk information om sambandet mellan intaget av koffein och andra metylxantiner hos kvinnor i barnafödande ålder och skadliga effekter via den gravida kvinnan på fostret och hennes barn. De skadliga effekter av metylxantiner som studerats är påverkan på fertiliteten, och risken för att drabbas av en spontan abort, föda ett barn med medfödda missbildningar, för tidig födsel, tillväxthämning under fosterstadiet och beteendepåverkan av fostret, de nyfödda eller småbarn. Varje epidemiologisk studie som fokuserat på något av dessa samband har granskats med ett kritiskt öga (kapitel 1017), varefter en sammanvägd slutsats formulerats för vardera av dessa tänkbara samband.

Den första delen av rapporten (kapitel 2-9) utgörs av bakgrundsinformation som är av värde vid den kritiska granskningen av epidemiologiska studier. Informationen omfattar uppgifter om förekomsten av metylxantiner i livsmedel (inklusive drycker) och läkemedel, och från dylika data beräknat intag av koffein, uppgifter om metylxantinernas farmakokinetik hos människa (med speciellt fokus på fostret) och uppgifter om farmakologisk och toxikologisk verkan av koffein.

\section{Förekomsten av metylxantiner och intaget av koffein}

Koffein upptäcktes i kaffebönor redan under tidigt 1820-tal av tyska och franska forskare oberoende av varandra. Den kemiska beskrivningen av ämnet skedde emellertid först vid sekelskiftet. Molekylens grundstruktur, som också karakteriserar andra metylxantiner, är 2,6-dioxypurin, vanligen kallad xantin. Hos koffein är xantinmolekylen metylerad i position 1, 3 och 7. Koffein är därför också känd som 1,3,7-trimetylxantin. Besläktade ämnen är teofyllin och teobromin, vilka också benämns 1,3dimetylxantin respektive 3,7-dimetylxanin. De moderna metoderna att separera, identifiera och kvantifiera metylxantiner från olika naturliga källor och livsmedel baseras på vätskekromatografi (HPLC). Metylxantiner förekommer i ett stort antal växtarter, tillhörande många olika släkten, familjer och ordningar. Man tror att metylxantinproducerande växter upplagrar dessa ämnen som resurser i sitt kemiska försvarssystem mot skadedjur och växtätare.

En mycket stor andel av de alkoholfria drycker som förekommer i sociala sammanhang innehåller koffein. De viktigaste dryckerna och livsmedlen som innehåller koffein är kaffe, te, guarana, maté, kolanötter, coladrycker, kakao, choklad, yaupon och yoco. Mängden koffein i dessa 
livsmedel varierar, men är ofta högt. Baserat på torrvikten, återfinns den största mängden koffein i guarana (4-6\%). Teblad innehåller ungefär $3.5 \%$ koffein, kaffebönor mellan 1.1 och $2.2 \%$, kolanötter $1.5 \%$ och kakaobönor $0.03 \%$. Kakaobönor innehåller dessutom cirka 1.8-2.5\% teobromin. Koffein förekommer även i vissa läskedrycker, energidrycker, och så kallade 'intelligens'-drycker, samt i läkemedel. Men i dessa produkter har framrenat eller syntetiskt koffein tillsatts livsmedlet.

Typen av kaffeböna som används vid framställningen av kaffe och metoden som används påverkar påtagligt halten av koffein i den slutliga drycken. Medelvärdet i koffeinhalt hos drycker av snabbkaffe, perkolerat kaffe och filterkaffe, beräknat utifrån 13 studier från olika länder, var 53, 84 respektive $103 \mathrm{mg} / \mathrm{kopp}(150 \mathrm{ml})$. Stora skillnader i konsumtionen av koffeininnehållande drycker och livsmedel kan påvisas såväl mellan olika personer som mellan olika kulturer. Detta är uppenbart för kaffe, men konsumtionen av te varierar ännu mer mellan olika länder än konsumtionen av kaffe.

Mänga läkemedel innehåller koffein, eftersom ämnet ofta används i till exempel smärtstillande, urindrivande, allergidämpande och uppiggande medel. I de nordiska länderna har dagsintaget av koffein vid den maximala terapeutiska dosen av läkemedlet beräknats ligga mellan 200 och $600 \mathrm{mg} / \mathrm{dag}$ beroende på preparat. Dessutom kan noteras att teofyllin används för behandling av astma.

Det är mycket svårt att uppskatta enskilda personers dagsintag av koffein. De flesta uppskattningarna av dagligt intag av koffein har därför gjorts per capita, men ingen uppskattning härstammar från de senaste åren. I USA har det dagliga koffeinintaget beräknats ligga mellan 186 och $227 \mathrm{mg}$. Motsvarande intag i Kanada, Australien, Brasilien, Sverige och Danmark ligger på $238 \mathrm{mg}, 240 \mathrm{mg}, 171 \mathrm{mg}, 425 \mathrm{mg}$ respektive $490 \mathrm{mg}$. Det är således uppenbart att koffeinintaget i de nordiska länderna är högre än annorstädes, huvudsakligen beroende på det stora tillskott kaffekonsumtionen ger till totalintaget av koffein. De nordiska länderna har den högsta kaffekonsumtionen i världen.

I medeltal minskar den gravida kvinnan sitt intag av koffein under graviditeten, framför allt på grund av illamående. Uppskattningar på koffeinintag har gjorts i USA, England och Danmark. Medelintaget av koffein hos gravida kvinnor i dessa länder var $144 \mathrm{mg}, 220 \mathrm{mg}$ respektive 375 mg per dag.

\section{Farmakokinetiken hos koffein och andra metylxantiner}

Metylxantinerna absorberas lätt från mag-tarmkanalen. Den högsta nivån i blodplasma erhålles 0.5-1.0 timme efter konsumtionen av det metylxantininnehållande livsmedlet. Ämnena distribueras via blodet till nästan alla vävnader i kroppen. De passerar moderkakan, når könsorganen och utsöndras i bröstmjölken. Halten som uppnås i de olika vävnaderna överensstämmer med nivån $\mathrm{i}$ blodet, men ingen upplagring av ämnena sker. 
Metabolismen av metylxantiner sker primärt i levern. Hos vuxna kan i det närmaste $98 \%$ av en dos som tillförts per oralt påvisas metaboliserad i urinen. Endast 1-3\% av dosen påträffas i avföringen. De fyra primärmetaboliterna av koffein hos människa är paraxantin (1,7-dimetylxantin), teobromin (3,7-dimetylxantin), teofyllin (1,3-dimetylxanthin) och 1,3,7trimetylurinsyra. Dessa metaboliter bryts i sin tur ned genom demetylering, oxidation och ringöppning. Halveringstiden för koffein i blodet ligger mellan 3 och 7 timmar. Den genetiska variationen i arvsanlagen för de koffeinmetaboliserande enzymen bidrar till en variation i koffeinmetabolism hos en människa över tiden och till en variation mellan olika individer. Halveringstiden av koffein är längre hos unga individer, hos modern under graviditeten, vid användning av preventivmedel och vid alkoholkonsumtion. Det skall också påpekas att koffeinets halveringstid hos fostret och spädbarnet är avsevärt längre än hos vuxna, närmare 100 timmar. Däremot leder rökning till förkortade halveringstider. Plasmanivåerna av koffein hos kaffekonsumenter ligger ofta vid 0.2-2 $\mu \mathrm{g} / \mathrm{ml}$. Straxt efter konsumtion av tre koppar kaffe stiger plasmanivån till ungefär $10 \mu \mathrm{g} / \mathrm{ml}$.

\section{Farmakologisk och toxikologisk verkan av koffein}

Det är känt att koffein påverkar många av kroppens vävnader. Koffeinets effekter på centrala nervsystemet inbegriper en ökad spontan elektrisk aktivitet, en förhöjd frisättning av neurotransmittorsubstanser, framkallande av kramper, stimulering av lokomotorisk aktivitet och en ökning av frekvensen operantsvar. Vidare har följande effekter observerats: positiv inotrop/kronotrop effekt på hjärtat, ökad diures, utvidgning av perifera kärl och en sammandragning av centrala kärl. Koffein stimulerar också en ökad magsaftssekretion och relaxerar den glatta muskulaturen i bronkerna. Man har visat att tolerans kan utvecklas mot visa effekter av koffein. Abstinenssymptom har beskrivits, men de tycks inte vara relaterade till den intagna dagsdosen av koffein. Den beteendeförstärkande effekten av koffein är mycket begränsad. När dosen ökar, övergår snabbt de positiva effekterna till negativa, vilket innebär att människor normalt själva begränsar sitt intag av koffein.

Vid intag av högre doser kan koffein ge upphov till många olika effekter som t ex oro, spänningstillstånd, huvudvärk, insomnia, nervositet, aptitlöshet, diarré, yrsel, irritabilitet, minskad stadighet på handen, och smärtlindring. Dessa symtom kan uppträda en kortare eller längre tid efter intag av koffein och liknar de symtom som ofta ingår $i$ ångestneuros. Detta tillstånd är känt som 'koffeinism' och kan observeras vid dosnivåer högre än 7-8 mg/kg kroppsvikt och dag, vilket motsvarar ett intag på mer än 500-600 mg/dag för vuxna. Den plasmakoncentration som förknippas med uttalade biverkningar har uppskattats till $>30 \mu \mathrm{g} / \mathrm{ml}$. Det bör tilläggas att en mängd olika toxiska effekter som har samband med hjärt/kärl systemet och matsmältningssystemet kan uppträda. 
Tillstånd som varit föremål för diskussion i samband med kroniskt intag av koffein är hjärtsjukdomar, osteoporos och olika former av cancer. Det tycks dock mycket osannolikt att normal exponering för koffein via livsmedel och drycker skulle kunna inducera mutationer hos människa. International Agency for Research on Cancer utvärderade koffein, teofyllin och teobromin 1991 och drog slutsatsen att det finns otillräckliga bevis ("inadequate evidence") för att dessa ämnen har cancerframkallande effekter på människa och försöksdjur vid normala intagsnivåer.

Expertgruppens slutsatser med avseende på sambandet mellan intaget av koffein eller andra metylxantiner och skadliga effekter på foster och unga barn via exponering över modern

Baserat på resultat av djurstudier som visade att koffein i höga doser gav upphov till teratogena effekter på avkomman, rekommenderade den amerikanska myndigheten 'Food and Drug Administration' 1980 att kvinnor skall begränsa sitt intag av koffeininnehållande drycker under graviditeten. Eftersom koffeinintaget är speciellt högt i de nordiska länderna, tillsatte den Nordiska arbetsgruppen för livsmedelstoxikologi och riskvärdering under det Nordiska Ministerrådet en expertgrupp med bland annat nordiska livsmedelstoxikologer för att utvärdera de epidemiologiska data som finns angående sambandet mellan moderns exponering för koffein och andra metylxantiner och skadliga effekter på hennes foster och unga barn. Expertgruppen drog följande slutsatser:

\section{Fertilitet:}

Det kan inte uteslutas att det föreligger ett samband mellan koffeinexponeringen och fertiliteten (befruktningssvårigheter) men bevisen för att ett sådant samband skulle existera är i dagsläget svagt. En viktig bidragande orsak till osäkerheten i bedömningen består i att man saknar tillförlitliga data på koffeinexponering under perioden innan befruktningen.

\section{Spontana aborter (missfall):}

Det tycks sannolikt att ett högt koffeinintag, speciellt tidigt under graviditeten, kan öka risken för missfall. Trots att resultaten från de tillgängliga epidemiologiska studierna av detta samband delvis är motsägelsefulla och svåra att tolka, huvudsakligen beroende på störfaktorer, stöds sambandet av flera moderna väl genomförda studier med god design.

\section{Medfödda missbildningar:}

I motsats till de data som visar att försöksdjur som givits höga koffeindoser under en kort tidsperiod av dräktigheten riskerar att få en avkomma med medfödda missbildningar, ger tillgängliga epidemiologiska data inget stöd för att höga intag av koffein (fördelat över dagen) hos människor resulterar i medfödda missbildningar. Antalet epidemiologiska studier är emellertid relativt få och av varierande kvalitet. 
Förtidsbörd:

Inget samband mellan moderns koffeinintag och förtidsbörd har påvisats i flertalet av de epidemiologiska studier av acceptabel kvalitet som studerat detta samband. Ett fătal studier har funnit ett positivt samband mellan koffeinintaget och förtidsbörd, men i dessa studier kan den observerade effekten förklaras av andra faktorer som studierna inte tillräckligt gott kontrollerat för. Expertgruppen drar slutsatsen att ett samband mellan prenatal koffeinexponering och förtidsbörd är osannolikt.

\section{Fetal tillväxthämning:}

Eftersom den sammanvägda bilden av studier som undersökt ett möjligt samband mellan moderns koffeinexponering och fostrets tillväxt (vanligen studerat som födelsevikt) är motsägelsefull, är det omöjligt att utesluta ett samband mellan höga intag av koffein och reducerad födelsevikt. Det skall dock påpekas att inget signifikant samband påvisats i flertalet senare prospektiva studier. Om ett samband föreligger mellan fetal tillväxthämning och intaget av koffein, är det sannolikt att reduktionen i födelsevikt är låg och följaktligen oftast av mindre klinisk betydelse.

\section{Effekter på fostret:}

Eftersom endast ett fåtal studier har undersökt sambandet mellan moderns intag av koffein och fostrets beteende och dessa studier dessutom har varit baserade på ett fåtal undersökta fall i studier med mycket olika försöksuppläggning, är det svårt att förutsäga vilka effekter som skulle tänkas kunna uppkomma. Det tycks sannolikt att konsumtion av koffeininnehållande livsmedel, drycker och läkemedel kan påverka fostrets beteende men det är betydligt svårare att avgöra huruvida denna påverkan kan anses skadlig. Följaktligen krävs nya och bättre upplagda studier för att undersöka detta eventuella samband.

Effekter på nyfödda, spädbarn och unga barn:

Tillgängliga studier av ett eventuellt samband mellan prenatal och postnatal koffeinexponering (över moderkakan respektive via bröstmjölken) och barnets beteende eller minneskapacitet har inte visat på något samband. Det måste dock påpekas att flertalet studier inom detta område varit av undermålig kvalitet. Av den anledningen är det omöjligt att uttala sig om ett eventuellt samband mellan moderns intag av koffein och effekter på den nyföddes, spädbarnets eller det unga barnets beteende eller minneskapacitet.

\section{Slutsats:}

Den tillgängliga informationen från epidemiologiska studier antyder att koffein, speciellt vid högre intag, kan ha en negativ påverkan på graviditeten (framkalla missfall och möjligen vara tillväxthämmande på fostret). 
Således rekommenderas kvinnor som är eller planerar att bli gravida och har ett högt koffeinintag att minska detta.

\subsection{In English}

This report summarises epidemiological information available on the relationship between intake of caffeine and other methylxanthines by women in childbearing age and adverse effects on pregnant women and their foetuses and young children. The adverse effects of methylxanthines studied are influence on fertility, spontaneous abortion, congenital malformation, pre-term delivery, foetal growth retardation, foetal behaviour, and effects on neonates, infants and older children. Each publication related to these different relationships has been critically assessed (chapters 10-17), and a conclusion based on all available studies formulated for each of these relationships.

The first part of the report (chapters 2-9) deals with background information of value when assessing these types of epidemiological studies. This information includes occurrence of methylxanthines in foods, beverages, and medicine, as well as data on caffeine intake, pharmacokinetics of methylxanthines (with special focus on caffeine), and pharmacological and toxicological actions of caffeine.

\section{Occurrence of methylxanthines and intake of caffeine}

German and French scientists first discovered caffeine in coffee beans independently during the early $1820 \mathrm{~s}$. The basic structure of the molecule is 2,6-dioxypurine, commonly known as xanthine. In caffeine, the xanthine molecule is methylated in positions 1,3 , and 7 . Thus, caffeine is also known as 1,3,7-trimethylxanthine. Related compounds are theophylline and theobromine, also known as 1,3-dimethylxanthine and 3,7dimethylxanthine, respectively. The modern technique used to separate, identify, and quantify methylxanthines from various natural sources and from foods is HPLC. Methylxanthines are produced by a large number of plant species belonging to numerous genera, families, and orders. It is believed that methylxanthine-producing plants accumulate these substances as part of a chemical defence system against pests and herbivores.

Interestingly, a very large proportion of the non-alcoholic beverages used in social settings contain caffeine. The most important beverages and foods containing caffeine are coffee, tea, guarana, maté, cola nuts, cola drinks, cocoa, chocolate, yaupon and yoco. The amount of caffeine found in these products varies, but is generally high. Based on dry weight, the highest amounts are found in guarana (4-7\%). Tealeaves contain approximately $3.5 \%$ caffeine, coffee beans $1.1-2.2 \%$, cola nuts $1.5 \%$, and cacao beans $0.03 \%$. Cacao beans in addition contain about $1.8-2.5 \%$ theobromine. Caffeine also occurs in certain soft drinks, energy drinks, 
and so called "smart" drinks, as well as in medicinal drugs. In these cases, however, purified or synthesised caffeine has often been added to the products.

The type of coffee beans used and the method of preparation of the drink influence the caffeine content of coffee drinks. The average caffeine content of instant coffee, percolated coffee, and filter coffee as calculated based on 13 studies carried out in various countries was 53, 84 and $103 \mathrm{mg} / \mathrm{cup}(150 \mathrm{ml})$, respectively. There are great differences between individuals and cultures regarding the consumed quantities of methylxanthine-containing beverages and foods. This is obvious for coffee but the consumption of tea varies even more than coffee from one country to another.

Many medicinal drugs contain caffeine, as the compound is widely used in e.g. analgesics, diuretics, allergy relief preparations, and alertness agents. In the Nordic countries maximal therapeutic doses of these drugs leads to caffeine intakes corresponding to 200 to $600 \mathrm{mg} / \mathrm{day}$. In addition, it may be noted that theophylline is used for treatment of bronchial asthma.

It is very difficult to estimate the total daily individual intake of caffeine. Therefore, most estimates are based on per capita calculations but none have been done in more recent years. In the United States, the average daily caffeine intake was estimated to be between 186 and $227 \mathrm{mg}$. Corresponding intakes in Canada, Australia, Brazil, Sweden, and Denmark are $238 \mathrm{mg}, 240 \mathrm{mg}, 171 \mathrm{mg}, 425 \mathrm{mg}$ and $490 \mathrm{mg}$, respectively. It is obvious that the intake is higher in the Nordic countries than elsewhere, mainly because of the high contribution to caffeine intake by coffee drinking in the Nordic countries. As a matter of fact, the Nordic countries are known to have the highest per capita consumption of coffee in the world.

The average pregnant woman reduces her intake of caffeine during pregnancy, mainly because of nausea. Intake estimates during pregnancy are available from the United States, the United Kingdom, and Denmark. The average daily caffeine intakes for the pregnant woman in these countries are $144 \mathrm{mg}, 220 \mathrm{mg}$ and $375 \mathrm{mg}$, respectively.

\section{Pharmacokinetics of methylxanthines with special focus on caffeine}

Methylxanthines are easily absorbed from the gastrointestinal tract. Peak plasma levels are reached 0.5-1.0 hours after ingestion. The compounds are distributed with blood to nearly all tissues. They cross the placenta, enter the gonadal tissue and are excreted into breast milk. The tissue levels reach nearly as high levels as in plasma, but there is no accumulation of methylxanthines in any tissue. The metabolism of methylxanthines primarily occurs in the liver. In adults, nearly $98 \%$ of an oral dose is found metabolised in the urine and $1-3 \%$ in the faeces. The four primary biotransformation products of caffeine seen in humans are paraxanthine (1,7-dimethylxanthine), theobromine (3,7-dimethylxanthine), theophylli- 
ne (1,3-dimethylxanthine) and 1,3,7-dimethyluric acid. These metabolites are further degraded by demethylation, oxidation and ring opening. Elimination half-life $\left(t_{1 / 2}\right)$ in humans ranges from 3 to 7 hours. Genetics (phenotypes of acetylations) contributes to inter- and intra-individual variations in caffeine elimination. The time for elimination increases with e.g. young age, pregnancy, and use of oral contraceptives and intake of alcohol. It should be noted that in the foetus and newborn, the elimination half-life ( $\left.t_{1 / 2}\right)$ of caffeine is much longer (4 days) than in adults. Furthermore, it is known that smoking decreases the elimination time. Plasma levels of caffeine commonly found in consumers of coffee are $0.2-2$ $\mu \mathrm{g} / \mathrm{ml}$. Shortly after the consumption of three cups of coffee the plasma level increases to around $10 \mu \mathrm{g} / \mathrm{ml}$.

\section{Pharmacological and toxicological actions of caffeine}

Caffeine is known to affect many tissues in the body. Effects on the central nervous system include: increase of spontaneous electrical activity, enhancement of neurotransmitter release, induction of convulsant activity, stimulation of locomotor activity and increase of operant response rates. Effects, which have been observed, are a positive inotropic/chonotropic effect on the heart, increased diuresis in the renal system, dilation in periferal vasculature, and constriction in central vasculature. Furthermore, caffeine stimulates an increase in gastric secretion in the gastrointestinal system and relaxes bronchial smooth muscle in the respiratory system. Tolerance has been shown to develop regarding certain effects of caffeine. A withdrawal syndrome has been described, although it does not seem to be related to the quantity of the daily intake. The reinforcement function of caffeine is very limited. When the dose is increased, there is a rapid transition from positive to negative effects, which makes the augmentation of caffeine intake self-limited.

At higher doses caffeine may cause a number of different effects, including anxiety, tension, headaches, insomnia, nervousness, loss of appetite, diarrhoea, dizziness, irritability, decrease in hand steadiness, and analgesia. These symptoms can occur after either a long-term or a shortterm ingestion and are similar to symptoms often encountered in anxiety neurosis. This condition is generally known as "caffeinism" and can be observed at dose levels greater then $7-8 \mathrm{mg} / \mathrm{kg}$ body weight/day or $500-$ $600 \mathrm{mg} /$ day in adults. The plasma concentration associated with untoward effects has been estimated to be $>30 \mu \mathrm{g} / \mathrm{ml}$. In addition, a variety of toxic effects related to the cardiovascular system and gastrointestinal system may appear. Conditions, which have been subjects for discussion in association with chronic intake of caffeine, include coronary heart disease, osteoporosis and different forms of cancer. It seems, however, highly unlikely that normal exposure to caffeine via foods and beverages will induce mutations in humans. The International Agency for Research on Cancer, which evaluated caffeine, theophylline, and theobromine in 
1991, concluded that there is inadequate evidence for the carcinogenicity of these methylxanthines in humans and experimental animals.

Conclusions of the expert group regarding intake of caffeine and other methylxanthines and adverse effects on pregnant women and their foetuses and young children

Based on results from studies on experimental animals showing teratogenic effects of caffeine at high doses, the American Food and Drug Administration (FDA) issued recommendations in 1980 to women to limit their intake of caffeine-containing beverages during pregnancy. As the mean consumption of caffeine is especially high in the Nordic countries, the Working Group on Food Toxicology and Risk Evaluation (NNT) within the Nordic Council of Ministers commissioned an expert group including Nordic food toxicologists to evaluate available epidemiological data concerning the relationship between maternal exposure to caffeine and other methylxanthines and adverse effects on pregnant women and their foetuses and young children. The expert group has reached the following conclusions:

Fertility:

It cannot be ruled out that an association exists between caffeine exposure and fertility (delayed conception), but the evidence for such an association must at present be considered weak. One important reason contributing to the uncertainty in this respect is the lack of reliable data on caffeine exposure during the period prior to pregnancy.

\section{Spontaneous abortion:}

It seems probable that high intakes of caffeine, especially early on in pregnancy, may increase the risk of having a spontaneous abortion. Although the results of the available epidemiological studies in this field partly are contradictory and not easy to interpret, depending mainly on problems with confounding, an association is currently supported by some modern studies, which can be considered well designed and performed.

\section{Congenital malformations:}

In contrast to experimental data on animals administered caffeine at high doses over a short period of time, the available epidemiological data give no evidence that high caffeine exposures are correlated with occurrence of congenital malformations in humans. However, the number of epidemiological studies is limited and their quality not always good.

Pre-term delivery:

No relationship between maternal caffeine exposure and pre-term delivery has been demonstrated in most acceptable epidemiological studies 
exploring this relationship. A few studies have found a positive association between these parameters, but this finding may be explained by other factors that were not well controlled in the studies. Hence, the expert group concludes that an association between prenatal caffeine exposure and pre-term delivery is unlikely.

\section{Foetal growth retardation:}

As the overall result of the studies on a possible relationship between caffeine exposure and foetal growth retardation (mainly studies on birth weight) is contradictory, it is not possible to exclude a relationship between high intake of caffeine and reduced mean birth weight. It should, however, be kept in mind that in most modern prospective studies investigating this relationship, no significant correlations have been observed. If a relationship between foetal growth retardation and caffeine intake exists, the resulting reduction in birth weight would probably be small and in most cases of minor clinical importance.

\section{Effects on the foetus:}

As only a few studies have been carried out, each with a fairly low number of participants and diverging design, it is very difficult to predict what effects will occur on the foetus. It seems probable that the consumption of caffeine-containing foods, beverages, and drugs could influence foetal behaviour but it is much less clear as to what extent the effects could be considered adverse. Consequently, new and better-designed studies are called for.

\section{Effects on neonates, infants and young children:}

The available studies on a possible correlation between prenatal and postnatal caffeine exposure (via the placenta and the breast milk, respectively) and behavioural or cognitive effects on infants have found no consistent effect. It should be pointed out, however, that most of the assessed studies in this area are of questionable quality. Therefore, an association between prenatal caffeine exposure and behavioural or cognitive effects in infants can neither be verified nor excluded.

It is concluded that available information from epidemiological studies indicates that caffeine, especially at high doses, could affect the pregnancy in a negative way (induce spontaneous abortions, and possibly result in foetal growth retardation). Hence, a reduction in (total) caffeine intake (from all sources) should be advised for women being pregnant or planning pregnancy and already having a high caffeine intake. 


\section{Introduction}

Caffeine from natural sources has been consumed and enjoyed by humans throughout the world for centuries. The widespread natural occurrence of caffeine in a variety of plants undoubtedly played a major role in the long-standing popularity of caffeine-containing products, especially beverages. It was only during the last century that consumers became exposed to caffeine as a food additive as well. Although commercial manufacturers argue that adding caffeine to beverages enhances flavour, it is difficult to not suspect that there is an attempt to create products whose effects resemble those of naturally occurring caffeine.

Caffeine is perhaps the pharmacological active compound to which we have the highest exposure. Caffeine has pharmacological effects on the central nervous system, the heart, the renal system, the peripheral and central vasculature, the gastrointestinal system, and the respiratory system. Some of these may be recognised by consumers as adverse effects. The most likely mechanism for many of these effects is a competitive antagonism for adenosine receptors, and possibly also a competitive inhibition of dopamine activity.

Early symptoms of acute toxicity are characterised by headache, nausea and stomach cramps, insomnia, agitation and restlessness, tachycardia, and extrasystoles. Many people have experienced at least one of these symptoms. Luckily very few have had the experience of acute symptoms of severe toxicity, which occur, at higher levels of exposure. Chronic toxicity is characterised as the poorly defined condition caffeinism and can occur at exposure levels of around $7-8 \mathrm{mg} / \mathrm{kg}$ body weight, which is not an uncommon level of exposure. Other conditions of chronic exposure to caffeine, which are discussed in the scientific literature, are effects on the heart via alterations in the serum cholesterol and lipid levels, osteoporosis, and influence on various types of cancer. Chronic consumption of caffeine may stimulate tolerance development, but could also result in withdrawal symptoms when caffeine is no longer supplied. Caffeine could actually be considered to fulfil certain WHO criteria for drug dependence, but the severity is not comparable to that of these psychoactive drugs classified and regulated as addictive drugs.

Very high doses of caffeine, much higher than those humans will ever be exposed to, are well known to cause congenital malformations in experimental animals. The developing foetus cannot choose which compounds to be exposed to. It is potentially subjected to the influence of all drugs ingested by the pregnant woman during gestation. Therefore, the Food and Drug Administration (FDA) in the United States considered it important already in the early 1980s that fertile woman is made aware of 
the pharmacological and potential toxicological potency of caffeine. As a consequence, the FDA recommended that women not consume more than $300 \mathrm{mg}$ caffeine daily during pregnancy.

Since 1949, caffeine has been known to be mutagenic in various experimental systems. The doses that are used to induce mutations in various systems are much higher than the doses humans are exposed to via the consumption of foods and beverages containing caffeine. It seems highly unlikely that normal exposure to caffeine via foods and beverages will induce mutations in humans.

The International Agency for Research on Cancer evaluated caffeine, theophylline, and theobromine in 1991, and concluded that there is inadequate evidence for the carcinogenicity of these methylxanthines in humans and experimental animals. The Scientific Committee on Foods within the European Commission evaluated caffeine in 1983 and 1999. The committee expressed the view that there is no reason for expressing concern about the carcinogenic and mutagenic effects of caffeine in humans at normal levels of intake. Neither is there any reason for concern regarding teratogenic effects in humans. According to the Scientific Committee for Foods, "risk assessment in relation to pregnancy is more difficult. Most data suggest there is no problem if total intake of caffeine is below $300 \mathrm{mg} /$ day. The question of possible effects on pregnancy and the offspring above this level remains open. This suggests that moderation of caffeine intake, from whatever source, is advisable during pregnancy". In this report we have evaluated available epidemiological data relating caffeine exposure to its effects on pregnant women and their offspring. 


\section{Discovery of caffeine and related compounds}

\subsection{The discovery of caffeine and related compounds}

The discovery of caffeine has been excellently reviewed by B.A. Kihlman in his book 'Caffeine and Chromosomes' (1977). Although not called caffeine or 1,3,7-trimethylxanthine at the time, German and French workers discovered the compound independently by in the early 1820s. In the book 'Neueste Phytochemische Entdeckungen zur Begründung einer wissenschaftlichen Phytochemie', Ferdinand Runge (1820) described a substance with basic properties which he had isolated from green coffee beans, and which he termed 'Kaffebase'. This publication appears to contain the first detailed description of caffeine. However, during the same year his German colleague F. von Giese (1820) reported in a letter to Scherer's 'Allgemeine nordische Annalen der Chemie für die Freunde der Naturkunde und Arzneiwissenschaft' that he had found a new alkaloid in extracts of coffee beans. He called the alkaloid 'Kaffeestoff', but subsequently declared it to be identical with Runge's 'Kaffebase' (von Giese, 1821).

Independent of the German discoveries, the French workers Robiquet (1823) and Pelletier (in collaboration with Caventou) (1826) discovered caffeine in extracts of coffee beans, and described it as a white crystalline volatile substance remarkable for its very high content of nitrogen, without referring to it by any particular name.

Who first named the compound caffeine is difficult to say. However, in the Dictionnaire des termes de Médicine of 1823, the substance is listed under the name 'cafiéne' or 'cofeina' and Fechner (1826) described it in his 'Repertorium der organischen Chemie' under the heading 'Caffeine oder Coffein'.

Table 1 lists plants, which contained a new substance, given a specific name by the discoverer, but which was subsequently shown to be caffeine. An analogous alkaloid, theobromine, was identified in Cacao beans (Theobromina cacao) by Woskresensky (1842) and another one, theophylline, in tea leaves by Kossel (1888). Both these compounds are dimethylxanthines. Thus, most remarkably, all the most important unfermented beverages in use in different parts of the globe are prepared from substances containing the same or closely allied alkaloids. 
Table 1. Plants shown to contain a 'new' substance subsequently identified as caffeine.

\begin{tabular}{|l|l|l|}
\hline Beverage/Food (Plant) & New compounds original name & Reference \\
\hline $\begin{array}{l}\text { Coffee } \\
\text { (Coffea arabica) }\end{array}$ & $\begin{array}{l}\text { Kaffebase } \\
\text { Kaffeestoff } \\
-\end{array}$ & $\begin{array}{l}\text { Runge (1820) } \\
\text { von Giese (1820) } \\
\text { Robiquet (1823) } \\
\text { Pelletier (1826) }\end{array}$ \\
\hline $\begin{array}{l}\text { Tea } \\
\text { Camelia sinensis) }\end{array}$ & thein & $\begin{array}{l}\text { Oudry (1827) } \\
\text { Mulder (1838) } \\
\text { Jobst (1838a, 1838b) }\end{array}$ \\
\hline $\begin{array}{l}\text { Guarana } \\
\text { (Paullina sorbilis) }\end{array}$ & guaranine & $\begin{array}{l}\text { Martius (1840) } \\
\text { Berthemot and Dechastelus } \\
(1840)\end{array}$ \\
\hline $\begin{array}{l}\text { Paraguay tea or maté (Ilex } \\
\text { paraguariensis) }\end{array}$ & & Stenhouse (1843a, 1843b) \\
\hline $\begin{array}{l}\text { Kola nuts } \\
\text { (Cola acuminata) }\end{array}$ & & $\begin{array}{l}\text { Daniell (1865) } \\
\text { Attfield (1865) }\end{array}$ \\
\hline
\end{tabular}

\subsection{The development of the structural formulae of caffeine and related compounds}

If the first phase in the history of methylxanthines was the discovery of the compounds, the second phase involved working out the structural formulae of caffeine. The research on caffeine chemistry lasted until the end of the 19th century and was intimately linked to studies on purine derivatives in general, including the nucleic acid components adenine and guanine. The credit for working out the structural formulae of caffeine and other purine derivatives goes mainly to Emil Fischer, who was awarded the Nobel Prize in Chemistry in 1902. It is true that the correct structural formula of caffeine was suggested by Medicus as early as 1875, although Fischer (1897) states this was more by chance than as a result of experimental evidence.

According to Fischer (1882), the history of working out the chemical structure of caffeine begins with the studies of Stenhouse and Rochleder. The work of Rochleder (1850a, 1850b) was particularly important since it suggested a relationship between caffeine and uric acid. The latter compound was discovered in human urine by Scheele in 1776. It took Fischer fifteen years of brilliant and methodical studies to arrive at the correct formulae for xanthine and its derivatives. The merit of Fischer's work lies not only in its development of a rigorously tested theory of the structure of uric acid, but also in its indication of uric acid's exact relationship to adenine, guanine, xanthine, hypoxanthine, and their methylated derivatives. His work has also given us valuable information on suitable methods for chemically synthesising the various methylated oxypurines. 


\subsection{Nomenclature of methylxanthines}

In order to obtain a uniform nomenclature for the purine compounds, Fischer (1897a) suggested that the nine links in the purine nucleus should be numbered as shown in Figure 1. As shown by Fischer and others, hypoxanthine is then 6-oxypurine, xanthine is 2,6-dioxypurine, and uric acid is 2,6,8-trioxypurine. The methylated oxypurine derivatives are commonly referred to as methylxanthines, the term used in the following text. Of the methylxanthines, caffeine is 1,3,7-trimethylxanthine, theophylline is 1,3-dimethylxanthine, theobromine is 3,7dimethylxanthine, and paraxanthine is 1,7 dimethylxanthine. In hydroxycaffeine, a hydroxy group to give 8-hydroxycaffeine or 1,3,7trimethyluric acid, substitutes the hydrogen at the 8-position in caffeine. Fischer's classical studies on the purine derivatives were summarised by the author in his work 'Untersuchungen in der Puringruppe' (1882-1906) published in 1907.

Table 2 summarises the trivial names, Chemical Abstract Names, and synonyms that have been used for the trimethylxanthine caffeine and the dimethylxanthines theophylline, theobromine and paraxanthine.

\subsection{Physical and chemical properties of methylxanthines}

Figure 2 shows the structural formulae of xanthine, some of the best known of the methylxanthines, and that of tetramethyluric acid. Methylxanthines are colourless and odourless substances, which taste slightly bitter. According to general opinion, they contribute, for example, to the typical bitter taste of cacao. Methylxanthines can be dissolved extremely well in hot (boiling) water, as the molecule is stable during such conditions. At room temperature, the solubility of caffeine is around $2.2 \mathrm{~g} / 100$ $\mathrm{ml}$, that of theobromine $0.05 \mathrm{~g} / 100 \mathrm{ml}$, and that of theophylline $0.8 \mathrm{~g} / 100$ $\mathrm{ml}$, whereas paraxanthine is only slightly soluble at room temperature. Close to $100^{\circ} \mathrm{C}$, around $4 \mathrm{~g}$ paraxanthine can be dissolved in $100 \mathrm{ml}$ water. Because of the many free electrons in the methylxanthine molecules, they are UV-active. This quality is purposefully used for analytical detection and determination.

Figure 1. The numbering of the ring atoms of the purine molecule.<smiles>c1ncc2nc[nH]c2n1</smiles> 
Table 2. Trivial names, Chemical Abstract Name and synonyms for the di- and trimethylxanthines.

\begin{tabular}{|l|l|l|l|}
\hline Common trivial name & Chemical Abstract Service Registry Number & Chemical Abstract Name & Synonyms \\
\hline Caffeine & $58-08-2$ & $\begin{array}{l}3,7-\text { dihydro-1,3,7- } \\
\text { trimethyl-1H-purine-2,6- } \\
\text { dione }\end{array}$ & $\begin{array}{l}\mathbf{1 , 3 , 7 - t r i m e t h y l x a n t h i n e ; ~} \\
1,3,7 \text {-trimethyl-2,6- } \\
\text { dioxypurine; methyl- } \\
\text { theophylline; methyl- } \\
\text { theobromine; anhydrous } \\
\text { caffeine; coffeine; coffei- } \\
\text { num; guaranine; thein; } \\
\text { theine }\end{array}$ \\
\hline Theophylline & $58-55-9$ & & $\begin{array}{l}\text { 1,3-dimethylxanthine } \\
\text { dimethyl-1H-purine-2,6- } \\
\text { dione }\end{array}$ \\
\hline Theobromine & $83-67-0$ & $\begin{array}{l}3,7-\text { dihydro-3,7- } \\
\text { dimethyl-1H-purine-2,6- } \\
\text { dione }\end{array}$ & $\mathbf{3 , 7 - d i m e t h y l x a n t h i n e ~}$ \\
\hline Paraxanthine & & $\begin{array}{l}3,7-\text { dihydro-1,7- } \\
\text { dimethyl-1H-purine-2,6- } \\
\text { dione }\end{array}$ & 1,7-dimethylxanthine \\
\hline
\end{tabular}

\subsection{Chemical analysis of methylxanthines}

Many chemical analytical techniques, based on completely different principles, have been used over the years to isolate, identify, and quantify methylxanthines in foodstuffs and medicinal drugs (Hurst et al., 1984). Most analytical techniques have focused on quantifying caffeine, theobromine, and theophylline. These methylxantines and their metabolites have also been determined in biological fluids (Christensen and Whitsett, 1979; Tobias, 1982; Christensen and Neims, 1984; Hurst et al., 1984).

Earlier procedures utilised spectrophotometry, titrimetry, column chromatography, and Kjeldahl nitrogen determination (IARC, 1991). These techniques were followed by paper chromatography and thin-layer chromatography. Many of the early techniques were unspecific, and are no longer used (Matissek, 1997). Considerably more accurate, and also more specific, is the spectrophotometric determination of the compounds in the UV range, a technique often used when analysing biological fluids. Drawbacks of this method are that the various methylxanthines are not separated, and that other UV absorbing compounds present in the sample extract interfere, which tends to result in too high concentrations of methylxanthines being quantified.

Modern methods of analysing methylxanthines are based on chromatographic separation procedures. The advantage of chromatographic procedures is that individual compounds are separated, which makes it possible to determine the exact contents of caffeine, theobromine, and theophylline individually (Matissek, 1997). The most important chromatographic techniques are various forms of high- 
Figure 2. Structural formulae of some methylxanthines and tetramethyluric acid.<smiles>O=c1[nH]c(=O)c2nc[nH]c2[nH]1</smiles>

Xanthine<smiles>Cn1c(=O)c2[nH]cnc2n(C)c1=O</smiles><smiles>Cn1c(=O)c2c(ncn2C)n(C)c1=O</smiles><smiles>Cn1cnc2c1c(=O)[nH]c(=O)n2C</smiles>

Theophylline<smiles>[13CH3]</smiles>

$\mathrm{CH}_{3}$ Theobromine<smiles></smiles>

Paraxanthine

performance liquid chromatography (HPLC) (for references, see IARC, 1991). In addition, various other methods, such as gas chromatography (GC), are useful because they are sensitive and separate the various methylxanthines. However, in general the gas chromatographic techniques require more sample preparation and derivatization, thereby significantly reducing their attractiveness. 



\section{Plants containing methylxanthines}

Caffeine has a wide distribution within the plant kingdom. In section 3.1. it was mentioned that caffeine was detected early on in coffee beans (Coffea arabica), tea leaves (Camellia sinensis), leaves of Ilex paraguariensis (maté), guaraná paste (Paullinia sorbilis), and kola nuts (Cola acuminata). After these early discoveries it has been found in many other plants, mainly members of the Dicotyledoneae. Altogether it is produced by a large number of species belonging to at least twenty-eight genera over seventeen families in thirteen orders of plants. A non-exhaustive list of such plants is given in Table 3, which also indicates which plants are used for preparation of beverages.

The highest number (twenty) of caffeine-containing species is found within the family Sterculiaceae, where the most important plants are Cola acuminata and Theobroma cacao. The great majority of caffeinecontaining plants contain only small amounts of the compound. Usually, caffeine is found only in certain parts of the plant, primarily in leaves, fruits, seeds, and bark. Caffeine is not found in xylem or, with certain exceptions (roots of seedlings of Cola and Paullinia), in subterranean parts.

Certain plant parts contain more than $1 \%$ of caffeine on a dry weight basis. This situation occurs in the leaves of the Ilex (Aquifoliaceae) and Camellia (Theaceae) species, in seeds from the Coffea (Rubiaceae), Cola (Sterculiaceae) and Paullinia (Sapindaceae) species, and in the bark of Paullinia yoco. The highest content of caffeine in plants is found in seeds from Paullinia cupana and Paullinia sorbilis, which may contain as much as $6 \%$ caffeine.

In some species, there is an accumulation of theobromine or methyluric acids rather than caffeine. In Theobroma cacao, for example, theobromine is the predominant methylxanthine (1-2\%), whereas the content of caffeine and theophylline is comparatively low. It was also recognised early on that tealeaves contain low quantities of theophylline. Subsequently, these compounds have been detected in many different plant species. Low quantities of theobromine and theophylline are, for example, often found in the caffeine-containing plant genera mentioned in Table 3 (Willaman and Schubert, 1961; Franzke et al., 1967).

Recently, a few reports have shown the presence of low amounts of caffeine in leaves and flowers of several Citrus species (data not shown in Table 3), including the orange, lemon, grapefruit, tangerine, and mandarin (Stewart, 1985; Trova et al., 1994; Vacca et al., 1997; 
Table 3. Tabulation of caffeine-containing plants according to Willaman and Schubert (1961) and O'Connel (1969).

\begin{tabular}{|c|c|c|c|}
\hline \multirow[t]{2}{*}{ Family } & \multirow[t]{2}{*}{ Species } & \multicolumn{2}{|c|}{ Number of } \\
\hline & & Genera & Species \\
\hline Annonaceae & Annona cherimolia & 1 & 1 \\
\hline \multirow{4}{*}{ Aquifoliaceae } & llex cassine* & & \\
\hline & Ilex cuiabensis & & \\
\hline & Ilex paraguariensis* & & \\
\hline & Ilex vomitora* $^{*}$ & 1 & 4 \\
\hline \multirow[t]{5}{*}{ Cactaceae } & Cereus jamacaru & & \\
\hline & Harrisia adscendens & & \\
\hline & Leocereus bahiensis & & \\
\hline & Pilocereus gounellei & & \\
\hline & Trichocereus sp. & 5 & $>5$ \\
\hline Celastraceae & Maytenus sp. & 1 & $>1$ \\
\hline \multirow[t]{2}{*}{ Combretaceae } & Combretum jaquinii & & \\
\hline & Combretum loeflingii & 1 & 2 \\
\hline \begin{tabular}{|l|} 
Dilleniaceae \\
\end{tabular} & Davilla rugosa & 1 & 1 \\
\hline Geraniaceae & Erodium cicutarium & 1 & 1 \\
\hline \multirow[t]{2}{*}{ Icacinaceae } & Villaresia congonha & & \\
\hline & Villaresia mucronata & 1 & 2 \\
\hline Liliaceae & Scilla maritima & 1 & 1 \\
\hline Malpighiaceae & Banisteriopsis inebrians & 1 & 1 \\
\hline Nyctaginaceae & Neea theifera & 1 & 1 \\
\hline Phytolaccaceae & Gallesia gorazema & 1 & 1 \\
\hline \multirow[t]{15}{*}{ Rubiaceae } & Coffea abeokutae & & \\
\hline & Coffea arabica* & & \\
\hline & Coffea bengalensis & & \\
\hline & Coffea canephora* & & \\
\hline & Coffea congensis & & \\
\hline & Coffea exelsa* & & \\
\hline & Coffea liberica* $^{*}$ & & \\
\hline & Coffea perrieri & & \\
\hline & Coffea quillon & & \\
\hline & Coffea robusta* & & \\
\hline & Coffea schumanniana & & \\
\hline & Coffea stenophylla & & \\
\hline & Coffea ugandae & & \\
\hline & Genipa americana & & \\
\hline & Oldenlandia corymbosa & 3 & 15 \\
\hline \multirow[t]{5}{*}{ Sapindaceae } & Paullinia cupana* & & \\
\hline & Paullinia scarlatina & & \\
\hline & Paullinia sorbilis* & & \\
\hline & Paullinia triantennata & & \\
\hline & Paullinia yoco* & 1 & 5 \\
\hline \multirow[t]{20}{*}{ Sterculiaceae } & Cola acuminata* & & \\
\hline & Cola ballayi & & \\
\hline & Cola johnsoni & & \\
\hline & Cola nitida* & & \\
\hline & Cola verticillata & & \\
\hline & Guazuma ulmifolia & & \\
\hline & Helicteres ovata & & \\
\hline & Sterculia chicha & & \\
\hline & Sterculia elata & & \\
\hline & Sterculia platanifolia & & \\
\hline & Sterculia pruriens & & \\
\hline & Sterculia speciosa & & \\
\hline & Theobroma bicolor & & \\
\hline & Theobroma cacao* & & \\
\hline & Theobroma grandiflora & & \\
\hline & Theobroma microcarpa & & \\
\hline & Theobroma obovata & & \\
\hline & Theobroma speciosa & & \\
\hline & Theobroma spruceana & & \\
\hline & Theobroma subincana & 5 & 20 \\
\hline
\end{tabular}




\begin{tabular}{|l|l|l|l|}
\hline \multirow{2}{*}{ Family } & Species & \multicolumn{2}{|c|}{ Number of } \\
\cline { 3 - 4 } & & Genera & Species \\
\hline Theaceae & Camellia sinensis* & 1 & 1 \\
\hline Turneraceae & Piriqueta ulmifolia & & \\
\hline & Turnera ulmifolia & 2 & 2 \\
\hline Total: 17 & & 28 & $>63$ \\
\hline
\end{tabular}

* Used for preparation of beverages

Kretschmar and Baumann, 1999). Certain Citrus hybrids also contain caffeine. These observations explain the presence of low quantities of caffeine in specific types of honey (Defilippi et al., 1995; Vacca and Fenu, 1996; Kretschmar and Baumann, 1999). The methylxanthines are not evenly distributed within the tissues of the flower. In Citrus paradisi and Citrus maxima, the andoecium had by far the highest concentration of caffeine, theobromine, theophylline, and paraxanthine (Kretschmar and Baumann, 1999). Caffeine was the most common methylxanthine. Some Citrus flower tissues (i.e. anthers and pollen) also showed considerable accumulation of theophylline, whereas theobromine and paraxanthine only occurred in trace amounts. Anthesis seemed to be co-ordinated with a rapid allocation of caffeine (and theophylline) to specific flower tissues. These specific tissues contained amounts close to that of the Arabica coffee bean (Kretschmar and Baumann, 1999).

Thus, caffeine, theobromine, and theophylline are synthesised by plants belonging to different unrelated families growing in very different parts of the world. However, the great majority of these plants grow in tropical or subtropical countries. A notable exception is the common Stork's Bill (Danish: Hejrenæb; Finnish: Peltokurjennokka; Icelandic: Hegranef; Norwegian: Tranehals; Swedish: skatnäva), Erodium cicutarium, which in Europe grows as far north as the Scandinavian countries. According to van Eijk (1952), a small amount of caffeine is present in this plant. It should be noted, however, that the gravimetric method used by van Eijk (1952) to detect caffeine is not specific for the compound. Therefore, the observation needs to be confirmed. There are no reports that Erodium cicutarium has ever been used for preparation of beverages.

Other methylxanthines found in plants are 7-methylxanthine (heteroxanthine), which has been detected in Beta vulgaris (Chenopodiaceae) (Bresler, 1904) and in the culture medium of growing tea callus tissue (Ogutuga and Northcote, 1970b); 1,3,7,9-tetramethyluric acid; and 2methoxy-1,9-dimethyl-6,8-dioxypurine. 1,3,7,9-Tetramethyluric acid has been reported to occur in extracts of tealeaves. Both of the latter compounds have been reported to occur in young leaves of the following species of the genus Coffea: C. liberica, C. arnoldiana, C. dewevrei var. excelsa and C. dewevrei var. aruwimiensis (Wanner et al., 1975). (According to Wellman (1961) who has followed Chevalier's system, C. arnoldiana and dewevrei are varieties of $C$. liberica, whereas $C$. excelsa is a separate species.) The concentrations of 1,3,7,9-tetramethyluric acid and 
2-methoxy-1,9-dimethyl-6,8-dioxypurine were far from negligible, and varied between 0.1 and $2 \%$ of the dry weight, depending on the age of the plant. In C. arnoldiana they were also found in the fruit at a concentration of $0.1 \%$. They were not found in twenty-three other Coffea species studied by the authors. In plants where the two methylxanthines occur, it has been suggested that they are the first products of caffeine catabolism (Wanner et al., 1975). 


\section{Biosynthesis of methylxanthines in plants}

The fact that caffeine and other methylxanthines are found in so many plant species raises the question of how and why these substances are formed. Are they produced by a separate metabolic pathway, or as byproducts of nucleic acid metabolism? Is the production of methylxanthines of value to the plants? These and other questions are dealt with in excellent recent reviews on the biosynthesis and metabolism of caffeine and related purine alkaloids in plants (Suzuki et al., 1992; Baumann, 1996; Ashihara and Crozier, 1999).

Many investigators have shown that formation of the ring nucleus of caffeine follows the classical scheme of purine nucleotide biosynthesis (for references, see Kihlman, 1977; Ashihara and Crozier, 1999). However, two pathways for biosynthesis of the methylated caffeine molecule have been discussed, one proceeding directly from the pool of purine precursors via xanthine to caffeine, the other suggesting caffeine to be formed during the catabolic breakdown of nucleic acids via 7methylguanosine, 7-methylxanthine, and theobromine. The early interpretation of experimental data suggesting nucleic acids as precursors in caffeine biosynthesis (Ogutuga and Northcote, 1970a,b; Suzuki and Takahashi, 1976a) has been abandoned. The results of more recent investigations, using tea and coffee as experimental material, have led to a general consensus that the purine skeleton of purine alkaloids is derived almost exclusively from the purine nucleotides AMP, GMP, and/or IMP. These nucleotides may be converted to xanthosine monophosphate (XMP). Most investigators are of the view that XMP is subsequently degraded to xanthosine, which may be methylated to 7-methylxanthosine (Negishi et al., 1985a, 1985b, 1992; Suzuki et al., 1992; Fujimori and Ashihara, 1993; Ashihara et al., 1996a). It is not until this point that the sugar residue is enzymatically removed and 7-methylxanthine is produced.

The last part of the caffeine biosynthesis pathway, the methylation of the ring nucleus, has been traced backwards step by step from caffeine. As purine alkaloids are xanthine derivatives, methylation may be performed at the nucleotide (XMP), nucleoside (xanthosine), or nucleobase (xanthine) levels. Recent experiments with cell-free preparations from tea and coffee leaves indicate that $\mathrm{N}$-methyltranferases involved in caffeine biosynthesis can use xanthosine and mono- and dimethylxanthines as methyl acceptors (Kato et al., 1996, 1998). Available evidence indicates that xanthosine, 7-methylxanthine, and theobromine are the in vivo methyl acceptors. There is, however, one report which proposes that 
XMP, rather than xanthosine, is the methyl acceptor in coffee leaves (Schulhess et al., 1996). Xanthine is a weak methyl acceptor, yielding only trace quantities of 3-methylxanthine (Negishi et al., 1985b; Kato et al., 1996).

The results of studies with radiolabelled precursor molecules and coffea plant and tea plant leaves strongly suggest that the major route from xanthosine to caffeine is xanthosine $\rightarrow$ 7-methylxanthosine $\rightarrow 7$ methylxanthine $\rightarrow$ theobromine $\rightarrow$ caffeine (for references, see Ashihara and Crozier, 1999). In addition to the main pathway, some minor routes (over paraxanthine and 3-methylxanthine) might also function (Kato et al., 1996). For example, theophylline may be salvaged for the synthesis of caffeine via a 3-methylxanthine $\rightarrow$ theobromine $\rightarrow$ caffeine pathway, at least in young tea leaves (Ashihara et al., 1997).

Similar to its role in the methylation of nucleic acids, L-methionine serves as a methyl-group donor in caffeine biosynthesis (Andersson and Gibbs, 1962; Inoue and Adachi, 1962; Ogutuga and Northcote, 1970a). In order to function as a methyl donor, methionine must be converted into an activated form, S-adenosyl-L-methionine (SAM). In the presence of appropriate $\mathrm{N}$-methyltransferases, SAM readily donates its methyl-group to suitable acceptors. The activities of 7-methylxanthine Nmethyltransferase and theobromine $\mathrm{N}$-methyltransferase, which catalyse the second and third methylation steps in the main pathway, were first demonstrated in crude extracts from tea leaves by Suzuki and Takahashi (1975a). The first methylation enzyme, xanthosine N- methyltransferase, which catalyses the formation of 7-methylxanthosine from xanthosine, was demonstrated in tealeaf extracts by Negishi et al. (1985b). Methyltransferase activity with a similar effect has also been found in green coffee beans (Roberts and Waller, 1979). Some of the genes coding for enzymes participating in purine and methylxanthine biosynthesis have been identified and cloned, and a number of the catalyzing enzymes purified (Ashihara and Crozier, 1999). It can be noted that several enzymes related to the de novo purine pathway and caffeine biosynthesis are located in chloroplasts (Kato et al., 1998; Ashihara and Crozier, 1999). The biosynthesis of caffeine, as understood today, is shown in Figure 3.

Although caffeine may still be regarded, at least in short-term experiments, as the end product of a long biosynthetic pathway, it can be catabolized by both tea and coffee plants. It has been reported that caffeine has a metabolic half-life of only a few months in tea plants. Caffeine is degraded at a variety of rates in different species of higher plants via a series of demethylation steps that are in a different sequence than the methylation steps of the biosynthesis pathway from xanthosine. There is evidence of diversity in the caffeine catabolism pathways operating in different plant species. In some species of Coffea,

Figure 3. Metabolic pathways illustrating both the biosynthesis of caffeine from purine nucleotides and the catabolism of purine nucleotides to $\mathrm{CO}_{2}$ and $\mathrm{NH}_{3}$ in leaves of Coffea arabica. 


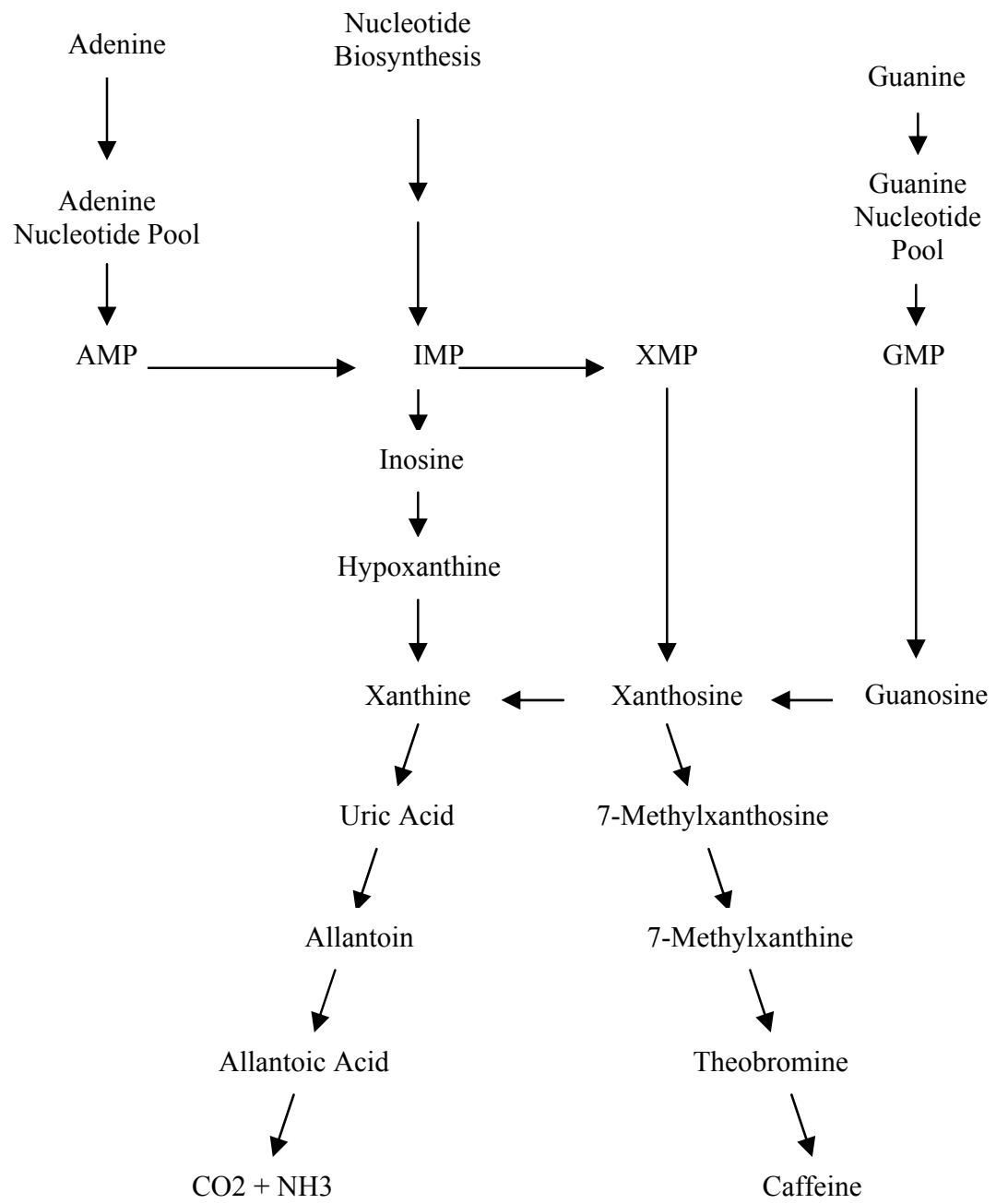

caffeine undergoes further methylation and oxidation rather than being demethylated (Mazzafera et al.,1991; Ashihara and Crozier, 1999).

The results obtained by Ashihara et al. (1996b) demonstrate that catabolism of caffeine in leaves of the coffee plant, C. arabica, involves a caffeine $\rightarrow$ theophylline $\rightarrow$ 3-methylxanthine $\rightarrow$ xanthine pathway. Xanthine is then further degraded in the conventional purine catabolism pathway (via uric acid, allantoin, and allantoate) to $\mathrm{CO}_{2}$ and $\mathrm{NH}_{3}$. The very slow degradation of caffeine compared with that of theophylline indicates that the conversion of caffeine to theophylline is a major ratelimiting step in the catabolism of caffeine, and provides a ready explanation for the high endogenous caffeine content of C. arabica leaves (Ashihara et al., 1996b). It is now clear that theophylline is associated primarily with caffeine biodegradation, whereas theobromine is involved in both biosynthesis and biodegradation of caffeine. The caffeine catabolism is not included in Figure 3. 
The caffeine biosynthesis and biodegradation reactions occur more rapidly within immature than mature fruit. Both immature and mature coffee fruits and leaves degraded caffeine to theobromine, theophylline, $\mathrm{N}^{3}$ methylxanthine, $\mathrm{N}^{7}$-methylxanthine, xanthine, allantoin, allantoic acid, and urea (Kalberer, 1965; Suzuki and Waller, 1984a; Ashihara et al., 1996b). When Suzuki and Waller (1984b) studied the pattern of formation of theobromine, theophylline, and caffeine in coffee berries during the growth stages of the bean, they found evidence that theophylline arises from the caffeine breakdown in excised mature coffee berries. The level of theophylline in mature and ripened fruit is twenty to fifty times that found in the immature green fruit of Coffea arabica.

Intracellular levels of xanthosine and methylxanthines in young, mature, and aged tealeaves are 200-2000 times lower than that of caffeine (Ashihara and Crozier, 1999). Therefore, they have frequently not been detected in biochemical studies. The observations explain to some extent the rather sporadic reports of methylxanthines other than caffeine, theobromine, and theophylline in plants. Nonetheless, the pool sizes of intermediates involved in caffeine biosynthesis are comparable to those of intermediates in other metabolic pathways.

Since high concentrations of caffeine inhibit mitosis and cell plate formation in plant cells, coffee embryos have specific strategies of avoiding caffeine autotoxicity (Friedman and Waller, 1983). Observations indicate that cell division in root tips begins only after the latter are pushed away from the caffeine-rich endosperm by the elongation of the hypocotyls, and then is maintained though cell elongation. In the embryonic cotyledons, caffeine is introduced for the most part after cell division is completed. Thus, coffee seedlings can avoid the autotoxic effects of endogenous caffeine by separating between sites where mitosis is occurring and those where caffeine is stored. This is achieved in root tips by a separation in space, and in the cotyledons by a separation in time (Friedman and Waller, 1983).

The transport of caffeine in small amounts from leaf to leaf, and in larger quantities from the pericarp to the seed has been demonstrated by the application of doubly labelled caffeine to C. arabica (Baumann and Wanner, 1972). It is plausible, in keeping with many other secondary metabolites, that caffeine and some purine alkaloids are stored in vacuoles (Wink, 1997a). 


\section{Occurrence of methylxanthines in food plants, beverages and pharmaceuticals}

During several centuries man has enjoyed food and beverages containing stimulating ingredients such as methylxanthines. This chapter presents the most important food sources of methylxanthines, as well as the pharmaceuticals containing caffeine, which are commonly used in the Nordic countries. The food sources are presented in alphabetical order, beginning with products naturally containing methylxanthines: cocoa, coffee, guaraná, maté, tea, and yoco. The most abundant methylxanthine is caffeine, a substance present in the majority of hot beverages consumed today (Table 4). Thereafter, foodstuffs and drugs with added synthetic caffeine are mentioned. It should be stressed that certain older data on the methylxanthine content of various food products should be interpreted with care, since the chemical techniques used to identify and quantify the compounds were inadequate.

Table 4. Important sources of caffeine (Gilbert, 1984).

\begin{tabular}{|c|c|c|c|c|}
\hline Source & Country of origin & Cultivation sites & Plant part used & Products \\
\hline $\begin{array}{l}\text { CACAO POD } \\
\text { Theobroma cacao }\end{array}$ & Mexico & Brazil, West Africa & Seed & $\begin{array}{l}\text { Cocoa, chocolate pro- } \\
\text { ducts }^{1}\end{array}$ \\
\hline $\begin{array}{l}\text { COFFEE BEAN } \\
\text { Coffea arabica } \\
\text { Coffea canephora } \\
\text { Coffea liberica }\end{array}$ & $\begin{array}{l}\text { Ethiopia } \\
\text { Arabia } \\
\text { Liberia }\end{array}$ & $\begin{array}{l}\text { Brazil, Colombia } \\
\text { Africa, } \\
\text { Indonesia } \\
\text { Africa }\end{array}$ & $\begin{array}{l}\text { Seed } \\
\text { Seed } \\
\text { Seed }\end{array}$ & $\begin{array}{l}\text { Coffee } \\
\text { Coffee } \\
\text { Coffee }\end{array}$ \\
\hline $\begin{array}{l}\text { GUARANA PASTE } \\
\text { Paullinia capana } \\
\text { Paullinia sorbilis } \\
\end{array}$ & Brazil & Brazil & Seed & $\begin{array}{l}\text { Guarana bars, } \\
\text { beverages }\end{array}$ \\
\hline $\begin{array}{l}\text { COLA NUT } \\
\text { Cola acuminata } \\
\text { Cola nitida }\end{array}$ & West Africa & West Africa & Seed & $\begin{array}{l}\text { Chewing nuts } \\
\text { Cola tea } \\
\text { Soft drinks Energy drinks } \\
\end{array}$ \\
\hline $\begin{array}{l}\text { MATÉ } \\
\text { Ilex paraguariensis }\end{array}$ & South America & South America & Leaf & $\begin{array}{l}\text { Mate } \\
\text { Paraguayan tea } \\
\text { Yerba mate }\end{array}$ \\
\hline $\begin{array}{l}\text { TEA } \\
\text { Camellia sinensis }\end{array}$ & China & China, India & Leaf, bud & Tea \\
\hline $\begin{array}{l}\text { YAUPON } \\
\text { llex cassine } \\
\text { llex vomitoria } \\
\end{array}$ & North America & Not cultivated & Leaf, berry & Cassina \\
\hline $\begin{array}{l}\text { YOCO } \\
\text { Paullinia yoco }\end{array}$ & South America & South America & Bark & Yoco infusion \\
\hline
\end{tabular}

${ }^{1}$ The main methylxanthine in chocolate products is theobromine. 


\subsection{Cocoa}

\subsubsection{The cacao tree}

The cacao tree, Theobroma cacao, is believed to have originated in the forests of the Amazon and Orinoco areas. Mexican and Central American Indians first cultivated it, but it was Linné (Linnaeus) who named the cacao tree Theobroma, which means 'food of the gods'. Early mythical legends indicate that the Mexican Indians used cacao in their religious rites. The cacao beverage used by the Aztecs consisted of ground-cured beans whipped up in hot water, flavoured with pepper and other spices. Christopher Columbus brought the first specimen of cacao beans to Spain as a souvenir from his fourth voyage. By 1580, it was in common use in Spain. A century later, cocoa was well known in most European countries.

The predominant methylxanthine in $T$. cacao is theobromine. Only small amounts of caffeine, approximately $10-15 \%$ of the concentration of theobromine, and traces of theophylline are found in cocoa. Studies by Hammerstone et al. (1994) have shown that the seeds of eleven other Theobroma species contained tetramethyluric acid rather than theobromine as the principal methylxanthine, as did 9 Herrania species with a similar morphology. None of these are used for the production of cocoa and chocolate.

The developmental variation in purine alkaloid content during maturation of Theobroma cacao seeds was studied by Bucheli et al. (2001). The major methylxanthine in cacao seeds, theobromine, started to accumulate at 125 days after pollination and the level increased thereafter to become about $2 \%$ of defatted material (the cocoa powder fraction). Caffeine was detected only towards the end of seed maturity, presumably as a result of the activation of N-methyltransferase enzyme that methylates theobromine to caffeine. In the two studied cacao varieties theobromine made up $78 \%$ and $86 \%$ of the methylxanthine content in the mature seeds (Bucheli et al., 2001). These observations confirm earlier findings (Timbie et al., 1978).

\subsubsection{Production areas}

The cacao tree requires a warm and humid climate. The tree takes seven years to mature and produces for twenty years, with an annual yield of around fifty to sixty pods. The ripe and colourful melon-like cocoa pod ripens in about six months, with a pulp that is sweet and citrus-like.

The major producers of cacao beans include the African, South East Asian and Central and South American countries (Willson, 1999). The Ivory Coast dominates among global producers and produced 1409000 tonnes - about $60 \%$ of the total output in 1999/2000. The Ivory Coast, 
together with Ghana and Indonesia, produce nearly three quarters of the world's cocoa production, which was 3073000 tonnes in 1999/2000 (Table 5).

\subsubsection{Fermentation and drying of cocoa beans}

When the pods are ripe, they are cut from the tree by hand. The harvested pods are cut open and the fresh seeds (twenty to forty per pod) with adhering pulp is taken out and fermented in a heap or a box. The fermentation period is four to six days, followed by drying the beans, which is usually done by placing them in direct sunlight for about one week (Feldman, 1998). The fresh unfermented seeds contain 1.8-3.8\% theobromine and $0.1-0.8 \%$ caffeine on a dry weight basis (Senanayake and Wijesekera, 1971; Chevalley, 1976; Fincke, 1989). The amount of the individual methylxanthines produced is dependent on the genotype of the cacao tree. For example, African cacaos contain less caffeine and more theobromine than cacaos from South America (Matissek, 1998).

During fermentation, the methylxanthine concentration based on dry weight decreases due to leakage from the seeds into the pulp. Hadorn (1980) measured the theobromine and caffeine content of well defined non-roasted, fermented, hand-shelled cocoa beans and found average values of $2.90 \%$ theobromine and $0.23 \%$ caffeine on a dry weight basis in beans from Africa $(n=7)$. Beans from Asia contained 2.33\% theobromine and $0.62 \%$ caffeine $(\mathrm{n}=7)$, and beans from Latin and South America $2.56 \%$ theobromine and $0.65 \%$ caffeine $(n=24)$.

\subsubsection{Production of cocoa mass and cocoa butter}

The fermented and dried cocoa beans are roasted to develop the flavour, often for about 40 minutes at $100^{\circ} \mathrm{C}$ to $220^{\circ} \mathrm{C}$ (Feldman, 1998). The roasted beans are broken up and the thin shell is removed by winnowing. The remaining kernels of the beans, the so-called nibs, are crushed between grinding stones to produce cocoa mass, sometimes also called

Table 5. Leading cocoa bean producers in the world (1000 tonnes) in 1999/2000 (ICCO Annual Report for 1999/2000, London; http://www.icco.org/anrep.htm, 2002-08-15).

\begin{tabular}{|l|r|}
\hline Producing countries & $\mathbf{1 9 9 9 / 2 0 0 0}$ \\
\hline Ivory Coast & 1,409 \\
\hline Ghana & 437 \\
\hline Indonesia & 410 \\
\hline Nigeria & 165 \\
\hline Brazil & 124 \\
\hline Cameroon & 115 \\
\hline Ecuador & 95 \\
\hline Papua New Guinea & 47 \\
\hline Malaysia & 45 \\
\hline Colombia & 38 \\
\hline Dominican Republic & 37 \\
\hline Mexico & 37 \\
\hline
\end{tabular}


cocoa liquor. The nib consists of 55\% cocoa butter and $45 \%$ solid material coming from the plant cells. Due to the heat generated as a result of grinding, the cocoa butter melts and can be separated. The water content is very low, less than $2 \%$. Cocoa mass is used for the production of chocolate, cocoa powder and cocoa butter.

Based on a study performed by Zoumas and co-workers (1980) it can be concluded that cocoa mass varies considerably as regards caffeine and theobromine content. The caffeine contents were between 0.06 and 0.42 $\%$ with an average of $0.2 \% \mathrm{w} / \mathrm{w}$, whereas the theobromine contents were between 0.8 and $1.7 \%$, with the average being $1.2 \% \mathrm{w} / \mathrm{w}$.

\subsubsection{Preparation of cocoa powder}

As stated above, the pressing of the cocoa mass removes the cocoa butter and produces a "pressing cake" containing between 10 and 22\% fat. Cocoa powder is produced by finely grinding the pressed cake. Thus, cocoa powder is a product comprised of between $80-90 \%$ fat-free dry matter of cocoa and between 10-22\% cocoa butter. Cocoa powders contain higher amounts of theobromine and caffeine than cocoa mass, because these components are present in the non-lipid portion of the cocoa mass. Since cocoa powders may be produced from cocoa mass from different cacao beans, the caffeine and theobromine content can vary considerably (Fincke, 1989). In a German study of eighty-eight samples of cocoa powder, the theobromine content varied from 1.8 to $3.8 \%$, with the highest seen in products from Western Africa, and the lowest seen in products from the Pacific. The caffeine content varied from negligible levels, predominantly in Western African products, to $0.99 \%$ in products from the Pacific and South America (Fincke, 1989). Hadorn (1980), De Vries et al. (1981) and Shively and Tarka (1984) reported similar levels in an analysis based on five, eighteen, and eight products, respectively. Slightly lower levels were reported by Zoumas et al. (1980).

\subsubsection{Production of dark chocolate}

Dark chocolate is produced from cocoa mass, cocoa butter, and sugar. The cocoa mass content is at least $30 \%$. The most common type of dark chocolate in the Nordic countries contains $40 \%$ cocoa mass. There is also a dark chocolate containing up to $70 \%$ cocoa mass, but this product is considered exclusive, and is sold only in small quantities. Since theobromine and caffeine occur in the cocoa mass, this type of eating chocolate has the highest amount of theobromine and caffeine per serving. However, as indicated, the level of the methylxanthines can vary considerably in dark chocolate, depending on the amount of cocoa mass used in the 
production. Samples reported by Zoumas et al. (1980). contained on average 4600 (3 600-6 300) $\mathrm{mg}$ theobromine per $\mathrm{kg}$ and 700 (200-1 700) $\mathrm{mg}$ caffeine per $\mathrm{kg}$ chocolate. Camargo et al. (1999) reported an average caffeine content of $870 \mathrm{mg} / \mathrm{kg}$ (range: 733-967) in dark chocolate products.

\subsubsection{Production of milk chocolate, white chocolate and chocolate confectionary}

Mixing sugar, cocoa butter and powdered milk with cocoa mass produces milk chocolate. Commercially produced milk chocolate contains between 10 and $15 \%$ cocoa mass. Milk chocolate contains about $1600 \mathrm{mg}$ theobromine and $250 \mathrm{mg}$ caffeine per $\mathrm{kg}$ (Shively and Tarka, 1984). Others have made similar observations (Table 6).

White chocolate contains sugar, milk powder, and cocoa butter but no cocoa mass, and is therefore considered free from methylxanthines (Kraft Freia Marabou, 1998).

Chocolate confectioneries, pralines, and similar products are made with a shell or covering of dark or milk chocolate. The chocolate constitutes between $25 \%$ and $50 \%$ of the total product. When the product is covered with milk chocolate, the chocolate shell/covering contains $10 \%$ cocoa mass, whereas a cover with dark chocolate contains $40 \%$ cocoa mass.

\subsubsection{Consumption of cocoa and chocolate foods}

With consumption levels of $10.1 \mathrm{~kg}$, Switzerland was one of the countries having the highest per capita consumption of chocolate confectioneries in the world in 2000. The corresponding figures for Belgium and France were 6.0 and $5.2 \mathrm{~kg}$, respectively. Among the Nordic countries, Iceland, Norway and Denmark had the highest per capita consumption of chocolate confectionery - 9.5 (data from 1997), 8.6 and $8.1 \mathrm{~kg}$, respectively (Table 7 and 8). Sweden had a per capita consumption of chocolate confectioneries of $5.8 \mathrm{~kg}$, while Finland had $4.7 \mathrm{~kg}$. Regarding Swedish consumption, the shares of various confectionery products during the late 1990s were: tablets and rolls $27 \%$, countlines $32 \%$, pralines $28 \%$, and dragees and other types $13 \%$. Around $80 \%$ of tablets, rolls, countlines and pralines were filled, while the rest were unfilled.

Table 6. Theobromine and caffeine contents in $1 \mathrm{~kg}$ of milk chocolate.

\begin{tabular}{|c|c|l|}
\hline \multicolumn{2}{|c|}{ Milk chocolate } & Reference \\
\hline Theobromine $(\mathrm{mg})$ & Caffeine (mg) & \\
\hline 1600 & 250 & Shively and Tarka (1984) \\
\hline 1530 & 220 & Zoumas et al. (1980) \\
\hline$(1350-1860)$ & $(50-540)$ & Morgan et al. (1982) \\
\hline- & 300 & \\
\hline
\end{tabular}


Table 7. Consumption of chocolate confectionery in USA and some European countries in 2000 (CAOBISCO IOCCC Statistical Bulletin Review - 2000, Brussels; http://www.caobisco.com/, 2002-08-15).

\begin{tabular}{|l|c|}
\hline Country & $\begin{array}{c}\text { Consumption of chocolate confectionery } \\
\text { (kg per capita) }\end{array}$ \\
\hline Switzerland & 10.1 \\
\hline Austria & 9.1 \\
\hline Ireland & 8.8 \\
\hline Germany & 8.2 \\
\hline Norway & 8.1 \\
\hline Denmark & 8.0 \\
\hline United Kingdom & 7.9 \\
\hline Belgium & 6.0 \\
\hline Australia & 5.9 \\
\hline Sweden & 5.8 \\
\hline United States & 5.3 \\
\hline France & 5.2 \\
\hline Netherlands & 4.8 \\
\hline Finland & 4.7 \\
\hline Italy & 2.8 \\
\hline Greece & 2.3 \\
\hline Japan & 1.8 \\
\hline Spain & 1.5 \\
\hline Portugal & 1.2 \\
\hline Brazil & 1.0 \\
\hline & \\
\hline & \\
\hline
\end{tabular}

Trends in the consumption of cocoa and chocolate confectionery during the 1990s in Iceland and Sweden are shown in Table 8 and 9.

\subsubsection{Methylxanthine content in hot cocoa, chocolate milk and other chocolate products as consumed}

Hot cocoa is prepared by mixing cocoa powder and sugar with hot milk or water. Chocolate milk is prepared by suspending cocoa powder in milk, and is generally consumed cold.

Table 10 shows the theobromine and caffeine contents of hot cocoa and chocolate milk reported in the literature. The theophylline content in these beverages is neglectable. It is generally not known where the beans used to prepare the cocoa powder for these beverages have been produced.

MAFF (1998) investigated the methylxanthine levels in eighteen powdered hot chocolate drinks in the United Kingdom, and found theobromine levels between 13 and $89 \mathrm{mg} / \mathrm{cup}$ (mean, $55 \mathrm{mg} / \mathrm{cup}$ ). The caffeine concentrations in the drinks were between 0.8 and $6.2 \mathrm{mg} / \mathrm{cup}$. Theophylline levels were $1.2 \mathrm{mg} / \mathrm{cup}$ or below, with a mean content close to 0.4 $\mathrm{mg} / \mathrm{cup}$. Some of the other investigations referred to

Table 8. Consumption of coffee, tea, cocoa, and chocolate confectionery (kg/person/year) in Iceland 1990-1997 (Johanesson, personal communication).

\begin{tabular}{|l|l|l|l|l|l|l|}
\hline Product & $\mathbf{1 9 9 0}$ & $\mathbf{1 9 9 3}$ & $\mathbf{1 9 9 4}$ & $\mathbf{1 9 9 5}$ & $\mathbf{1 9 9 6}$ & $\mathbf{1 9 9 7}$ \\
\hline Coffee, roasted & 7.5 & 7.8 & 7.3 & 7.5 & 7.7 & 7.1 \\
\hline Tea & 0.2 & 0.3 & 0.2 & 0.3 & 0.1 & 0.1 \\
\hline Cocoa (unsweetened) & 1.4 & 1.1 & 1.0 & 1.2 & 1.0 & 0.9 \\
\hline Chocolate confectionery & 10.3 & & & & & 9.5 \\
\hline
\end{tabular}


Table 9. Consumption of coffee, tea, and cocoa (kg/person/year) in Sweden 19901999 (Statens Jordbruksverk, 1997, 2001).

\begin{tabular}{|l|l|l|l|l|l|l|l|l|}
\hline Product & $\mathbf{1 9 9 0}$ & $\mathbf{1 9 9 3}$ & $\mathbf{1 9 9 4}$ & $\mathbf{1 9 9 5}$ & $\mathbf{1 9 9 6}$ & $\mathbf{1 9 9 7}$ & $\begin{array}{l}\mathbf{1 9 9 8} \\
\text { prel. }\end{array}$ & $\begin{array}{l}1999 \\
\text { prel. }\end{array}$ \\
\hline Coffee, roasted & 9.0 & 8.5 & 8.7 & 7.5 & 8.4 & 7.7 & 7.5 & 7.5 \\
\hline Tea & 0.3 & 0.3 & 0.3 & 0.3 & 0.3 & 0.3 & 0.3 & 0.3 \\
\hline Instant coffee and tea & 0.2 & 0.3 & 0.2 & 0.1 & 0.2 & & & \\
\hline Cocoa (unsweetened) & 0.3 & 0.3 & 0.3 & 0.3 & 0.4 & & & \\
\hline $\begin{array}{l}\text { Cocoa (sweetened), } \\
\text { drinking chocolate and } \\
\text { chocolate sauces }\end{array}$ & 1.2 & 1.1 & 1.0 & & & & & \\
\hline
\end{tabular}

in Table 10 recorded somewhat higher methylxanthine contents. The average theobromine content in the listed studies was $57 \mathrm{mg} / \mathrm{cup}$. The corresponding average caffeine level was $5 \mathrm{mg} /$ cup.

Three investigations have analysed the methylxanthine content of chocolate milk (Table 10). Similar results were found in all studies (Zoumas et al., 1980, Morgan et al., 1982, MAFF, 1998). The average theobromine and caffeine contents in the listed studies were 39 and 3 $\mathrm{mg} /$ cup, respectively.

Chocolate cakes, cookies and other homemade foods containing chocolate vary in their methylxanthine content (Table 11). Some of the data given by Shively and Tarka (1984) confirm observations on caffeine content previously reported by Morgan et al. (1982). The latter investigators found that a piece of chocolate cake on average contains $13.8 \mathrm{mg}$ caffeine, a nut fudge brownie $7.7 \mathrm{mg}$ caffeine, and half a

Table 10. Mean caffeine and theobromine content in hot cocoa and chocolate milk.

\begin{tabular}{|c|c|c|c|}
\hline Chocolate beverage & $\begin{array}{l}\text { Theobromine } \\
(\mathrm{mg} / 150 \mathrm{ml})\end{array}$ & $\begin{array}{c}\text { Caffeine } \\
(\mathrm{mg} / 150 \mathrm{ml})\end{array}$ & Reference \\
\hline \multicolumn{4}{|l|}{ HOT COCOA } \\
\hline 18 brand average & $55(13-89)$ & $3.5(0.8-6.2)$ & MAFF (1998) \\
\hline $\begin{array}{l}\text { Cadbury's drinking } \\
\text { chocolate } \\
(n=3)\end{array}$ & 65.8 & 7.0 & $\begin{array}{l}\text { Scott et al. } \\
(1989)^{1}\end{array}$ \\
\hline $\begin{array}{l}\text { Cadbury's cocoa } \\
(n=3)\end{array}$ & 39.0 & 1.6 & $\begin{array}{l}\text { Scott et al. } \\
(1989)^{1}\end{array}$ \\
\hline $\begin{array}{l}\text { Cocoa from mix } \\
(n=9)\end{array}$ & $\begin{array}{c}62.3 \pm 13.9 \\
(39.5-78.4)\end{array}$ & $4.1 \pm 2.3$ & Blauch and Tarka, 1983 \\
\hline Cocoa from mix & No data & 6 & $\begin{array}{l}\text { Institute of Food Technology } \\
\text { (1983) }\end{array}$ \\
\hline 5 brands, mean & $65(54-94)$ & $4(2-10)$ & $\begin{array}{l}\text { Zoumas et al. } \\
(1980)\end{array}$ \\
\hline $\begin{array}{l}\text { Cocoa } \\
(n=5)\end{array}$ & No data & $8.1(6.3-10.6)$ & $\begin{array}{l}\text { Bunker et al. } \\
(1979)^{1}\end{array}$ \\
\hline \multicolumn{4}{|l|}{ CHOCOLATE MILK } \\
\hline 6 brands, average & $41(21-56)$ & $2.3(1-3)$ & MAFF (1998) \\
\hline Chocolate milk & No data & 4.7 & $\begin{array}{l}\text { Morgan et al. } \\
(1982)^{1}\end{array}$ \\
\hline \multirow[t]{2}{*}{4 brand average } & $36(22-62)$ & $3(1-4)$ & $\begin{array}{l}\text { Zoumas et al. } \\
(1980)^{1}\end{array}$ \\
\hline & $\begin{array}{c}\text { Mean } \\
\text { theobromine content }\end{array}$ & $\begin{array}{c}\text { Mean } \\
\text { caffeine content }\end{array}$ & \\
\hline Hot cocoa & 57 & 5 & \\
\hline Chocolate milk & 39 & 3 & \\
\hline
\end{tabular}


Table 11. Average theobromine and caffeine content per serving of chocolate foods prepared from home recipes (Shively and Tarka, 1984). The amount of each food per serving was not stated.

\begin{tabular}{|l|c|c|}
\hline $\begin{array}{l}\text { Food } \\
\text { (number of samples) }\end{array}$ & $\begin{array}{c}\text { Theobromine } \\
(\mathbf{m g} / \mathbf{s e r v i n g})\end{array}$ & $\begin{array}{c}\text { Caffeine } \\
\text { (mg/serving) }\end{array}$ \\
\hline Chocolate brownies $(\mathrm{n}=16)$ & 57 & 7 \\
\hline Chocolate brownies (with frosting) $(\mathrm{n}=16)$ & 102 & 13 \\
\hline Chocolate brownies $(\mathrm{n}=16)$ & 24 & 3 \\
\hline Fudge cake $(\mathrm{n}=14)$ & 96 & 14 \\
\hline Dark chocolate cake $(\mathrm{n}=14)$ & 109 & 14 \\
\hline Sour cream chocolate cake $(\mathrm{n}=15)$ & 73 & 9 \\
\hline Chocolate chip biscuits $(\mathrm{n}=20)$ & 67 & 8 \\
\hline Chocolate cupcakes $(\mathrm{n}=30)$ & 63 & 8 \\
\hline Chocolate frosting & 724 & 90 \\
\hline Fudge frosting $(\mathrm{n}=14)$ & 72 & 9 \\
\hline Chocolate custard ice cream $(\mathrm{n}=8)$ & 159 & 20 \\
\hline Chocolate cream pie( $\mathrm{n}=8)$ & 91 & 11 \\
\hline Chocolate cream pie $(\mathrm{n}=8)$ & 84 & 10 \\
\hline Chocolate pudding $(\mathrm{n}=6)$ & 125 & 16 \\
\hline Fudge $(\mathrm{n}=6)$ & 224 & 28 \\
\hline Hot cocoa $(\mathrm{n}=5)$ & 127 & 16 \\
\hline Chocolate shake $(\mathrm{n}=3)$ & 250 & 31 \\
\hline Chocolate topping & 255 & 32 \\
\hline
\end{tabular}

cup of chocolate pudding $5.5 \mathrm{mg}$ caffeine. They also reported that a $2 / 3$ cup of chocolate ice cream contains $4.5 \mathrm{mg}$ caffeine.

Craig and Nguyen (1984) reported on the average theobromine and caffeine contents per serving of chocolate foods purchased on the open market on the West Coast of the United States. In total, they analysed 79 commonly used household foodstuffs containing cocoa or chocolate. They found amounts that were only about one third of the amounts reported in Table 11.

MAFF (1998) analysed the methylxanthine content of six chocolate bars and two chocolate mousses. Cocoa content in these products varied between $20 \%$ and $70 \%$ cocoa solids from beans. Theobromine levels ranged from 1300 to $10370 \mathrm{mg} / \mathrm{kg}$, and caffeine levels from 110 to 710 $\mathrm{mg} / \mathrm{kg}$. Caffeine and theobromine levels were clearly related to cocoa contents. The two chocolate mousses contained 390 and $650 \mathrm{mg}$ theobromine and 20 and $50 \mathrm{mg}$ caffeine per $\mathrm{kg}$ product. Theophylline levels in bars and mousses were below the detection limit.

\subsubsection{Methylxanthine intake from chocolate foods and beverages}

The daily per capita consumption of theobromine in the USA via foodstuffs and beverages was estimated to be $39 \mathrm{mg}$ in 1980 (IARC, 1991). Assuming that the caffeine content of chocolate is $10-15 \%$ of the theobromine content, this would correspond to approximately $4 \mathrm{mg}$ caffeine/person/day. More recent data, from the United States and elsewhere, is unfortunately not available.

Kraft Food Sweden (Lindblom, personal communication) has, however, calculated the average caffeine intake from chocolate during the late 
1990 s in Sweden. Approximately $20 \%$ of the chocolate consumed was unfilled products $(>95 \%$ milk chocolate), corresponding to 1.0 $\mathrm{kg} /$ person/year. The rest were filled products (a 1:1 ratio of milk chocolate:dark chocolate, $50 \%$ of products with $25 \%$ chocolate, and $50 \%$ with $50 \%$ chocolate), $4.1 \mathrm{~kg} /$ person/year. As shown in Table 12, the average annual caffeine intake from chocolate was estimated at $720 \mathrm{mg}$ per person, corresponding to $2 \mathrm{mg} /$ person/day.

As shown in Table 13, caffeine intake from chocolate foods and beverages in relation to body weight seems to decrease with age (except for children under 1 year of age). The highest weight-standardised intake was found among younger people both in the United States and in the United Kingdom. In the American study, children aged 1-5 and 6-11 years had mean caffeine intakes of 0.16 and $0.13 \mathrm{mg} / \mathrm{kg}$ body weight from these food products, respectively (Barone and Roberts, 1983). In the United Kingdom, caffeine intakes from chocolate foods and beverages among adults, who often prefer dark chocolate, were never above $0.02 \mathrm{mg} / \mathrm{kg}$ body weight/day (Scott et al., 1989).

It should be pointed out that a negative correlation between caffeine intake from chocolate and caffeine intake from coffee has been observed in an American investigation (Scheiber et al., 1988). Coffee drinkers, who already have a relatively high caffeine intake from coffee, had the lowest intake of caffeine from chocolate. The daily caffeine intake from chocolate among current coffee drinkers was $0.9 \mathrm{mg}$, whereas it was 1.1 $\mathrm{mg}$ among former drinkers, and $1.5 \mathrm{mg}$ among those who never drank coffee (Scheiber et al. 1988).

\subsection{Coffee}

The coffee plant Coffea arabica originates from the forests of Ethiopia and Zaire. The plant was cultivated in the Middle East and it was in this area that coffee as a beverage was first prepared. The custom of drinking the beverage hot spread to Turkey, and then spread to the Eastern and Northern African regions. At the beginning of the 17th century, the coffee beverage spread to Europe, where the drink soon became very popular (Graham, 1978).

Table 12. Calculated average annual caffeine intake from chocolate in Sweden at the end of the 1990's (Kraft Food Sweden, personal communication).

\begin{tabular}{|l|c|}
\hline Type of chocolate product & Average amount of caffeine/year \\
\hline Unfilled products & $150 \mathrm{mg}$ \\
\hline Products filled with $25 \%$ milk chocolate & $40 \mathrm{mg}$ \\
\hline Products filled with $50 \%$ milk chocolate & $80 \mathrm{mg}$ \\
\hline Products filled with $25 \%$ dark chocolate & $150 \mathrm{mg}$ \\
\hline Products filled with $50 \%$ dark chocolate & $300 \mathrm{mg}$ \\
\hline & \\
\hline TOTAL & $720 \mathrm{mg}$ \\
\hline
\end{tabular}


Table 13. Mean caffeine intake from chocolate foods and beverages.

\begin{tabular}{|l|l|l|l|}
\hline $\begin{array}{l}\text { Age-group } \\
\text { (years) }\end{array}$ & $\begin{array}{l}\text { Caffeine from chocolate products } \\
\text { (mg/kg bw/day) }\end{array}$ & Country & Reference \\
\hline$<1$ & 0.02 & United States & Barone and Roberts (1983) \\
\hline $1-5$ & 0.16 & United States & Barone and Roberts (1983) \\
\hline $6-11$ & 0.13 & United States & Barone and Roberts (1983) \\
\hline $12-17$ & 0.08 & United States & Barone and Roberts (1983) \\
\hline$>18$ & 0.03 & United States & Barone and Roberts (1983) \\
\hline $10-20$ & $0.021^{1}$ & United Kingdom & Scott et al. (1989) \\
\hline $21-40$ & $0.004^{2}$ & United Kingdom & Scott et al. (1989) \\
\hline $41-60$ & $0.02^{2}$ & United Kingdom & Scott et al. (1989) \\
\hline $61-80$ & $0.01^{2}$ & United Kingdom & Scott et al. (1989) \\
\hline
\end{tabular}

${ }^{1)}$ Calculated with a mean weight of $52 \mathrm{~kg}$ (Lindgren et al., 1997).

${ }^{2)}$ Calculated with a mean weight of $70 \mathrm{~kg}$.

\subsubsection{Types of coffee}

The genus Coffea is large, but the majority of coffee consumed comes from the beans of one of the two most common species, Coffea arabica and Coffea canephora, the latter often-called Robusta coffee (Willson, 1999). Today, Coffea arabica, the original species, is cultivated in almost every coffee producing country. Almost $75 \%$ of the coffee produced in the world is Arabica coffee (coffee produced from Coffea arabica). Coffea canephora is more tolerant, and can be cultivated under a wider range of conditions than Coffea arabica, but it produces a bitter coffee with a rather acrid taste. Arabica coffees contain less caffeine, are milder, and are commonly considered better tasting than the coffee from Robusta beans, which are mostly used in instant coffees. In a study of the caffeine content in different plants, Somorin (1974) found a caffeine content of 1 $558 \mathrm{mg}$ in $100 \mathrm{~g}$ powdered Arabica beans (1.6\% of the dry weight). The caffeine content of beans of Coffea canephora can be as high as $2.2 \%$ of the total weight. In countries with only a relatively recent tradition of coffee drinking, the Robusta content in coffee can be as high as $50 \%$, while in traditional coffee-drinking countries, the Robusta percentage is much lower (International Coffee Organisation, 1991). Terada and Sakabe (1984) reported a caffeine-content of $2.6 \%$ in instant coffee and $0.08 \%$ in decaffeinated instant coffee. Coffea liberica beans are less commonly used for coffee production (grown in Liberia, Surinam and Malaysia) and contain about $1.4 \%$ caffeine on a dry weight basis. Coffea racemosa is grown on a very reduced scale in Mocambique, and Coffea dewevrei in the Ivory Coast and Zaire. These species produce lower-quality beans, which are only acceptable on the local market (Söndahl, 1989). Mazzafera and Carvalho (1992) studied the caffeine content of seeds of different Coffea species and found that that the content varied from 0.4 to $2.4 \%$. Most cultivars of C. arabica contained 1.0-1.1\% caffeine. In their study, C. canephora contained $1.7 \%$ caffeine, while C. liberica contained $1.4 \%$. The methylxanthine content in the natural plant products is influenced by the geographical location of its growth, the variety of plant, the climate, and cultural practices (Graham, 1978). 


\subsubsection{Production}

When the beans are ripe, they are harvested by hand or mechanically. The pulp and coats of the harvested beans are peeled off by wet or dry methods. The wet method is more demanding than the dry method, and includes a fermentation process. This process highly influences the taste and quality of the final product. The raw coffee beans are roasted at about $200^{\circ} \mathrm{C}$ for five to ten minutes to bring out the taste and aroma, and then rapidly cooled. The roasted beans are finally ground and vacuum-packed.

Table 14 summarises the geographical areas of coffee production. The major areas cultivating Coffea arabica are Brazil, Colombia, and other countries in South and Central America. Brazil produced close to 22\% of the world production in 1996. Colombia, with $14 \%$ of the world production, is the second most important producer. Coffea robusta is cultivated, for example, in Indonesia and in many African countries, and Coffea liberica in Liberia, but to a very limited extent. It accounts for less than 1 $\%$ of all cultivated coffee plants. In most coffee producing countries, coffee represents a majority of the export income. In Kenya and Guatemala, it accounts for $30 \%$ of export income, and in Colombia and Costa Rica, $18 \%$ and $15 \%$, respectively (Svensk Kaffe Information, 1993).

The first method of producing decaffeinated coffee was introduced by a German company (Kaffee H.A.G.) in 1905 and was based on extraction of caffeine from coffee seeds with organic solvents. The demand for decaffeinated coffee has increased since the early 1970s. In some countries, it currently accounts for around one fifth of the market (Ashihara and Crozier, 1999). Commercial decaffeination is now a sophisticated process and, although it is not completely free of solvent residues, there have been major improvements in the quality of the

Table 14. Production of coffee (in 1000 tonnes) in 1996 (from FAO, 1996a).

\begin{tabular}{|l|c|}
\hline Producing countries & Production 1996 \\
\hline Brazil & 1290 \\
\hline Colombia & 822 \\
\hline Indonesia & 431 \\
\hline Mexico & 325 \\
\hline Uganda & $257^{\star}$ \\
\hline Ethiopia & $230^{*}$ \\
\hline Guatemala & 207 \\
\hline Vietnam & $198^{\star}$ \\
\hline India & $180^{\star}$ \\
\hline Ivory Coast & 165 \\
\hline Ecuador & 155 \\
\hline Philippines & 149 \\
\hline Costa Rica & $143^{\star}$ \\
\hline Honduras & 131 \\
\hline El Salvador & 126 \\
\hline Peru & 107 \\
\hline Others & 1016 \\
\hline World & 5932 \\
\hline
\end{tabular}

Unofficial figure(FAO, 1996a) 
product in recent years. The latest methodology involves the use of supercritical fluid extraction with $\mathrm{CO}_{2}$ to eliminate the health problems posed by the toxicity of residues from solvents such as dichloromethane (Ashihara and Crozier, 1999).

\subsubsection{Genetic modification of Coffea species}

Breeding programs for the genus Coffea are striving for genetic modifications, which alter the caffeine content, increase pest and disease resistance, provide cold tolerance, confer cytoplasmic male sterility, confer herbicide tolerance, etc. However, conventional breeding of Coffea species has limitations as far as coffee improvement, because of the genetic barriers of chromosome number (some species are diploid, others tetraploid), the presence of auto-incompatible alleles (diploid species), and long breeding cycles. As a result, the introduction of genetic traits selected from wild outbreed species of the genus to cultivated species is quite difficult. It requires the selection of plants with a specific trait from wild populations followed by hybridisation and progeny evaluation, backcrossing and inter-specific crosses. When natural variation is missing, induction of variation by mutation breeding might be necessary. Further complications are coffee's lengthy period of fruit development, and the 24 year bean-to-bean generation time, which make such traditional approaches costly and time consuming. Release of a new coffee variety has been estimated to require a minimum of 24 years of continuous breeding (Sreenath and Naveen, 1999). Furthermore, the resulting seed production and distribution is insufficient in terms of satisfying the needs of coffee growers.

To overcome the limitations of conventional breeding techniques for the genetic improvement of coffee plants, interest has in recent years turned to modern biotechnology approaches such as in vitro cell culture and recombinant DNA techniques. These techniques can provide the coffee breeder with additional tools for genetic improvement, particularly the potential to multiply genotypes of superior value at a faster rate. Several methods of in vitro regeneration and propagation have already been optimised successfully. These methods include somatic embryogenesis and scale-up of somatic embryogenesis using bioreactors and Erlenmeyer flasks, apical meristem and axillary bud culture, induction and development of adventitious buds, culture of zygotic embryos, anther/pollen culture, cell suspension culture, and protoplast culture. Those coffee regeneration systems, which were improved by using in vitro techniques, have recently been reviewed (Söndahl, 1989; Carneiro, 1999).

The advances made to date in in vitro coffee techniques have allowed for the manipulation of the coffee plant at the cellular and molecular levels, making coffee a suitable crop for the application of biotechnological breeding programmes, including genetic transformation. Most improve- 
ments wished for in coffee quality are attributable to improved agronomic practices and processing that directly affects farm production costs and/or increases yield (Söndahl, 1990). Disease and pest control in coffee plantations can account for $10-20 \%$ of direct plantation costs. The most important fungal diseases are coffee leaf rust (Hemileia vastatrix), coffee berry disease (Colletotrichum coffeanum) and brown eye spot (Cercospora coffeicola). Other pests of agronomic significance for coffee bean production include the coffee berry borer (Hyposthenemus hampei), the white stem borer (Xylotrechus quadripes), the leaf miner (Perileucoptera coffeela), and root nematodes (Meloidogyne sppp., Pratylenchus spp.). The release of new coffee cultivars resistant or tolerant to such pathological agents will greatly increase crop yields and provide significant economic benefits to the farmer (Söndahl, 1990).

Development of new cultivars with increased efficiency for nutrient absorption and utilisation, and increased resistance to herbicides and environmental conditions (mineral toxicity, drought, cold temperatures) are also greatly desirable (Söndahl, 1990). Since preliminary hybridisation studies have demonstrated hybrid vigour in coffee, the development of hybrid seeds between Coffea arabica and Coffea canephora is being explored.

Traits related to improved processing that could be targeted though genetic modification of the coffee plant include uniformity of maturity, a shorter maturation cycle, enhanced total soluble solids, larger and more uniform bean size, and improved bean density and texture. In addition, the two qualities that directly affect the end-user, the coffee drinker, are aroma and taste. Caffeine content of beans is also a major consideration. Beans with both high and low caffeine-content may be desirable, albeit to different market sectors. Free sulphur-containing amino acids (cysteine and methionine) in the bean may contribute to the formation of aroma. It may be possible to select for cell lines with increased intracellular pools of these amino acids. Unfortunately, very few genes that encode processing and consumer qualities have been identified.

Plant regeneration via in vitro tissue culture is a basic system for achieving genetic transformation, and there have been many reports involving somatic embryogenesis in coffee plants (Staritsky, 1970; Hatanaka et al., 1999; Menéndez-Yuffá and de Garcia, 1996). However, data on successful genetic transformation of coffee are limited. The first report on a successful transformation of the coffee plant appeared early in the 1990s. In 1991, Ocampo and co-workers observed the infection of coffee hypocotyls by wild type Agrobacterium strains, a soil bacteria known to naturally infect and transform various plant species. The infection incited tumours that were able to grow on chemically defined medium without hormones. Although Agrobacterium tumefaciens-mediated transformation seems to be hindered by an extremely low infection rate of coffee plant material (Ocampo and Manzanera, 1991), this observation indicated 
the potential to use Agrobacterium to transform coffee. The same year, Spiral and Petiard reported that coffee protoplasts, co-cultivated with Agrobacterium tumefaciens carrying a kanamycin resistance gene (NPTII) and a visual marker gene (GUS $=\beta$-glucuronidase), and allowed to develop into callus tissue, expressed the GUS activity (Spiral and Pétiard, 1991; Spiral and Pétiard, 1993). However, early studies revealed that expression of transgenes in transformed Coffea cells varied (Grèzes et al., 1993). Using another transformation system, Barton et al. (1991) electroporated Coffea arabica protoplats in suspension culture in the presence of plasmids carrying the kanamycin resistance gene (NPTII). Subsequently, they were able to induce callus formation, and the production of embryos and plantlets from the electroporated protoplasts. By using Southern blot analysis, the authors detected the introduced trait in transformed tissue, but only in one regenerated plantlet that subsequently died due to its feeble root system. Genetic transformation of Coffea species with Agrobacterium species has also been reported by Feng et al. (1992) and Freire et al. (1994). Spiral and co-workers subsequently reported that somatic embryos of different coffee species (C. canephora, C. arabica cv. Caturra and one interspecies hybrid "Arabusta") infected with Agrobacterium rhizogenes were able to develop either calli, with direct secondary transformed somatic embryos, or roots (Spiral and Pétiard, 1993; Spiral et al., 1993). Although the efficiency of transformation was low, the GUS marker gene could be detected from regenerated transformed plantlets by the histochemical $\beta$-glucuronidase assay. These observations were subsequently confirmed by Sugiyama et al. (1995). A few years later, plantlets were also produced from somatic embryos transformed via Agrobacterium tumefaciens (Leroy et al., 1997). Van Boxtel et al. (1995) reported transient expression of the GUS marker gene following the delivery of foreign DNA into leaves of micro cuttings, somatic embryos, and suspension cultures of Coffea arabica, Coffea canephora, and Arabusta (a hybrid between the two species) by particle acceleration technology (with a "gene gun"). The author stressed the critical use of tissue in order to obtain success in the regeneration of plants from protoplats.

In 1998, Madhova Naidu and co-workers succeeded in transforming cells of leaf explants of Coffea canephora by co-cultivating the plant tissue with Agrobacterium tumefaciens. Calli, expressing the transferred kanamycin resistance and GUS marker ( $\beta$-glucuronidase) genes were produced from the transformed explants. From the resulting transformed explants, somatic embryos could be induced. Subsequently, transgenic plants of Coffea canephora were produced from embryogenic calli (from leaf explants) co-cultured with Agrobacterium tumefaciens containing genes coding for $\beta$-glucuronidase, hygromycin phosphotranferase (HPT) and neomycin phosphotransferase (Hatanaka et al., 1999). Somatic embryos were formed from the tranformed calli, and small plantlets with roots and shoots were regenerated. Both the roots and shoots of plantlets 
exhibited strong $\beta$-glucuronidase activity. The GUS and HPT genes were solidly integrated into the genome of the coffee plants.

Recently, insect-resistant transgenic coffee plants (Coffea canephora and Coffea arabica) containing a synthetic Bacillus thuringiensis gene (cry1Ac) were produced, rendering the coffee plants resistant to the coffee leaf miner (Leroy et al., 1999, 2000). The transformed plants were regenerated from transformed somatic embryos obtained by cocultivating somatic embryos of the two plant species with Agrobacterium tumefasciens containing the cry $1 \mathrm{Ac}$ gene. The transformation rendered the coffee plants resistant to the coffee leaf miner, which has an economically important impact on coffee production in East Africa and Brazil. More than 100 transformed coffee plants from independent transformation events were obtained for each coffee genotype. The results of this study open the way for new opportunities of improving the coffee species, not only for other agronomic traits but also for traits with technological interest, such as low caffeine content.

Molecular biology offers the ultimate technology along with biotechnology, when the aim is to transform and regenerate plantlets in order to provide coffee plants capable of fulfilling specific agronomic, processing, and consumer needs. Molecular biology in this respect includes gene tagging, gene isolation, and cassette construction. The identification and isolation of useful genes is still one of the most limiting factors in applying this technique on a more routine basis. The classical method for gene identification is based on applying reverse transcriptase on RNA, which is limited to genes that produce abundant amounts of RNA and proteins. A more recent method of gene identification is based on transposons (gene tagging), which now permits the isolation of any genes within a plant as long as the transposon system is applicable. Once the gene is isolated, the next step is to construct a proper cassette expression system with proper initiating and stop sequences and an efficient promotor. Site or organ specific promotors are now being developed in such a way that the expression of an inserted gene can be restricted to one plant organ or tissue. This level of specificity can be very useful for coffee, since resistance genes for disease insects or herbicides can be directed to vegetative parts only (leaves, stems, roots), thus avoiding the cherry tissues. Inversely, genes that can affect cherry qualitative properties can be targeted to coffee fruits, leaving vegetative parts unaffected. As regards these perspectives, the recent cloning of a coffee seed specific promoter (Marraccini et al., 1999) is an important contribution towards further developments.

The expression of new gene products is the most frequent goal in molecular programs. However, in some cases the benefit involves turning on silent genes (or enhancing low expressing genes) or turning off undesirable genes. Types of new genes to be inserted in coffee will depend on the specific interest, i.e., agricultural, processing, or consumer benefits. 


\subsubsection{Preparation of the beverage}

Coffee (referring to the heated beverage made from coffee beans) can be prepared in a number of different ways. The type of coffee used when preparing the beverage is determined by individual taste and is influenced by the mixture of different coffee beans, different grounds, and different roasting. Preferences for different methods of coffee preparation vary around the world, as does the volume of coffee consumed on each occasion. Instant coffees seem to be very popular in the United States, while people in the Scandinavian countries mostly consume drip coffee or boiled coffee. These preparation methods are almost totally restricted to Northern Europe. Some people drink their coffee with milk and sugar, while other prefers to consume it strictly black. The way coffee is consumed can also vary during the day (Debry, 1994). Different methods of coffee preparation are explained and described by Dámicis and Viani (1993), and Debry (1994) and are summarised below.

\section{Boiled coffee}

50 to 70 grams of ground coffee is used per litre of water.

The coarsely ground, light-roasted coffee is infused in hot water for at least 10 minutes. The coffee is then consumed, in cups usually ranging from 150 to $190 \mathrm{ml}$, without separating the grinds from the beverage.

\section{Espresso}

6 to 8 grams of finely ground, medium to dark-roasted coffee is extracted with seething water at a pressure of 8 to 12 bars for at least $15-25$ seconds. The volume of the cup can differ between countries. In Italy the volume of a cup is $25-50 \mathrm{ml}$ and in France and Switzerland it is $150 \mathrm{ml}$.

\section{Dripolated/Filtered coffee}

Boiling water is poured over finely ground coffee in a paper filter. The types of roasting of coffee used for this method of preparation differ between countries; light-roasted in North America; medium-roasted in the United Kingdom, Sweden, and Switzerland; dark-roasted in France and Belgium. There may also be differences in the amount of coffee used: North America 28-40 g/l and other countries 50-70 g/l. The volume of the cups usually used for this type of coffee is $150-190 \mathrm{ml}$. This is the method most frequently used in the Nordic countries, and the coffee beverages prepared here are often stronger than in other countries.

\section{Infusion}

Coarsely ground coffee is infused in boiling water for a few minutes. Coffee in North America is very light-roasted and the amount used is 28$40 \mathrm{~g} / 1$, whereas coffee used in northern Europe and Australia is 55-65 g/l medium-roasted. After infusion, the grounds are removed by pouring the beverage though a screen strainer. 
Mocha coffee

Medium to dark-roasted, finely ground coffee is used in a Neapolitan coffee maker. Hot water is forced though the coffee, and the beverage is served in cups of about $50 \mathrm{ml}$ (Italy and Spain: 6-10 g coffee/cup).

\section{Percolated coffee}

Boiling water is recirculated though the coffee until the desired strength of the beverage is obtained. Coffee used is coarsely ground, in North America lightly roasted $28-40 \mathrm{~g} / \mathrm{l}$, and in the United Kingdom medium roasted $60 \mathrm{~g} / \mathrm{l}$. Cup volume is between 150 and $190 \mathrm{ml}$.

\section{Soluble/Instant coffee}

1.5-3.0 grams of coffee powder are dissolved into 150-190 $\mathrm{ml}$ of hot water to obtain the beverage.

\section{Greek coffee/Turkish coffee}

5 grams of medium to darkly roasted, finely ground coffee is placed in 60 $\mathrm{ml}$ boiling water until foaming occurs. The hot beverage is served in cups between 40 and $60 \mathrm{ml}$ in volume. In the Middle East 5 to 10 grams of sugar is added before consumption of the coffee.

\subsubsection{Amount of coffee sold in different countries}

Table 15 shows the volume of coffee sold in select European countries during the period 1990-1995. Germany was the largest market, but in France and Italy large amounts of coffee were also sold during this period. Overall the total amount of coffee sold in Europe has been fairly constant. This is, for example, illustrated by the trade figures for Denmark and Sweden. Whereas the volume sold has decreased in Finland during the 1990s, it has increased in Norway.

\subsubsection{Per capita consumption of coffee}

Since the early 1970s the Nordic countries, aside from Iceland, have had the highest coffee consumption per capita in the world, with around 10 $\mathrm{kg} /$ person/year. A small decrease in the per capita consumption has occurred since the late $70 \mathrm{~s}$ and the early $80 \mathrm{~s}$. In comparison, it can be mentioned that the per capita consumption of coffee in the United States 
Table 15. Volume of coffee (1000 tonnes) sold in Europe 1990-1995 (Consumer Europe, 1996).

\begin{tabular}{|r|r|r|r|r|r|r|}
\hline Country & $\mathbf{1 9 9 0}$ & $\mathbf{1 9 9 1}$ & $\mathbf{1 9 9 2}$ & $\mathbf{1 9 9 3}$ & $\mathbf{1 9 9 4}$ & $\mathbf{1 9 9 5}$ \\
\hline Austria & 64 & 63 & 58 & 50 & 42 & 42 \\
\hline Belgium & 62 & 62 & 63 & 63 & 64 & 64 \\
\hline Denmark & 35 & 35 & 39 & 37 & 36 & 37 \\
\hline Finland & 51 & 50 & 51 & 51 & 47 & 42 \\
\hline France & 178 & 182 & 181 & 184 & 186 & 188 \\
\hline Germany & 341 & 359 & 362 & 360 & 360 & 362 \\
\hline Greece & 34 & 33 & 32 & 33 & 34 & 35 \\
\hline Italy & 159 & 161 & 164 & 166 & 167 & 168 \\
\hline Ireland & 5 & 5 & 6 & 6 & 6 & 6 \\
\hline Luxembourg & 3 & 3 & 3 & 3 & 3 & 3 \\
\hline Netherlands & 86 & 87 & 87 & 87 & 88 & 88 \\
\hline Norway & 34 & 36 & 37 & 37 & 36 & 41 \\
\hline Portugal & 25 & 28 & 30 & 30 & 26 & 27 \\
\hline Spain & 70 & 69 & 68 & 67 & 70 & 68 \\
\hline Sweden & 76 & 78 & 76 & 76 & 75 & 75 \\
\hline Switzerland & 59 & 59 & 60 & 57 & 57 & 57 \\
\hline United Kingdom & 53 & 56 & 54 & 53 & 50 & 47 \\
\hline & & & & & &
\end{tabular}

and the United Kingdom in 1994 were $4.5 \mathrm{~kg}$ and $2.4 \mathrm{~kg}$, respectively (Lavazza Training Centre Internal Data, 1994, http://sovrana.com/chart. htm, 2002-08-15).

Coffee consumption in Finland is among the highest in the world. During the last decade the consumption has dropped (Table 16), and is now approximately at the same level as the other Scandinavian countries. The data on coffee consumption in Finland presented in Table 16 does

\subsubsection{Per capita consumption of coffee}

Since the early 1970s the Nordic countries, aside from Iceland, have had the highest coffee consumption per capita in the world, with around 10 $\mathrm{kg} /$ person/year. A small decrease in the per capita consumption has occurred since the late $70 \mathrm{~s}$ and the early $80 \mathrm{~s}$. In comparison, it can be mentioned that the per capita consumption of coffee in the

United States and the United Kingdom in 1994 was $4.5 \mathrm{~kg}$ and $2.4 \mathrm{~kg}$, respectively (Lavazza Training Centre Internal Data, 1994, http://sovrana.com/chart. htm, 2002-08-15).

Coffee consumption in Finland is among the highest in the world. During the last decade the consumption has dropped (Table 16), and is now approximately at the same level as the other Scandinavian countries.

Table 16. Consumption of coffee and cola drinks (kg/person/year) in Finland 19901998 (Elintarvikeliitto, 1998).

\begin{tabular}{|l|c|c|c|c|c|c|}
\hline Product & 1990 & 1993 & 1994 & 1995 & 1996 & 1997 \\
\hline Coffee, roasted & 10.2 & 10.2 & 9.5 & 8.3 & 9.7 & 9.2 \\
\hline $\begin{array}{l}\text { Soft drinks } \\
\text { cola drinks }\end{array}$ & 9.01 & 9.53 & 11.42 & 14.39 & 14.67 & 15.96 \\
\hline
\end{tabular}


Table 17. Consumption of coffee and soft drinks (kg/person/year) in Norway 1990 1998 (www.kaffe.no/presseservice.htm, 2000-06-02; Meltzer, personal communication).

\begin{tabular}{|l|c|c|c|c|c|c|c|c|}
\hline Product & $\mathbf{1 9 9 0}$ & $\mathbf{1 9 9 3}$ & $\mathbf{1 9 9 4}$ & $\mathbf{1 9 9 5}$ & $\mathbf{1 9 9 6}$ & $\mathbf{1 9 9 7}$ & $\mathbf{1 9 9 8}$ & $\mathbf{1 9 9 9}$ \\
\hline Coffee, raw & 10.5 & 10.5 & 10.1 & 9.7 & 10.1 & 9.4 & 9.5 & 9.9 \\
\hline Soft drinks & & 95 & 113 & 111 & 114 & 119 & & \\
cola drinks & & & & 62 & 61 & 68 & & \\
others & & & & 49 & 53 & 51 & & \\
\hline
\end{tabular}

The data on coffee consumption in Finland presented in Table 16 does not include consumption of instant coffee, which was used by only 1 to $2 \%$ of the Finnish population.

The per capita intake of coffee in Norway is shown in Table 17. These data are based on raw coffee instead of roasted coffee, the preferred type of coffee being C. arabica ( $98 \%$ of the market). The per capita intake of caffeine free coffee in Norway was $0.016 \mathrm{~kg} /$ person in 1996, 0.032 $\mathrm{kg} /$ person in 1997, and $0.027 \mathrm{~kg} /$ person in 1998 (Meltzer, personal communication). A slight reduction in coffee intake has occurred during the 1990s. In 1997 men in Norway consumed 501 g/day, and women 449 g/day (Johansson and Solvoll, 1999).

In Iceland the per capita coffee intake has been between 7.1 and 7.8 $\mathrm{kg}$ during the period 1990 to 1997 (Table 8).

The consumption of roasted coffee increased from $8 \mathrm{~kg}$ to over $11 \mathrm{~kg}$ per person in Sweden between 1960 and 1976, but has since then declined (Statens Jordbruksverk, 1997). Table 9 shows the consumption of coffee, tea and cocoa in Sweden during the period 1990-1996. The rise in coffee prices in 1994 and 1995 led to a considerable reduction in coffee consumption. After the prices were reduced in 1996, the consumption increased to $8.5 \mathrm{~kg}$ per person and year, returning to approximately the same level as seen in the early 1990s.

Viewed based on a number of cups per day (Table 18), the consumption was 3.8 cups in Finland, 3.7 cups in Sweden, and 3.5 cups in Norway and Denmark in 1991 (Svensk Kaffe Information, 1993). Table 19 shows Finnish data the on frequency of coffee consumption among various age groups of men and women in 1997 (Helakorpi et al., 1997). It can be noted that $10 \%$ of men and $5 \%$ of women consume 9 or more cups of coffee/day.

Table 18. Daily per capita intake of coffee in different countries in 1991 (Svensk Kaffe Information, 1993).

\begin{tabular}{|l|l|l|l|}
\hline Country & Number of cups of coffee & Country & Number of cups of coffee \\
\hline Finland & 3.8 & France & 1.9 \\
\hline Sweden & 3.7 & USA & 1.6 \\
\hline Norway & 3.5 & Italy & 1.5 \\
\hline Denmark & 3.5 & Japan & 1.0 \\
\hline Netherlands & 3.3 & Australia & 0.9 \\
\hline Germany & 2.6 & United Kingdom & 0.8 \\
\hline Belgium & 2.4 & & \\
\hline
\end{tabular}


Table 19. Frequency of coffee consumption among Finnish men and women in 1997 (Helakorpi et al., 1997).

\begin{tabular}{|r|r|r|r|r|r|r|}
\hline Consumer group & $\begin{array}{r}\text { Non- } \\
\text { consumers }\end{array}$ & $\mathbf{1 - 2}$ cups/day & $\mathbf{3 - 4}$ cups/day & $\mathbf{5 - 6}$ cups/day & $\mathbf{7 - 8}$ cups/day & $\begin{array}{r}\mathbf{9} \text { or more } \\
\text { cups/day }\end{array}$ \\
\hline Men, 15-24 years & 33.8 & 27.8 & 19.4 & 12.2 & 2.7 & 4.2 \\
\hline Men, 25-34 years & 11.3 & 14.5 & 28.6 & 25.8 & 7.1 & 12.7 \\
\hline Men, 35-44 years & 5.2 & 16.2 & 25.5 & 30.1 & 9.9 & 13.2 \\
\hline Men, 45-54 years & 6.8 & 12.6 & 30.6 & 30.1 & 9.3 & 10.7 \\
\hline Men, 55-64 years & 9.9 & 22.0 & 28.9 & 24.3 & 6.6 & 8.2 \\
\hline \hline Men, total & 12.3 & 18.1 & 26.9 & 25.2 & 7.4 & 10.1 \\
\hline \multicolumn{7}{|r|}{} \\
\hline Women, 15-24 years & 46.8 & 3.1 & 16.1 & 5.1 & 1.7 & 0.3 \\
\hline Women, 25-34 years & 22.2 & 31.0 & 23.3 & 17.3 & 4.3 & 2.0 \\
\hline Women, 35-44 years & 9.0 & 18.8 & 30.0 & 29.0 & 9.0 & 4.0 \\
\hline Women, 45-54 years & 5.5 & 21.7 & 34.6 & 26.0 & 8.4 & 3.7 \\
\hline Women, 55-64 years & 6.5 & 30.4 & 42.5 & 17.0 & 2.0 & 1.6 \\
\hline \hline Women, total & 15.0 & 22.3 & 28.2 & 22.2 & 6.4 & 5.9 \\
\hline
\end{tabular}

\subsubsection{Patterns of coffee consumption}

In an American survey, $62 \%$ reported consumption of coffee on a weekly basis (Hughes et al., 1997). Some of the coffee drinkers only consumed coffee prepared in a particular way, whereas others did not discriminate between types of coffee. Among coffee users, $73 \%$ consumed filtered coffee, $17 \%$ percolated, and $29 \%$ instant coffee. In another American study, $78.2 \%$ of the surveyed population was identified to be consumers of caffeinated coffee. Within this population, $16.4 \%$ consumed decaffeinated coffee (Scheiber et al., 1988).

Habits of drinking social beverages change over time. In the United States, the percentage of consumers (region not specified) drinking coffee decreased from $77.3 \%$ in 1957 to $56.3 \%$ in 1982. People generally consume regular coffee, i.e. caffeine-containing coffee. The highest daily intake of regular coffee in the United States, 2.45 cups, was recorded in 1962. This decreased to 1.33 cups in 1982, and had again increased to 1.6 cups in 1991 (Table 18) (Svensk Kaffe Information, 1993). Instant coffee has become more popular with time, peaking in 1972. In 1982, people in United States on average consumed 0.56 cups of instant coffee per day. Decaffeinated coffee became more and more popular between 1957 and 1982. In 1982, an American on average consumed 0.38 cups of decaffeinated coffee per day.

Filtered or brewed coffee is the most popular type of coffee in the Nordic countries. This is illustrated by Finnish data (Vartiainen et al., 1998). As shown in Table 20, a very large majority of the population from the various regions of Finland prefers filtered coffee to other types of coffee. This preference is the same for both genders. The variation shown in Table 20 reflects the geographical differences in coffee consumption.

In Norway, the habit of drinking coffee and tea has been studied in relation to length of education. Interestingly, although there was no clear difference in the habit of coffee consumption (all types summed up) 
Table 20. Type of coffee preferred by the Finnish population (Vartiainen et al., 1998). The range in consumer choice is due to differences between various counties of Finland.

\begin{tabular}{|l|c|c|}
\hline Product consumed & \% males & \% females \\
\hline Filter coffee & $82.7-86.4$ & $80.2-87.1$ \\
\hline Boiled coffee & $1.3-7.8$ & $1.8-8.1$ \\
\hline Instant coffee & $0.8-4.6$ & $0.9-3.9$ \\
\hline Other types of coffee & $0.0-1.3$ & $0.5-1.5$ \\
\hline Non-drinkers of coffee & $5.1-9.0$ & $5.6-10.2$ \\
\hline
\end{tabular}

depending on the length of education, consumption of boiled coffee was more common among people with a shorter education than among those having a longer education (Johansson and Solvoll, 1999). This finding fit rather well with the observation that boiled coffee is more popular on the countryside than in the cities. Another finding among Norwegian coffee consumers was a negative correlation to the frequency of exercise - the more people exercised the less coffee they consumed. People who tended to consume healthy food to a larger extent preferred tea to coffee than people who did not seek this type of food (Johansson and Solvoll, 1999).

\subsubsection{Coffee consumption related to age}

In a British nation-wide study the percentage of people (adults) consuming coffee was shown to rise with age (Gregory et al., 1990). Among people aged 16-24 year, coffee was consumed by $67 \%$. In the age groups $25-34$ years and $35-49$ years, $82 \%$ and $86 \%$ of the population consumed coffee, respectively. Out of people from the highest age bracket, $81 \%$ were coffee consumers.

In an American study on coffee consumption between 1957 and 1982, the most frequent coffee consumers were found in the age group 30 to 49 years. However, during that period consumption decreased from 3.7 to 2.7 cups per day in this group. During the same time period, the coffee consumption among children aged 10 to 14 years decreased from 0.19 to 0.03 cups per day. Altogether, the general trend of a decreased coffee consumption during the studied time period was most evident among children and young adults, and least marked among older persons (Gilbert, 1984).

Table 21 shows the consumption of coffee, tea, and soft drinks (g/person/day) in Norway. The data are obtained from Johansson and Solvoll (1999), a dietary survey on men and women ranging from the ages of 16-79 from all parts of Norway. Women below 20 years of age only consumed on average $90 \mathrm{~g} / \mathrm{day}$. The intake was $268 \mathrm{~g} / \mathrm{day}$ in women aged 20-29 years, $484 \mathrm{~g} /$ day in women aged 30-39 years and $568 \mathrm{~g}$ /day in women aged 40-49 years. Older women consumed somewhat less coffee. 
Table 21. Intake of coffee, tea and soft drinks (g/day) in Norwegian men and women of various age (Johansson and Solvoll, 1999).

\begin{tabular}{|c|c|c|c|c|c|c|c|}
\hline Product & $\begin{array}{r}\text { Men } \\
16-19 \\
\end{array}$ & $\begin{array}{r}\text { Men } \\
20-29 \\
\end{array}$ & $\begin{array}{r}\text { Men } \\
30-39 \\
\end{array}$ & $\begin{array}{r}\text { Men } \\
40-49 \\
\end{array}$ & $\begin{array}{r}\text { Men } \\
50-59\end{array}$ & $\begin{array}{r}\text { Men } \\
60-69\end{array}$ & $\begin{array}{r}\text { Men } \\
70-79 \\
\end{array}$ \\
\hline Coffee & 99 & 393 & 629 & 645 & 611 & 549 & 387 \\
\hline Tea & 110 & 139 & 156 & 160 & 166 & 170 & 198 \\
\hline Soft drinks & 613 & 573 & 380 & 224 & 153 & 133 & 112 \\
\hline
\end{tabular}

\begin{tabular}{|l|r|r|r|r|r|r|r|}
\hline Product & Women & Women & Women & Women & Women & Women & Women \\
& $\mathbf{1 6 - 1 9}$ & $\mathbf{2 0 - 2 9}$ & $\mathbf{3 0 - 3 9}$ & $\mathbf{4 0 - 4 9}$ & $\mathbf{5 0 - 5 9}$ & $\mathbf{6 0 - 6 9}$ & $\mathbf{7 0 - 7 9}$ \\
\hline Coffee & 90 & 268 & 484 & 568 & 508 & 457 & 416 \\
\hline Tea & 117 & 236 & 279 & 232 & 241 & 204 & 252 \\
\hline Soft drinks & 462 & 397 & 292 & 184 & 134 & 79 & 105 \\
\hline
\end{tabular}

\subsubsection{Coffee consumption in relation to gender}

In the British dietary survey by Gregory et al. (1990) a slightly higher coffee consumption could be seen for women than for men - $82 \%$ as compared to $79 \%$. The five other studies that have specifically reported on gender differences in coffee consumption have all observed a slightly higher coffee consumption among males than among females (Scott et al., 1989; Gilbert, 1984; Scheiber et al., 1988; Solvoll et al., 1989; Johansson and Solvoll, 1999). The Norwegian data are shown in Table 21.

As already mentioned in section 6.2.6., there was no difference between Finnish men and women regarding any preference of the type of coffee consumed (Table 20).

\subsubsection{Time and place of coffee consumption}

In $1990,72 \%, 70 \%$ and $54 \%$ of coffee was consumed at home in United States, Japan and Germany, respectively (D'Amicis and Viani, 1993). The workplace comes next, with $17 \%, 19 \%$ and $24 \%$, respectively, followed by other locations such as restaurants, coffee shops, bars etc.

In the United States, it is common to drink coffee during meals. In the American study mentioned above, a daily mean of 0.88 cups of coffee was consumed at breakfast, 0.36 cups at other meals, and 0.66 cups between meals.

Scheiber et al. (1988) found fewer Americans consuming coffee on weekends than on weekdays. $61 \%$ reported drinking coffee on weekdays, and $56 \%$ on weekends. The relative amounts of coffee consumed on these occasions differed as well. On weekends, $18.3 \%$ consumed more than 5 cups of coffee, but on weekdays this number increased to $23.1 \%$.

In the United Kingdom, only small differences in coffee consumption were found between different geographical areas (Gregory et al., 1990).

The consumption of coffee is obviously influenced by several factors, including sex, age and the time of the day. Manners of preparing coffee and the amounts of coffee consumed differ throughout the world. 


\subsubsection{Methylxanthine content in coffee as consumed}

Using reports from the European Coffee Federation (ECF, 1990) it is possible to obtain information concerning the types of coffee consumed in Europe. Northern European countries belong to a group of countries where $C$. arabica accounts for more than $70 \%$ of the beans in coffee $(100 \%$ of the coffee beans in Sweden and Finland, and close to $100 \%$ in Norway come from this species). Consumers from a second group of countries use around $50 \%$ C. arabica. France, Italy, the Netherlands and the United Kingdom are examples of countries belonging to this group. In the third group of countries, including Spain and Portugal, more than $50 \%$ of the consumption is $C$. canephora (robusta coffee).

Many coffees are mixtures of various grinds, each with specific caffeine content. Therefore, the type of mixture will influence the caffeine content of the final beverage. The particle size of the ground coffee will also have a strong influence on the caffeine content of the beverage. More caffeine tends to be extracted from finely ground coffees than from more coarsely ground, presumably due to the relatively larger surface area exposed to the hot water (Bunker et al. 1979). The method of preparation also has a major impact on the caffeine content in the consumed beverage, as has the brewing time. Not unexpectedly, the more coffee used to prepare the beverage, the stronger the coffee gets, and the more caffeine it contains. As mentioned previously, the caffeine content is also influenced by the Coffea species used for coffee production.

Gilbert and co-workers (1976) looked at data on caffeine contents in coffee published between 1952 and 1974. A wide range in caffeine content was found. Ground coffee ranged from 88 to $190 \mathrm{mg} / \mathrm{cup}$ and instant coffee from 30 to $80 \mathrm{mg} / \mathrm{cup}$. Table 22 summarises the results of studies on the caffeine content of instant, percolated and filtered coffee published since 1976. Some of the individual studies are discussed in the following text.

Scheiber et al. (1988) provided data on the caffeine content per cup of several beverages in the United States (volume $5 \mathrm{oz}$, close to $150 \mathrm{ml}$ ). Instant coffee had mean caffeine content of $60 \mathrm{mg}$, and drip and percolated coffees $115 \mathrm{mg}$ and $85 \mathrm{mg}$ per cup, respectively. Based on these averages in caffeine content for various types of coffee, the investigators calculated the average caffeine content of a cup of coffee in the United States to be $87 \mathrm{mg} /$ cup. Using average caffeine content in coffee to calculate caffeine exposure might, however, lead to false conclusions. If, for example, an individual consumes mainly drip coffee, using the mean caffeine content of coffee to calculate the caffeine intake will underestimate the exposure. This illustrates the danger of not taking the method of coffee preparation into consideration.

Even higher caffeine levels in coffee than the levels reported by Scheiber et al. (1988), were reported by the US Expert Panel on Food Safety and Nutrition. They stated a caffeine content of 110-150 mg/150 
Table 22. Caffeine content (mean) in coffee beverages prepared by different methods in different countries. Volume of cup standardised to $150 \mathrm{ml}$. Number of samples studied $(n)$ is indicated when information is available.

\begin{tabular}{|c|c|c|c|c|}
\hline \multirow{2}{*}{ Studied population } & \multicolumn{3}{|c|}{ Caffeine content (mg/cup) } & \multirow[t]{2}{*}{ Reference } \\
\hline & Instant & Percolated & Filtered & \\
\hline US & $\begin{array}{c}49 \\
15-84 \\
(n=21)\end{array}$ & $\begin{array}{c}65 \\
29-176 \\
(n=11)\end{array}$ & $\begin{array}{c}93 \\
33-113 \\
(n=14)\end{array}$ & Gilbert $(1976)^{1,2}$ \\
\hline US & $\begin{array}{c}66 \\
61-70 \\
(n=5)\end{array}$ & $\begin{array}{c}118^{3} \\
105-125 \\
(\mathrm{n}=4)\end{array}$ & $\begin{array}{c}142^{3} \\
137-146 \\
(n=2)\end{array}$ & Bunker et al. (1979) \\
\hline US & 58.9 & \multicolumn{2}{|c|}{73.3} & Morgan et al.(1982 ${ }^{11}$ \\
\hline US & $\begin{array}{c}60.0 \pm 6.4 \\
46.7-67.6 \\
(n=8)\end{array}$ & $\begin{array}{c}\text { Nonautomatic } \\
107.5 \pm 10.3 \\
93.0-129.5 \\
(n=10) \\
\text { Automatic } \\
117.0 \pm 11.4 \\
99.0-134.2 \\
(n=9)\end{array}$ & $\begin{array}{c}\text { Nonautomatic } \\
124.1 \pm 11.5 \\
106.0-144.8 \\
(n=7) \\
\text { Automatic } \\
136.6 \pm 17.4 \\
109.5-163.5 \\
(n=10)\end{array}$ & Blauch and Tarka (1983) \\
\hline US & 60 & 85 & 115 & \begin{tabular}{|l} 
Scheiber et al. $(1988)^{1}$ \\
\end{tabular} \\
\hline Canadian & $\begin{array}{c}47.7^{5} \\
(n=10)\end{array}$ & & $\begin{array}{c}84.2^{6} \\
(\mathrm{n}=27)\end{array}$ & Stavric et al. $(1988)^{1}$ \\
\hline Canadian & $\begin{array}{c}44.5 \\
12.5-71.9 \\
(n=10)\end{array}$ & $\begin{array}{c}56.2 \\
23.5-88.2 \\
(n=10)\end{array}$ & $\begin{array}{c}54.5 \\
26.2-111.1 \\
(n=13)\end{array}$ & \begin{tabular}{|l} 
Stavric et al. $(1988)^{1}$ \\
\end{tabular} \\
\hline Australia & $\begin{array}{c}27 / 48 / 68 \\
(n=22 / 75 / 23)\end{array}$ & & & Shirlow et al. (1983) \\
\hline Australia & $\begin{array}{c}42.8 \pm 15.4 \\
8.0-92.2 \\
(n=75)\end{array}$ & $\begin{array}{c}50.1 \pm 11.9 \\
25.1-75.3 \\
(n=37)\end{array}$ & & Lelo et al. $(1985)^{1}$ \\
\hline British & 60 & \multicolumn{2}{|c|}{83} & Barone and Roberts (1984) \\
\hline British & $\begin{array}{c}48.2 \pm 5.6 \\
(n=4)\end{array}$ & $\begin{array}{c}99.8 \pm 66.7 \\
55.5-197.3 \\
(n=3)\end{array}$ & & Scott et al. (1989) \\
\hline British & $\begin{array}{c}43.2 \\
31.5-51 \\
(n=16)\end{array}$ & $\begin{array}{c}27^{4} \\
15.8-32.3 \\
(n=8)\end{array}$ & & MAFF (1998) \\
\hline South African & 63.1 & & & Galasko et al. (1989) \\
\hline & Mean: 53 & Mean: 84 & Mean: 103 & \\
\hline
\end{tabular}

$\mathrm{ml}$ cup of coffee prepared by the drip method in the United States, and a caffeine content of 64-124 mg/150 ml cup for percolated coffee (Institute of Food Technologists, 1983).

Data from two Australian studies (Shirlow, 1983; Lelo et al., 1985) agree fairly well. When individuals in the study by Shirlow (1983) made their own instant coffee, not unexpectedly, beverages with a broad difference in caffeine content were found. The cup used by the volunteers had a volume of $150 \mathrm{ml}$, and they used the same type of coffee and spoon. The caffeine content in the coffee powder was estimated to $3.5 \mathrm{~g}$ per 100 $\mathrm{g}$ coffee. Most of the prepared coffees (almost $63 \%$ ) had medium strength with mean caffeine content of $48 \mathrm{mg}$. Weak and strong coffees were prepared by an almost equal number of persons and had mean caffeine contents of $27 \mathrm{mg}$ and $68 \mathrm{mg}$, respectively.

Lelo et al. (1985) reported the caffeine content of coffee beverages of various volumes, prepared by different persons at different places and 
times. The caffeine content of instant coffee ranged from the very moderate amount of $12.5 \mathrm{mg}$ per drink to the considerably higher amount of $169.0 \mathrm{mg}$ per drink. The mean value of all 75 coffee drinks was $60.4 \mathrm{mg}$ (42.8 mg per $150 \mathrm{ml}$ ). Brewed coffee ranged from 39.8 to $110.4 \mathrm{mg}$ per drink, with a mean of $80.1 \mathrm{mg}$ per drink $(50.1 \mathrm{mg}$ per $150 \mathrm{ml})$. However, when calculating the mean caffeine content of brewed coffee, the method of preparation was not taken into consideration.

Although prepared the same way an equal volume of different brands of coffees can contain different amounts of caffeine. Thus, when Scott et al. (1989) in a British study investigated the caffeine content in four brands of instant coffees, caffeine contents between 42.7 and $56.0 \mathrm{mg}$ per cup of $150 \mathrm{ml}$ were found. The mean caffeine content was $48.2 \mathrm{mg} / \mathrm{cup}$. The variation in caffeine content between various blends of percolated and filter coffees was even larger, being between 55.5 and $197.2 \mathrm{mg}$ per cup of $150 \mathrm{ml}$, with the mean caffeine content calculated at $99.8 \mathrm{mg} / \mathrm{cup}$. In this investigation, instant coffees had a caffeine content half of that of percolated and filter coffees.

MAFF (1998) investigated the methylxanthine levels in coffee products in the United Kingdom. Caffeine levels of 31.5-51 mg per $150 \mathrm{ml}$ cup were found in 16 instant coffees, corresponding to a mean caffeine level of $43.2 \mathrm{mg} / 150 \mathrm{ml}$ cup. In agreement with earlier observations that reported a caffeine content of $2.2 \pm 0.8 \mathrm{mg} / \mathrm{cup}$ in decaffeinated instant coffees (Blauch and Tarka, 1983), MAFF found two decaffeinated coffees to contain 1.5 and $1.7 \mathrm{mg}$ caffeine per $150 \mathrm{ml}$ cup, respectively. Theobromine and theophylline contents in regular and decaffeinated instant coffees were similar and low (means, $0.2 \mathrm{mg} / \mathrm{cup}$ of $150 \mathrm{ml}$ ). In filtered and percolated regular coffees the caffeine levels ranged from 15.8 to $32.3 \mathrm{mg} /$ cup (mean, $27 \mathrm{mg} / \mathrm{cup}$ ). These caffeine concentrations are considerably lower than those reported in earlier reports. The beverages in this study were prepared using $2.6 \mathrm{~g}$ of coffee, while most consumers typically use 2.3-11.3 g coffee/cup of $150 \mathrm{ml}$. Only low levels of the other methylxanthines were found in percolated and filtered coffee.

Stavric et al. (1988) investigated the caffeine content of coffee prepared both in Canadian households and in Canadian commercial establishments and laboratories. Instant coffee prepared at home contained between 13-72 $\mathrm{mg}$ caffeine/cup $(150 \mathrm{ml})$, with the mean being $44.5 \mathrm{mg}$ per cup. Drip coffees contained levels between $26 \mathrm{mg}$ and $111 \mathrm{mg}$ caffeine per cup, with the mean being $55 \mathrm{mg}$ per cup. Percolated coffee had a mean caffeine-content of $56 \mathrm{mg}$ /cup and ranged between $24 \mathrm{mg}$ and 88 $\mathrm{mg} / \mathrm{cup}$. At commercial establishments the caffeine content for 16 different drip coffees ranged between $48 \mathrm{mg}$ and $156 \mathrm{mg} / \mathrm{drink}$, with the mean caffeine content per $150 \mathrm{ml}$ cup being $84 \mathrm{mg}$. For instant coffee of different brands prepared in the laboratory, the mean quantity of caffeine in a $150 \mathrm{ml}$ cup was $48 \mathrm{mg}$; the content in the different brands ranged from 32 $\mathrm{mg}$ to $64 \mathrm{mg}$ per cup. 
Recently, Verheijen (1999) analysed the caffeine content of 155 samples of coffee collected in commercial establishments and workplace cafeterias in Iceland during June and July 1999. Figure 4 shows that most samples contained between 400 and $600 \mathrm{mg}$ caffeine per litre, corresponding to between $60 \mathrm{mg}$ and $90 \mathrm{mg}$ caffeine per $150 \mathrm{ml}$. Three coffee samples are not included in the Figure. They contained $242 \mathrm{mg}, 419 \mathrm{mg}$, and $509 \mathrm{mg}$ caffeine per cup $(150 \mathrm{ml})$.

Verheijen (1999) also used the four most common Icelandic coffee brands to test the reproducibility of coffee machines in brewing experiments. A cup of coffee on average contained $84 \mathrm{mg}$ caffeine. Since the amount of ground coffee used for the coffee production was standardised, it could be calculated that $13.8 \mathrm{mg}$ caffeine was extracted from each gram of coffee.

The available information tells us that different individuals are exposed to different amounts of caffeine though their consumption of coffee. The mean value of caffeine content in a $150 \mathrm{ml}$ cup of coffee in the studies reported in Table 22 is $53 \mathrm{mg}$ for instant coffee, $84 \mathrm{mg}$ for percolated coffee, and $103 \mathrm{mg}$ for filtered (brewed) coffee. It should be noted, however, that most data in Table 22 originates from the United States, and North American coffee seems to be less concentrated than the typical coffee prepared in the Nordic countries.

When drinking coffee, the consumer ingests several hundred different compounds in addition to caffeine, and no doubt coffee contains several

Figure 4. The caffeine content of 152 samples of Icelandic coffee collected in commercial establishments and workplace cafeterias during the summer of 1999 (Verheijen, 1999).

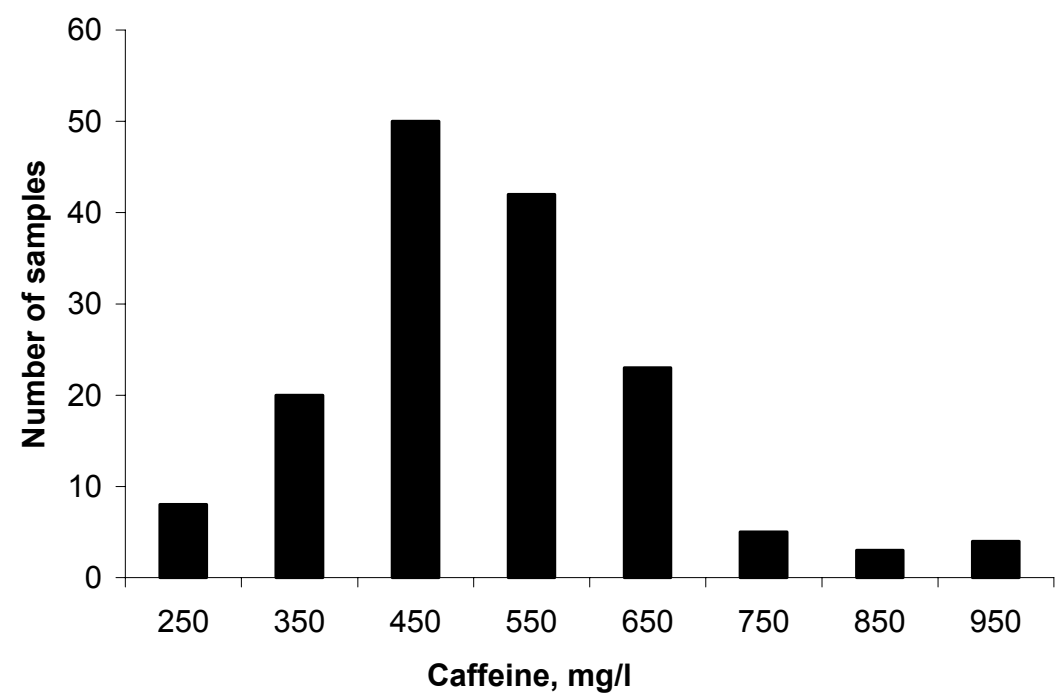


other compounds yet to be identified. Important compounds in coffee have been reviewed by Viani (1993). The majority of these have no effect on the consumer besides stimulating the senses (by contributing to the specific aroma) and possibly contributing to general nutrition. However, a few of the compounds in coffee might have advantageous or adverse effects if their intake is high enough. The methylxanthines, and particular caffeine, are examples known for both their positive (e.g. contributing to alertness) and adverse effects (e.g. resulting in difficulties to sleep).

\subsubsection{Methylxanthine intake from coffee}

The per capita caffeine intake from coffee in the world was $38 \mathrm{mg} /$ day in 1981/82. In the United States, Canada, Sweden, and the United Kingdom the corresponding intakes were $125,128,340$, and $84 \mathrm{mg} /$ day, respectively (Gilbert, 1984). No later data on per capita intake is available.

Two British studies and three American studies have tried to determine the individual caffeine intake from coffee. In 1983 Scott and coworkers studied 174 British males and females, and found that coffee consumption led to a daily average caffeine intake of $198 \mathrm{mg}$ per person. Some years later, Gregory et al. (1990) investigated the total intake of coffee during one week in a substantially larger British test population. They observed a total quantity of $3398 \mathrm{~g}$ of coffee beverage consumed during the seven-day recording period. Using the data of Barone and Roberts (1984) and Scott et al. (1989) for caffeine content of British coffee, a daily caffeine intake of 268 and $323 \mathrm{mg}$ could be estimated, respectively.

The estimated daily intake of caffeine from coffee in adults as seen in the three American studies was found to be in the region of 250 to 300 mg per person. Whereas Scheiber et al. (1988) reported that coffee drinking resulted in a caffeine intake of $298.5 \mathrm{mg} /$ day in the United States, Hughes et al. (1997) reported a mean caffeine intake from coffee of 229 $\mathrm{mg}$ /day among 202 consumers in Vermont. Young people have a lower caffeine intake from coffee than older people. On an $\mathrm{mg} / \mathrm{kg}$ body weight basis, an American test population of children aged 6-11 year ingested $0.10 \mathrm{mg} / \mathrm{kg}$, whereas those aged $12-17$ years ingested $0.16 \mathrm{mg} / \mathrm{kg}$ body weight (Morgan et al., 1982).

In the study by Scheiber et al. (1988) mentioned above, $16.4 \%$ of the United States test population consumed decaffeinated coffee. A Canadian investigation has shown that close to one third of decaffeinated coffees prepared commercially actually contain low concentrations of caffeine (Stavric et al., 1988). Thus, people who try to avoid caffeine probably are exposed to the substance without their knowledge.

In a Norwegian dietary study of 11,912 males and 12,328 females, the mean number of cups of coffee consumed by males and females were 4.7 and 4.3 per day, respectively (Solvoll et al., 1989). In this study a cup of 
coffee was estimated to contain approximately $115 \mathrm{ml}$ coffee. Based on the assumption that a $150 \mathrm{ml}$ cup of coffee contains $100 \mathrm{mg}$ caffeine (Kurppa et al., 1983; Olsen et al., 1991), this frequency of consumption leads to a caffeine intake of $360 \mathrm{mg} /$ day in females and $330 \mathrm{mg} /$ day in males.

Hemminki et al. (1988) studied coffee consumption among Finnish youths between 1977 and 1985. For 18-year-old girls and boys the mean number of cups consumed per day was 2.3 and 3.1, respectively. This coffee consumption approximately corresponds to a caffeine intake of 230 and $310 \mathrm{mg}$ caffeine/day, respectively (calculated from a caffeine content of $100 \mathrm{mg} / 150 \mathrm{ml}$ cup according to Kurppa et al. (1983) and Olsen et al. (1991).

For the period of one month in 1997, the National Food Administration in Sweden invited all blood donors in Visby, the main city of the county of Gotland, to participate in a study that among other parameters investigated the coffee consumption of this particular Swedish population segment (Thuvander et al., 2001). Of the 202 persons who accepted the invitation, 198 gave enough information to be included in the study. In addition to giving information on how often study participants consumed coffee, they also indicated as to whether they mainly consumed filtered (dripolated), boiled, or instant coffee. The use of decaffeinated coffee was not investigated, nor was the strength of the coffee consumed. Only 5\% of the females and $0.7 \%$ of the males did not drink coffee. The majority of males and females consumed mainly brewed (filter) coffee (Table 23). Consumption was higher in males than in females. Among participants aged 30-59 years, the average male consumed between 600 and $650 \mathrm{ml}$ coffee/day, whereas the average female had a lower coffee consumption, 415-540 ml/day, with coffee intake being dependent on age (Table 23). Assuming that a $150 \mathrm{ml}$ cup of brewed coffee contains $103 \mathrm{mg}$ caffeine (average in Table 21), males aged 30-59 years would be exposed to 412$446 \mathrm{mg}$ caffeine, and females of the same age group to $285-371 \mathrm{mg}$ caffeine. Although males drank significantly more coffee than females, the caffeine exposure from coffee, calculated on per kg body weight basis, was only slightly higher in males than in females. The participant with the highest intake of coffee consumed $2240 \mathrm{ml}$ a day (1538 mg caffeine). Sixteen percent of the participants consumed more than $900 \mathrm{ml}$ coffee/day, or $618 \mathrm{mg}$ caffeine/day. 
Table 23. Average caffeine intake from coffee among blood donors of Gotland, Sweden, 1997.

\begin{tabular}{|l|l|l|c|c|}
\hline Type of coffee & Age group & Sex (sample size) & $\begin{array}{c}\text { Intake of coffee } \\
(\mathbf{m} / \text { day })\end{array}$ & $\begin{array}{c}\text { Caffeine exposure } \\
(\mathbf{m g} / \mathbf{k g} \text { BW/day) }\end{array}$ \\
\hline Filter coffee & -29 years & male $(\mathrm{n}=5)$ & $672.0 \pm 584.4$ & $6.34 \pm 5.19$ \\
\hline & -29 years & female $(\mathrm{n}=2)$ & $2812 \pm 394.2$ & $3.22 \pm 4.51$ \\
\hline & $30-39$ years & male $(\mathrm{n}=36)$ & $654.7 \pm 481.7$ & $5.52 \pm 4.41$ \\
\hline & $30-39$ years & female $(\mathrm{n}=11)$ & $518.0 \pm 240.0$ & $5.39 \pm 2.51$ \\
\hline & $40-49$ years & male $(\mathrm{n}=46)$ & $637.0 \pm 321.8$ & $5.34 \pm 2.72$ \\
\hline & $40-49$ years & female $(\mathrm{n}=22)$ & $414.8 \pm 268.8$ & $4.21 \pm 2.84$ \\
\hline & $50-59$ years & male $(\mathrm{n}=30)$ & $602.1 \pm 313.1$ & $5.01 \pm 2.69$ \\
\hline & $50-59$ years & female $(\mathrm{n}=16)$ & $539.6 \pm 278.9$ & $5.43 \pm 2.59$ \\
\hline & $60-$ years & male $(\mathrm{n}=4)$ & $583.3 \pm 220.6$ & $4.86 \pm 2.03$ \\
\hline & $60-$ years & female $(\mathrm{n}=2)$ & $350.0 \pm 297.0$ & $3.56 \pm 3.46$ \\
\hline Boiled coffee & all ages & male $(\mathrm{n}=6)$ & $840.0 \pm 537.8$ & $6.25 \pm 3.35$ \\
\hline & all ages & Female $(\mathrm{n}=3)$ & $328.9 \pm 362.1$ & $2.81 \pm 3.20$ \\
\hline Instant coffee & all ages & male $(\mathrm{n}=5)$ & $504.0 \pm 276.9$ & $4.62 \pm 2.41$ \\
\hline & all ages & female $(\mathrm{n}=1)$ & 933.3 & 14.1 \\
\hline Mixed types of coffee & all ages & male $(\mathrm{n}=5)$ & $774.7 \pm 860.2$ & $6.56 \pm 6.89$ \\
\hline & all ages & female $(\mathrm{n}=0)$ & - & - \\
\hline
\end{tabular}

\subsection{Guaraná}

Guaraná is the most stimulating of all caffeine-containing beverages. It is derived from the nut-shaped and eye-like seeds of the climbing vines or sprawling shrubs Paullinia cupana and Paullinia sorbilis native to the central Amazon Basin.

As these two plants are very similar they are now usually considered to be races of the same species. The high caffeine content of the seeds, 2$6 \%$, is responsible for the strong stimulating effect of the beverage. Guaraná also contains low quantities of theophylline and theobromine (Baltassat et al., 1985; Belliardo et al., 1985; Bempong et al., 1993).

There is an unexpectedly large difference in the caffeine content of various tissues or organs of the fruits and seeds of guaraná (Baumann et al., 1995). The bulky, soft and mealy aril is completely devoid of any methylxanthines. As expected, the caffeine content is highest in the cotyledons, the seeds $(4.28 \%)$, and distinctly lower in the seed coats $(1.64 \%)$. The septa contained $0.67 \%$ caffeine and the pericarp only $0.02 \%$. Both theobromine and theophylline are minor alkaloids in all tissues, except for theobromine in the pericarp, where it is the main alkaloid $(0.20 \%)$.

The plants are cultivated in a small area (6 000 ha) of the Amazonas near Manaus, just south of the equator (Erickson et al., 1984). The Indians used guarana long before the Europeans came to Brazil.

The seeds are picked as soon as a few fruits open. The 'white of the eye', botanically an aril of mealy consistency, is rubbed off manually, and the seeds are gently roasted to facilitate the removal of the glossy, tough, and dark brown seed coat. The kernels are then ground and crushed in a hard wood mortar and mixed with water into dough. This dough is then formed into long reddish-brown or brownish-black sticks and dried to a nourishing food, well suited for storage in the hot and humid 
climate (Baumann et al., 1995). A more comprehensive description of guaraná preparation is given by Kihlman (1977).

For use as a beverage, the pasta guaraná is powdered and the powder is prepared with hot or cold water, like cocoa, and sweetened. Owing to the high tannin content (2-5\%), the beverage is slightly bitter, astringent and acid. But it has no marked odour.

In recent years, industrially processed guaraná has gained popularity as an ingredient of carbonated beverages (soft drinks) and as an herbal stimulant, not only in Brazil but also in the United States and in Europe. In particular the recent introduction of high caffeine sodas based on guaraná has drawn attention to this natural product. There are several differences in the processing of guaraná seeds for traditional and industrial use. For example, the seed coats are removed prior to roasting during traditional procedures, while they are retained in the powders obtained from industrial manufacturers. Other differences involve the roasting of the seeds and the drying process of the guaraná paste (MeurerGrimes et al., 1998). There is no use of guaraná in the Nordic countries that resembles the traditional use of the plant. Instead, guaraná in this part of the world is mostly found in energy drinks and smart drinks, in which guaraná extracts are used as an important ingredient. Chemical analytical studies of commercial products sold in solid dosage form indicate that a number of these products contain less than the declared quantity of guaraná, or may not even contain authentic guaraná at all (Carlson and Thompson, 1998).

Table 24 shows the caffeine, theophylline and theobromine contents in various guaraná samples and products obtained in Brazil, or purchased on the open market in Brazil, Italy, the United Kingdom, the United States and Germany. Whereas guaraná seeds contain high amounts of caffeine and small quantities of theobromine and theophylline, the quantity of these methylxanthines in commercial products varies from sample to sample. Many of the products contain caffeine as the major alkaloid, with traces of theophylline and theobromine. Numerous sodas and syrups contained up to ten times more theobromine than caffeine, indicating that these products are adulterated with cocoa, the major source of theobromine.

Until now no decaffeinated guaraná products have been available on the Nordic market. However, a method using supercritical carbon dioxide for extraction of caffeine from wet guaraná seeds has been developed. It took around $8 \mathrm{~h}$ for the method to extract most of the caffeine present in the seeds of smallest particle size, which is quicker than with conventional organic solvents presently used for decaffeination (Mehr et al., 1996). 
Table 24. Content of caffeine, theophylline and theobromine (\% dry weight or $\mathrm{mg} / 100 \mathrm{ml}$ ) in various guaraná samples and products collected in Brazil, or purchased on the open market in Brazil, Italy, the United Kingdom, the United States or Germany.

\begin{tabular}{|c|c|c|c|c|c|c|c|}
\hline Sample type (number) & $\begin{array}{c}\text { Caffeine content } \\
\% \text { dry weight }\end{array}$ & $\begin{array}{c}\text { Caffeine content } \\
\mathrm{mg} / 100 \mathrm{ml}\end{array}$ & $\begin{array}{c}\text { Theophylline content } \\
\% \text { dry weight } \\
\end{array}$ & $\begin{array}{c}\text { Theophylline content } \\
\mathrm{mg} / 100 \mathrm{ml}\end{array}$ & $\begin{array}{c}\text { Theobromine conent } \\
\% \text { dry weight }\end{array}$ & $\begin{array}{c}\text { Theobromine content } \\
\mathrm{mg} / 100 \mathrm{ml}\end{array}$ & Reference \\
\hline Seeds $(n=2)$ & $3.0-3.7$ & & $0-0.03$ & & $0.01-0.02$ & & Meurer-Grimes et al., 1998 \\
\hline Seeds $(n=1)$ & 4.6 & & & & & & Bempong et al., 1993 \\
\hline Seeds $(n=3)$ & $3.98-4.79$ & & $0-0.25$ & & 0.02 & & Baltassat et al., 1985 \\
\hline Seeds $(n=4)$ & 4.28 & & 0.007 & & 0.015 & & Baumann et al., 1995 \\
\hline Seeds $(n=2)$ & $4.33-4.42$ & & 0.18 & & $0.035-0-039$ & & Carlson and Thompson, 1998 \\
\hline Seed coat $(n=1)$ & 5.1 & & 0 & & 0.06 & & Meurer-Grimes et al., 1998 \\
\hline Seed coat $(n=2)$ & $3.69-4.31$ & & $0-0.15$ & & $0.04-0.06$ & & Baltassat et al., 1985 \\
\hline Seed coat $(n=4)$ & 1.64 & & 0.005 & & 0.027 & & Baumann et al., 1995 \\
\hline Guaraná sticks $(\mathrm{n}=2)$ & $2.0-4.2$ & & tr. & & $0-0.02$ & & Meurer-Grimes et al., 1998 \\
\hline Guaran'a sticks $(n=2)$ & $3.82-4.30$ & & & & & & Bempong et al., 1993 \\
\hline Guaraná sticks $(\mathrm{n}=1)$ & 2.44 & & 0.007 & & 0.033 & & Carlson and Thompson, 1998 \\
\hline Powder $(n=8)$ & $1.6-6.6$ & & tr. ${ }^{1}-0.06$ & & tr. -0.03 & & Meurer-Grimes et al., 1998 \\
\hline Powder $(\mathrm{n}=2)$ & $3.53-4.04$ & & & & & & Bempong et al., 1993 \\
\hline Powder $(n=5)$ & $2.95-3.75$ & & $0.006-0.13$ & & & & Belliardo et al., 1985 \\
\hline Powder $(n=2)$ & $4.08-4.44$ & & $0-0.02$ & & $0.03-0.04$ & & Baltassat et al., 1985 \\
\hline Powder $(n=2)$ & $0.5-2.6$ & & $0.006-0.01$ & & $0.01-0.016$ & & Willetts et al., 1994 \\
\hline Powder $(n=5)$ & $4.02-9.14$ & & $0.005-0.048$ & & tr. -0.051 & & Carlsson and Thompson, 1998 \\
\hline Powder in capsule $(n=1)$ & 3.53 & & & & & & Bempong et al., 1993 \\
\hline Tincture $(n=3)$ & $0.04-11.0$ & & tr. -0.48 & & $0.01-0.18$ & & Meurer-Grimes et al., 1998 \\
\hline Drink mix $(n=2)$ & $0.02-0.07$ & & 0 & & 0 & & Meurer-Grimes et al., 1998 \\
\hline Gel cap $(n=2)$ & $1.9-4.7$ & & tr. -0.03 & & 0.02 & & Meurer-Grimes et al., 1998 \\
\hline Capsule $(n=2)$ & $3.2-4.5$ & & $0.025-0.03$ & & $0.022-0.044$ & & Willetts et al., 1994 \\
\hline Gel capsules $(n=5)$ & $0-8.27$ & & $0-0.003$ & & $0-0.024$ & & Carlson and Thompson, 1998 \\
\hline Comfits $(n=1)$ & 0.91 & & 0.08 & & & & Belliardo et al., 1985 \\
\hline Gum $(n=1)$ & 0.4 & & 0 & & 0 & & Meurer-Grimes et al., 1998 \\
\hline Tablet $(n=1)$ & 3.8 & & 0.02 & & 0.02 & & Meurer-Grimes et al., 1998 \\
\hline Tablet $(n=1)$ & 1.20 & & 0.01 & & & & Belliardo et al., 1985 \\
\hline Tablet $(\mathrm{n}=2)$ & $1.5-2.6$ & & $0-0.01$ & & $0.002-0.015$ & & Willetts et al., 1994 \\
\hline Tablet $(n=9)$ & $0.52-5.30$ & & $0-0.005$ & & $0-0.016$ & & Carlsson and Thompson, 1988 \\
\hline Elixir $(n=1)$ & $3.52(w / v)$ & & & & & & Bempong et al., 1993 \\
\hline Syrup $(n=5)$ & & tr. -364 & & $0-23$ & & tr. -2293 & Meurer-Grimes et al., 1998 \\
\hline 'Guarana' beverage $(n=1)$ & & 7.5 & & 0.06 & & & Marx and Maia, 1990 \\
\hline Carb. $\left.{ }^{2}\right)$ beverages $(n=15)$ & & $8-54$ & & tr. -2 & & tr. -366 & Meurer-Grimes et al., 1998 \\
\hline Carb $^{.2}$ beverages $(n=2)$ & & $8.3-17.4$ & & $0-0.02$ & & $0-0.004$ & Carlson and Thompson, 1998 \\
\hline Carb $^{2 .}$ beverages $(n=3)$ & & 1.4 & & & & & Camargo and Toledo, 1999 \\
\hline $\begin{array}{l}\text { Carbonated diet } \\
\text { beverages }(n=3)\end{array}$ & & 0.8 & & & & & Camargo and Toledo, 1999 \\
\hline Carb $^{2)}$ beverages $(n=9)$ & & 0.9 & & & & & Camargo et al., 1999 \\
\hline $\begin{array}{l}\text { Carbonated diet } \\
\text { beverages }(n=3)\end{array}$ & & 1.1 & & & & & Camargo et al., 1999 \\
\hline Carb $^{2)}$ beverage $(n=1)$ & & 9.6 & & & & & Vergnes and Alary, 1986 \\
\hline Carb. ${ }^{2}{ }^{2}$ beverages $(n=5)$ & & $0.5-128$ & & $0.02-1.0$ & & $0-1.0$ & Willetts et al., 1994 \\
\hline Others $(n=2)$ & $0.6-2.8$ & & 0 & & $0-1.6$ & & Meurer-Grimes et al., 1998 \\
\hline Others $(n=1)$ & & 422 & & 0 & & 50 & Meurer-Grimes et al., 1998 \\
\hline
\end{tabular}

1) $\operatorname{tr}=$ traces; 2 ) carb = carbonated 


\subsection{Maté}

Maté, also called Paraguayan tea, is produced from the leaves of Ilex paraguariensis (also called Ilex paraguayensis), which accumulate significant amounts of caffeine - between 0.4 and 2\% (Graham, 1978; Gilbert, 1984; Vergnes and Alary, 1986; Mazzafera, 1994; Carlson and Thompson, 1998; Salaňa et al., 1999). Early studies on the occurrence of the methylxanthines caffeine, theobromine and theophylline in I. paraguariensis have been reviewed by Alikaridis (1987). Later studies show that the amounts are strongly affected by the agronomic conditions under which the plants have been grown. Thus, extracts from plants grown in shadow areas contain at least three times higher amounts of caffeine and theobromine than extracts from plants unprotected from light (Esmelindro et al., 2004). Young I. paraguariensis leaves also contain 0.08$0.10 \%$ theobromine and less than $0.02 \%$ theophylline (Mazzafera, 1994; Carlsson and Thompson, 1998). The method of drying harvested leaves may influence the extractability of methylxanthines. The longer the storage of dried mate leaves the lower is the caffeine and theobromine content (Esmelindro et al., 2004). Among the first to use maté were the Quichas, the aboriginal population of Peru, who believed that the beverage had the property of stimulating resistance to fatigue. Later, the Jesuits undertook the cultivation of the plant. Today large quantities of I. paraguariensis are grown in Southern Brazil, Argentina and Paraguay and the maté beverage are consumed daily by about 20 million people in South America, most of it in Argentina. However, the per capita consumption is highest in Paraguay and Uruguay.

The botany of I. paraguariensis, the history of maté consumption, the chemical composition of maté, the production of the maté beverage, and the use and physiological effects of maté has been reviewed by Bartsch (1998). The following description on how maté is used is given by Cheney (1947): Processing of maté involves a series of distinct steps, specifically: cutting, toasting, breaking, drying, threshing (beating), sifting, aging and manufacturing. Bitter maté ('cimarron' or 'chimarro') is brewed in a gourd without sugar. If sugar is added it makes sweet maté ('maté dulce' or 'maté doce'). Maté tea or 'Te de Yerba' is prepared like Chinese or Indian tea in a teapot by pouring boiling water on the leaf fragments. Tea maté should have rather large leaf fragments and the quantity per cup should be about twice that required for ordinary tea. Maté-tea is the form used in cities, whereas cimarron brewed from finely ground leaves mixed with a few twig fragments is preferred by the people of the rural districts and by the cowboys of the pampas.

The extraction of methylxanthines from mate leafs is influenced by, temperature, pressure, and presence of co-solvents. This has been adequa- 
tely shown for supercritical carbon dioxide extraction with ethanol as cosolvent (Saldaňa et al., 1999, 2002). In mate preparation these factors are standardised. Samples of five types of maté leaf, obtained from retail outlets in the United Kingdom and Germany, and beverages consequently prepared from them, were analysed for caffeine, theobromine and purine alkaloid-like compounds (Clifford and Ramirez-Martinez, 1990). Two products produced brown extracts and infusions with 1.84 and $1.42 \%$ total alkaloid content (on a dry weight basis), corresponding to 31 and 18 mg purine alkaloids per cup of beverage. The other three leaf samples produced green extracts and infusions with higher alkaloid contents $2.68,2.21$ and $1.73 \%$, corresponding to 50,36 and $29 \mathrm{mg}$ per cup, respectively. Around two thirds of the methylxanthines were caffeine, and close to one-third theobromine. No theophylline was found. Whether the differences in extracts were due to the drying process to which the samples had been subjected or arose from the use of leaves of different Ilex species was not known. Camargo et al. (1999) analysed maté products on the Brazilian market for caffeine content. They found beverages prepared from tea bags $(\mathrm{n}=9)$ to contain only $2-16 \mathrm{mg}$ caffeine $/ 150 \mathrm{ml}$ cup (average $10 \mathrm{mg} / \mathrm{cup}$ ), whereas even less was found in beverages prepared from leafs ( $\mathrm{n}=9$ ), $1-7 \mathrm{mg}$ caffeine/cup (average $5 \mathrm{mg} /$ cup).

Available information indicates that mate prepared in the normal way contains less caffeine than regular tea, and only small amounts of theobromine and theophylline. Gilbert (1984) suggested an average daily intake of $85 \mathrm{mg}$ caffeine in Paraguay and Uruguay.

Mazzafera (1997), however, came to a rather different conclusion after having analysed 18 samples of mate tea infusions prepared according to the methods used by the gauchos (cowboys) of South America. The caffeine samples were heated at $85^{\circ} \mathrm{C}$ for 30 minutes, centrifuged and the supernatant filtered. A cup of infusion prepared in this way typically contained between 0.29 and $0.79 \mathrm{mg}$ caffeine per $\mathrm{ml}$. Since the cup ('cuia') used to drink maté is fairly large (around $250 \mathrm{ml}$ ) in relation to cups used for coffee, and the regional habit of maté consumption often implies the consumption of two 'cuia', this would correspond to an intake of $260 \mathrm{mg}$ caffeine. Thus, compared to other caffeine-containing beverages, consumption of herbal mate tea prepared according to the gauchos' method provided a higher intake of caffeine.

According to Saldaňa et al. (2002), a high intake of mate can provoke irritability, loss of sleep, cerebral depression, and nervous tremor.

\subsection{Tea}

Tea is produced from leaves of the perennial shrub Camellia sinensis, and is the most widely consumed non-alcoholic beverage in the world because of its taste, aroma, and effects on well-being. The information reported 
lately that tea is good for your health does not reduce its popularity. Tealeaves contain substantial amounts of caffeine, small amounts of theobromine, and traces of theophylline (Cloughley, 1981). Several workers have observed that caffeine contributes to the briskness of black tea (Obanda et al., 1997). The genus Camellia includes more than 82 species. When Nagata and Sakai (1984) examined the caffeine content of 23 of these species, they found caffeine in the young leaves of first flush shoots from only three species. Understandably, most data are available from studies on C. sinensis. In certain other species, theobromine was the predominant methylxanthine. Thus, information on $C$. sinensis cannot be used to draw conclusions on the amount of caffeine and other methylxanthines in other Camellia species.

Camellia sinensis occur in two variants, $C$. sinensis var. assamica and C. sinensis var. sinensis, with the latter divided into Chinese and Japanese subgroups. In an extensive investigation of 1500 cultivars, Takeda (1994) found that the young leaves of first flush shoots of Assam tea (var. assamica) on average contain 4.1\% (range: $2.7-5.5 \%$ ) caffeine. Young leaves of China tea (var. sinensis) and Japan tea (var. sinensis) contain 3.1\% (range: $1.6-4.6 \%$ ) and $2.9 \%$ (range: $1.9-3.9$ ), respectively.

\subsubsection{Types of tea}

There are five main groups of tea: green, paocong, oolong tea, pu-erh (red teas), and black tea. The oxidation-state of the tea flavonols accounts for the most important differences between these products. In green tea the flavonols are reduced. During the preparation of pu-erh and black tea they are oxidised, a process known as fermentation. Paochong and oolong tea are products where the flavonols are only partially oxidised. Flavoured teas are produced by spraying the crushed leaves with flavour extract, or by mixing them with stabilised flavours in solid form prior to distribution. Instant tea, a powdered extract of tealeaves, is directly dissolved in water. This type of tea is primarily consumed and manufactured in the United States (Graham, 1978). Caffeine-free tea contains negligible amounts of caffeine, but may contain as much theobromine and theophylline as regular tea (MAFF, 1998).

When black tea is manufactured, plucked tea is subjected to withering under ambient conditions. The goal is to achieve a moisture-content of $720 \mathrm{~g} / \mathrm{kg}$ or less over a period of $18-21 \mathrm{~h}$. After withering, the leaves are macerated repeatedly, using a Crush, Tear and Curl (CTC) machine, and fermented at an ambient temperature $\left(22^{\circ} \mathrm{C}\right)$ for 90 minutes. Fermentation is terminated by drying, using a miniature fluid bed dryer.

The different methods of manufacturing of thevarious tea products, account for the marked difference in their chemical compositions. Although the various steps of production influence the caffeine content, there is not a pronounced change in caffeine content during production of 
either black or green tea (Astill et al., 2001). Caffeine, however, seems to be very quickly extracted into the infusion, around $80-90 \%$ being extracted in boiling water within 30 seconds (Hodgson et al., 1999; Lakenbrink et al., 2000).

\subsubsection{Production}

The total production of tea in the world has increased so that the production level in 1994 was 1.5 times that of 1978. One reason for this development could be that the tea plant is less sensitive to cultivation problems such as frost and diseases than the coffee plant (Gilbert, 1984). China and India grew more than $50 \%$ of the world total tea production in 1996 (Table 25). Black tea accounts for over $75 \%$ of the world production of tea, green tea for approximately $22 \%$, and oolong tea for the remaining part of the world production. Oolong tea is mainly manufactured in Taiwan and China (Graham, 1978).

Decaffeinated tea is currently produced by solvent/supercritical fluid extraction (Ashihara and Crozier, 1999).

\subsubsection{Genetic modification of Camellia sinensis}

The tea plant (Camellia sinensis) is rather difficult to transform. One reason is that regeneration of whole plants from tea protoplasts in tissue culture is difficult. However, it is possible from stem tissues or cotyledons. Although the rate is low, Agrobacterium is able to infect the tea plant and deliver its extrachromosomal DNA. Xi et al. (1997) and Konwar et al. (1998) reported that hairy roots develop in in vitro derived calli, shoots and leaves of tea infected with Agrobacterium rhizogenes (also after the bacteria had been eliminated). By applying acetosyringone to tea plant tissue, Matsumoto and Fukui (1998) were able to demonstrate that Agrobacterium tumefaciens co-cultured with leaf explants mediated

Table 25. Tea production (1000 tonnes) in 1996 (from FAO, 1996c).

\begin{tabular}{|l|l|}
\hline Production countries & Production 1996 \\
\hline India & $715^{*}$ \\
\hline China & $609^{*}$ \\
\hline Kenya & 255 \\
\hline Sri Lanka & $246^{*}$ \\
\hline Indonesia & 169 \\
\hline Turkey & 124 \\
\hline Japan & $90^{*}$ \\
\hline Iran & 56 \\
\hline Bangladesh & 48 \\
\hline Vietnam & $40^{*}$ \\
\hline Argentina & 40 \\
\hline Malawi & 37 \\
\hline Georgia & 34 \\
\hline World & 2633 \\
\hline
\end{tabular}


gene transfer to the plant tissue. Acetosyringone is a phenolic compound produced by wounded plant tissue that stimulates the transfer of T-DNA from Agrobacterium to plants. Transformed calli could be produced from the leaf explants. Similarly, genetic transformation was induced in somatic embryos infected with Agrobacterium tumefasciens (Mondal et al., 1999). The highest transformation efficiency was observed in intact uninjured embryos; a maximum transient expression of the marker gene (GUS $=\beta$-glucuronidase) of $40-48 \%$ was observed when sucrose rather than acetosyringone was used as an inducing agent and when embryos were co-cultivated for five days on a medium of $\mathrm{pH}$ 5.8.

Recently, the caffeine synthase gene from tea leafs was cloned by Japanese scientists (Kato et al., 2000). The caffeine synthase gene catalyses the final two steps in the caffeine biosynthesis pathway. The cloning of the gene is an important advance towards the development of transgenic caffeine-deficient Camellia sinensis and Coffea arabica plants though antisense messenger RNA technology or gene silencing.

\subsubsection{Amount of tea sold in different countries}

The United Kingdom is the main tea market in Europe (Table 26), accounting for around $50 \%$ of the total European market. Other large markets in Europe are Germany, Ireland and Russia. The Nordic market is not very impressive.

\subsubsection{Per capita consumption of tea}

Ireland's per capita consumption of tea was $3.21 \mathrm{~kg}$ in 1993 (Table 27). Three years earlier the per capita consumption was $2.6 \mathrm{~kg}$ in the United Kingdom and $2.08 \mathrm{~kg}$ in Turkey. China consumed $0.34 \mathrm{~kg}$, and the United States 0.35 kg tea per capita (Anonymous, 1995; http://www.teatime.com/tea/consumption.html, 2000-04-13).

Table 26. Quantity of tea sold on the European market - in 1000 tonnes (Consumer Europe, 1996).

\begin{tabular}{|c|c|c|c|c|c|c|}
\hline Country & 1990 & 1991 & 1992 & 1993 & 1994 & 1995 \\
\hline Austria & 2 & 2 & 2 & 2 & 3 & 3 \\
\hline Belgium & 1 & 2 & 2 & 2 & 2 & 2 \\
\hline Denmark & 2 & 2 & 2 & 2 & 3 & 3 \\
\hline Finland & 1 & 1 & 1 & 1 & 1 & 1 \\
\hline France & 7 & 8 & 7 & 8 & 8 & 8 \\
\hline Germany & 29 & 29 & 31 & 32 & 33 & 35 \\
\hline Greece & 1 & 1 & 1 & 1 & 1 & 1 \\
\hline Italy & 4 & 4 & 4 & 4 & 5 & 6 \\
\hline Ireland & 12 & 11 & 11 & 12 & 12 & 12 \\
\hline Netherlands & 8 & 8 & 9 & 9 & 9 & 9 \\
\hline Norway & 1 & 1 & 1 & 1 & 1 & 1 \\
\hline Spain & 1 & 1 & 1 & 1 & 1 & 1 \\
\hline Sweden & 3 & 3 & 3 & 3 & 3 & 3 \\
\hline Switzerland & 1 & 1 & 1 & 1 & 1 & 1 \\
\hline United Kingdom & 129 & 126 & 117 & 110 & 106 & 104 \\
\hline
\end{tabular}


Table 27. Yearly per capita consumption of tea (in $\mathbf{~ k g}$ ) in major consuming countries 1990

\begin{tabular}{|l|l|}
\hline Country & $\begin{array}{l}\text { Tea consumption } \\
(\mathbf{k g})\end{array}$ \\
\hline Ireland & $3.21^{1}$ \\
\hline United Kingdom & 2.60 \\
\hline Turkey & 2.08 \\
\hline Syria & 1.67 \\
\hline Iran & 1.46 \\
\hline Sri Lanka & 1.27 \\
\hline Marocco & 1.15 \\
\hline Egypt & 1.14 \\
\hline Japan & 1.04 \\
\hline Pakistan & 0.95 \\
\hline Poland & 0.8 \\
\hline India & 0.63 \\
\hline CIS & 0.46 \\
\hline USA & 0.35 \\
\hline China & 0.34 \\
\hline Sweden & $0.3^{3}$ \\
\hline
\end{tabular}

The majority of the tea consumed in the United States, around $65 \%$, was in the form of ice-tea preparations. In other countries, tea is generally consumed as a hot beverage (James, 1991).

The per capita consumption of tea in Sweden has been constant at 0.3 $\mathrm{kg} /$ year between 1990 and 1996 (Table 9), corresponding to approximately 0.38 cups of tea/day. The per capita consumption of instant tea, together with instant coffee, during this same period has fluctuated between 0.1 and $0.3 \mathrm{~kg} /$ year (Statens Jordbruksverk, 1997). In Finland the majority of the population do not consume tea (Table 28). Of those who do consume tea, most drink only 1-2 cups/day (Helakorpi et al., 1997).

Two recent reports have documented how common it is to drink tea. The habit differs between countries. In a dietary survey in the United

Table 28. Frequency of tea consumption among Finnish men and women in 1997 (Helakorpi et al., 1997).

\begin{tabular}{|l|l|l|l|l|}
\hline Consumer group & Non-consumers & $\mathbf{1 - 2}$ cups/day & $\mathbf{3 - 4}$ cups/day & $\begin{array}{l}\mathbf{5} \text { or } \text { more } \\
\text { cups/day }\end{array}$ \\
\hline Men, 15-24 years & 63.7 & 33.2 & 3.1 & 0.0 \\
\hline Men, 25-34 years & 67.8 & 24.7 & 6.4 & 1.1 \\
\hline Men, 35-44 years & 69.9 & 26.0 & 2.7 & 1.4 \\
\hline Men, 45-54 years & 66.0 & 26.0 & 6.8 & 1.1 \\
\hline Men, 55-64 years & 59.5 & 31.6 & 6.9 & 2.0 \\
\hline \hline Men, total & 65.6 & 28.1 & 5.2 & 1.1 \\
\hline & \multicolumn{3}{|l|}{} \\
\hline Women, 15-24 years & 53.2 & 38.9 & 5.6 & 2.3 \\
\hline Women, 25-34 years & 52.4 & 39.7 & 6.8 & 1.1 \\
\hline Women, 35-44 years & 59.0 & 31.9 & 6.9 & 2.1 \\
\hline Women, 45-54 years & 61.5 & 31.1 & 5.5 & 1.8 \\
\hline Women, 55-64 years & 58.8 & 34.0 & 5.9 & 1.3 \\
\hline \hline Women, total & 57.3 & 34.8 & 6.1 & 1.8 \\
\hline
\end{tabular}


Kingdom, a test population of individuals aged 16-64 years over a period of seven days reported their consumption of tea at home and at commercial establishments (Gregory et al., 1990). Around $88 \%$ of the test population consumed tea. The average total intake during the seven-day reporting period was 4.15 litres of tea beverage. Tea consumption seen in the British test population (including all age groups) was slightly higher than coffee consumption. Among 16-24 year olds, tea was consumed by $77 \%$ of subjects, whereas in individuals aged 25-34 years and 35-49 years, tea was consumed by 86 and $90 \%$, respectively. In the oldest age brackets the percentage of tea consumers included nearly $96 \%$ of the participants.

In contrast to the situation in the United Kingdom, only $24 \%$ of the Americans studied by Hughes et al. (1997) consumed tea on a weekly basis.

\subsubsection{Tea consumption related to gender and geographical region}

In a British dietary survey tea consumption was equally popular among males and females; $88 \%$ from each gender consumed tea (Gregory et al., 1990). However, according to Scott et al. (1989) the caffeine intake from tea was slightly higher for British females than for males. The consumption of tea did not differ between various geographical regions of the United Kingdom (Gregory et al., 1990).

Table 28 shows Finnish data on the frequency of tea consumption in 1997 (Helakorpi et al., 1977). The data is split up into various age groups of males and females. It can be noted that tea is slightly more preferred by females than by males, but the beverage is not very popular. Only around $5 \%$ of the Finnish population consume three or more cups of tea per day.

\subsubsection{Caffeine content in raw material and tea sold on the market}

Tea is made from the fresh green shoots of the tea plant Camellia sinensis. This plant is found in two variants, $C$. sinensis var. sinensis (China) and $C$. sinensis var. assamica (Assam), which differ significantly in caffeine content. Thus, the fresh green leaves from Assam teas are generally higher in caffeine $($ mean $=4.1 \%)$ than Chinese cultivars $($ mean $=3.1 \%$ ) (Takeda, 1994). As Assam cultivars are commonly used for production of black tea, and China cultivars for production of green tea, black teas on average contain higher amounts of caffeine than green teas (Astill et al., 2001). However, there is a considerable variation in caffeine content between various types of tea.

The caffeine content of tealeaves and non-brewed tea is not only influenced by genetic, but also by seasonal, climatic, and agronomic and horticultural factors (soil, water, minerals, fertilizers, etc.), as well as age of the tealeaves. Cloughley (1981) found that high levels of caffeine were 
associated with high growth rate in shoots. The caffeine concentration also varied among different shoot parts, being much higher in leaf and younger tissue than in the stem. It also seemed that the caffeine level in leaves could be influenced by environmental factors, such as the use of fertilising agents. An increased application of nitrogen and potassium fertilisers resulted in increased caffeine levels in leaves (Cloughley, 1981). Consequently, the caffeine level in the raw material depends on the plant variety, the cultural methods, the harvesting season, and the plant parts investigated. All of these factors contribute to the caffeine level in the crushed product used to brew tea.

In addition to the factors mentioned above, the degree to which the tea is fermented during tea manufacturing also influences the caffeine content of the marketed tea. In studies on a Taiwanese Camellia sinensis hybrid, Lin and co-workers (1998) made the interesting observation that fermentation had no significant influence on the level of caffeine when the degree of fermentation was low (10\%, corresponding to paochong tea, and $25 \%$ corresponding to oolong tea). At higher degrees of fermentation (85\%, black tea), however, a significantly increased level of caffeine was noted. Thus, in their study, the caffeine content of black tea was twice as high as the amount seen in green tea. Whereas the level of caffeine increased during tea fermentation, theobromine and theophylline were progressively lost.

The caffeine content of black teas commonly used for tea brewing in the United Kingdom $(\mathrm{n}=11)$ were reported to be between 22 and $28 \mathrm{mg} / \mathrm{g}$ dry matter (Khokhar and Magnusdottir, 2002). Lin and co-workers (1998) analysed several commercial tea samples, including green (nonfermented tea), paochong (partly fermented tea), oolong (partly fermented tea), pu-erh (fermented tea), and black (fermented) Chinese, Japanese, and Taiwanese teas for their caffeine, theobromine, and thephylline content. The caffeine content in the dry tea varied between 5.2 and $17 \%$ in 15 commercial Chinese green tea products (average 7.73\%). Lesser amounts of theobromine $(0.6 \%)$ and theophylline $(0.08 \%)$ were found. One pulverised green tea powder produced from dried fresh tea leaves contained $7.1 \%$ caffeine, $0.4 \%$ theobromine and $0.04 \%$ teophylline. Similar amounts were found in 13 Japanese green tea products - the average content of caffeine, theobromine, and theophylline being $7.7 \%, 0.3 \%$, and $0.06 \%$, respectively. Nine samples of Chinese Oolong and Paochong tea products (semifermented teas) on average contained $6.4 \%$ caffeine, $0.3 \%$ theobromine, and $0.04 \%$ theophylline, and seven samples of pu-erh tea (which, like black tea, is fermented) on average contained $7.7 \%$ caffeine, $0.6 \%$ theobromine, and $0.03 \%$ theophylline.

Similarly, Fernández et al. (2002) analysed 13 samples of green tea, 27 samples of black tea and 5 samples of red tea. On a dry weight basis green tea contained between 1.5 and $3.9 \%$ caffeine, between 0.01 and $0.20 \%$ theobromine, and non-detectable levels of theophylline, black tea 
between $3.0 \%$ and $4.9 \%$ caffeine, $0.05 \%$ and $0.46 \%$ theobromine, and non-detectable and $0.049 \%$ teophylline, and red tea between $2.4 \%$ and $3.9 \%$ caffeine, $0.11 \%$ and $0.30 \%$ teobromine, and $0.036 \%$ and $0.046 \%$ teophylline.

Obanda and co-workers (1997) reported that the green leaves of 15 clones of tea grown in Kenya contained between 2.76 and $4.97 \%$ caffeine. MAFF (1998) found mean caffeine content of 2.2 (range: 1.7-2.8\%) in regular bagged tea, and $1.24 \%$ (range: $1.2-1.3 \%$ ) in loose tea, respectively. Similar levels of caffeine in leaf teas, between 2.73 and $4.1 \%$, had also been found in 21 commercial teas from Sri Lanka, China, Zimbabwe and India (Kaplan et al., 1974). French workers found Russian, Chinese, Vietnamese and Ceylonese tea to contain between 2.6 and 3.3\% caffeine (Vergnes and Alary, 1986), whereas Camargo and Toledeo found between 0.76 and $1.74 \%$ in black tea purchased on the Brazilian market. In bags with decaffeinated tea, the mean caffeine content was $0.32 \%$ (range: $0.03-0.82 \%)$.

\subsubsection{Influence of preparation method on caffeine content of beverage}

As with coffee, the smaller the particle size of the crushed tea leaves, the higher the level of caffeine extracted during preparation of the tea beverage. This probably depends on the relatively larger surface area of the crushed smaller particles compared to their volume. It has also been shown that the extraction of caffeine in loose tea increases with brewing time (Bunker et al., 1979).

The temperature of the water used to prepare the tea beverage also affects the caffeine content. The warmer the water is, the more caffeine is dissolved in the water (Stavric et al., 1988). If milk is added to the tea infusion, the concentration of methylxanthines in the cup is reduced because the total volume is increased.

\subsubsection{Methylxanthine content in tea infusions}

Table 29 summarises data on the caffeine and theobromine content of brewed tea published during the last twenty years. Some of the individual studies are discussed in the following text. 


\begin{tabular}{|c|c|c|c|c|c|}
\hline \multirow[t]{2}{*}{ Studied population } & \multicolumn{2}{|c|}{$\begin{array}{l}\text { Caffeine content } \\
\text { (mg/cup) }\end{array}$} & \multicolumn{2}{|c|}{$\begin{array}{l}\text { Theobromine content } \\
\text { (mg/cup) }\end{array}$} & \multirow[t]{2}{*}{ Reference } \\
\hline & Bag & Leaf & Bag & Leaf & \\
\hline US & \multicolumn{2}{|c|}{$\begin{array}{c}27(8-91)^{2} \\
(n=37)\end{array}$} & & & Gilbert (1976) \\
\hline US & & 30 & & 2 & Graham (1978) \\
\hline US & $\begin{array}{l}28(1 \mathrm{~min}) \\
47(5 \mathrm{~min}) \\
\end{array}$ & $\begin{array}{l}31(1 \mathrm{~min}) \\
40(5 \mathrm{~min}) \\
\end{array}$ & & & Bunker et al. (1979) \\
\hline US & \multicolumn{2}{|c|}{$34.5^{1}$} & & & Morgan et al. (1982) \\
\hline US & \multicolumn{2}{|c|}{$55.0 \pm 7.6(\mathrm{n}=7)(5 \mathrm{~min})^{1)}$} & $2.7 \pm 0.8$ & & Blauch and Tarka, 1983 \\
\hline US & 42 & $41(30-48)$ & & & \begin{tabular}{|l|} 
Barone and Roberts \\
$(1983)$
\end{tabular} \\
\hline US & \multicolumn{2}{|c|}{40} & & & \begin{tabular}{|l} 
Schreiber et al. (1988) \\
\end{tabular} \\
\hline US & 30 & 30 & & & \begin{tabular}{|l|l} 
Barone and Roberts (1996) \\
\end{tabular} \\
\hline Australian & & 46 & & & \begin{tabular}{|l|} 
Shirlow (1983) \\
\end{tabular} \\
\hline Australian & \multicolumn{2}{|c|}{$\begin{array}{c}26.8 \pm 13.7 \quad(9.1-51.0)^{1} \\
(n=14)\end{array}$} & & & Lelo et al. (1985) \\
\hline British & $\begin{array}{c}41.3(32.1-51.6) \\
(n=6)\end{array}$ & $\begin{array}{cc}41.7 & (38.7-47.4) \\
(n=3)\end{array}$ & $\begin{array}{c}2.2 \\
(0.8-3.2) \\
\end{array}$ & $\begin{array}{c}2.5 \\
(2.2-2.8) \\
\end{array}$ & Scott et al. (1989) \\
\hline British & $\begin{array}{c}48.9(5 \mathrm{~min}) \\
(3.8-64.5) \\
(\mathrm{n}=14)\end{array}$ & $\begin{array}{c}15.3^{3}(5 \mathrm{~min}) \\
(14.3-15.8) \\
(\mathrm{n}=3)\end{array}$ & $\begin{array}{c}3.3(5 \mathrm{~min}) \\
(1.5-4.7) \\
(\mathrm{n}=14)\end{array}$ & $\begin{array}{c}1.0(5 \mathrm{~min}) \\
(0.9-1.1) \\
(\mathrm{n}=3)\end{array}$ & MAFF (1998) \\
\hline British & $\begin{array}{c}36.2(26.6-45.5) \\
(n=8)\end{array}$ & & & & Astill et al., 2001 \\
\hline Canada & \multicolumn{2}{|c|}{22.7} & & & \begin{tabular}{|l|} 
Watkinson and Brief (1985) \\
\end{tabular} \\
\hline Canada & $\begin{array}{c}35.1(2 \mathrm{~min}) \\
60.45(5 \mathrm{~min}) \\
\end{array}$ & $\begin{array}{l}28.3(2 \mathrm{~min}) \\
44.3(5 \mathrm{~min}) \\
\end{array}$ & $\begin{array}{l}2.2(2 \mathrm{~min}) \\
3.7(5 \mathrm{~min}) \\
\end{array}$ & $\begin{array}{l}2.2(2 \mathrm{~min}) \\
3.4(5 \mathrm{~min}) \\
\end{array}$ & Stavric et al. (1988) \\
\hline Brazil & $35(32-36)(n=12)$ & & & & \begin{tabular}{|l} 
Camargo et al. (1999) \\
\end{tabular} \\
\hline South Africa & \multicolumn{2}{|c|}{$44.1(n=7)$} & & & Galasko et al. (1989) \\
\hline & Mean: $40^{4}$ & Mean: $36^{4}$ & Mean: $3.1^{4}$ & Mean: $2.2^{4}$ & \\
\hline
\end{tabular}

1) Methylxanthine content recalculated to cup of $150 \mathrm{ml} ;{ }^{2}$ Median methylxanthine content instead of mean; ${ }^{3)}$ Noted by authors as a very low value and therefore excluded from mean; ${ }^{4)}$ Mean value calculated from 5 minutes methylxanthine content when two brewing times are given. 
Gilbert (1976) reported caffeine contents of tea infusions of low, medium, and high strength to be 6,22 , and $60 \mathrm{mg} / \mathrm{cup}$. On average, the tea contained $29 \mathrm{mg}$ caffeine/cup. In 1979 Bunker and co-workers reported that a longer brewing (steeping) time of green, black, and oolong teas increases the amount of caffeine extracted from the tealeaves. In bagged black tea the range in caffeine content after 1 minute of brewing was 21$33 \mathrm{mg} / \mathrm{cup}$, after 3 minutes, 35-46 mg/cup, and after 5 minutes, 39-50 $\mathrm{mg} / \mathrm{cup}$. After 1 minute of brewing, the caffeine content in two samples of green tea was 9 and $19 \mathrm{mg} / \mathrm{cup}$, after 3 minutes 20 and $33 \mathrm{mg} / \mathrm{cup}$, and after 5 minutes 29 and $36 \mathrm{mg} / \mathrm{cup}$. In general, the mean caffeine content of beverages from green bag tea was lower than that from the same brands of black tea. Oolong tea had a mean caffeine content of $13 \mathrm{mg} / \mathrm{cup}$ after 1 minute of steeping, $30 \mathrm{mg} / \mathrm{cup}$ after 3 minutes of steeping, and 40 $\mathrm{mg} /$ cup after 5 minutes of steeping. In green loose tea, the investigators made the observation that the same amount of caffeine was extracted from the different brands per gram of tealeaves. Black loose tea had a mean of $40 \mathrm{mg}$ per serving, and green loose tea a mean of $35 \mathrm{mg}$ per serving after 5 minutes of steeping. The Japanese loose green tea had the lowest caffeine content, $20 \mathrm{mg}$ per serving.

Amounts of caffeine (45.9 mg/cup) and theobromine (2.3 mg/cup) similar to those reported by Bunker et al. (1979) in brewed tea were found by Blauch and Tarka (1983) in seven brands of American-packed tea brewed for $5 \mathrm{~min}$. Two imported black bag teas had caffeine contents of 55.8 and $52.2 \mathrm{mg} / \mathrm{cup}$, and theobromine contents of 3.7 and $3.0 \mathrm{mg} / \mathrm{cup}$, respectively. Brewing of orange and spice tea, and mint-flavoured tea for 1 min (as suggested by the manufacturer) produced an herbal tea with only around half the caffeine content of traditional black tea. One brand of decaffeinated tea was found to contain less than $1 \mathrm{mg}$ caffeine/cup and around $0.3 \mathrm{mg}$ theobromine/cup (Blauch and Tarka, 1983).

Also Stavric et al. (1988) investigated the influence of brewing time on the caffeine and theobromine content of different brands of bagged and loose tea. The caffeine contents in beverages from bagged tea were between 32.3 and $37.4 \mathrm{mg} / \mathrm{cup}$ when brewing time was 2 minutes. Caffeine content varied between 59.9 and $61.1 \mathrm{mg} /$ cup when brewed for 5 minutes. Similarly, the theobromine content depended on the brewing time, but the amounts were substantially lower (Table 29). No significant differences in caffeine and theobromine content between different brands of bagged tea were found, while different lengths of brewing time significantly influenced the methylxanthine content of the beverage. The theophylline content was very low, and was therefore not reported. The caffeine and theobromine content of beverages prepared from seven types of leaf teas varied significantly. After 2 minutes of brewing, the caffeine contents per cup were between 18.6 and $34.5 \mathrm{mg}$. After 5 minutes of brewing, the caffeine was found to be between 30.7 and $51.1 \mathrm{mg} / \mathrm{cup}$. 
One brand brewed for 2 minutes contained more caffeine than another brand brewed for 5 minutes.

MAFF (1998) analysed the methylxanthine content in 26 tea products. Caffeine concentrations in tea infusions made from 14 bags ranged from 3.8 to $64.5 \mathrm{mg} /$ cup (mean: $48.9 \mathrm{mg} / \mathrm{cup}$ ). Theobromine levels ranged from 1.5 to $4.7 \mathrm{mg} / \mathrm{cup}$ (mean: $3.3 \mathrm{mg} / \mathrm{cup}$ ), whereas theophylline levels were $0.3 \mathrm{mg} / \mathrm{cup}$ or lower. In infusions made from 3 samples of loose tea, the caffeine levels ranged from 14.3 to $15.8 \mathrm{mg} / \mathrm{cup}$ (mean: $15.3 \mathrm{mg} / \mathrm{cup}$ ). Theobromine and theophylline levels were $0.9-1.1 \mathrm{mg} / \mathrm{cup}$ and $0.05-0.08$ $\mathrm{mg} / \mathrm{cup}$, respectively. The caffeine levels in infusions made from two samples of decaffeinated tea bags were 0.8 and $3 \mathrm{mg} / \mathrm{cup}$. In one "low caffeine" product a caffeine content of $18.8 \mathrm{mg} /$ cup was discovered. Theobromine and theophylline levels in the low caffeine and decaffeinated products were of the same order as those in the regular bagged teas (2.3-4.0, and 0.15-0.23 mg/cup, respectively). At the end of the 1970s Graham (1978) reported that tea infusions contained no more than $1 \mathrm{mg}$ theophylline per cup.

Fernández et al. (2000) reported the caffeine content of black teas from a variety of origins to range between 25.7 and $34.2 \mathrm{mg} / \mathrm{g}$. One sample of decaffeinated tea contained $2.7 \mathrm{mg}$ caffeine per gram (Khokhar and Magnusdottir, 2002).

The average content $(\mathrm{n}=8)$ of caffeine in black tea prepared according to instructions from tea bags was $241 \mathrm{mg}$ per litre, with a variation between 177 and $303 \mathrm{mg} / \mathrm{l}$. The corresponding figure for green tea was 125 $\mathrm{mg} / \mathrm{l}$. Green tea prepared from loose leaf was less strong in relation to caffeine content, $93 \mathrm{mg} / \mathrm{l}$ (Astill et al., 2001).

Bonoli et al. (2003) used a newly developed analytical technique to quantify the level of methylxanthines in bottled green tea drinks on the Italian market and infusions prepared from bagged green tea. Only low levels of the methylxanthines were found. A $150 \mathrm{ml}$ cup of the tea infusions (5 minutes of brewing time) contained $15 \mathrm{mg}$ caffeine and less than $0.5 \mathrm{mg}$ theobromine. No theophylline was detected. The amounts of methylxanthine in the bottled green tea drinks varied significantly between products: the caffeine content from traces to $73 \mathrm{mg} / \mathrm{l}$; the theobromine content from traces to $10 \mathrm{mg} / \mathrm{l}$; and traces of theophylline. In agreement with these observations, Khokhar and Magnusdottir (2003) reported green teas $(n=7)$ to contain lower caffeine contents than black teas, having contents between 12 and $20 \mathrm{mg} / \mathrm{g}$ (Khokhar and Magnusdottir, 2002). Fernández et al. (2000) reported higher caffeine contents in green tea, between 8 and $34 \mathrm{mg} / \mathrm{g}$.

Instant teas are particularly popular in the United States. The five studies which investigated the caffeine content of instant teas, reported between 20 and $28.3 \mathrm{mg} /$ cup of beverage. Thus, Thomas J Lipton Inc. reported $20 \mathrm{mg} /$ cup (personal communication), Barone and Roberts (1983) 28 mg/cup (range: 24-31), Morgan et al. (1982) 24.4 mg/cup, Fernández et 
al. (2000) $37.6 \mathrm{mg} / \mathrm{cup}$ (range: 36.9-38.3), and MAFF (1998) between 26.5 and $29.5 \mathrm{mg} / \mathrm{cup}$ in three types of instant tea. In the latter investigation, theobromine and theophylline levels ranged from 1.2-1.5 and 0.1$0.2 \mathrm{mg} /$ cup, respectively.

A single study reports measurement of the caffeine content in iced tea. In a volume of $360 \mathrm{ml}$, two brands of iced tea contained 22 and $36 \mathrm{mg}$ caffeine, respectively (Bunker et al., 1979).

All fruit-flavoured teas $(\mathrm{n}=6)$ examined by Khokhar and Magnusdottir (2002) contained between 24 and $25 \mathrm{mg}$ caffeine per gram. This could have been expected as all samples were of the same brand (Pickwich) and presumably reflects the addition of different flavours to a common tea base.

Herbal teas are generally considered to contain very limited amounts of caffeine (Bunker et al., 1979). However, Stavric and co-workers (1988) measured the amounts of caffeine and theobromine in an herbal tea brewed for 5 minutes, and found 31.2 and $9.0 \mathrm{mg}$ per cup, respectively. The types of herbs were not specified.

\subsubsection{Methylxanthine intake from tea infusions}

In 1981/1982 the per capita caffeine intake in the world from tea was 30 $\mathrm{mg} /$ day. In the United States, Canada, Sweden, and the United Kingdom the corresponding intakes were $35,79,34$ and $320 \mathrm{mg} /$ day, respectively (Gilbert, 1984).

The huge difference in caffeine intake from tea between American consumers and British consumers has been confirmed in studies on individuals. Scott et al. (1989) studied 174 British consumers and found that the average caffeine intake from tea was $159 \pm 150 \mathrm{mg} /$ day. The highest intake, $255 \pm 179 \mathrm{mg} / \mathrm{day}$, was found among the oldest consumers. This level of intake among older consumers resulted in tea contributing more to the caffeine intake than coffee in this age group. In all other age groups, the contribution from tea to overall caffeine intake was lower than the contribution from coffee. For children and young adults aged 1020 years, the caffeine intake from tea was $120 \pm 141 \mathrm{mg} /$ day, and for people aged 21-40 and 41-60 years, it was 138 \pm 144 and $167 \pm 143$ $\mathrm{mg} /$ day, respectively.

Lower caffeine intakes from tea were reported in the American studies. Scheiber et al. (1988) reported that tea contributed to a caffeine intake of $35.6 \mathrm{mg}$ /day in current coffee drinkers in the United States, whereas the contribution of caffeine from tea in former coffee drinkers and in those who never had consumed coffee were 57.9 and $44.2 \mathrm{mg} / \mathrm{day}$, respectively. Hughes and Oliveto (1997) reported a mean total caffeine intake from all beverages of $186 \mathrm{mg}$ /day among a studied population in Vermont, Canada. Around 10\% of this intake came from tea. Among tea- 
consumers the mean intake was $63 \mathrm{mg} /$ day, close to $1 \mathrm{mg} / \mathrm{kg}$ body weight/day.

Among 6-11 year old American youngsters, the intake of caffeine from tea was higher than the intake from coffee (Morgan et al., 1982). The caffeine intake from tea was $0.41 \mathrm{mg} / \mathrm{kg} /$ day.

In Sweden, the per capita consumption of tea was $0.3 \mathrm{~kg}$ dry product in 1996, corresponding to 0.38 cups of tea beverage per day (Statens Jordbruksverk, 1997). Assuming a caffeine content of $31 \mathrm{mg} /$ cup (Table 29 ), this would correspond to a caffeine intake of approximately 15 $\mathrm{mg}$ /day.

\subsection{Yaupon or cassina tea}

Ilex cassine and Ilex vomitoria, growing in North America, have been traditionally used to prepare a beverage. It was known in the sixteenth century that the natives of Florida prepared a beverage, which they called 'yaupon' from the leaves and shoots of this plant. The beverage, also known as Cassina tea or 'black drink', never became popular among the white settlers, and is not used today (Kihlman, 1977). However, during the American civil war, when coffee and tea were hard to get, this beverage became popular again. The plant used to prepare Yaupon is also known as Cassina, Chistmas berry tree, or the North American tea plant. It is not known whether cassina tea contains caffeine.

\subsection{Yoco}

Yoco is made from the bark of the wild plant Paullinia yoco. It is used as a stimulant by Indians living in a small part of southern Colombia or in the adjacent regions of Ecuador and Peru. Of all caffeine-containing beverages, yoco is the one with most limited use. However, in the area where it is used, it is one of the most important plants in the diet of the Indians, although it is a stimulant, not a food. The bark of the yoco plant contains $2.7 \%$ caffeine.

This quotation on the preparation of yoco is taken from Schultes (1942): "In the preparation of the beverage from the yoco stems, the epidermis, cortex and phloem (all of the softer tissues external to the xylem) are rasped. The scraps of material thus obtained are squeezed to express the caffeine-bearing sap into cold water. After extraction, the remains of the rasped tissues are discarded. Yoco is never made with hot water. In this respect it differs markedly from Paullinia cupana and other caffeineyielding plants, for the extraction of caffeine from these plants is usually accomplished with warm or hot water. 
Each dosage of yoco consists of the expressed sap of approximately 90-100 grams of rasped material served in a 'jicara', a bowl made from the fruit of Crescentia cujete. One or two 'jicaras', each half full of the beverage, are sufficient to allay all sensations of hunger for at least three hours and to supply muscular stimulation."

\subsection{Kola}

This caffeine-containing stimulant falls within a special category since it is usually used in its solid form (chewed), rather than for the preparation of a beverage. Although the carbonated soft drinks marketed under the name of colas are flavoured with extracts of the kola nut, most of their caffeine content is due to added synthetic caffeine (see section 6.9).

Kola is the dried cotyledons of the seeds of species belonging to the genus Cola of the family Sterculiaceae. The plants are evergreen trees, usually of small or moderate size. Most species of the genus Cola have seeds that are hard and inedible. Of the six species with edible seeds, four are of importance: (1) Abata (C. acuminata), the kola favoured by the people of the Yoruba country in southern Nigeria; (2) Gbanja (C. nitida), the main kola of commerce; (3) Owé ( $C$. verticillata), a kola nut of inferior quality; (4) Abidum (probably C. verticillata), used medicinally, and (5) the bamenda kola (C. anomala) grown in the high Cameroons. Only Abata and Gbanja, that is, the kola nuts of C. acuminata and C. nitida, are extensively consumed and therefore economically important (Kihlman, 1977).

Cola acuminata is the kola nut used ceremonially and socially by the Yoruba people of western Nigeria and valued by them above all others. The main kola of commerce is Gbanja or Goro, the kola nut of $C$. nitida. The chewing of goro-nuts is a widespread and almost universal habit in northern Nigeria, which has to some extent been compared with tea drinking or cigarette smoking of western countries. Like C. acuminata amongst the Yorubas, $C$. nitida in the north has its social and ceremonial uses (Russel, 1955).

Thanks to its content of caffeine and theobromine, gbanja kola is a sustainer and stimulant, and it enables the user to travel long distances without fatigue, allowing him to endure food and water shortage (Russel, 1955). In addition to being grown in West Africa, with Nigeria as the world's largest producer of kola nuts, it is extensively cultivated in the West Indies and South America as well.

As shown in Table 4, around $1.5 \%$ of the dry weight of kola nuts is caffeine. Similar amounts of caffeine (1.38-2.24\%) were found by Belliardo and co-workers (1985) in three samples of kola seed powder. Two samples of powder produced from a Cola nut extract contained 0.76 and $8.9 \%$ caffeine, respectively (Belliardo et al., 1985). 


\subsection{Cola drinks and other caffeinated soft drinks}

In addition to being chewed, kola nuts are also used in other ways. Nuts are dried and exported to North America and Europe, where they are used for beverages and pharmaceutical purposes. Kola furnishes the base for many cola soft drinks. However, the amount used for flavouring would provide only a few milligrams of caffeine per 7-oz $(210 \mathrm{ml})$ cola bottle. Therefore, in order to make the beverages popular, synthetic caffeine is added (Kihlman, 1977).

Other soft drinks than those based on a cola extract have also been produced. Soft drinks, not regarded as cola drinks, require labelling that indicates caffeine has been added to the beverage. According to a recent EU directive (2002/67/EC), on a beverage containing more than $150 \mathrm{mg}$ caffeine per litre, the message "High caffeine content" must appear on the label in the same field of vision as the name under which the product is sold. The message shall be followed, in brackets, by the caffeine content expressed in $\mathrm{mg} / 100 \mathrm{ml}$. Thus, it might be hard for the consumer to get information on the quantity of caffeine that has been added to soft drinks with contents below $150 \mathrm{mg} / 1$.

\subsubsection{Soft drink consumption}

The consumption of soft drinks varies substantially between countries. The higher the consumption of soft drinks, the less the consumption of coffee.

According to Gilbert (1984) the United States per capita consumption of all soft drinks increased by $231 \%$ between 1960 and 1980, with the major part of this increase attributed to caffeinated sodas. Leading caffeine-containing soft drinks accounted for $85 \%$ of the soda market in the early 1980s. In 1982 the per capita consumption of soft drinks in the United States was 149 litres per year, whereas it was 68 litres in Canada. In Sweden the annual per capita consumption of mineral water and soft drinks (including caffeinated drinks) increased from 27 litres in 1960 to about 66 litres in 1996 (Statens Jordbruksverk, 1997).

Although the per capita intake of soft drinks is high in the United States, far from all Americans consume these beverages. In a survey $47 \%$ of a test population (with a mean age of 38.4 years) consumed soft drinks at present, and $23 \%$ had formerly consumed soft drinks (Hughes and Oliveto, 1997).

Soft drink consumption in the United States varies over the day. A twenty years old study indicates that out of the group representing children aged five to eighteen years, $1.8 \%$ consume soft drinks for breakfast and $9.2 \%$ drink it later in the morning. During the day, the consumption is higher $-38 \%$ drink soft drinks at lunch, and $37 \%$ later in the af- 
ternoon. Almost half of the test population had soft drinks at dinner, and over $40 \%$ consumed it later in the evening (Barone and Roberts, 1983).

\subsubsection{Caffeine source and content in soft drinks}

Estimating the quantity of caffeine ingested from soft drinks is usually much simpler than estimating the caffeine intake from tea and coffee. Since soft drinks are sold in bottles or cans of known size, the volume consumed is most probably that of the bottle or can. Bottles and cans commonly contain the same quantity of liquid. Because the different soft drinks are made from special recipes, the variation in caffeine content within a certain brand is minimal. The problem of estimating caffeine intake from soft drinks is therefore reduced to determining the numbers and types of soft drinks consumed, and to obtain information on their exact caffeine content.

Among soft drinks, cola beverages contain the most caffeine. The origin of the caffeine in these drinks, however, mainly comes from caffeine being supplied as a food additive. The caffeine coming from the kola nut accounts for less than $5 \%$ of the total caffeine content in these soft drinks (Institute of Food Technology, 1983). The stated reason for adding caffeine to the drink is that the extract from the cola nut loses most of its caffeine content during cleanup.

When six brands of cola beverages and two other brands of soft drinks were analysed for caffeine by Bunker et al. (1979), they found that $12 \mathrm{oz}$ $(360 \mathrm{ml}$ ) of the beverage (a can) contained between 32 and $65 \mathrm{mg}$ caffeine. According to the authors, there has been an increase in the caffeine content of cola beverages during the 1970s. These figures agree fairly well with 1983 data from the National Soft Drink Association, Institute of Food Technologies in Washington D.C. (Chou, 1992).

Monte and Ashoor (1985) quantified the caffeine content of twentyfive different soft drinks. The studied beverages ranged in caffeine content from slightly over $50 \mathrm{mg}$ per bottle to non-detectable amounts (in most non-cola drinks). The cola drinks usually contained between 30 and $40 \mathrm{mg}$ caffeine per bottle. Among non-cola drinks, very high caffeine content was found in Sunkist Orange, $38 \mathrm{mg}$ per bottle $(360 \mathrm{ml})$. Similar levels were found by Darragh et al. (1979) in three out of six different soft drinks.

In 1998 MAFF investigated the caffeine levels in cola and miscellaneous drinks. The caffeine concentrations in 32 samples of diet and regular cola ranged from 10 to $77 \mathrm{mg} /$ bottle $(360 \mathrm{ml})$. In the 4 colas labelled as caffeine-free, no caffeine was detected. Theobromine and theophylline levels were negligible. The caffeine contents in Mountain Dew and Mountain Dew Diet, defined as miscellaneous drinks, were $44 \mathrm{mg} /$ bottle. Theophylline levels were 0.5 and $0.4 \mathrm{mg} / \mathrm{bottle}$, and detectable only in 
these miscellaneous drinks. None of the miscellaneous drinks contained detectable amounts of theobromine.

Similarly, Verheijen (1999) investigated the caffeine content of 19 samples of soft drinks available on the Icelandic market. The caffeine content in a serving of the various soft drinks $(360 \mathrm{ml})$ ranged from 20 to $52 \mathrm{mg}$, with the highest amount being found in Mountain Dew and cola beverages from international companies Local brand products contained less caffeine.

In agreement with the studies presented above, Camargo and Toledo (1999), and Camargo et al. (1999) found between 20 and $48 \mathrm{mg}$ caffeine per can $(360 \mathrm{ml})$ in 12 samples of cola drinks on the Brazilian market. Vergnes and Alary (1986) found $41 \mathrm{mg}$ caffeine in a corresponding amount of Coca-Cola on the French market. In the latter study, PepsiCola only contained $26 \mathrm{mg}$ caffeine.

Table 30 shows the caffeine content in 6 of the most commonly consumed caffeinated soft drinks. The caffeine content in diet versions of the beverages was comparable to the caffeine content in the original brands.

\subsubsection{Caffeine intake from soft drinks}

Most information on caffeine intake from soft drinks comes from North America. Gilbert (1984) estimated the per capita intake of caffeine from caffeinated soft drinks to be $35 \mathrm{mg} /$ day in the United States, and 16 $\mathrm{mg} /$ day in Canada.

In 1982 Morgan and co-workers reported that American children aged 5-18 years consumed $33 \pm 17.7 \mathrm{mg}$ caffeine from soft drinks on each

Table 30. Caffeine content in some of the most commonly consumed caffeinated soft drinks. The caffeine content is expressed as amount in a can, $360 \mathrm{ml}$ (12 oz).

\begin{tabular}{|c|c|c|c|c|c|c|}
\hline \multicolumn{6}{|c|}{ Caffeine (mg/can) in } & \multirow[t]{2}{*}{ Reference } \\
\hline Coca cola & Tab & Pepsi & Diet Pepsi & Dr Pepper & $\begin{array}{l}\text { Dr Pepper } \\
\text { Diet }\end{array}$ & \\
\hline $64.7 \pm 0.3$ & $49.4 \pm 4.3$ & $43.1 \pm 0.1$ & & $60.9 \pm 1.5$ & $54.2 \pm 1.7$ & $\begin{array}{l}\text { Bunker et al. } \\
(1979)^{2}\end{array}$ \\
\hline 45.0 & 46.5 & 38.4 & 36.0 & 39.6 & 39.6 & $\begin{array}{l}\text { Morgan et al. } \\
\text { (1982) }\end{array}$ \\
\hline $\begin{array}{l}32.4 \pm 0.41 \\
(n=6)\end{array}$ & $\begin{array}{l}41.6 \pm 0.82 \\
(n=6)\end{array}$ & $\begin{array}{l}35.1 \pm 0.51 \\
(n=6)\end{array}$ & $\begin{array}{l}31.4 \pm 0.43 \\
(n=6)\end{array}$ & $\begin{array}{l}37.1 \pm 0.94 \\
(n=6)\end{array}$ & & $\begin{array}{l}\text { Monte and } \\
\text { Ashoor } \\
(1985)\end{array}$ \\
\hline $37.6(n=3)$ & traces $^{1}(n=3)$ & $25.6(n=3)$ & $26.9(n=3)$ & & & $\begin{array}{l}\text { Galasko et } \\
\text { al. }(1989)^{3}\end{array}$ \\
\hline $32.4(n=3)$ & & $23.4(n=3)$ & & & & $\begin{array}{l}\text { Scott et al. } \\
(1989)^{3}\end{array}$ \\
\hline $33(n=2)$ & & $38(n=2)$ & $36(n=2)$ & $40(n=2)$ & $43(n=2)$ & MAFF (1998) \\
\hline 34 & 42 & 31 & 31 & 38 & 42 & Mean $^{4}$ \\
\hline
\end{tabular}


occasion of consumption. The average daily intake from soft drinks during a seven day period was $9.8 \pm 12.6 \mathrm{mg}$. Scheiber et al. (1988) stated a caffeine intake of $19.1 \mathrm{mg} /$ day from soft drinks for American people who also consume coffee. The caffeine intake from soft drinks for former coffee users was higher, $27.3 \mathrm{mg} /$ day, whereas people who never consumed coffee had the highest caffeine intake from soft drinks, $31.9 \mathrm{mg} /$ day. These data show that the caffeine intake from soft drinks is higher for people who consume less of other caffeine-containing beverages.

A considerably lower daily caffeine intake from soft drinks has been reported in the United Kingdom (Scott et al., 1989). The British test population ( $\mathrm{n}=174$, age 10-80 years), including both consumers and abstainers of soft drinks, ingested $0.47 \pm 2.19 \mathrm{mg}$ caffeine from soft drinks daily.

In Denmark the seven-day average daily intake of caffeine from soft drinks was $14 \mathrm{mg}$, with the highest intake being $35 \mathrm{mg}$ (Barone and Roberts, 1996).

\subsubsection{Soft drink consumption and caffeine intake in relation to gender and age}

Soft drink consumption may differ between men and women. Solvoll et al. (1989) reported that males in Norway consumed more soft drinks than females. Males who did not consume coffee, consumed soft drinks 2.4 times a week, whereas females from the same category consumed soft drinks 2.0 times during a week.

The consumption of soft drinks often differs between agegroups. Table 31 shows the caffeine exposure from soft drinks in people of different ages in Australia, Denmark, the United Kingdom, and the United States.

Table 31. Mean daily caffeine intake from caffeinated soft drinks in Denmark, the United Kingdom and the United States (Barone and Roberts, 1983; Barone and Roberts, 1996; Scott et al., 1989), in $\mathrm{mg} /$ day/kg body weight.

\begin{tabular}{|l|l|l|l|l|}
\hline Age-group & \multicolumn{5}{|l|}{} \\
\hline & Australia $^{3}$ & Denmark $^{2}$ & United Kingdom $^{2}$ & United States $^{3}$ \\
\hline$>1$ & & & & 0.02 \\
\hline $1-5$ & & 0.3 & 0.42 & 0.34 \\
\hline $6-9$ & & 0.3 & 0.27 & \\
\hline $6-11$ & & & & 0.21 \\
\hline $10-14$ & $0.8^{1,3}$ & 0.3 & 0.26 & \\
\hline $12-17$ & & & & 0.16 \\
\hline $15-19$ & & 0.2 & 0.26 & \\
\hline 18 and older & & & & 0.03 \\
\hline $20-24$ & & 0.2 & 0.20 & \\
\hline $25-34$ & & 0.2 & 0.21 & \\
\hline $35-49$ & & 0.1 & 0.12 & \\
\hline 50 and older & & 0.1 & $0.06-0.09$ & \\
\hline
\end{tabular}

${ }^{1)}$ Age-group $10-15$ years; ${ }^{2)}$ Consumers only; ${ }^{3)}$ Consumers and abstainers.

In Denmark the highest daily caffeine intake from soft drinks, 0.3 $\mathrm{mg} / \mathrm{kg}$ body weight, was found among children aged 1-14 years. People 
aged 15-34 years ingested $0.2 \mathrm{mg}$ caffeine $/ \mathrm{kg}$, and those over 35 years 0.1 $\mathrm{mg} / \mathrm{kg}$.

Barone and Roberts (1996) reported the mean daily caffeine intake from soft drinks, adjusted to body weight, for British soft drink consumers of various ages. The highest intake, $0.42 \mathrm{mg} / \mathrm{kg}$, was found among 1-5 year olds. Children aged 6-9 years ingested $0.27 \mathrm{mg} / \mathrm{kg}$, and 10-19 year $0.26 \mathrm{mg} / \mathrm{kg}$. The caffeine intake from soft drinks decreased within higher age groups. People aged 20-24 years ingested $0.20 \mathrm{mg} / \mathrm{kg}, 25-34$ years $0.21 \mathrm{mg} / \mathrm{kg}$, and $35-49$ years $0.12 \mathrm{mg} / \mathrm{kg}$. Older persons consumed below $0.1 \mathrm{mg}$ caffeine $/ \mathrm{kg}$.

The data in Table 31 on the caffeine intake from soft drinks (per $\mathrm{kg}$ body weight) in the United States is the daily average for consumers as well as abstainers (Barone and Roberts, 1983).

\subsection{Energy drinks}

A new type of caffeinated beverage entered the market a few years ago. These beverages are called energy drinks, and may contain much higher amounts of caffeine than the well-known cola soft drinks. The purpose of consuming these drinks is to obtain energy, and they are frequently marketed as "revitalising" and "stimulating" beverages.

\subsubsection{Consumption of energy drinks and caffeine intake}

Most of the drinks referred to in this section are distributed in cans with a volume of $250 \mathrm{ml}$, and are therefore probably often consumed in this quantity. Consumption of a can of a brand containing $320 \mathrm{mg}$ caffeine per litre results in a caffeine intake of $80 \mathrm{mg}$. This is a quantity similar to the caffeine content in a cup of percolated coffee (Burg, 1975, Gilbert, 1984, Stavric et al., 1988), and indicates that consumption of energy drinks can give a substantial contribution to total caffeine intake.

Even in 1996, when the products were rather new on the market, 93.6 $\%$ of the pupils in a German school knew about the new caffeinated drinks. More than half of the population interviewed (53.3\%) reported to have tasted the drinks. $3 \%$ of the consumers drank 1 to 7 cans/week and $23 \%$ consumed 1 can/week (Viell et al., 1996). The youngest adolescents in the investigation, aged 10-13 years, had tasted the drinks as well, although consumption was clearly related to age and gender. The fact that a fraction of the population consumes high amounts of new (caffeinated) drinks and the fact that very young children also drink them, indicate, according to the authors, that the consumption pattern ought to be studied more closely.

The consumption of energy drinks among young people in Sweden was investigated in a survey designed by the Swedish National Food 
Administration (unpublished data). This investigation was carried out via the Internet in November 2001, and involved a total of 1089 young males and females aged 16-25 years from all of Sweden. The participants were asked how often they consumed energy drinks, how much they consumed on each occasion, and if their consumption had been affected by media reports concerning energy drinks. The reason for asking the last question was that reports appeared at the time in newspapers on the adverse effects presumed to be related to the intake of energy drinks.

More than half of the test population (on average $54 \%$; $67 \%$ females, $35 \%$ males) reported that they never consumed energy drinks. $31 \%$ of the consumers in the study drank energy drinks no more than once a month. It was apparent that males were responsible for the greatest part of the consumption. $7 \%$ of the participating males consumed energy drinks 1-3 times weekly in comparison with $1 \%$ of the females in the study. A very low percentage of study participants reported consumption every day or every week ( $1 \%$ and $6 \%$, respectively).

$45 \%$ of the consumers in the study drank one can or less, while $8 \%$ consumed two cans, and $2 \%$ three or more cans on each occasion. Males consumed more cans at each occasion than women.

Three quarters of the study participants reported that their consumption was unaffected by news in the media concerning energy drinks (National Food Administration, unpublished data).

\subsubsection{Possible future consumption}

Because energy drinks are relatively new products on the market, one can imagine that the main consumers are, and will be, teenagers and young adults. These groups of people are commonly open-minded, and are not afraid to try new products such as these. In Sweden, many bars and restaurants serve alcoholic drinks containing the energy drink Red Bull. As a result, even more people will consume this beverage, and thus be exposed to high amounts of caffeine with or without their knowledge.

\subsubsection{Caffeine content in energy drinks}

The caffeine, which occurs in energy drinks, can be a natural product from plants such as guarana or the kola nut (MAFF, 1998), but it is more often added to the drink as a synthetic compound for various reasons. In Sweden energy drinks with caffeine contents of $135 \mathrm{mg}$ per litre or less can be sold like ordinary soft drinks. Energy drinks containing higher concentrations of caffeine cannot be sold without special permission. Table 32 shows the maximum allowable caffeine content or the actual 
Table 32. Energy drinks sold with special permission on the Swedish market 1998. Drinks are usually sold in $\mathbf{2 5 0} \mathrm{ml}$ containers. Values within brackets show the caffeine contents of these products as determined by MAFF (1998).

\begin{tabular}{|c|c|c|}
\hline Type of energy drink & $\begin{array}{l}\text { Caffeine content } \\
(\mathrm{mg} / \mathrm{l})\end{array}$ & $\begin{array}{l}\text { Theobromine content } \\
\text { (mg/l) }\end{array}$ \\
\hline Black Booster $(A \& B)^{1}$ & $320(143,318)^{1}$ & 0.2 \\
\hline Blau Sau & 320 & 0.3 \\
\hline Blue jeans & 320 & \\
\hline Bullit & 240 & \\
\hline Coolfire & 320 & \\
\hline Dark Dog Lemon & 320 & \\
\hline Dynamite & $320(295)$ & (not detected) \\
\hline Erectus Guarana & 300 & \\
\hline Flying Horse & $320(316)$ & (not detected) \\
\hline $\mathrm{GUVI}^{3}$ & $250(324)$ & 0.2 \\
\hline $\begin{array}{l}\text { Hype Energy MFP } \\
\text { Cranberry \& Raspberry }\end{array}$ & $320(313)$ & (not detected) \\
\hline Hype Energy MorningRush, Grapefruit3 & $320(311)$ & \\
\hline $\begin{array}{l}\text { Hype Energy } \\
\text { Night Boost, Peach }\end{array}$ & $320(291)$ & (not detected) \\
\hline $\begin{array}{l}\text { Hype Energy } \\
\text { Passion attack, Passion } \text { fruit }^{3}\end{array}$ & $320(318)$ & (not detected) \\
\hline $\mathrm{M}-150$ & 320 & \\
\hline Mississippi & 320 & \\
\hline Red Bull & $320(314)$ & (not detected) \\
\hline Red Bull (Thailand) & 320 & \\
\hline Red Energy & 320 & \\
\hline Red Kick $^{2}$ & $320(349)$ & (not detected) \\
\hline Rio Amazon Guarana Breeze $^{3}$ & $240(185)$ & (not detected) \\
\hline Semtex & 144 & \\
\hline Semtex Forte & 320 & \\
\hline Shark & 320 & \\
\hline Speed Unlimited & 320 & \\
\hline Top Secret & 238 & \\
\hline Warp $(4)^{3}$ & $320(304)$ & (not detected) \\
\hline
\end{tabular}

caffeine content of energy drinks sold with special permission on the Swedish market in 1998.

MAFF measured the caffeine content in 26 energy drinks. The caffeine content ranged from 0.1 to $87 \mathrm{mg} / \mathrm{can}$ of $250 \mathrm{ml}$, with a mean of 60 $\mathrm{mg} / \mathrm{can}$ and a median of $73 \mathrm{mg} / \mathrm{can}$. All but one brand contained over 28 $\mathrm{mg} / \mathrm{can}$, and most had significantly higher levels than cola soft drinks. Theobromine and theophylline levels in these energy drinks were much lower than caffeine levels $(<0.03-1.6 \mathrm{mg} / \mathrm{can}$, and $<0.03-0.3 \mathrm{mg} / \mathrm{can}$, respectively).

Verheijen (1999) analysed five brands of energy drinks on the Icelandic market and found all five to contain around 30-33 mg caffeine per can ( $250 \mathrm{ml})$, corresponding to $117-133 \mathrm{mg} / \mathrm{litre}$. Thus, all samples were below the maximum limit of $135 \mathrm{mg}$ per litre.

A drink called Lucozade, promoted as a tonic for ill and recuperating patients, is sold as an energy drink in South Africa. According to Galasko et al. (1989) it contained $62 \mathrm{mg}$ caffeine per can of $360 \mathrm{ml}$, a very large quantity for a soft drink. Its label reads inter alia that it is particularly useful during pregnancy and breast-feeding. These are conditions in 
which many women wish to be very restrictive in their caffeine consumption. There was no indication on the bottle that the beverage contained high quantities of caffeine. The same was true for bottles sold in Ireland and Great Britain.

MAFF (1998) found a caffeine-content of $32 \mathrm{mg} / \mathrm{can}$ in Lucozade. Another version of the drink, Lucozade NRG, contained only $0.07 \mathrm{mg}$ caffeine per can.

\subsection{Smart drinks}

Smart drinks belong to an even newer group of beverages, once restricted to techno clubs and rave parties. Smart drinks emerged as a part of the rave culture to keep dancers active for hours on the dance floor (Steven Rose. http://www.damicon.fi/sd/nsa-sd-article.html, 2002-08-15). The present definition of smart drinks is very vague. It may be used to denote a beverage consumed to increase memory capacity and cognitive performance. It can also be a health drink, full of vitamins, ginseng, and other ingredients thought to increase physical and mental wellbeing. In either case, the beverage often contains substances or extracts with reviving effects, like caffeine.

Smart drinks may contain a wide range of more or less controlled ingredients, for example, nutrients that supply precursors and cofactors used by the body in the production of neurotransmitters (Steven Rose. http://www.damicon.fi/sd/nsa-sd- article.html, 2002-08-15). The intellect and memory is believed to be stimulated as a result. Plant extracts, like guarana, kava-kava, and ginseng are common ingredients.

Among synthetic versions of natural products, amino acids have become popular. Antioxidants, such as vitamins $\mathrm{C}$ and $\mathrm{E}$ and carotenoids (precursor to vitamin A) are added to protect against oxidative damage, whereas B vitamins, choline and lecithin may be added, aiming at influencing the neural system.

\subsubsection{Consumption of smart drinks}

The smart drink industry sells its products as a healthy alternative to caffeine-, nicotine-, and alcohol-containing stimulants. The smart drink buyer is described as health-conscious, active and young, or at least young at heart. Smart drink consumers want to live maximally active lives without compromising with their vitality and health. Smart drinks are mostly sold to younger people, but older people are said to slowly be catching up.

\subsubsection{Caffeine content in smart drinks}

It is possible to infer that smart drinks contain caffeine and other methylxanthines, since products from plants containing caffeine are the basis of 
most smart drinks. Thus, guarana often provides the smart drink with a variety of methylxanthines, among them caffeine. The effect of guarana is said to be similar to that of caffeine, but with a slower and more lasting effect (Smartbomb.com. http://www.mg.co.za/mg/news/ smartdr1.htm, 2000-04-13).

All smart drinks listed on the Internet site Smartbomb.com (Smartbomb.com. http://www.mg.co.za/mg/news/ smartdr1.htm, 2000-04-13) contained caffeine from natural sources such as tea, kola nuts, and guarana. With the exception of a very limited Icelandic study (Verheijen, 1999), the levels of caffeine in smart drink products are unknown. The Icelandic study quantified the caffeine content of four alcoholic beverages. Two types of soda stream contained $45 \mathrm{mg} / \mathrm{l}$, a type of smart drink tablet $67 \mathrm{mg} / \mathrm{l}$ and a 'wild brew vodka guarana drink' (4\% alcohol) 177 $\mathrm{mg} / \mathrm{l}$.

\subsection{Caffeinated water}

Caffeinated waters are a relatively new type of beverage. The water can be consumed as it is, or it can be used to increase the caffeine level in coffee and tea.

\subsubsection{Caffeine content in caffeinated water}

The caffeine content of six different brands of caffeinated water was provided at the Internet site 'The caffeine page' at the late 1990's (Source of literature not specified. http://andes.ip.ucsb.edu/ krend/caffeine.html, 1998-03-14). Most of these types of water were said to contain an amount of caffeine about equal to that of cola soft drinks (Table 33). The highest amount of caffeine was found in Edge 2O. This water contained $290 \mathrm{mg}$ caffeine per litre. Nitro Water and The Buzzwater Company have thereafter launched similar products to those mentioned in Table 33. Nitro Water is spring water containing $56 \mathrm{mg}$ caffeine per one-half litre bottle (http: //www.nitrowater.com/ drink.htm, 2002-08-15). The Buzzwater Company sells two types of water with added caffeine: Premium Certified Natural Spring water with $100 \mathrm{mg}$ caffeine per bottle $(500 \mathrm{ml})$, and Rocket Fuel. The first of these products contains amounts of caffeine equivalent to one large coffee or three and a half dark colas. Rocket Fuel is illegal in the United States because it contains $200 \mathrm{mg}$ caffeine per bottle $(500 \mathrm{ml})$. The company advertises the "product as not being for caffeine amateurs but for connoisseurs who need the immediate power, strength and competitive edge in sports, work or life and find that sometimes to achieve one's life-goals, sleep is overrated. This product is definitely an alertness aid and no helmets are safe ..." (http://www.buzzwater.com, 2002-08-15). 
Table 33. Caffeinated water and their caffeine content (Source of literature not specified. http://andes.ip.ucsb.edu/ krend/caffeine.html, 1998-03-14).

\begin{tabular}{|l|l|}
\hline $\begin{array}{l}\text { Caffeinated waters } \\
\mathbf{5 0 0} \mathbf{~} \mathbf{l})\end{array}$ & $\begin{array}{l}\text { Caffeine content } \\
(\mathbf{m g})\end{array}$ \\
\hline Edge 2O & 145 \\
\hline Java Water & 125 \\
\hline Krank 2O & 100 \\
\hline Aqua Blast & 90 \\
\hline Water Joe & 70 \\
\hline Aqua Java & 60 \\
\hline
\end{tabular}

\subsection{Pharmaceuticals}

According to Shirlow (1983) caffeine has been therapeutically used as a cardiac and bronchial stimulant and in the treatment of infant apnoea and a variety of skin disorders. In addition, Shirlow (1983) mentions the use of caffeine in analgesics, diuretics, allergy relief preparations, alertness compounds, and weight-control agents and in the treatment of migraine.

In Sweden the main use of caffeine in pharmaceuticals is found in analgesics, and in drugs for migraine treatment and in preparations with central stimulating properties.

Theophylline is to some extent used in the treatment of asthma (SBU, 2000). Theobromine has earlier been used for pharmaceutical purposes. For example, Graham (1978) mentions theobromine for treatment of diuresis in the United States.

\subsubsection{Caffeine content of pharmaceuticals}

Table 34 lists pharmaceuticals containing caffeine available on the Nordic market during 1997-1998. The amount of caffeine usually present in these pharmaceuticals is 50 or $100 \mathrm{mg} /$ tablet, or about $2-3 \mathrm{mg} / \mathrm{ml} \mathrm{mix-}$ ture.

Graham (1978) pointed out that the caffeine content in nonprescription drugs in the United States might range from 15 to $200 \mathrm{mg}$ per tablet. According to the author, this can result in a significant caffeine intake for some individuals.

In 1986, 51 analgesics were available on prescription in the United Kingdom. Of these, 12 contained a mean caffeine content of $26 \mathrm{mg}$. According to Scott et al. (1989), $36 \%$ of the 'over the counter' preparations of systemic analgesics in the United Kingdom in 1985 contained caffeine. The mean caffeine content was $35 \mathrm{mg}$. 


\subsubsection{Consumption of pharmaceuticals and caffeine intake from such products}

Many people use caffeine-containing pharmaceuticals during limited periods of their lives. But not all are aware of the increased caffeine intake the consumption of these drugs can give.

Caffeine intake, after a maximum dose used for therapy, has been calculated for the caffeine-containing pharmaceuticals, and is presented in Table 34. Doses ranging from 200 to $600 \mathrm{mg} /$ day are registered for different migraine preparations, while analgesics can provide caffeine contributions of $150-400 \mathrm{mg} /$ day. Pharmaceuticals taken with the purpose of giving strength, so-called tonics, have lower caffeine contents, resulting in intakes ranging from 90 to $112.5 \mathrm{mg}$ /day (Medical Products Agency, 1998). Thus, it is clear that pharmaceuticals may provide a considerable contribution to the total intake of caffeine. If more than one caffeinecontaining drug is used at the same time, the caffeine intake from pharmaceuticals alone can be substantial.

There seems to be very little point in calculating averages in caffeine intake from drugs, since people use pharmaceuticals individually and sporadically. Nonetheless, there is data on this from Iceland. The per capita intake of caffeine from pharmaceuticals was found to be 35.53 $\mathrm{mg}$ /day in Iceland in 1998. This amount was lower than the amounts consumed between 1989-1997, which was between 35.60 and $41.21 \mathrm{mg}$ /day (Johannesson, personal communication). In the United States, the caffeine intake from caffeine-containing pharmaceutical drugs may be from 30 to $200 \mathrm{mg}$ /day if a single dose is administered. Sometimes further doses are taken and then, consequently, the intake is increased (Institute of Food Technologists' Expert Panel on Food Safety and Nutrition, 1983).

Scheiber et al. (1988) presented values of average caffeine intake from drugs in current coffee drinkers, former drinkers, and those who never drank coffee in the United States. The intakes were $10.3 \mathrm{mg}, 21.6$ $\mathrm{mg}$ and $13.9 \mathrm{mg}$, respectively. None of these differences were statistically significant.

Finally, it should also be mentioned that caffeine is used in skin care products, as caffeine easily absorbs (around 20\%) via the dermal route. Although amounts corresponding to a cup of coffee $(100 \mathrm{mg})$ may be absorbed in a person of $60 \mathrm{~kg}$ after applying a cream with 3\% caffeine to half of the body surface (Moksnes, 2001), none of the epidemiological studies discussed in chapters 11-17 have included caffeine exposure from skin care products when calculating the total caffeine exposure. 
Table 34. Registered caffeine-containing pharmaceuticals in Denmark (2000), Finland (1997), Iceland (1998), Norway (1998), and Sweden (1997), and the possible daily caffeine intake from these products.

\begin{tabular}{|c|c|c|c|}
\hline Pharmaceutical & Marketed in & $\begin{array}{c}\text { Caffeine } \\
(\mathrm{mg} / \text { tablet or } \mathrm{mg} / \mathrm{ml})\end{array}$ & $\begin{array}{l}\text { Total caffeine intake for user } \\
\text { at maximum dose (mg/day) }\end{array}$ \\
\hline \multicolumn{4}{|l|}{ Analgesics, antipyretics } \\
\hline Antineuralgica & $\mathrm{N}$ & 50 & 200 \\
\hline Bamyl - caffeine tablets & $S$ & 50 & 300 \\
\hline Bamyl - S - caffeine effervescent tablets & $\mathrm{S}$ & 50 & 300 \\
\hline Coldrec tablets & $\mathrm{F}$ & 15 & 150 \\
\hline Fanalgin & $\mathrm{N}$ & 50 & 300 \\
\hline Fenazon-koffein & $\mathrm{N}$ & 100 & 600 \\
\hline Finnrexin C-300 powder & $\mathrm{F}$ & 30 & 120 \\
\hline Finnrexin C-300 Neo powder & $\mathrm{F}$ & 30 & 120 \\
\hline Fortal C-200 tablets & $\mathrm{F}$ & 50 & 250 \\
\hline Hota powder & $\mathrm{F}$ & 50 & 150 \\
\hline Kodamid1 & DK & 50 & 300 \\
\hline Koffein-fenazon & DK & 50 & 400 \\
\hline Koffisal & DK & 50 & 400 \\
\hline Magnecyl - caffeine tablets & $\mathrm{S}$ & 50 & 300 \\
\hline Magnecyl - caffeine effervescent tablets & S & 50 & 300 \\
\hline Optimal tablets & $\mathrm{F}$ & 100 & 300 \\
\hline Panadol Comp. tablets & $\mathrm{F}$ & 65 & 390 \\
\hline Pervitin tablets & $\mathrm{F}$ & 50 & 300 \\
\hline Pika 7 tablets & $\mathrm{F}$ & 32.5 & 97.5 \\
\hline Posivil capsel & $\mathrm{F}$ & 25 & 150 \\
\hline Ring tablets & $\mathrm{F}$ & 50 & 300 \\
\hline Seliran tablets & $\mathrm{F}$ & 50 & 150 \\
\hline Somadril Comp tablets ${ }^{1}$ & $\mathrm{I}, \mathrm{S}$ & 32 & 256 \\
\hline TREO effervescent tablets & DK, F, I, S & 50 & $300-400$ \\
\hline TREO lemon effervescent tablets & $\mathrm{s}$ & 50 & 300 \\
\hline TREO Comp effervescent tablets ${ }^{1}$ & $\mathrm{~S}$ & 50 & 400 \\
\hline \multicolumn{4}{|l|}{ Antihistaminic } \\
\hline Lergigan Comp tablets $^{1}$ & $\mathrm{~s}$ & 50 & 500 \\
\hline \multicolumn{4}{|l|}{ Central stimulating } \\
\hline Dolvipar tablets & 1 & 50 & $?$ \\
\hline Dolvipar suppositories & 1 & 50 & $?$ \\
\hline Koffazon tablets & $\mathrm{I}, \mathrm{S}$ & 50,100 & $300-600$ \\
\hline Koffazon dose powder & $S$ & 100 & 600 \\
\hline Koffein rec. tablets $100 \mathrm{mg}$ & $\mathrm{S}$ & 100 & 600 \\
\hline Letigen $^{1}$ & DK & 200 & 600 \\
\hline \multicolumn{4}{|l|}{ Migraine treatment } \\
\hline Anervan tablets ${ }^{1}$ & $\mathrm{~F}, \mathrm{I}, \mathrm{N}, \mathrm{S}$ & 50 & $200-250$ \\
\hline Anervan suppositories $^{1}$ & $\mathrm{~F}, \mathrm{~N}, \mathrm{~S}$ & 100 & $200-500$ \\
\hline Cafergot tablets $^{1}$ & $\mathrm{~F}, \mathrm{~N}, \mathrm{~S}$ & 100 & $400-600$ \\
\hline Cafergot suppositories $^{1}$ & $\mathrm{~F}, \mathrm{~S}$ & 100 & 300 \\
\hline Cafergot comp. Capsels & $\mathrm{DK}, \mathrm{F}$ & 100 & $300-600^{2)}$ \\
\hline Ergokoffin ${ }^{1}$ & DK & 100 & $600^{3)}$ \\
\hline Gynergen comp. Suppositories $^{1}$ & $\mathrm{DK}, \mathrm{I}$ & 100 & $300^{2)}$ \\
\hline \multicolumn{4}{|l|}{ Tiredness } \\
\hline Koffinátín Tablets & 1 & 50 & $?$ \\
\hline Caffeine tablets & $\mathrm{F}$ & 100 & 300 \\
\hline Cofi-tablets & $\mathrm{F}$ & 100 & 300 \\
\hline \multicolumn{4}{|l|}{ Tonic } \\
\hline Astratonil forte mixture & $\mathrm{S}$ & 2.5 & 112.5 \\
\hline Ferritamin mixture & $S$ & 2 & 90 \\
\hline Lixir mixture & $S$ & 3 & 90 \\
\hline Lixir S mixture & $S$ & 3 & 90 \\
\hline Vitatonin mixture & $S$ & 2 & 90 \\
\hline Vitatonin forte mixture & $\mathrm{S}$ & 2.5 & 112.5 \\
\hline \multicolumn{4}{|l|}{ Vitamin B supplements } \\
\hline B-tonin & $\mathrm{N}$ & 1.45 & 43.5 \\
\hline Malvitona mixture $^{1}$ & $\mathrm{~s}$ & 1.65 & 99 \\
\hline
\end{tabular}

${ }^{1)}$ Prescription drug; ${ }^{2)}$ In Denmark not exceeding $500 \mathrm{mg} / \mathrm{month} ;{ }^{3)}$ Not exceeding $3000 \mathrm{mg} / \mathrm{month}$. 


\subsection{Conclusion on occurrence of methylxanthines in food plants, beverages and pharmaceuticals}

With the exception of soft drinks and energy drinks that are sold in bottles and cans of defined sizes and containing regulated levels of added caffeine, it is very difficult to estimate the caffeine content of a standard serving of caffeine-containing beverages. The amount of caffeine present in one cup of cocoa, coffee and tea, or the drinks guaraná, maté and yoco (less consumed in the Nordic countries), depends on a number of factors that differ from individual to individual. Among these factors can be mentioned the species of the plant used to prepare the beverage, how the plant material has been treated, the particle size of the used plant material, the method and time used to prepare the drink, the temperature of the water used during preparation, and the size of the cup from which the beverage is consumed.

Not taking all the factors that influence the caffeine content of a beverage consumed by an individual into consideration allows for an estimation of the caffeine content of a standard serving of different beverages. These data are shown in Table 35.

The consumer is exposed to methylxanthines not only though beverages, but also though consumption of chocolate products and pharmaceutricals. The average caffeine intake from chocolate during the late 1990s has been calculated to be around $2 \mathrm{mg} /$ person/day in Sweden. Chocolate is also often used in cakes, cookies and desserts, but the amounts and type of chocolate used varies. One serving of a chocolate cake or chocolate biscuits may contain around $75 \mathrm{mg}$ theobromine and 10 mg caffeine.

The exposure to caffeine (or theophylline) though pharmaceuticals varies very much from individual to individual, and depends on the type of medicinal preparation used. The daily caffeine intake for users of a drug used in the treatment of migraine at the maximum dose level may be 600 $\mathrm{mg}$, and is commonly 200-400 for other types of drugs containing caffeine. Although the per capita intake of caffeine from medical preparations is a very artificial exposure parameter, it has been calculated in Iceland and found to range from 36 to $41 \mathrm{mg} /$ day during the 1990s.

Table 35. Average contents of caffeine in various beverages commonly consumed in the Nordic countries.

\begin{tabular}{|l|l|l|l|}
\hline Beverage & Caffeine content per serving & Theobromine content per serving & Volume per serving \\
\hline Hot cocoa & 5 & 57 & $150 \mathrm{ml}$ \\
\hline Chocolate milk & 3 & 39 & $150 \mathrm{ml}$ \\
\hline Instant Coffee & 53 & & $150 \mathrm{ml}$ \\
\hline $\begin{array}{l}\text { Brewed (dripolated) } \\
\text { coffee }\end{array}$ & 103 & & $150 \mathrm{ml}$ \\
\hline Guaraná & Variable & Low & variable \\
\hline Maté & 33 & Low & $150 \mathrm{ml}$ \\
\hline Tea & 38 & 3 & $150 \mathrm{ml}$ \\
\hline Soft drinks/Cola drinks & 36 & 0 & $360 \mathrm{ml}$ \\
\hline Energy drinks & 80 & 0 & $250 \mathrm{ml}$ \\
\hline
\end{tabular}





\section{Total caffeine exposure}

Total caffeine intake may differ considerably between individuals of the same nationality, but only a few studies have investigated individual caffeine intake. Most estimates are on the population level. The estimated average caffeine exposure in different countries is presented in Table 36.

Shirlow (1983) estimated the average caffeine intake in Australia by interviewing 4,757 persons on their frequency of consumption of instant and brewed coffee, tea, and soft drinks. With the exception of the caffeine content of instant coffee, which was measured by the investigators in drinks prepared by the study participants, information on caffeine content of the beverages was taken from Gilbert (1976). An average caffeine intake of $240 \mathrm{mg}$ caffeine/day was found.

Subsequently Lelo et al. (1985) quantified the consumption of caffeine-containing foods and measured the plasma caffeine, theophylline, theobromine, and paraxanthine concentrations over 24 hours in 17 adults in Australia. The test population was selected based on their moderate to heavy caffeine intake. The caffeine content of all coffee and tea beverages consumed by the study participants was determined and used to calculate their actual caffeine consumption over a day. The estimated mean daily caffeine intake of these high consumers of caffeine-containing beverages was $462.9 \pm 172.8 \mathrm{mg} /$ day. According to the authors, tea, brewed coffee, and instant coffee accounted for $11 \%, 29.4 \%$, and

Table 36. The total daily caffeine exposure from foods and beverages in some countries.

\begin{tabular}{|c|c|c|c|c|}
\hline $\begin{array}{l}\text { Average caffeine exposure } \\
\text { and/or range }(\mathrm{mg})\end{array}$ & Country & Population size & Caffeine sources & Reference \\
\hline $462.9^{1,2}$ & Australia & 17 & Coffee, tea & Lelo et al. (1985) \\
\hline 240 & Australia & 4,757 & All foods & Shirlow (1983) \\
\hline 238 & Canada & Per capita & All foods & Gilbert (1984) \\
\hline $49-1022$ & Canada & 58 & Coffee, tea & Stavric et al. (1988) \\
\hline $490^{2,3}$ & Denmark & & All foods & Barone and Roberts (1996) \\
\hline $280^{2,3}$ & UK & & All foods & Barone and Roberts (1996) \\
\hline 444 & UK & Per capita & All foods & Gilbert (1984) \\
\hline $\begin{array}{l}327 \\
(0-1055)\end{array}$ & UK & 142 & All foods & James et al. (1989) \\
\hline 359 & UK & 174 & All foods & Scott et al. (1989) \\
\hline 211 & USA & Per capita & All foods & Gilbert (1984) \\
\hline 186 & USA & 202 & Coffee, tea, soft drinks & Hughes et al. (1997) \\
\hline $210^{3}$ & USA & & All foods & Barone and Roberts (1996) \\
\hline $227^{2}$ & USA & & All foods & Kalow (1993) \\
\hline $156.0-301.6$ & USA & 2,714 & All foods & Scheiber (1988) \\
\hline 186 & USA & & All foods & Graham (1978) \\
\hline 171 & Brazil & 600 & All foods & Camargo et al., 1999 \\
\hline 425 & Sweden & Per capita & All foods & Gilbert (1984) \\
\hline
\end{tabular}


$59.5 \%$ of the total caffeine intake among coffee and tea consumers. No significant difference was found between the reported (usual) coffee and tea intake and the intake measured by plasma concentration. The highest plasma concentrations of methylxanthines were found late in the evening (caffeine $9.69 \mu \mathrm{g} / \mathrm{ml}$ ) - concentrations that commonly are considered to be associated with pharmacological effects.

The two reports on caffeine exposure in Canada give complementary information. Gilbert (1984) estimated the per capita intake from all food sources in 1982/1983 to be $238 \mathrm{mg} /$ day. Studying the caffeine intake from coffee and tea among 58 Canadians, Stavric and co-workers (1988) observed a large inter-individual variation; between 49 and $1022 \mathrm{mg} /$ day.

Most studies on caffeine exposure come from the United States, where the total caffeine exposure generally is a little lower than in otherwise comparable countries. Gilbert (1984) estimated the per capita intake of caffeine from all food sources in USA to $211 \mathrm{mg}$ /day in 1982/1983. A similar estimate was given by Barone and Roberts (1996). More than a decade later, these authors suggested a mean daily intake of $3 \mathrm{mg} / \mathrm{kg}$ body weight for American consumers. For a person of $70 \mathrm{~kg}$ this is equivalent to $210 \mathrm{mg}$ caffeine/day. For heavy users of caffeine-containing beverages the daily caffeine intake ranged from $350-490 \mathrm{mg}$. Only a few studies have focused on the caffeine exposure of specific age-groups. Kalow (1993) reported a mean caffeine intake of $227 \mathrm{mg} /$ day among 18-year-old consumers in the United States (see also the last part of this section), whereas Graham (1978) stated that consumers 18 years old and older had a mean caffeine intake of $186 \mathrm{mg} /$ day. People with the highest caffeine intake come close to $563 \mathrm{mg} /$ day (Graham, 1978).

In a study based on 202 adults in Vermont, subjects were interviewed by telephone and in person about their usual weekly consumption of coffee, tea and soft drinks (Hughes and Oliveto, 1997). The caffeine contents of these food products were taken from the literature. Caffeine from chocolate and medications were not assessed because the contribution to overall caffeine intake was believed to be low. The mean adjusted caffeine intake was $186 \mathrm{mg} /$ day.

In a larger study by Scheiber et al. (1988), based on 2,714 American adults, of whom $78.2 \%$ were current coffee drinkers, the mean daily intake of caffeine from all sources was $363.5 \mathrm{mg}$ for coffee consumers. The average total caffeine intake for former coffee drinkers from all sources was $106.8 \mathrm{mg}$, and for those who never drank coffee the total intake was $90.6 \mathrm{mg}$. Usually, coffee consumers had the lowest caffeine intake from non-coffee sources.

Camargo and co-workers (1999) estimated the daily caffeine intake from dietary sources in the city of Campinas in Brazil. The 600 participants in the study were selected from consumers who shopped at various supermarkets at different times over a period of five days. Slightly more than two thirds were 20 years of age or older. Although the investigators 
tried to reduce selection phenomena, the manner of selecting the participants must have influenced the outcome of the study. Individual total daily intake of caffeine was estimated from the consumption data of coffee, tea, chocolate products, and soft drinks generated by the survey, as well as the caffeine levels determined in the identified products. According to this investigation, Brazilians seem to consume relatively low amounts of caffeine, on average $171 \mathrm{mg} /$ day, with coffee being the main dietary source of caffeine. There was no difference in caffeine intake between males and females in this study, and no correlation between smoking and coffee consumption. Expressed as exposure per kg body weight, coffee, tea, chocolate products and carbonated beverages accounted for median individual daily intakes of $1.90,0.32,0.19$ and $0.19 \mathrm{mg} / \mathrm{kg}$ body weight, respectively. Approximately $4.3 \%$ of the studied population were exposed to more than $8.0 \mathrm{mg}$ caffeine $/ \mathrm{kg}$ body weight from coffee, and only $12 \%$ of more than $1.0 \mathrm{mg} / \mathrm{kg}$ body weight from tea. High exposures to caffeine from chocolate products and soft drinks were very rare.

In Europe, caffeine intakes have been estimated in the United Kingdom, Denmark, and Sweden. Whereas coffee consumption gives the highest contribution to caffeine intake in the Scandinavian countries, tea gives an equally high contribution in the United Kingdom.

Gilbert (1984) estimated the per capita intake of caffeine in the United Kingdom from all food sources in 1982/1983 to be $444 \mathrm{mg} /$ day. Other investigators have reported lower average caffeine intakes. Barone and Roberts (1996) estimated caffeine intake to be $280 \mathrm{mg} /$ day for an average consumer. For high consumers of caffeine-containing beverages the intake can be as high as $525 \mathrm{mg} /$ day. Two studies in the United Kingdom investigated the caffeine intake in small population groups. In one of these studies, based on 142 adults, caffeine intake was found to vary between 0 and $1,055 \mathrm{mg} / \mathrm{day}$, with a mean of $327 \pm 210 \mathrm{mg} / \mathrm{day}$ among the 174 studied adults (Scott et al., 1989). In the latter study, coffee was the major dietary source of caffeine, accounting for $55 \%$ of the per capita intake. $44 \%$ of the per capita intake was derived from tea. Caffeine intake from cola drinks and chocolate accounted for less than $4.4 \%$.

In the Nordic countries people are generally considered to have a higher coffee consumption than people elsewhere, and coffee consumption provides the predominant contribution to caffeine intake. Gilbert (1984) estimated the per capita intake of caffeine from all food sources in Sweden to be $425 \mathrm{mg} /$ day in 1982/1983. The average intake of caffeine in Denmark has been estimated to be $490 \mathrm{mg} / \mathrm{day}$ (Barone and Roberts, 1996). High consumers of caffeinated beverages in Denmark ingested $1,043 \mathrm{mg}$ caffeine per day.

Verheijen (1999) made a partial estimation of the average daily caffeine intake in Iceland. He concluded that coffee is the main source of caffeine in the Icelandic diet, contributing with approximately $340 \mathrm{mg}$ caffeine in adult people (15-80 years). Other contributions to the total 
caffeine intake come from soft drinks (22 $\mathrm{mg}$ ), energy drinks (less than 1 $\mathrm{mg})$, and tea (6 mg).

It is easy to underestimate caffeine intake in children because of the comparatively low consumption of coffee, which is the beverage with the highest relative amount of caffeine. However, children often consume large amounts of tea, chocolate candies, and caffeinated soft drinks that may contain significant amounts of caffeine. Because children have lower body weight and different rates of metabolism, it is important to establish the amount of caffeine that children actually are exposed to (Kalow, 1993). Available information is summarised in Table 37.

Within the Bogalusa Heart Study, dietary intake (24-h recall) of infants and children was recorded in a biracial population $(60 \%$ white and $40 \%$ black) with the help of parents. Also teenagers, 13, 15 and 17 years old, gave information on their diet. The information was used to calculate the caffeine intake (Arbeit et al., 1988). Whites consumed significantly more caffeine than blacks as early as at 1 year of age and persisted at a higher intake level from 2 to 17 years. The daily caffeine intake in white boys $0.5,2,4,10,13$ and 17 years old were on average 12, 95 67, 58, 138 and $147 \mathrm{mg}$, respectively (data not shown in Table 34). On a per kilogram body weight basis, 2- and 3-year-old children consumed the greatest amounts of caffeine, that is, about 2 to 4 times the amounts that were consumed by adolescents. Significant sex differences occurred for the older teenagers. The most frequent sources of caffeine were regular

Table 37. Total daily caffeine exposure in children of different nationalities.

\begin{tabular}{|c|c|c|c|c|}
\hline \multicolumn{2}{|c|}{ Caffeine exposure } & \multirow[t]{2}{*}{ Country } & \multirow[t]{2}{*}{ Caffeine sources } & \multirow[t]{2}{*}{ Reference } \\
\hline (mg) & (mg/kg b.w.) & & & \\
\hline & 1.3 & Australia & All foods & Gilbert (1984) \\
\hline & $<2.5$ & Denmark & All foods & Gilbert (1984) \\
\hline \multirow[t]{2}{*}{$\begin{array}{l}230 \text { (girls) } \\
310 \text { (boys) } \\
\end{array}$} & & Finland & Coffee & Hemminki et al. (1988) \\
\hline & $<3$ & UK & All foods & Gilbert (1984) \\
\hline 37.4 & & USA & All foods & Morgan et al. (1982) \\
\hline $\begin{array}{c}2.1-11.9(1 / 2 y o) \\
22-44 \text { (1 yо) } \\
35-95 \text { (2 yо) } \\
41-94 \text { (3 уо) } \\
39-72 \text { (4 уо) } \\
22-62 \text { (10 уо) } \\
26-138 \text { (13 уо) } \\
26-108 \text { (15 уо) } \\
45-147 \text { (17 уо) }\end{array}$ & $\begin{array}{l}0.3-1.5 \text { (1/2yo) } \\
2.2-4.6 \text { (1 yо }) \\
2.5-7.8 \text { (2 yо) } \\
2.8-6.4 \text { (3 уо }) \\
2.3-4.5 \text { (4 уо }) \\
0.7-2.0 \text { (10 уо) } \\
0.6-2.8 \text { (13 уо) } \\
0.5-2.0 \text { (15 уо }) \\
0.7-2.5 \text { (17 уо })\end{array}$ & USA & All foods & Arbeit et al. (1988) \\
\hline 29 & & USA & All foods & Kalow (1993) \\
\hline \multirow[t]{2}{*}{$\begin{array}{c}12.3 \text { (7 yo) } \\
13.9 \text { (8 yo) } \\
17.9 \text { (9 yo) } \\
24.8 \text { (10 yo) } \\
\end{array}$} & $\begin{array}{c}0.44 \text { (7 yо) } \\
0.46 \text { (8 yо) } \\
0.53 \text { (9 уо) } \\
0.68 \text { (10 уо) }\end{array}$ & USA & All foods & Ellison et al. (1995) \\
\hline & 1 & USA & All foods & Barone and Roberts (1996) \\
\hline 28 (median) & & USA & All foods & Goldstein and Wallace (1997) \\
\hline
\end{tabular}

carbonated beverages, chocolate-containing foods, and tea. Mean intakes of caffeine for 10-year-olds were consistent from 1973 to 1982. 
Four other studies on caffeine intake among children in the United States give relatively similar quantities regarding average daily intake. Goldstein and Wallace (1997) found a median daily caffeine intake from all foods of $28 \mathrm{mg}$ among 175 schoolchildren aged 11-12 years. Seventeen percent of the children regularly consumed $100 \mathrm{mg}$ caffeine or more per day. Kalow (1993) reported a similar figure, $29 \mathrm{mg} /$ day, among children aged 6-17 years, whereas Morgan et al. (1982) found a mean daily caffeine intake of $37.4 \mathrm{mg} /$ day in 1,135 children aged 4-18 years. In the latter study, $98 \%$ of the children consumed caffeine-containing foods. If the average value was calculated only from subjects consuming caffeine-containing foods and the days when caffeine was consumed, the mean daily caffeine intake would be $47.9 \mathrm{mg}$. Tea gave the highest contribution to caffeine intake, followed by soft drinks, in this study. There was a considerable variation in caffeine intake between individuals, with some consuming an amount as high as $250 \mathrm{mg}$ caffeine per average day.

The estimation of caffeine exposure in epidemiological studies is usually based on dietary recall, a methodology subject to random error for more reasons than one. To circumvent some of the problems related to dietary interviews, collection of saliva for chemical analysis of caffeine has been investigated. This methodology has particular advantages for children, as it does not require repeated venipunctures, as would be necessary in order to obtain plasma levels. The methodology was tried in the Framingham Children's Study, a longitudinal study on cardiovascular risk behaviours in young children. The current caffeine intake in American children (aged 8-11 years) was judged in this cohort based on both reported dietary intake and caffeine concentration in saliva. A preliminary report based on dietary data on 78 children and on salivary caffeine data from the initial 24 subjects showed that the average intake was 19 $\mathrm{mg} /$ day $(0.57 \mathrm{mg} / \mathrm{kg}$ body weight/day), mainly from soft drinks (55\%), dairy products $(16 \%)$, and baked goods $(16 \%)$. There was a wide range of caffeine concentrations in saliva, with an overall mean of $0.74 \mu \mathrm{M} /$ litre. The relationship between dietary intake of caffeine and salivary levels seems to be modest (Ellison et al., 1993).

In following up the previous study Ellison et al. (1995) investigated the caffeine intake in 96 schoolchildren (58 boys and 38 girls) on the American East coast. The children were between 6 and 10 years old and the caffeine intake estimated from 3-day food diaries. The calculated caffeine intake was on average based on data from 7.4 days per child. A total of 1057 foods containing caffeine were identified on the food diaries. Strangely enough none of the children consumed coffee. Soft drinks furnished $55 \%$ of the caffeine, and chocolate $38 \%$. Mean caffeine intake were comparatively low for these children, being for 7-year-olds 12.3 $\mathrm{mg}$ /day; for 8-year-olds $13.9 \mathrm{mg} /$ day; for 9-year-olds $17.9 \mathrm{mg} /$ day; and for 10 -year-olds $24.8 \mathrm{mg} /$ day. The increased intake with age was also 
significant after adjusting for body weight. The mean of caffeine in boys was $0.51 \mathrm{mg} / \mathrm{kg}$ body weight and in girls $0.45 \mathrm{mg} / \mathrm{kg}$.

In agreement with the data of Ellison et al. (1993), Barone and Roberts (1996) reported a mean daily intake of caffeine of less than $1 \mathrm{mg} / \mathrm{kg}$ body weight in American children younger than 18 years.

Barone and Roberts (1996) have also reported on the mean caffeine intake outside the United States. In Australia it was $1.3 \mathrm{mg} / \mathrm{kg}$ body weight among children aged 10-15 years, in the United Kingdom $3 \mathrm{mg} / \mathrm{kg}$ body weight among infants and children, and in Danish children less than $2.5 \mathrm{mg} / \mathrm{kg}$ body weight. Hemminki and co-workers (1988) estimated the caffeine intake in Finnish youths in an investigation of their coffee use. In 1981 18-year-old Finnish females on average consumed 2.3 cups of coffee per day. The corresponding consumption for 18-year-old males was 3.1 cups per day. Assuming a caffeine content of $100 \mathrm{mg}$ per cup these 18 -year-olds consumed $230 \mathrm{mg}$ and $310 \mathrm{mg}$ caffeine per day from coffee alone. Since young people often drink soft drinks and cocoa in addition to coffee, the total caffeine exposure among Finnish youth is expected to be considerably higher.

\subsection{Caffeine intake among pregnant women}

It is far from easy to draw conclusions from surveys based on relatively small sample sizes. However, two observations have been made concerning pregnant women in the United States in relation to caffeine intake. Their intake of caffeine during pregnancy is about half of that of the general population, and they consume less than they did before pregnancy (Barone and Roberts, 1996). Barone and Roberts (1996) reported a 20-22 $\%$ reduction in caffeine intake during pregnancy. This reduction was mainly due to reduced coffee consumption, which occurs early on in pregnancy, to a large extent within the first and second trimester (Dlugosz and Bracken, 1992). It is not known whether the change in caffeine intake has a biological reason or if it is a result of responding to advice. However, it is clear that a number of women experience nausea during pregnancy. In 1987/1988 the mean daily caffeine intake from coffee was $168 \mathrm{mg}$ for females weighing $64.7 \mathrm{~kg}$ - the average weight among pregnant women in the United States (Barone and Roberts, 1983).

Similar observations have been made in two earlier American studies. In the study done by Graham (1978), three quarters of the studied pregnant women consumed coffee, on average 1.7 cups per day, which corresponds to $144 \mathrm{mg}$ caffeine per day calculated on all women. The 99th percentile was $676 \mathrm{mg}$ caffeine per day, an amount equivalent to that in 7-8 cups of coffee. When caffeine intake was calculated based on all women, the caffeine intake from drinking coffee was $196 \mathrm{mg} /$ day. Also Watkinson and Fried (1985) observed that coffee consumption was redu- 
ced during pregnancy. The reduction was a result of coffee being consumed less often and in smaller quantities during pregnancy. Coffee was the major caffeine source in this population. Nonetheless, $90-95 \%$ of the test subjects consumed caffeine from some source during pregnancy, and $2 \%$ consumed over $400 \mathrm{mg} /$ day.

Higher intakes of caffeine during pregnancy than those seen in the United States have been reported from the United Kingdom and Denmark. But even in these cases the intake of caffeine during pregnancy was lower than before pregnancy. In the United Kingdom, caffeine intake from all food sources during pregnancy in 1988 was $3.4 \mathrm{mg} / \mathrm{kg}$ body weight or $220 \mathrm{mg}$ per day (Barone and Roberts, 1993). In 1991, Danish pregnant women ingested a mean of $375 \mathrm{mg}$ caffeine per day or $5.8 \mathrm{mg}$ caffeine/kg body weight. Mean caffeine intake from coffee for the heaviest users was $12.8 \mathrm{mg} / \mathrm{kg}$ or $828 \mathrm{mg} /$ day. Table 38 summarises information on caffeine intake by pregnant women in different countries.

\subsection{Caffeine intake and lifestyle}

The huge difference in caffeine intake observed between individuals can be interpreted being subject to influence from different environmental factors. In Norway coffee consumption has been claimed to be associated with lifestyle (Solvoll et al., 1989). Higher coffee consumption in the United Kingdom has been associated with younger age and a higher social class and education level. Results from the Second National Health and Nutrition Examination Survey indicate differences in caffeine sources among American people in different life situations. Subjects who ingest caffeine from tea were more likely to be female, less educated, younger, non-Caucasian, and to have a comparatively low consumption of alcohol. People obtaining most of their caffeine intake from coffee were older, Caucasian, heavier alcohol drinkers, and had higher incomes (Klesges et al., 1994). The typical Canadian heavy caffeine user in the study by Watkinson and Fried (1985), however, had a lower family income, less education, more children and was a habitual cigarette smoker. These results indicate that the major caffeine source may differ among people with different lifestyles.

Table 38. Daily caffeine intake among pregnant women.

\begin{tabular}{|l|l|l|}
\hline Caffgine intake (mg) & Country & Reference \\
\hline 375 & Denmark & Barone and Roberts (1996) \\
\hline 168 & USA & Barone and Roberts (1983) \\
\hline 144 & USA & Watkinson and Fried (1985) \\
\hline 220 & UK & Barone and Roberts (1983) \\
\hline
\end{tabular}

${ }^{1)}$ Recalculated from $\mathrm{mg} / \mathrm{kg}$ body weight for a woman of $64.7 \mathrm{~kg}$ (Barone and Roberts, 1983). 


\subsubsection{Smoking and alcohol}

Several investigations from different countries have studied the relationship between caffeine intake and the uses of cigarettes and alcohol. Many of the studies have disclosed positive correlations between use of these substances. For example, Hughes and Oliveto (1997) found that American smokers had a higher caffeine intake than ex-smokers, who in turn ingested more caffeine than non-smokers. One hypothesised explanation as to why smokers might consume more caffeinated beverages is that smoking enhances caffeine metabolism. Hence smokers must consume more caffeine than non-smokers to receive a similar serum level (Klesges et al., 1994). Smoking may also act as a behavioural stimulant, producing an increased use of caffeine, alcohol, or other psychoactive substances. There is also a possibility that the relationship between caffeine and smoking may be coincidental and linked to similar situational factors like stress (Scott et al. 1989).

A correlation between dietary caffeine intake and smoking was also indicated also in a German study on 422 males and 315 females aged 20 to 64 years (Brasche et al., 1998). Non-smokers of both genders drank significantly less coffee than smokers. On average, non-smoking men and women drank 401 and $388 \mathrm{ml}$ coffee per day, whereas smokers drank 457 and $491 \mathrm{mg} / \mathrm{day}$, respectively. The tea consumption was lower in nonsmokers than in smokers, but the difference was not significant.

Enhanced caffeine metabolism in smokers as an explanation for the positive correlation between caffeine intake and cigarette smoking is questioned by studies indicating that the relationship between smoking and caffeine may differ depending on whether the source of caffeine is tea or coffee. The results of the Second National Health and Nutrition Examination Survey in the United States indicate that smokers are much more likely to drink coffee. Cigarette smoking and caffeine intake from coffee were positively correlated to total exposure to caffeine. In contrast, smokers were not more likely to consume tea (Klesges et al., 1994). Similar data have been reported by Jarvis (1993). On the other hand, it seems likely that it is the non-methylxanthines of coffee (but not tea), which induces the enzymes that have caffeine as a substrate.

The association between coffee consumption and alcohol intake is also complex. In the United States, Scheiber et al. (1988) found that coffee consumption is correlated with alcohol consumption in a crude analysis, adjusting only for age. If tea consumption and age were both controlled for, the correlation between alcohol and coffee was no longer significant. Tea consumption and alcohol intake were significantly negatively correlated when controlled for age and coffee consumption.

Only a few studies have specifically analysed the correlation between caffeine intake and smoking or alcohol consumption in the Nordic coun- 
tries. In Norway, Solvoll et al. (1989) reported a positive correlation between the habits of drinking coffee and smoking.

Smoking is a confounding factor in many of the studies reviewed in this report. Norwegian investigators have touched upon the question whether pregnant smokers eat differently from pregnant non-smokers (Trygg et al., 1995).

It is well known that smoking during pregnancy represents a health hazard to the foetus, affecting the duration of pregnancy and foetal growth and development. It has been assumed that the nutrition of the foetus is compromised by the combined effect of carbon monoxideinduced hypoxia and reduced placental blood flow caused by the vasoconstrictive effect of nicotine (Ahlsten, 1988). Norwegian investigators have shown that smoking could also indirectly affect the nutritional status of the mother. In this study, two 3-day dietary records were collected during the $17^{\text {th }}$ and $33^{\text {rd }}$ week of pregnancy from 821 pregnant women (Trygg et al., 1995). The smokers (mean consumption 9.8 cigarettes/day) consumed significantly less than non-smokers of bread, cakes and cookies, vegetables, fruits and berries, cheese, yoghurt, low fat milk, juice and tea. But smokers consumed more meat, margarine, whole milk, soft drinks and coffee than the non-smokers on both occasions. Among the food items, coffee came out as the strongest predictor of smoking. Similar differences have earlier been recognised between non-pregnant smokers and non-smokers (Morabia and Wynder, 1990; Larkin et al., 1990; Nuttens et al., 1992). The authors concluded that the diet of the pregnant smokers in the Norwegian study was less nutritious than that of the nonsmokers throughout pregnancy and contained significantly less protein, carbohydrate, dietary fibre, thiamin, riboflavin, vitamin C, calcium and iron as compared with the non-smokers. However, the reason for smokers having a less nutritious diet is not known. It has been speculated that smoking affects the smell and taste, thereby influencing the food choice, but it has also been argued that smokers take dietary advice less seriously than non-smokers.

The development of aversions to or cravings for ingested items during pregnancy is a well-known phenomenon, although the causes of these are not well understood. Interviews of 250 women concerning dietary changes during their pregnancies were undertaken by Hook (1978) immediately after delivery. Of women who regularly drank coffee or alcoholic items prior to conception, almost $30 \%$ reported a significant drop in ingestion during pregnancy. For coffee this change was attributed primarily to "endogenous" factors e.g., provocation of nausea or a loss of taste for the beverage. Concern regarding maternal or infant health was the most frequent reason for decrease in alcoholic beverages, although endogenous factors were also mentioned. Soda beverages were also ingested less frequently. Chocolate was one of the foods for which cravings were frequently cited. 


\subsection{Methods and problems to estimating caffeine intake}

The amount of methylxanthines, primarily caffeine, ingested by people can be estimated in different ways. The methods that give more reliable estimates are often much more difficult to perform. Information on the import or sale of caffeine-containing foods gives a very rough estimate of caffeine exposure in a country. Using this type of trade statistics in combination with the average content of caffeine in the product to calculate per capita caffeine intake gives information that is more useful but far from good. Patterns of caffeine consumption among population groups and individuals can be investigated in epidemiological studies. These are, however, often based on food-frequency questionnaires, a methodology which does not easily allow for a focused investigation of caffeine intake (Scheiber et al., 1988).

The plasma concentration of methylxanthines may be measured to estimate the methylxanthine exposure, but this possibility has not been used very often. The plasma levels can be compared to the reported caffeine intake from a sub-sample of the tested population, thereby providing an estimate of the self-reporting ability of the tested population. A problem with many biomarker studies is that the number of participants often is relatively small, and that there usually is only a single biological sample taken per participant, leading to the question of whether the samples are representative for the subjects or not. For example, the consumption of coffee, tea, and cocoa usually varies widely over time. It differs between seasons and even between the various days of a week (weekday/weekend difference).

\subsubsection{Caffeine content analysis}

When evaluating reported caffeine contents, the method used to obtain these values must be considered. There are several methods to determine the caffeine levels in foods and beverages, and over time more simple and accurate methods of analysis, such as HPLC, have been developed. When estimating caffeine intake, data on caffeine content obtained using new and more precise analytical techniques are more likely to give the true caffeine content. Many older methods that have been used to analyse chocolate products for methylxanthines are, for example, unable to separate caffeine and theobromine. Data derived from measurements using such techniques tended to result in too high concentrations of the studied methylxanthine being registered (Zoumas et al., 1980).

\subsubsection{Self-report reliability}

When estimating caffeine intake, researchers are often forced to trust selfreported intake estimates from study participants. This is often the only 
way, since the number of participants must be relatively large to obtain reliable information. In some surveys, additional studies are performed to validate the self-report reliability among the test subjects (Scheiber et al. 1988, Solvoll et al., 1989, Hughes et al., 1997). James and co-workers (1989) studied the caffeine concentration in salivary samples from test subjects, and found the levels to be significantly correlated with selfreported caffeine intake. However, a substantial imprecision in measurement could be discerned, indicating that the results should be interpreted with caution. Self-reported information on brewing time and the amount of beverage left in the cup after consumption has also been found unreliable (Hughes et al., 1997).

Kennedy et al. (1991) examined the relationship between self-reported intake of caffeine from foods and the actual plasma concentrations of caffeine and its major metabolites. The caffeine intake was estimated based on information regarding the consumption of caffeine-containing beverages and caffeine contents of these beverages obtained from the literature. Plasma levels of caffeine and its metabolites were compared to intake estimates obtained though interviews. The actual plasma concentrations correlated poorly with the caffeine intake reported by the test participants. The poor correlation could be the result of a number of factors such as failure to estimate volume or caffeine concentration of the beverage, consumption of caffeine-containing non-investigated foods, individual differences in caffeine clearance, or poor memory.

It is necessary to distinguish between the reliability of self-reporting in retrospective and in prospective ("diary") studies. The prospective studies are ongoing, and allow considerable practice for the test subjects to improve self-report accuracy over time. In retrospective questionnaires, the respondents usually do not receive any training to improve their selfreporting ability, and the reports are typically brief and general.

\subsubsection{Consumption reported as number of cups}

Very often in epidemiological studies and in larger intake studies the caffeine exposure is measured in terms of consumed cups of coffee, tea, and cocoa. This estimation is rather rough, since the caffeine concentration of the beverage and the cup volume can differ considerably.

When consumption is reported in number of cups, the actual contribution of caffeine to adverse health effects may be hard to distinguish (Gilbert et al., 1976). The number of cups consumed has been identified as a poor index of the caffeine intake - only $42 \%$ of the variability in caffeine intake depended on differences in number of cups (Lelo et al., 1985).

Although coffee contains a relatively high amount of caffeine, it is not possible to approximate total caffeine intake solely by caffeine intake from coffee. The contribution from other caffeine-containing foods, beverages, and drugs has to be accounted for. In the United Kingdom, for 
example, the caffeine intake may mainly emanate from tea rather than from coffee. Soft drinks and cocoa may be the major contributors to caffeine intake among children and teenagers. The actual caffeine exposure may be considerably increased if pharmaceutical drugs containing caffeine are used. Hughes and Oliveto (1997) noted that if caffeine intake were estimated only from coffee consumption, the mean caffeine intake would be underestimated by more than $50 \mathrm{mg}$ in $24 \%$ of the test subjects.

Stavric and co-workers (1988) also showed that the number of cups of coffee is a poor measure of total caffeine intake. These investigators showed that $39 \%$ of subjects consuming 3 cups of coffee would overestimate their consumption, and $36 \%$ would actually have consumed more caffeine than the amount estimated.

\subsubsection{Volume variation of consumed cup}

In the case of hot beverages, the drink is often prepared and consumed in cups or mugs of no standardised size. The volume of the beverage consumed at each occasion is individual and can vary widely (Table 39). Barone and Roberts (1996) claim that a usual cup has a volume from 20 to $190 \mathrm{ml}$, depending on geographic location. Scheiber and co-workers (1988) have studied the type of beaker, mug or cup, and the amount of beverage actually consumed. A mug was estimated to contain 1.5 times the volume of a cup. Mugs were mostly used among the heavy coffee consumers, who altogether representing $35 \%$ of the population sample. $63 \%$ of the subjects drank from cups exclusively. About $15 \%$ of the respondents in their survey also left $20 \%$ of the beverage, but this was found to have less influence on caffeine intake than cup size.

Cup size can be a problem when comparing caffeine intake in different studies. For example, Solvoll et al. (1989) assumed a cup to contain $115 \mathrm{ml}$ of beverage, whereas Bunker and Williams (1979) assumed it to contain $150 \mathrm{ml}$. The different volumes will of course lead to different estimates in caffeine intake. Lelo et al. (1985) observed that almost $60 \%$ of the variability in caffeine intake estimated in their study could be ascribed to differences in volume (mainly due to cup size) and strength of the coffee consumed. When preparing their own beverages at home or at work, people tend to pour more of the beverage into the cup than do commercial establishments (Stavric et al., 1988). There is also a considerable difference between individuals in the amount poured into a cup or beaker (Gilbert et al., 1976). The volume of percolated coffee showed greatest variation, while the volumes of drip or filtered coffee varied less. The median cup sizes of drip or filter and instant coffee were the same (Table 39). 


\subsubsection{Misclassification of test subjects}

The way different subgroups are defined when data are analysed statistically may be a source of error. Hughes and Oliveto (1997) claimed that many of the non-users of caffeine in epidemiological and clinical studies are former users who might have stopped the consumption due to adverse health effects. These former users, placed in the non-user group, might produce false-negative results when considering adverse effects of caffeine on health.

\subsubsection{Time limited surveys}

Considerable variations in coffee intake have been reported during different seasons of the year and also during various periods of life. This has to be taken into consideration when asking about caffeine intake. The difference in consumption between weekdays and weekends must also be taken into account to get a more reliable estimation of the average daily consumption. Higher coffee consumption has been reported on weekdays than on weekends (Scheiber et al., 1988). Thus, for example, if intake estimates are based on data from weekdays only, there could be a significant overestimate in caffeine exposure.

Table 39. Differences in volume of beaker in consumption of tea and coffee.

\begin{tabular}{|l|cc|l|}
\hline Caffeine source & \multicolumn{2}{|c|}{$\begin{array}{l}\text { Volume of serving (ml) } \\
\text { mean }\end{array}$} & \multicolumn{1}{c|}{ range } \\
\hline $\begin{array}{l}\text { Household coffee } \\
(\mathrm{n}=38)\end{array}$ & $223.6 \pm 55.3$ & $25-330$ & Stavric et al. (1988) \\
\hline $\begin{array}{l}\text { Household tea } \\
(\mathrm{n}=20)\end{array}$ & $215.3 \pm 51.1$ & $89-355$ & Stavric et al. (1988) \\
\hline Commercial coffee & $170.8 \pm 7.6$ & $130-205$ & Stavric et al. (1988) \\
\hline Coffee club & $233.6 \pm 30.6$ & $170-280$ & Stavric et al. (1988) \\
\hline $\begin{array}{l}\text { Instant coffee } \\
(\mathrm{n}=75)\end{array}$ & $218.5 \pm 36.3$ & $100-320$ & Lelo et al. (1985) \\
\hline $\begin{array}{l}\text { Brewed coffee } \\
(\mathrm{n}=37)\end{array}$ & $238.7 \pm 38.0$ & $170-290$ & Lelo et al. (1985) \\
\hline Tea ( $\mathrm{n}=14)$ & $208.9 \pm 34.8$ & $180-320$ & Lelo et al. (1985) \\
\hline $\begin{array}{l}\text { Instant coffee } \\
(\mathrm{n}=21)\end{array}$ & 226.7 & $170-285$ & $\begin{array}{l}\text { Gilbert } \text { et al. } \\
(1976)\end{array}$ \\
\hline $\begin{array}{l}\text { Drip or filter coffee } \\
(\mathrm{n}=14)\end{array}$ & 216.7 & $\begin{array}{l}\text { Gilbert } \text { et al. } \\
(1976)\end{array}$ \\
\hline $\begin{array}{l}\text { Percolated coffee } \\
(\mathrm{n}=11)\end{array}$ & 208.3 & $\begin{array}{l}\text { Gilbert } \text { et al. } \\
(1976)\end{array}$ \\
\hline $\begin{array}{l}\text { Tea } \\
(\mathrm{n}=37)\end{array}$ & 213.3 & $\begin{array}{l}\text { Gilbert } \text { et al. } \\
(1976)\end{array}$ \\
\hline
\end{tabular}

\subsection{Total intake of theobromine and theophylline}

The main sources of theobromine are cacao and/or products containing cacao, as well as tea. Cacao and products containing cacao have approximately ten times as much theobromine as caffeine. 
The biological effects produced by a specific amount of theobromine is much more pronounced when the compound is administered as a more or less pure drug, than when the equivalent amount is given in the form of a cacao product. It is not known whether the reduced physiological effect of theobromine in the form of cacao products in comparison to the pure substance is to be attributed to the presence of tannins, the coating in a fat emulsion or to other circumstances. Even after high consumption of chocolate no striking or even detrimental effect of theobromine is noticeable, even in the case of children (Fincke, 1965).

There are very few data on the daily per-capita consumption of theobromine for various age groups. There are data on theobromine intake in the United States via foodstuffs and beverages in 1980, which resulted in an estimated daily per-capita intake of $39 \mathrm{mg}$ (IARC, 1991). 


\section{Pharmacokinetics of methylxanthines}

Because methylxanthines exert several pharmacological actions, which may be therapeutically used, it is only natural that their absorption, fate and excretion in the mammalian organism have attracted special interest. Since this report deals with the assessment of epidemiological studies evaluating the relationship between intake of methylxanthines and adverse effects on women and their foetuses, this chapter is heavily focused on human pharmacokinetics. Some information is also given on the pharmacokinetics of various types of experimental animals. Although bacteria and fungi have been found to be capable of degrading methylxanthines, degradation of methylxanthines by these organisms is not further mentioned in the report. It should be noted that the majority of the studies on absorption, distribution and metabolism of methylxanthines have been performed with pure compounds, not with foods containing these substances.

\subsection{Absorption and distribution in man}

In adult humans, caffeine and the other methylxanthines are rapidly and essentially completely absorbed from the gastrointestinal tract and distributed into body tissues in approximate proportion to their water content. The apparent volume of distribution is around $0.51 / \mathrm{kg}$ for caffeine, $0.3-$ $0.7 \mathrm{l} / \mathrm{kg}$ for theophylline, and $0.6-0.8 \mathrm{l} / \mathrm{kg}$ for theobromine (Yesair et al., 1984). These data are consistent with distribution of the methylxanthines into all tissues in the body. When a substance distributes into total body water, i.e. is in equilibrium with all tissues, the apparent volume of distribution is approximately $0.6 \mathrm{l} / \mathrm{kg}$. Caffeine crosses the placenta, enters gonadal tissue and is secreted into milk (see, section 8.3). Caffeine, and to a lesser extent theophylline, also diffuses though the blood/brain barrier (Somani et al., 1980). There is no accumulation of caffeine in any tissue or organ (for references see Kihlman, 1977; Graham, 1978; Gilbert, 1976; ACSH, 1981; von Borstel, 1983; Yesair et al., 1984).

The peak plasma level of caffeine is reached within 30 min after consumption of the pure compound. After an oral dose of $5 \mathrm{mg} / \mathrm{kg}$ body weight, an average maximum plasma concentration of $10 \mu \mathrm{g} / \mathrm{ml}$ was found in 10 healthy male volunteers, aged 19-30 years (Blanchard and Sawers, 1983). If we assume that one cup of coffee contains $100 \mathrm{mg}$ of caffeine, a dose of $5 \mathrm{mg} / \mathrm{kg}$ (300-350 mg for a $60-70 \mathrm{~kg}$ person) cor- 
responds to about 3 cups of coffee. After the ingestion of one cup of strong coffee, the peak blood plasma level of caffeine appears to be in the order of $6 \mathrm{ug} / \mathrm{ml}$ (Gilbert, 1976). Weinstein and co-workers (1972) observed a peak plasma concentration of $30 \mu \mathrm{g} / \mathrm{ml}$ in 8 human volunteers, who over the period of one month had taken 4 tablets of caffeine per day, each tablet containing $200 \mathrm{mg}$ of caffeine.

Although peak plasma levels of $10 \mu \mathrm{g} / \mathrm{ml}$ and above are not unusual, the concentration of caffeine in plasma does not stay that high for very long. The half-life of caffeine in the blood plasma of adult humans is normally about 3-6 h (Figure 5), with females often having a shorter halflife than males. One of the reasons for the rather wide variation in halflife for caffeine in humans is that different doses of caffeine have been studied. The metabolism of caffeine is dose-dependent (Denaro et al., 1990; Kaplan et al., 1997). In one study where the metabolism of very small doses of radio-labelled caffeine was studied concomitantly with substantially higher doses of non-labelled caffeine, it was observed that the half-life of caffeine after dosing with placebo, $4.2 \mathrm{mg}$ caffeine $/ \mathrm{kg}$ body weight, and $12 \mathrm{mg}$ caffeine/ $\mathrm{kg}$ body weight was 4.0, 6.1 and 8.7 hours, respectively (Danero et al., 1990). Similarly, Kaplan et al. (1997) observed dose-dependent pharmacokinetics of caffeine in a randomized, double blind single-dose crossover study with 250 and $500 \mathrm{mg}$ caffeine.

The half-life of caffeine at the lower dose, 3.94 hours, was shorter than at the double dose, where it was 4.74 hours. The dose-dependent metabolism of caffeine results in the non-linear accumulation of caffeine and metabolites in the body, and may partly explain the inter-individual and within individual responses to caffeine-containing beverages and foodstuffs. It is possible, however, that the peak level in plasma may shift in time by increasing the dose of caffeine, since it is known that the drug affects gastric emptying and intestinal motility.

The half-life of caffeine in human plasma is, however, dependent on a number of other factors, such as age, hormonal status, smoking habits and the presence of other drugs (see, section 8.2). Thus, in the foetus and newborn, which do not possess the liver enzymes that metabolise the drug, caffeine has a much longer half-life. In the newborn it is close to 4 days (Aldridge et al., 1979). Due to the hormonal changes resulting from the use of oral contraceptives or the hormones that accompany pregnan$\mathrm{cy}$, the half-life of caffeine in plasma is prolonged to about $10 \mathrm{~h}$ under these conditions (Yesair et al., 1984; Berger, 1988). Caffeine elimination is essentially unchanged during the first trimester of pregnancy, which is the period of greatest risk for the development of morphologic anomalies. The rate then slows progressively to one-half and then to one- third that in the non-pregnant state during the second and third trimesters, respectively (Aldridge et al., 1981; James and Paull, 1985). Patients with severe liver failure clear caffeine slowly from the plasma, as do persons with a moderate daily alcohol intake. An intake of $50 \mathrm{~g}$ alcohol per day prolongs 
the half-life of caffeine by $72 \%$ and diminishes caffeine clearance by $36 \%$ (George et al., 1986). These results demonstrate that alcohol, in amounts commonly consumed, strongly inhibits the caffeine metabolism. In contrast, the plasma half-life of caffeine is shorter than the 'normal' 3$6 \mathrm{~h}$ in premature and full- term newborns and in young children, in normally ovulating women, and in adult smokers (in comparison to nonsmokers) (Figure 5). The reason for these variations are probably immature, inhibited, or induced biotransformation systems. For references to original articles on this subject, see Aranda et al. (1979a), ACSH (1981), von Borstel (1983), Brazier et al. (1983), Yesair et al. (1984) and Pons et al. (1988).

A "normal" concentration of caffeine in tissues of consumers of caffeinecontaining beverages has been found to be in the range 0.2-2 $\mu \mathrm{g} / \mathrm{ml}$ (von Borstel, 1983). Although individuals vary greatly in their sensitivity to heavy doses of caffeine, toxic symptoms, such as severe restlessness and muscular tension and twitching, do not begin to appear until concentrations rise higher than $30 \mu \mathrm{g} / \mathrm{ml}$ (Rall, 1980). Fatal poisoning in man by ingestion of caffeine is rare (Curatolo and Robertson, 1983). The shortterm lethal dose of caffeine in adult humans appears to be about 5 to $10 \mathrm{~g}$ in a normal sized person. One cup of coffee contains approximately $0.1 \mathrm{~g}$ caffeine.

Since most data on methylxanthine absorption, distribution, and metabolism have been produced after ingestion of pure compounds, Mumford and co-workers (1996) compared caffeine and theobromine absorption after oral administration of capsules, cola beverages and

Figure 5. Average caffeine elimination (half-life) from plasma in humans as a function of age.

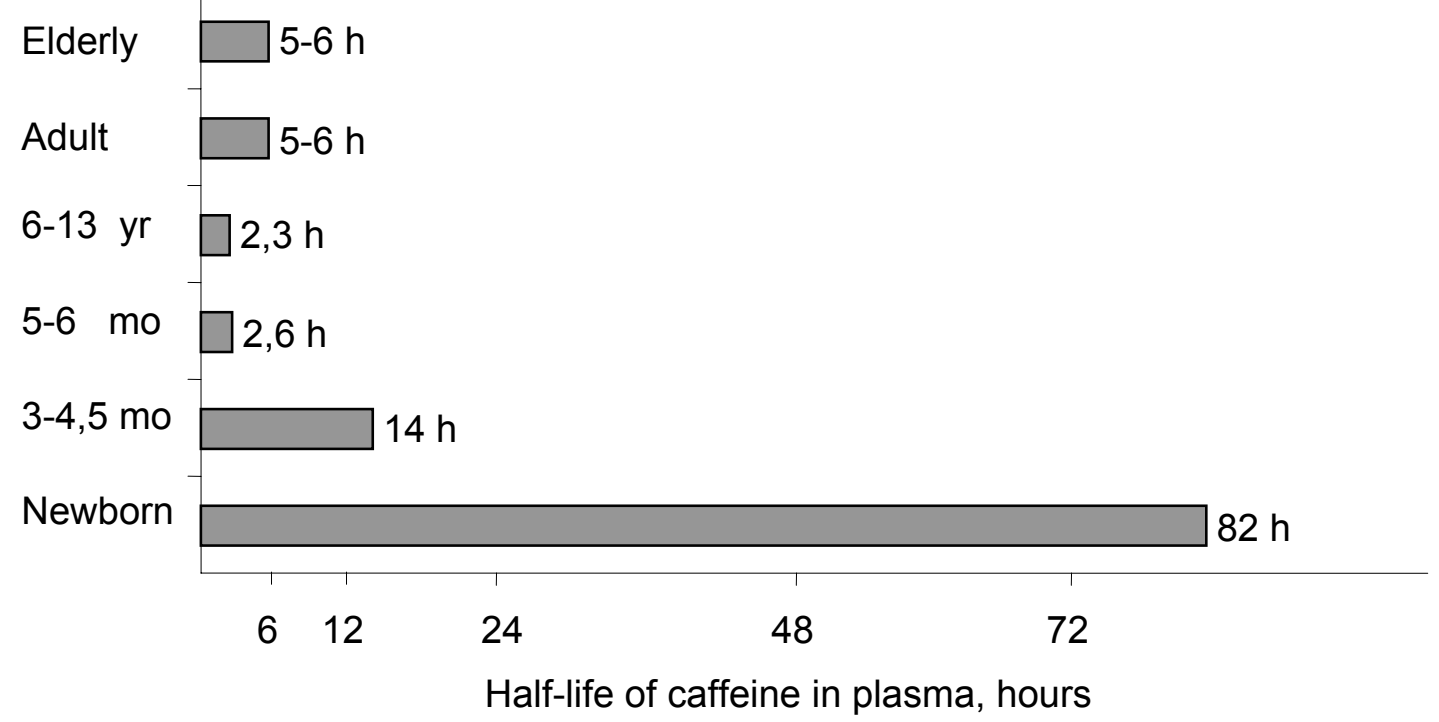


chocolate candy. In comparison to capsules, caffeine absorption from cola and chocolate was delayed, and produced lower maximum caffeine plasma concentrations (around 75\%), which peaked at 1.5-2.0 h after treatment. The maximum caffeine plasma concentration was around 2 $\mu \mathrm{g} / \mathrm{ml}$ after consumption of capsules, $1.57 \mu \mathrm{g} / \mathrm{ml}$ after consumption of cola, and $1.50 \mu \mathrm{g} / \mathrm{ml}$ after consumption of chocolate candy. Theobromine plasma concentrations peaked at $6.72 \mu \mathrm{g} / \mathrm{ml}$ approximately $3 \mathrm{~h}$ after capsule administration. In comparison to capsules, theobromine absorption from chocolate was more rapid, and produced higher maximum theobromine plasma concentrations, which peaked $(8.05 \mu \mathrm{g} / \mathrm{ml})$ approximately 2 $\mathrm{h}$ after treatment. Although absorption is delayed, the results suggest that an ordinary dietary portion of cola or chocolate may result in plasma levels of biological significance (Mumford et al., 1996).

Theophylline and its derivatives have earlier been used in the treatment of many different conditions. Nowadays theophylline is mainly used for treatment of apnea in pre-term infants. Theophylline also has proven efficacy as a bronchodilator in asthma, and formerly was considered first-line therapy. It now has been relegated to a far less prominent role, primarily because of the modest benefits it affords, its narrow therapeutic window, and the required monitoring of drug levels (Hardman et al., 1996). Like caffeine, theophylline is readily absorbed orally - $96 \%$ in $2 \mathrm{~h}$ (Ogilvie, 1978). After passing the placenta, theophylline uses the neonate as a pharmacokinetic deep compartment, with slow elimination of the drug. The neonate serum half-life was found to be 10.6-15.0 h (Dasta, 1979). Theophylline also passes into amniotic fluid and breast milk. When theophylline passes into breast milk, the human infant receives less than $10 \%$ of the maternal dose (Yurchak and Jusko, 1978).

\subsection{Metabolism in the adult human being}

Less than $2 \%$ of the ingested caffeine is excreted unchanged in the urine. At least $98 \%$ is transformed in the liver by demethylation, oxidation at the 8-position in the purine ring, or ring opening between positions 8 and 9 to yield di- and monomethylxanthines, tri-, di-, and monomethyluric acids, and various methylated uracil derivatives (Arnaud and Welsch, 1980; Arnaud 1984, Kalow 1985). Only 1-3 \% is excreted in faeces (Arnaud, 1985). The four different primary biotransformation products of caffeine being formed in humans and the six being formed in rodents are shown in Figures 6 and 7. Most of these metabolites are further metabolised to secondary and to tertiary metabolites. The most 
Figure 6. Metabolism of caffeine in humans. The major metabolic route is indicated by bold arrows.

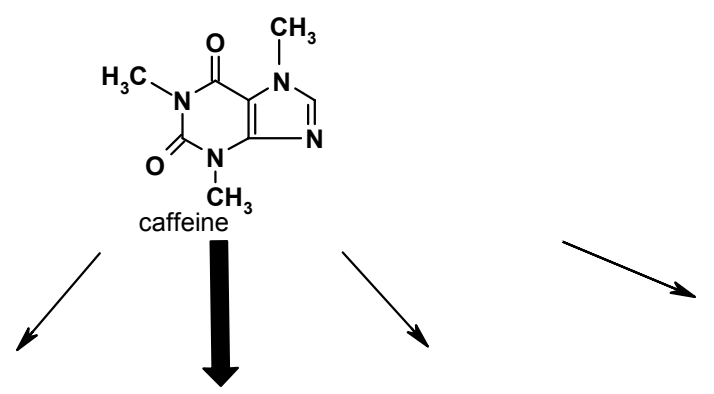<smiles>Cn1c(=O)c2c(nc(O)n2C)n(C)c1=O</smiles>

1,3,7-trimethyluric acid<smiles>Cn1c(=O)[nH]c2nc(O)n(C)c2c1=O</smiles>

1,7-dimethyluric acid<smiles>Cn1c(=O)[nH]c2nc(O)[nH]c2c1=O</smiles>
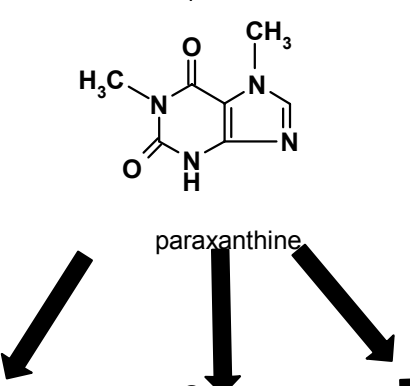

$\mathrm{H}_{3} \mathrm{C}$

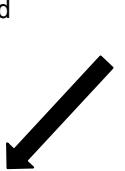

hylxanthine<smiles>Cn1cnc2c1c(=O)[nH]c(=O)n2C</smiles>

theobromine<smiles>Cn1c(=O)[nH]c(=O)c2[nH]cnc21</smiles>

3amethylxanthine<smiles>Cn1cnc2[nH]c(=O)[nH]c(=O)c21</smiles>

7-methylxantine<smiles>Cn1c(=O)c2[nH]cnc2n(C)c1=O</smiles>

theophylline<smiles>Cn1c(=O)c2[nH]c(O)nc2n(C)c1=O</smiles>

1,3-dimethyluric acid<smiles>CC(=O)Nc1c(N)[nH]c(=O)n(C)c1=O</smiles>

important first step in the biotransformation of caffeine in man is the removal of the 3-methyl group to yield 1,7-dimethylxanthine or paraxanthine. Metabolism of caffeine to paraxanthine usually represents almost $80 \%$ of the primary caffeine metabolism (Callahan et al., 1982; Callahan et al., 1983), but different factors affecting this reaction may change the kinetics of caffeine metabolism. Paraxanthine is further oxidized to 1-methylxanthine and 1,7-dimethyluric acid, or is acetylated to 5acetyl-6-formylamino-3-methyluracil (Callahan et al., 1982, Branfman et al., 1983; Tang et al., 1983; Kalow, 1985). A substantial part of the 1methylxanthine formed is hydroxylated to 1-methyluric acid. In human urine paraxanthine represents about $11 \%$ of the total metabolites of caffeine, 1,7-dimethylxanthine $14 \%$, 1-methylxanthine $24 \%$, 5-acetyl-6formylamino-3-methyluracil $10 \%$, and 1-methyluric acid $28 \%$ (Cornish and Chistman, 1957; Branfman et al., 1983; Tang et al., 1983; Callahan et 
al., 1982; Callahan et al., 1983). Minor primary metabolites of caffeine are theobromine, theophylline, and 1,3,7-trimethyluric acid, which are formed in reactions of 1-N-demethylation, 7-N-demethylation, and 8hydroxylation, respectively. The peak plasma concentrations of these caffeine metabolites occur hours after the peak level of caffeine is reached. For example, the highest level of theophylline is reached between 7.5 to $24 \mathrm{~h}$ after ingestion of caffeine (Sved et al., 1976). Some of these products are further metabolised. The two compounds 3-methylxanthine and 1,3-dimethyluric acid is formed from theobromine, and 7methylxanthine from theophylline. However, all together they represent only about $20 \%$ of the total urinary metabolites of caffeine in the average human being.

Kiyohara and co-workers (1999) recently made an interesting observation when they noted an inverse association between coffee consumption and serum concentration of uric acid in a large study of middle-aged Japanese males. No such correlation was observed between consumption of green tea and uric acid level in serum. It is not known whether it is caffeine, caffeine metabolites, or other components of coffee that results in the redistribution of caffeine metabolites in serum, in this study observed as a reduced level of uric acid in the blood.

Our knowledge about the enzymology of caffeine metabolism in man (Table 40) has increased during recent years (Kalow, 1985; Berthou et al., 1988, 1991; Butler et al., 1989; Fuh et al., 1992; Tassaneeyakul et al., 1994; Chung and Cha, 1997). CYP1A2 is the most essential enzyme in the metabolism of caffeine, although other CYP enzymes, flavin monooxygenase, and $\mathrm{N}$-acetyltransferase are also involved in its metabolism (Kalow, 1985; Butler et al., 1989; Berthou et al., 1991; Fuh et al., 1992; Tassaneeyakul et al., 1994; Chung and Cha, 1997). The role of CYP1A2 has been nicely demonstrated with CYP1A2 deficient knockout mice, whose half-life of caffeine is seven times longer, and whose metabolic pattern of caffeine is changed compared to mice expressing the CYP1A2 enzyme in the normal manner(Buters et al., 1996). CYP2E1, CYP3A4 and mutant CYP2D6 are three other CYP enzymes able to metabolise caffeine, but with lower affinity for the compound, and, therefore, have roles at physiological relevant caffeine concentrations in

Table 40. Enzymes involved in primary metabolism of caffeine in humans (Butler et al., 1989; Berthou et al., 1991; Fuh et al., 1992; Tassaneeyakul et al., 1994; Chung and Cha, 1997). Caffeine is oxidised in four primary reactions in humans: N1-, N3- and N7demethylation of caffeine and 8-hydroxylation of caffeine. A - symbolise no catalytic activity and ++++ a very high catalytic activity of the enzyme.

\begin{tabular}{|l|l|l|l|l|}
\hline Enzyme & N1-demethylation & N3-demethylation & N7-demethylation & 8-hydroxylation \\
\hline CYP1A1 & + & + & - & ++ \\
\hline CYP1A2 & ++ & ++++ & + & + \\
\hline CYP2D6met & + & + & + & + \\
\hline CYP2E1 & + & - & + & + \\
\hline CYP3A4 & - & - & - & + \\
\hline flavin mono-oxygenase & + & - & + & - \\
\hline
\end{tabular}


human beings. However, compared to CYP1 A2, these enzymes are quantitatively less important (Tassaneyakul et al., 1994; Berthou et al., 1991). The fifth enzyme in humans that can oxidise caffeine is CYP1A1. However, this enzyme is usually nearly absent in the liver, but may be induced by compounds acting via the Ah-receptor, as, for example compounds occurring in tobacco (Parkinson, 1996). The flavin monoxygenase is able to catalyse N1- and N7-demethylations of caffeine, but not the other primary reactions, whereas all $\mathrm{N}$-acetyltransferases except $\mathrm{N}$ acetyltransferase 2 are unable to conjugate acetyl groups to caffeine (Kalow, 1985; Hardy et al., 1988; Chung and Cha, 1997). N-acetyltransferase 2, on the other hand, forms 5-acetylamino-6-formylamino-3-methyluracil by acetylating paraxanthine (Kalow 1985; Ohsako and Deguchi, 1990; Grant et al., 1991). Human beings are divided into poor and extensive acetylators of paraxanthine. Caffeine is used as a probe to classify individuals to either of these two groups. Thus, it can be concluded that several enzymes are involved in the metabolism of caffeine, but quantitatively CYP1A2 is the key and most important enzyme in the metabolism and kinetics of caffeine. This conclusion is strengthened by in vitro observations of caffeine metabolism in a battery of human cytochome P-450 isoenzyme transformed human B-lymphoblast cell lines (Hu et al., 1996).

It is noteworthy that CYP1A1, CYP1A2, CYP2Dmet and CYP2E1 are able to catalyze several different types of primary metabolic reactions of caffeine. The product pattern produced by CYP1A2 from rats, mice and humans acting on caffeine is different (Fuh et al., 1992). Human CYP1A2 predominantly N3-demethylates caffeine to paraxanthine and produces less than $15 \%$ other products. Paraxanthine is also the major product in the catalytic reaction of mouse CYP1A2 but here theobromine represents about $25 \%$, and theophylline and 1,3.7-trimethyluric acid together about $10 \%$ of the total metabolism. The rat CYP1A2, however, metabolises caffeine to equal parts paraxanthine and theobromine (about $40 \%$ each), less than $20 \%$ theophylline, and only a few per cent 1,3,7trimethyluric acid. The different types of caffeine degradation profiles via CYP1A2 are probably the main reason for the different metabolic pattern of caffeine between species.

Both environmental and host factors may alter the caffeine metabolism (Grant et al., 1983; Kalow 1985). Firstly, cigarette smoking, exposure to polychlorinated biphenyls, or to rifampicin drugs has been shown to increase caffeine metabolism, thereby reducing its half-life (Kalow, 1985; Zevin and Benowitz, 1999). Since they all induce CYP1A2 enzymes in humans, the mechanism for the increased caffeine metabolism is increased amounts of CYP1A1 and CYP1A2 in the liver. In agreement with this notion, other CYP1A enzyme inducing xenobiotics, like omeprazol, cause a similar type of effect (Nousbaum et al., 1994; Kinizig-Schippes et al., 1999). Secondly, a prolonged half-life of caffeine is observed when the catalysis via CYP1A2 is reduced, either due to inhibition by the si- 
multaneous presence of specific CYP1A2 xenobiotic inhibitors or due to reduced amount of the enzyme being present in the liver (Kalow, 1985). Of course, diseases that have damaged the liver may also decrease caffeine metabolism. This has been reported to be the case with liver cirrhosis, viral hepatitis, and alcohol-induced fatty liver (Kalow, 1985). Pregnancy and use of oral contraceptives are also known to increase the half-life of caffeine, due to decreased expression/activity of CYP1A2 in the liver (Kalow, 1985). The half-life of caffeine has been reported to increase seven times during pregnancy (Kalow, 1985). Thirdly, partly due to the genetic traits in humans, an inter-individual variation of caffeine metabolism exists (Kalow, 1985; Hardy et al., 1988). Caffeine acetylation is used as a probe method to determine if an individual is a rapid or a slow acetylator, although it is actually the acetylation of paraxanthine that is quantified. Among Scandinavians, 36 - $49 \%$ are rapid acetylators of caffeine (Wadelius et al., 2000). As a result of slow acetylation (in comparison to fast acetylation) the amount of 5-acetyl-6-formylamino-3-methyluracil is decreased in urine and the amount of 1-methylxanthine and 1-methyluric acid is increased. Slow acetylators seem to have a longer half-life of caffeine than fast acetylators. Polymorphism of CYP1A2 is not known but there is probably a Gaussian type of distribution of this enzyme in the human population.

No difference in CYP1A2-dependent caffeine metabolism could be found during the menstrual cycle in healthy women (Zaigler et al., 2000). When the spectrum of caffeine metabolites in the urine from pregnant women was compared with the spectrum in urine from the same women after pregnancy or with the spectrum in urine from (other) non-pregnant women, it was noted that the pregnant women produced smaller amounts of 1-methylxanthine and 1-methyluric acid, whereas they tended to excrete more of the other metabolites (Scott et al., 1986; Tsutsumi et al., 2001). It was suggested that the observations were a result of hormonal influences on the hepatic caffeine metabolising enzymes. CYP1A2 activity decreased not only in late pregnancy, but also in early and middle pregnancy. Similarly, the metabolic rate ratio for $\mathrm{N}$-acetyltransferase 2 in the early phases of pregnancy was significantly lower than after delivery (Tsutsumi et al., 2001). The longer plasma half-lives for caffeine in women on oral contraceptives, referred to above, were mainly attributed to lower plasma paraxanthine levels over the first $48 \mathrm{~h}$ after dose administration (Callahan et al., 1983). The removal of the 3-methylgroup from caffeine to then form paraxanthine was still the preferential path of metabolism in these women, but the rate of demethylation was slower.

There are more studies on the pharmacokinetics of theophylline than there are on theobromine, probably because the former is used for the treatment of asthma. The biological half-life of theophylline intravenously injected into adult volunteers ranged from 1.4 to $7.9 \mathrm{~h}$, reflecting a rather broad inter-individual difference in the elimination rate of this 
methylxanthine (Ellis et al., 1976). Kadlec et al. (1978) found a mean half-life of $4.9 \mathrm{~h}$ for theophylline elimination in a population of 54 children who were between three months and six years old and were given the compound orally. The half-life was much longer, $30 \mathrm{~h}$, in six premature newborn children 3 to 15 days old (Aranda et al., 1976). The main pathway of theophylline metabolism in adult humans agrees fairly well with the pathway of caffeine metabolism. Thus, based on a number of studies, the average amount of the most important products found in human urine after theophylline ingestion were unchanged theophylline (11\%), 1,3-dimethyluric acid (38\%), 1-methyluric acid (19\%), and 3methylxanthine (16\%) (Tserng et al., 1981). Whereas 3-methylxanthine and 1,3-dimethyluric acid were found to be end products, 1-methyluric acid was produced from 1-methylxanthine. In premature newborns an additional metabolic pathway, $\mathrm{N}$-methylation of theophylline to caffeine, has been demonstrated. The amount of caffeine recovered in urine and plasma of infants amounted to $10-20 \%$ of the total metabolic products. The major urinary metabolite of these infants was 1,3-dimethyluric acid but substantial amounts of 1-methyluric acid was also found. This observation indicates that ring oxidation at $\mathrm{C}-8$ readily occurs in these subjects (Tserng et al., 1981). These findings of theophylline metabolism have been confirmed in studies on premature new-borns, a young infant, children and adults (Bonati et al., 1981).

Shively and co-workers (1985) studied the disposition of theobromine in 12 normal men who had been given the compound orally. The plasma half-life was somewhat longer than that of caffeine, being around $10 \mathrm{~h}$. $72 \mathrm{~h}$ after ingestion, $18 \%$ was found in urine as unchanged theobromine, $42 \%$ as 7 -methylxanthine, $20 \%$ as 3 -methylxanthine, $10 \%$ as $7-$ methyluric acid, and $10 \%$ as 6-amino-5[N-methylformylamino]-1methyluracil. Similar observations were made by Rodopoulos et al. (1996). The latter investigators also studied the metabolism of theobromine in saliva. In addition to theobromine, 7-methylxantine and 3methylxanthine were consistently found. Small amounts of 6-amino-5[Nmethylformylamino]-1-methyluracil and 7- methyluric acid were also detected. The levels of theobromine were similar in plasma and saliva, whereas the saliva concentration of 7-methylxantine and 3methylxanthine was 2/3-3/4 of that in plasma. In total, the studies of Rodopoulos et al. (1996) indicated that N3-demethylation of theobromine accounted for most of the urinary metabolites (58 $7 \%$ ), with N7demethylation ( $27 \pm 6 \%$ ), C-8 oxidation of 7-methylxantine (22 $\pm 4 \%$ ), and the formation of 6- amino-5[N-methylformylamino]-1-methyluracil being other important metabolites in urine.

When considering the possible genetic hazards involved in the consumption of caffeine-containing beverages, it is important to note that caffeine is able to enter the gonads and foetus, where it reaches about the same concentration as in plasma. As stated by Goldstein and Warren: "If 
a man or woman drinks coffee or strong tea several times daily, his (or her) germ cells are bathed in a caffeine solution of fluctuating concentration, estimated as equivalent to a continuous exposure at about $1 \mu \mathrm{g} / \mathrm{ml}$ " (Goldstein and Warren, 1962). Fabro and Sieber (1969) found that caffeine is able to pass from the maternal plasma into the uterine secretion, penetrating the blastocyst before implantation.

\subsection{Methylxanthines during pregnancy, in the foetus, and in the newborn}

As mentioned above, the half-life of caffeine is doubled or tripled during pregnancy due to the hormonal changes that take place in the body of the woman. Similarly, the half-life of caffeine in saliva increases from an average of $3 \mathrm{~h}$ for non-pregnant women to $10.5 \mathrm{~h}$ during the last 4 weeks of pregnancy (Knutti et al., 1982). The prolonged half-life results in the accumulation of caffeine in the body, unless the consumption is reduced appropriately. The increase is, however, progressive, and may in part be apparent during the first phase of pregnancy. The significantly increased half-life of caffeine during pregnancy is expected to significantly increase the tissue concentration of caffeine. It has been calculated that the tissue level amount increases by three when the half-life of caffeine is increased from 4 to $12 \mathrm{~h}$. Thus, adverse effects of caffeine could be produced after the consumption of less than eight cups of coffee (Knutti et al., 1982).

\subsubsection{Methylxanthine exposure of the foetus}

Because methylxanthines readily cross the placenta, the exposure of the foetus to methylxanthines is dependent on the consumption habits of the pregnant woman. As $0.2-2 \mu \mathrm{g} / \mathrm{ml}$ is a normal concentration of caffeine in the tissue of consumers, similar or higher amounts could be expected to be present in the foetus.

Caffeine metabolism was studied in human liver microsomes from foetuses, neonates, infants and adults (Cazeneuve et al., 1994). The formation of dimethylxanthines (paraxanthine, theophylline and theobromine) was significantly less in foetuses, neonates and infants than in adults, as observed previously in vivo, whereas the formation of 1,3,7trimethyluric acid (C-8 hydroxylation) was not significantly different between the age groups. In the foetal samples, the production of total dimethylxanthines, as well as the individual metabolites paraxanthine and theobromine, decreased significantly with increasing gestational age. Only CYP3A has previously been detected in human foetal livers; neither CYP1A1 nor CYP1A2 were present, suggesting that the metabolic pathways of caffeine depend on CYP3A at this stage of development, and that this metabolism is not very efficient. 
Most measurements of foetal exposure have been done at the time of delivery by analysing the umbilical cord blood. Eleven of seventy-nine pre-term infants had detectable caffeine concentrations ranging from 1.1 to $3.7 \mu \mathrm{g} / \mathrm{ml}$ (mean: 2.5 \pm 0.8 ) in cord blood (McCulloch et al., 1989). Caffeine has also been detected in the majority of blood samples from the cord blood of infants in full-term pregnancies (Dumas et al., 1982; Van't Hoff, 1982; Honsky and Emory, 1987). Amounts commonly detected are at a level of a few $\mu \mathrm{g} / \mathrm{ml}$. In one of these studies, where the women on average ingested $290 \pm 230 \mathrm{mg}$ caffeine per day, a quarter of the babies had a plasma caffeine concentration greater than $3.0 \mu \mathrm{g} / \mathrm{ml}$, which was the minimum concentration reported to stimulate respiration (Van't Hoff, 1982). The highest caffeine concentration measured was $12 \mu \mathrm{g} / \mathrm{ml}$, which could be compared to the lowest concentration suggested to give rise to toxicity, which is $50 \mu \mathrm{g} / \mathrm{ml}$. Similar data were reported by Honsky and Emory (1987) in cord blood serum taken at the birth of 40 full-term infants. They found an average of $1.2 \mu \mathrm{g}$ caffeine per $\mathrm{ml}$ (range: 0.065-5.69 $\mu \mathrm{g} / \mathrm{ml})$. The studied women reported a mean intake of $45.9 \mathrm{mg}$ caffeine on the day of testing, and $49.0 \mathrm{mg}$ on the day before testing.

One example which illustrates that the caffeine level in the newborn (umbilical cord blood) is dependent on the life-style of the mother involves the observation that the mean caffeine plasma concentration was lower in women using cocaine than in women not using this drug (Dempsey et al., 1998).

Caffeine has not only been detected in cord blood but also in the meconium, a dark greenish mass of desquamated cells, mucus, and bile that accumulates in the bowel of a foetus and is discharged shortly after birth (Baranowski et al., 1998). The average amount of caffeine detected in such material was $21.9 \pm 10.0 \mathrm{ng} / \mathrm{g}$ (range 10-45 ng/g).

A case involving a premature infant with an unusually high concentration of transplacentally acquired caffeine was reported by Khanna and Somani (1984). On the fifth day after birth, the caffeine concentration in the serum of this infant was $40.3 \mu \mathrm{g} / \mathrm{ml}$, and at birth it must have been considerably higher. In spite of this high concentration, no evidence of toxicity was observed. The mother of this infant drank 24 cups of coffee per day during pregnancy. Blood samples drawn on the tenth day after delivery revealed a caffeine concentration of $14.6 \mu \mathrm{g} / \mathrm{ml}$. In the postpartum period, the mother was drinking less than six cups of coffee per day.

There is very little data on theophylline and theobromine. Haley (1983) has reviewed the earlier pharmacokinetic studies involving theophylline. Interestingly, Aranda et al. (1979b) observed that the predominant pathway of theophylline metabolism in the foetus seems to be a methylation reaction producing caffeine, rather than a demethylation reaction producing paraxanthine. In their study, liver explants from foetuses produced caffeine when incubated with theophylline. 


\subsubsection{Methylxanthine exposure of the newborn}

Since a high proportion of newborn babies are breast-fed, considerable attention has been directed towards neonatal exposure to methylxanthines (caffeine in particular) via breast milk. It has been shown that the time courses for caffeine and its primary degradation products in milk parallel their respective serum time profiles (Stavchansky et al., 1988; Oo et al., 1995). Tyrala and Dodson (1979) reported that peak concentrations of caffeine in serum and breast milk were attained 60 minutes after the oral intake of caffeine. The peak concentration in milk was lower than in serum. Caffeine was associated with the cream layer of the milk, and correlated with the butterfat content. Breast milk collected during the first hour after the mothers consumed 1 cup of coffee (with $150 \mathrm{mg}$ caffeine) contained approximately $1.5 \mu \mathrm{g} / \mathrm{ml}$ caffeine, that is, around $1 \%$ of the amount ingested by the mother. These observations were confirmed by Berlin et al. (1984) on studies of fifteen lactating women and their nursing infants (between 2 weeks and 9 months old). The mothers ingested various but known amounts of a caffeinated beverage. Caffeine was detected in saliva and breast milk from 11 of the 15 women as soon as 15 minutes after consumption. Peak levels in milk $(2.09-7.17 \mu \mathrm{g} / \mathrm{ml})$ and saliva $(1.24-9.22 \mu \mathrm{g} / \mathrm{ml})$ were achieved within 1 hour, and the potential exposure of the nursing infant to caffeine was 0.06 to $1.5 \%$ of the maternal dose estimated (based on a consumption of $720 \mathrm{ml}$ breast milk per day). On average elimination half-lives were $4.0 \pm 3.7 \mathrm{~h}$ for saliva and $6.1 \pm 4.4 \mathrm{~h}$ for milk. Oo et al. (1995) reported a $5.5 \pm 1.8 \mathrm{~h}$ half-life for caffeine in breast milk six to twenty-eight weeks post partum. The corresponding half-lives of paraxanthine, theobromine, and theophylline were $6.7 \pm 2.8 \mathrm{~h}, 12 \pm 2.5 \mathrm{~h}$ and $8.2 \pm 3.7 \mathrm{~h}$, respectively (Oo et al., 1995). Other investigations have confirmed that the longer half-lives for theobromine and thephylline in breast milk as compared to caffeine. Berlin (1981) determined the half-life of theobromine in saliva and breast milk after consumption of a single chocolate bar. The mean saliva halflife from ten mothers was 9.80 hours, a figure that correlates well with data published by Drouillard et al. (1978). The half-life in milk was 14.7 hours. Yurchak and Jusko reported a 4.0 hour half-life of theophylline in breast milk, with the peak level occurring one to three hours after the intake of theophylline. Whereas theophyllline in plasma to $50 \%$ was bound to proteins, there was essentially no binding to proteins in milk.

Using the data of Oo et al. (1995) on the pharmacokinetics of methylxanthines in mother's milk, and assuming neonatal milk consumption to be $150 \mathrm{ml} / \mathrm{kg} /$ day, the newborn would ingest an equivalent of $18 \%$ of the maternal caffeine dose (on a body weight basis). Around 7\% of this $18 \%$ would be caffeine. Aranda et al. (1979a) and Le and Billon (1987) reported slightly lower estimates for caffeine. Since the demethylated metabolites of caffeine possess considerable pharmacological activity (Soyka, 1979; Karlsson et al., 1985), and the newborn may accumulate methyl- 
xanthines due to the slow metabolism of particularly caffeine, the impact of their ingestion by the newborn following maternal caffeine should be addressed further (Oo et al., 1995). Data on caffeine excretion into breast milk similar to the data reported by Oo et al. (1995), were obtained by Ryu (1985a, 1985b).

In a 3 day study on lactating mothers from different ethnic and socioeconomic backgrounds who were given no specific dietary advice, the methylxanthine levels in breast milk were $0.46-0.65 \%$ of the ingested amount of caffeine, $60 \%$ of the ingested amount of theophylline, and 3.4$5 \%$ of the ingested amount of theobromine (Blanchard et al., 1992). Although caffeine is excreted to a limited extent in breast milk, and the dose of caffeine presented to the infant is generally regarded as small (i.e. $<5 \%$ of maternal dose), clinical concern continues to focus on the inability of the neonate to metabolise caffeine. The newborn and, in particular the premature newborn, is at greater risk of accumulating caffeine compared to adults, since a newborn's ability to metabolise methylxanthines may not be fully developed.

In cases of repeated consumption of caffeine-containing beverages by the mother, the amount of caffeine accumulated by the baby depends on several factors. These factors are the average caffeine concentration in the mother's serum and breast milk while nursing, the amount of milk ingested by the baby, the absorption of caffeine by the infant, and, most important, the baby's rate of caffeine elimination. Caffeine elimination in newborns varies from one infant to another, and is very slow in the premature or full-term newborn human infant (Tyrala and Dodson, 1979; Le Guennec and Billon, 1987; Parsons and Neims, 1981).

There is no real consensus on the amount of caffeine, which is absorbed by the infant from breast milk (for references, see Nehlig and Debry, 1994a, 1994b). According to the studies of Blanchard et al. (1992), an infant weighing $4 \mathrm{~kg}$ would absorb only $3.0 \mathrm{mg}$ methylxanthine/ $\mathrm{kg}$ body weight/day. Those quantities are well below the dose of caffeine used in apnea therapy. Analytical data show that methylxanthines can be detected in the infant's serum only if the mother has ingested a relatively large quantity of the compounds (Ryu, 1985a). Usually the amount of caffeine ingested is considered too small to induce any measurable clinical effects. Yet irritability and insomnia are observed in some breast-fed babies when their mothers have ingested coffee, beverages and/or medication with a high caffeine content (Rivera-Calimlin, 1977; Hill et al., 1977; Bailey et al., 1982; Lawrence, 1989).

Less than one month after delivery, Ryu (1985b) measured the caffeine content of breast milk in 9 lactating women who ingested known amounts of caffeine over 9 days ( 5 days $750 \mathrm{mg} /$ day, 4 days $0 \mathrm{mg} /$ day), and in the serum of their infants. On the fifth day, breast milk contained on average $4.3 \mu \mathrm{g}$ caffeine $/ \mathrm{ml}$ milk (range: undetectable $-15.7 \mu \mathrm{g} / \mathrm{ml}$ ), and the sera of the infants contained $1.4 \mu \mathrm{g} / \mathrm{ml}$ (range: undetectable -2.8 
$\mu \mathrm{g} / \mathrm{ml}$ ). The reduction in the serum level of caffeine in the infants was modest after the mothers' four days on a caffeine free diet. When similar studies were performed on two older infants, the caffeine concentration in milk consumed at the end of the caffeine diet period was 13.4 and 28.6 $\mu \mathrm{g} / \mathrm{ml}$, respectively. At that time the concentration in infants' sera was undetectable in one newborn and $3.2 \mu \mathrm{g} / \mathrm{ml}$ in the other. Caffeine could not be detected in breast milk or in the infant serum of these two subjects after four days on a caffeine free diet.

Le Guennec and Billon (1987) have reported data that indicate that the normal maturation process of caffeine metabolism by hepatic cytochome P-450 is inhibited or repressed in breast-fed infants as compared to formula-fed infants. At an age of 47 to 50 weeks, the breast-fed infants had a caffeine half-life of $76 \pm 13 \mathrm{~h}$, whereas that of formula-fed infants was $21 \pm 28 \mathrm{~h}$. The corresponding values for infants 51 to 54 weeks old were $54 \pm 9 \mathrm{~h}$ and $16 \pm 13 \mathrm{~h}$, respectively. Thus, some components of human milk (free fatty acid, lipase activity, or other factors) may inhibit or repress the postnatal normal maturation process of caffeine metabolism.

Aldridge and co-workers (1979) studied the concentration of caffeine and its metabolites in the urine of breast-fed newborns as a function of age. During the first month of life, caffeine accounted for more than $85 \%$ of the identifiable products in urine. Caffeine remained the predominant component for the first 3 months, but its percentage gradually decreased to the adult value of less than $2 \%$ by the age of 7 to 9 months. The change was a result of increased metabolite production. The adult metabolite pattern of partially demethylated xanthines and ureates was attained by 7 to 9 months. The data indicate that the approximately 4 days long halflife of caffeine characteristic of the newborn depends in large part on a slow urinary excretion of the unchanged drug, since there is little or no metabolism. The subsequent decrease in the half-life to about $4 \mathrm{~h}$ by the age of 8 months correlates closely with the rise in metabolite production.

As a consequence of the slow metabolism, the steady-state concentrations of caffeine reached in the newborn may approach maternal concentrations despite the fact that the infant receives less than $10 \%$ of the maternal dose via nursing (Oo et al., 1995). However, neonatal risk assessment should consider not only the dose of the parent drug, but also the exposure/dose of active metabolites and the ability of the neonate to clear xenobiotics.

The best current example of the clinical importance of the development of hepatic xenobiotic cytochome P450s is CYP1A2 (Oesterheld, 1998), which is strongly related to the metabolism of caffeine and theophylline. Several CYP isoforms are involved in the metabolism of caffeine and theophylline ( $\mathrm{Gu}$ et al., 1992). Although CYP1A2 is not present in any quantity during foetal life (Ratanasavanh et al., 1991), foetal tissue can demethylate caffeine in vitro (Cazenauve et al., 1994). CYP3A7 may be the cytochome enzyme responsible, as both the level of 
CYP3A7 and the demethylation capacity decline in late pregnancy (Cazeneuve et al., 1994; Kitada et al., 1987). Clinical documentation for CYP1A2's gradual emergence in the early months of postnatal life is widely available because theophylline and caffeine are extensively used for the treatment of apnea in premature deliveries, newborns, and infants. In premature infants, caffeine is only metabolised to theophylline and is to a large extent excreted unchanged in the urine (Berthou et al., 1988). When CYP1A2 develops after the third to fifth month of life (Sonnier and Cresteil, 1998), N-3 and N-7 demethylations begin, and the infant demonstrates the metabolic pattern that characterises mature hepatic metabolism (Berthou et al., 1988; Kraus et al., 1993; Cazeneuve et al., 1994). Hydroxylation capability matures as early as one month in some children, and may be higher in infants than in adults. N-1 Demethylation is unchanged throughout the first 19 months of life (Carrier et al., 1988). Why the N-1 demethylation pathway and N-7 demethylation pathway should differ in maturation despite being serviced by the same CYPs is not known, but may be related to the different catalytic rates for dissimilar reactions (Oesterheld, 1998). In addition to the caffeine metabolites that characterise the adult, a new uracil derivative in premature infants, 6amino-5-[N-methylformylamino]-1,3-dimethyluracil, has been identified (Gorodischer et al., 1986).

Data on theophylline clearance support the CYP maturation process summarised for caffeine above. In newborns, theophylline is handled via two processes: it is cleared by the kidney as unchanged drug, and it is methylated at the 7 position to caffeine (Troger and Meyer, 1995). Clearance of theophylline reaches adult values 4 to 5 months postnatally, and is primarily related to the maturation of the CYP1A2 pathway (Kraus et al., 1993). Theophylline metabolism is greatest from 3 to 5 years of age, and decreases by $50 \%$ between 8 and 16 years of age before reaching adult capabilities (Troger and Meyer, 1995).

The methylation of theophylline to caffeine has been shown in newborn infants receiving therapeutic doses of theophylline orally for the treatment of apnea (Bory et al., 1978, 1979; Boutroy et al., 1979a, 1979b; Bada et al., 1979). In adults receiving a similar theophylline therapy for apnea, only about $6 \%$ of the theophylline dose is converted to caffeine (Tang-Liu and Riegelman, 1981). In the newborn, caffeine will accumulate, but in the adult, the caffeine produced is subsequently metabolised further to a series of degradation products.

\subsection{Absorption and distribution in experimental animals}

A number of pharmacokinetic studies have also been performed with experimental animals. The results of a subjective selection of these pharmacokinetic studies are summarised in Table 41. The data in the table 
agree fairly well with what has been stated above for humans. Thus, the data show that (1) the absorption of caffeine from the gastrointestinal tract is rapid and complete; (2) the absorbed caffeine is distributed in various tissues in approximate proportion to their water content; (3) within the tissues caffeine is rapidly broken down, with the biological half-life varying from 0.8 to $2 \mathrm{~h}$ in rats to 11 to $12 \mathrm{~h}$ in squirrel monkeys, and pigs - the half-lives in mice, hamsters, rabbits, and monkeys laying in between; (4) the main metabolite in the tissues appears to be 1,7dimethylxanthine, i.e. paraxanthine (the concentration of paraxanthine never exceeding that of caffeine), whereas the degree of degradation and the degradation products excreted in the urine seem to vary considerably between the different species studied: the smallest amount (1\%) of unchanged caffeine is found in humans, the largest (9\%) in the rat; (5) there are differences between strains.

The long biological half-life of caffeine in pigs, and squirrel monkeys has different causes. Whereas in the pig the large fat deposits retain caffeine, the squirrel monkeys appear to have some enzymatic defect, which makes them incapable of metabolising caffeine effectively (Burg et al., 1974).

Galli et al. (1975) injected radiolabelled caffeine to pregnant rats, and observed the compound and metabolites diffuse into foetal tissues and accumulate in the foetal brain.

\subsection{Metabolism in experimental animals}

Most studies of caffeine breakdown in mammals other than humans have been performed in the rat. Similar metabolic reactions to those in humans seem to occur in experimental animals. Caffeine was eliminated by first-order kinetics in humans, monkeys, rabbits, rats and mice (Bonati et al., 1984-85). However, there are quantitative differences, and additional metabolic reactions of caffeine occur in experimental animals such as rat, mouse and hamster (Figure 7). Firstly, in rats, mice, and hamsters the metabolic pathway via paraxanthine is still the major one but quantitatively less important than in humans, because in rats about 
Table 41. Caffeine metabolism in mammals. References are given within brackets.

\begin{tabular}{|c|c|c|c|c|c|c|c|c|}
\hline \multirow[t]{2}{*}{ Species } & \multirow{2}{*}{$\begin{array}{l}\text { Absorption } \\
\text { from gastrointestinal } \\
\text { tract }\end{array}$} & \multirow{2}{*}{\begin{tabular}{|l} 
Distribution \\
in tissues
\end{tabular}} & \multicolumn{3}{|c|}{ Concentration after 'normal' consumption in: } & \multirow{2}{*}{$\begin{array}{l}\text { Biological } \\
\text { half-life (h) }\end{array}$} & \multirow{2}{*}{\begin{tabular}{|l} 
Main \\
metabolite(s) in tissues
\end{tabular}} & \multirow{2}{*}{$\begin{array}{l}\text { Main metabolite(s) } \\
\text { in urine (\% of ingested caffeine) }\end{array}$} \\
\hline & & & Plasma & Ovary, testis and fetus & $\begin{array}{l}\text { Preimplantation blasto- } \\
\text { cyst }\end{array}$ & & & \\
\hline Man & $\begin{array}{l}\text { rapid and complete } \\
\text { (1) }\end{array}$ & & $\begin{array}{l}0.5-5 \mu \mathrm{gg} / \mathrm{ml} \\
(1,2)\end{array}$ & Same as plasma (2) & & $\begin{array}{l}3.5 \mathrm{~h} \text { in plasma } \\
\text { (1) }\end{array}$ & $\begin{array}{l}\text { 1,7-dimethylxanthine } \\
\text { (3) }\end{array}$ & \begin{tabular}{|l|} 
1-methyluric acid, $28 \%$ \\
1 -methylxanthine, $21 \%$ \\
5 -acetylamino-6-amino-3-methyluracil, \\
$13 \%$ \\
1,7 -dimethyluric acid, $9 \%$ \\
1,7(3)-dimethylxanthine, $8 \%$ \\
a diaminouracil metabolite, $5 \%$ \\
1,3-dimethyluric acid, 3\% \\
3-methylxanthine, $3 \%$ \\
unchanged caffeine, $2 \%(4)$ \\
\end{tabular} \\
\hline Mouse & $\begin{array}{l}\text { Rapid and complete } \\
(5,14)\end{array}$ & $\begin{array}{l}\text { Appears in all tissues } \\
\text { within } 5 \text { min. Distributed in } \\
\text { proportion to tissue water } \\
\text { only at } 1 \mathrm{~h} \text { after dosage, } \\
\text { entering and leaving } \\
\text { various organs at different } \\
\text { rates (5) }\end{array}$ & & & & $\begin{array}{l}3 \mathrm{~h} \text { maximum in } \\
\text { organ (5) }\end{array}$ & $\begin{array}{l}\text { 1,7-dimethylxanthine } \\
\text { (5) }\end{array}$ & \begin{tabular}{|l|} 
polar metabolites, $28.7 \%$ \\
1,7-dimethylxanthine, $16.9 \%$ \\
amino 1,3,7-trimethyl ruacil derivative, \\
$11.6 \%$ \\
1-methyluric acid, $9.8 \%$ \\
1,3-dimethyluric acid, $7.9 \%$ \\
1-methylxanthine, $7.2 \%$ \\
1,7-dimethyluric acid, $7.0 \%$ \\
trimethyluric acid, $5.6 \%$ \\
amino 1,7-dimethyl uracil derivative, $1.7 \%$ \\
1,3 -dimethylxanthine, $0.8 \%$ \\
trimethylallantion, $<0.5 \%$ \\
unchanged caffeine, $2.2 \%$ (14) \\
\end{tabular} \\
\hline Rat & $\begin{array}{l}\text { Rapid and complete } \\
\text { (14) }\end{array}$ & Very rapid $(7)$ & & & & $\begin{array}{l}0.8-2 \mathrm{~h} \text { depen- } \\
\text { ding on dose } \\
(7,8)\end{array}$ & & \begin{tabular}{|l|} 
amino $1,3,7$-trimethyl ruacil derivative, \\
22.6\% \\
1,7-dimethylxanthine, $18.2 \%$ \\
trimethyluric acid, $9.7 \%$ \\
1,3-dimethylxanthine, $8.1 \%$ \\
polar metabolites, $7.9 \%$ \\
1-methyluric acid, $6.5 \%$ \\
1-methylxanthine, $5.8 \%$ \\
trimethylallantoin, $5.4 \%$ \\
1,3-dimethyluric acid, 5.3 \\
1,7-dimethyluric acid, 4.1\% \\
amino 1,7-dimethyl uracil derivative, 3.0\% \\
unchanged caffeine, 3.1\% (14) \\
\end{tabular} \\
\hline $\begin{array}{l}\text { Chinese } \\
\text { hamster }\end{array}$ & $\begin{array}{l}\text { Rapid and complete } \\
\text { (14) }\end{array}$ & $\begin{array}{l}\text { Small quantities appear in } \\
\text { all tissues (14) }\end{array}$ & & & & & & \begin{tabular}{|l|} 
1,7-dimethylxanthine, $25.6 \%$ \\
1-methylxanthine, $12.5 \%$ \\
amino 1,3,7-trimethyluracil derivatives, \\
$11.9 \%$ \\
amino 1,7 -dimethyl uracil derivative, $10.6 \%$ \\
1-methyluric acid, $10.5 \%$ \\
polar metabolites, $10.5 \%$ \\
trimethyluric acid, $7.2 \%$ \\
\end{tabular} \\
\hline
\end{tabular}




\begin{tabular}{|c|c|c|c|c|c|c|c|c|}
\hline \multirow[t]{2}{*}{ Species } & \multirow{2}{*}{$\begin{array}{l}\text { Absorption } \\
\text { from gastrointestinal } \\
\text { tract }\end{array}$} & \multirow{2}{*}{\begin{tabular}{|l|} 
Distribution \\
in tissues
\end{tabular}} & \multicolumn{3}{|c|}{ Concentration after 'normal' consumption in: } & \multirow{2}{*}{$\begin{array}{l}\text { Biological } \\
\text { half-life }(\mathrm{h})\end{array}$} & \multirow{2}{*}{\begin{tabular}{|l} 
Main \\
metabolite(s) in tissues
\end{tabular}} & \multirow{2}{*}{$\begin{array}{l}\text { Main metabolite(s) } \\
\text { in urine (\% of ingested caffeine) }\end{array}$} \\
\hline & & & Plasma & Ovary, testis and fetus & $\begin{array}{l}\text { Preimplantation blasto- } \\
\text { cyst }\end{array}$ & & & \\
\hline & & & & & & & & \begin{tabular}{|l|} 
1,3-dimethyluric acid, $5.3 \%$ \\
1,7-dimethyluric acid, $2.7 \%$ \\
trimethylallantoin, $1.0 \%$ \\
1,3 -methylxanthine, $0.7 \%$ \\
unchanged caffeine, $1.0 \%$ (14) \\
\end{tabular} \\
\hline Rabbit & & & $2.35 \mu \mathrm{g} / \mathrm{ml}(10)$ & & $2.49 \mu \mathrm{g} / \mathrm{g}(10)$ & & & \\
\hline Pig & $\begin{array}{l}\text { Rapid and complete } \\
(11)\end{array}$ & \begin{tabular}{|l|} 
In approximate proportion \\
to water content (11)
\end{tabular} & & & & $\begin{array}{l}12 \mathrm{~h} \text { in plasma } \\
(11)\end{array}$ & & unchanged caffeine, $6 \%$ (11) \\
\hline Dog & & \begin{tabular}{|l} 
In approximate proportion \\
to water content (1)
\end{tabular} & & & & $\begin{array}{l}5 \mathrm{~h} \text { in plasma } \\
\text { (1) }\end{array}$ & & \begin{tabular}{|l|} 
3-methylxanthine, 30\% \\
1,3-dimethyluric acid, 30\% \\
1-methyluric acid, 22\% \\
1,7-dimethyluric acid, 6\% \\
theobromine, 3\% \\
1,3,7-trimethyluric acid, 3\% \\
paraxanthine, 1.6\% \\
1-methylxanthine, 1.5\% \\
theophylline, 1\% \\
7-methyluric acid, 1\% \\
unchanged caffeine, 1\% (12)
\end{tabular} \\
\hline $\begin{array}{l}\text { Squirrel } \\
\text { monkey }\end{array}$ & & & & & & $11 \mathrm{~h}(13)$ & $\begin{array}{l}\text { 1,7-dimethylxantine } \\
\text { (13) }\end{array}$ & $\begin{array}{l}\text { 1,7-dimethylxanthine, } 5-16 \% \\
\text { acid metabolites including } 1 \text {-methyluric } \\
\text { acid, 1,3-dimethyluric acid and products of } \\
\text { more extensive catabolic transformation, } \\
40 \% \\
\text { unchanged caffeine, } 4-6 \%(13)\end{array}$ \\
\hline
\end{tabular}

(1) Axelrod and Rechenthal, 1953; (2) Goldstein and Warren, 1962; (3) Warren, 1969; (4) Callahan et al., 1983; (5) Burg and Werner, 1972; (6) Burg and Stein, 1972; (7) Czok et al., 1969; (8) Aldridge et al., 1977; (9) Arnaud, 1976b; (10) Fabro and Sieber, 1969; (11) Cunningham, 1970; (12) Aldridge and Neims, 1980; (13) Burg et al., 1974; (14) Arnaud, 1985 
$40 \%$ of caffeine is metabolised via paraxanthine, in mice about 60 $\%$, and in hamsters $50 \%$ (Arnaud, 1976a; Arnaud, 1985). In humans about $80 \%$ is metabolised by this route (Callahan et al., 1982, 1983). Secondly, no 6-amino-5(N-formylmethylamino)-1,3-dimethyluracil is formed in humans, whereas this metabolite represents as much as $22 \%$ of the products of caffeine metabolism in the rat, and $10 \%$ in the mouse and hamster (Arnaud, 1985). Thirdly, in humans only 1-2 \% of caffeine is 8hydroxylated to 1,3,7-trimethyluric acid, whereas in the mouse and hamster the amount is $5-8 \%$ and in rat even more caffeine is degraded by this mechanism. In the rat, 1,3,7-trimethyluric acid is further metabolised to trimethylallantoin, so that this pathway represents $15 \%$ of the total caffeine metabolism (Callahan et al., 1982, 1983; Arnaud, 1985). Fourthly, the rat, mouse and hamster metabolise caffeine to hydrophilic products not found in humans (Callahan et al., 1982, 1983; Arnaud, 1985). In mice $\beta$-N-glucuronide of paraxanthine constitutes as much as $22 \%$ of all caffeine metabolites in urine (Arnaud et al., 1986; Arnaud, 1987). Fifthly, and in contrast to the situation in humans, sulphur-containing metabolites of caffeine have been detected in experimental animals. After the administration of caffeine, $\alpha$ [7-(1,3-dimethylxanthinyl)] methyl methylsulphoxide was identified in urine from horses, rabbits, rats, and mice (Kamei et al., 1975). In addition, in urine from mice $\alpha$ [7-(1,3-dimethylxanthinyl)] methyl methylsulphide and $\alpha$ [7-(1,3-dimethylxanthinyl)] methyl methylsulphone were found (Rafter and Nilsson, 1981). However, Arnaud (1985) did not find these sulphur metabolites in the urine from mice, rats, or hamsters, and he stated that their amount is less than $1 \%$ of the total amount of caffeine. On the whole, toxicokinetic parameters showed closer similarity between humans and monkeys than between monkeys and rabbits, rats, and mice (Bonati et al., 1984-85). In rats, mice, and hamsters caffeine metabolism is more diverse than in humans.

Studies on beagle dogs have shown that the metabolism of caffeine in 2-day old puppies is limited but increases substantially during the first days of life. Close to 18 percent of orally administered caffeine was excreted in urine in 2-day old puppies, but this fraction was reduced to 6 and $1 \%$ in 8 - and 15-day old dogs (Aldridge and Neims, 1980). A similar limited capacity to metabolise caffeine in newborn animals has been detected in vitro in liver slices during postnatal development in the rat (Warszawski et al., 1981). Thus, this situation seems to resemble the situation in humans.

Further metabolism of the caffeine-metabolites theobromine, paraxanthine and theophylline has been studied in rats both in vivo and in vitro. $24 \mathrm{~h}$ after the oral administration of theobromine to rats, around $50 \%$ of the urinary activity was unchanged theobromine. The other major metabolite was 4-amino-5-(N-methylformylamino)-3-methyluracil (36\%), which also has been detected in human urine (Arnaud and 
Figure 7. Metabolites formed in mice, rat or hamster from caffeine in addition to the metabolites shown in Figure 6.<smiles>CN1C(=O)C(N(C)C(N)=O)N(C)C1=O</smiles><smiles>CNC(N)=O</smiles><smiles>CN(C)C(N)=O</smiles><smiles>CC(=O)Nc1c(N)n(C)c(=O)n(C)c1=O</smiles>

Welsch, 1979a). Demethylation leads to 7-methylxanthine (6\%), 7methyluric acid (4\%), and 3-methylxanthine and 3-methyluric acid, which together made up 5.8\% of the activity. Other metabolites were 3,7dimethyluric acid and low amounts of dimethylallantoin and Nmethylurea (Arnaud and Welsch, 1979a).

Chemical analysis of whole urine $24 \mathrm{~h}$ after tail vein injection of paraxanthine in rats showed that unchanged paraxanthine was the most common compound (52\%), followed by 1-methyluric acid (21\%), 1,7dimethyluric acid (15\%), 4-amino-5-(N-methylformylamino)-1methyluracil (15\%) and 1-methylxanthine (11\%) (Arnaud and Welsch, 1979b).

Theophylline metabolism has been studied both in vivo and in vitro in rats. The quantitatively most important metabolites produced in vivo were 1,3-dimethyluric acid and 1-methyluric acid. A tissue survey utilising tissue slices demonstrated that the metabolism is localised only in the liver, and subcellularly to the microsomal system (Lohmann and Miech, 1976). 


\section{Pharmacological and toxicological actions of methylxanthines - a short overview}

A detailed discussion regarding the pharmacological actions of methylxanthines is beyond the scope of this report. Excellent reviews have been written by Nehlig et al. (1992), Sawynok and Yaksh (1993), Fredholm (1995), Sawynok (1995), Garrett and Griffiths (1997) and Fredholm et al. (1999). This chapter will shortly review general aspects of the pharmacological and toxicological actions of methylxanthines in man. No data from studies in experimental animals will be discussed.

The review primarily deals with the pharmacological effects of caffeine, as the majority of available studies have been devoted to this methylxanthine. Less has been published on the pharmacological effects of theophylline and, particularly, theobromine in foods, which is clearly reflected in this review.

In order to understand the pharmacological effects of methylxanthines, a general introduction to the theories of molecular mechanisms of action is given.

\subsection{Mechanisms of methylxanthine action}

Several mechanisms of action of caffeine and related metylxanthines have been proposed (Daly, 1993; Sawynok and Yaksh, 1993; Garrett and Griffiths, 1997). Initially it was postulated that the pharmacological effects of these compounds were due to the inhibition of phosphodiesterase activity (Sawynok and Yaksh, 1993; Chou and Benowitz, 1994). However, this is not a likely mechanism, since the serum concentrations of metylxanthines resulting from intake of caffeine-containing beverages and foods is much lower than the serum concentrations that are required in order to inhibit this enzyme (Chou and Benowitz, 1994).

Another proposed mechanism of action - induction of mobilisation of calcium - could be criticised for the same reason (Fredholm, 1995). The most important mechanism of action of caffeine seems to be a competitive antagonism for adenosine receptors. This mode of action is currently 
believed to account for most of the pharmacological effects of caffeine (Chou and Benovitz, 1994, Fredholm, 1995, Fredholm et al, 1999).

\subsubsection{Antagonism on adenosine receptors}

Adenosine, an $\mathrm{N}$-glycoside of adenine, is a normal cell constituent. The chemical structure of the purine part of the molecule, adenine, resembles that of caffeine. Adenosine is not only involved in nucleic acid metabolism but also in many other reactions in the cell. Interestingly, caffeine generally has the opposite pharmacological effect of adenosine (Garrett and Griffiths, 1997), Table 42.

Adenosine interacts with four different receptors, called the $A_{1}, A_{2 A}$, $\mathrm{A}_{2 \mathrm{~B}}$ and $\mathrm{A}_{3}$ receptors. Upon activation, these receptors affect the cellular concentration of cyclic AMP via adenyl cyclase in the cell membrane. Activation of the high affinity receptor $\mathrm{A}_{1}$ generally leads to inhibition of adenyl cyclase via a guanyl nucleoside binding protein called $\mathrm{Gi}$, whereas activation of the low affinity $\mathrm{A}_{2 \mathrm{~A}}$ receptor stimulates adenyl cyclase via another guanyl receptor binding protein called Gs (Fredholm, 1995, Fredholm et al, 1999). Thus, the $\mathrm{A} 1$ and $\mathrm{A}_{2 \mathrm{~A}}$ receptors partly mediate opposing actions at the cellular level (Fredholm, 1995 and Fredholm et al, 1999).

Cyclic AMP acts as a second messenger. By activating a cAMP dependent kinase, selected proteins in the cell are phosphorylated. Phosphorylation/dephosphorylation of proteins is a way to regulate a number of different cellular functions (Fredholm, 1995). In addition to the effects on cyclic AMP, adenosine may also influence signal transduction via modulation of $\mathrm{K}^{+}$and $\mathrm{Ca}^{2+}$ channel activity in neural and non-neural tissue (Fredholm, 1995).

Caffeine is a non-selective antagonist of adenosine interaction with the $A_{1}$ and $A_{2 A}$ receptors (Figure 8). Inhibition constants $\left(K_{i}\right)$ in the range

Table 42. Opposing pharmacological actions of caffeine and adenosine analogues (Garrett and Griffiths, 1997).

\begin{tabular}{|l|l|l|}
\hline $\begin{array}{l}\text { Physiological function } \\
\text { influenced }\end{array}$ & Caffeine & Adenosine \\
\hline CNS & $\begin{array}{l}\text { Increases spontaneous electrical } \\
\text { activity } \\
\text { Enhances neurotransmitter release } \\
\text { Convulsant activity } \\
\text { Stimulates locomotor activity } \\
\text { Increases operant response rates }\end{array}$ & $\begin{array}{l}\text { Decreases spontaneous electrical } \\
\text { activity } \\
\text { Inhibits neurotransmitter release } \\
\text { Anticonvulsant activity } \\
\text { Depresses locomotor activity } \\
\text { Decreases operant response rates }\end{array}$ \\
\hline Heart & Positive inotropic/chonotropic effects & Negative inotropic/chonotropic effects \\
\hline Renal & Diuresis; stimulates renin release & Antidiuresis; stimulates renin release \\
\hline Peripheral vasculature & Dilation & $\begin{array}{l}\text { Constriction } \\
\text { Dilation }\end{array}$ \\
\hline Gastrointestinal & Constriction & \\
\hline Respiratory & Increases gastric secretion & $\begin{array}{l}\text { Constricts/dilates bronchial smooth } \\
\text { muscle }\end{array}$ \\
\hline Adipose & Relaxes bronchial smooth muscle & Inhibits lipolysis \\
\hline
\end{tabular}


Figure 8. Effect of caffeine on different biochemical targets in relation to its level in humans. Note that caffeine is able to significantly block adenosine effects on $A_{2 A}$ (most potent) and $A_{1}$ receptors already at the low concentrations achieved after a single cup of coffee. To inhibit cyclic nucleotide breakdown via inhibition of phosphodiesterase, 20 times higher concentrations are required; to block GABA $_{A}$ receptors, $\mathbf{4 0}$ times higher concentrations; and to mobilise intracellular calcium depots, concentrations of $\mathbf{1 0 0}$ times higher are needed. These latter levels are unlikely to be reached in humans by any form of normal use of caffeine-containing beverages (modified from Fredholm, 1980).

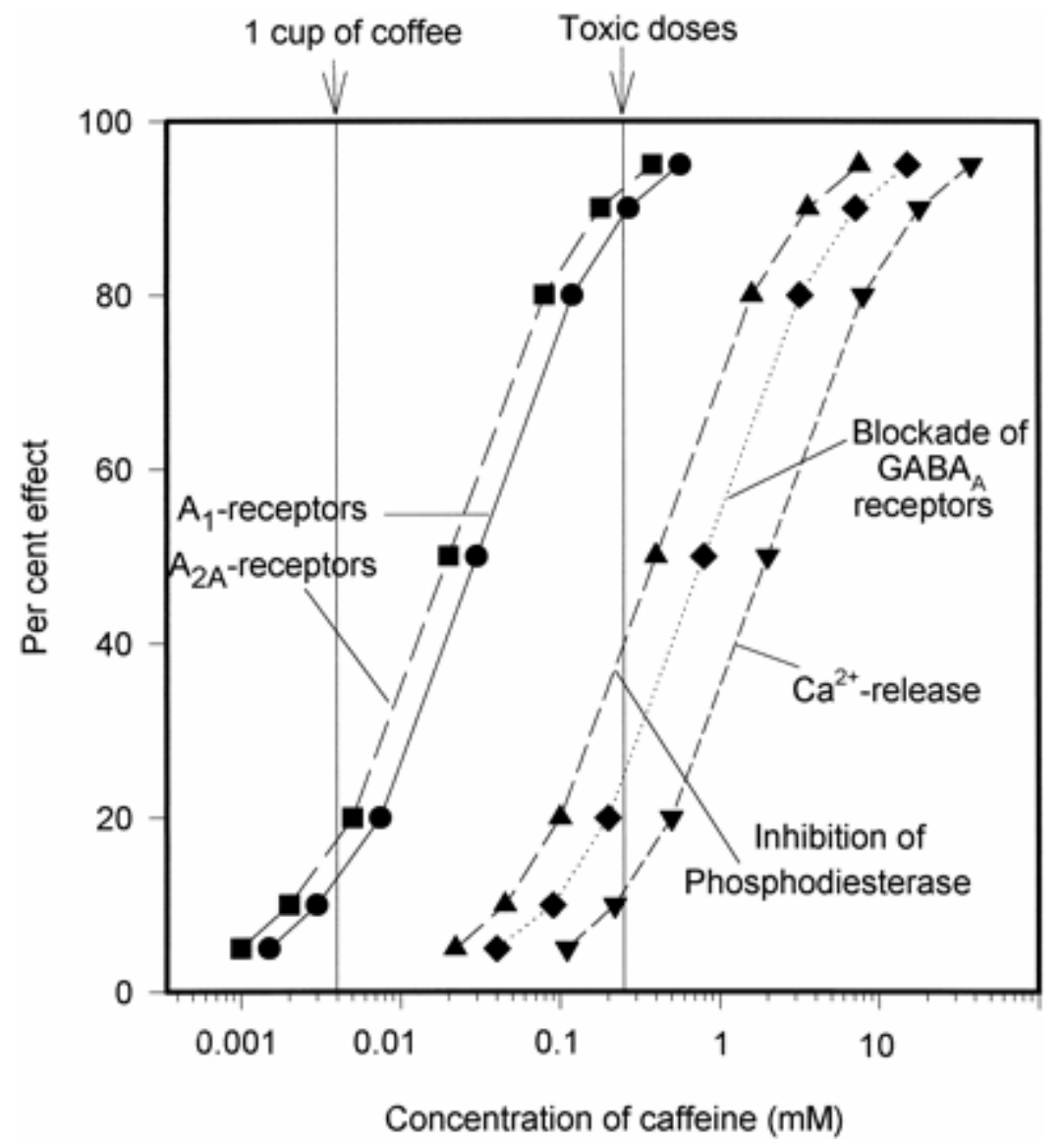

27-55 $\mu \mathrm{M}$ have been reported for caffeine on the $\mathrm{A}_{1}$ receptor, and in the range $46-50 \mu \mathrm{M}$ at the $\mathrm{A}_{2 \mathrm{~A}}$ receptor (Sawynok and Yaksh, 1993). A plasma concentration of caffeine in this range may be expected after an intake of approximately two to six cups of coffee/day. Somewhat lower inhibition constants $\left(\mathrm{K}_{\mathrm{i}}\right.$ for the $\mathrm{A} 1$ receptor 8.5-14 $\mu \mathrm{M}$ and for the $\mathrm{A}_{2 \mathrm{~A}}$ receptor 11-25 $\mu \mathrm{M}$ ) have been reported for theophylline, thus indicating that theophylline is slightly more potent as an adenosine receptor antagonist than caffeine (Sawynok and Yaksh, 1993).

From these observations it can be concluded that a plasma concentration of $10-100 \mu \mathrm{M}$ methylxanthines is required to cause antagonism of the adenosine receptors (Garrett and Griffiths, 1997). This plasma concentration approximately corresponds to an intake of between 1 and 10 cups of strong coffee (150-1500 mg caffeine) in the ordinary (non- preg- 
nant) consumer. Binding of methylxanthines to the adenosine receptors is actually the only known mechanism that is relevant at the serum levels achieved by intake of caffeine/theophylline via foods and beverages (Garrett and Griffiths, 1997). Adenosine receptor antagonism has also been implicated in the indirect action of caffeine on dopamine receptors (Garrett and Griffiths, 1997). This is due to the fact that adenosine and dopamine receptors exert opposing effects on the same nerve cells in the brain (Fredholm et al. 1999).

\subsubsection{Influence on dopamine activity}

Some of the behavioural effects of caffeine have been proposed to be mediated by dopamine, because caffeine induces several behaviours that are similar to those induced by amphetamine and cocaine, whose actions are known to be dopaminergically mediated (Garrett and Griffiths, 1997). Caffeine enhances dopaminergic activity presumably by competitive antagonism of adenosine receptors that are co-localised and functionally interact with dopamine receptors. Behavioural effects similar to those induced by dopaminergic agents like cocaine and amphetamines have been observed in pre-clinical studies on experimental animals after treatment with caffeine (Garrett and Griffiths, 1997). These behavioural effects include increased locomotor activity, increased rotational behaviour, drug discrimination and self-administration. It has also been observed that caffeine may potentiate behavioural effects induced by other substances. The additional observation that dopamine receptor antagonists can block behavioural effects induced by caffeine also supports the hypothesis that dopamine receptors may be involved in the modifying effect of methylxanthines on behaviour (Garrett and Griffiths, 1997).

It should be noted that for the time being, human data showing potentiation and antagonism of the effects of caffeine by dopamine antagonists are lacking. On the other hand, caffeine produces subjective, discriminative stimuli and reinforcing effects that in some respects are similar to these observed following the administration of dopaminergic agents (Garrett and Griffiths, 1997).

\subsubsection{Mobilisation of intracellular calcium and inhibition of phosphodiesterase activity}

Caffeine is able to mobilise calcium ions $\left(\mathrm{Ca}^{++}\right)$from intracellular storage sites in skeletal and cardiac muscle and neural tissue (Sawynok, 1995). By promoting the translocation of calcium though the plasma membrane and sarcoplasmatic reticulum, caffeine may lower the excitability threshold and prolong the duration of the active period of muscle contraction (Nehlig et al., 1992). However, it seems unlikely that the mobilisation of intracellular calcium represents an important mechanism of action for 
caffeine in muscles, because the caffeine concentration required to induce this effect $(>1 \mathrm{mM})$ is much higher than the concentration reached in body fluids following the consumption of foods and beverages containing methylxanthines (Nehlig et al., 1992; Sawynok, 1995). On the other hand, this mechanism of action might constitute a relevant explanation for certain toxic effects of caffeine, such as seizure production.

Caffeine may inhibit a number of phosphodiesterases, one of the most important being adenosine cyclase, producing cyclic AMP (cAMP) (Sawynok, 1995). As mentioned in the introduction to this chapter, it is unlikely that inhibition of phosphodiesterases is the mechanism for the pharmacological effects of caffeine, as concentrations of 0.1 to $1 \mathrm{mmol}$ caffeine per litre are required in the tissue to produce this effect. The estimated caffeine dose necessary to produce this plasma concentration in man has been estimated to between 1500 and $15000 \mathrm{mg}$, which would correspond to at least 10 to 100 cups of coffee (Garrett and Griffiths, 1997).

It has, however, been proposed that the inhibition of phosphodiesterases by caffeine specifically may contribute to the stimulation of cardiac activity and relaxation of bronches and trachea (Sawynok, 1995).

\subsubsection{Summary of mechanism of action}

The most important mechanism of action of caffeine seems to be a competitive antagonism for the adenosine receptors. This mode of action is currently believed to account for most of the pharmacological effects of caffeine (Chou and Benovitz, 1994; Fredholm, 1995)

\subsection{Pharmacological effects of the metylxanthines}

As already mentioned in the introduction to this chapter, most published data concern caffeine. As a consequence, it is primarily the pharmacological effects of caffeine that will be reviewed in this section. If published data concerning theophylline and theobromine in foods exist, they will be mentioned.

\subsubsection{Tolerance and dependence}

Before reviewing the pharmacological effects of caffeine, the concept of tolerance and dependence will be briefly mentioned. Tolerance to some pharmacological effects of methylxanthines will develop rapidly (within hours to a couple of days) when caffeine (and presumably theophylline) is consumed on a regular basis (Chou and Benowitz, 1994; Hardman et al., 1996).

It is known that tolerance develops to some, but not all, pharmacological effects of caffeine. Tolerance develops at least to the cardiovascular 
effects of caffeine, while the development of tolerance to the effects of caffeine in the central nervous system is equivocal, although adaptive changes take place in the brain (Fredholm et al., 1999). For example, the blood pressure increasing effect of caffeine shows virtually complete tolerance, the stimulant effects show partial tolerance, whereas the effects on sleep show little tolerance (Fredholm et al., 1999).

It is possible that the wide inter-individual variation in pharmacological responses to caffeine may partly be accounted for by what is regarded as tolerance. The inter-individual variation may also be due to variation between individuals in the metabolism of caffeine (Abbott, 1986). The mechanism of development of tolerance during long-term exposure to caffeine is not yet completely understood. One possibility is an increased number of cellular adenosine receptor sites being produced, which thus influences the sensitivity to adenosine (Abbott, 1986).

Termination of the intake of caffeine after daily ingestion of the compound during a long period results in withdrawal symptoms. The level at which withdrawal symptoms occur is corresponds to the amount of caffeine in approximately 2.5 cups of coffee per day (Silverman et al., 1992). The well-known major abstinence symptoms that are described are headache and increased fatigue. Anxiety, impaired psychomotor performance, and nausea/vomiting have also been reported (Chou and Benowitz, 1994). At the molecular level, an exaggerated adenosine response has been proposed as a likely mechanism to explain the symptoms of withdrawal (Abbott, 1986). It can be noted that withdrawal symptoms have also been observed also in newborn infants whose mothers ingested large quantities of coffee during pregnancy (Nehlig et al., 1992). For more details, see chapter 15 .

\subsubsection{Effects on the Central Nervous System (CNS)}

The primary pharmacological effect of methylxanthines is stimulation of the central nervous system (Abbott, 1986). Caffeine and theophylline are regarded as potent stimulants of the CNS, while theobromine is virtually inactive in this respect. In comparison with caffeine, theophylline exerts a more profound and potentially more dangerous stimulation of the CNS (Hardman et al., 1996).

Stimulation has commonly been described as increased arousal and vigilance, relief from fatigue and increase in sleep latency, improved performance (decreasing of psychomotor reaction time), and improved mood (Abbott, 1986). Apart from these mainly beneficial effects, high exposure to caffeine and theophylline may produce signs of nervousness or anxiety, restlessness and insomnia, tremors, and hyperethesia (Hardman et al., 1996). These effects of caffeine and theophylline on the CNS could be characterised as fairly modest, and to a great extent seem to depend on the individual genetic constitution of metabolising enzymes 
(Nehlig et al., 1992). The human CNS does not seem to develop tolerance towards these stimulant effects of caffeine, although dependence and withdrawal symptoms have been reported (Nehlig et al., 1992).

A review on the psychopharmacological profile of caffeine is available (Bättig and Welzl, 1993).

\subsubsection{Effects on the cardiovascular system}

In many ways, both caffeine and theophylline have prominent effects on the cardiovascular system (Hardman et al., 1996). As these effects are complex and sometimes even antagonistic, it may be difficult to predict the resulting effects. Generally, the following acute effects of caffeine and theophylline on the cardiovascular system have been reported in individuals who have not developed tolerance: a modest increase in blood pressure (both systolic and diastolic), an effect on heart rate (bradychardia or tachycardia depending on dose), and neuroendocrine effects such as release of adrenalin, noradrenalin and renin (Hardman et al., 1996).

It is known that tolerance towards the cardiovascular effects of caffeine and theophylline develops rapidly (Fredholm, 1984). Thus, the effects on the cardiovascular system seem to be transient, and disappear after long-term ingestion of caffeine. Consequently a moderate coffee consumption is not believed to exert persistent effects on the cardiovascular system very much above normal daily fluctuations (Fredholm, 1984). Intake of high doses of caffeine and theophylline, on the other hand, will result in tachycardia with systemic cathecolamine release at very high levels, and sensitive persons may experience arrhythmias (Hardman et al., 1996).

\subsubsection{Effects on the respiratory system}

The primary effect of caffeine on the respiratory system is to increase the respiratory rate, probably by sensitising the medullary centre to carbon dioxide (Benowitz, 1990). Both caffeine and theophylline have been used for treatment of idiopathic apnoea in premature infants (Sawynok, 1995). In asthmatic patients, caffeine and to an even greater extent theophylline increase bronchodilation (Benowitz, 1990). As large doses of caffeine (which can be associated with toxicity of the CNS) are required in order to achieve the bronchodilating effects, caffeine is not used in the treatment of asthma (Benowitz 1990). Therefore, theophylline is the preferred methylxanthine for the treatment of bronchial asthma (Abbott, 1986).

\subsubsection{Effects on the renal system}

Caffeine, theophylline, and theobromine increase the renal excretion of sodium and water. The most pronounced diuretic effect is exerted by 
theophylline. Increased diuresis is brought about by an increased glomerular filtration rate and inhibited reabsorbtion of sodium and water. Theophylline and caffeine increase sodium excretion by enhancing renin release from the kidney (Fredholm, 1984). Renin indirectly stimulates the production of aldosterone, the hormone responsible for regulating the balance between sodium and potassium. Tolerance to the diuretic effect develops after long-term use, which is important to note as it suggests that chronic intake of caffeine/theophylline will not affect blood pressure secondarily via an increased level of renin (Fredholm, 1984).

\subsubsection{Effects on the gastrointestinal tract}

Caffeine has been shown to stimulate gastric secretion of hydrochloric acid and pepsin (Abbott, 1986; Chou and Benowitz, 1994). These effects have, however, also been reported after intake of decaffeineated coffee, which indicates that other components of coffee than caffeine may also be of importance for the enhancement of gastric secretion (Abbott, 1986). In some studies it has been observed that caffeine and coffee may decrease the pressure of the lower oesophagal sphincter (Abbott, 1986).

\subsubsection{Effects on metabolism and nutritional balance}

Caffeine and theophylline are known to increase circulating cathecolamines, predominantly epinephrine, and to influence plasma renin activity, free fatty acids, cortisol, metabolic rate, and glucose (Benowitz, 1990; Cooling, 1993). In addition, increased calciuria and inhibited absorption of iron and other essential trace elements have been reported after caffeine exposure (Abbott 1986). Very little is known about the long-term effects that may be associated with these observations - it has been speculated that high chronic exposure to methylxanthines may contribute to the development of osteoporosis (Etherton and Kochar, 1993). However, most published studies have not shown any consistent effect of caffeine consumption on the incidence of bone fracture (Bruce and Spiller, 1998). In this context, it may be noted that high amounts of caffeine during pregnancy in some cases have resulted in hypokalemia and even paralysis (Appel, 2001; Young, 2001; Matsunami, 1994). The symptoms resolved when caffeine intake was stopped.

\subsubsection{Other possible relevant pharmacological effects in relation to pregnancy}

The possible effects of intake of caffeine via beverages on lactation will be discussed in chapter 15 . In chapter 16 maternal intake of caffeine in relation to possible effects on children's behaviour will be discussed. 


\subsection{Toxicological effects of the methylxanthines}

\subsubsection{Acute toxicity}

At higher doses caffeine may cause a number of different effects, including anxiety, tension, headaches, insomnia, nervousness, loss of appetite, diarrhoea, dizziness, irritability, decrease in hand steadiness, and analgesia. These symptoms can occur after either a long-term or a short-term ingestion, and are similar to symptoms often encountered in anxiety neurosis. This condition is generally known as "caffeinism" and can be observed at dose levels greater then $7-8 \mathrm{mg} / \mathrm{kg}$ body weight/day or $500-600$ $\mathrm{mg} /$ day in adults (corresponding to approximately five cups of coffee) (Abbott, 1986). The plasma concentration associated with untoward effects have been reported to be $>30 \mu \mathrm{g} / \mathrm{ml}(150 \mu \mathrm{mol} / \mathrm{L})$ (Sawynok, 1995). In addition, a variety of toxic effects of caffeine related to the cardiovascular system and gastrointestinal system may appear. Among the effects are hypotension, palpitations, tachycardia, arrhythmias, flushing and marked circulatory failure, nausea, diarrhoea, epigastric pain, and occasionally peptic ulcer and haematomesis (Abbott 1986).

The estimated lethal dose of caffeine in man is approximately 140 $170 \mathrm{mg} / \mathrm{kg}$ body weight, equivalent to $8-10$ grams/day (corresponding to approximately 60 to 100 cups of coffee) (Ritchie, 1970, Abbott, 1986; Sawynok, 1995). Fortunately, fatal poisoning associated with caffeine exposure is not common (Eteng et al., 1997; Sawynok, 1995; Holmgren et al., 2004).

\subsubsection{Chronic toxicity}

A variety of adverse effects have been suggested to be related to the exposure to methylxanthines via foods and beverages. However, it is generally very difficult to assess whether it is caffeine or another methylxanthine, or, in fact, other concomitant exposures that are responsible for the adverse effects observed. Common confounding factors in reports of this kind are smoking and/or alcohol consumption. Thus, these factors also have to be carefully considered in the assessment of factors giving rise to chronic toxicity.

It may be mentioned that the relationships between exposure for methylxanthines and myocardial infarction, serum cholesterol levels, psychiatric disturbances, and synergistic effects with sympathomimetic drugs have been discussed. As a discussion of these issues are beyond the scope of this report, the interested reader could consult 'Caffeine \& Health' (James, 1991) and 'Coffee and Health (Debry, 1994) for reviews. 


\subsubsection{Mutagenicity}

The potential health effects of methylxanthines have been investigated for over three decades in a variety of model systems including human populations. Caffeine is probably one of the most extensively studied naturally occurring dietary chemicals. One question, which has received a great deal of attention involve the potential genotoxic properties of caffeine and the other methylxanthines. To better understand whether it is the methylxanthines themselves that exhibit genotoxic effects, or whether it occurs in combination with other agents, thousands of research studies have been reviewed by other researchers e.g. Timson (1975), Kihlman (1977), Legator and Zimmering (1979), Tarka (1982), Rosenkranz and Ennever (1987), Kihlman and Andersson (1987), IARC (1991), and D'Ambrosio (1994). In addition, there are reviews on the teratogenic and antimutagenic effects of caffeine and the other methylxanthines (Clarke and Shankel, 1975; Nehlig and Debry, 1994b)

The evaluations have utilised data from a number of prokaryotic and eukaryotic cell culture model systems, as well as in vivo systems. They have investigated the effects of caffeine and the other methylxanthines alone or in combination with other physical and chemical agents on many aspects of cell division, chromosome stability, toxicity, and mutagenicity.

The results from the few animal models that have been used indicate that caffeine at doses ten times higher than would be consumed by humans, causes significant increase in the frequency of spontaneous chromosomal alterations but only in animals with dietary folate deficiency (perturbing nucleotide pool balances). However, these special experimental conditions make it difficult to extrapolate the animal data to humans (D'Ambrosio, 1994). Furthermore, the apparent lack of mutagenic activity of theophylline and theobromine in humans may, according to Timson (1972), be due to the fact that the antimitotic threshold is the same as the mutagenic threshold, so that any mutant cells produced are unable to reproduce. The net effect is therefore non-mutagenicity.

Using in vitro model systems, caffeine even at $\mathrm{mM}$ doses does not appear to be genotoxic in many experimental systems. Only when certain genotoxin-exposed cell types are exposed to these high concentrations of caffeine in the $G_{2}$ phase of the cell cycle does caffeine appear to enhance the cytogenetic effects of the genotoxins (Kihlman and Andersson, 1987). Mechanistic studies indicate that caffeine interacts in different ways with the DNA structure and DNA metabolism. A possible mechanism for the potentiating effect of chromosome damage could be that caffeine reduces the delay during the $\mathrm{G}_{2}$ phase that is necessary to repair genotoxininduced DNA damage before the cell enters cell division. In the presence of high concentrations of caffeine, the damaged cells that have not yet repaired the damage are forced into cell division, where they express their damage as chromosomal aberrations that subsequently may result in cell death or other types of biological effects. 
Nonetheless, the published data on the mutagenicity and genotoxicity of theobromine and caffeine were analysed by the Carcinogen Prediction and Battery Section (CPBS) method (Rosenkranz and Ennever, 1987). In spite of some positive responses in various short-term tests, these analyses did not predict a potential for causing cancer by virtue of a genotoxic mechanism as regards theobromine. Caffeine, on the other hand, clearly has a potential for genotoxic carcinogenicity according to the CPBS method. Rosenkranz and Ennever (1987) also evaluated the predictive performance of cost-effective test batteries consisting of selected combinations of four assays. They found that the predictions were similar to those derived when all available test results were considered. It is reassuring that no carcinogenic effects (see next section) have been observed in experimental animals despite the indication by the CPBS method that caffeine might be a genotoxic agent.

The dietary exposure of humans to methylxanthines results in much lower doses than those required to induce responses in short-term tests. The peak serum levels in humans is often in the micromolar range, which is 10 to 1000 times lower than the levels used in animal and cell culture models. This pronounced difference in exposure level makes it difficult to interpret the potential effect of methylxanthines at the dietary levels. Thus, it seems unlikely that caffeine is genotoxic in humans at the doses generally reached by dietary intake of caffeine-containing beverages and foods.

\subsubsection{Carcinogenicity}

In 1991, the International Agency for Research on Cancer (IARC) evaluated the carcinogenic potential of the methylxanthine-containing beverages coffee, tea and maté, as well as the individual methylxanthines caffeine, theophylline and theobromine. Since the beverages contain many different potential carcinogenic compounds (although the concentrations are low) and this report deals with the methylxanthines, only IARC's conclusions on the potential risks of consuming coffee, tea and maté will be mentioned. For coffee IARC (1991) concludes that there is limited evidence in humans that coffee drinking is carcinogenic in the urinary bladder, and that there is evidence suggesting the lack of carcinogenicity from coffee drinking as seen in the human female breast and in the large bowel. However, there is inadequate evidence in humans that coffee drinking is carcinogenic in the pancreas, ovaries and other body sites. IARC (1991) also found that there is inadequate evidence for carcinogenicity in humans caused by tea drinking and limited evidence for carcinogenicity caused by hot maté drinking in humans. No data were available on the drinking of cold maté.

Five years after the IARC report was published, Nehlig and Debry (1996) published a review of the human and animal data linking coffee 
consumption and cancer. The situation had not changed substantially during those five years.

IARC (1991) also evaluated caffeine, theophylline, and theobromine for carcinogenicity.

\section{Studies in experimental animals.}

Caffeine had been tested for carcinogenicity in five studies in rats by oral administration. In two of these studies (Takayama and Kuwabara, 1982; Moh et al., 1984), no significant difference in the incidence of tumours at any site was found. The other three studies (Yamagami et al., 1983; Johansson, 1981; Brune et al., 1981) were found to be inadequate for evaluation (IARC, 1991). All studies on oral and intraperitoneal administration of caffeine to mice were found inadequate for evaluation. In one study (Würzner et al., 1977a, 1977b), decaffeinated coffee to which caffeine was added was tested by oral administration to rats; overall, no increase in the incidence of tumours at any site was observed as compared to appropriate controls (IARC, 1991).

No data were available from studies on the carcinogenicity of theophylline and theobromine in experimental animals.

A number of short-term carcinogenicity studies in model systems have been performed. Administration of caffeine in combination with known carcinogens resulted in decreased incidences of lung tumours in mice treated with urethane, of mammary tumours in rats treated with diethylstilboestrol, and of skin tumours in mice treated with ultraviolet light or cigarette-smoke condensate. Caffeine did not influence the incidence of bladder tumours induced in rats by N-nitroso-N-butyl(4hydroxybutyl)amine in three experiments, or, in another study, of pancreatic tumours induced in rats by 4-hydroxyaminoquinoline-1-oxide (IARC, 1991).

In one short-term carcinogenicity study of questionable quality, intraperitoneally injected theobromine reduced the number of lung tumours induced by urethane in mice (Nomura, 1983). When theophylline was substituted for theobromine, no influence on the lung tumour frequency and multiplicity was found (Nomura, 1983). In a separate study, mice that had a theophylline solution applied to their ears and were then exposed to ultra-violet light developed a lower frequency of skin tumours than mice that were exposed to the vehicle for theophylline and ultra-violet light (Zajdela and Latarjet, 1973, 1975, 1978a, 1978b).

\section{In humans.}

Martin et al. (1988) examined the effect of caffeine consumption on mortality from cancer at all sites among the 10064 participants in the Hypertension Detection and Follow-up Program in the USA after four years of follow-up. The exposure to caffeine was estimated from questionnaire data giving information on the consumption of coffee, tea and medicinal 
drugs. No information on the consumption of cocoa, chocolate, and soft drinks was available. The unadjusted relative risks showed no association between caffeine consumption and mortality from cancer or any other cause.

Among the more extensively studied cancer types, three are more strongly associated with consumption of methylxanthines than other types. These are breast cancer, cancer in the lower urinary tract (mainly bladder cancer), and prostate cancer.

The idea that caffeine might be involved in the aetiology of breast disease was proposed by Minton et al. in 1979. These investigators reported that women with benign breast disease who abstained from methylxanthines experienced resolution of the symptoms of breast disease more frequently than did women who did not abstain from methylxanthines. Ten years later, an association between coffee and tea consumption and breast cancer mortality ratios was reported after adjusting for dietary fat (Phelps and Phelps, 1988). Most studies did not show a correlation, however. Although using various information to calculate the methylxanthine intake, four case-control studies of breast cancer and methylxanthine consumption (Lubin et al., 1984, 1985; Schairer et al., 1987; Rohan and McMichael, 1988; Iscovich et al., 1989) were unable to find an association to breast cancer. In a separate study, with a totally different design, Pozner et al. (1986), however, noted that women with moderately or well-differentiated breast tumours had higher intakes of coffee (all types), caffeinated coffee, decaffeinated coffee, cola, and tea.

Reviews on the relationship between the consumption of methylxanthine-containing beverages and the risk of developing breast cancer have been published (Lubin and Ron, 1990; Welsch, 1994). They conclude that results from studies on benign and malign breast disease have been inconsistent, with some investigators observing a positive association, others no association, and some a negative association.

Bladder cancer is another cancer type that has been suspected to be related to methylxanthine exposure. In a Danish case-control study a weak association was found between cancer of the urinary bladder and caffeine intake from coffee and tea (Jensen et al., 1986). The association was significant in men after adjustment for consumption of beer and soft drinks, age, and smoking.

IARC (1991) noted that caffeine and coffee consumption is highly correlated in most of the population studies, making it very difficult to separate the two exposures in epidemiological studies. It is therefore not possible to adequately evaluate the effect of caffeine per se. IARC (1991) concluded that there is inadequate evidence for carcinogenicity in humans and experimental animals of caffeine, theophylline and theobromine. Therefore these methylxanthines were not classified as to their carcinogenicity to humans. 
After the IARC (1991) report was published, Slattery and West (1993) observed an increased risk for prostate cancer in older men with a high intake of theobromine (11 to 20 , or over $20 \mathrm{mg}$ per day). This observation was made in a case-control study on males with prostate cancer in Utah, in the United States. The Utah population from which cases and controls were recruited predominantly comprised Mormons or members of the Church of Jesus Chist of Latter-day Saints. Caffeine intake was unrelated to prostate cancer risk. The finding that high intakes of theobromine may be associated with an increased risk for prostate cancer in older men needs further exploration in studies with a wider range of theobromine exposure and more males with aggressive tumours. 
Evaluation of epidemiological studies 



\section{The epidemiological instrument with special reference to nutritional questions}

Epidemiological studies are often used to test hypotheses on the association between dietary components and disease. In this review it is the association between intake of caffeine or caffeine-containing beverages or drugs and various conditions related to pregnancy or the foetus that has been scrutinized (the outcome variable). Depending on the type of epidemiological study, the quality of the data that are used to calculate associations between exposure and effect varies.

Epidemiological studies may be observational studies or intervention studies. The types of observational studies are, in ascending order based on their scientific value: 1) cross-cultural and cross-sectional studies, 2) case-control studies, 3) nested case-control studies, and 4) cohort studies. Intervention studies in the form of randomized controlled trials (RCT) have an even higher scientific value and use an experimental design. The strengths and weaknesses of these different types of epidemiological studies are shortly described and discussed below.

The exposure variables in the majority of the observational studies that form the basis for these studies are the intake of caffeine-containing beverages, foods and drugs and/or the intake of caffeine in the subjects' diet. Hence, the methodology is dominated by studies of dietary habits. The exposure variables may also include the concentration of caffeine or caffeine metabolites in body fluids (plasma and breast milk). The weaknesses inherent in the methodology of studies of dietary habits that are important in judging the scientific value of the studies will be described and discussed in section 10.2. "Methodology for Studying Dietary Habits".

The outcome variable is the clinical event (the disease) diagnosed according to predetermined criteria.

\subsection{Types of epidemiological studies}

Cross-cultural studies compare the exposure levels and prevalence of the investigated condition in populations from different cultural backgrounds. Cross-sectional studies examine this relationship in a defined population at a particular point in time. Essentially, studies of these types aim at generating a hypothesis. The data are obtained from official statistics on 
morbidity or mortality, and dietary information is obtained from food balance sheets. Otherwise, the studies involve as many representative groups as possible. The scientific weight of the evidence of these studies is usually limited, since individual differences and confounders usually cannot be adequately noted or considered.

Because of the inborn weaknesses in these types of observational studies, cross-cultural and cross sectional studies have received very little emphasis in terms of forming the final conclusion as to whether a relationship is present or not between the variable representing caffeine exposure and the conditions studied.

In case-control studies, the researcher identifies a number of cases with certain parameters to be tested for their relationship to the specific condition. Defining suitable criteria for the inclusion and exclusion of individuals from the study is important. For each case, the researcher attempts to find one or more controls that are free from symptoms from the studied condition, but otherwise fulfil the same inclusion criteria. The number of cases varies widely among the different studies, and must be taken into consideration during evaluation. The odds ratio (OR) is calculated, which is a measure of the relative incidence of the condition at different exposure levels (set at 1.00 at the lowest level), and determines significance with a $95 \%$ confidence level, or "p for trend". An ideal study would be one that could describe the dietary habits at the time when the pathological process began - a point in time that is highly improbable to identify. One can only hope that the diet during the course of the studied condition did not change substantially from the diet at the time when monitoring was started.

"Well-chosen controls" is a key phase when determining the scientific value of a study. The controls should represent all of the population who do not suffer from the disease being studied. Necessarily, this involves individuals who are not affected by the question under investigation. Many people are not motivated enough to participate. This problem is probably greater than usual when the controls are asked to report on their dietary habits. There is a risk that people with "good" habits are more willing to participate in a control group than people who know or believe they have "poor" habits. Hence, there is a risk for bias toward better dietary habits among the controls than in the population they are supposed to represent.

It is usual to match controls from patients at the inpatient or outpatient clinic where the cases are selected (obviously, from those patients who are free from the condition being studied). Dropout is usually quite low among hospital controls, since patients are used to being asked about many things, and believe that their answers may contribute toward their own treatment (Kelly et al., 1990). Controlling of "confounders" is usually better here than in other control subjects. Nevertheless, the use of such 
control objects has been criticised mainly because they do not constitute a representative sample of the population.

The dropout rate is usually high if the controls are selected by the "digital dial" method, a common method in the United States. This method involves selecting the controls among those in the population whose telephone numbers begin with the same three or more digits as the telephone numbers of the cases. The method was originally used in marketing analysis, and is thought to identify controls and cases with similar social backgrounds. However, the dropout rate is high when subjects are asked to report on their dietary habits (Hartge et al., 1984). The most representative controls are those selected randomly from the census registry, where the dropout rate tends to be low.

If a chemical analysis of body fluids or tissue is included in the study, the specimen in the cases is usually obtained after the onset of the studied condition. Hence, one cannot eliminate the possibility that the concentration levels are a result of the condition, not the cause of it. Such analyses are of questionable value in case-control studies.

In a cohort study, a large number of people are invited to participate who fulfil predetermined inclusion criteria (apart from being free from the disease under study). They also must be willing to participate throughout the study period, usually for many years. Specific exposure variables are surveyed at the outset of the study, e.g. intake of caffeine and/or consumption of caffeine-containing beverages and drugs. Often body fluid samples (blood and breast milk) are taken and frozen for later analysis. Subjects who contract the condition in question during the study period are registered (and are documented according to predefined clinical events). The prevalence of known and suspected confounders among the subjects is also registered.

A typical cohort study attempts to determine the relative risk (RR) for the onset of the studied condition among those exposed to a variable being studied, e.g. coffee consumption in relation to the non-exposed population. When it concerns nutritional epidemiological cohort studies such as those estimating an association between the dietary intake of caffeine and a particular condition, all of the subjects might be "exposed", and, therefore, the "non-exposed" group is represented by the tertile, quartile, or quintile of the cohort with the lowest intake, $R R=1.00$.

Those who accept participation are not always representative of the population. For example, they may be generally more interested in nutritional issues and therefore have better dietary habits. Hence, the distribution of exposure variables may be less, and this bias can reduce opportunities of demonstrating an actual association. Also, those who agree to participate may differ from the population at large, e.g. concerning lifestyle and social and genetic factors. These confounders are often not measured, and therefore cannot be adjusted for. Nevertheless, it should be stressed that cohort studies are superior to other observational studies, 
since the exposure variables are determined long before the clinical event occurs. A longitudinal prospective study, however, allows many more observations of the subjects, a factor that may be important to the outcome of the study.

However, cohort studies also have many weaknesses, e.g. many of those invited do not agree to participate, or there may be a higher dropout rate of dropout than expected during the study, requiring dropout analysis. A common weakness in cohort studies is that data from a single dietary examination or a single blood test are linked to a clinical event that can occur much later. One cannot ignore the possibility that dietary intake may have changed in an unknown but meaningful way among an unknown number of participants during the course of the study. Therefore, it is beneficial if the dietary survey and sampling of blood and tissue are repeated during the course of the study, even allowing for potential seasonal variations. This has occurred in some of the cohort studies reviewed. However, it is notable that the results from these complementary surveys are often neither reported nor considered in the analysis.

Body fluid or tissue analyses are usually not performed before the end of the study. Storage at the temperature $-20^{\circ} \mathrm{C}$ was common in the past, but meant that many substances were destroyed during storage, even after 6 months. Storage at temperatures of at least $-70^{\circ} \mathrm{C}$ is necessary for samples to retain their scientific value (Edmonds and Nierenberg, 1993). The storage temperature is not critical for caffeine, which is rather stable, but could have been for potential confounders studied.

After the conclusion of an original study (e.g. devoted to the preventive effects of beta-carotene on breast cancer development), researchers quite often decide to use the raw data to estimate the intake of other food constituents, such as caffeine in relation to breast cancer or even other conditions (e.g. colorectal cancer, fertility). This is understandable, considering the work and cost involved, but can be scientifically questioned since the dietary study designed many years ago was, or should have been, focused on covering the subjects' consumption of the most important sources of beta-carotene, but probably was not equally as thorough as far as caffeine sources in the diet was concerned. Furthermore, the inclusion criteria should probably have been different.

Generally, the cohorts in nested case-control studies are selected and studied in the way described above. When a sufficient number of cases have been found, their dietary history and plasma/tissue samples are analysed. This also concerns the selected matched controls for the cases in the cohort. By design, it is a longitudinal, prospective study. The analysis, however, does not reveal the relative risk of the exposed in relation to the unexposed, but is retrospective and reports odds ratios for the incidence of disease at various levels of exposure.

Intervention studies with a randomized and controlled design (a randomized controlled trial (RCT)) have the highest scientific value. Here, it 
is decided what the subjects will eat - usually in the form of dietary supplements (caffeine) or placebo, and the outcome is measured in terms of clinical events. There must be a large number of participants, and subjects must be randomly allocated to the study group or control group. The study must continue for several years. Placebo tablets and potential side effects must be designed so that neither the subjects nor the investigators know which substance is given to the subject. However, potential toxic effects must be revealed so the trial can be discontinued in time. The doses of tested substances should not be at pharmacological levels, nor should they be so low that variations in the content of the diet would have an impact. Compliance must be measured though plasma analyses and counts of tablet consumption. The results from an RCT of caffeine in tablet form cannot necessarily be applied directly to caffeine in food, since interaction with other nutrients may play a decisive role in the studied effects. There is no large intervention study available relating caffeine intake to the main outcome variables reviewed.

\subsection{Methodology for studying dietary habits.}

The methods that have been used in the reviewed analytical studies published since the middle of the 1970s on the role of caffeine or caffeinecontaining beverages in influencing fertility, birth weight, rate of preterm delivery, spontaneous abortion and birth defects, and effects on foetuses and children are similar and often identical to the methods used in descriptive studies. They are briefly presented here, but their weaknesses and strengths are discussed more thoroughly in section 10.1., which addresses the methodology of the various types of analytical studies.

\subsubsection{Methods used in descriptive dietary studies}

Individual dietary studies have been used for over 100 years to survey the consumption of foodstuffs and estimate the intake of energy and nutrients within geographically defined populations, specified by, e.g. gender, age, and social status. The general results are presented for the entire group, using mean or median values and the usual measures of distribution. Findings are compared to the recommended daily intake for the population. Such studies describe the nutritional situation in a population and the results can be used in developing dietary information.

The methods used in these studies (Bingham et al., 1994) are usually retrospective and based on interviews concerning consumption during the past day (24-hour recall) or a longer period, usually the past year (dietary history), or are done with a more comprehensive self-administered dietary questionnaire (food frequency questionnaire, FFQ). Some prospective methods require the subjects, for a certain number of consecutive days, to 
either register all consumption in household measures (usually a 7-day food record), or weigh all components (7-day weighted food record), or duplicate the portions of all food consumed and place the extra portion in a container for later chemical analysis (double portion technique).

All of these methods require dedicated subjects. Dietary habits are highly personal and are often not shared with others. The continual and often contradictory information, not least in the media, concerning good and poor dietary habits and the relationship between diet and disease increases the risk in retrospective studies for conscious and unconscious discrepancies between real and reported beverage and food consumption (Sörensen et al., 1994). In prospective studies, it increases the risk for overly deviant dietary habits during the registration (Bingham, 1987) or collection period (Isaksson, 1993), not least for reasons of convenience.

Participants often find it difficult to give precise answers concerning portion size and how often they eat or drink a particular food or beverage, no matter how honest they want to be. Apart from the unavoidable bias regarding the fact that particularly obese individuals regularly underreport food intake (Prentice et al., 1986; Hultén et al., 1990; Heitmann, 1993; Heitmann and Lissner, 1995), the information from others can be expected to deviate randomly from reality (at least if it is not sweets and other unwholesome foods), since the estimated mean or median values and measures of distribution should be reasonably close to the actual values. They should, however, apply if the group studied is sufficiently large, if the obese subjects do not comprise a major portion of the group, and if the research team is qualified for the task.

Equally good consistency between the actual and estimated intake of energy or individual nutrients is, however, not self-evident. The food tables used in conversions from foodstuffs to nutrients have sources of error. This does not affect macronutrients as much as micronutrients and secondary metabolites such as caffeine. Here again, the individual discrepancies should be random. The content of caffeine may differ considerably among servings in different geographic regions. Factors influencing the caffeine intake from foods and beverages have been extensively discussed in chapter 6 of this review. National food tables cannot take such information into account, and therefore bias cannot be excluded.

\subsubsection{Methods in analytical studies - association between diet and studied condition/disease}

The level of precision required for individual dietary histories is higher in analytical studies than in descriptive studies. In a cohort study, it is not group data which is of interest but individual data, particularly data on the few individuals in the group (often less than $1 \%$ and rarely over $3 \%$ of the subjects) who contract the disease in question during the course of the study. In the statistical analysis, they are distributed across 3 to 5 groups of equal size whose limits are determined by the participants in the co- 
hort. Since no one knows who will contract the disease at the onset of the study, the demand for precision applies to all subjects, even though the number of participants is large.

In case-control studies, the total number of participants is substantially lower (although the number of cases assembled may be clearly larger) than in a cohort, but one must also consider confounders. To secure that as many subjects as possible are placed correctly when assigning the 3 to 5 groups, one must require the same level of precision on individual data, for both the cases and controls, as required in cohort studies.

The systematic review of nutritional epidemiology articles on the association between caffeine and the studied conditions has heightened the suspicion that the precision of the methods used is deficient to the extent that the significance of the positive or negative associations reported must be questioned. This can be illustrated by using several examples from the reviewed literature. Of course, as regards the statistical axiom "regression toward the mean" in either type of study, an association between the observation variable and the exposure variable that is statistically significant despite imprecise measures would be even more significant if the measures were more precise. It is regrettable that some studies missed the opportunity to show real associations, since the authors did not place adequate demands on precision by using methods developed for descriptive studies. Not only do they create uncertainty about the overall assessment of the literature and raise demands for further study, they have also cost substantial sums in research resources and manpower that could have been benefited better-designed research projects.

The requirements for precision that should be placed on studies are so great that one can ask if it is possible to conduct epidemiological studies using dietary methods, particularly when the interest concerns microelements such as caffeine. Namely, the precision of collected dietary data does not depend only on the subjects' participation. The research instrument has equal or even greater importance.

Non-prospective methods (other than validation instruments, see below) in analytical studies are not used since they are too resource demanding for both the investigators and the subjects. Furthermore, as mentioned earlier, they influence dietary habits so that these deviate from the normal consumption pattern. Many of the studies reviewed here have used the 24-hour recall method to collect dietary data. They have all been found (Bingham et al., 1994) to be of low scientific value - hopes of finding a real association between disease and consumption at a point in time very much earlier (sometime years) is rather optimistic. Most of the reviewed studies used a FFQ as the survey instrument, the benefits and weaknesses of which are discussed in greater detail below. 


\subsubsection{Food Frequency Questionnaire (FFQ)}

This method requires the subjects to fill in a standard questionnaire that covers a range of foodstuffs, systematically classified into food groups. The respondent can choose from among several alternatives for each food item. Portion size is usually given in household measures that correspond to a presumed standard portion, or several different portion sizes are given.

The design of the FFQ determines the scientific value of the study. Unfortunately, the descriptions in the literature are usually not thorough enough to be able to render a fair judgement. In many cases, the questionnaires have been developed by other research groups for other target groups, exposure, and/or outcome variables (e.g, Rimm et al., 1992; Willett et al., 1985; Block et al., 1986), and are described as "slightly modified" without defining the modification.

Time period. The information usually applies to the subject's consumption habits during the past 9 months. Some studies have been based on data from 5 to 10 years ago, or even further back in time, but only in exceptional cases can they be given a scientific value (Sörensen et al., 1994).

The number of food items that appear in a questionnaire varies widely, e.g. from 20 to 200 . Of course, a questionnaire that covers only a few dozen items must be very well designed in order to show the individual and actual intake of a specific dietary component, and cannot be applied in any other context. Despite the wealth of detail, larger questionnaires are usually developed with the intent to specifically quantify an investigated exposure variable. Therefore, they cannot be directly applied in estimates of other dietary components. Using coffee and tea consumption as the sole beverages or foods to estimate caffeine intake may be quite accurate for some consumers but totally wrong for others. Furthermore, the content of caffeine in beverages and food varies widely. One example from another area of research, which clearly demonstrates the problem with FFQs, is the 1986 Nurses' Health Study. The questionnaire if this study includes $53 \beta$-carotene containing foods, of which 38 have such a low content that they are not interesting in this context - 5 to $10 \mathrm{~kg}$ of a random assortment of these items contain no more $\beta$-carotene than 100 grams of carrot. However, the questionnaire lacks at least 25 foods rich in $\beta$-carotene that should be represented in a survey intended to test hypotheses on the preventive effects of these antioxidants.

Unfortunately, questionnaires must present a wide range of frequency alternatives. But even questionnaires with as many as 9 alternatives from "never" to "4 to 6 cups per day" have weaknesses. The alternative "2 to 4 cups/week" is in the midrange, and is an attractive choice in conjunction with a standard portion, e.g, "half a cup of coffee", both for those who consume a small half a cup 2 times per week and for those who enjoy a large half cup 4 times per week. The latter consumes 8 times as 
much as the former, but both are noted in the same column and are entered into the computer program with a consumption that is less than half and nearly 3 times greater than the actual consumption. This has no importance if the subject's vitamin $\mathrm{E}$ intake is calculated, but can be decisive if the study concerns caffeine.

If the questionnaire presents 3 portion alternatives, possibly including weight information or photographic representation, the estimates should be closer to reality than if only the "standard portion" concept were used and presented in household measures, e.g, one-half cup. One should consider that a questionnaire with 125 food stuffs, 9 frequency alternatives, and 3 portion sizes forces the subject to choose between $125 \times 9 \times 3=$ 3275 alternatives. It is a reasonable assumption that filling in such a questionnaire is tedious and involves a risk that the answers become increasingly imprecise, particularly when the process takes place in the home. (This is less of a problem if a qualified interviewer administers the questionnaire.)

In some epidemiological studies (but rarely in the studies reviewed in this report), a proxy is interviewed, i.e. the husband/wife or other relative to the person interviewed, concerning the outcome variable. Reasonably, they provide less precise responses on quantity and frequency, and much of the information tends to cluster around the middle alternatives (Samet, 1989; Metzner et al., 1989).

\subsubsection{Food tables and other sources of error}

Consumption information in FFQ questionnaires is going to be translated into the exposure to a number of nutrients, minerals and secondary metabolites using national tables (now computerized) on foodstuffs. Numerous studies were started during the 1970s and 1980s when many food tables lacked information on the prevalence of caffeine in food. Many of the early table values are based on less-specific analytical methods. It is not possible to determine the importance this might have for individual data, but it generally lowers the scientific value of older studies. Later studies have had access to more complete tables. The fact remains that many FFQs are incomplete. What is clear is that the table values never take into account the individuals' preferences as to how strong they like their coffee, tea or chocolate drinks to be. Questionnaires also frequently omit information on the type of coffee preparation and the habit of mixing the coffee with milk is not asked about, nor, cup size, etc. (see chapter 6 for more examples). If information is missing concerning the demands placed on this aspect, the studies are difficult to assess.

A source of error always remains, regardless of the precision of the data collection, namely the discrepancy between the actual intake and that calculated from information in the food tables used. For example, the amount of caffeine in confectionery varies substantially by geographic 
location (e.g. different persons having different preferences for various types of chocolate). The nearly limitless trade with foodstuffs means that the individual consumer does not know where products come from. Furthermore, very few FFQ would even consider this factor, or the potential effects that food processing has in industry and in the home. Furthermore, one cannot ignore the fact that the level of absorption in the intestine can vary among individuals, and can depend on interactions with other food components. Combined, these factors could have a decisive impact on particular cohort studies where only a few percent of all subjects contract the disease.

\subsubsection{Validating dietary studies}

In many of the studies reviewed, the authors state that the methodology has been validated with satisfactory results. A few studies describe the procedure in greater or lesser detail.

Usually they have allowed a subgroup of participants to conduct a 7day (possibly weighed) food record that is designated as "a golden standard", despite the knowledge we have about its impact on dietary habits, and then they compare their own "simpler" method with this "standard". They measure concurrence with the reference method and express the strength by a correlation coefficient. It is hardly remarkable that it is found to be significant, but by no means does it suggest that the estimated quantities of different foodstuffs and nutrients are the same in their own method as in the reference method.

A somewhat more acceptable validation method is the one where the reference method data is divided into a number of equally large classes, probably quintiles, where the boundaries are established. Naturally, one's method is better if more data cluster in the same class as in the reference method and less data cluster in the most distant class. In the few validation studies of this type, which have been presented in sufficient detail (e.g. Rimm et al., 1992) only $40 \%$ to $50 \%$ of the subjects have clustered correctly in the lowest and highest quintiles, which is hardly sufficient for a "passing grade".

English epidemiologists (Bland and Altman, 1986) have shown that a real validation test should show, in quantitative terms, how much one's own method differs from the reference method. This requires a reference method that measures the true value and uses a methodology other than the applied dietary study method, i.e. a biochemical or physiological method. To date there are only two well-documented methods (but neither of these have been used in the reviewed studies), namely a 24hour urinary nitrogen output that can give the true value of protein intake at the group level (Isaksson, 1980; Bingham and Cummings, 1985), and the double-labelled water method (Coward, 1991) which gives the true value for energy expenditure (and is equal to energy intake in weight 
stability). Agreement in the data between one's own method and these methods as regards intake of protein and energy does not necessarily guarantee that the method yields correct values for all other dietary components as well. However, poor agreement suggests that one's own method is deficient, and/or that the subjects do not provide correct information about their consumption. Both of the methods have revealed that obese individuals regularly underreport their consumption (Hosmer and Lemeshow, 1989; Heitmann, 1993; Heitmann and Lissner, 1995).

Estimating a cut-off value for energy intake (Goldberg et al., 1991), i.e. the lowest value for an individual's energy needs, provides opportunities to assess the methodology or to identify underreporting in published studies. This is established at $1.35 \mathrm{x}$ BMR (basal metabolism, calculated from height and weight), where 1.35 expresses the lowest normal physical activity level (PAL value). Unfortunately, information about the subject's height, weight, and energy intake is seldom found in the reviewed studies, but where such information is available and gives an estimation of the PAL value (e.g. Stampfer et al., 1993), a value of only 1.2 raises many questions.

\subsubsection{Specific compounds in foods as exposure variable}

The many, and difficult-to-overcome, sources of error discussed above give reason to doubt that current dietary study methods can provide sufficiently specific data for each study participant on the consumption of food items containing a specific compound to allow analytical studies of this dietary component's role in influencing adverse conditions.

Therefore, this raises the question as to whether analysis would be more informative if it remained at the foodstuffs level, and, in this report, primarily concerned the consumption of caffeine-containing beverages. Of course, even this information is associated with sources of error, which applies both to the type of foodstuff and the frequency and quantity of consumption. However, it eliminates the most serious sources of error in converting to caffeine intake. Another advantage is that such an analysis does not isolate a particular component, but looks at the possible effects of the "orchestra of compounds in coffee" in association with other components in the diet. The distinguishing variable would mainly be the consumption frequency. Even an incomplete FFQ, as regards the multiplicity of caffeine sources, should be able to satisfactorily distinguish between high and low consumers of coffee or tea.

Nonetheless, this report in depth reviews the epidemiological studies which explore a possible relationship between the intake of caffeine or caffeine-containing foods and beverages and adverse effects on the pregnancy that have been published since the middle of the 1970s. The effects studied include influence effects on: (1) fertility, (2) spontaneous abortion, (3) birth defects, (4) pre-term delivery, (5) foetal growth retardation, 
(6) foetal behaviour, and (7) on neonates, infants and children. The weaknesses and strengths of the various studies are presented in detail in chapter 11-17. 


\section{Caffeine intake and fertility}

Many investigators have studied the question as to whether caffeine could influence fertility. It has been addressed both in experimental mechanistic studies and in epidemiological research. There are several plausible biological mechanisms though which caffeine could exert an effect on fertility (Hatch and Bracken, 1993), but none are consistently well studied.

In women, caffeine could directly affect ovulation though alterations in hormone levels. It has been reported that caffeine consumption is inversely correlated with levels of estradiol in both pregnant and perimenopausal women, and positively correlated with levels of sex hormonebinding globulin (London et al., 1991; Petridou et al., 1992). Caffeine has been associated with increased severity of pre-menstrual symptoms, which, in turn, may have a hormonal aetiology (Rossignol, 1985). Prolactin levels may also be altered, which might result in a disruption of ovulation (Casas et al., 1989).

The length of time for the conceptus to travel from the fallopian tube into the uterus could also be affected by caffeine, either though hormonal effects on tubal cilia or by the relaxation of smooth muscle. Since the endometrium is receptive to the fertilised conceptus for a limited time period, alterations in tubal transport time may affect the process of implantation (Takizawa and Mattison, 1983).

Additionally, caffeine may affect the viability of the fertilised ovum. Caffeine has been found to penetrate the blastocyst prior to implantation in rabbits (Hirsh, 1984). If this results in abnormalities of the developing embryo and it also occurs in humans, this could increase the risk of early pregnancy losses prior to clinical recognition of pregnancy, which would result in a seemingly delayed conception.

An additional possibility is that some other component of caffeinecontaining beverages may be responsible for the observed effects. Phytooestrogens, naturally occurring substances with estrogenic activity, have been identified in coffee, and have been linked to reduced fertility in some animal species (Fredericks et al., 1981). It has also been suggested that tannic acid, which is present in coffee and tea, may be associated with reduced fertility (Cramer, 1990).

While the maternal role in chemically induced teratogenesis has been well established, the importance of male involvement in such birth defects has been less extensively investigated. For example, the induction of male-mediated dominant lethal mutations by caffeine in mice remains controversial (for references, see Beach et al., 1984).

Fifteen epidemiological studies have investigated the relationship between caffeine intake and fertility. In studies of this type, it is crucial to 
know the caffeine intake at the time of conception attempts. However, this has rarely been the case. Therefore, a common limitation in many studies is that other time periods have been used as substitutes for the suitable time period. Another problem is how well the calculated caffeine intake describes the real intake. Caffeine intake has usually been calculated by summing up the amount of caffeine in coffee, tea and soft drinks (cola beverages). The calculations have been based on the assumption that on average a cup of coffee contains $100 \mathrm{mg}$ caffeine, a cup of tea 50 $\mathrm{mg}$ caffeine and a can/drink of soft drink $40 \mathrm{mg}$ caffeine. Not taking lifestyle, culture, tradition, and behaviour into account when studying coffee, tea and cola consumption obviously is expected to have some bearing on the results, since these factors will determine how the beverages are prepared and how they are consumed, and therefore influence caffeine intake. Similarly, not including exposure of caffeine from medical preparations when calculating caffeine intake could be expected to influence the result.

Fertility is typically defined as the occurrence of pregnancy within 12 months of regular unprotected intercourse. This definition originally was intended to identify the time when couples should seek medical care for infertility. Demography has distinct conceptual and methodological definitions for fecundity and fertility that contrast with the inconsistent use of these terms by epidemiologists. Fecundity refers to the biological capacity to conceive, whereas fertility refers to the ability to reproduce or bear a live born offspring. The fertility parameters in the studies summarised below have varied, the most common criteria being: time to conception/time to pregnancy; fecundability; and pregnancy rate. Other criteria are success of in vitro fertilisation and embryo transfer, and sperm quality.

Sections 11.1 to 11.7 in more detail present the epidemiological studies on a possible relationship between caffeine intake and fertility. Our conclusions based on a critical evaluation of these epidemiological studies are presented in section 11.8. The most important results of the separate studies are summarised in chronological and geographical order in Table 43 (relationship between caffeine intake and time to pregnancy), Table 44 (relationship between consumption of caffeine-containing beverages and time to pregnancy), Table 45 (relationship between caffeine intake and fecundability) and Table 46 (relationship between consumption of caffeine-containing beverages and fecundability).

\subsection{Caffeine intake and time to conception/pregnancy, alternatively Caffeine intake and fecundability}

Time to conception and time to pregnancy are common parameters for fertility and seem to have been used in epidemiological studies without 
distinction. Generally, these time periods have been determined by a set of questions, which ask when the studied women stopped using contraception/protection, and questions on how many months it took before they became (clinically) pregnant. The probability of becoming clinically pregnant in each menstrual cycle, the fecundability, is a similar fertility parameter used in many studies. One version of this parameter is the "fecundability ratio", which is defined as group differences in fecundability as measured by calculating the per-cycle probability of pregnancy for exposed and unexposed groups, and expressing the results as a ratio (Wilcox et al., 1988a).

Table 43 summarises the five retrospective studies that have investigated the relationship between caffeine intake and time to conception/pregnancy, whereas the eight studies that have presented data on caffeine intake and fecundability are summarised in Table 45 . Some of the studies appear in both tables. Investigations on the relationship between the consumption of specific caffeine-containing beverages and time to conception/pregnancy, alternatively fecundability, are presented in Tables 44 and 46, respectively.

For historical reasons we first describe one of the studies that related caffeine intake to fecundability. This was the scientific report that started the discussion on a possible relationship between caffeine intake and fertility. It was published in 1988 and written by Wilcox and co-workers. These investigators prospectively studied the association between consumption of caffeine-containing beverages and the ability of 221 women from North Carolina, the United States, to become pregnant. The study base was a selection of women that agreed to participate in the study and planned to become pregnant after stopping their use of birth control. The study sample was a mixture of women who had never conceived and women that had been pregnant before. The total caffeine intake was estimated for the 104 women of the study base who did not become pregnant in their first three months of trying by assuming standard quantities of caffeine in brewed coffee, tea, and soft drinks. Instant coffee was estimated to contain $65 \mathrm{mg}$ caffeine per cup. Most of these women reduced their caffeine intake after they had stopped birth control; mean intake decreased from 147 to $127 \mathrm{mg} /$ day. The median, $105 \mathrm{mg} /$ day (about one brewed cup of coffee a day) was used to separate women into those with a lower and those with a higher caffeine intake. After adjusting statistical calculations for factors that might contribute to an association between caffeine intake and fecundability, the investigators made the remarkable observation that women with a "high" caffeine intake (approximately one cup of brewed coffee per day) were half as likely to become pregnant (per cycle) as women who ingested less (Table 45). A dose-response effect was present. When data from all 221 enrolled women on caffeine intake before trying to conceive were analysed, the adjusted mean fecundability ratio for higher caffeine users was non-significant. The weaker overall associa- 
tion was suggested to be due to the lack of an association between caffeine consumption and fecundability in the first two cycles after the women stopped using birth control.

When Wilcox and co-workers in the original study investigated whether any particular caffeine-containing beverage was responsible for the altered fecundability (Table 45), a reduced fecundability ratio was observed for coffee as well as for non-coffee sources of caffeine (Wilcox et al., 1988a). In a latter report, Wilcox and Weinberg (1991) analysed the intake of non-coffee beverages such as tea and caffeinated soft drinks. Whereas tea had a negligible association to fertility, soft drinks were surprisingly strongly related to lower fertility. A statistical evaluation of the results showed that one caffeinated soft drink per day was associated with a $50 \%$ reduction in the monthly chance of conception, after coffee consumption, frequency of intercourse, and age were controlled for (Table 46). Later studies have generally found no correlation between intake of caffeinated soft drinks and fertility. Severe limitations of Wilcox's studies include the small and poorly defined study base, and the fact that only a subset of the women enrolled in the study provided data on caffeine consumption during the time they were actually trying to conceive.

The surprisingly strong effect of comparatively low daily intakes of caffeine on fertility in the study of Wilcox et al. (1988), however, stimulated many investigators to explore the relationship between caffeine intake and fertility parameters. Four out of the five studies that have looked at the relationship between caffeine intake and time to conception/pregnancy (Table 43) have found a statistically significant relationship between these parameters, whereas two studies have found these parameters to not be related. Three of the four studies that found an association between delayed conception and caffeine consumption were performed in the United States. The fourth study was a European multicentre study that explored risk factors of infertility and included participants from Denmark, Germany, Italy, Poland, and Spain.

One of the American studies was large, and originally designed to examine whether prior induced abortion affects future pregnancy outcome. This study comprised 1909 (46\% of the study base) women who were married to their first husband and who did not conceive while using a method of birth control. When they later tried and succeeded at becoming pregnant, the participants were interviewed during early pregnancy about their daily caffeine intake from coffee, tea, and soft drinks during the period between the date of conception and the date of the interview (Hatch and Bracken, 1993). The investigators assumed that the cups used for coffee and tea drinking were of equal size $(150 \mathrm{ml})$ and estimated that a cup of coffee contained $107 \mathrm{mg}$ caffeine and a cup of tea $34 \mathrm{mg}$ caffeine. One serving of soft drinks $(360 \mathrm{ml})$ was estimated to contain $47 \mathrm{mg}$ 
caffeine. The average daily caffeine intake among the participants was as low as $95.8 \mathrm{mg}$, with individual values ranging from 0 to $1273 \mathrm{mg}$.

According to the statistical calculations, which were adjusted for most recent method of birth control, parity, and cigarette smoking, women who ingested $151 \mathrm{mg}$ caffeine or more per day had a significantly delayed time to conception in comparison to women having no intake of caffeine (Table 43). None of the estimates for individual beverages (coffee, tea or cola drinks) were statistically significant (Table 44). Caffeine intake was found to have no influence on the fecundability ratio (the relative risk of monthly probability of conception) before adjusting for confounding factors. In these studies, the fecundability ratio was calculated from information on the caffeine intake of women who took longer than 12 months to conceive and women who conceived within 12 months of stopping a birth control method by comparing exposed and unexposed groups. However, caffeine was found to influence fecundability when the method of birth control, parity, and cigarette smoking were adjusted for (Table 45). Women who reported drinking over $300 \mathrm{mg} /$ day of caffeine had a $27 \%$ lower chance of conceiving during each cycle, and those who reported drinking $1-150$ or $150-300 \mathrm{mg} /$ day had a $10 \%$ reduction in per cycle conception rate compared with women who consumed no caffeine. The study design had several limitations. In this study, like in many other epidemiological studies of this kind, the frequency of intercourse of the study subjects was unknown, and no information on the caffeine intake of their husbands was available (compare section 10.3). It could also be argued that the women might not have accurately recalled when they stopped using birth control. The most serious limitation of the study was, however, the potential for misclassification of caffeine intake due to the estimation of beverage volume and beverage consumption during early pregnancy, as opposed to during the time when the women were attempting to conceive.

The latter limitation was commented upon in a letter to the American Journal of Epidemiology (Caan and Coates, 1994). In this letter Caan and Coates presented results of a recently completed study in which 210 women who were attempting to conceive were surveyed each month for 12 months or until they reported a confirmed pregnancy. The results presented were on pregnancy status and intake of caffeinated beverages during the previous month. The women were also asked about their caffeine intakes in the month in which they became pregnant. Women who conceived reported a caffeine intake in the month in which they became pregnant that was $29.4 \mathrm{mg}$ lower than the average of previous months. Most women were less than 4 weeks post-conception at the time that they reported decreases in caffeine intake. The fraction of women who reduced their caffeine intake by more than $100 \mathrm{mg}$ during the month in which they became pregnant, (in comparison with their average caffeine intake during previous months), was close to 33 percent among women that 
conceived in either their first or second month of trying, but only 10.4 percent among women who conceived in months 3-12 of trying. Thus, it appears that women with shorter conception times were more apt to reduce their caffeine intake than did women with longer conception times. These data indicate that data collected for exposure periods after pregnancy confirmation will not reliably capture intakes from the relevant exposure period, and will produce risk estimates that are biased by a significant degree of misclassification.

The relationship between caffeine intake and delayed conception has also been studied in the Reproductive Health Study. This is an eastern American retrospective study of 1430 well-educated non-contracepting parious women who were interviewed in 1989-1990 about their consumption of caffeinated beverages (coffee, tea and soft drinks) during the first month of pregnancy (Stanton and Gray, 1995). During the ten previous years these women had had 2501 pregnancies. The ten-years-long timeperiod between pregnancy and time of interview may of course have resulted in recall bias. As in the previous study, delayed conception was defined as a waiting time to conception of more than 12 months of unprotected intercourse, which conforms to the widely used definition of infertility. It was assumed that the consumption levels of caffeine reported during the first month of pregnancy reflected consumption levels before pregnancy. After adjustment for potential confounders, there was no association between caffeine consumption and risk of delayed conception (>12 months) when pregnancies of all the women were taken into consideration. However, using non-smokers who reported no caffeine consumption as the referent group in the statistical calculations revealed a significantly increased risk of delayed contraception in non-smokers (but not in smokers) having the highest intake of caffeine (Table 43). The trend in increased risk for delayed conception among non-smokers was also statistically significant. The investigators proposed that a possible explanation for the differential effect in smokers and non-smokers could be that the caffeine metabolism is enhanced in the former group (Stanton and Gray, 1995). When the caffeine intake was related to the probability of pregnancy per menstrual cycle for all participants, a decreasing fecundability with increased caffeine consumption was observed (Table 45). In general, the more caffeine ingested, the lower the probability of pregnancy. The trend of decreasing fecundability with increasing caffeine consumption was statistically significant. At the highest caffeine intake $(\geq 301 \mathrm{mg} /$ day), the adjusted estimated fecundability for all women was 17 percent lower than for women who consumed no caffeine. Nonsmokers who consumed high levels of caffeine had a 26 percent lower monthly probability of pregnancy compared with non-smokers who reported no caffeine consumption (Table 45). Smoking reduced the fecundability ratio, but the authors observed no significant effect of caffeine in smokers (Stanton and Gray, 1995). The caffeine intake was low in the 
studied population (few women consumed more than $300 \mathrm{mg} /$ day), and referred to the first month of pregnancy. Some investigators have criticised the conclusions drawn from sub-group analysis, when effects were observed only in the subgroup but not in the entire material.

Because infertility has a multifactorial aetiology, it is understandable that it might be difficult to establish a firm relationship between exposure and probability of conception. To provide new insights into the causative mechanisms of infertility, one American study investigated the effect of caffeine intake in women who had been diagnosed with specific infertility disorders. This was a case-control study from the United States and Canada, originally undertaken to examine the relation between contraceptive practices and a woman's ability to conceive. The caffeine intake was investigated in 1050 white women with primary infertility, diagnosed as ovulatory failure, tubal disease, cervical factors, endometriosis, or idiopatic infertility, and was compared to the intake of 3833 white women who during the period 1981-1983 had given birth to live-born children (Grodstein et al., 1993).

Caffeine exposure was estimated as in the previous studies, except that only cola drinks were included among the caffeine-containing soft drinks. The caffeine intake referred to the time period prior to the likely onset of infertility; that is, the period prior to conception or the attempted conception. A significant increase in the risk of infertility (inability to conceive within 12 months of unprotected sexual intercourse or the failure to deliver a live-born child) due to tubal disease and endometriosis was observed for the upper levels of caffeine intake (Table 43). The elevated risk of tubal infertility was observed for women consuming more than $233 \mathrm{mg}$ of caffeine per day, in comparison with those who consumed 0$100 \mathrm{mg} /$ day. The corresponding intake that elevated the risk of endometriosis was $170 \mathrm{mg}$ caffeine per day. The exact mechanism of these effects remains unclear. Caffeine intake was not related to infertility due to ovulatory failure, cervical factors, or idiopatic infertility (Table 43). Due to the traumatic endpoints studied, it is possible that infertile women overestimated caffeine consumption in comparison with fertile women who were instructed specifically to report only caffeine use before pregnancy. Limitations with the study were that cigarette smoking among mothers was not quantified, that the likelihood of underreporting caffeine intake might have differed between groups, and that the frequency of intercourse was unknown. The missing information on cigarette smoking was a drawback because of the correlation between smoking and coffee consumption and the influence of smoking on caffeine metabolism (Grodstein et al., 1993).

Only one of the studies relating caffeine intake to fertility has tried to differentiate coffee consumption based on the participants habits of preparing and drinking coffee. In this study, women aged 25-44 years from five European countries (Denmark, Germany, Italy, Poland, and Spain) 
were randomly selected from population registers, census registers, and electoral rolls to participate in the study. They were interviewed between 1991-1993 on their consumption of caffeine-containing beverages and many other parameters at the starting time of unprotected sexual intercourse, which could have been up to 31 years earlier (Bolúmar et al., 1997). Only $68 \%$ of the 6630 randomly identified women decided to participate. Women who had been treated for infertility were not included in the study population. Further exclusion resulted in a study limited to 3 187 women who reported that their first pregnancy was planned. The caffeine intake from coffee was estimated from information on consumption rate, as well as from ecological data on average cup size, types of coffee mixtures, and brewing methods in each country (no individual data were available). Thus, a cup of coffee contained $130 \mathrm{mg}$ caffeine in Denmark, and $115 \mathrm{mg}$ in Germany and Southern Europe. It was assumed that a cup of tea contained $50 \mathrm{mg}$ caffeine and a drink of cola $40 \mathrm{mg}$ caffeine. The average daily caffeine intake varied significantly between the five populations in the study. Intake was $707 \mathrm{mg}$ in Denmark, $353 \mathrm{mg}$ in Germany, $278 \mathrm{mg}$ in Poland, $286 \mathrm{mg}$ in northern Italy and $199 \mathrm{mg}$ in Spain.

Time between stopping a birth control method and conception increased with increasing levels of caffeine intake (Bolúmar et al., 1997). After adjustment was made for potential confounders, a significantly increased odds ratio for time to first pregnancy $\geq 9.5$ months (defined as subfecundity by the authors) was observed among women with an intake of more than $500 \mathrm{mg}$ of caffeine per day (Table 43). Similar results were obtained when reported time to first pregnancy was $\geq 12$ months (Table 45). When the exposure was ascertained from coffee consumption, a similar although not significant result was obtained after controlling for the same set of confounding variables (Table 44). The associations were observed consistently in all countries as well as for the most recent waiting time episode. The authors carefully pointed out possible confounding factors, and discussed the likelihood that these variables could have influenced the result. It should be stressed, however, that it might be very difficult to recall your consumption or habits many years back in time, and this might have introduced a recall bias. Another problem with the statistical analysis was that smoking was categorised into a small number of discrete groups (none, $1-11,11+$ ) rather than as a continuous variable, and that alcohol consumption was not controlled for.

One of the two studies that reported no relationship between caffeine intake and fertility was performed by Joesoef and co-workers (1990) in North America between 1981 and 1983. These investigators studied both 2817 women who had had no history of infertility and who delivered a live-born child as a result of a planned pregnancy at one of seven institutions, and 1818 women that contacted the same institutions and had a diagnosis of primary infertility. Both groups were interviewed with the 
same type of food-frequency questionnaire. In addition to standard questions about consumption of caffeinated beverages, the questionnaire also asked about consumption of decaffeinated coffee. Questions about consumption of caffeine-containing beverages referred to the time period when the women were not pregnant (Weinberg and Wilcox, 1990). The quantity of caffeine consumed had little or no effect on the reported time it took to conceive in fertile women who planned their pregnancy. For each type of caffeinated beverage, aside from tea, time taken to conceive was unrelated to increasing levels of consumption (Table 44). The mean number of months to conception increased significantly with an increasing consumption of tea. One of the authors has subsequently suggested that it is the tannins in tea that are responsible for the reduced fertility seen with a high intake of this beverage (Cramer, 1990). In the group of women with primary infertility, an association between consumption of caffeine-containing beverages and risk of infertility disappeared after an adjustment for confounding factors. The monthly probability of conception (fecundability ratio) was similar for women consuming more than $233 \mathrm{mg}$ caffeine per day and for women consuming less than that amount (Table 45). Interestingly, the association between primary infertility and consumption of decaffeinated coffee remained after an adjustment for confounding factors (Joesoef et al., 1990). The odds ratio for drinking 1-2 cups of decaffeinated coffee per day was 1.5 and, for drinking more than this, 2.5. This rather odd observation could not be explained.

The other negative study was a small prospective study performed on the American west coast, in which 210 women who volunteered to participate reported the consumption of caffeinated beverages and pregnancy status monthly (Caan et al., 1998).

The mean total caffeine intake was very low in the studied group, only $610 \mathrm{mg}$ per week. There was no significant decrease in fertility associated with total caffeine, coffee, decaffeinated coffee, or caffeinated soda for either moderate or high consumption (Tables 43 and 44). However, the highest level of tea consumption ( $>0.5$ serving/day) was significantly associated with an increase in fertility, but this relationship was observed only in pregnancy cycles 1 though 3 . This very low tea consumption had no influence on time to pregnancy in other studies. Therefore, it is possible that this finding was spurious or due to chance alone or, alternatively, that tea consumption may be associated with other lifestyle characteristics that could enhance fertility.

A group of studies have focused entirely on the relationship between fecundability and caffeine intake. The Ontario Farm Health study was originally designed to address the relation between pesticides and reproductive health, and was based on information from families on grain farms and fruit and vegetable farms. The data used to investigate the relationship between caffeine intake and fecundability was collected in 19911992 (Curtis et al., 1997). Although close to 3000 couples were identi- 
fied to fulfil the set criteria for inclusion, only 1898 (64 percent) of these completed the interview questionnaires. Over the previous 30 years, the participating families reported 2607 planned pregnancies. Almost all respondents (both husband and wife) reported some caffeine intake at the time of the interview, the only time period investigated. The time that had passed between the date of conception and the questionnaire interview was between 1 month and 26 years. Therefore, recall problems were a severe limitation of the study, which might have led to misclassification. The mean time between the time of the questionnaire interview and the date of conception was 9 years. Among consumers of caffeinated beverages, close to one third of both men and women reported an intake of less than $100 \mathrm{mg}$ of caffeine per day. Another third consumed between 101 and $300 \mathrm{mg}$ per day, one fifth between 301 and $500 \mathrm{mg}$ and 12 percent of women and 16 percent of men reported consuming more than $500 \mathrm{mg}$ caffeine per day. There was no relationship between caffeine intake and fecundability (monthly probability of conception) for either men or women, and no dose-response in fecundability with an increase in caffeine consumption (Table 45). Adjustment for confounding variables (e.g. cigarette smoking, use of decaffeinated coffee, interaction between women's and men's caffeine consumption) did not influence the final result. However, a possible, but questionable, association was noted between women's coffee consumption and decreased fecundability (Table 46).

The Reproductive Health Study is a prospective observational study on 124 women 23-41 years old and employed at two semiconductor plants in the north-western region of the United States from May 1989 to August 1991. Its purpose is to address the effects of semiconductor manufacturing on reproductive health. In this cohort, Hakim et al. (1998) prospectively ascertained consumption of alcohol and caffeine for each month of participation. The study participants delivered daily urine specimens and daily documentation of menstrual cycles and sexual activity so that the full spectrum of conception could be ascertained during 678 menstrual cycles, including sub-clinical pregnancy losses. The data were used to analyse the independent effects of alcohol and caffeine consumption association on the probability of conception per menstrual cycle.

Conception was defined as the combination of live births, clinical miscarriages and sub-clinical losses (because previous analyses had shown caffeine consumption to have an equivalent effect on conception probability regardless of outcome). To identify clinical miscarriages and sub-clinical losses, estrogens were assayed to detect day of ovulation, and hCG to detect pregnancy before implantation. The caffeine intake was estimated from information on the consumption of coffee, tea and caffeinated soft drinks during the last month obtained at entry into the study, and then at monthly intervals.

The adjusted odds ratio for rate of conception suggested a negative association to caffeine consumption, but the statistical evaluation revealed that the independent association was non-significant (Table 45). 
that the independent association was non-significant (Table 45). Furthermore, there was no significant trend. However, there were indications that caffeine enhanced the negative effect of alcohol on conception in nonsmoking women. The study was based on a very limited number of women who had a very modest consumption of caffeine $-63 \%$ of the nonsmoking women consumed 1 cup of coffee per day or less. The influence of their male partners on the conception rate (e.g. frequency of intercourse) was not controlled for.

In a Dutch prospective study (Florack et al., 1994) investigating the influence of occupational and other environmental factors on early pregnancy failure, data was collected on the caffeine intake of 259 invited (by letter) female non-medical hospital workers and their partners. Partners consumed more caffeine (median $=700 \mathrm{mg}$ a day) than participants (median $=375 \mathrm{mg}$ a day). Not less than 155 women had already started trying to conceive before enrolment in the study - 56 began trying already more than 1 year before the initiation of the study. In the subgroup of 104 participants who was followed prospectively since they started trying to conceive, $81 \%$ became pregnant within 1 year. No support was obtained for the hypothesis that a high caffeine intake had an adverse effect on fecundability (Table 45). The strongest reduced fecundability was found when partners drank more than 7 cups of caffeine drinks per day. Moderate caffeine consumption (3-7 cups per day) was associated with a higher fecundability than either low or high caffeine consumption. Of the caffeine-containing beverages, only the tea consumption of participants influenced fecundability compared with that seen in non-drinkers of the particular beverage (Table 46).

This prospective study might be influenced by three types of bias: selection bias (less fertile couples were more likely to enrol in the study), information bias (the prospective design resulted in information on the caffeine intake for 155 women being gathered during the period they tried to conceive, and for 104 women before this period) and confounding bias. In this study, confounding bias could in particular result from missing information on the frequency of intercourse and the fact that the study population was restricted to a specific occupational group.

An invitation to participate in a study on caffeine intake and fecundability was given to 52255 Danish trade union members who were 20 to 35 years old, lived with a partner and had no children. Of those who accepted, 423 couples were recruited into the study after being checked to fulfil rigorous inclusion criteria (Jensen et al., 1998a). The couples were enrolled into the study when they discontinued birth control, and were followed for six menstrual cycles, or until a pregnancy was clinically recognised. Stringent criteria were used for exclusion of data from specific menstrual cycles (i.e. poor frequency of self-reported answers on the monthly questionnaire, no intercourse from day 11 to 20 in the menstrual cycle, azoosperma). Finally, 423 couples with 1596 cycles were included 
in the analysis. At enrolment both partners were interviewed on personal and demographic factors, and the men provided a semen sample. During the study they completed a monthly questionnaire on changes in occupational exposures and lifestyle factors. Important parameters investigated were smoking, alcohol, and caffeine intake. Each person's daily caffeine intake was estimated, assuming the content of caffeine to be $100 \mathrm{mg}$ in one cup of coffee, $50 \mathrm{mg}$ in one cup of tea, $25 \mathrm{mg}$ in one cup of chocolate beverage, $100 \mathrm{mg}$ in $250 \mathrm{ml}$ cola and $12.5 \mathrm{mg}$ in a $50 \mathrm{~g}$ chocolate bar. The effect of each investigated exposure was calculated separately for each sex. The following variables were identified as potential confounders in relation to pregnancy within the six menstrual cycles, and were, if required, controlled for in the statistical calculations: male and female smoking, females whose mother smoked during pregnancy, male and female diseases of the reproductive organs, female alcohol intake, sperm concentration, duration of menstrual cycle, use of oral contraceptives as last method of birth control, and female body mass index. Variables of potential interest but with no association to cycles to pregnancy were the centre of enrolment, age of menarche, male body mass index and alcohol intake, and age of both genders.

Almost all participants (97.5\%) consumed caffeine daily, which made comparison with unexposed participants impossible. The median daily intake was $250 \mathrm{mg}$ in women $\left(5^{\text {th }}\right.$ and $95^{\text {th }}$ percentiles: 43 and $\left.819 \mathrm{mg}\right)$, and $423 \mathrm{mg}$ in men $\left(5^{\text {th }}\right.$ and $95^{\text {th }}$ percentile: 36 and $1164 \mathrm{mg}$ ). Around $15 \%$ consumed chocolate beverages daily, and $40-45 \%$ reported no cola consumption during an entire week. No adverse effect of caffeine on fecundability among female and male smokers was found (Table 45). Among non-smoking women, the point estimate of the fecundability ratio decreased with increasing amounts of caffeine consumed after adjusting for female body mass index and alcohol intake, diseases of the female reproductive organs, semen quality, and duration of the menstrual cycle. Although the $95 \%$ confidence intervals included unity at both 300-699 and $\geq 700 \mathrm{mg}$ caffeine/day, and the point estimates, therefore, were statistically non-significant, a trend test was statistically significant (Table 45). Smoking women whose only source of caffeine was coffee ( $>300$ $\mathrm{mg}$ /day) actually had a reduced fecundability ratio (Table 46). In males, the same tendency for the point estimate was present after adjustment for female body mass index, smoking and alcohol intake, diseases of the male and female reproductive organs, and duration of the menstrual cycle (Table 46). At the high dose in non-smoking men, more than $700 \mathrm{mg}$ caffeine/day, the $95 \%$ confidence interval of the fecundability ratio (when comparing with caffeine intakes between 0 and $299 \mathrm{mg}$ caffeine/day) excluded unity (Table 45).

The strength of the study was that the chosen design allowed caffeine intake to be estimated during each menstrual cycle before any knowledge about an occurrence of pregnancy in the specific cycle was obtained. A 
weakness of the data was that very few participants were unexposed or had a very low caffeine intake. Thus, if caffeine has a low threshold of effect, it is possible that the study failed to reveal this. Another weakness was that the frequency of intercourse was not analysed as a confounder, simply because diary information on this parameter was missing among couples who became pregnant in the first cycle (Jensen et al., 1998b). That the male exposure had an effect on the fecundability ratio is rather unexpected, and the data should be interpreted with care. Male exposure could be mediated through an impact on semen quality or directly if the caffeine content of seminal fluid is sufficient to interfere with conception and implantation. However, the study found no association between caffeine intake and semen quality. The possible association between male and female caffeine intake and decreased fecundability was found only among non-smokers. According to the authors, their data, along with data from other investigators, suggest that especially non-smoking women who wish to achieve a pregnancy might benefit from reduced caffeine intake (Jensen et al., 1998a).

Information on the relationship between consumption of caffeinecontaining beverages and time to conception has been presented in two studies from the United States (Christianson et al., 1989; Alderete et al., 1995). Christianson and co-workers scrutinised their own data collected 1959-1967 from 6303 women interviewed early during pregnancy for usual consumption before pregnancy of caffeinated and alcoholic beverages and use of tobacco. Their questionnaire also contained questions on whether or not the woman had any trouble becoming pregnant (Van den Berg et al., 1988). A preliminary analysis showed a dose-related effect of coffee consumption and reported difficulties in becoming pregnant (Chistianson et al., 1989). The women who were heavy coffee drinkers before pregnancy ( 7 or more cups per day) had almost a doubled risk of difficulty in becoming pregnant compared with women who drank little or no coffee (Table 44). The results should be interpreted with care, since the original questions in the questionnaire were not designed to answer the questions asked in this study, and, therefore, were rather crude for the performed calculations. A consequence was that adjustment for smoking could only be performed qualitatively (smoker or non-smoker), not quantitatively.

During the first half of the 1960s 2453 women living in the San Francisco East Bay area were recruited while receiving prenatal care to participate in the Child Health and Development Studies (Alderete et al., 1995). Of these women, 1341 gave enough information on when they last used contraceptives, and how much they smoked and drank coffee before pregnancy, for the investigators to be able to use the information to estimate the effect of coffee drinking on time to conception. Time to conception was defined as the time interval between termination of contraception and the gravida's last menstrual period as reported in inter- 
views. Among non-smokers, no reduced fertility was observed in coffee drinkers compared with non-drinkers (Table 44). Coffee drinking also did not increase the risk of delayed conception among smokers over the risk posed by smoking itself. The most severe limitations of the study were the facts that only women who became pregnant (for the first time) were included in the study, and that $30 \%$ of the primigravidas interviewed did not report when they last used contraception. In the absence of this information they could not be included in the analysis (Alderete et al., 1995).

Two studies focused solely on the relationship between consumption of tea or coffee and fecundability/time to conception. In one of these, a large Danish population-based survey of life-style factors and prolonged time to pregnancy (subfecundity), the investigators estimated the association between consumption of coffee and tea during the time period before becoming pregnant and subsequent time to pregnancy. The required information was obtained from a questionnaire that was answered during the last trimester of pregnancy and that asked for consumption of coffee and tea, but not any other caffeine-containing foods (Olsen, 1991). Altogether, 10886 women who had not been treated for infertility and who responded to the questionnaire satisfactory was included in the study. The large size and the population-base are the main strengths of the study. In the analysis, two cups of tea was assumed to be equivalent to one cup of coffee; an assumption that might have led to misclassification (see, Bolúmar et al., 1997) . Among non-smokers, no association was found between subfecundity (defined as a waiting time of 1 year or more from cessation of contraception to achievement of pregnancy) and consumption of coffee/tea (Table 44). For women who smoked and also consumed at least 8 cups of coffee per day (or an equivalent amount of tea), a statistically significant increase in waiting for 1 year or more was noted (Table 44). In addition to the non-complete knowledge on caffeine intake, other factors not considered in the analysis may have confounded the results. No data on previous sexually transmitted diseases or on frequency and timing of sexual intercourse were available, something this study has in common with most other related studies. Perhaps of more importance was that coffee/tea consumption was measured as average intake prior to delivery, and was therefore a proxy measure of the women's intake in the actual period in which she was trying to become pregnant.

A large American study on over 12000 non-diabetic, non-asthmathic post partum women from the Boston area has been used by many investigators to explore the relationship between coffee consumption during the first trimester and adverse outcome of pregnancies. The original information, collected 1977-1980, was used to calculate the probability of 3010 married women, who planned their pregnancy and who delivered a single baby after 20 or more gestational weeks, becoming clinically pregnant in each menstrual cycle (Williams et al., 1990). When the time to concep- 
tion was examined for different levels of daily coffee intake, it was noted that this was longest for the 129 women who drank four or more cups of coffee per day. Times for those drinking three, two, one or no cups of coffee were similar but lower. Consumers of four or more cups of coffee were consistently less likely to become pregnant than women who did not drink coffee, also after adjustment for confounding factors (Table 46). Within a menstrual cycle, women exposed to four or more cups of coffee per day had only an $81 \%$ chance of conceiving as compared to unexposed women. The adjusted estimated relative risk of failure to conceive within one year was $80 \%$ higher among consumers of four or more cups of coffee than in non-coffee drinkers (Table 46). A drawback of the calculation was that the coffee consumption during the first trimester was used as a proxy measurement for caffeine exposure during the time the women were trying to conceive. If many women reduced their coffee intake during pregnancy, this misclassification of coffee consumption would underestimate the true risk of exposure to coffee while attempting to conceive. 
Table 43. Caffeine intake and time to pregnancy/conception.

\begin{tabular}{|c|c|c|c|c|c|}
\hline $\begin{array}{l}\text { Reference } \\
\text { Location of study }\end{array}$ & Sample size and selection & $\begin{array}{l}\begin{array}{l}\text { Exposure period consi- } \\
\text { dered }\end{array} \\
\text { Sources of caffeine }\end{array}$ & End-point(s) & \begin{tabular}{|l|} 
Results \\
Risk estimate adjusted odds ratios \\
including 95\% confidence interval \\
(NS = non significant) \\
\end{tabular} & Comments \\
\hline $\begin{array}{l}\text { Grodstein et al., } 1993 \\
\text { Case-control } \\
\text { study } \\
\text { USA and } \\
\text { Canada }\end{array}$ & $\begin{array}{l}1050 \text { infertile women and } 3 \\
833 \text { women who had recently } \\
\text { given birth }\end{array}$ & $\begin{array}{l}\text { Time period prior to } \\
\text { the likely onset of } \\
\text { infertility. } \\
\text { Coffee, tea, cola } \\
\text { drinks }\end{array}$ & $\begin{array}{l}\text { Infertility = inability to } \\
\text { conceive after } 12 \\
\text { months }\end{array}$ & 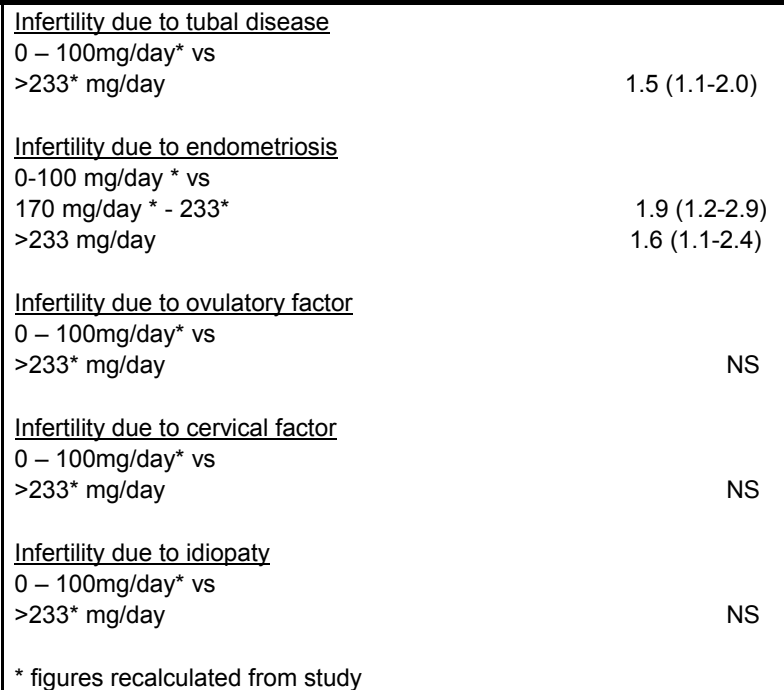 & $\begin{array}{l}\text { Overestimation of caffeine consumption in } \\
\text { infertile women is possible. Cigarette smoking } \\
\text { among mothers was not quantified. Frequency } \\
\text { of intercourse unknown. }\end{array}$ \\
\hline $\begin{array}{l}\text { Hatch and Bracken, } \\
1993 \\
\text { Cross-sectional study } \\
\text { USA }\end{array}$ & $\begin{array}{l}1909 \text { married pregnant } \\
\text { women (with previously } \\
\text { induced abortions) }\end{array}$ & $\begin{array}{l}\text { Period between date } \\
\text { of conception and } \\
\text { inter-view (usually } \\
\text { before } 15^{\text {th }} \text { week of } \\
\text { gestation) } \\
\text { Coffee, tea, soft drinks }\end{array}$ & $\begin{array}{l}\text { Delayed conception = } \\
\text { inability to conceive } \\
\text { within } 12 \text { months }\end{array}$ & $\begin{array}{l}0 \mathrm{mg} / \text { day vs } \\
1-150 \mathrm{mg} / \text { day } \\
151-300 \mathrm{mg} / \mathrm{day} \\
>301 \mathrm{mg} / \mathrm{day}\end{array}$ & $\begin{array}{l}\text { Misclassification of caffeine intake during the } \\
\text { time when attempting to conceive is possible. } \\
\text { Possibly poor recall of when birth control was } \\
\text { stopped. No information on frequency of inter- } \\
\text { course. }\end{array}$ \\
\hline $\begin{array}{l}\text { Stanton and Gray, } 1995 \\
\text { Retrospective cohort } \\
\text { study } \\
\text { USA }\end{array}$ & $\begin{array}{l}1430 \text { well educated parious } \\
\text { women } \\
2501 \text { pregnancies }\end{array}$ & $\begin{array}{l}\text { First month of preg- } \\
\text { nancy (which was } \\
\text { assumed to reflect } \\
\text { pregnancy levels) } \\
1980-1990 \\
\\
\text { Coffee, tea, caffeina- } \\
\text { ted soft drinks }\end{array}$ & & 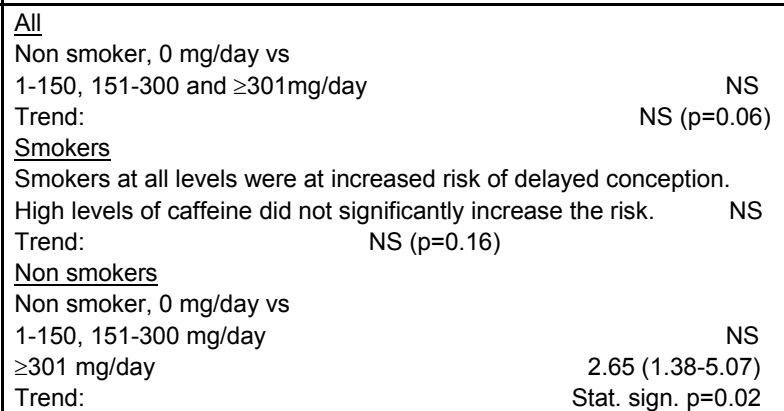 & Low caffeine intake in the studied population. \\
\hline
\end{tabular}




\begin{tabular}{|c|c|c|c|c|c|c|}
\hline $\begin{array}{l}\text { Reference } \\
\text { Location of study }\end{array}$ & Sample size and selection & $\begin{array}{l}\text { Exposure period consi- } \\
\text { dered } \\
\text { Sources of caffeine }\end{array}$ & End-point(s) & $\begin{array}{l}\text { Results } \\
\text { Risk estimate adjusted odds ratios } \\
\text { including } 95 \% \text { confidence interval } \\
\text { (NS = non significant) }\end{array}$ & & Comments \\
\hline $\begin{array}{l}\text { Bolúmar et al., } 1997 \\
\text { Retrospective } \\
\text { multi-center study } \\
\text { Denmark, Italy } \\
\text { Germany, Spain, Po- } \\
\text { land }\end{array}$ & $\begin{array}{l}3187 \text { women }(25-44 \text { years }) \\
\text { randomly selected from } \\
\text { population registers }\end{array}$ & $\begin{array}{l}\text { During starting time of } \\
\text { first episode. } \\
\text { Coffee, tea, cola } \\
\text { drinks }\end{array}$ & $\begin{array}{l}\text { Time to pregnancy }= \\
\text { (subfecundity) }=\text { time } \\
\text { to first pregnancy } \geq 9.5 \\
\text { months }\end{array}$ & $\begin{array}{l}\text { All } \\
0-100 \mathrm{mg} / \text { day vs } \\
101-300,301-500 \mathrm{mg} / \mathrm{day} \\
>500 \mathrm{mg} / \text { day } \\
\text { Smokers only } \\
0-100 \mathrm{mg} / \text { day vs } \\
>500 \mathrm{mg} / \text { day } \\
\\
\text { Non-smokers only } \\
0-100 \mathrm{mg} / \text { day vs } \\
>500 \mathrm{mg} / \text { day }\end{array}$ & $\begin{array}{r}\text { NS } \\
1.45(1.03-2.04) \\
\text { NS } \\
\\
\text { NS }\end{array}$ & $\begin{array}{l}\text { Recall bias very likely. } \\
\text { Cigarette smoking categorised into a small } \\
\text { number of discrete groups instead of into a } \\
\text { continuous variable. }\end{array}$ \\
\hline $\begin{array}{l}\text { Caan et al., } 1998 \\
\text { Prospective cohort } \\
\text { study } \\
\text { USA }\end{array}$ & $\begin{array}{l}210 \text { volunteers from the } \\
\text { Kaiser Permanent Medical } \\
\text { Program trying to conceive }\end{array}$ & $\begin{array}{l}\text { Each menstrual cycle } \\
\text { Regular coffee and tea } \\
\text { decaffeinated coffee } \\
\text { and tea, caffeinated } \\
\text { and diet sodas }\end{array}$ & $\begin{array}{l}\text { Time to conception: } \\
\text { participants were } \\
\text { followed for } 12 \text { months } \\
\text { or until they became } \\
\text { pregnant }\end{array}$ & $\begin{array}{l}\leq 10.4 \mathrm{mg} / \mathrm{day} \text { vs } \\
10.5-106.8 \mathrm{mg} / \mathrm{day} \\
>106.8 \mathrm{mg} / \mathrm{day}\end{array}$ & $\begin{array}{l}\text { NS } \\
\text { NS }\end{array}$ & $\begin{array}{l}\text { A small study with a very low mean weekly } \\
\text { intake of caffeine. }\end{array}$ \\
\hline
\end{tabular}


Table 44. Intake of caffeine containing beverages and time to pregnancy.

\begin{tabular}{|c|c|c|c|c|c|c|}
\hline $\begin{array}{l}\text { Reference } \\
\text { Location of study }\end{array}$ & Sample size and selection & $\begin{array}{l}\text { Exposure period considered } \\
\text { Sources of caffeine }\end{array}$ & End-point(s) & $\begin{array}{l}\text { Results } \\
\text { Risk estimate adjusted odd ratios, } \\
\text { including } 95 \% \text { confidence interval } \\
\text { (NS = non significant) }\end{array}$ & & Comments \\
\hline $\begin{array}{l}\text { Christiansson } \\
\text { et al., } 1989 \\
\text { Prospective longitu- } \\
\text { dinal } \\
\text { study } \\
\text { USA }\end{array}$ & $\begin{array}{l}6303 \text { pregnant women } \\
\text { selected from the Child } \\
\text { Health and Development } \\
\text { Study }\end{array}$ & $\begin{array}{l}\text { Before pregnancy } \\
\text { Coffee }\end{array}$ & $\begin{array}{l}\text { Difficulty in becoming } \\
\text { pregnant }\end{array}$ & $\begin{array}{l}\text { Coffee } \\
<1 \text { cup/day vs } \\
1-3 \text { cups/day - } \\
4-6 \text { cups/day - } \\
>7 \text { cups/day - } \\
\text { (no confidence intervals were given) }\end{array}$ & $\begin{array}{l}1.20 \\
1.88 \\
1.96\end{array}$ & $\begin{array}{l}\text { Original questions in the questionnaire not } \\
\text { designed to answer the questions asked in } \\
\text { this study. Poor adjustment for smoking. }\end{array}$ \\
\hline $\begin{array}{l}\text { Joesoef et al., } \\
1990 \\
\text { Retrospective multi- } \\
\text { center case-control } \\
\text { study } \\
\text { USA and Canada }\end{array}$ & $\begin{array}{l}2817 \text { fertile women and } \\
1818 \text { women with primary } \\
\text { infertility. }\end{array}$ & $\begin{array}{l}\text { No information about } \\
\text { exposure period. } \\
\text { Coffee, } \\
\text { decaffeinated coffee, tea, } \\
\text { cola drinks. }\end{array}$ & \begin{tabular}{|l|} 
Average time to \\
conception
\end{tabular} & $\begin{array}{l}\text { Fertile women } \\
\text { Regular coffee: Trend: } \\
\text { Decaffeinated coffee: Trend: } \\
\text { Tea: Trend: } \\
\text { Cola: Trend: } \\
\text { Infertile women } \\
\text { Decaffeinated coffee: "none" vs } \\
1-2 \text { cups } \\
>2 \text { cups }\end{array}$ & $\begin{array}{r}\text { NS } \\
N S \\
\text { significant }(p<0.01) \\
N S \\
\\
1.5(p<0.05) \\
2.5(p<0.05)\end{array}$ & $\begin{array}{l}\text { Effects of tea consumption subsequently } \\
\text { suggested to be unrelated to time to } \\
\text { pregnancy (Cramer, 1990). }\end{array}$ \\
\hline $\begin{array}{l}\text { Williams et al., } 1990 \\
\text { Cross-sectional study } \\
\text { USA }\end{array}$ & $\begin{array}{l}3010 \text { non diabetic married } \\
\text { women planning pregnancy }\end{array}$ & $\begin{array}{l}\text { First trimester of pregnan- } \\
\text { cy } \\
\text { Coffee }\end{array}$ & $\begin{array}{l}\text { Time to conception } \\
\text { (Within one year of } \\
\text { unprotected inter- } \\
\text { course) }\end{array}$ & $\begin{array}{l}\text { Coffee } \\
0 \text { cup/day vs } \\
\geq 4 \text { cups/day }\end{array}$ & $1.8(1.1-3.0)$ & $\begin{array}{l}\text { Coffee consumption was only registered } \\
\text { during } 1^{\text {st }} \text { trimester, which could lead to } \\
\text { misclassification of exposure during con- } \\
\text { ceiving time. }\end{array}$ \\
\hline $\begin{array}{l}\text { Olsen, } 1991 \\
\text { Retrospective cohort } \\
\text { study } \\
\text { Denmark }\end{array}$ & 10886 women & $\begin{array}{l}\text { Before pregnancy } \\
\text { Coffee, tea }\end{array}$ & $\begin{array}{l}\text { Time to pregnancy } \\
\text { (expressed as subfe- } \\
\text { cundity) }\end{array}$ & $\begin{array}{l}\text { Coffee/tea, non-smokers } \\
0-3 \text { cups/day vs } \\
4-7, \geq 8 \text { cups/day } \\
\\
\text { Coffee/tea, smokers } \\
0-3 \text { cups/day vs } \\
4-7 \text { cups/day } \\
\geq 8 \text { cups/day }\end{array}$ & $\begin{array}{r}\text { NS } \\
\text { NS } \\
1.35(1.02-1.48)\end{array}$ & $\begin{array}{l}\text { Information on caffeine consumption was } \\
\text { not complete. No information on frequency } \\
\text { of intercourse. }\end{array}$ \\
\hline
\end{tabular}




\begin{tabular}{|c|c|c|c|c|c|c|}
\hline $\begin{array}{l}\text { Reference } \\
\text { Location of study }\end{array}$ & Sample size and selection & $\begin{array}{l}\text { Exposure period considered } \\
\text { Sources of caffeine }\end{array}$ & End-point(s) & $\begin{array}{l}\text { Results } \\
\text { Risk estimate adjusted odd ratios, } \\
\text { including } 95 \% \text { confidence interval } \\
\text { (NS = non significant) } \\
\end{array}$ & & Comments \\
\hline $\begin{array}{l}\text { Hatch and } \\
\text { Bracken, } 1993 \\
\text { Cross-sectional study } \\
\text { USA }\end{array}$ & $\begin{array}{l}1909 \text { married pregnant } \\
\text { women (with previously } \\
\text { induced abortions) }\end{array}$ & $\begin{array}{l}\text { Period between date of } \\
\text { conception and interview } \\
\text { (usually before the } 15^{\text {th }} \\
\text { week of gestation) } \\
\text { Coffee, tea, soft drinks }\end{array}$ & $\begin{array}{l}\text { Delayed conception = } \\
\text { inability to conceive } \\
\text { within } 12 \text { months }\end{array}$ & $\begin{array}{l}\text { Coffee } \\
\text { None vs }> \\
1-150,151-300,>300 \mathrm{mg} / \mathrm{day} \\
\frac{\text { Tea }}{\text { None vs }} \\
1-50,51-100,>100 \mathrm{mg} / \mathrm{day} \\
\frac{\text { Colas }}{\text { None vs }} \\
1-50,51-100,>100 \mathrm{mg} / \text { day }\end{array}$ & $\begin{array}{l}\text { NS } \\
\text { NS }\end{array}$ & $\begin{array}{l}\text { Misclassification of caffeine intake during } \\
\text { the time when attempting to conceive is } \\
\text { possible. } \\
\text { Possible poor recall of when birth control } \\
\text { was stopped. No information on frequency } \\
\text { of intercourse. }\end{array}$ \\
\hline $\begin{array}{l}\text { Alderete et al., } 1995 \\
\text { Prospective longitu- } \\
\text { dinal } \\
\text { study } \\
\text { USA }\end{array}$ & $\begin{array}{l}1341 \text { primigravida (only) } \\
\text { from } \\
\text { the Child Health and Deve- } \\
\text { lopment Study }\end{array}$ & $\begin{array}{l}\text { Before pregnancy } \\
\text { Coffee }\end{array}$ & $\begin{array}{l}\text { Time to conception }= \\
\text { stop of } \\
\text { contraception to last } \\
\text { menstrual period } \\
\\
\text { Results from }>12 \\
\text { months vs } \leq 12 \\
\text { months }\end{array}$ & $\begin{array}{l}\text { Coffee } \\
\text { Non coffee drinking and non smoking vs } \\
1-3 \text { cups and smoking } 0,1-9,10-19 \text { or } \\
\geq 20 \text { cigarettes } \\
\text { Non coffee drinking and non smoking vs } \\
\geq 3 \text { cups and smoking } 0,1-9,10-19 \text { or } \\
\geq 20 \text { cigarettes }\end{array}$ & NS & $\begin{array}{l}\text { Only women who became pregnant were } \\
\text { included. A high drop-out rate due to no } \\
\text { information about last time using contra- } \\
\text { ception from } 30 \% \text { of the primigravidas. }\end{array}$ \\
\hline $\begin{array}{l}\text { Bolúmar et al., } 1997 \\
\text { Retrospective multi- } \\
\text { center study ( } 5 \\
\text { count-ries) }\end{array}$ & $\begin{array}{l}3187 \text { women between } 25 \\
\text { and } 44 \text { years randomly } \\
\text { selected from population } \\
\text { registers. }\end{array}$ & $\begin{array}{l}\text { During starting time of first } \\
\text { episode. } \\
\text { Coffee, tea and cola } \\
\text { drinks. }\end{array}$ & $\begin{array}{l}\text { Time to pregnancy } \\
\geq 9.5 \text { months }\end{array}$ & $\begin{array}{l}\frac{\text { Regular coffee }}{0 \text { cups/day vs }} \\
\geq 5 \text { cups } / \text { day }\end{array}$ & $1.40(1.01-1.95)$ & $\begin{array}{l}\text { Recall bias very likely. } \\
\text { Cigarette smoking categorised into a small } \\
\text { number of discrete groups instead of into a } \\
\text { continuous variable. }\end{array}$ \\
\hline $\begin{array}{l}\text { Caan et al., } 1998 \\
\text { Prospective cohort } \\
\text { study } \\
\text { USA }\end{array}$ & $\begin{array}{l}210 \text { volunteers from the } \\
\text { Kaiser Permanent Medical } \\
\text { Program trying to conceive }\end{array}$ & $\begin{array}{l}\text { Each menstrual cycle } \\
\text { Regular coffee and tea } \\
\text { decaffeinated coffee and } \\
\text { tea, caffeinated and diet } \\
\text { sodas }\end{array}$ & $\begin{array}{l}\text { Time to conception } \\
\text { Participants were } \\
\text { followed for } 12 \\
\text { months or until they } \\
\text { became pregnant }\end{array}$ & $\begin{array}{l}\text { Regular coffee } \\
0 \text { servings/day vs } \\
0.1-1,>1 \text { servings/day } \\
\text { Decaffeinated coffee } \\
0 \text { servings/day vs } \\
0.1-1,>1 \text { servings/day } \\
\text { Regular tea } \\
0 \text { servings/day vs } \\
0.1-0.5 \text { servings/day } \\
>0.5 \text { servings/day } \\
\text { Caffeinated soda } \\
0 \text { servings/day vs } \\
0.1-0.5,>0.5 \text { servings/day }\end{array}$ & $\begin{array}{r}\text { NS } \\
\text { NS } \\
\text { NS } \\
2.05(1.09-3.88)\end{array}$ & $\begin{array}{l}\text { A small study with a very low mean weekly } \\
\text { intake of caffeine. } \\
\text { Sign. relationship between tea consump- } \\
\text { tion and increase in fertility only observed } \\
\text { in pregnancy cycles } 1 \text { through } 3 \text {. }\end{array}$ \\
\hline
\end{tabular}


Table 45. Caffeine intake and fecundability.

\begin{tabular}{|c|c|c|c|c|c|c|}
\hline $\begin{array}{l}\text { Reference } \\
\text { Location of study }\end{array}$ & Sample size and selection & $\begin{array}{l}\text { Exposure period considered } \\
\text { Sources of caffeine }\end{array}$ & End-point(s) & $\begin{array}{l}\text { Results } \\
\text { Risk estimate adjusted odds ratios } \\
\text { including } 95 \% \text { confidence interval } \\
\text { (NS = non significant) }\end{array}$ & & Comments \\
\hline $\begin{array}{l}\text { Wilcox et al., } 1988 \\
\text { Prospective cohort } \\
\text { study } \\
\text { USA }\end{array}$ & $\begin{array}{l}104 \text { women } \\
\text { (of 221) who did not } \\
\text { become pregnant in their } \\
\text { first three months } \\
\text { of trying }\end{array}$ & $\begin{array}{l}\text { During the study (inter- } \\
\text { views at } 0,3 \text { and } 6 \\
\text { months) } \\
\text { Brewed coffee, instant } \\
\text { coffee, tea, caffeinated } \\
\text { soft drinks }\end{array}$ & $\begin{array}{l}\text { Fecundability } \\
\text { defined as the proba- } \\
\text { bility of becoming } \\
\text { clinically pregnant in a } \\
\text { given menstrual } \\
\text { cycle }\end{array}$ & $\begin{array}{l}\frac{104 \text { women }^{<}}{<105 \mathrm{mg} / \mathrm{day}^{*} \text { vs }} \\
>105 \mathrm{mg} / \mathrm{day}{ }^{*} \\
\frac{\text { All } 221 \text { women }}{<105 \mathrm{mg} / \mathrm{day}^{*} \text { vs }} \\
>105 \mathrm{mg} / \mathrm{day}^{*} \\
\\
\frac{\text { Estimated risk of infertility }}{<105 \mathrm{mg} / \mathrm{day}^{*} \text { vs }} \\
>105 \mathrm{mg} / \mathrm{day}^{*} \\
\text { * figures recalculated from the study }\end{array}$ & $\begin{array}{r}0.51(0.35-0.75) \\
\text { NS } \\
4.7(p<0.005)\end{array}$ & $\begin{array}{l}\text { Only a subset of the women provided data } \\
\text { on caffeine consumption during the concei- } \\
\text { ving time. } \\
\text { Small study base with a mixture of women } \\
\text { who had conceived previously and who } \\
\text { had not. }\end{array}$ \\
\hline $\begin{array}{l}\text { Joesoef et al., } \\
1990 \\
\text { Retrospective multi- } \\
\text { center case-control } \\
\text { study } \\
\text { USA and Canada }\end{array}$ & $\begin{array}{l}2817 \text { fertile women and } \\
1818 \text { women with primary } \\
\text { infertility }\end{array}$ & $\begin{array}{l}\text { No information about } \\
\text { exposure period. } \\
\text { Coffee, } \\
\text { decaffeinated coffee, tea, } \\
\text { cola drinks }\end{array}$ & $\begin{array}{l}\text { Fecundability } \\
\text { ratio }\end{array}$ & $\begin{array}{l}\leq 17 \mathrm{mg} / \mathrm{day}^{*} \text { vs } \\
>233 \mathrm{mg} / \mathrm{day}^{*} \\
\end{array}$ & & \\
\hline $\begin{array}{l}\text { Hatch and } \\
\text { Bracken, } 1993 \\
\text { Cross-sectional study } \\
\text { USA }\end{array}$ & $\begin{array}{l}1909 \text { married pregnant } \\
\text { women (with previously } \\
\text { induced abortions) }\end{array}$ & $\begin{array}{l}\text { Period between date of } \\
\text { conception and interview } \\
\text { (usually before the } 15^{\text {th }} \\
\text { week of gestation) } \\
\text { Coffee, tea, soft drinks }\end{array}$ & $\begin{array}{l}\text { Delayed conception }= \\
\text { inability to conceive } \\
\text { within } 12 \text { months }\end{array}$ & $\begin{array}{l}0 \mathrm{mg} / \text { day vs } \\
1-150 \mathrm{mg} / \text { day } \\
151-300 \mathrm{mg} / \mathrm{day} \\
>301 \mathrm{mg}\end{array}$ & $\begin{array}{c}0.90(0.81-0.99) \\
N S \\
0.73(0.61-0.88)\end{array}$ & $\begin{array}{l}\text { Misclassification of caffeine intake during } \\
\text { the time when attempting to conceive is } \\
\text { possible. } \\
\text { Possible poor recall of when birth control } \\
\text { was stopped. No information on frequency } \\
\text { of intercourse. }\end{array}$ \\
\hline $\begin{array}{l}\text { Florack et al., } 1994 \\
\text { Prospective } \\
\text { Cohort study } \\
\text { The Netherlands }\end{array}$ & $\begin{array}{l}259 \text { women and their } \\
\text { partners } \\
\text { planning pregnancy }\end{array}$ & $\begin{array}{l}\text { During the study. } \\
\text { Coffee, tea, cola }\end{array}$ & $\begin{array}{l}\text { Time to pregnancy } \\
\text { expressed as fecun- } \\
\text { dability = probability in } \\
\text { each cycle to become } \\
\text { pregnant }\end{array}$ & $\begin{array}{l}\text { Women } \\
<400 \mathrm{mg} / \text { day vs } \\
400-700 \mathrm{mg} / \text { day } \\
\geq 700 \mathrm{mg} / \text { day } \\
\\
\text { Partners } \\
<400 \mathrm{mg} / \text { day vs } \\
400-700 \mathrm{mg} / \text { day } \\
\geq 700 \mathrm{mg} / \text { day }\end{array}$ & $\begin{array}{c}2.1(1.2-3.7) \\
\text { NS } \\
\\
\text { NS } \\
0.6(0.3-0.97)\end{array}$ & $\begin{array}{l}\text { Small study base. } \\
\text { Selection, information and confounding } \\
\text { bias possible. }\end{array}$ \\
\hline
\end{tabular}




\begin{tabular}{|c|c|c|c|c|c|c|}
\hline $\begin{array}{l}\text { Reference } \\
\text { Location of study }\end{array}$ & Sample size and selection & $\begin{array}{l}\text { Exposure period considered } \\
\text { Sources of caffeine }\end{array}$ & End-point(s) & \begin{tabular}{|l|} 
Results \\
Risk estimate adjusted odds ratios \\
including $95 \%$ confidence interval \\
(NS = non significant)
\end{tabular} & & Comments \\
\hline $\begin{array}{l}\text { Stanton and Gray, } \\
1995 \\
\text { Retrospective cohort } \\
\text { study } \\
\text { USA }\end{array}$ & $\begin{array}{l}1430 \text { well educated } \\
\text { parious women. } \\
2501 \text { pregnancies }\end{array}$ & $\begin{array}{l}\text { First month of pregnancy } \\
\text { (which was assumed to } \\
\text { reflect pregnancy levels) } \\
\\
\text { Coffee, tea, caffeinated } \\
\text { soft drinks }\end{array}$ & $\begin{array}{l}\text { Fecundability = } \\
\text { probability in each } \\
\text { cycle to become } \\
\text { pregnant }\end{array}$ & $\begin{array}{l}\text { All women } \\
0 \mathrm{mg} / \mathrm{day} \text { vs } \\
1-150,151-300 \mathrm{mg} / \mathrm{day} \\
\geq 301 \mathrm{mg} / \mathrm{day} \\
\text { Trend: } \\
\\
\text { Non smokers } \\
0 \mathrm{mg} / \mathrm{day} \mathrm{vs} \\
1-150,151-300 \mathrm{mg} / \text { day } \\
\geq 301 \mathrm{mg} / \mathrm{day} \\
\text { Trend: } \\
\\
\text { Smokers } \\
0 \mathrm{mg} / \mathrm{day} \text { non smoker vs } \\
\text { smokers consuming } \\
0 \mathrm{mg} / \mathrm{day} \\
1-150 \mathrm{mg} / \mathrm{day} \\
151-300 \mathrm{mg} / \mathrm{day} \\
\geq 300 \mathrm{mg} / \mathrm{day} \\
\text { Trend: }\end{array}$ & $\begin{array}{r}\mathrm{NS} \\
0.83(0.71-0.99) \\
\text { stat. sign. } \\
\\
\mathrm{NS} \\
0.74(0.59-0.92) \\
\text { stat. sign. } \\
\\
\\
\\
\\
0.78(0.62-1.00) \\
0.81(0.69-0.95) \\
0.83(0.69-0.99) \\
\mathrm{NS} \\
\mathrm{NS}\end{array}$ & $\begin{array}{l}\text { The caffeine intake was low in the studied } \\
\text { population. }\end{array}$ \\
\hline $\begin{array}{l}\text { Curtis et al., } \\
1997 \\
\text { Retrospective cohort } \\
\text { (Ontario Farm Family } \\
\text { Health) study } \\
\text { Canada }\end{array}$ & $\begin{array}{l}1277 \text { farming couples: } \\
2,607 \text { planned pregnan- } \\
\text { cies during the previous } \\
30 \text { years }\end{array}$ & $\begin{array}{l}\text { Information of the con- } \\
\text { sumption at the time of the } \\
\text { questionnaire } \\
\text { 1991-1992 } \\
\text { Coffee, tea, cola }\end{array}$ & $\begin{array}{l}\text { Fecundability }=\text { the } \\
\text { monthly probability of } \\
\text { conception }\end{array}$ & $\begin{array}{l}\text { Women } \\
0 \mathrm{mg} / \text { day vs } \\
1-100,101-300,301-500 \text { and } \\
>500 \mathrm{mg} / \mathrm{day} \\
\frac{\text { Men }}{0 \mathrm{mg} / \mathrm{day} \text { vs }} \\
1-100,101-300,301-500 \text { and } \\
>500 \mathrm{mg} / \mathrm{day}\end{array}$ & $\begin{array}{l}\text { NS } \\
\text { NS }\end{array}$ & $\begin{array}{l}\text { Misclassification of consumption is pro- } \\
\text { bable depending on recall problems }\end{array}$ \\
\hline $\begin{array}{l}\text { Haakim et al., } 1998 \\
\text { Prospective cohort } \\
\text { study } \\
\text { USA }\end{array}$ & $\begin{array}{l}124 \text { women employed in } \\
\text { a semiconductor plant in } \\
\text { the Northwest of the } \\
\text { United States }\end{array}$ & $\begin{array}{l}\text { Each menstrual cycle } \\
\text { Coffee, tea, caffeinated } \\
\text { soft drinks }\end{array}$ & $\begin{array}{l}\text { Fecundability }= \\
\text { probability in each } \\
\text { cycle to become } \\
\text { pregnant }\end{array}$ & \begin{tabular}{|l|} 
N Non-smoking women \\
$0-25 \mathrm{mg} /$ day vs \\
$26-100,101-300, \geq 301 \mathrm{mg} /$ day
\end{tabular} & NS & $\begin{array}{l}\text { Very small study base with women having } \\
\text { a low caffeine consumption. }\end{array}$ \\
\hline
\end{tabular}




\begin{tabular}{|c|c|c|c|c|c|c|}
\hline $\begin{array}{l}\text { Reference } \\
\text { Location of study }\end{array}$ & Sample size and selection & $\begin{array}{l}\text { Exposure period considered } \\
\text { Sources of caffeine }\end{array}$ & End-point(s) & $\begin{array}{l}\text { Results } \\
\text { Risk estimate adjusted odds ratios } \\
\text { including } 95 \% \text { confidence interval } \\
\text { (NS = non significant) }\end{array}$ & & Comments \\
\hline $\begin{array}{l}\text { Jensen et al., 1998a } \\
\text { Prospective cohort } \\
\text { study } \\
\text { Denmark }\end{array}$ & $\begin{array}{l}423 \text { couples who discon- } \\
\text { tinued birth control }\end{array}$ & $\begin{array}{l}\text { Each menstrual cycle } \\
\text { Exposure data from 1992- } \\
1995 \\
\text { Coffee, tea, cocoa, cola, } \\
\text { chocolate bars }\end{array}$ & $\begin{array}{l}\text { Fecundability }= \\
\text { probability in each } \\
\text { cycle to become } \\
\text { pregnant }\end{array}$ & $\begin{array}{l}\text { Non-smoking women (nsw) } \\
0-299 \mathrm{mg} / \mathrm{day} \text { vs } \\
300-699, \geq 700 \mathrm{mg} / \mathrm{day} \\
\text { Smoking women (sw) } \\
0-299 \mathrm{mg} / \mathrm{day}(\mathrm{nsw}) \mathrm{vs} \\
300-699, \geq 700 \mathrm{mg} / \mathrm{day} \\
\text { Non-smoking men (nsm) } \\
0-299 \mathrm{mg} / \mathrm{day}(\mathrm{nsm}) \mathrm{vs} \\
300-699 \mathrm{mg} / \mathrm{day} \\
\geq 700 \mathrm{mg} / \mathrm{day} \\
\text { Smoking men (sm) } \\
0-299 \mathrm{mg} / \mathrm{day}(\mathrm{nsm}) \mathrm{vs} \\
300-699, \geq 700 \mathrm{mg} / \mathrm{day}\end{array}$ & $\begin{array}{r}\text { NS } \\
\text { NS } \\
\text { NS } \\
0.56(0.32-0.96) \\
\text { NS }\end{array}$ & $\begin{array}{l}\text { Original questions in questionnaires not } \\
\text { designed for the study. } \\
\text { Few participants were unexposed or had a } \\
\text { low intake. Frequency of intercourse } \\
\text { unknown. }\end{array}$ \\
\hline
\end{tabular}


Table 46. Intake of caffeine-containing beverages and fecundability

\begin{tabular}{|c|c|c|c|c|c|c|}
\hline $\begin{array}{l}\text { Reference } \\
\text { Location of study }\end{array}$ & Sample size and selection & $\begin{array}{l}\text { Exposure period considered } \\
\text { Sources of caffeine }\end{array}$ & End-point(s) & \begin{tabular}{|l|} 
Results \\
Risk estimate adjusted odds ratios \\
including $95 \%$ confidence interval \\
\end{tabular} & & Comments \\
\hline $\begin{array}{l}\text { Williams et al., } 1990 \\
\text { Cross-sec-tional } \\
\text { study } \\
\text { USA }\end{array}$ & $\begin{array}{l}3010 \text { non diabetic married } \\
\text { women planning pregnan- } \\
\text { cy. }\end{array}$ & $\begin{array}{l}\text { First trimester of pregnan- } \\
\text { cy } \\
\text { Coffee }\end{array}$ & Fecundability & $\begin{array}{l}\text { Coffee } \\
0 \text { vs } \geq 4 \text { cups/day }\end{array}$ & $0.81(0.67-0.97)$ & $\begin{array}{l}\text { Coffee consumption was only registered } \\
\text { during } 1^{\text {st }} \text { trimester, which could lead to } \\
\text { misclassification of exposure during con- } \\
\text { ceiving time. }\end{array}$ \\
\hline $\begin{array}{l}\text { Wilcox and Wein- } \\
\text { berg, } 1991 \\
\text { Prospective } \\
\text { cohort study } \\
\text { USA }\end{array}$ & $\begin{array}{l}104 \text { women (originally } \\
221 \text { ) trying to become } \\
\text { pregnant }\end{array}$ & $\begin{array}{l}\text { During the study (inter- } \\
\text { views at } 0,3 \text { and } 6 \\
\text { months) } \\
\text { Brewed and instant coffee, } \\
\text { tea, caffeinated soft drinks }\end{array}$ & \begin{tabular}{|l|} 
Fecundability \\
defined as the proba- \\
bility of becoming \\
clinically pregnant in a \\
given menstrual cycle
\end{tabular} & $\begin{array}{l}\text { Tea } \\
\text { One soft } \\
1 \text { drink/day }\end{array}$ & $\begin{array}{c}N S \\
0.50(p=0.01)\end{array}$ & $\begin{array}{l}\text { Only a subset of the women provided data } \\
\text { on beverage consumption during the } \\
\text { conceiving time. } \\
\text { Small study base with a mixture of women } \\
\text { who had conceived previously and who } \\
\text { had not. }\end{array}$ \\
\hline $\begin{array}{l}\text { Florack et al., } 1994 \\
\text { Prospective cohort } \\
\text { study } \\
\text { The Netherlands }\end{array}$ & $\begin{array}{l}259 \text { women and their } \\
\text { partners } \\
\text { planning pregnancy }\end{array}$ & $\begin{array}{l}\text { During the study } \\
\text { Coffee, tea ,cola }\end{array}$ & $\begin{array}{l}\text { Time to pregnancy } \\
\text { expressed as fecun- } \\
\text { dability (defined as } \\
\text { probability in each } \\
\text { cycle to become } \\
\text { pregnant }\end{array}$ & \begin{tabular}{|l} 
Tea \\
0 cups/day vs \\
$1-5$ cups/day \\
$>5$ cups/day \\
Coffee \\
0 cups/day vs \\
$1-5,>5$ cups/day \\
Cola \\
Trend:
\end{tabular} & $\begin{array}{r}1.9(1.2-3.0) \\
3.2(1.3-7.7) \\
\text { NS } \\
\text { NS }\end{array}$ & $\begin{array}{l}\text { Small study base. } \\
\text { Selection, information and confounding } \\
\text { bias possible }\end{array}$ \\
\hline $\begin{array}{l}\text { Curtis et al., } \\
1997 \\
\text { Retrospective cohort } \\
\text { (Ontario Farm Family } \\
\text { Health) study } \\
\text { Canada }\end{array}$ & $\begin{array}{l}1277 \text { farming couples: } \\
2607 \text { planned pregnan- } \\
\text { cies that had occurred } \\
\text { during the previous } 30 \\
\text { years }\end{array}$ & $\begin{array}{l}\text { Information on consump- } \\
\text { tion at the time of the } \\
\text { questionnaire. } \\
\text { Coffee, tea, cola }\end{array}$ & Fecundability & $\begin{array}{l}\text { Coffee } \\
0 \text { cups/day vs }>6 \text { cups/day } \\
\text { women: } \\
\text { men: } \\
\text { Tea } \\
0 \text { cups/day vs }>3 \text { cups/day } \\
\text { women: } \\
\text { men: } \\
\text { Cola } \\
0 \text { cups/day vs }>2 \text { cups/day } \\
\text { women: } \\
\text { men: }\end{array}$ & $\begin{array}{l}\text { NS } \\
\text { NS }\end{array}$ & $\begin{array}{l}\text { Misclassification of consumption is pro- } \\
\text { bable depending on recall problems. }\end{array}$ \\
\hline
\end{tabular}




\begin{tabular}{|c|c|c|c|c|c|c|}
\hline $\begin{array}{l}\text { Reference } \\
\text { Location of study }\end{array}$ & Sample size and selection & $\begin{array}{l}\text { Exposure period considered } \\
\text { Sources of caffeine } \\
\end{array}$ & End-point(s) & \begin{tabular}{|l} 
Results \\
Risk estimate adjusted odds ratios \\
including 95\% confidence interval
\end{tabular} & & Comments \\
\hline $\begin{array}{l}\text { Jensen et al., 1998a } \\
\text { Prospective cohort } \\
\text { study } \\
\text { Denmark }\end{array}$ & $\begin{array}{l}423 \text { couples who discon- } \\
\text { tinued birth control }\end{array}$ & $\begin{array}{l}\text { Each menstrual cycle } \\
\text { Coffee, tea, cocoa, cola, } \\
\text { chocolate bars }\end{array}$ & $\begin{array}{l}\text { Fecundability = } \\
\text { probability in each } \\
\text { cycle to become } \\
\text { pregnant }\end{array}$ & $\begin{array}{l}\text { Coffee } \\
\text { O-299 mg/day vs } \geq 300 \mathrm{mg} / \mathrm{day} \\
\text { Non-smoking women } \\
\text { Smoking women } \\
\text { Non-smoking men } \\
\text { Smoking men } \\
\text { Other beverages } \\
\text { All categories } \\
\end{array}$ & $\begin{array}{r}\text { NS } \\
0.34(0.12-0.98) \\
0.48(0.24-0.97) \\
\text { NS } \\
\text { NS } \\
\end{array}$ & $\begin{array}{l}\text { Prospective design is a strength. Original } \\
\text { questions in questionnaires not designed } \\
\text { for the study. } \\
\text { Few participants were unexposed or had a } \\
\text { low intake. Frequency of intercourse } \\
\text { unknown. }\end{array}$ \\
\hline
\end{tabular}




\subsection{Caffeine intake and pregnancy rate after induced abortion}

The evidence that legal induced abortion as presently practised has any adverse effect on subsequent ability to conceive is scant. Early evidence that abortion produces sterility comes from Europe and Japan (for references, see Stubblefield et al., 1984), but more recent studies have found no significant association between legal abortion and sterility (for references, see Stubblefield et al., 1984). An American cohort study examined this issue by following 1235 post-abortal women, 912 women that had recently delivered, and 939 women from the authors' gynecological clinics for as long as 3.5 years. In this study base the investigators explored the influence of caffeine intake on the pregnancy rate (per 1000 person months). Induced abortion status did not influence pregnancy rates in this study, except for the fact that the women reporting three or more induced abortions had a higher pregnancy rate. After controlling the occurrence of pregnancy for a number of independent factors, coffee consumption was unrelated to pregnancy rate (Stubblefield et al., 1984).

\subsection{Caffeine and menstrual function}

The relationship between caffeine intake and menstrual function has been investigated in a single study. This study was performed with 403 healthy premenopausal women who belonged to Kaiser Permanente Medical Care Program in 1990-1991 (Fenster et al., 1999). A telephone interview collected information on the intake of caffeinated beverages, as well as on other lifestyle, demographic, occupational, and environmental factors. Subjects collected daily urine samples and completed a daily consumption diary over a period of on average five menstrual cycles. Metabolites of oestrogen and progesterone were measured in the urine, each cycle was characterised as anovulatory or ovulatory, and a probable day of ovulation was selected when appropriate. Women whose caffeine consumption was heavy (>300 mg of caffeine per day) had less than a third of the risk for long menses ( $\geq 8$ days) compared with women who did not consume caffeine. Those whose caffeine consumption was substantial also had a doubled risk for a short cycle length ( $\leq 24$ days); this association was also evident in those whose caffeine consumption was substantial but who did not smoke. Caffeine intake was not strongly related to an increased risk for an ovulation, a short luteal phase ( $\leq 10$ days), a long follicular phase ( $\geq 24$ days), a long cycle ( $\geq 36$ days), or measures of within-woman cycle variability. 


\subsection{Caffeine and sperm activity}

While the maternal role in chemically induced reduced fertility and teratogenesis has been well established, the importance of male involvement has not been extensively investigated. As indicated below, there are theoretical reasons to assert that caffeine is able to influence fertility.

Beach and co-workers (1984) showed a close correlation between blood and semen concentration of caffeine. After caffeine consumption as tablets or coffee the peak level of caffeine was reached within around $1 \mathrm{~h}$ in both types of fluid. After exposure to $400 \mathrm{mg}$ caffeine, the concentration in semen reached a maximum value of 6 to $9.5 \mu \mathrm{g} / \mathrm{ml}$, whereas an intake of half that amount resulted in concentrations between 3 and 4 $\mu \mathrm{g} / \mathrm{ml}$. After reaching the peak, the concentration of caffeine declined in both blood and semen over a period of several hours, indicating that absorption is rapid relative to elimination. The half-life of caffeine in blood was $3.7 \pm 0.3$ hours in this study, and that in semen $3.6 \pm 0.3$ hours. It was recognised in this study that a single dose of up to $400 \mathrm{mg}$ caffeine failed to affect the number of sperm or volume of semen produced in the ejaculate (Beach et al., 1984).

In the 1970s and 1980s it was recognised that incubation of human semen with caffeine in vitro appears to increase the motility of both fresh and previously frozen human spermatozoa (Schoenfeld et al., 1975; Schill et al., 1979; Barkay et al., 1977; Barkay and Zuckerman, 1978, 1980; Harrison, 1978; Schill et al., 1979; Harrison et al., 1980; Makler et al., 1980; Levin et al., 1981; Aitken et al., 1983; Moussa, 1983; Jiang et al., 1984; Prins and Ross, 1985; Ruzich et al., 1987; Cai and Marik, 1989). Similar motility stimulating effects have been reported after exposure of spermatozoa to other methylxanthines, such as theophylline, lysinetheophylline and 3-isobutyl-1-methylxanthine (Jiang et al., 1984). Spermatozoal motility is a function of its metabolism, with exogenous hexose driving glycolysis and producing ATP. Calcium and magnesium ions mediate the appropriate ATP activity. The mechanism by which caffeine stimulates sperm motility is thought to involve the inhibition of phosphodiesterase activity, with a subsequent accumulation of cyclic nucleotides, especially cAMP, within the sperm cells. Cyclic nucleotides are known to stimulate sperm motility. The precise way in which elevated intracellular cAMP levels induce an increase in motility is not clearly understood, although the control of calcium ion fluxes across the sperm plasma membrane is probably involved.

Although many studies have shown that caffeine increases the percentage of motile spermatozoa and the velocity of sperm (Traub et al., 1982; Ruzich et al., 1987), it has been claimed that the quality of movement is not influenced (Aitken et al., 1983). On the other hand,

Prins and Ross (1985) observed that caffeine influences two motility parameters of epididymal sperm: (1) it increases the percent motile 
sperm; and (2) changes the motility from non-progressive ("twitching") to progressive type, with forward drives of grades 2 to 4 . Caffeine treatment of frozen-thawed human spermatozoa also increases the number of spermatozoa penetrating cervical mucus in unit time (Schill et al., 1979), by increasing the frequency rather than the success of collisions between spermatozoa and the cervical mucus interface (Aitken et al., 1983). Caffeine has to be continuously present for this effect to be expressed.

Early claims that incubation of spermatozoa with caffeine, especially spermatozoa from infertile patients, appears to disrupt the normal architectural pattern of the sperm head (Harrison et al., 1980), have not been confirmed in later studies with $7.2 \mathrm{mM}$ caffeine (Barkay et al., 1984). In the early studies there were indications that the elemental composition in the caffeine-exposed spermatozoa was altered, in particular with relation to the concentration of calcium and chlorine (Harrison et al., 1980).

The caffeine enhancement of sperm motility has been detected in the concentration range 1-10 mM, and is dose-dependent. At 1 and 7-7.5 $\mathrm{mM}$, caffeine stimulated the in vitro spermatozoa penetration of hamster oocytes as measured by the sperm penetration assay (Rogers, 1981; Prins and Ross, 1985), at least when previously frozen human sperm was used (Cai and Marik, 1989). However, higher doses of caffeine (10 mM) have been reported to be partly toxic (Aitken et al., 1983).

Only one investigation has come close to studying the relationship between caffeine exposure in vivo and sperm activity. In this study, the daily quantity of coffee consumed was the studied exposure variable. Marshburn and co-workers (1989) examined semen parameters in 445 eligible subjects from an Eastern American infertility population (a total of 546 subjects), stratified according to their level of coffee drinking, cigarette smoking, and alcohol consumption. The control group was considered to be the subjects who did not use coffee, cigarettes, or alcohol. The study demonstrated an association between coffee drinking with certain changes in semen parameters - increase in sperm density and percentage of abnormal forms. However, the assessment of the effect of environmental factors of male reproductive potential is made difficult by the plethora of influences encountered in daily life that could confound the detection of subtle changes in semen quality. For example, in this study, subjects who drank more coffee tended to smoke more cigarettes. Therefore, it is very difficult to single out a specific parameter being responsible for the observed effect in this study.

The effect of caffeine treatment $(7.2 \mathrm{mM})$ of donor sperm on sperm morphology and fertilising capacity was studied in a controlled study on 60 women (with infertile husbands) given frozen/thawed semen from fertile donors for artificial insemination during 12 months (Barkay et al., 1984). Caffeine treated sperm was used every second month. The patients were inseminated on 3 to 4 consecutive days, starting 1 day before the estimated time of ovulation. Frozen pellets of semen, either with or 
without caffeine, were thawed together and injected intracervically. During the 6-month period without caffeine addition, 7 inseminated women became pregnant, while during the 6-month caffeine-treatment period, 14 women became pregnant. Three of the caffeine-treated inseminated pregnancies and one of the caffeine-free inseminated pregnancies occurred in the first month of treatment. It was concluded that in vitro caffeine treatment of fertile donor semen seems to improve the fertilising capacity (Barkay et al., 1984).

Since aneuploidy is a common cause of poor reproductive outcome in humans and is associated with severe medical problems in live born offspring (see also chapter 13), and a substantial amount of aneuploidy is contributed by the father through cytogenetically abnormal sperm, Robbins and co-workers (1997) investigated the potential contribution of caffeine intake (among other lifestyle factors) to the aneuploidy load in sperm from 45 healthy male volunteers 19-35 years of age. Since the subjects originally were enrolled in a study on the effect of smoking on DNA damage, this confounding factor was carefully controlled for, as was the quantity of alcohol consumed. Unfortunately, no information was given on how the caffeine exposure was calculated and to which time period the exposure referred. The subjects were allocated to one of three exposure groups - no cups, one cup, or two or more coffee cup equivalents per day. After adjusting for alcohol intake, age and the occurrence of cotinine (a metabolite of nicotine) in urine, caffeine in a dosedependent manner increased the frequency of sperm aneuploidy and diploidy (extra sex chromosomes and chromosome 18). Due to the information missing on caffeine exposure, the study does not add to our understanding of the paternal contribution to the possible relationship between caffeine exposure and either production of aneuploidy and teratogenicity in the offspring, or reduced fertility.

\subsection{Caffeine intake and in vitro fertilisation and embryo transfer}

In a Canadian prospective cohort study attempting to evaluate the impact of cigarette smoking in males and females on in-vitro fertilisation and embryo transfer, coffee consumption was studied as a confounding factor (Hughes et al., 1992). The study base was 222 couples that underwent 297 cycles of treatment. The participants were interviewed on the first day of ovarian stimulation, and on the day of embryo transfer. The fertilisation rate was higher in heavy smokers than in non-smokers, but the rate of embryo cleavage was retarded in a dose-dependent fashion by smoking. On average, non-smokers consumed 1.85 cups of coffee per day, light smokers (1-14 cigarettes per day) 3.21 cups of coffee per day, and heavy smokers ( $\geq 15$ cigarettes per day) 3.41 cups per day. However, after 
adjustment for confounding factors, a low socio-economic status had a greater detrimental effect on embryo cleavage rate than female smoking.

\subsection{Caffeine intake and insemination}

No studies have been published on this specific question, but two investigations related to it should be pointed out. In the first of these, the exposure to caffeine was partly artificial and took place in vitro. The natural exposure to caffeine was not controlled for, which was a severe limitation regarding this study. For each of 34 couples that had been diagnosed with infertility (average duration 5.3 years) at Chelsea Hospital in Dublin, Ireland, and underwent a course of artificial insemination with husband's semen, caffeine was added in vitro in one-half of the inseminations performed (Harrison, 1978). Normal coitus was prohibited during the couple's fertile period. Although the dropout rate from the study was high (59\%), ten patients completed 12 months of inseminations and another four patients discontinued the study, as they became pregnant. Altogether, 400 inseminations were carried out, 201 with placebo plus semen and 199 with caffeine-enhanced semen $(6 \mathrm{mM})$. Of the four pregnancies registered in the series, only one could be attributed to artificial insemination (with placebo). The author draws the conclusion that artificial insemination is of little value when the semen sample is subnormal. It could, however, not be excluded that caffeine damaged the sperm.

In the second related study, a prospective Dutch cohort study, 500 healthy women seeking help to obtain artificial insemination with donor sperm for the first time were interviewed upon enrolment about life-style factors, including cigarette smoking and consumption of alcohol and coffee (Zaadstra et al., 1994). The women were followed for between 12 and 33 menstrual cycles. Insemination was defined as successful if menses did not appear at the expected time and the pregnancy test subsequently became positive. This occurred for $52 \%$ of the women. No relationship was found between the probability of conception per cycle and the coffee consumption. Although the data were unadjusted for possible confounding variables, and the women's own coffee consumption during the period conception took place was unknown, the investigators claimed it is unlikely that adjustment would change the result and conclusion.

\subsection{Consumption of caffeine-containing beverages and adverse pregnancy outcomes}

In a large American study based on 12205 non-diabetic, non-asthmatic women from the area around Boston, Linn and co-workers (1982) studied the effect of coffee consumption during the first trimester on the adverse 
outcome of pregnancies. Only women pregnant with a single child were included in the study. The quantity of coffee consumed was unrelated to frequency of bleeding during pregnancy, toxemia and eclampsia, preadmissions for false and premature labour, abnormal presentation, low birth weight, shorter gestation, and occurrence of malformations in offspring. However, the frequency of premature membrane ruptures was correlated to the number of cups of coffee consumed.

\subsection{Summary of caffeine intake and fertility}

The question as to whether caffeine can influence fertility has been studied extensively, both in experimental mechanistic studies and in epidemiological research. Several plausible biological mechanisms for such a relationship have been proposed, but none is consistently well studied and given support to be most likely.

The following important parameters related to fertility have been studied to explore a possible relationship to caffeine intake: time to pregnancy/time to conception, fecundability, pregnancy rate, success of in vitro fertilisation and embryo transfer, and effects on sperm quality.

In most studies time to pregnancy/time to conception was defined as the time between stopping contraception and clinically diagnosed pregnancy. Fecundability was defined as the probability to become clinically pregnant in each menstrual cycle. Caffeine exposure in all studies has been assessed by food frequency questionnaires. In some studies the exposures have been reported as the daily caffeine intake (mg), and in other studies as the number of cups/cans of caffeinated beverage consumed each day.

In a substantial number of the epidemiological studies discussed in this section, the criteria for including participants in the study and the methodology to estimate caffeine exposure can be called in question. Monitoring of exposure is crucial, and estimating individual intakes from food frequency questionnaires are known to have severe limitations, in particular when the questions asked referred to consumption a long time ago. In studies of fertility it is very important to consider what time period of exposure the study actually has referred to. The appropriate period should be the time when attempts to get pregnant were made, that is, the time directly before conception, not during pregnancy, as it has been shown that many women tend to reduce their caffeine intake early in pregnancy. Thus, investigating caffeine intake during pregnancy retrospectively may result in an underestimation of the actual exposure during the period prior to conception. Consequently, information in epidemiological studies on daily levels of caffeine intake during various parts of the pregnancy and resulting in delayed conception/reduced fecundability must be interpreted with great care. 
Time to pregnancy in relation to caffeine exposure (Table 43) has been investigated in five retrospective studies. Four (Grodstein et al., 1993; Hatch and Bracken, 1993; Stanton and Gray, 1995; Bolúmar et al., 1997) of these studies observed a statistically significant prolonged time to pregnancy/conception. All four studies can, however, be criticised in more than one respect. Therefore, they only give a very limited support for the hypothesis of a relationship between caffeine intake and time to pregnancy/time to conception. The lowest daily caffeine intake resulting in delayed conception differed between the studies, from $151 \mathrm{mg}$ in one study (Hatch and Bracken, 1993) to $500 \mathrm{mg}$ or more in another (Bolúmar et al., 1997).

Eight studies explored the time to pregnancy in relation to the number of cups/cans of caffeinated beverages consumed each day (Table 44). In general, each type of caffeine-containing beverage (coffee, decaffeinated coffee, tea and caffeinated soft drinks) has been studied separately. Available studies give no indication of a relationship between consumption of decaffeinated coffee, tea, or caffeinated soft drinks and time to pregnancy. Studies on the relationship between coffee consumption and time to pregnancy give a less clear picture. Williams et al. (1990) observed a prolonged time to pregnancy in women who drank 4 or more cups of coffee during the first trimester of pregnancy. Whether the coffee consumption during the period directly before pregnancy was the same is unknown. A relationship between coffee consumption and prolonged time to pregnancy was also indicated in a study on Danish women. The relationship was observed only in smoking women who consumed in total more than eight cups of coffee or tea per day (Olsen et al., 1991). This effect was not observed in non-smokers. In a letter to Lancet, Christianson et al. (1989) reported that the relative risk for difficulty in becoming pregnant increased with coffee consumption. Unfortunately, the study was not designed to investigate the effects analysed, smoking was poorly adjusted for, and the $95 \%$ confidence interval for the risk was not given. In a study having a comparatively good exposure characterisation, but probably being burdened by recall bias, and possibly including non-optimal adjustment for smoking and alcohol consumption, Bolúmar et al. (1997) observed an increased time to first pregnancy $>9.5$ months in women drinking five cups of coffee per day or more. When the analysis was restricted to the most recent pregnancy, or when smoking and nonsmoking women were analysed separately, the relationship was no longer statistically significant. In conclusion, taking the limitations of the studies into consideration, most of them thus indicate that high coffee consumption is not strongly correlated with an increased time to pregnancy.

Fecundability in relation to caffeine exposure has been explored in eight studies (Table 45). Four studies observed no relationship between this indicator of fertility and caffeine intake. In two studies (Hatch and Bracken, 1993; Stanton and Gray, 1995) a significantly reduced fecunda- 
bility was observed in women reporting an intake of more than $301 \mathrm{mg}$ caffeine per day. In two other studies, a reduced fecundability was seen only in couples where the partner reported an intake of more than $700 \mathrm{mg}$ caffeine/day (Florack et al., 1994; Jensen et al., 1998a), but these high intakes among the women did not influence the fecundability.

The fecundability has also been investigated in relation to the number of cups/cans of caffeinated beverages consumed each day (Table 46). As many of the assessed studies suffer from severe limitations, the interpretation is difficult. One remarkable finding was made in the study of Wilcox and Weinberg (1991), who in a re-analysis of data from an earlier study found that one soft drink daily reduced the fecundability with $50 \%$ $(\mathrm{p}=0.01)$. Other investigators have not been able to confirm this observation.

A study designed to answer the question whether legally induced abortion has any adverse effect on subsequent ability to conceive found no relationship between coffee consumption and pregnancy rate (Stubblefield et al., 1984).

To what extent the male partner may influence reduced fertility, besides influencing the frequency of intercourse and having semen of nonoptimal quality, has usually not been explored in the epidemiological studies, and therefore not controlled for. The few studies that have been performed give very contradictory results. In vitro incubation of human semen with caffeine, as well as with other methylxanthines, appears to increase the motility of fresh and previously frozen human spermatozoa. The caffeine-induced enhancement in sperm motility seems to be dosedependent, and is observed in the concentration range 1-6(10) $\mathrm{mM}$ (Harrison et al., 1980, Traub et al., 1982; Aitken et al., 1983), around ten times higher than the amount expected in a high consumer of coffee. There are indications that in vitro caffeine treatment of fertile donor semen may improve the fertilising capacity during artificial insemination (Barkay et al., 1984). Thus, there are some data available that indicate that the quantity of caffeine ingested by the male partner of the studied women could influence fertility. At present, this possibility is not more than a hypothesis open for testing.

Caffeine consumption was observed as a confounding factor in a $\mathrm{Ca}-$ nadian prospective cohort study trying to evaluate the impact of cigarette smoking in males and females on in-vitro fertilisation and embryo transfer. The rate of embryo cleavage was retarded in a dose-dependent manner by smoking. On average smokers consumed significantly more coffee per day. After adjustment for confounding factors, a low socio-economic status had, however, a greater detrimental effect on embryo cleavage rate than female smoking (Hughes et al., 1992).

In a study on artificial insemination no relationship was found between the probability of conception per cycle and the woman's coffee consumption (Zaadstra et al., 1994). 
It can thus be concluded that the results obtained in epidemiological studies concerning a possible relationship between caffeine and fertility are contradictory and difficult to interpret. The data of many studies have limitations due to their experimental designs. A relationship between caffeine intake and time to pregnancy/time to conception/fecundability cannot be ruled out, but at present the evidence for such a relationship must be considered weak. The reason for this conclusion is that there is no consistency in results between studies, and that accurate data regarding caffeine exposure during the time period shortly before pregnancy seldom has been available in the epidemiological studies. Furthermore, there are only a few studies that have related caffeine exposure to effects on spermatozoa in vivo. 



\section{Caffeine intake and spontaneous abortions}

In experimental animals, including monkeys, several studies have suggested a possible link between caffeine exposure and foetal resorption (Collins, 1981; Gilbert et al., 1988). Although the extrapolation of findings from animal studies to humans is not straightforward, the U.S. Food and Drug Administration in 1980, mainly on the basis of these animal experiments, cautioned pregnant women to avoid caffeine or to use it sparingly (FDA, 1980).

Spontaneous abortion is the most common complication of pregnancy. Typically, spontaneous abortions are defined as pregnancies that end at 22 complete weeks of gestation or less, and do not end in a live birth. It is customary to calculate the gestational age from the first day of the last menstrual cycle. Spontaneous abortions are normally determined clinically. However, spontaneous abortions can also be determined biochemically by measuring biomarkers for specific hormonal activity. The true rate of spontaneous early pregnancy loss in women is unknown. When the abortion occurs very early in pregnancy, it is likely that the woman has not recognised the pregnancy or the abortion (Wilcox et al., 1990). Roberts and Lowe (1975) used a statistical model to postulate a 78\% loss of all human conceptions. Since approximately $2 \%$ of pregnancies end in perinatal deaths after 28 weeks gestation, and $10-25 \%$ of pregnancies end in a recognised spontaneous abortion before week 28 (Warburton and Fraser, 1964; Claireaux, 1975), most conceptual losses must occur before pregnancy has been diagnosed, often before the first missed period. As many early abortuses are known to have chromosomal abnormalities, it seems likely that early spontaneous abortion may act as a quality control of the pregnancy (Roue and Roue, 1968; Wright, 1976). In the following discussion, epidemiological studies on the relationship between caffeine intake and late and early spontaneous abortions, respectively, are presented in separate sections. A total separation of studies into sections is not possible, however, since some investigators have neglected to focus specifically on early or late spontaneous abortions.

When analysing the relationship between caffeine intake and spontaneous abortion, it is important to control for other risk factors for spontaneous abortion. Besides chromosomal abnormalities and uterine/cervical causes, the factors most consistently associated with recognised spontaneous abortion risk are prior spontaneous abortion and older maternal age. Other factors investigated for their correlation to spontaneous abortion are previous adverse reproductive events and exposure to exogenous 
factors such as tobacco, alcohol or a particular occupational environment, as well as psychological conditions. The results of studies on these factors are, however, contradictory.

One exogenous factor that has been suggested to influence spontaneous abortion rate is caffeine intake. Potential effects of caffeine on foetal development may follow prolonged accumulation of caffeine in pregnant women and passage of the alkaloid to the foetus, which lacks the enzymes necessary for the metabolism of caffeine until several days after birth. Caffeine is known to increase the cellular pool of adenosine$3^{\prime}: 5^{\prime}$-cyclic monophosphate, and may interfere with foetal cell growth. It may also result in genotoxic effects and increase catecholeamines. The latter effect may result in a restriction of uteroplacental circulation though vasoconstriction, resulting in foetal hypoxia. Foetal death, decrease of foetal weight, foetal malformations, and shortened gestational age can follow foetal hypoxia (Srisuphan and Bracken, 1986).

In the following text we have defined early spontaneous abortion as abortions occurring during the first trimester of pregnancy, and later spontaneous abortions as those occurring later. Epidemiological studies on the relationship between caffeine exposure and early spontaneous abortion are extensively presented in section 12.1, whereas studies on the relationship between caffeine intake and late spontaneous abortion are dealt with in section 12.2. It should be stated that a number of investigators have not made a distinction between early and late spontaneous abortions, and therefore present a mixed study base. These publications are discussed in section 12.2. Section 12.3 presents a study on the relationship between caffeine intake and stillbirth. The main results of the separate studies are summarised in chronological and geographical order in Table 47 (studies related to caffeine intake), Table 48 (studies related to consumption of caffeine-containing beverages) and Table 49 (studies related to caffeine metabolites as biomarkers). Conclusions based on a critical evaluation of these epidemiological studies are presented in section 12.4.

\subsection{Caffeine intake and early spontaneous abortions}

The first serious investigation on a possible association between caffeine intake and spontaneous abortion was published by Weathersbee et al. (1977). Their data was obtained from 489 of 800 invited households in Utah, the United States. The studied subjects were predominantly Mormons (members of the Church of Jesus Christ of Latter-Day Saints), a sect that proscribes the use of alcohol, caffeine, and tobacco. No less than 246 invited households (31\%) declined the invitation to participate in the study, and a further 65 households could not be reached. This high drop out rate might be seen in relation to what the sect requires from its mem- 
bers, and could have introduced a bias. A similar speculation was put forward by Srisuphan et al. (1986). These investigators noted an unusually high stillbirth rate of $12.7 \%$ in the studied population. The information on the outcome of recent pregnancies and consumption of caffeinecontaining beverages was obtained from the answers to a 52-item questionnaire. However, the investigators do not report which time period the consumption estimates refer to. The daily caffeine intake was calculated using the values of $75 \mathrm{mg}$ for a serving of coffee, $30 \mathrm{mg}$ for a serving of tea, and $45 \mathrm{mg}$ for a serving of cola. 356 of the participating 489 women reported no caffeine consumption.

The analysis identified 16 households with severely complicated pregnancies in which the women's estimated daily caffeine intake was $600 \mathrm{mg}$ or more (mean $686 \mathrm{mg}$ ) and the man's $566 \mathrm{mg}$ or more (Table 47). With one exception, the pregnancies had ended in spontaneous abortion in the first trimester ( 8 patients), stillbirth (5 patients), or premature birth of a live infant (2 patients). An inordinately high rate of reproductive loss was also noted in 13 households where the males estimated daily intake of caffeine was greater than $600 \mathrm{mg}$ (and the females $>400$ $\mathrm{mg} /$ day).

The study was performed on a selected population group and had many severe limitations. Certainly, other factors than caffeine intake may influence reproductive loss in Utah. For example, information on smoking, a possible confounder for the studied effect, was not collected in this study. Thus, the finding of this study that a high daily caffeine intake may predispose a woman towards reproductive difficulty, for instance, having a spontaneous abortion, cannot be taken for the establishment of a cause-effect relationship between caffeine intake and spontaneous abortion.

In several studies the investigators explored the possibility of an association between women's caffeine exposure and the risk of early pregnancy loss by identifying pregnancy by high urinary or blood levels of human chorionic gonadotropin (hCG). The first of these investigations constituted one part of a prospective Eastern American study on 230 volunteers planning a pregnancy and enrolled in the study at the time they stopped using birth control - see section 11.1 (Wilcox et al., 1988b). Upon enrolment, as well as 3 and 6 months later, the women were interviewed, given that they were not yet pregnant, about their caffeine intake during the most recent month. Caffeine consumption was calculated using standard quantities of caffeine in coffee, tea and soft drinks.

There were 199 biochemically detectable pregnancies (urinary hCG) among the 171 women who conceived while participating in the study (Wilcox et al., 1990). Since only the first pregnancy for each woman was included in the analysis, the number of studied pregnancies was 171. Of these, 128 were clinically determined pregnancies and 43 early losses (which ended in menstrual-like bleeding within 42 days of the last 
menstrual period), that is, $25 \%$ of pregnancies ended in early spontaneous abortion. Since the sample size was small, only simple statistical calculations on risks for early pregnancy losses were performed with the data; adjusting only for a single factor at a time (usually the age of the woman) for each studied variable. The investigators looked at risk of spontaneous abortion in relation to a woman's age, pregnancy history, weight, education, prenatal diethylstilbestrol exposure, cigarette smoking, use of caffeinated and alcoholic beverages, marijuana, cigarette smoking by the baby's father, and other variables. None of these factors were significantly associated with early pregnancy loss (Table 47).

In a subset of the women in this study (104 women only), Wilcox and coworkers (1988a) found an association between the consumption of caffeine-containing beverages and reduced fertility. Also in this subset, there was no significantly increased risk for heavy caffeine consumers having an early spontaneous abortion. Critical comments to the study are given in the discussion of the study of Wilcox et al. (1988a), see section 11.1.

Parazzini and co-workers $(1991,1994,1998)$ have published three studies correlating coffee consumption and early spontaneous abortion. Caffeine intake was not calculated. The first of these studies was a small case-control study in which the coffee consumption in 94 cases who had had two or more 'unexplained' miscarriages before three months of gestation and no full-term pregnancies (67 women reported two miscarriages, 20 three, and seven four or more) were compared with that in 176 women with a normal delivery (Parazzini et al., 1991). Information on personal characteristics and habits, including coffee consumption during the last miscarrying pregnancy for cases and during the first trimester of the index pregnancy for controls, was collected at the Milan hospital to which the women were referred. Thus, the exposure period studied was different for cases and controls. Women with spontaneous abortion had a family history of foetal wastage, were more frequently cigarette smokers, and had their first menarche at an early age. No association was found between spontaneous abortion and indicators of social class, marital status, paternal age, body mass index, and alcohol and coffee consumption (yes or no) (Table 48). Coffee drinkers had a non-significantly elevated risk $(\mathrm{RR}=1.4 ; 0.7-2.6)$ for recurrent miscarriage.

The second Italian study was also a case-control study. It reported primarily on alcohol and risk of spontaneous abortion. Cases were 782 women admitted to hospital for spontaneous abortion ( 298 were between the fourth and eight week of gestation, and 484 were between the ninth and twelfth week). The controls were 1543 women recruited among 
Table 47. Intake of caffeine and spontaneous abortion (misscarriage).

\begin{tabular}{|c|c|c|c|c|c|}
\hline $\begin{array}{l}\text { Reference } \\
\text { Type and location of } \\
\text { study }\end{array}$ & Sample size and selection & \begin{tabular}{|l} 
Exposure period \\
Sources of caffeine
\end{tabular} & $\begin{array}{l}\text { Definition of end- } \\
\text { point(s) } \\
\text { (Spontaneous } \\
\text { abortion=SA) }\end{array}$ & \begin{tabular}{|l|} 
Results \\
Risk estimate adjusted odds ratios \\
including 95\% confidence interval \\
(NS = non significant) \\
\end{tabular} & Comments \\
\hline $\begin{array}{l}\text { Weathersbee } \\
\text { et al ., } 1977 \\
\text { Retrospective study } \\
\text { USA }\end{array}$ & 489 women & $\begin{array}{l}\text { No information } \\
\text { Coffee, tea and cola }\end{array}$ & $\begin{array}{l}\text { Early abortion } \\
\text { Spontaneous abortion } \\
\text { in first trimester, still } \\
\text { birth, } \\
\text { premature births }\end{array}$ & \begin{tabular}{|l}
$<600^{*} \mathrm{mg}$ caffeine/day vs \\
$\geq 600 \mathrm{mg} / \mathrm{day}$
\end{tabular} & $\begin{array}{l}\text { Selected population (mormons). } \\
\text { No information on smoking. } \\
\text { No adjustments made. }\end{array}$ \\
\hline $\begin{array}{l}\text { Srisuphan } \\
\text { et al., } 1986 \\
\text { Prospective study } \\
\text { USA }\end{array}$ & 3135 women & $\begin{array}{l}\text { Prospective data } \\
\text { during pregnancy } \\
\text { (usually late first or } \\
\text { second trimester of } \\
\text { pregnancy. } \\
\\
\text { Coffee, tea, caffein- } \\
\text { ated soft drinks, } \\
\text { caffeine-con-taining } \\
\text { drugs. }\end{array}$ & $\begin{array}{l}\text { Late abortion } \\
\text { Spontaneous abortion } \\
\text { at less than } 28^{\text {th }} \text { week } \\
\text { of gestation }\end{array}$ & $\begin{array}{l}\text { none vs } \\
1-150, \geq 151 \mathrm{mg} \text { caffeine/day } \\
0-150 \mathrm{mg} \text { caffeine/day vs } \\
\geq 151 \mathrm{mg} \text { caffeine/day } \\
\\
\text { *light caffeine consumption }(1-150 \mathrm{mg} / \mathrm{day}) \text { was associated with } \\
\begin{array}{l}\text { increased risk, } 4.18(\mathrm{p}=0.04), \text { among women who aborted in } \\
\text { their last pregnancy }\end{array}\end{array}$ & $\begin{array}{l}\text { The caffeine intake was low in the } \\
\text { study base. Results were not ade- } \\
\text { quately adjusted for maternal age, } \\
\text { consumption of alcohol, cigarette and } \\
\text { drug use. }\end{array}$ \\
\hline $\begin{array}{l}\text { Wilcox et al., } 1990 \\
\text { Prospective cohort } \\
\text { study } \\
\text { USA }\end{array}$ & $\begin{array}{l}171 \text { women } \\
\text { conceiving while participating } \\
\text { in the study }\end{array}$ & $\begin{array}{l}\text { During pregnancy } \\
\text { Coffee (brewed, } \\
\text { instant) tea, soft } \\
\text { drinks }\end{array}$ & $\begin{array}{l}\text { Early abortion } \\
\text { Spontaneous abortion } \\
\text { before } 6 \text { weeks of } \\
\text { gestation }\end{array}$ & $\begin{array}{l}<1000 \mathrm{mg} \text { caffeine/month vs } \\
1000-3499, \geq 3500 \mathrm{mg} \\
\text { caffeine/month }\end{array}$ & $\begin{array}{l}\text { Only a subset of the women provided } \\
\text { data on caffeine consumption during } \\
\text { the conceiving time. Small study base } \\
\text { with a mixture of women who had } \\
\text { conceived previously and who had } \\
\text { not. A pilot study. }\end{array}$ \\
\hline $\begin{array}{l}\text { Fenster et al., 1991a } \\
\text { Case control study } \\
\text { USA }\end{array}$ & $\begin{array}{l}607 \text { women with sponta- } \\
\text { neous abortion, and } 1284 \\
\text { with normal live births }\end{array}$ & $\begin{array}{l}\text { First trimester } \\
\text { Coffee, tea and soda }\end{array}$ & $\begin{array}{l}\text { Late abortion } \\
\text { Spontaneous abortion } \\
\text { before } 20 \text { weeks of } \\
\text { gestation }\end{array}$ & $\begin{array}{l}\text { All women } \\
\text { No caffeine vs } \\
1-150,151-300 \mathrm{mg} \text { caffeine/ day } \\
>300 \mathrm{mg} \text { caffeine/day } \\
\\
\text { Women without nausea } \\
\text { No caffeine vs } \\
1-150,151-300, \\
>300 \mathrm{mg} \text { caffeine/day } \\
\\
\text { Women with nausea } \\
\text { No caffeine vs } \\
1-150,151-300 \mathrm{mg} \text { caffeine/day } \\
>300 \mathrm{mg} \text { caffeine/day }\end{array}$ & $\begin{array}{l}\text { The magnitude of subsample analysis } \\
\text { in the statistical analysis of data not } \\
\text { cleary stated in primary hypothesis to } \\
\text { be tested. }\end{array}$ \\
\hline
\end{tabular}




\begin{tabular}{|c|c|c|c|c|c|}
\hline $\begin{array}{l}\text { Reference } \\
\text { Type and location of } \\
\text { study }\end{array}$ & Sample size and selection & $\begin{array}{l}\text { Exposure period } \\
\text { Sources of caffeine }\end{array}$ & $\begin{array}{l}\text { Definition of end- } \\
\text { point(s) } \\
\text { (Spontaneous } \\
\text { abortion=SA) }\end{array}$ & $\begin{array}{l}\text { Results } \\
\text { Risk estimate adjusted odds ratios } \\
\text { including } 95 \% \text { confidence interval } \\
\text { (NS = non significant) }\end{array}$ & Comments \\
\hline $\begin{array}{l}\text { Kline et al., } 1991 \\
\text { Case control study } \\
\text { USA }\end{array}$ & $\begin{array}{l}899 \text { women with spontane- } \\
\text { ous abortions }(510 \text { chromo- } \\
\text { somally normal and } 389 \\
\text { chromosomally abnormal) } \\
\text { and } \\
1423 \text { with normal delivery at } \\
>28^{\text {th }} \text { week }\end{array}$ & $\begin{array}{l}\text { Perifertilization period, } \\
\text { and during pregnancy } \\
\\
\text { Coffee (normal and } \\
\text { decaffeinated)tea, } \\
\text { chocolate drinks, } \\
\text { caffeinated soft drinks }\end{array}$ & $\begin{array}{l}\text { Late abortion } \\
\text { Spontaneous abortion } \\
\text { before } 28^{\text {th }} \text { week of } \\
\text { gestation }\end{array}$ & \begin{tabular}{|lc} 
Perifertilization period \\
chromosomally normal cases \\
$0-27 \mathrm{mg}$ caffeine/day vs \\
$28-124,125-224$, \\
$\geq 225 \mathrm{mg}$ caffeine/day \\
abnormal karyotypes with \\
$28-124 \mathrm{mg}$ caffeine/day \\
$125-224 \mathrm{mg}$ caffeine/day \\
$\geq 225 \mathrm{mg}$ caffeine/day \\
& $\mathrm{NS}$ \\
During pregnancy & $\mathrm{NS}$ \\
chromosomally normal cases vs controls & $\mathrm{NS}$ \\
$0-27 \mathrm{mg}$ caffeine/day vs & \\
$28-124,125-224 \mathrm{mg}$ caffeine/day & \\
$\geq 225 \mathrm{mg}$ caffeine/day & $\mathrm{NS}$ \\
& $\mathrm{NS}$ \\
chromosomally abberant cases vs contr. & \\
$0-27 \mathrm{mg}$ caffeine/day vs & \\
$28-124,125-224 \mathrm{mg}$ caffeine/day & $\mathrm{NS}$ \\
$\geq 225 \mathrm{mg}$ caffeine/day & \\
chromosomally normal cases vs controls chromosomally aber- \\
rant \\
$28-124,125-224 \mathrm{mg},>225 \mathrm{mg}$ caffeine/day
\end{tabular} & $\begin{array}{l}\text { The high drop out rate among cases } \\
\text { might have introduced a bias. Possi- } \\
\text { bly the study was not adequately } \\
\text { adjusted for nausea. }\end{array}$ \\
\hline $\begin{array}{l}\text { Infante-Rivard } \\
\text { et al., } 1993 \\
\text { Case control study } \\
\text { Canada }\end{array}$ & $\begin{array}{l}331 \text { women with foetal loss } \\
\text { and } 993 \text { women with normal } \\
\text { pregnancies }\end{array}$ & $\begin{array}{l}\text { The month before } \\
\text { pregnancy and aver- } \\
\text { age intake during } \\
\text { pregnancy } \\
\text { Coffee, tea and cola }\end{array}$ & $\begin{array}{l}\text { Late abortion } \\
\text { Clinically confirmed } \\
\text { spontaneous abor- } \\
\text { tions from } 16^{\text {th }} \text { to } 28^{\text {th }} \\
\text { weeks pregnancy }\end{array}$ & $\begin{array}{l}\text { Caffeine intake before pregnancy } \\
<48 \mathrm{mg} \text { caffeine/day vs } \\
48-162,163-321 \mathrm{mg} \text { caffeine/day } \\
>321 \mathrm{mg} \text { caffeine/day } \\
\text { Trend: } \\
\\
\text { Caffeine intake during pregnancy } \\
<48 \mathrm{mg} \text { caffeine/day vs } \\
48-162 \mathrm{mg} \text { caffeine/day } \\
163-321 \mathrm{mg} \text { caffeine/day } \\
>321 \mathrm{mg} \text { caffeine/day }\end{array}$ & $\begin{array}{l}\text { Bias in data collection likely. Caffeine } \\
\text { exposure during the whole period of } \\
\text { pregnancy was registered without } \\
\text { controlling adequately for nausea. }\end{array}$ \\
\hline
\end{tabular}




\begin{tabular}{|c|c|c|c|c|c|c|}
\hline $\begin{array}{l}\text { Reference } \\
\text { Type and location of } \\
\text { study }\end{array}$ & Sample size and selection & $\begin{array}{l}\text { Exposure period } \\
\text { Sources of caffeine }\end{array}$ & $\begin{array}{l}\text { Definition of end- } \\
\text { point(s) } \\
\text { (Spontaneous } \\
\text { abortion=SA) }\end{array}$ & \begin{tabular}{|l} 
Results \\
Risk estimate adjusted odds ratios \\
including 95\% confidence interval \\
(NS = non significant)
\end{tabular} & & Comments \\
\hline $\begin{array}{l}\text { Mills et al., } 1993 \\
\text { Prospective multi-center } \\
\text { cohort study } \\
\text { USA }\end{array}$ & $\begin{array}{l}431 \text { pregnant women en- } \\
\text { rolled within } 21 \text { days of } \\
\text { conception }\end{array}$ & $\begin{array}{l}\text { During pregnancy at } 5, \\
6,8,10 \text { and } 12 \text { weeks } \\
\text { Coffee (regular, de- } \\
\text { caffeinated) tea, cocoa } \\
\text { and cola drinks }\end{array}$ & $\begin{array}{l}\text { Early abortion All } \\
\text { spontaneous abor- } \\
\text { tions } 21 \text { days post- } \\
\text { conception } \\
\\
\text { Other end-points were } \\
\text { intrauterine growth, } \\
\text { birth weight, head } \\
\text { circumference }\end{array}$ & $\begin{array}{l}0 \mathrm{mg} \text { caffeine/day vs } \\
1-99,100-199,200-299, \\
\geq 300 \mathrm{mg} \text { caffeine/day } \\
\text { Trend: }\end{array}$ & $\begin{array}{l}\text { NS } \\
\text { NS }\end{array}$ & $\begin{array}{l}\text { Rate of sponaneous abortion was far } \\
\text { lower than expected. Very few women } \\
\text { consumed more than } 300 \mathrm{mg} / \mathrm{day}, \\
\text { and for } 8 \text { women the consumption } \\
\text { was unknown. No adjustment for } \\
\text { nausea. }\end{array}$ \\
\hline $\begin{array}{l}\text { Dlugosz } \\
\text { et al., } 1996 \\
\text { Prospective study } \\
\text { USA }\end{array}$ & $\begin{array}{l}2849 \text { pregnant women } \\
\text { seeking prenatal care before } \\
\text { the } 16^{\text {th }} \text { week of gestation }\end{array}$ & $\begin{array}{l}\text { During } 1^{\text {st }} \text { month of } \\
\text { pregnancy } \\
\text { Coffee, tea, soda }\end{array}$ & $\begin{array}{l}\text { Late abortion } \\
\text { Spontaneous abor- } \\
\text { tions before } 28^{\text {th }} \text { week } \\
\text { of gestation }\end{array}$ & $\begin{array}{l}0 \mathrm{mg} \text { caffeine/day vs } \\
1-50,151-300, \\
\geq 301 \mathrm{mg} \text { caffeine/day }\end{array}$ & NS & $\begin{array}{l}\text { Selection bias due to strict inclusion } \\
\text { criteria possible. Nausea not meas- } \\
\text { ured. }\end{array}$ \\
\hline $\begin{array}{l}\text { Fenster et al., } 1997 \\
\text { Prospective cohort } \\
\text { study } \\
\text { USA }\end{array}$ & $\begin{array}{l}5144 \text { pregnant women } \\
\text { (at } 13 \text { weeks of gestation or } \\
\text { less) }\end{array}$ & $\begin{array}{l}\text { The week around the } \\
\text { last menstrual period, } \\
\text { as well as the } 7^{\text {th }} \text { week } \\
\text { of pregnancy } \\
\text { Coffee, tea soda }\end{array}$ & $\begin{array}{l}\text { Late abortion } \\
\text { Spontaneous abor- } \\
\text { tions before } 20 \text { weeks } \\
\text { of gestation }\end{array}$ & $\begin{array}{l}\text { Before pregnancy } \\
0 \text { mg caffeine/day vs } \\
1-150,151-300, \\
>300 \text { mg caffeine/day } \\
\text { During pregnancy: } \\
0 \text { mg caffeine/day vs } \\
1-150,151-300, \\
>300 \text { mg caffeine/day }\end{array}$ & NS & $\begin{array}{l}\text { Bias resulting from relations among } \\
\text { nausea, foetal viability and consump- } \\
\text { tion pattern. Few "heavy" consumers. }\end{array}$ \\
\hline
\end{tabular}




\begin{tabular}{|c|c|c|c|c|c|}
\hline $\begin{array}{l}\text { Reference } \\
\text { Type and location of } \\
\text { study }\end{array}$ & Sample size and selection & \begin{tabular}{|l} 
Exposure period \\
Sources of caffeine
\end{tabular} & $\begin{array}{l}\text { Definition of end- } \\
\text { point(s) } \\
\text { (Spontaneous } \\
\text { abortion=SA) }\end{array}$ & \begin{tabular}{|l|} 
Results \\
Risk estimate adjusted odds ratios \\
including 95\% confidence interval \\
(NS = non significant) \\
\end{tabular} & Comments \\
\hline $\begin{array}{l}\text { Cnattingius et al., } 2000 \\
\text { Population based case- } \\
\text { control study } \\
\text { Sweden }\end{array}$ & $\begin{array}{l}562 \text { women who had sponta- } \\
\text { neous abortion at 6-12 weeks } \\
\text { of gestation and } 953 \text { women } \\
\text { with normal pregnancy } \\
\text { (matched for gestational age) }\end{array}$ & $\begin{array}{l}4 \text { weeks before preg- } \\
\text { nancy until present } \\
\text { time of pregnancy. } \\
\text { Coffee, tea, cocoa, } \\
\text { chocolate, soft drinks, } \\
\text { caffeine-containing } \\
\text { drugs }\end{array}$ & $\begin{array}{l}\text { Early abortion } \\
\text { Spontaneous abor- } \\
\text { tions from } 6^{\text {th }} \text { to } 12^{\text {th }} \\
\text { week of gestation }\end{array}$ & \begin{tabular}{|l} 
Non smokers \\
0-99 mg caffeine/day vs \\
$100-299 \mathrm{mg} /$ day \\
$300-499 \mathrm{mg} /$ day \\
$\geq 500 \mathrm{mg} / \mathrm{day}$ \\
Trend: \\
Smokers \\
$0-99 \mathrm{mg}$ caffeine/day vs \\
$100-299,300-499, \geq 500 \mathrm{mg} /$ day \\
Trend: \\
Stratified analysis on karyotype \\
Non-smokers, normal karyotype \\
Non-smokers, abnormal karyotype \\
Non-smokers, unknown karyotype \\
$0-99$ mg caffeine/day vs \\
$100-299,300-499$, \\
$\geq 500 \mathrm{mg} / \mathrm{day}$ \\
Smokers, normal karyotype \\
Smokers, abnormal karyotype \\
Smokers, unknown karyotype
\end{tabular} & $\begin{array}{l}\text { Very good study. Nausea controlled } \\
\text { for. }\end{array}$ \\
\hline $\begin{array}{l}\text { Wen et al., } 2001 \\
\text { Nested opulation based } \\
\text { case-control study } \\
\text { USA }\end{array}$ & $\begin{array}{l}575 \text { women with normal live } \\
\text { births and } 75 \text { women with } \\
\text { spontaneous abortion. } \\
\text { Women were recruited from } \\
\text { the Diana Study cohort. }\end{array}$ & $\begin{array}{l}\text { Before pregnancy and } \\
\text { during the first tri- } \\
\text { mester. } \\
\text { Coffee, tea, hot choco- } \\
\text { late, cola, soda drinks, } \\
\text { foods containing } \\
\text { chocolate }\end{array}$ & $\begin{array}{l}\text { Early and late abortion } \\
\text { Spontaneous abortion } \\
\text { during the first tri- } \\
\text { mester }\end{array}$ & 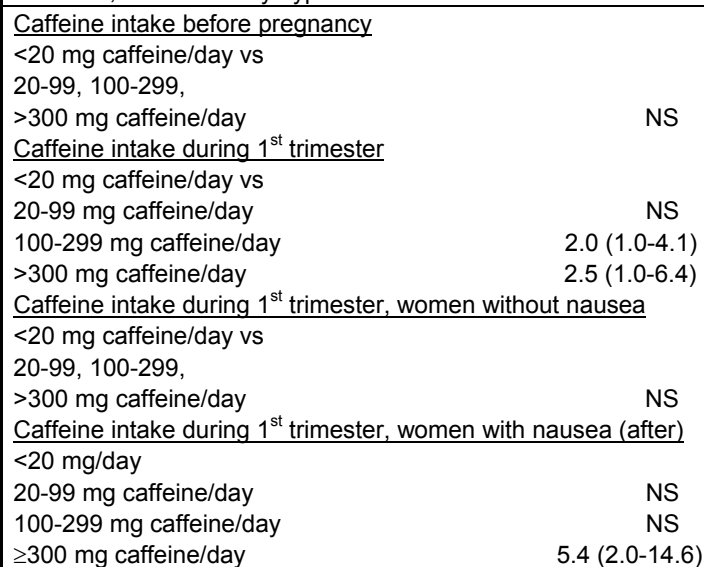 & $\begin{array}{l}\text { A prospecitve study with good expo- } \\
\text { sure assessment. However, the study } \\
\text { size was relatively small. Adjustment } \\
\text { for smoking (yes/no) could have been } \\
\text { better. }\end{array}$ \\
\hline
\end{tabular}


women who gave birth at term ( $>37$ weeks gestation) to healthy infants at the same hospitals where the cases were defined. Cases were interviewed in the first trimester of pregnancy and during controls in connection with delivery, using standard questionnaires that also contained questions on coffee, tea, cola, and decaffeinated coffee consumption in the three months before conception and during the first trimester of gestation ( $\mathrm{Pa}-$ razzini et al., 1998). When cases and controls were stratified into coffee and non-coffee drinkers, a significant association was observed between coffee drinking and spontaneous abortion - the adjusted odds ratios were 1.5 and 4.0 for consumption of four or more cups of coffee per day before and during the first trimester of pregnancy, respectively (Table 48). No association was found between maternal consumption of other methylxanthine-containing beverages or paternal coffee drinking and risk of spontaneous abortion. On the other hand, very few women reported consumption of more than one serving per day of these beverages. Obvious limitations of the study were that only cases that contacted a hospital were included in the study, and that the time of data collection differed for cases and controls. A part of this study was published already in 1994 (Parazzini et al., 1994).

In one of five American studies, the relationship between spontaneous abortion and caffeine exposure was examined using data collected prospectively (beginning within 21 days of conception) in the nondiabetic control population of the National Institute of Child Health and Human Development Diabetes in Early Pregnancy Study (Mills et al., 1993). This is a multicentre collaborative study conducted between 1980 and 1985 . The women in the control group of the original study were recruited from defined populations of volunteers that had their pregnancies carefully planned, and were willing to put considerable effort into enhancing their chances for a favourable outcome. To ensure accurate dating of pregnancy, subjects were encouraged to use basal body temperature monitoring; $56.6 \%$ did so. For all 431 subjects, serum levels of $\beta$-human chorionic gonadotropin were measured 2 days after the expected first day of menstruation if menstruation had not begun. This allowed all pre-clinical and clinical abortions occurring after 21 days post-conception to be identified. The cohort experienced only 60 spontaneous abortions, corresponding to a spontaneous abortion frequency of about $14 \%$ - a rate that was far lower than the expected spontaneous abortion rate of over $30 \%$ previously reported using urinary human chorionic gonadotropin to ascertain postimplantation spontaneous abortions (Eskenazi, 1993).

Current caffeine intake from regular coffee, decaffeinated coffee, hot tea, cocoa, iced tea, regular cola drinks, diet cola drinks, or other diet drinks during the first trimester was ascertained at the time of pregnancy diagnosis 5 weeks after the last menstrual period. Interviews on caffeine intake were repeated at intervals during the pregnancy period (at 5, 6, 8, 10 and 12 weeks after the last menstrual period). For the analysis, coffee 
was assigned a caffeine content of $100 \mathrm{mg}$; tea, $40 \mathrm{mg}$; decaffeinated coffee, $1.5 \mathrm{mg}$; cocoa, $13 \mathrm{mg}$, and cola, $40 \mathrm{mg}$. The major source of caffeine in the studied population was coffee $(59.5 \%)$, followed by tea $(20.5$ $\%)$, cola (19.1\%), cocoa (0.5\%), and decaffeinated coffee $(0.3 \%)$.

Neither the crude nor the adjusted spontaneous abortion rate was affected by caffeine intake (Table 47). There was no significant increase in spontaneous abortion with increasing caffeine intake. Caffeine did not affect the time at which abortion occurred. The statistical calculations were not adjusted for nausea. However, the greatest percentage of subjects experienced nausea at weeks 8 and 10. At these same weeks, women who experienced nausea consumed significantly less caffeine than women who did not experience nausea. This gives the impression that caffeine caused spontaneous abortion when, in fact, those women already destined to abort experienced less nausea and, therefore, had less desire to avoid caffeine.

One of the best-controlled studies on a relationship between caffeine intake during early pregnancy and spontaneous abortion is a populationbased case-control study carried out in Uppsala County, Sweden, from 1996 though 1998 by Cnattingius et al. (2000). The cases were 562 women who had spontaneous abortion at 6 to 12 completed weeks of gestation and the controls were 953 pregnant women who did not have spontaneous abortion. Control patients were matched to cases according to week of gestation and area of residence. In addition, 273 women with induced abortions were added to the control group in order to limit bias in the selection of control subjects. Information on the ingestion of caffeine was obtained from in-person interviews on a weekly basis. The following caffeine sources were reported: brewed coffee (115 mg/cup), boiled coffee $(90 \mathrm{mg} / \mathrm{cup})$, instant coffee (60 mg/cup), decaffeinated coffee $(0$ $\mathrm{mg} / \mathrm{cup}$ ), loose tea or tea bags ( $39 \mathrm{mg} / \mathrm{cup})$, herbal tea $(0 \mathrm{mg} / \mathrm{cup})$, soft drinks (cola) $(15 \mathrm{mg} / 150 \mathrm{ml})$, hot chocolate $(4 \mathrm{mg} / 150 \mathrm{ml})$, and chocolate bars $(0.3 \mathrm{mg} / \mathrm{g})$. A few medications included 50 to $100 \mathrm{mg}$ of caffeine per tablet. Plasma levels of cotinine were determined from blood samples and used as indicators of smoking, complementing the information obtained in interviews. The interview also obtained information each week on symptoms related to pregnancy, such as nausea and fatigue. Aborted foetuses were karyotyped when possible. Among the 293 women with abortion in whom chorionic villi were identified in tissue obtained at curettage, karyotyping was successful in 258. The karyotype analysis revealed that 101 foetuses were chromosomally normal and 157 were abnormal.

Coffee accounted for $76 \%$ and tea for $23 \%$ of the caffeine ingested. Nausea and fatigue were significantly more prevalent and severe among the control subjects than among cases. Among non-smokers, more spontaneous abortions occurred in women who ingested at least $100 \mathrm{mg}$ of caffeine per day than in women who ingested less than $100 \mathrm{mg}$ per day, with the increase in risk related to the amount ingested (Table 47). Those 
that consumed $500 \mathrm{mg}$ caffeine or more per day had an odds ratio of 2.2 with a $95 \%$ confidence interval, 1.3 to 3.8 . The addition of women with induced abortion to the control group had little effect on the results. Among smokers, caffeine ingestion was not associated with an excess risk of spontaneous abortion. When the analyses were stratified according to the results of karyotyping, the ingestion of moderate or high levels of caffeine was found to be associated with an excess risk of spontaneous abortion when the foetus had a normal or unknown karyotype, but not when the foetal karyotype was abnormal. The investigators conclude that their study indicates that ingestion of caffeine might increase the risk of an early spontaneous abortion among non-smoking women carrying foetuses with normal karyotypes (Cnattingius et al., 2000). This study was well designed and carried out in a careful way.

Urinary samples and blood samples from 101 women with normal karyotype spontaneous abortions and from 953 pregnant women at 6-12 gestational weeks (controls) in the study of Cnattingius et al. (2000), was collected to explore a possible relationship between caffeine metabolism and the risk of spontaneous abortion of normal karyotype foetuses (Signorello et al., 2001). The urine was analysed for phenotyping of cytochome P4501A2 (CYP1A2) and the blood for genotyping N-acetylation (NAT2). Both CYP1A2 and NAT2 enzymes are involved in caffeine metabolites. The acetylator phenotype may be one of two types, slow or fast acetylators. No significant relationship was found between acetylator type and risk for spontaneous abortion with normal karyotype. In contrast, low CYP1A2 activity, resulting in a slow metabolism of caffeine to paraxanthine, 1,7-dimethyluric acid, 5-methylamino-6-formylamino-3methyluracil, 1-methylxanthine, and 1-uric acid, was associated with a significantly decreased risk for spontaneous abortion. Caffeine was a risk factor for spontaneous abortion among women with high, but not low, CYP1A2 activity (Table 49). The investigators conclude that CYP1A2 activity may increase the risk of spontaneous abortion, independently or by modifying the effect of caffeine. One explanation could be that a metabolite(s) of caffeine may play a role in the aetiology of spontaneous abortion. The results regarding NAT2 are much less conclusive, but do not contradict the hypothesis that slow acetylators may be at elevated risk for spontaneous abortion. Since the study relied on a relatively small number of participants, producing statistically imprecise estimates of relative risk, the results should be interpreted with care. They do, however, indicate that it is necessary to study caffeine metabolism and normal karyotype spontaneous abortion.

There is a potential risk that missing information on CYP1A2 phenotype in slightly more than $30 \%$ of cases and controls, and missing information on NAT2 genotype in $10-15 \%$ of participants, might have introduced bias in the statistical calculations. 
Table 48. Intake of caffeine containing beverages and spontaneous abortions (misscarriages).

\begin{tabular}{|c|c|c|c|c|c|}
\hline $\begin{array}{l}\text { Reference } \\
\text { Type and location of } \\
\text { study }\end{array}$ & Sample size and selection & $\begin{array}{l}\text { Exposure period considered } \\
\text { Beverages considered }\end{array}$ & $\begin{array}{l}\text { Definition of end- } \\
\text { point(s) } \\
\text { (Spontaneous } \\
\text { abortion=SA) }\end{array}$ & $\begin{array}{l}\text { Results } \\
\text { Risk estimate adjusted odds ratios } \\
\text { including } 95 \% \text { confidence interval }\end{array}$ & Comments \\
\hline $\begin{array}{l}\text { Furuhashi et al., } 1985 \\
\text { Prospective study } \\
\text { Japan }\end{array}$ & $\begin{array}{l}9921 \text { healthy pregnant } \\
\text { women } \\
\text { after a gestational age of } \\
24 \text { weeks }\end{array}$ & $\begin{array}{l}\text { "During pregnancy" } \\
\text { Coffee, green tea }\end{array}$ & $\begin{array}{l}\text { Late abortion } \\
\text { Spontaneous abortion } \\
\text { after week } 24\end{array}$ & $\begin{array}{l}\text { Coffee consumers vs non-coffee and non-green tea group } \\
\text { (control): rate of spontaneous abortion significantly increased. } \\
\\
<5 \text { cups of coffee/day vs } \\
\geq 5 \text { cups of coffee/day: } \\
\text { Rate of spontaneous abortion significantly higher in all coffee } \\
\text { groups }\end{array}$ & $\begin{array}{l}\text { No information on smoking. } \\
\text { No control for confounders. }\end{array}$ \\
\hline $\begin{array}{l}\text { Axelsson et al., } 1989 \\
\text { Retrospective cohort } \\
\text { study } \\
\text { Sweden }\end{array}$ & 654 women & $\begin{array}{l}\text { Month before pregnancy } \\
\text { and } \\
\text { First trimester } \\
\text { Coffee }\end{array}$ & $\begin{array}{l}\text { Late abortion } \\
\text { Spontaneous abortion } \\
\text { during entire pregnan- } \\
\text { cy. } \\
\text { Only cases verified in } \\
\text { hospital records }\end{array}$ & $\begin{array}{l}\frac{\text { Coffee consumption the month before pregnancy }}{\leq 3 \text { cups of coffee/day vs }} \\
>3 \text { cups/day } \\
\text { Coffee consumption during first trimester } \\
<3 \text { cups of coffee/day vs } \\
>3 \text { cups/day }\end{array}$ & $\begin{array}{l}\text { Recall bias likely. Poor } \\
\text { presentation of data. }\end{array}$ \\
\hline $\begin{array}{l}\text { Parazzini et al., } 1991 \\
\text { Case control study } \\
\text { Italy }\end{array}$ & $\begin{array}{l}94 \text { women (age 25-39) } \\
\text { with two or more unex- } \\
\text { plained spontaneous } \\
\text { abortions and } \\
176 \text { women with normal } \\
\text { deliveries }\end{array}$ & $\begin{array}{l}\text { Last miss-carrying preg- } \\
\text { nancy for cases, } \\
\text { 1st trimester of the index } \\
\text { pregnancy for controls } \\
\text { Coffee }\end{array}$ & $\begin{array}{l}\text { Early abortion within } \\
12 \text { weeks of gestation }\end{array}$ & $\begin{array}{l}\text { Non-coffee drinkers vs } \\
\text { coffee-drinkers }\end{array}$ & $\begin{array}{l}\text { Small study with a selected } \\
\text { population with recurrent } \\
\text { aborters. } \\
\text { Only coffee consumption } \\
\text { considered (no quantitative } \\
\text { data), but exposure period } \\
\text { differed for cases and } \\
\text { controls. }\end{array}$ \\
\hline $\begin{array}{l}\text { Armstrong et al., } 1992 \\
\text { Cross-sectional study } \\
\text { Canada }\end{array}$ & $\begin{array}{l}7146 \text { pregnancies } \\
\text { were analysed, but } \\
\text { exposure data were only } \\
\text { available for } \\
35848 \text { pregnancies }\end{array}$ & $\begin{array}{l}\text { During } 1^{\text {st }} \text { trimester } \\
\text { Coffee only }\end{array}$ & $\begin{array}{l}\text { Late abortion Sponta- } \\
\text { neous abortion during } \\
\text { entire pregnancy }\end{array}$ & $\begin{array}{l}0 \text { cup coffee/day vs } \\
1-2,3-4 \text { cups/day } \\
5-9 \text { cups/day } \\
10+\text { cups/day }\end{array}$ & $\begin{array}{l}\text { Overall high rate of sponta- } \\
\text { neous abortions in studied } \\
\text { population. Bias in retro- } \\
\text { spective interviews possible. }\end{array}$ \\
\hline $\begin{array}{l}\text { Parazzini et al., } 1994 \\
\text { Case control study } \\
\text { Italy }\end{array}$ & $\begin{array}{l}462 \text { women with sponta- } \\
\text { neous abortion between } \\
\text { week } 4 \text { and } 12 \text { of preg- } \\
\text { nancy, and } 814 \text { women } \\
\text { with live term births }\end{array}$ & $\begin{array}{l}\text { Three months before } \\
\text { conception and during } 1^{\text {st }} \\
\text { trimester } \\
\text { Coffee only }\end{array}$ & $\begin{array}{l}\text { Early abortion Spon- } \\
\text { taneous abortion } \\
\text { within } 12 \text { weeks of } \\
\text { gestation }\end{array}$ & $\begin{array}{l}\text { Non-coffee drinkers vs } \\
\text { cofffee-drinkers }\end{array}$ & $\begin{array}{l}\text { Only cases contacting a } \\
\text { hospital were included. Time } \\
\text { of interview differed for } \\
\text { cases and controls. Coffee } \\
\text { consumption not quantified. }\end{array}$ \\
\hline $\begin{array}{l}\text { Dominguez-Rojas et al., } \\
1994 \\
\text { Retrospective cohort } \\
\text { study } \\
\text { Spain }\end{array}$ & $\begin{array}{l}691 \text { pregnancies of } 711 \\
\text { hospital workers }(20-41 \\
\text { years) who had at least } \\
\text { had one pregnancy }\end{array}$ & $\begin{array}{l}\text { No information } \\
\text { Coffee }\end{array}$ & $\begin{array}{l}\text { Late abortion } \\
\text { Foetal loss before or } \\
\text { at the } 20^{\text {th }} \text { week of } \\
\text { gestation }\end{array}$ & $\begin{array}{l}0-140 \mathrm{mg} \text { caffeine/day vs } \\
141-280 \mathrm{mg} / \text { day } \\
281-420 \mathrm{mg} / \mathrm{day} \\
>420 \mathrm{mg} / \text { day }\end{array}$ & $\begin{array}{l}\text { No information about expo- } \\
\text { sure period. Six women with } \\
\text { no consumption were exclu- } \\
\text { ded from analysis. }\end{array}$ \\
\hline
\end{tabular}




\begin{tabular}{|c|c|c|c|c|c|c|}
\hline $\begin{array}{l}\text { Reference } \\
\text { Type and location of } \\
\text { study }\end{array}$ & Sample size and selection & $\begin{array}{l}\text { Exposure period considered } \\
\text { Beverages considered }\end{array}$ & $\begin{array}{l}\text { Definition of end- } \\
\text { point(s) } \\
\text { (Spontaneous } \\
\text { abortion=SA) }\end{array}$ & $\begin{array}{l}\text { Results } \\
\text { Risk estimate adjusted odds ratios } \\
\text { including } 95 \% \text { confidence interval }\end{array}$ & & Comments \\
\hline $\begin{array}{l}\text { Dlugosz } \\
\text { et al., } 1996 \\
\text { Prospective study } \\
\text { USA }\end{array}$ & $\begin{array}{l}2849 \text { pregnant women } \\
\text { seeking prenatal care } \\
\text { before the } 16^{\text {th }} \text { week of } \\
\text { gestation }\end{array}$ & $\begin{array}{l}\text { During } 1^{\text {st }} \text { month of preg- } \\
\text { nancy } \\
\text { Coffee, tea and caffeinated } \\
\text { sodas }\end{array}$ & $\begin{array}{l}\text { Late abortion Sponta- } \\
\text { neous abortion before } \\
28^{\text {th }} \text { week of gestation }\end{array}$ & $\begin{array}{l}\frac{\text { Coffee }}{0 \text { cup coffee/day vs }} \\
<1,1, \text { or } 2 \text { cups/day } \\
\geq 3 \text { cups/day } \\
\frac{\text { Tea }}{0 \text { cups tea/day vs }} \\
<1,1,2, \geq 3 \text { cups/day } \\
\text { Soda drinks } \\
0 \text { cans/day vs } \\
<1,1,2, \geq 3 \text { cans/day }\end{array}$ & $\begin{array}{r}\text { NS } \\
2.63(1.29-5.34) \\
\text { NS } \\
\text { NS } \\
\end{array}$ & $\begin{array}{l}\text { Selection bias due to strict } \\
\text { inclusion criteria possible. } \\
\text { Nausea not measured. }\end{array}$ \\
\hline $\begin{array}{l}\text { Fenster et al., } 1997 \\
\text { Prospective cohort } \\
\text { study } \\
\text { USA }\end{array}$ & $\begin{array}{l}5144 \text { pregnant women } \\
\text { (at } 13 \text { weeks of gestation } \\
\text { or less) }\end{array}$ & $\begin{array}{l}\text { The week around the last } \\
\text { menstrual period, as well } \\
\text { as the } 7^{\text {th }} \text { week of preg- } \\
\text { nancy } \\
\text { Coffee, tea soda }\end{array}$ & $\begin{array}{l}\text { Spontaneous abor- } \\
\text { tions before } 20 \text { weeks } \\
\text { of gestation }\end{array}$ & $\begin{array}{l}\text { Before pregnancy } \\
\text { Normal or decaffeinated coffee, tea, or soda, } \\
0 \text { cups/day vs } \\
0.5-1,2, \geq 3 \text { cups/day } \\
\text { During pregnancy: } \\
\text { Normal coffee, tea or soda } \\
0 \text { cups/day vs } \\
0.5-1,2, \geq 3 \text { cups/day } \\
\text { Decaffeinataed coffee } \\
0 \text { cups/day vs } \\
0.5-1,2, \geq 3 \text { cups/day }\end{array}$ & $\begin{array}{r}\text { NS } \\
\text { NS } \\
2.37(1.22-4.60)\end{array}$ & $\begin{array}{l}\text { Bias resulting from relations } \\
\text { among nausea, foetal } \\
\text { viability and consumption } \\
\text { pattern. }\end{array}$ \\
\hline $\begin{array}{l}\text { Parazzini et al., } 1998 \\
\text { Case control study } \\
\text { Italy }\end{array}$ & $\begin{array}{l}782 \text { women with sponta- } \\
\text { neous abortion within } 12 \\
\text { weeks of pregnancy, and } \\
1543 \text { women with live } \\
\text { term births }\end{array}$ & $\begin{array}{l}\text { Before pregnancy and } \\
\text { during } 1^{\text {st }} \text { trimester } \\
\text { Coffee (regular and decaf- } \\
\text { feinated), tea, cola drinks }\end{array}$ & $\begin{array}{l}\text { Early abortion Spon- } \\
\text { taneous abortion } \\
\text { within } 12 \text { weeks of } \\
\text { gestation }\end{array}$ & $\begin{array}{lr}\text { Coffee } & \\
\text { Before pregnancy } & \\
0 \text { cups vs } & \mathrm{NS} \\
1 \text { cups/day } & \\
2-3 \text { cups/day } & 1.34(1.04-1.73) \\
\geq 4 \text { cups/day } & 1.47(1.07-2.02) \\
\text { During 1st trimester } & \\
0 \text { cups vs } & \mathrm{NS} \\
1 \text { cups/day } & \\
2-3 \text { cups/day } & 1.75(1.23-2.29) \\
\geq 4 \text { cups/day } & 3.98(2.55-6.21) \\
\text { All other beverages } & \\
& \end{array}$ & & $\begin{array}{l}\text { Part of the study already } \\
\text { published in } 1994 \text {. Only } \\
\text { cases contacting a hospital } \\
\text { were included. Time of data } \\
\text { collection differed for cases } \\
\text { and controls. } \\
\text { Few women consuming }>1 \\
\text { serving of decaffeinated tea } \\
\text { and cola. }\end{array}$ \\
\hline
\end{tabular}




\subsection{Caffeine intake and late spontaneous abortions}

Although the study of Weathersbee et al. (1977) mentioned in section 12.1 had many weaknesses, its conclusion that a high daily caffeine intake in early pregnancy may predispose women to reproductive difficulty stimulated many research groups to further explore a possible association between caffeine intake (or intake of caffeine-containing beverages) and spontaneous abortion. Many of these studies relate caffeine intake in late pregnancy or during a longer time of the pregnancy to late spontaneous abortion (abortion after week 12 of pregnancy). These studies are discussed in this section. The results are summarised in Table 47 and 48.

In a Japanese study 9921 healthy pregnant women were interviewed at week 24 of gestation about their caffeine ingestion during pregnancy (Furuhashi et al., 1985). The women were divided into five categories; those that consumed less than 5 cups of coffee per day during pregnancy, those consuming more than 5 cups of coffee per day, those consuming both coffee and green tea, those consuming only green tea, and those consuming neither coffee nor green tea (controls). Subsequently, their intake was correlated to pregnancy outcome: mean birth weight; length of labour; mean amount of intrapartum haemorrhage and incidence of intrauterine growth retardation; spontaneous abortion; premature labour, and foetal abnormality.

There was no significant difference in maternal weight gain during pregnancy between the five groups, but the incidence of heart failure and anaemia was higher in the group that consumed more than 5 cups of coffee/day. There was also a significant high incidence of impending abortion and premature labour in this group, but, on the other hand, the same group had the lowest incidence of pregnancy-induced hypertension or EPH gestosis (maternal obstetrical complications). The rate of spontaneous abortions in all the coffee-drinking groups (independent of quantity) was $2.0 \%$. This rate was significantly higher than in the control group (Table 48). Although having the advantage of being a large prospective study, this study has a very limited value in this context, as it had substantial shortcomings, and did not try to control for the women's age and for environmental factors that may influence abortion rate, such as smoking.

In a retrospective study on a Spanish well-controlled cohort of over 700 hospital workers who had had at least one pregnancy, there were 169 spontaneous abortions of 691 pregnancies considered (Dominguez-Rojas et al., 1994). Only the first pregnancy after entering the study was taken into consideration. The original information on coffee intake (expresso) was, after chemical analysis of the coffee, recalculated to $140 \mathrm{mg}$ caffeine per cup and the total intake stratified into four categories. Using the group 
with an intake of $140 \mathrm{mg}$ caffeine per day (1 cup of coffee/day) as the reference, the adjusted risk of spontaneous abortion increased significantly with the daily caffeine intake (Table 47). The fact that the six women who did not consume coffee were excluded from the analysis, that the time period of coffee consumption was not specified, that consumption of no other caffeine-containing beverage was investigated, and that the investigators did not adjust for smoking and other environmental factors, severely limits the conclusions that can be drawn from the study.

A Swedish investigation on the outcome of pregnancy in relation to irregular and inconvenient work schedules was based on pregnancies occurring during the period 1965-1984 among women who worked at a hospital in the west-coast region of Sweden some time between 1980 and 1984 (Axelsson et al., 1989). Around $81 \%$ of the 807 women (654) who had been employed during this time period answered a questionnaire that in addition to working habits asked for factors that might confound a relationship between irregular working hours and abortion. One of these factors was coffee consumption. A significantly increased risk of miscarriage was found for those who reported that they drank more than three cups of coffee a day during the first trimester (Table 45). Although the risk was also increased for women consuming three cups of coffee per day during the month before pregnancy, this increase was not statistically significant. This study is likely to be confounded by missing information and recall bias, as some questions in the questionnaire related to periods up to twenty years back in time.

The first of two Canadian investigations analysed data from a survey of occupational factors and pregnancy outcome aimed at examining the effects of cigarette smoking, alcohol use and coffee consumption on pregnancy outcome (Armstrong et al., 1992). Over the course of two years, some 56000 women, comprising all who had had a delivery or a spontaneous abortion in 11 hospitals in Montreal, were interviewed on occupational, personal, and social factors. Of a total of 48582 previous pregnancies (ongoing pregnancies not included), 1436 were excluded because of missing information, leaving 47146 for analysis. However, as questions on coffee consumption during the first trimester of previous pregnancies were not asked until after the survey began, information on this factor was available only for 35848 of the 47146 pregnancies.

After adjusting for potential confounding factors, both smoking habit and alcohol consumption were clearly associated with elevated risk for spontaneous abortion. Coffee consumption increased the risk of spontaneous abortion on average by a factor of 1.017 for each cup per day; a statistically significant trend. Although there was a statistically significant increased odds ratio for drinking 5-9 cups of coffee per day in comparison with none, the odds ratio for drinking 10 or more cups per day was not significantly increased (Table 48). It should be noted that the overall rate of spontaneous abortion was relatively high in the studied population 
(21.6\%). Whether this indicated that it was selected or not is not known. The retrospective nature of the enquiry and the mistake of not asking about coffee consumption and intake of other caffeinated beverages in the first interview (leading to a focus on the question and reduced participation rate in answering this question) could have led to biased reporting.

The second Canadian study was a spin-off from a case-control study initially planned to examine the association between lupus anticoagulants, anticardiolipin antibodies, and foetal loss, but data on caffeine intake, smoking, and alcohol use were collected as potential confounding variables in the study. The collected information was used to explore the relationship between caffeine consumption before and during pregnancy and foetal loss (Infante-Rivard et al., 1993). Cases were women hospitalised during working days with a clinically confirmed diagnosis of spontaneous abortion or foetal death who accepted to having a blood sample drawn. A relatively large proportion of the cases were women who had stillbirths during the third trimester of pregnancy. Of 516 eligible women, only 331 $(64 \%)$ were enrolled in the study. Controls were women who were at the same period of pregnancy as the cases, based on last menstrual period, and had not yet experienced a foetal loss. Three controls were matched to each case, giving a control group of 993 control women.

A face-to-face interview with all cases and controls was carried out at the hospital at the time of ascertainment. A special feature of the study was that women were asked both about their intake of beverages containing caffeine before pregnancy (the month preceding conception) and during pregnancy (an average over pregnancy up to the time of study enrolment). For the purposes of calculating caffeine intake, a cup of coffee was estimated to contain $107 \mathrm{mg}$ caffeine, a cup of tea $34 \mathrm{mg}$ and a can of cola $47 \mathrm{mg}$.

After adjusting for confounding factors, the incidence of foetal loss was strongly associated with caffeine intake during pregnancy, and moderately associated with caffeine use before pregnancy (Table 47). Based on the fact that pregnancy affects caffeine metabolism by lengthening its half-life, this finding is not surprising. A majority of women reduced coffee intake during pregnancy; women with higher education did so more frequently than women with less education. Overall, $55 \%$ of the study population reduced their caffeine intake, $42 \%$ reported no change, and 3\% increased their consumption. During the first 16 weeks of pregnancy, controls reduced their caffeine intake more than cases (a $10 \%$ difference in reduction), whereas the reverse was true in the period starting after 16 weeks of gestational age.

The validity of the findings in this study has been questioned by Wei (1994) because the risk of spontaneous abortion was almost identical in smokers and non-smokers and in drinkers and non-drinkers. At the same time, the risk was strongly associated with caffeine intake. According to Wei (1994) this raises the question as to whether there was a bias in data 
collection, perhaps due to $60 \%$ of potential cases being excluded because of overnight discharge of the mothers, exclusion of patients arriving at the hospital during weekends or legal holidays, or refusal to have blood drawn.

Furthermore, the study did not measure nausea. It is possible that the minor reduction of caffeine intake between cases and controls during the earlier weeks of pregnancy could be due to differences in factors other than nausea. The nausea hypothesis cannot explain the observation that $10 \%$ more cases than controls reduced their intake later in pregnancy. The observation, mentioned above, that more educated women reduced their caffeine intake more frequently than less educated women indicates that advice and personal knowledge may have a strong influential effect, and may even precede the influence of nausea on food changes (InfanteRivard et al., 1993).

The study of Infante-Rivard and co-workers (1993) has also been criticised by Kline et al. (1994) in relation to the control of potential factors that might influence cases and controls to reduce caffeine intakes differently. Since case-control differences may be an artefact of longer gestations among controls than cases and women tend to decrease caffeine intake early in pregnancy, Kline and colleagues (1994) pointed out that longer gestations allow more time for a decreased caffeine intake to influence the average intake, and may have resulted in an artefact in this study.

The first of the six American studies was published by Srisuphan and Bracken in 1986. During the period 1980-1982 no less than 4073 women who sought their prenatal care at private obstetrical practices and planned to be delivered at a hospital in Connecticut, USA, were invited by the investigators to participate in a study aimed at providing a detailed description of caffeine exposure in a large population of pregnant women and to investigate the relationship between caffeine consumption during pregnancy and spontaneous abortion during the late first or second trimester (non-deliberate interruption of an intrauterine pregnancy of $<28$ week's gestation in which the foetus was dead when expelled). Interviews were completed with 3340 (82\%) of eligible women, and necessary information was collected during pregnancy by a trained interviewer from 3155 of these subjects. The interview included questions on caffeine intake from caffeine-containing beverages and drugs at the time of the interview. A serving of coffee, tea, and soft drinks was assumed to contain 107, 34, and $47 \mathrm{mg}$ caffeine, respectively.

Of the caffeinated beverages, tea was most popular. The frequency for drinking three or more servings per day of coffee, tea, and colas was 5.2 $\%, 5.1 \%$ and $2.2 \%$, respectively. Interestingly, the investigators also studied the intake during the first trimester of prescription and nonprescription caffeine-containing drugs. Most women (95.1\%) used only one caffeine-containing drug. On average, the daily intake of caffeine 
from drugs was modest (5.1 $\mathrm{mg}$ or less). In all (beverages and drugs), $20.8 \%$ of the women used no caffeine during pregnancy, $51.2 \%$ were light (1-150 mg/day) caffeine users, and $28.0 \%$ moderate to heavy $(\geq 151$ $\mathrm{mg}$ /day) caffeine users. Coffee was the major source of caffeine in moderate-to-heavy caffeine users $(72 \%)$. The average daily intake of caffeine was low, $99.3 \mathrm{mg}$ from all sources.

$2.2 \%$ of the study subjects spontaneously aborted after the interview (including early spontaneous abortions, the rate was $7.2 \%$ ). The rate for non-caffeine users was the same as for the light users, $1.8 \%$, whereas it was $3.1 \%$ for the moderate-to-heavy users. Because of the similar spontaneous abortion rate in the no caffeine and light caffeine users, the group was combined $(0-150 \mathrm{mg} /$ day). The adjusted relative risk (not including smoking and alcohol) for spontaneous abortion after moderate-to-heavy caffeine consumption was significantly increased, 1.73 (Table 47). Light caffeine use (1-150 mg/day) was associated with an increased risk for spontaneous abortion only among women who aborted in their last pregnancy. Taslimi and Herrick (1986) have pointed out that the investigators failed to stratify heavy caffeine consumption by advanced maternal age, consumption of alcohol, and use of cigarettes and drugs. The size and design of the study should have allowed a statistical analysis controlling for these confounding factors.

The association between intake of caffeine from coffee, tea, and soda drinks and spontaneous abortions identified by pathology reports was investigated in another American study. This was a case-control study focusing on the importance of water consumption and exposure to solvents, and was based on 607 cases and 1284 controls from California (Fenster et al., 1991a). The average intake of caffeine during the first trimester (or during the entire pregnancy, if shorter) was calculated from information obtained from computer-assisted telephone interviews, usually within 1 year after the pregnancy ended. The recall consistency for reporting caffeinated beverage consumption was examined and found to be acceptable (Fenster et al., 1991b). About $70 \%$ of the women consumed caffeinated coffee, tea and/or soda. Caffeine consumption was calculated by summing the average amount of caffeine in consumed coffee, tea, and soda, assuming caffeine contents of $107 \mathrm{mg} / \mathrm{cup}, 34 \mathrm{mg} / \mathrm{cup}$, and 47 $\mathrm{mg} / \mathrm{can}$, respectively. $7 \%$ of the women consumed more than an average of $300 \mathrm{mg}$ of caffeine daily.

Before adjusting for potential confounding variables, the investigators observed a significantly increased crude likelihood of heavy caffeine consumption for cases compared with controls. After adjustment, however, the increased likelihood (22\%) was no longer statistically significant (Table 47). There was no suggestion of interaction between cigarette smoking and caffeine consumption or between alcohol and caffeine consumption in this study. 
Since nausea is associated with a reduced risk of spontaneous abortion (Weigel and Weigel, 1989) and the presence of nausea may reduce caffeine consumption, the association between caffeine intake and spontaneous abortion was examined by stratifying on reports of nausea (any versus none) to determine whether the condition confounded or modified the investigated association. It was seen that nausea was an effect modifier of the caffeine and spontaneous abortion relation, but only for the highest level of caffeine consumption (Fenster et al., 1991a). The association between heavy caffeine consumption and spontaneous abortion was seen among women who reported nausea but was absent among those who did not (Table 47). The stratification of miscarriages by the presence of nausea in the statistical analysis, and the suggestion of an apparent protective effect on miscarriage of heavy caffeine consumers in the absence of nausea have been criticised by Stein and Susser (1991). They point out that "to avoid the error of assigning consumption occurring after the outcome event to the antecedent hypothesised causal exposure, the history of nausea must be timed no less closely than the history of caffeine consumption" - a simple information on nausea (any versus none), is not enough. In addition, the severity as well as the duration of the symptom of nausea might differentiate successfully from failing or vulnerable pregnancies. Karyotyping of miscarriages could contribute importantly to such differentiation.

Early reduction in heavy caffeine consumption was also examined by Fenster and colleagues (1991a), in order to determine whether changes in habit might affect spontaneous abortion rates. About $53 \%$ of the women who cut down their intake from greater than $300 \mathrm{mg}$ /day to less than that amount within 6 weeks of their last menstrual period had a similar risk of abortion compared to those who did not consume caffeinated beverages. The presence of nausea was associated with a tendency to decrease caffeine consumption.

The investigators concluded that heavy caffeine consumption might contribute to $4 \%$ of spontaneous abortions or $14 \%$ of spontaneous abortions in women reporting nausea. Thus, in their opinion, decreasing heavy caffeine intake early in pregnancy may reduce the risk of spontaneous abortions.

The third American study investigating the relationship between caffeine intake and spontaneous abortion was a cohort study devoted to the effect of environmental risk factors on pregnancy (Dlugosz et al., 1996). A total of 2849 pregnant women seeking prenatal care before the sixteenth week of gestation and planning to give birth at a hospital in Connecticut were recruited. Interviews were completed in their homes (82.6 $\%$ of the eligible subjects). The usual daily caffeine intake was calculated from information on the frequency of consumption of caffeinated beverages the first month of pregnancy, and information on standard quantities of caffeine in the beverages (107 $\mathrm{mg}$ in a cup of coffee, $34 \mathrm{mg}$ per ser- 
ving of tea, and $47 \mathrm{mg}$ per serving of soda). Spontaneous abortions were defined as non-deliberate interruption of an intrauterine pregnancy of less than 28 weeks' gestation in which the foetus was dead when expelled.

By restricting the analysis of caffeine intake to the first month of pregnancy, the potential confounding due to pregnancy-induced changes in dietary caffeine intake (that is, caffeine aversion and metabolism) should have been reduced. However, nausea, a potentially influential confounding factor, was not measured. The mean daily caffeine consumption during the first month of pregnancy was $89.0 \mathrm{mg}$ per day for the women who miscarried, and $72.4 \mathrm{mg}$ per day for the women who delivered live-born infants. Consumption of more than $300 \mathrm{mg}$ caffeine per day was associated with a nearly twofold increase in the odds ratio of spontaneous abortion. However, the linear dose-response trend was weak, and adjustment for covariates lowered the risk estimate $(\mathrm{OR}=1.75 ; 95 \%$ $\mathrm{CI}=0.88-3.47$ ) for the high caffeine dose to non-significant levels (Table 47). The odds ratio of spontaneous abortion was significantly increased when daily coffee consumption reached three or more cups (Table 48). On the other hand, the intake of soda drinks, and probably also tea, had no influence on the risk of spontaneous abortion. An unexpected observation was that caffeine consumption was more strongly related to spontaneous abortion than alcohol or cigarette use in early pregnancy in this study. It should also be noted that the spontaneous abortion rate $(4.5 \%)$ was relatively low in this study, possibly because only abortions occurring after a confirmed pregnancy diagnosis and subsequent interview to ascertain exposure were included in the study.

The fourth American study had a rather specialised design. It was based in a New York City hospital, and aimed at investigating the association of caffeine intake from beverages shortly before or during pregnancy with spontaneous abortions of known karyotype (Kline et al., 1991). The 899 cases (510 chromosomally normal, 237 trisomies, 54 monosomies X, 49 triploidies and 49 others) were drawn from 2067 spontaneous abortions identified in the study during 3.5 years, for which the women were both interviewed and their abortus retrieved and karyotyped. The 1423 controls were registered at the same hospital before completing 22 weeks gestation (to maximise chances of interviewing controls at gestations similar to those of cases at time of loss) and delivered at 28 completed weeks or later. Controls were matched to cases by maternal age and sociodemographic characteristics. It is not unlikely that the rather high drop out rate $(57 \%)$ of non-karyotyped cases might have lead to a bias in the study. Another factor that might influence the result was that the gestation at abortion on average was 9 days longer in the cases than in spontaneous abortions for which the abortuses were not karyotyped.

Caffeine exposure was estimated from interviews and separately covered the time period "during pregnancy" (one month after the last menstrual period until the time of loss for cases or of interview for 
controls), and the time of "perifertilization" (two months before and one month after the last menstrual period). Total daily caffeine intake was calculated from consumption information and estimates (in milligrams per 8-ounce serving) of caffeine content for brewed coffee $(136 \mathrm{mg})$, instant coffee (96 mg), brewed and instant coffee equally $(116 \mathrm{mg})$, decaffeinated coffee $(4.8 \mathrm{mg})$, tea $(56 \mathrm{mg})$, and cocoa and chocolate milk (5.7 mg). Caffeine content of colas was estimated at $3.5 \mathrm{mg} /$ ounce and of caffeinated non-cola sodas (3.5-4.5 mg/ounce) by brand. Data was insufficient to estimate intake from medications. However, only $3.2 \%$ of the women reported a use of caffeine-containing medications; $52 \%$ of them less often than once a week. Estimated daily caffeine intake was higher in the perifertilization period than during pregnancy: arithmetic means were $164 \mathrm{mg}$ and $99.6 \mathrm{mg}$, respectively, with caffeinated coffee the source of about $70 \%$.

Caffeine intake in the perifertilization period did not differ among groups of cases and the controls. For the groups having the highest caffeine intake, at least $225 \mathrm{mg} /$ day, odds ratios adjusted for payment group (public or private patients) and maternal age were 1.0 for chromosomally normal abortions, 0.9 for trisomies, 1.6 for monosomies $\mathrm{X}$, and 0.8 for triploidies. The authors inferred that caffeine intake in the perifertilization period does not influence the risk of spontaneous abortions having a normal karyotype or trisomy. Although no statistically significant associations were observed for abortions with monosomy $\mathrm{X}$ and triploidy, the number of pregnancies studied were insufficient to rule out moderate effects.

Caffeine intake during pregnancy was tested for associations with chromosomally normal spontaneous abortions using the chromosomally aberrant cases to provide a robust comparison group. Although the proportion of subjects with an intake of at least $225 \mathrm{mg} /$ day of caffeine was higher in cases than in controls (probably due to greater decrease in caffeine intake in the control group than in the case group), it was similar for subjects with chromosomally normal and chromosomally abnormal spontaneous abortions (Table 47). There is more than one possibility for a stronger decrease in caffeine intake among women in the control group, as compared to women in the case group. One potential source should be pointed out. Whereas cases did not necessarily receive prenatal care, this was always the case for the controls. In the public facilities, caretakers advised patients to decrease caffeine intake, while it is not known what proportion of private physicians gave similar advice.

A fifth American study explored the relationship between caffeine intake and spontaneous abortion prospectively in a cohort established to investigate the association between various environmental factors and spontaneous abortion (Fenster et al., 1997; Windham et al., 1997). The study population was recruited from Californian women making their first prenatal control. Computer-assisted telephone interviews were con- 
ducted at between 4 and 13 weeks gestational age (on average 8 weeks) for 5342 of the 6179 eligible women. Of these 5144 met eligibility criteria. Pregnancies that did not end in a live birth were defined as spontaneous abortions if the pregnancy ended at 20 completed weeks of gestation or less, and as stillbirths if the pregnancy ended at a time period greater than 20 weeks gestation. There were 499 spontaneous abortions, 4613 live births, and 32 stillbirths.

Subjects were asked to quantify their daily consumption of decaffeinated coffee and caffeine-containing beverages (coffee, tea, and soda) in the week before the interview. As interviews were conducted on average during the eighth week of pregnancy, women were on average reporting consumption for the seventh week of gestation. The same questions were asked referring to the week around their last menstrual period. The usual daily caffeine intake was calculated from information on the frequency of consumption of caffeine-containing beverages and standard quantities of caffeine in these beverages (107 $\mathrm{mg}$ in a cup of coffee, $34 \mathrm{mg}$ per serving of tea, and $47 \mathrm{mg}$ per serving of soda).

About three-quarters of the studied women ingested caffeine before pregnancy, but only about $50 \%$ during the first trimester of pregnancy. Approximately $13 \%$ reported heavy consumption (>300 mg per day) before pregnancy, and about $4 \%$ reported heavy consumption during the first trimester. Although heavy consumers of caffeinated and decaffeinated coffee were less likely to have experienced nausea in early pregnancy compared with non-consumers, they were similar to moderate consumers of these beverages with respect to nausea. Among women who drank normal coffee, about $75 \%$ had reduced their intake by the time of the interview, whereas the corresponding figure among women who drank decaffeinated coffee was about $47 \%$. The percentage distributions of these changes did not differ appreciably between women with spontaneous abortions and those with live births or stillbirths for either normal coffee or decaffeinated coffee. The overall spontaneous abortion rate in this population was $9.7 \%$.

Heavy caffeine intake before pregnancy was not related to the risk for spontaneous abortion; neither was consumption of any of the individual caffeinated beverages (Table 47 and 48). Whereas the adjusted odds ratio for heavy decaffeinated coffee intake during the first trimester was significantly increased, the adjusted odds ratio for heavy caffeine consumption during the same time period was elevated, but not significantly so. The increased risk for spontaneous abortion related to heavy decaffeinated coffee consumption was not accounted for by women who had increased their consumption after becoming pregnant. The effect estimate for heavy decaffeinated coffee consumption was similar in women who did not report either smoking or drinking alcohol before or during the first trimester. The investigators suspected that the association between beverage consumption and spontaneous abortion was due to bias resulting from the 
relations among foetal viability, symptoms of pregnancy such as nausea, and consumption patterns during pregnancy, but could not confirm their suspicion with experimental data.

In the sixth American study, Wen et al. (2001) investigated the association of maternal caffeine consumption and nausea with spontaneous abortions using data from the Diana project, a population-based prospective study that included 968 women enrolled before pregnancy. The aim of the Diana project is to identify pre-conceptual and early pregnancy exposures that are related to reproduction outcomes. The study subjects were women 22-35 years of age recruited 1989-1992 in Minnesota, USA. After exclusion of women who did not meet the inclusion criteria and/or did not want to participate, the final study participants were traced to delivery of a live-born singleton infant (575 women) or an early or late spontaneous abortion ( 75 women). Medical data were collected prospectively via medical records. Dietary intake was assessed using the Willett food frequency questionnaire. Mean caffeine intake was calculated prospectively from data obtained in food frequency questionnaires given to the women every third month before pregnancy and monthly during the entire pregnancy. Caffeine consumption was calculated from regular coffee (139.2 $\mathrm{mg} / \mathrm{cup})$, tea (64 mg/cup), hot chocolate (16 mg/cup), cola (46 $\mathrm{mg} / 12 \mathrm{oz}$ ), soda drinks (46 mg/cup), and chocolate containing foods (like brownies). Nausea status (yes/no) and its duration (days) were registered monthly.

Spontaneous abortion was more common among women who did not report nausea than among women reporting this condition. Among those reporting nausea, the duration of nausea was shorter in those who aborted than in those who delivered a live-born infant. Although the average caffeine intake was reduced during the first trimester of pregnancy, the risk of spontaneous abortion was higher among women who reported a 'higher' caffeine consumption (Table 47). Maternal caffeine consumption before pregnancy or in women who did not experience nausea did not increase the risk for spontaneous abortions. However, women who consumed $\geq 300 \mathrm{mg}$ caffeine per day in the first trimester after experiencing nausea had an increased risk for spontaneous abortion (risk ratio: 5.4; 95\% CI 2.0-14.6) compared with women who had a caffeine consumption of $<20 \mathrm{mg}$ per day. The authors concluded that their results suggest that maternal caffeine consumption during pregnancy may influence the viability of the foetus in women experiencing nausea. The strength of this study is the prospective design, the enrolling of participants in early pregnancy, and the frequent exposure measurements. On the other hand, the study size was small (due to the restrictive recruitment of the study subjects), which results in low precision, which is especially apparent in the analyses of subgroups. The study could have been better adjusted for smoking, since only qualitative information was used (smoker/nonsmoker). 
The level of caffeine in body fluids is not only dependent on the amount of caffeine consumed but also on the rate at which caffeine is eliminated from the body. Since caffeine metabolism was not analysed in the original study of Fenster and co-workers (1997), a subgroup of 445 women from the original study were invited to participate in a follow-up study, aiming at specifically exploring an association between rate of caffeine metabolism and risk of spontaneous abortion (Fenster et al., 1998). Of the invited women, 121 declined to participate, 102 were not eligible due to various conditions that may affect caffeine metabolism (i.e. current use of oral contraceptives), and one had to be deleted because her biological samples were lost. Among the 211 women that made up the final study base, 72 were cases with at least one spontaneous abortion and 139 controls without abortions. Thus, the drop out rate was as high as $53 \%$. The investigators reported, however, that there was not a big difference in caffeine consumption during pregnancy between women that accepted participating and women that refused. As many as $34 \%$ of the women consumed no caffeine during pregnancy, and as few as around $5 \%>300 \mathrm{mg} /$ day (approximately 3 cups of coffee/day).

The first objective of the study was to examine the possibility that slower metabolizers of caffeine are more susceptible to an effect of caffeine on spontaneous abortion. The second objective was to examine whether the risk for spontaneous abortion was associated with differential activity of one or more of three enzymes known to be important for caffeine metabolism; CYP1A2, xanthine oxidase and N-acetyltransferase 2. To estimate the enzyme activities, the concentration of various caffeine metabolites in urine was measured after administrating a test dose of caffeine. The metabolic indices for the three enzymes were then calculated from the metabolite ratios. Because smoking is strongly related to CYP1A2 activity, and 24 women reported that they had changed their smoking behaviour during the time between performance of the metabolism test and the pregnancy, the authors tried to prevent misclassification of these women's CYP1A2 indices. This was done in two ways - by deleting the women from the statistical analysis or by changing the enzyme indices of CYP1A2. The statistical evaluation of the data (Table 49) showed no evidence for the presence of an interaction between the enzyme activities (CYP1A2, N-acetyltransferase 2, xanthine oxidase) and caffeine intake on the risk of either first or recurrent spontaneous abortion (Fenster et al., 1998). The major weaknesses of the study were that the enzyme activity measurements were performed on urine samples collected after pregnancy (on the assumption that the relative measures of enzyme activity remained the same, with the exception of women with discrepant smoking behaviours), and that the study was not controlled for the occurrence of chromosomal abnormalities in the abortuses. It is well known that the majority of spontaneous abortions are a result of chromosomal abnormalities. Another weakness was that the caffeine intake was low in 
the studied population, and only a few women consumed more than 3 cups of coffee per day.

A similar approach of studying the relationship between caffeine exposure and spontaneous abortion to that of Fenster et al. (1998) was undertaken by Klebanoff and co-workers (1999). These investigators used the blood samples of women enrolled in the Collaborative Perinatal Project, a prospective study of pregnancy, labour, and child development conducted at 12 sites in the United States from 1959 to 1966. The blood samples were collected once every two months during pregnancy, at delivery and six weeks after delivery. Among the approximately 55000 births registered, a total of 830 women had foetal losses less than 140 days after the first day of the last menstrual period. Serum samples and time of sampling in relation to spontaneous abortion was available from 591 of these women (women with induced abortion were not included). Four control women giving birth to living neonates after at least 28 weeks of gestation at the same centres were selected for each case, making up a control group of 2558 matched women. The serum samples were used to assay caffeine and paraxanthine, the latter compound being the primary metabolite of caffeine. Preliminary investigations showed that serum paraxanthine was better correlated to caffeine intake than serum caffeine. A total of 487 women who had spontaneous abortions (82\%) and 2087 controls $(82 \%)$ had quantifiable serum paraxanthine concentrations. The mean serum concentration of paraxanthine was significantly higher in the abortion group than in the control group (752 vs $583 \mathrm{ng} / \mathrm{ml}$ ). After adjusting the statistical calculations for maternal age, smoking status, and race or ethnic group, the significantly increased risk of spontaneous abortion was restricted to women with serum paraxanthine concentrations higher than $1845 \mathrm{ng} / \mathrm{ml}$, corresponding to the 5 percent of controls with the highest concentrations (Table 49).

As the study of Klebanoff et al. (1999) was planned quite a bit after the original Collaborative Perinatal Project cohort, it is understandable that several caveats can be pointed out. One is that participants were enrolled relatively late in gestation, and that the majority of the abortions occurred in the second trimester. It would also have been preferable to perform the analyses on aborted foetuses with normal karyotype, as 
Table 49. Intake of caffeine, caffeine metabolism and spontaneous abortion (misscarriage)

\begin{tabular}{|c|c|c|c|c|c|}
\hline $\begin{array}{l}\text { Reference } \\
\text { Type and location of study }\end{array}$ & Sample size and selection & $\begin{array}{l}\text { Exposure period } \\
\text { Sources of caffeine }\end{array}$ & $\begin{array}{l}\text { Definition of end- } \\
\text { point(s) }\end{array}$ & $\begin{array}{l}\text { Results } \\
\text { Risk estimate adjusted odds ratios; including 95\% } \\
\text { confidence interval }\end{array}$ & Comments \\
\hline $\begin{array}{l}\text { Fenster et al., } 1998 \\
\text { Case-control study } \\
\text { USA }\end{array}$ & $\begin{array}{l}72 \text { cases with at least one } \\
\text { spontaneous abortion and } \\
139 \text { controls with normal } \\
\text { pregnancies (Subgroup } \\
\text { from Fenster et al., 1997) }\end{array}$ & $\begin{array}{l}\text { Week around the last } \\
\text { menstrual period, as } \\
\text { well as the } 7^{\text {th }} \text { week of } \\
\text { pregnancy } \\
\text { Coffee, tea soda }\end{array}$ & $\begin{array}{l}\text { Late abortion } \\
\text { Rate of caffeine } \\
\text { metabolism (deter- } \\
\text { mined by urinary } \\
\text { metabolites) and risk } \\
\text { for spontaneous } \\
\text { abortions before } 20^{\text {th }} \\
\text { week of gestation } \\
\end{array}$ & $\begin{array}{l}\text { Low vs high CYP 1A2 activity, low vs high xanthine } \\
\text { oxidase activity, and slow vs fast acetylator ( } \mathrm{N} \text { - } \\
\text { acetyltransferase 2) activity } \\
0 \mathrm{mg} \text { caffeine/day vs } \\
1-150,>150 \mathrm{mg} \text { caffeine/day }\end{array}$ & $\begin{array}{l}\text { Urinary samples (for me- } \\
\text { tabolism studies) taken after } \\
\text { pregnancy. High drop-out } \\
\text { rate of invited women. Low } \\
\text { caffeine intake in studied } \\
\text { women. Occurrence of } \\
\text { chromosomal abnormalities } \\
\text { not controlled for. }\end{array}$ \\
\hline $\begin{array}{l}\text { Klebanoff et al., } 1999 \\
\text { Nested case-control } \\
\text { study } \\
\text { USA }\end{array}$ & $\begin{array}{l}590 \text { women with sponta- } \\
\text { neous abortion less than } \\
140 \text { days after the first day } \\
\text { of the last menstrual period, } \\
\text { and } 2558 \text { matched women } \\
\text { who gave birth to a healthy } \\
\text { child. }\end{array}$ & $\begin{array}{l}\text { Blood samples collec- } \\
\text { ted at every two } \\
\text { months during preg- } \\
\text { nancy, at delivery and } \\
\text { six weeks after delive- } \\
\text { ry }\end{array}$ & $\begin{array}{l}\text { Late abortion } \\
\text { Rate of caffeine } \\
\text { metabolism (determi- } \\
\text { ned by blood metabo- } \\
\text { lites) and risk for } \\
\text { spontaneous abor- } \\
\text { tions at less than } 140 \\
\text { days of gestation }\end{array}$ & $\begin{array}{l}\text { High serum concentrations of paraxanthine (>1 } 845 \\
\mu \mathrm{g} / \mathrm{ml} \text { ) was significantly associated with an increa- } \\
\text { sed risk for spontaneoeus abortion. }\end{array}$ & $\begin{array}{l}\text { Blood samples stored for } 30 \\
\text { years. Stability of para- } \\
\text { xanthine not well known. No } \\
\text { information on karyotype of } \\
\text { the aborted foetus. }\end{array}$ \\
\hline $\begin{array}{l}\text { Signorello et al., } 2002 \\
\text { Population-based case- } \\
\text { control study } \\
\text { Sweden }\end{array}$ & $\begin{array}{l}101 \text { women who had spon- } \\
\text { taneous abortion at 6-12 } \\
\text { weeks of gestation and } 953 \\
\text { women with normal preg- } \\
\text { nancy (matched for gesta- } \\
\text { tional age) }\end{array}$ & $\begin{array}{l}4 \text { weeks before preg- } \\
\text { nancy until present } \\
\text { time of pregnancy. } \\
\text { Coffee, tea, cocoa, } \\
\text { chocolate, soft drinks, } \\
\text { caffeine-containing } \\
\text { drugs }\end{array}$ & $\begin{array}{l}\text { Early abortion } \\
\text { Spontaneous abor- } \\
\text { tions from } 6^{\text {th }} \text { to } 12^{\text {th }} \\
\text { week of gestation } \\
\text { shown to have a } \\
\text { normal karyotype }\end{array}$ & $\begin{array}{l}\text { CYP1A2 index below median } \\
0-99 \mathrm{mg} \text { caffeine/day vs } \\
100-299 \mathrm{mg} / \mathrm{day} \\
>300 \mathrm{mg} / \text { day } \\
\text { CYP1A2 index above median } \\
0-99 \mathrm{mg} \text { caffeine/day vs } \\
100-299 \mathrm{mg} / \mathrm{day} \\
>300 \mathrm{mg} / \mathrm{day} \\
\text { Slow acetylators } \\
0-99 \mathrm{mg} \text { caffeine/day vs } \\
100-299 \mathrm{mg} / \mathrm{day} \\
>300 \mathrm{mg} / \text { day } \\
\text { Fast acetylators } \\
0-99 \mathrm{mg} \text { caffeine/day vs } \\
100-299 \mathrm{mg} / \mathrm{day} \\
>300 \mathrm{mg} / \text { day }\end{array}$ & $\begin{array}{l}\text { A small, but relatively well } \\
\text { performed study. The mis- } \\
\text { sing urinary samples from } \\
\text { around } 30 \% \text { of cases and } \\
\text { controls might have introdu- } \\
\text { ced bias. }\end{array}$ \\
\hline
\end{tabular}


abnormal karyotype predisposes to spontaneous abortion. But no karyotype analyses were performed. In contrast to caffeine, the serum paraxanthine concentration does not fluctuate greatly during the day. Therefore, it is possible that some of the women would have been allocated to other exposure groups if caffeine had been analysed instead of paraxanthine. Furthermore, the biological samples had been stored at $-20^{\circ} \mathrm{C}$ for 30 years, and the stability of paraxanthine during this time period at these conditions is not well known. However, a marked deterioration of paraxanthine seems unlikely.

\subsection{Caffeine intake and stillbirth}

Among pregnancies, which reach at least 20 weeks gestation, nearly one in every hundred infants is born dead. The reason for the death is frequently unknown, and only a few clear risk factors have been identified. Little and Weinberg (1993) used data from the 1980 National Natality Survey and the National Fetal Mortality Survey to examine risk factors for stillbirth, separating antepartum deaths (foetal deaths that occur before labor) from the intrapartum deaths (those that occur during labour and delivery). Foetal deaths were defined as being at the point of at least 28 weeks of gestation, or $1000 \mathrm{~g}$ in weight if gestation was unknown. Similar criteria were used for live births. There were 9941 cases of live birth and 6386 cases of foetal death appearing in statistics from 1980. All married women in the two samples were invited to participate in the study, and 2832 and 1835 agreed to participate, respectively. Differences in regular coffee and/or tea use during pregnancy were modest for live births and defined stillbirths. Whereas normal coffee and/or tea use had no apparent relation to intrapartum stillbirth risk, this factor was suggestive of increased antepartum stillbirth risk $(p<0.1)$. The possibility of a correlation between exposure to caffeine and antepartum deaths has to be investigated more thoroughly.

\subsection{Summary of caffeine and spontaneous abortion}

Spontaneous abortion is one of the most common complications of pregnancy. The definition of spontaneous abortion varies over the world. According to one accepted definition, spontaneous abortions is a pregnancy that ends before 22 completed weeks of gestation, or results in a birth weight of 500 grams or less, and does not end in a live birth. In Sweden the definition is a pregnancy that ends before 28 complete weeks. Miscarriages, which are not recognised as such by the mothers, are of course unlikely to be registered. Therefore, the frequency of early (pre-clinical) 
loss is not very well known, mainly because of the difficulties in recognising the condition (Wilcox et al., 1990).

One complication in the assessment of studies concerning spontaneous abortion is that there obviously are many causes of this pregnancy outcome. Spontaneous abortions may thus be regarded as a heterogenous group of disorders. Besides chromosomal abnormalities, which are responsible for about $60 \%$ of clinically recognised spontaneous abortions during the first three months of pregnancy (Lauritsen, 1977), and uterine/cervical causes, the factors most consistently associated with recognised spontaneous abortion risk are prior spontaneous abortion and older maternal age. Previous reproductive events of other types, exposure to exogenous factors such as tobacco, alcohol, and chemicals in the occupational setting, and psychological factors have all given conflicting results within epidemiological studies. One of the exogenous factors, which have been suggested to influence spontaneous abortion rate, is caffeine intake. Potential effects of caffeine on foetal development may follow prolonged accumulation of caffeine in pregnant women and passage to the foetus, which lacks the enzymes necessary for the metabolism of caffeine until several days after birth.

Since the end of the 1970s, eighteen epidemiological studies have explored the relationship between caffeine/coffee consumption and spontaneous abortion. Eleven of these studies have been carried out in the United States and Canada, six in Europe (Spain, Italy and Sweden), and one in Japan. When assessing these epidemiological studies, it is important to consider the following issues.

Investigators have defined the studied endpoint spontaneous abortion or misscarriage differently. As the risk factors and cause for spontaneous abortion may vary during the pregnancy, it is very important that the condition is accurately defined. In the studies by Weathersbee et al. (1977), Parazzini et al. (1991, 1994, 1998), Armstrong et al. (1992), Wilcox et al. (1990) and Cnattingius et al. (2000) the investigators limited their study base to patients with early foetal loss (before 12 weeks of gestation). Two studies were devoted to miscarriages only in late pregnancy (InfanteRivard et al., 1993; Furuhashi et al., 1985), whereas the remaining studies included both fairly early and late abortions.

A difficult circumstance to control for is the non-equal influence of environmental factors on different foetuses. The fraction of foetuses carrying chromosomal abnormalities non-compatible with survival differs during pregnancy. The fraction is very high in early pregnancy, then drops during the late first trimester, becoming comparatively low at the end of pregnancy. As environmental factors such as caffeine might have a potential to influence healthy foetuses but not foetuses already likely to be aborted, carefully controlling for the karyotype of the foetus might be very difficult. It will be particularly important to control for karyotype during early pregnancy when the fraction of chromosomally abnormal 
foetuses is higher, as the rate of abnormal foetuses drops quickly with gestational age.

The majority of the studies devoted to a possible relationship between caffeine intake (or intake of caffeine-containing beverages) and spontaneous abortion have used a retrospective design. Retrospective studies could have introduced bias in the study, in particular in case-control studies, by default recall of consumption. Women who have experienced a spontaneous abortion may have been more likely to report their caffeine intake more thoroughly or even in an exaggerated fashion. However, eight studies (Furuhashi et al., 1985; Srisuphan and Bracken, 1986; Dlugoz et al., 1996; Wilcox et al., 1990; Mills et al., 1993; Fenster et al., 1997; Cnattingius et al., 2000; Wen et al., 2001) had a prospective design. Unfortunately, not all sources of caffeine have been considered in the studies, and often consumption during only one time period around or during pregnancy has been studied. In most cases, intake of coffee has been reported. A number of studies have also registered consumption of tea and caffeinated soft drinks. Rarely has caffeine intake from cocoa, chocolate, bakery products, and drugs also been considered. The weakness of studying caffeine intake only during one time period of pregnancy is that the changes taking place in the pregnant woman might introduce aversion to or fondness for caffeine-containing beverages.

The problem of confounding factors pushing a non-existent relationship into appearing like a relationship exists, or, on the contrary, reducing an existing relationship into non-significance, has to be addressed. Not all investigators have controlled for such confounding factors. A very important confounding factor that should not be neglected in this context is smoking. In several prospective and retrospective studies, an increased rate of spontaneous abortion has been reported in smokers; with relative risks being in the range 1.2 to 1.8 . It might not be enough to only adjust qualitatively for smoking (yes/no), as the amount of smoking might govern, for example, how much the caffeine metabolism is influenced.

Maternal illness during pregnancy might also be a confounding factor. Nausea coupled to pregnancy typically begins at 4-6 weeks of gestation, and peaks in incidence and severity by $8-12$ weeks (Deuchar, 1995; Furneaux et al., 2001). It has been anticipated that women with a viable pregnancy are more likely to experience nausea and thus reduce their intake of caffeine (and other compounds) than women who have a nonviable pregnancy and experience nausea less frequently. Mothers who have gastrointestinal or cardiovascular problems that may predispose them to spontaneously abort might be advised to avoid or limit caffeine consumption. In both cases, the bias introduced would spuriously reduce the risk estimates for caffeine.

Another factor in these studies that may influence the estimation of risk is misclassification. The greatest problem in this case is that many clinically recognised pregnancies are not susceptible to any added risk of 
miscarriage from an exposure during gestation because loss is inevitable from the outset. Thus, at least $40 \%$ of karyotyped miscarriages carry lethal chromosomal aberrations (Kline et al., 1989). The false assumption that the survival to term of these conceptuses is subject to an environmental risk must therefore spuriously lower the apparent risk from the exposure. Another severe misclassification problem is, of course, the risk that the exposure assessment will allocate the participating women to the wrong exposure group due to poor data on caffeine intake.

No association was found between caffeine consumption and spontaneous abortion in the studies of Wilcox et al. (1990), Kline et al. (1991), Mills et al. (1993), Dlugoz et al. (1996) and Fenster et al. (1997). All five studies were carried out in the United States, where the caffeine consumption is considerably lower than in most European countries (Barone and Roberts, 1996; Hughes and Oliveto, 1997). One study from this side of the Atlantic by Parazzini and co-workers (1991) found no association between coffee consumption and spontaneous abortion.

Two thirds of the epidemiological studies investigating the relationship between caffeine intakes or intake of caffeine-containing beverages and spontaneous abortion have reported a significantly increased risk for abortion at higher intake levels. Thus, a positive association between caffeine consumption and spontaneous abortion was found in the studies carried out by Weathersbee et al. (1977), Srisuphan and Hacken (1986), Fenster et al. (1991a), Infante-Rivard et al. (1993), Cnattingius et al. (2000), and Wen et al. (2001). It should, however, be noted that in the study of Fenster et al. (1991a), the association was found only in women reporting nausea and consuming more than $300 \mathrm{mg}$ caffeine daily. In addition, positive associations between consumption of coffee and spontaneous abortion have been reported by Furuhashi et al. (1985), Axelsson et al. (1992), Armstrong et al. (1992), Domiguez-Rojas et al. (1994), Dlugoz et al. (1996) and Parazzini et al. (1994, 1998). Fenster et al. (1997) unexpectedly found an association between consumption of decaffeinated coffee and spontaneous abortions.

Three studies have been devoted to a possible relationship between caffeine metabolism and spontaneous abortion. These studies made use of biomarkers of caffeine metabolism in blood and urine, as well as information on acetylator genotypes (slow or fast). The profile of caffeine and caffeine metabolites in the body fluids portrays the caffeine metabolic activity and reflects the capacity for caffeine clearance and hence the ultimate caffeine load on the body. The speed of caffeine metabolism also determines exposure of caffeine metabolites, mainly paraxanthine. Whereas Fenster et al. (1998) observed no interaction between caffeine intake and enzyme activities, Signorello et al. (2001) found women with a high CYP1A2 activity to have an increased risk for normal karyotype spontaneous abortion. The data of the latter study could be interpreted as indicating that metabolites of caffeine play a role in the aetiology of sponta- 
neous abortions. At present, there are no experimental data to confirm this theory. However, the third study found that women with the highest quintile of serum paraxanthine had an increased risk for both early and late spontaneous abortion (Klebanoff et al., (1999). Since the studies of Fenster et al. (1998) and Klebanoff et al. (1999) have been criticised for shortcomings in design and performance, a possible relationship between caffeine metabolism and spontaneous abortion requires further study. It should be stressed that the main enzyme metabolising caffeine, CYP1A2, is also involved in the metabolic activation of numerous chemical carcinogens, and therefore data of this kind may reflect the interplay of various unmeasured factors that are possibly related to spontaneous abortion.

Most of the studies presented in this chapter have been criticised for having severe limitations. For example, the studies of Fenster et al. (1991a), Infante-Rivard et al. (1993), Dlugosz et al. (1996) and Klebanoff et al. (1999) have been criticised for not adequately considering, or omitting from consideration, as to whether nausea during pregnancy could influence the exposure to caffeine. Adjustment for smoking has been insufficient or omitted in some studies (e.g., Weathersbee et al., 1977; Furuhashi et al., 1985; Wen et al., 2001). Other studies have selected the study base in such a way that it is far from unlikely that it has introduced a bias (e.g., Armstrong et al., 1992; Parazzini et al., 1994), or have not presented adequate statistical treatment of the data (Weathersbee et al., 1977; Furuhashi et al., 1985). Several other shortcomings, such as excluding women who did not drink coffee from the statistical analysis, and omitting statements as to which time period the caffeine intake referred to, limit the conclusions that can be drawn from the study carried out by Dominguez-Rojas et al (1994).

It can be concluded that the results of more than half of the described epidemiological studies concerning intake of caffeine/caffeine-containing beverages and spontaneous abortions indicate a positive relationship. However, as repeatedly pointed out above, most studies have weaknesses regarding the adjustment of potential confounding factors, and in the selection of the study base. Thus, the results are not easy to interpret. Based on all information, however, it does not seem unlikely that high intake of caffeine during pregnancy, at least during early pregnancy, may increase the risk for spontaneous abortions. One condition in these types of study that need more attention is the chromosomal constitution of the whole or parts of the foetus, as the prognosis for survival differs markedly between chromosomally normal and abnormal foetuses. Another condition which need more attention is nausea, which could introduce a bias, as pregnant controls may be more apt to reduce their caffeine/coffee consumption (due to nausea) than women who have miscarriages (and don't experience nausea). Nausea has been controlled for in the studies by Cnattingius et al. (2000) and Wen et al. (2001), which at present seem to 
be the most accurate investigations of the relationship between caffeine/coffee consumption and early spontaneous abortion.

Since epidemiological studies involving caffeine consumption by pregnant women have resulted in different results concerning adverse foetal outcomes, Fernandes and co-workers (1998) undertook a metaanalysis of six studies that met the criteria to be included. The inclusion criteria for the meta-analysis were: English language articles; pregnant human females; case-control or cohort design; caffeine exposure during pregnancy; documented quantity of caffeine consumption; control group with minimal or no caffeine consumption (0 to $150 \mathrm{mg}$ caffeine/day); and documented data regarding spontaneous abortion. All studies included in the meta-analysis have been presented above (Srisuphan and Bracken, 1986; Fenster et al., 1991a; Armstrong et al., 1992; Infante-Rivard et al., 1993; Mills et al., 1993; Dominguez-Rojas et al., 1994). Using five of the studies (Srisuphan and Bracken, 1986; Fenster et al., 1991a; Armstrong et al., 1992; Infante-Rivard et al., 1993; Dominguez-Rojas et al., 1994) for a statistical evaluation, a modest but statistically significant relationship between moderate to heavy caffeine consumption during pregnancy $(>150 \mathrm{mg} /$ day) and the risk of spontaneous abortion was found. The combined odds ratio in the meta-analysis was 1.36 , with a $95 \%$ confidence interval of 1.29-1.45. The sensitivity and subgroup analyses performed within the spontaneous abortion analysis indicated that no group of studies (cohort or case-control) or individual investigation influenced, to any degree, the overall main analysis of the summary odds ratio (Fernandes et al., 1998). Altogether, the study of Dominguez-Rojas et al. (1994) contributed to the heterogeneity of the analysis. Omitting the study to obtain non-heterogeneity did not change the summary odds ratio significantly. One particular note of caution should be given, and that is that the potential confounders identified in the separate studies were not adjusted for in the meta-analysis because they were too poorly presented in some of the individual studies. Nonetheless, the meta-analysis of Fernandes et al. (1998) arrives at the same conclusion as the Nordic working group responsible for this report, namely that high intakes of caffeine during pregnancy may increase the risk for spontaneous abortion. 


\section{Caffeine intake and congenital malformations}

The question as to whether high caffeine intake by mothers-to-be can cause malformations in the human foetus has been discussed and investigated in a number of reports. Concern about the possible harmful effects of caffeine or caffeine-containing beverages and foods in pregnancy have evolved mainly from results of animal studies. However, it is unclear to what extent findings in experimental animals can be extrapolated to man. Differences in the mode of caffeine exposure and the way the compound is metabolised are particularly hard to interpret.

\subsection{Studies in animals}

Several reports on the teratogenic nature of caffeine on mammalian foetuses have been published during the last thirty years. These experimental studies have been performed mainly with rodents, and the majority indicates that caffeine has a variable but low level of teratogenic activity in laboratory animals, mainly in mice and rats (Nash and Persaud, 1988). However, the congenital malformations discovered in rodent foetuses have appeared at caffeine levels that are about ten times higher than the levels generally pertaining to humans.

Sivak (1994) reviewed the co-teratogenic effects of caffeine with various physical and chemical agents. Single bolus doses of caffeine (50$200 \mathrm{mg} / \mathrm{kg}$ body weight) enhanced the teratogenic effect of ionising radiation and various pharmaceutical agents in experimental animals. Together with nicotine or alcohol, caffeine had an additive effect. Mixed results have been obtained when caffeine have been combined with chemical carcinogens. The interpretation of the experimental studies in terms of human hazard is complicated by the general use of high-dose bolus exposures to caffeine in these experiments, which is not typical of human exposure. As discussed extensively in this chapter, the epidemiological studies on humans have revealed no teratogenic activity of caffeine alone. In the few instances where interactions between coffee consumption and either alcohol consumption or smoking have been investigated on pregnancy outcome, no significant effects have been observed (Sivak, 1994). It should be borne in mind, however, that these types of studies are very difficult to perform. 


\subsubsection{Mode of administration}

The teratogenic effects of caffeine depend on dosage and route of administration. Caffeine can induce malformations in foetuses when administered as a single dose by gavage or by injection. However, when the same amount of caffeine is split up in several smaller doses given throughout the day, malformations is much less frequent. Table 50 summarises some studies on caffeine exposure during gestation and the occurrence of malformations in animal foetuses.

Smith et al. (1987) treated pregnant rats with 10 or $100 \mathrm{mg}$ caffei$\mathrm{ne} / \mathrm{kg}$ body weight on days 6 to 20 of gestation, as a single dose by gavage, or divided into four administrations by gavage throughout the day. Administration of a single dose of $100 \mathrm{mg}$ caffeine/kg body weight produced a high incidence of malformed foetuses, whereas the same dose given over four occasions had no teratogenic effect.

When pregnant rats were given a single intraperitoneal injection of $150 \mathrm{mg}$ caffeine/kg body weight on days 10 to 11 of gestation, cardiovascular anomalies were found in $87.8 \%$ of the foetuses (Matsouka et al., 1987). In rats given total doses of 30 or $60 \mathrm{mg}$ caffeine $/ \mathrm{kg}$ body weight by injection, divided into four applications, $36.5 \%$ and $50.9 \%$ of the foetuses, respectively, developed cardiovascular anomalies.

In contrast to results in studies using gavage and injection, no doserelated anomalies were induced when caffeine $(10-204.5 \mathrm{mg} / \mathrm{kg}$ body weight) was given in drinking water (Collins et al., 1983). A similar result was seen by Ikeda et al. (1982). When rats repeatedly were administered daily doses of $80 \mathrm{mg}$ caffeine $/ \mathrm{kg}$ body weight in drinking water on days 12 to 15 of gestation, or $80 \mathrm{mg}$ by gavage on day 12 of gestation, ectrodactyly was observed only in the offspring of the gavage group. In addition, when coffee of different concentrations was given to pregnant rats, instead of pure drinking water, no teratogenic effects were seen (Nolen, 1981). The same result was indicated when Collins and co-workers in 1981 studied the teratogenic effects of caffeine in pregnant rats. Administrating caffeine by gavage induced a number of adverse effects on the foetuses, but when the study was repeated and caffeine at different concentrations was given as coffee consumed ad libidum, many of the adverse effects observed in the gavage study did not appear (Collins et al., 1983). Similarly, Elmazar et al. (1982) observed no gross anomalies when mice were treated with caffeine in food and drinking water. No teratogenic effects in the offspring of rats were found in a study of Palm et al. (1978) when the animals were given a single dose of $30 \mathrm{mg}$ caffeine/kg body weight by gavage or the same dose via drinking water. In this case, however, the given dose was lower than the dose administered in the studies mentioned above.

Taken together, available data indicate that the likelihood of a teratogenic effect of caffeine being produced in mammalian foetuses is significantly lower if the caffeine exposure is spread out throughout the day as 
compared to when it is administered only once a day (Nolen, 1988). It is also obvious that the time of exposure during pregnancy is of major importance in the induction of different types of malformations (The National Food Agency of Denmark, 1989).

\subsubsection{Types of malformations}

The malformations produced by high caffeine intakes in experimental animals tend to be limited in type. The most prevalent types of anomalies reported, regardless of species, are cleft palate, digital reduction defects and vascular defects (Elmazar et al., 1982; Scott, 1983; Smith et al., 1987; Nolen, 1988 and Purves and Sullivan, 1993). Table 50 gives some information on the types of malformation produced in the offspring of dams exposed to caffeine during gestation.

When Fujii and Nishimura (1972) throughout gestation fed rats an oral daily dose of caffeine corresponding to 180 and $330 \mathrm{mg} / \mathrm{kg}$ body weight, malformations were found in $56.8 \%$ of the foetuses, compared to none in the control group. The types of malformation discovered in foetuses receiving the high dose were hydrocephaly $(13.5 \%)$, intravitreous haemorrhage (27.0\%), esophagectopy (18.9\%), and ventricular septal defect $(8.1 \%)$.

Other types of malformation have been observed as well. Matsouka et al. (1987) found cardiovascular malformations in the majority of rat foetuses after a single intraperitoneal injection of $150 \mathrm{mg} / \mathrm{kg}$ body weight caffeine. The eye lenses were examined in 10 foetuses, and degeneration was found in all. Skeletal abnormalities were discovered in 3 of the foetuses of mothers treated with $60 \mathrm{mg}$ caffeine $/ \mathrm{kg}$ body weight and in 1 of the foetuses of mothers injected with $150 \mathrm{mg}$ caffeine $/ \mathrm{kg}$ body weight. Caffeine exposure in utero almost always to some extent causes delayed ossification of the foetal skeleton (Fujii and Nishimura, 1972; Palm et al., 1978; Collins et al., 1981; Collins et al., 1983; Elmazar et al., 1982; and Nolen, 1981). The effect is not a true reduction, but a transient and quantitatively small delay (a few days), which can be seen during the perinatal development. Exposure of pregnant macaque monkeys to caffeine in drinking water $(0.15$ and $0.35 \mathrm{mg} / \mathrm{ml})$, resulting in daily exposures of 10 15 and 25-30 mg caffeine $/ \mathrm{kg}$, induced a delay in somatic development of the offspring, including a retarded growth of the long bones in the body. This delay was manifested during the first 30 days but had disappeared after the first year post-exposure (Gilbert and Rice, 1991). In several studies, generalised oedema has been present in the majority of foetuses, the severity and frequency of the condition apparently being dose-dependent. 
Table 50. Teratogenic activity of caffeine exposure during gestation in experimental animals.

\begin{tabular}{|c|c|c|c|c|c|}
\hline Animal & $\begin{array}{l}\text { Dose } \\
\text { (mg/kg/day) }\end{array}$ & Administration & $\begin{array}{l}\text { Days of gestation } \\
\text { treated }\end{array}$ & \begin{tabular}{|l} 
Malformations \\
(Mainly ectrodactyly)
\end{tabular} & Reference \\
\hline Rat & $\begin{array}{l}180 \\
330\end{array}$ & Diet & $0-22$ & $\begin{array}{l}- \\
\text { Hydrocephaly } \\
\text { Intravenous haemorrhage } \\
\text { Esophagectopy } \\
\text { Ventricular septal defect }\end{array}$ & $\begin{array}{l}\text { Fujii and Nishimura, } \\
\text { (1972) }\end{array}$ \\
\hline Rat & $\begin{array}{l}9 \\
19 \\
38 \\
30 \\
30\end{array}$ & $\begin{array}{l}\text { Coffee consumed as sole } \\
\text { beverage } \\
\text { By gavage } \\
\text { Caffeine in water }\end{array}$ & All & $\begin{array}{l}- \\
- \\
- \\
- \\
-\end{array}$ & Palm et al., (1978) \\
\hline Rat & $\begin{array}{l}20 \\
40 \\
80\end{array}$ & Coffee as sole beverage & All & $\begin{array}{l}- \\
- \\
-\end{array}$ & Nolen (1981) \\
\hline Rat & $\begin{array}{l}80 \\
80\end{array}$ & \begin{tabular}{|l} 
Gavage \\
Drinking water
\end{tabular} & \begin{tabular}{|l|}
12 \\
$12-15$
\end{tabular} & $\begin{array}{l}\text { Ectrodactyly } \\
- \\
\text { (no statistical analysis) } \\
-\end{array}$ & Ikeda et al., (1982) \\
\hline Rat & $10-204.5$ & Drinking water & $0-19$ & - & Collins et al., (1983) \\
\hline Rat & \begin{tabular}{|l|}
10 \\
100 \\
$2.5 \times 4$ \\
$25 \times 4$ \\
\end{tabular} & By gavage & $6-20$ & $\begin{array}{l}- \\
\text { Ectrodactyly } \\
- \\
- \\
\end{array}$ & Smith et al., (1987) \\
\hline Rat & \begin{tabular}{|l|}
30 \\
60 \\
150 \\
\end{tabular} & Intraperitoneal & $10-11$ & Cardiac anomalies & $\begin{array}{l}\text { Matsouka et al., } \\
\text { (1987) }\end{array}$ \\
\hline Mouse & \begin{tabular}{|l|}
50 \\
150 \\
$140-280$ \\
$207-242$ \\
\end{tabular} & \begin{tabular}{|l} 
Gavage \\
Gavage \\
Drinking water \\
Drinking water \\
\end{tabular} & $\begin{array}{l}6-16 \\
6-16 \\
5-18 \\
5-18 \\
\end{array}$ & $\begin{array}{l}- \\
\text { Other } \\
- \\
- \\
\end{array}$ & Elmazar et al., (1982) \\
\hline Mouse & \begin{tabular}{|l|}
80 \\
$100-150$ \\
$175-250$ \\
\end{tabular} & Intraperitoneal & $11-12$ & $\begin{array}{l}\text { Cleft palate and limb } \\
\text { malformations } \\
\text { (no statistical analysis) }\end{array}$ & Scott, (1983) \\
\hline
\end{tabular}

\subsubsection{Teratogenic dose of caffeine}

Although some studies were unable to detect a clear teratogenic effect of caffeine in experimental animals (Palm et al., 1978; Nolen, 1981), the majority of the studies have found that caffeine induces a dose-related teratogenic effect in rodents. No adverse effect level has been established.

However, the relatively high concentration of caffeine required to induce foetal malformations, and the limited number of affected foetuses, indicates that caffeine can be considered a weak teratogen in rodents. Caffeine seems to belong to the group of teratogenic agents that exert adverse effects only when a threshold of plasma or tissue concentration has been exceeded. The results of the animal studies indicate that the threshold plasma concentration is somewhere in the region $60-80 \mu \mathrm{g} / \mathrm{ml}$. However, different species of rodents have been found to vary in their sensitivity to the teratogenic effects of caffeine. Malformations in rats are never observed at daily single doses below $50 \mathrm{mg}$ caffeine/kg body weight, and rarely below $80-100 \mathrm{mg} / \mathrm{kg}$ body weight (James, 1991; Wilson and Scott, 1984). Mice seem to be somewhat more sensitive to caf- 
feine, with malformations being induced at a dose of about $50-75 \mathrm{mg}$ caffeine/kg body weight (Wilson and Scott, 1984; Nehlig and Debry, 1994b).

\subsubsection{Teratogenic effects of caffeine in combination with other substances in experimental animals}

Caffeine is well known to interact with other teratogens and carcinogens in high dose animal experiments. For example, X-rays are known to produce cleft palate in mice and rats. When rodents are treated with X-rays together with caffeine, a significant increase in the rate of this malformation is observed.

The same type of synergism can occur with chemical compounds. It could be mentioned that caffeine in in vivo studies has been shown to potentiate chemically induced chromosome damage (Nolen, 1988; Sivak, 1994). Chromosome damage could be one reason for induction of congenital malformations. Thus, when studying the frequency of chromosomal aberrations induced in bone marrow cells of mice administered with the two well-known mutagens MNU (N-methyl-N-nitrosourea) and MMS (Methyl Methanesulfonate) by single injection, Frei and Venitt (1975) observed a much higher percentage of metaphases with chromosomal aberrations in animals that had received $1 \%$ caffeine in their drinking water during the experimental period than in animals that received drinking-water without caffeine. Other workers have reported a significant increase in the frequency of chromosomal aberrations induced by thiotepa and triethylenemelamine in bone marrow cells of mice when caffeine, at concentrations between 50 and $150 \mathrm{mg} / \mathrm{kg}$ body weight, was applied simultaneously with the alkylating agents (Hansson, 1978, Dulout et al., 1981). In bone marrow cells of the Chinese hamster, an enhancement of cyclophosphamide-induced chromosome damage was obtained with caffeine at $200 \mathrm{mg} / \mathrm{kg}$ body weight, but not at lower doses (Röhborn and Buckel, 1976). These observations indicate that there must be a mechanism for caffeine potentiating a teratogenic or embryotoxic effect induced by other compounds. The observed potentiating effect has been attributed to inhibition of DNA repair (Kihlman and Andersson, 1987). It should be pointed out that in most of these in vivo experiments in rodents, enhancement of the mutagen-induced chromosome damage was obtained only at near-lethal doses of caffeine. These doses were much higher than those humans are ever likely to be exposed to as a result of consumption of caffeine-containing beverages. 


\subsection{Studies in humans}

There are several factors that must be considered when interpreting the findings in animal studies as regards human health. The majority of substances shown to be teratogenic in rodents do not have these effects in humans at the levels at which they are commonly ingested. Furthermore, rodents are generally much more susceptible to teratogenic influences than are primates (Wilson and Scott, 1984). A caffeine dose of $50 \mathrm{mg} / \mathrm{kg}$ body weight in a rodent corresponds to a human caffeine intake of $3.5 \mathrm{~g}$ an intake considerably higher than the amount ingested by the heaviest users of caffeinated beverages. Teratogenic effects in rodents, at doses below $100 \mathrm{mg} / \mathrm{kg}$ body weight, are seen only when the total dose is given on a single occasion by gavage or injection (Wilson and Scott, 1984). Humans are, however, never exposed to single high doses of caffeine.

\subsubsection{Teratogenic effects of caffeine}

In 1981, the United States Food and Drug Administration encouraged pregnant women to limit their daily caffeine intake to approximately 300 $\mathrm{mg}$. Since then, a limited number of reports on the teratogenic effects of caffeine on human foetuses have been published. Thirteen human studies on the subject are discussed and evaluated below. These studies have been carried out in the United States (6), Canada (1), Japan (2), France (1), Finland (2), and Denmark (1). In addition, information from an abstract describing a study not yet published is mentioned (Correa et al., 2000).

Heinonen et al. (1977) investigated the possible teratogenic role of pharmaceutical drugs, as used in a cohort (Collaborative Perinatal Project) of more than 50282 mother-child pairs recruited in 12 centres in the United States during the years 1959 to 1965 . The purpose of the study was to evaluate whether there are associations between drugs taken during pregnancy and malformations in offspring. Upon their entering the study, usually while visiting the participating clinic for the first time during the pregnancy, the women were interviewed by trained interviewers. With regard to medications, the women were questioned about current drug use as well as drug use extending back beyond the date of the last menstrual period. In this study, children were considered to be malformed when they had structural defects at or soon after birth, including tumours and syndromes that tend to be prominently associated with structural defects. In total, there were 3248 malformed children with 4446 malformations. There was no correlation between use of caffeine-containing drugs or drugs containing other methylxanthines and the occurrence of teratogenic effects (Table 51). The absence of evidence linking caffeine (or other methylxanthines) to malformations in this study should be interpreted with uttermost caution, as the study was not controlled for the 
intake of methylxanthines from foods and beverages. In reality, the methylxanthine exposure was incorrect in nearly all women. Therefore, the study has no value for assessing the potential of methylxanthines to induce congenital malformations.

In a case-control study from the 1970s, Borlée et al. (1978) compared the coffee consumption among 202 women giving birth to malformed children and 175 women giving birth to healthy children, matched for age, gender and socio-economic status. Consumption of more than 8 cups of coffee a day was associated with an increased frequency of congenital malformations (Table 51). As the study was poorly controlled for other factors which could influence congenital malformations, the data do not permit a conclusion claiming a direct relationship between coffee consumption and birth defects.

Linn et al. (1982) used epidemiological methods to evaluate the relationship between coffee consumption during each trimester of pregnancy and adverse outcome. 12205 American women were interviewed 1 or 2 days after delivery, $5 \%$ reported drinking four or more cups of coffee per day, and less than $1 \%$ reported drinking seven or more cups of coffee per day (Table 51). The authors stated that women consuming at least four cups of coffee per day were not at increased risk of delivering a malformed child. The most common malformation found was clubfoot. Other common malformations in the study population were skeletal, cardiovascular, and central-nervous-system malformations. The sample size endowed this study with a power of 0.93 to identify a 1.5 -fold increase (probability 0.93 for 1.5 increase) in the risk of malformations associated with daily consumption of four or more cups of coffee. A small reduction of the power to 0.85 was required to establish a threefold risk of skeletal malformations and a twofold risk of major malformations. However, the ability to identify a correlation between coffee intake and malformations must be considered greatly reduced because of the insufficient measurement of caffeine consumption (number of cups of tea and coffee only). No information was given about the consumption of soft drinks, cocoa, chocolate, or caffeine-containing drugs. Subjects placed in the group with no caffeine exposure may still have been exposed to caffeine from other sources. There was no information about consumption of decaffeinated coffee or methods of coffee preparation.

In the study of Rosenberg et al. (1982), 2030 malformed children were evaluated in an American case-control study in relation to maternal intake of caffeine from coffee, tea, and cola during pregnancy (Table 51). The consumption of decaffeinated coffee was also noted. The report provided information about the risks of specific congenital malformations. Malformations examined in the report were inguinal hernia (380), oral clefts (299), cardiac defects (277), pyloric stenosis (194), isolated cleft palate (120), and neural tube defects (101). Children with other malformations (712) served as the control group to the cases. Special attention 
was given to the risk of cleft lip or palate since these are the types of anomalies seen in foetal rodents after high maternal caffeine intake during pregnancy. The choice of other malformed children as the control group may be a source of error if caffeine were found to cause any kind of malformations. However, teratogens usually do not have a broad teratogenic spectrum.

The mothers were interviewed about coffee, tea, and cola intake during pregnancy within 6 months after delivery. One percent of the mothers was estimated to have consumed as much as $1000 \mathrm{mg}$ caffeine daily and $11 \% 400 \mathrm{mg}$ or more (about four cups of coffee or more). The maternal caffeine consumption for cases and controls was considered similar. Risk estimates for all anomalies were low and non-significant.

The effects of caffeine ingestion during pregnancy were investigated in 9921 Japanese women in the study by Furuhashi et al. (1985). The women were divided into five groups depending on their caffeine consumption. Only coffee and green tea were considered as caffeine sources, but the group of women consuming more than five cups per day was small, only $0.5 \%$ of the total population. Thus, the number of individuals having a high caffeine intake was insufficient in the study. The rate of congenital anomalies was not significantly different among the five groups. However, all coffee drinking groups (less than five cups of coffee per day, less than five cups of coffee and green tea, and more than five cups of coffee per day) had a higher incidence of chromosomal abnormality $(0.28 \%)$ and congenital multi-anomalies $(0.43 \%)$ than the control group $(<0.05 \%)$ (Table 51$)$.

This Japanese study has several drawbacks. The data were not adjusted for potential confounding factors that could interfere with estimating the risk. Nor were multivariate models used in the statistical processing of data. The increased frequency of chromosomal abnormalities and congenital multi-anomalies observed in coffee-drinking mothers could therefore equally well reflect the effect of some co-variate such as alcohol or cigarette smoking.

Data from a survey of occupational factors that may influence pregnancy, conducted in Montreal, Canada, between 1982 and 1984, were used by McDonald (1992b) to investigate the relationship between coffee consumption during the first trimester of pregnancy and congenital defects. Altogether, coffee consumption was investigated in 80319 pregnancies, and eight types of congenital defects were analysed. The only significant result was that women who consumed three or more cups of coffee a day had a slightly increased risk, 1.52 (95\% confidence interval, 1.1-2.2), of delivering children with any kind of heart defect (Table 51). However, this evidence was not considered strong. 
Table 51. Studies investigating the risks of different congenital malformations in children of mothers exposed to caffeine during pregnancy.

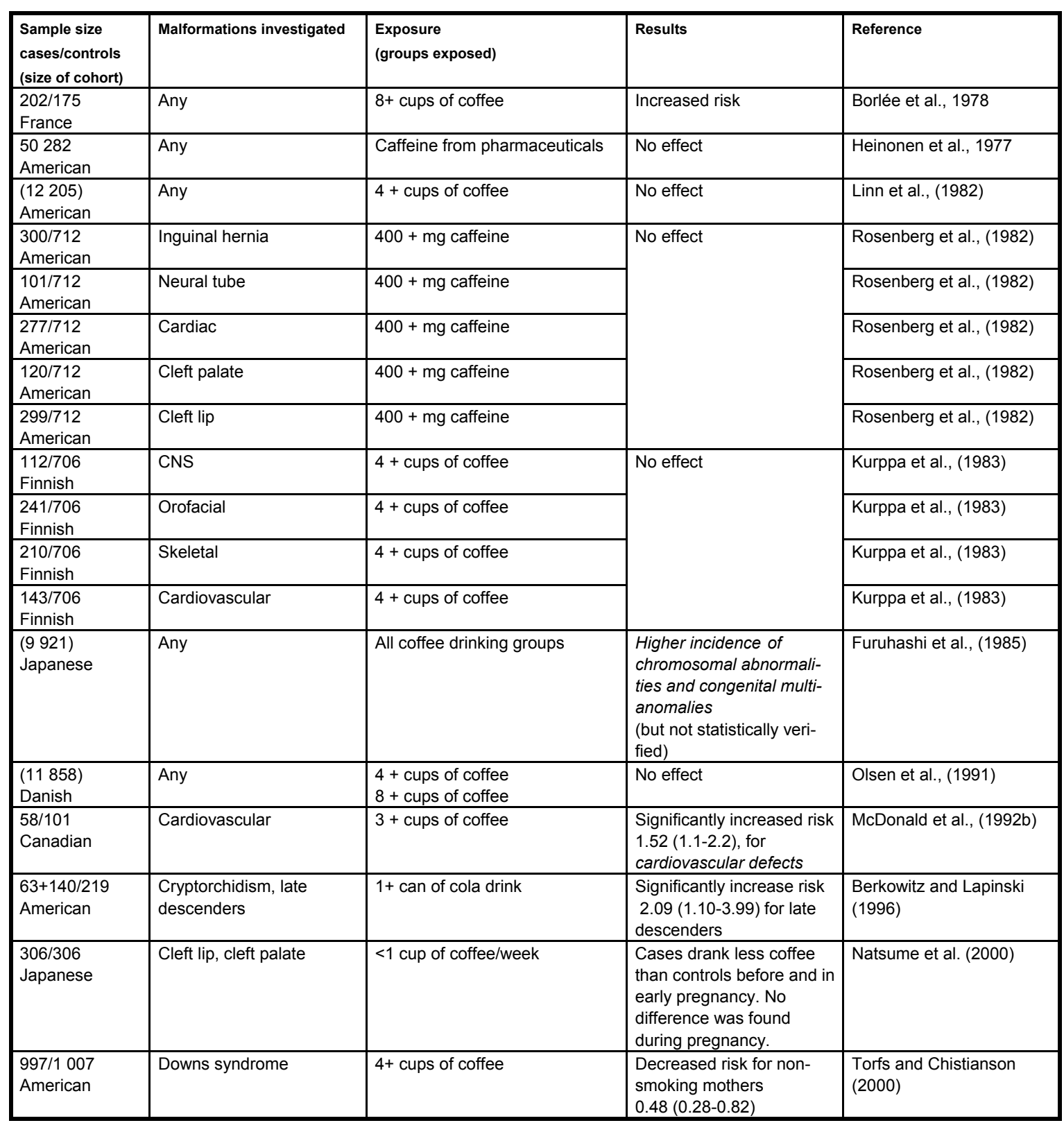


In a Finnish case-control study, Kurppa et al. (1983) investigated the relationship between coffee consumption during pregnancy and congenital malformations in 1412 mothers interviewed about their coffee consumption and other exposures within on average 3 months after delivery. The malformations studied were defects of the central nervous system (112), orofacial clefts (241), structural defects on the skeleton (210), and cardiovascular malformations (143) (Table 51). Coffee consumption during pregnancy was similar for the case and control mothers. Close to $27 \%$ of the women consumed at least four cups of coffee per day during pregnancy, $7.2 \%$ consumed seven cups or more and 3.5\% at least ten cups. No increased risk of orofacial clefts, cardiovascular, central nervous system, or skeletal defects was detected for mothers consuming four or more cups of coffee per day.

A possible relationship between maternal caffeine intake from coffee, tea and cola during the first trimester of pregnancy and cardiovascular malformations was investigated by Tikkanen and Heinonen (1991) in 573 cases and 1055 controls through interviews approximately three months after delivery. The cases represented all verified cardiovascular malformations in Finland from 1982 to 1984. Forty-one different types of cardiovascular anomalies were found. The most common malformations were ventricular septal defect (215), patent ductus arteriosus (135), atrial septal defect (70), coarctation of the aorta (65), transposition of the great arteries (56), hypoplastic left ventricle (54), tetralogy of Fallot (36), and pulmonary stenosis (35). The risk of cardiovascular malformations was not associated with maternal consumption of coffee, tea, or cola (data not shown in Table 51). However, the number of malformed children noted during this time period was much lower than expected, largely because of incomplete reporting of defects. Furthermore, the measurement of caffeine exposure must be considered crude, as it is only estimated as the number of cups of beverage consumed.

The effect of coffee consumption on congenital malformations was studied in 11858 Danish women between 1985 and 1987 (Olsen, 1991). The women responded to a mailed questionnaire on eating and drinking habits during pregnancy, handed out in the 36th week of gestation. The women were asked about the number of cups of coffee and tea consumed before and during pregnancy. The answers were crude, stating one of three categories: 0-3, 4-7 and over 8 cups a day. Thirty-five percent of the women drank four or more cups of coffee a day and $7 \%$ consumed eight or more cups a day. The coffee consumed was usually filter coffee. Very weak and non-significant associations between coffee intake and congenital anomalies were found (Table 51). The adjusted risk of any malformation for the heaviest coffee consumers (eight or more cups a day) was 1.5 (95\% confidence interval, 0.3-6.1). Some congenital malformations could not be investigated owing to the small numbers of children 
affected. Nonetheless, the investigators mention that the effect of coffee seemed most pronounced in the subgroup of cleft lip and/or palate.

A nested case-control study of cryptorchidism was carried out by Berkowitz and Lapinski (1996) as part of a hospital-based cohort study of 6 699 male neonates in New York City. The cases $(n=63)$ were infants from single and twin births whose testes had not descended into the normal position in the scrotum at one year after birth. As some of the cryptorchid infants experienced spontaneous descent of their testes after birth but before they were one year old, separate analysis was performed for the 140 'late descenders'. Controls $(\mathrm{n}=219)$ were the next male infant who was born immediately after an infant who was cryptorchid at birth. The mothers were interviewed during their post partum hospital stay about socio-demographic characteristics, occupation, indicators of maternal body build, medical history including medications, complications during pregnancy, and drug abuse. In addition, the mothers were asked about their consumption of cigarettes, alcohol, regular coffee, regular tea, cola drinks, and diet soda drinks.

After adjustment for other risk factors for chyptorchidism by logistic regression, analysis consumption of coffee, tea, and cola drinks during pregnancy was not associated with the abnormalities (Table 51). However, consumption of $\geq 1$ cup of tea per day was of borderline significance for a protective effect against cryptorchidism. Similar analyses revealed that late testicular descent was associated with drinking one cola drink or more during pregnancy (Table 51). The investigators found the observations related to tea and cola drink consumption perplexing, and pointed out that selection bias when determining the study base, the size of the investigation, and recall bias in the interview might have contributed to the findings.

Correa et al. (2000) examined data from the population-based Atlanta Birth Defects Case-Control Study 1968-1980 but have hitherto published their finding only in an abstract. The aim of the study was to evaluate the relationship between prenatal tea consumption and risk of anencephaly and spina bifida. Cases were defined as infants with anencephaly ( $\mathrm{n}=$ $122)$ or spina bifida $(r=154)$ and no other associated anomalies, and were identified between 1968 and 1980. Infants without birth defects $(\mathrm{n}=$ 3029) identified from birth certificates of the same birth cohort and frequency matched to cases by race, period of birth, and hospital of birth were defined as controls. Tea consumption of the mothers was unrelated to anencephaly, but increased the risk for spina bifida, the adjusted odds ratio, OR (for gender, race, period of birth, maternal age, education, alcohol consumption, smoking, and periconceptional multivitamins) being 2.3 (CI 1.2-4.4). The odds ratio increased with tea consumption. Intake of other caffeinated beverages was not found to be associated with risk for anencephaly or spina bifida. The authors concluded that further studies are warranted to corroborate and elucidate the observed association bet- 
ween tea consumption and spina bifida. As the study has not yet been fully publicised, the investigation has not been included in the final assessment of a potential relationship between intake of caffeine or caffeinecontaining beverages and congenital malformations, and is not presented in Table 51.

In a relatively small and not well-documented Japanese case-control study, Natsume et al. (2000) investigated maternal risk factors for cleft lip and/or cleft palate in their offspring. In total, 306 mothers giving birth to babies with these congenital malformations and 306 area- and timematched control mothers giving birth to healthy babies were interviewed about their coffee consumption before and during pregnancy, and also about many other personally related factors. The investigators report that the mothers who gave birth to babies with defects tended to drink less coffee before or in early pregnancy than women giving birth to healthy babies (Table 51), but they did not adjust for other factors influencing the rate of these malformations. Coffee consumption was generally low in the studied population, and once the pregnancy was confirmed, similar proportions of mothers in the two groups gave up coffee consumption. No difference in coffee consumption between case mothers and control mothers was found during pregnancy (Table 51). This study has limited value in assessing the risk of coffee consumption of mothers influencing congenital malformations in their offspring.

Torfs and Christianson (2000) analysed data from a case-control study of live born infants or foetuses (spontaneous abortions, stillbirths and elected terminations) with Down's syndrome in order to evaluate the possible effects of maternal smoking and caffeine or coffee consumption on the occurrence of a recognised pregnancy with Down syndrome. The study was performed in California during the period 1991 to 1993 and comprised 997 live born infants or foetuses with Down's syndrome and 1007 live born controls without a birth defect matched to the cases based on hospital of birth. Interviews with mothers included questions concerning demographic information, pregnancy, medical history, and use of tobacco, alcohol, and caffeinated beverages. Regarding caffeine intake, the mothers were asked about consumption of regular coffee, non-herbal tea, and caffeine-containing soft drinks around the time of conception. Four categories were used, 0, 1-3, 4-6 and $\geq 7$ cups or drinks per day. The caffeine content was estimated by assuming that a cup of coffee contains $100 \mathrm{mg}$, a cup of tea $50 \mathrm{mg}$, and a caffeinated soft drink $40 \mathrm{mg}$ caffeine. As the investigators did not ask for the exact number of cups or drinks consumed daily, caffeine consumption could only be estimated by using the midpoint of each range in number of cups stated, and, therefore, gives a very crude approximation of caffeine intake. Furthermore, no information on other sources of caffeine (cocoa, chocolate and medicinal drugs) was given. 
After adjustment for the age of the mothers, only maternal ingestion of $\geq 4$ cups of coffee per day was inversely associated (OR $=0.63 ; 95 \% \mathrm{CI}$ : 0.41-0.96) with having a recognised pregnancy with Down syndrome (Table 51). Multivariate analysis of inclusive factors related to the risk of giving birth to children with Down syndrome revealed a significant interaction between coffee drinking and smoking. After stratification by level of coffee consumption and smoking, the inverse association remained only for non-smoking mothers who drank four or more cups of coffee per day $(\mathrm{OR}=0.48 ; 95 \% \mathrm{CI}: 0.28-0.82)$. No significant interactions were found between intake of either caffeine or consumption of tea or soft drinks and risk for recognised Down syndrome. The authors concluded that their results suggest that among non-smoking mothers, high coffee consumption is more likely to reduce the viability of a Down syndrome conceptus than that of a normal conceptus.

A major strength of this study was the large number of participants, but on the other hand, the case group was a mixture of mothers with live birth and mothers with stillbirth or spontaneous or elected abortion. The cases were interviewed about half a year after delivery, whereas controls were interviewed more than a month earlier. This might have influenced the recall bias. Furthermore, the questions related to coffee consumption did not ask for the exact number of cups consumed daily, only whether the women consumed coffee within the specific ranges based on number of cups per day. The chosen method to quantify exposure might have introduced bias. It can also be noted that there were few heavy coffee drinkers in the study.

Tennes and Blackard (1980) investigated the effect of alcohol consumption on pregnancy outcome in 278 pregnancies in America. To control for confounders, intake of caffeine and certain other drugs were also investigated. The mothers were interviewed on 3 occasions, before pregnancy, at 6-7 months of gestation, and after delivery. The caffeine intake was estimated from the number of cups of coffee, tea, and cola consumed per day. No relationship could be established between caffeine intake and minor physical anomalies. Since the main purpose of the study was to investigate the effects of alcohol consumption on pregnancy outcomes, the results of the use of additional drugs on the studied endpoint should be interpreted with care.

\subsubsection{Teratogenic effects of caffeine in combination with other compounds}

Although the majority of the studies with adequate quality presented above found no or only a very marginal association between congenital malformations and caffeine intake, it could still be questioned whether caffeine has the ability to interact with other teratogens. For example, Hughes and Goldstein (1988) describe a case where birth defects occur- 
red following maternal exposure to the vasoconstrictive agents ergotamine and caffeine. The brain abnormality and cord lesion in the infant could be accounted for by a vascular disruptive mechanism. The mother of the infant was treated for migraine with a variety of medications, including ergotamine and caffeine, and the infant was exposed to these substances during the first 14 to 20 weeks of gestation. The results of the brain investigations were compatible with an arrest of cerebral development early in the second trimester of pregnancy. The authors suggested that a synergistic effect of caffeine and ergotamine might result in a more pronounced vasoconstriction of cerebral vessels than the vasoconstriction resulting from ergotamine only.

However, no human epidemiological evidence have been found that indicate that caffeine potentiates the risks of potential teratogens to the point where it causes birth defects (Sivak, 1994; Golding, 1995).

\subsubsection{Conclusions}

Based on the literature reviewed, there is virtually no convincing evidence linking human maternal caffeine intake during pregnancy to infant birth defects (Linn et al., 1982; Rosenberg et al., 1982; Kurppa et al., 1983; Furuhashi et al., 1985; Tikkanen and Heinonen, 1991; Tennes and Blackard, 1980; Olsen et al., 1991; McDonald et al., 1992b). Although exposure of laboratory animals to high doses of caffeine during gestation results in an increased risk for the development of facial clefts and limb anomalies, epidemiological studies have not revealed any obvious relationship between maternal caffeine intake and foetal facial clefts and skeletal malformations. The finding of a relationship between late testicular descent into the scrotum and intake of a low number of cola drinks (Berkowitz and Lapinski, 1996) is very puzzling, and needs confirmation by other researchers. In addition, heavy coffee consumption $(\geq 4$ cups/day) in one study appeared to be associated with a reduced incidence of Down syndrome (Torfs and Chistianson, 2000). This phenomenon could, however, be explained by the fact that high coffee consumption (possibly caffeine intake) is more likely to reduce the viability of a Down syndrome conceptus than that of a normal conceptus.

Most reports, which have investigated the teratogenicity of caffeine in humans, have deficiencies. The caffeine of coffee intake may be poorly estimated (Heinonen et al., 1977; Linn et al., 1982; Furuhashi et al.,1985; Olsen, 1991; and Tikkanen and Heinonen, 1991; Berkowitz and Lapinski, 1996; Natsume et al., 2000; Torf and Chistianson, 2000), the group of high caffeine consumers may be too small to allow a reliable result to be obtained (Furuhashi et al.,1985; Berkowitz and Lapinski, 1996; Natsume et al., 2000; Torf and Chistianson, 2000), the reported number of congenital anomalies may not be correct (Tikkanen and Heinonen ,1991), important confounders were not controlled for (Borlée et al., 1978; Natsume 
et al., 2000), and insufficient statistics were used when analysing the data (Furuhashi et al., 1985). Although the available data give no evidence that high caffeine exposures cause congenital malformations in humans, the results do not exclude the possibility that caffeine may induce a very weak teratogenic effect.

Because of the limited number and huge variation in the quality of epidemiological data available, the question as to whether caffeine is teratogenic or not in humans cannot be considered completely settled. However, at present, there is no evidence from epidemiological studies that high caffeine exposures cause congenital malformations in humans. 



\section{Caffeine and pre-term delivery}

One of the main causes of perinatal death and neonatal morbidity is preterm delivery. These conditions may result in immense grief for the persons involved and the economic costs can be high (Peacock et al 1995). Many factors have been associated with pre-term birth, the most important being maternal age (both young and old), low socio-economic status, racial factors, single marital status, low weight prior to pregnancy, a history of adverse pregnancy, antepartum haemorrage, cigarette smoking, coffee consumption during pregnancy, foetal gender, and multiple gestation. However, only low socio-economic status, a history of adverse pregnancy, and antepartum haemorrhages have been consistently reported as risk factors (Williams et al, 1992).

The general definition of pre-term delivery and pre-term birth is a gestational age of less than 37 completed weeks of pregnancy. This definition has been used in all studies referred to below. In many of the older studies, gestational age was determined by recording the last menstrual period. This method is not regarded to be as reliable as using ultrasonographic measurements. Some investigators have also defined births of an infant weighing less than 2500 grams as pre-term births. Studies that have dealt with this endpoint are, however, presented in chapter 14. Preterm delivery is a heterogenous condition caused by, for example, premature rupture of membranes, premature onset of labour, vaginal bleeding, including placenta previa and abruptio placentae, and maternal illness (most often preeclampsia). Many earlier studies referring to pre-term birth are difficult to interpret, in part because of inconsistent definition of the condition, in part because of failure to differentiate between spontaneous and induced labour (Williams et al., 1992).

Since the end of the 1970s predominantly American and Canadian studies have explored the relationship between caffeine intake/consumption of caffeine-containing beverages and prematurity. There are also five European studies, one Brazilian study and one Japanese study in this field. All these studies are reviewed in sections 14.1 and 14.2 below. The separate studies are summarised in chronological and geographical order in the two sections, with the main results related to caffeine intake presented in Tables 52, and the main results related to consumption of caffeine-containing beverages presented in Table 53. 


\subsection{Pre-term delivery and caffeine exposure}

The first serious investigation exploring a possible association between caffeine intake and premature birth was published by Weathersbee et al. (1977). Their data was obtained from 489 of 800 invited households in Utah, the United States. The studied subjects were preponderantly Mormon (members of the Church of Jesus Chist of Latter-Day Saints), a sect which proscribes the use of alcohol, caffeine, and tobacco. No less than 246 invited households (31\%) declined the invitation to participate in the study, and a further 65 households could not be reached. It would come as no surprise if this high drop out rate introduced a bias, particularly in relation to what the sect requires from its members. Srisuphan and Bracken (1986) have also speculated about this possibility. The information on the outcome of recent pregnancies was obtained from obstetric records and the information on consumption of caffeine-containing beverages from the answers to a 52-item questionnaire. The questionnaire included questions related to caffeine intake. The investigators, however, did not give the time period during which the consumption took place. The daily caffeine intake was calculated using the values of $75 \mathrm{mg}$ for a serving of coffee, $30 \mathrm{mg}$ for a serving of tea, and $45 \mathrm{mg}$ for a serving of cola. 356 of the participating 489 women reported no caffeine consumption.

The study identified 16 households in which the women's estimated daily caffeine intake was $600 \mathrm{mg}$ or more (mean $686 \mathrm{mg}$ ). For eight of the patients, pregnancies ended in spontaneous abortion in the first trimester, for five in stillbirth, and for two in premature birth of a live infant (reason not stated), whereas one had an uncomplicated delivery. The study gives no information on how the gestational age of infants was determined. An inordinately high rate of reproductive loss was also noted in 13 households where the men's estimated daily intake of caffeine was greater than $600 \mathrm{mg}$. The study was performed on a selected population group, and had many severe limitations. Certainly other factors than caffeine intake may influence premature birth. Thus, the finding that a high daily caffeine intake may predispose a woman to reproductive difficulty, such as pre-term delivery, cannot be taken as a cause-effect relationship established between caffeine intake and this endpoint.

Although the study of Weathersbee and co-workers (1977) had many limitations, its findings stimulated research groups to explore a possible association between caffeine intake and problematic pregnancies.

All women participating in the Ottawa Prenatal Prospective study whose offspring was at least one year old were asked to participate in a study on maternal use of caffeine before, during, and after pregnancy and its effects upon the offspring (Watkinson and Fried, 1985). Altogether, 284 mothers were interviewed in detail about their intake of caffeinecontaining foods and beverages, using a food frequency questionnaire. The method of preparation of beverages was also asked for. Some women 
provided samples of coffee and tea prepared at home for a chemical analysis of the caffeine. The questions on consumption related to seven different periods: the third, second, and first years before pregnancy; the first, second, and third trimester; and the year after pregnancy. The food frequency questionnaire data on amounts consumed and the preferred strength of beverage seemed to describe caffeine intake accurately, whereas the method of coffee preparation (drip, percolated and instant) poorly explained the variation in caffeine ingested.

Upon becoming pregnant, $62 \%$ of the women reduced their intake of coffee, but their intake of other sources of caffeine. As coffee to such a great extent contributes to total caffeine intake, this behaviour, nonetheless, usually resulted in a reduced caffeine intake anyhow. As a consequence, only twelve women consumed $300 \mathrm{mg}$ or more caffeine per day during pregnancy. No relationships were found between pre pregnancy or pregnancy maternal caffeine intake and birth weight, birth length, head circumference, ponderal index, Apgar, length of labour, and gestation, when caffeine was considered a continuous variable. When caffeine intake was categorised ( $\leq 300 \mathrm{mg}$ and $>300 \mathrm{mg}$ daily), no significant associations were found between caffeine use before pregnancy and any of the studied parameters. However, some pregnancy outcomes were correlated with caffeine intake during pregnancy (Table 52). Thus, maternal intake of more than $300 \mathrm{mg}$ daily during pregnancy was associated with reduced birth weight of infants (difference between groups: 352 grams) and smaller head circumference (difference between groups: $1.1 \mathrm{~cm}$ ) when smoking had been controlled for. No association was found between heavy caffeine use and pregnancy weight gain, gestation, Apgar, length of labour, or birth length, as well as incidence of caesarean sections, breech births, miscarriages or premature births. No figures were presented concerning premature births when considering caffeine use during pregnancy. The main weaknesses of the study were the low number of women in the group who had the highest caffeine exposure, the fact that only one confounding factor was adjusted for at a time during the statistical treatment of the data, and that no information was given regarding how gestational age was determined.

Martin and Bracken (1987) carried out a prospective study of 3891 antenatal patients at Yale-New Haven Hospital between 1980 and 1982. Average daily exposure of caffeine during pregnancy was calculated from information on consumption of coffee, tea, caffeine-containing colas, and drugs, assuming coffee, tea, and cola drinks to contain 107, 34, and 47 $\mathrm{mg}$ caffeine per serving, respectively. About one quarter of the participants had no caffeine intake from the sources investigated. Only $8 \%$ of the women ingested more than $300 \mathrm{mg}$ of caffeine daily. Gestational age was determined solely from information on the last menstrual period. Preterm delivery and mean gestational age were not found to be associated with caffeine exposure (Table 52). In addition to non-confirmed length of 
gestation, this study has some weaknesses in its exposure assessment. As information on chocolate and cocoa consumption was not obtained, the contribution of these foods to caffeine intake was not included. Furthermore, only consumption during the first trimester of pregnancy was considered. Smoking was adjusted for qualitatively, but not quantitatively.

A case control study with retrospective design was carried out in California, USA, in order to examine the association between maternal caffeine consumption and low birth weight, intrauterine growth retardation, and pre-term delivery (Fenster et al., 1991a). The study base (1 230 women with singleton live births) was recruited during 1986-1987 from the control group of a case control study on spontaneous abortion.

Participants were interviewed on average nine months after delivery regarding their consumption of coffee, tea and soft drinks during the month before pregnancy. They were asked whether their consumption had changed during pregnancy, and, if so, when and to what extent. Caffeine intake during the first trimester was calculated from the intake data by assuming that a cup of coffee contains $107 \mathrm{mg}$ caffeine, a cup of tea $34 \mathrm{mg}$ caffeine, and soft drinks $47 \mathrm{mg}$ caffeine/can. The gestational age was determined solely from information on the last menstrual period.

There was no significant association between heavy caffeine consumption (>300 mg caffeine daily) and pre-term delivery (Table 52). Women who did not reduce their caffeine consumption when becoming pregnant, however, had a higher risk of pre-term delivery than those who reduced their intake of caffeine, but the risks were still not significant. The exposure assessment could have been better in this study. There was no collection of information on caffeine intake from caffeinated drugs, chocolate and cocoa, and the consumption data only referred to the first trimester of pregnancy.

In another Californian study, the total caffeine intakes from coffee, tea, cola soft drinks, and non-cola caffeinated soft drinks in 408 women delivering pre-term infants ( $<37$ weeks gestation) were compared with the total caffeine intakes in 490 women with normal-weight full-term live births (Pastore and Savitz, 1995). Telephone interviews were performed to obtain the requested information on intake during each trimester of pregnancy. During the first trimester, $12.5 \%$ of both cases and controls stopped drinking coffee, whereas no or only minor changes in consumption were noted for the other caffeine-containing beverages. Thus, the decline in coffee consumption fully accounted for the decline in total caffeine consumption. The investigators gave no information regarding determination of gestational age. However, they reported no relationship between pre-term delivery and total caffeine intake during the first, second, or third trimester. The observation that consumption of 1-150 mg caffeine/day, but not higher amounts of caffeine, during 


\begin{tabular}{|c|c|c|c|c|c|}
\hline $\begin{array}{l}\text { Reference } \\
\text { and location of study }\end{array}$ & \begin{tabular}{|l|} 
Sample size and selection \\
\end{tabular} & $\begin{array}{l}\text { Exposure period consi- } \\
\text { dered } \\
\text { Sources of caffeine }\end{array}$ & End-point(s) & \begin{tabular}{|l|} 
Results \\
Risk estimate adjusted odd ratios, \\
Including 95\% confidence interval \\
(NS=non-significant)
\end{tabular} & Comments \\
\hline $\begin{array}{l}\text { Weathersbee et al., } 1977 \\
\text { Retrospective cross sectional } \\
\text { study } \\
\text { USA }\end{array}$ & $\begin{array}{l}243 \text { of } 489 \text { invited } \\
\text { house-holds agreed to } \\
\text { participate. }\end{array}$ & $\begin{array}{l}\text { Exposure period not } \\
\text { stated } \\
\text { Coffee, tea, cola }\end{array}$ & $\begin{array}{l}\text { Pre term delivery, } \\
\text { definition not given }\end{array}$ & $\begin{array}{l}15 \text { of } 489 \text { pregnancies resulted in premature birth. Of these } 15 \text { cases, } \\
2 \text { mothers had consumed }>600 \mathrm{mg} \text { caffeine/day, } 2 \text { fathers had consu- } \\
\text { med }>600 \mathrm{mg} \text { caffeine/day (mothers less), } 5 \text { mothers and/or fathers } \\
\text { less than } 300 \mathrm{mg} \text { caffeine/day, whereas } 6 \text { did not have any caffeine } \\
\text { intake. }\end{array}$ & $\begin{array}{l}\text { Selected population. No information on how gesta- } \\
\text { tional age was determined and about smoking } \\
\text { habits. Data not adjusted for confounders. }\end{array}$ \\
\hline $\begin{array}{l}\text { Tebbutt et al., } 1984 \\
\text { Prospective cohort study } \\
\text { UK }\end{array}$ & $\begin{array}{l}39 \text { women at } 6-22 \text { weeks } \\
\text { of pregnancy. }\end{array}$ & $\begin{array}{l}\text { Exposure period not } \\
\text { stated. } \\
\text { Coffee (instant or } \\
\text { ground), tea, cocoa, } \\
\text { soft drinks containing } \\
\text { caffeine, and chocola- } \\
\text { te. }\end{array}$ & $\begin{array}{l}\text { Pre term labour and } \\
\text { pregnancy induced } \\
\text { hypertension. }\end{array}$ & $\begin{array}{l}\text { Women with no complication of pregnancy versus women with pre } \\
\text { term labor and/or pregnancy-induced hypertension }\end{array}$ & $\begin{array}{l}\text { Very small sample. Method of determining gesta- } \\
\text { tional age not given. The study was not controlled } \\
\text { for smoking and alcohol consumption. }\end{array}$ \\
\hline $\begin{array}{l}\text { Watkinson and Fried, } 1985 \\
\text { Retrospective case-control } \\
\text { study } \\
\text { USA }\end{array}$ & $\begin{array}{l}284 \text { women participating } \\
\text { in the Ottawa Prenatal } \\
\text { Study }\end{array}$ & $\begin{array}{l}3^{\text {rd }}, 2^{\text {nd }}, 1^{\text {st }} \text { years before } \\
\text { pregnancy, during } \\
1^{\text {st }}, 2^{\text {nd }}, 3^{\text {rd }} \text { trimesters, } \\
\text { and } 1 \text { year after birth. } \\
\text { Coffee, tea, caffeina- } \\
\text { ted soft drinks, choco- } \\
\text { late drinks and bars, } \\
\text { caffeine-containing } \\
\text { drugs }\end{array}$ & $\begin{array}{l}\text { Pre term delivery not } \\
\text { defined }\end{array}$ & $\begin{array}{l}\text { No relationship observed between maternal caffeine use and prematu- } \\
\text { re birth. }\end{array}$ & $\begin{array}{l}\text { No information given about how the gestational } \\
\text { age was determined. Only a few participants had a } \\
\text { high caffeine intake. The data was controlled for } \\
\text { only one confounder at the time. }\end{array}$ \\
\hline $\begin{array}{l}\text { Martin and Bracken, } 1987 \\
\text { Prospective study } \\
\text { USA }\end{array}$ & $\begin{array}{l}3891 \text { antenatal patients } \\
\text { from the Yale Pregnancy } \\
\text { Outcome Interview } \\
\text { Study }\end{array}$ & \begin{tabular}{|l|} 
During \\
$1^{\mathrm{st}}$ trimester. \\
Coffee, tea, colas, and \\
drugs
\end{tabular} & $\begin{array}{l}\text { Pre term delivery } \\
\text { defined as }<37 \text { weeks } \\
\text { gestational age }\end{array}$ & $\begin{array}{l}0 \mathrm{mg} \text { caffeine/day vs } \\
\geq 301 \mathrm{mg} \text { caffeine/day }\end{array}$ & $\begin{array}{l}\text { No information concerning caffeine intake from } \\
\text { chocolate and cocoa consumption available. Few } \\
\text { heavy consumers of caffeine. Only consumption } \\
\text { during } 1^{\text {st }} \text { trimester investigated. } \\
\text { No quantification of smoking. Gestational age } \\
\text { determined solely from information on last } \\
\text { menstrual cycle. }\end{array}$ \\
\hline
\end{tabular}




\begin{tabular}{|c|c|c|c|c|c|}
\hline $\begin{array}{l}\text { Reference } \\
\text { and location of study }\end{array}$ & \begin{tabular}{|l} 
Sample size and selection \\
\end{tabular} & $\begin{array}{l}\text { Exposure period consi- } \\
\text { dered } \\
\text { Sources of caffeine }\end{array}$ & End-point(s) & \begin{tabular}{|l|} 
Results \\
Risk estimate adjusted odd ratios, \\
Including $95 \%$ confidence interval \\
(NS=non-significant)
\end{tabular} & Comments \\
\hline $\begin{array}{l}\text { Fenster et al.,1991a } \\
\text { Case-control study } \\
\text { USA }\end{array}$ & $\begin{array}{l}1230 \text { women with } \\
\text { singelton live birth }\end{array}$ & $\begin{array}{l}\text { 1st trimester of preg- } \\
\text { nancy } \\
\text { Coffee, tea and soft } \\
\text { drinkt }\end{array}$ & $\begin{array}{l}\text { Pre term delivery } \\
\text { defined as gestational } \\
\text { age less than } 37 \\
\text { weeks }\end{array}$ & $\begin{array}{l}\text { All women } \\
0.300 \mathrm{mg} \text { caffeine/day vs } \\
>300 \mathrm{mg} \text { caffeine/day } \\
\\
\text { Women who reduced their caffeine intake } \\
0.300 \mathrm{mg} \text { caffeine/day vs } \\
>300 \mathrm{mg} \text { caffeine/day } \\
\\
\text { Women who continued their caffeine intake } \\
0.300 \mathrm{mg} \text { caffeine/day vs } \\
>300 \mathrm{mg} \text { caffeine/day }\end{array}$ & $\begin{array}{l}\text { The exposure only considered 1st trimester of } \\
\text { pregnancy and did not include caffeine from drugs, } \\
\text { chocolate and cocoa. Adjustment for smoking and } \\
\text { alcohol consumption was not optimal. Stratification } \\
\text { of data may not be adequate. }\end{array}$ \\
\hline $\begin{array}{l}\text { Godel et al.,1992 } \\
\text { Prospective cohort study } \\
\text { Canada }\end{array}$ & $\begin{array}{l}162 \text { women who delive- } \\
\text { red } \\
\text { in ten communities in } \\
\text { Northwest Canada }\end{array}$ & $\begin{array}{l}\text { Caffeine intake the } \\
\text { last } 24 \text { hours prenatal- } \\
\text { ly and at delivery" } \\
\text { Coffee, tea and cola }\end{array}$ & $\begin{array}{l}\text { Gestational age at } \\
\text { delivery. }\end{array}$ & $\begin{array}{l}\leq 300 \mathrm{mg} \text { caffeine/day vs } \\
>300 \mathrm{mg} / \text { day }\end{array}$ & $\begin{array}{l}\text { A small study with a very heterogenous population } \\
\text { No definitions of pre term delivery and gestational } \\
\text { age were given. Data for caffeine intake not pre- } \\
\text { sented. }\end{array}$ \\
\hline $\begin{array}{l}\text { Fortier et al., } 1993 \\
\text { Retrospective cohort study } \\
\text { Canada }\end{array}$ & $\begin{array}{l}7025 \text { women from the } \\
\text { Quebec city area }\end{array}$ & $\begin{array}{l}\text { The first } 16 \text { weeks, } \\
\text { and } \\
\text { the rest of the preg- } \\
\text { nancy. } \\
\text { Coffee, tea, chocolate, } \\
\text { and colas }\end{array}$ & $\begin{array}{l}\text { Pre term delivery was } \\
\text { defined as }<37 \text { weeks. }\end{array}$ & $\begin{array}{l}\text { Pre term delivery } \\
0-10 \mathrm{mg} \text { caffeine/day vs } \\
11-150,151-300, \text { and } \\
>300 \mathrm{mg} / \text { day }\end{array}$ & Few "heavy" consumers in the study base. \\
\hline $\begin{array}{l}\text { Pastore and Savitz, } 1995 \\
\text { Case-control study } \\
\text { USA }\end{array}$ & $\begin{array}{l}408 \text { pre term infants and } \\
490 \text { normal infants }\end{array}$ & $\begin{array}{l}\text { All trimesters. } \\
\text { Coffee, } \\
\text { tea, cola soft drinks, } \\
\text { and non-cola caffeina- } \\
\text { ted soft }\end{array}$ & $\begin{array}{l}\text { Pre term defined as } \\
<37 \text { weeks gestation }\end{array}$ & 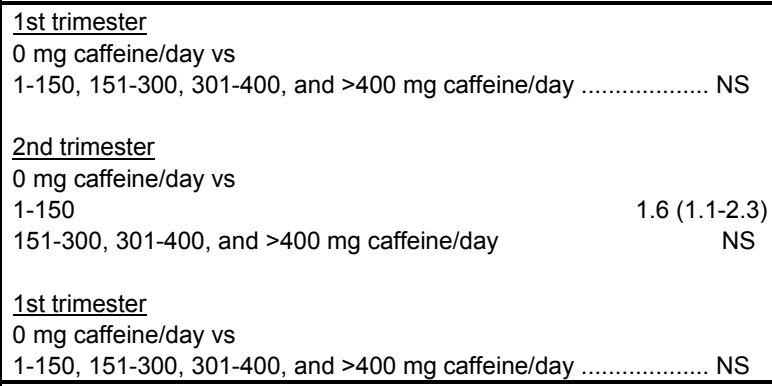 & $\begin{array}{l}\text { No consumption data on cocoa and chocolate, and } \\
\text { caffeine-containing drugs were available. The } \\
\text { study had a relatively high drop out rate. Interviews } \\
\text { were quick for some participants. The study gave } \\
\text { no information on how the gestational age was } \\
\text { determined. }\end{array}$ \\
\hline $\begin{array}{l}\text { Peacock et al., } 1995 \\
\text { Prospective population study } \\
\text { United Kingdom }\end{array}$ & $\begin{array}{l}\text { The total sample was } 1 \\
513 \text { women, but only } 1 \\
201 \text { were studied in } \\
\text { relation to pre term } \\
\text { delivery. }\end{array}$ & $\begin{array}{l}\text { Interviews at first visit } \\
\text { to clinic and at } 17,28, \\
\text { and } 36 \text { weeks of } \\
\text { gestation }\end{array}$ & $\begin{array}{l}\text { Pre term delivery was } \\
\text { defined as }<37 \text { weeks. }\end{array}$ & \begin{tabular}{|l|} 
Pre term delivery \\
$<100 \mathrm{mg}$ caffeine/day vs \\
$100-299, \geq 300 \mathrm{mg}$ caffeine/day
\end{tabular} & $\begin{array}{l}\text { Same patients used more than once in the study. } \\
\text { Selection of controls could be questioned. Con- } \\
\text { sumption of caffeinated beverages poorly reported } \\
\text { Mean caffeine intake very low. Quantity of smoking } \\
\text { not reported. Gestational age determined by the } \\
\text { method of Capurro et al. (1978). Still births } \leq 28 \\
\text { weeks included. }\end{array}$ \\
\hline
\end{tabular}




\begin{tabular}{|c|c|c|c|c|c|c|}
\hline $\begin{array}{l}\text { Reference } \\
\text { and location of study }\end{array}$ & Sample size and selection & $\begin{array}{l}\text { Exposure period consi- } \\
\text { dered } \\
\text { Sources of caffeine }\end{array}$ & End-point(s) & \begin{tabular}{|l|} 
Results \\
Risk estimate adjusted odd ratios, \\
Including 95\% confidence interval \\
(NS=non-significant)
\end{tabular} & & Comments \\
\hline $\begin{array}{l}\text { Santos, } 1998 \\
\text { Multi centre case-control } \\
\text { study } \\
\text { Brazil }\end{array}$ & $\begin{array}{l}1205 \text { mothers ( } 401 \\
\text { cases and } 804 \text { controls) } \\
\text { Cases were women with } \\
\text { children having a birth } \\
\text { weight }<2500 \mathrm{~g} \text { and } \\
\text { gestational age } \\
\geq 28 \text { weeks }\end{array}$ & $\begin{array}{l}\text { During each trimester } \\
\text { of pregnancy. } \\
\text { Coffee, maté, } \\
\text { tea, chocolate, soft } \\
\text { drinks, } \\
\text { and medicines }\end{array}$ & $\begin{array}{l}\text { Pre term delivery was } \\
\text { defined as }<37 \text { weeks, } \\
\text { and low birth weight } \\
\text { as } \\
<2500 \mathrm{~g} \text { at gestatio- } \\
\text { nal age } \geq 28 \text { weeks }\end{array}$ & \begin{tabular}{|l} 
Pre term delivery \\
$<100 \mathrm{mg}$ caffeine/day vs \\
$100-299, \geq 300 \mathrm{mg}$ caffeine/day
\end{tabular} & NS & $\begin{array}{l}\text { Same patients used more than once in the study. } \\
\text { Selection of controls could be questioned. Con- } \\
\text { sumption of caffeinated beverages poorly reported. } \\
\text { Mean caffeine intake very low. Quantity of smoking } \\
\text { not reported. Gestational age determined by the } \\
\text { method of Capurro et al. (1978). Still births } \leq 28 \\
\text { weeks included. }\end{array}$ \\
\hline $\begin{array}{l}\text { Wisborg et al., } 1998 \\
\text { Prospective study } \\
\text { Denmark }\end{array}$ & $\begin{array}{l}4111 \text { nulliparous women } \\
\text { with singleton pregnan- } \\
\text { cies } \\
\text { (2 } 707 \text { non-smokers and } \\
1404 \text { smokers). } \\
\text { In total } 178 \text { pre term } \\
\text { deliveries. }\end{array}$ & $\begin{array}{l}\text { No specific informati- } \\
\text { on; } \\
\text { Presumably mean } \\
\text { consumption during } \\
\text { pregnancy. } \\
\text { Coffee, tea, cocoa, } \\
\text { cola }\end{array}$ & $\begin{array}{l}\text { Pre term delivery } \\
\text { defined as }<37 \text { weeks. }\end{array}$ & $\begin{array}{l}\leq 400 \text { mg caffeine/day } \\
\text { non-smokers vs smokers (all) } \\
\text { non-smoker vs } \\
1-5,6-10, \text { and } 11+\text { cigarettes/day } \\
\\
>400 \text { mg caffeine/day } \\
\text { non-smokers vs smokers (all) } \\
\text { non-smoker vs } \\
1-5 \text { cigarettes/day } \\
6-10 \text { cigarettes/day } \\
11+\text { cigarettes/day }\end{array}$ & $\begin{array}{c}\text { NS } \\
\text { NS } \\
\\
2.8(1.6-4.9) \\
\\
\text { NS } \\
2.9(1.6-5.4) \\
4.9(2.9-9.2)\end{array}$ & $\begin{array}{l}17 \% \text { of the women gave inadequate information } \\
\text { about consumption of coffee, but deleting them } \\
\text { from the statistical calculation had no influence on } \\
\text { the results. }\end{array}$ \\
\hline
\end{tabular}


the second trimester of pregnancy increased the risk of pre-term delivery was probably a spurious finding (Table 52).

When the consumption of coffee, tea, cola, or non-cola soft drinks during the second or third trimesters of pregnancy were individually correlated to incidence of pre-term delivery, a statistically significant increased risk for pre-term delivery was observed only for consumption of $0-3$ non-cola soft drinks (corresponding to $1-150 \mathrm{mg}$ caffeine/day) during the second trimester of pregnancy (Table 53). Higher intakes of non-cola soft drinks showed no relationship to an increased risk of pre-term delivery. In absence of a dose-response relationship, the investigators concluded that they found no support for a causal association between consumption of caffeinated beverages and pre-term delivery. This might be an accurate conclusion, since it is well recognised that retrospective collection of data could lead to an inaccurate recall of consumption parameters. Furthermore, no information was collected on the consumption of cocoa, chocolate, and medical preparations containing caffeine.

A small English study primarily focusing on investigating the relationship between dietary intake of caffeine and the plasma level of caffeine also presented data on the outcome of pregnancies (Tebutt et al., 1984). When attending an antenatal clinic between week 6 and 22 of pregnancy, the 39 participating women were interviewed about their intake of caffeine-containing dietary constituents (instant or ground coffee, tea, cocoa, soft drinks, and chocolate) as part of a general dietary survey. They were also asked to give a blood sample. No differences were observed between intake of caffeine, or plasma levels of caffeine, theobromine and theophylline in women with no complication of pregnancy, and patients with pre-term labour or pregnancy-induced hypertension (Table 52). Since the study was small, with the data poorly presented and not controlled for smoking, the study has no value when assessing the relationship between caffeine intake and pre-term delivery.

The relationship between pre-term birth and caffeine intake was studied prospectively in a cohort of 1513 white women arranging for delivery in a district general hospital in inner London (Peacock et al., 1995). The studied endpoint for pre-term delivery was gestational age $(<37$ weeks), which was determined from ultrasonographic measurements and last menstrual period. No association was found in this study between intake of caffeine and length of gestation (Table 52).

A Canadian prospective cohort study carried out 1987-1990 was used to correlate the prevalence of smoking and caffeine and alcohol intake during pregnancy to pre-term delivery in 162 women (56 Inuit, 38 Indian, 37 white and 31 of mixed race) (Godel et al., 1992) from northern Canada. The women were recruited when they appeared for prenatal care in their community, and were asked to fill in a food frequency questionnaire. Daily caffeine intake was calculated from the questionnaire data, assuming $120 \mathrm{mg}$ caffeine per serving of coffee, $65 \mathrm{mg}$ per serving of tea 
and $35 \mathrm{mg}$ per serving of cola. Fifty-seven per cent (88/154) of the women ingested more than $300 \mathrm{mg}$ caffeine/day - a high caffeine intake was most frequent among the Inuit and Indian mothers. After adjustment for smoking, there was no association between caffeine intake and gestational age (Table 52). No information was given on how the gestational age was determined. The study gives no data for specific consumption categories, and no information regarding the number of persons in each category of consumption. The definitions or explanations concerning outcome parameters are poor.

Another Canadian study was a retrospective cohort study aiming at assessing the relationship between smoking and caffeine intake during pregnancy and intrauterine growth retardation, pre-term birth, and low birth weight (Fortier et al., 1993). The cohort was made up of 7025 women from the Quebec city area who had given birth to a singleton live born neonate January - October 1989. Consumption data were obtained by telephone interview a few weeks after delivery. Among other questions, the interviewer asked for intake of coffee, tea, chocolate, and cola drinks during the first 16 weeks, and the rest of the pregnancy, respectively. Information on several potential confounders including age, education, marital status, family income, obstetric history, weight before pregnancy, height, weight gain during pregnancy, passive smoking, alcohol intake, occupational factors, and leisure-time physical activity were also asked for. Gestational age was adequately determined.

Consumption of caffeine-containing foods during pregnancy had no influence on pre-term delivery (Table 52). Shiono and Klebanoff (1993) have criticised the exposure data of the study. They claim that the retrospective character of the study could lead to an inaccurate recall of consumption of caffeine-containing products. Although recall is a problem in most retrospective studies, this study does not seem to be particularly handicapped by this bias. However, no information was available on the use of caffeine-containing drugs. It should be noted that the caffeine intake was low in the studied population. Only $4 \%$ of the population consumed $>300 \mathrm{mg}$ caffeine/day.

A Danish study aiming at evaluating the association between smoking during pregnancy and pre-term birth also investigated caffeine intake as a confounder of smoking (Wisborg et al., 1998). The 4111 pregnant women who answered the questionnaires satisfactorily were included in the study. Sixty-six percent $(n=2707)$ of the women did not smoke. Caffeine intake during pregnancy was calculated from daily intakes of coffee (1 cup=100 mg), tea, cocoa ( 1 cup=50 mg), and cola soft drinks $(0.25$ litre $=50 \mathrm{mg}$ ). Of the total caffeine intake of the cohort, $59 \%$ was from coffee, $38 \%$ from tea, $2 \%$ from cocoa and $1 \%$ from cola drinks. Caffeine intake was dichotomised into low ( $<400 \mathrm{mg}$ caffeine/day) and high intake $(\geq 400 \mathrm{mg}$ caffeine/day). 1217 of the 4111 women had a high caffeine intake. Gestational age was determined by ultrasonographic measure- 
ments. Among women with an intake of less than $400 \mathrm{mg}$ of caffeine per day, no difference in the risk of pre-term birth between smokers and nonsmokers was found. However, among women with an intake of more than $400 \mathrm{mg}$ of caffeine per day, the risk of pre-term birth was almost threefold higher among smokers than among non-smokers (Table 52). Among women with a high intake of caffeine, a dose response relationship was found between smoking and risk of pre-term delivery. One drawback of the study was that $17 \%$ of the women gave poor or no information on coffee consumption. The statistical evaluation did not change qualitatively, however, as women who gave a poor response to the question on coffee consumption were excluded.

A multicentre study with matched case-control design was performed in Southern Brazil in order to investigate the effects of caffeine intake during each trimester of pregnancy on the eventual birth weight (Santos et al., 1998a). During the first 24 hours after delivery, the mothers (401 cases and 804 controls) were interviewed and their newborns examined to assess birth weight and gestational age using the method seen in Capurro et al. (1978). The cases were mothers who gave birth to children with weights below $2500 \mathrm{~g}$ and had a gestational age of $\geq 28$ weeks. Cases and controls were matched for time of birth and hospital of delivery. To assess caffeine intake, $10 \%$ of the mothers were re-interviewed in their homes, and samples of drip coffee and maté (a caffeine-containing drink widely used in South America) collected and analysed for caffeine content. The beverages were reported to contain low quantities of caffeine, between 19.8-45 mg per cup of coffee, depending on the strength of the beverage. A gourd of maté only contained $10 \mathrm{mg}$ caffeine. Instant coffee was estimated to contain $3 \mathrm{mg}$ caffeine/g powder from a reference table. Exposure of caffeine from tea, chocolate, soft drinks, and medicinal drugs was estimated from a reference table: tea to contain $34-54 \mathrm{mg} / 180 \mathrm{ml}$ serving (depending on strength), drinking chocolate $4 \mathrm{mg} / 200 \mathrm{ml}$ serving, chocolate bars $20 \mathrm{mg} / 30 \mathrm{~g}$ bar, and soft drinks $20 \mathrm{mg} / 200 \mathrm{ml}$ serving

The mean intake of caffeine from all sources was low - $148 \mathrm{mg}$ for cases and $146 \mathrm{mg}$ for controls. Crude analyses showed the caffeine intake to have no influence on low birth weight, pre-term births or intrauterine growth retardation (Table 52). The results did not change after controlling for confounders.

\subsection{Pre-term delivery and intake of caffeine-containing beverages}

One of the earliest published studies looking at the relationship between consumption of caffeine-containing beverages and pre-term delivery or low birth weight was the prospective cohort study by Mau and Netter (1974). The study base consisted of 5200 pregnant women from 20 Ger- 
man clinics for gynecology and pediatrics. The women were interviewed regarding their intake during the first trimester of pregnancy of coffee, alcohol, and many other foods and beverages, but no quantitative data were collected. Instead the coffee intake was quantified as "never", "seldom" or "often". As shown in Table 53, there was no statistically significant association between coffee consumption and pre-term delivery (defined as a delivery before 260 days of pregnancy, approximately $<37$ weeks, but not well characterised). A severe shortcoming of the study was the poor quantification of coffee consumption and the timing of the consumption. It only referred to the first trimester of pregnancy. No consumption data were available for the second and third trimesters. Another shortcoming was that the adjustment for potential confounders was done one by one.

Data from the Child Health and Development Studies performed in Oakland, California between 1960 and 1967 were used by van den Berg (1977) to investigate the relationship between birth weight, length of gestation (although the determination of gestational age was not specifically defined), and coffee consumption. The data used were obtained from medical records and from interviews with the women. Among the 15000 interviewed gravidas, $67 \%$ were white, 23\% black, 3\% MexicanAmerican, 4\% Oriental, and another 3\% were from other ethnic backgrounds. Prematurity was defined either as birth weights less than $2500 \mathrm{~g}$ or as a gestational length of not more than 37 weeks (Yerushalmy, 1967). The double definition of prematurity resulted in newborn infants being allocated to one of four groups: 1) premature by both criteria, 2) premature by birth weight, but mature by length of gestation, 3) mature by birth weight but premature by gestation, and 4) mature by both criteria. In the crude analysis, coffee appeared to be associated with increased rates of prematurity in all subclasses. However, when smoking was controlled for, the coffee effect on prematurity disappeared (Table 53). The shortcomings in this study were the poor definition of the study base and period of coffee consumption studied, as well as a non-optimal control for confounding factors.

A case control study of 166 mothers of singleton pre-term infants $(<37$ weeks gestation) and 299 mothers of singleton term infants ( $>37$ weeks gestation) was undertaken by Berkowitz et al. (1982) at the Yale-New Haven Hospital during 1977. Gestational age was determined according to the scoring method used by Dubowitz et al. (1970). The study explored the risks of pre-term delivery in relation to smoking and consumption of alcohol, coffee and tea, respectively. Intake of coffee and tea was evaluated on the basis of information given in an interview as the average number numbers of cups of coffee and tea consumed daily by the women during each trimester. Intake of iced coffee and iced tea was also asked for. Cases as compared to controls were more likely to be young, unmarried, black, and have low socio-economic status. The mothers of pre-term 
infants were of higher gravidity (number of previous pregnancies) than mothers of term infants, although their parity distribution was similar. Close to $59 \%$ of all women reported no coffee consumption, $41 \%$ did not consume tea, and $27 \%$ abstained from both types of beverage. There was no association between intake of coffee or tea and pre-term delivery (Table 53). Other sources of caffeine such as cola drinks, chocolate, and certain medications were not included in the study.

In a large American study based on 12205 non-diabetic, nonasthmatic women from the Boston area, Linn and co-workers (1982) studied the effect of coffee consumption during the first trimester on pregnancies. Only women pregnant with a single child were included in the study. About one third of those interviewed reported drinking no coffee or tea during the first trimester, and $56.6 \%$ reported drinking no coffee. Only $5 \%$ of the population reported drinking four or more cups of coffee per day (defined as "heavy" coffee drinkers). Heavy coffee consumption was related to older maternal age, white ethnicity, and Catholicism, but not to marital status, college education, or socio-economic status. The heavy coffee drinkers also had a higher alcohol intake and smoked more frequently than those with a lower coffee intake. There was no correlation between coffee intake and bleeding during pregnancy, toxemia and eclampsia, pre-admission for false and premature labour, abnormal presentation, low birth weight ( $>2500$ grams), shorter gestation (definition not stated), and malformations (Linn et al., 1982), Table 53. However, the frequency of a premature rapture of membranes was correlated to the number of cups of coffee consumed. The adjusted odds ratio determined by logistic regression was 1.52 . In interpreting the results of this study, it is important to remember that only consumption during the first trimester was considered. Furthermore, the women in the control group might have been exposed to caffeine from other sources than coffee and tea, and might therefore have been misclassified.

In a Japanese study, 9921 healthy pregnant women with a gestational age of 24 weeks were asked about their consumption of caffeinecontaining beverages during the earlier part of their pregnancies (Furuhashi et al., 1985). The women were divided into five categories: those consuming less than 5 cups of coffee per day during pregnancy $(n=3$ $815)$; those consuming more than 5 cups of coffee per day $(n=53)$; those consuming both coffee and green tea $(n=473)$; those consuming only green tea $(n=348)$; and those consuming neither coffee or green tea (controls) $(n=5$ 232). Intake of these beverages was correlated to various variables related to pregnancy outcome: mean birth weight (definition not stated), length of labour, mean amount of intrapartum haemorrhage and incidence of intrauterine growth retardation (definition not stated), spontaneous abortion, premature labour, and foetal abnormality. Women who consumed more than five cups of coffee per day had a significantly higher incidence of pre-term labour, and more often delivered babies 
small for their gestational age (no information on how gestational age was determined was given), Table 53. According to the authors, however, socio-economic variables might be more important for the induction of pre-term delivery than any direct effect from coffee. One of the reasons for this conclusion being drawn was that there was only one category of coffee drinkers (dose response could not be established), the number of heavy coffee drinkers was very small, and the study was not controlled for confounding factors.

The only Nordic study investigating the influence of coffee consumption on birth weight, pre-term births, and congenital malformations was performed by Olsen et al. (1991). The participants, 11858 pregnant women, were identified in two Danish cities between April 1985 and April 1987. The women responded to a mailed questionnaire on their eating and drinking habits during pregnancy. The women were asked how many cups of coffee and tea they consumed daily before becoming pregnant, as well as during the first two trimesters of pregnancy. Low birth weight was defined as $<2500$ grams. Thirty-five percent of the women in the study drank four cups of coffee or more per day (preferably filter coffee), and seven percent 8 or more cups daily. Tea consumption was less common. No data on consumption within the individual trimesters of pregnancy were presented. The study found no significant association between coffee and tea consumption and pre-term births (Table 53).

A Canadian retrospective cross-sectional study in Montreal analysed the importance of occupational and social factors such as cigarette smoking and alcohol and coffee consumption on pregnancy outcome (Mc Donald et al., 1992a). Of the 51512 pregnancies registered, 11067 were excluded for various reasons, but mainly because of factors known to affect length of gestation and birth weight, leaving 40445 pregnancies for analysis. Birth weights were studied in connection with prematurity. Prematurity was defined in three ways: low birth weight $(\leq 2500 \mathrm{~g})$; preterm birth ( $<37$ weeks); and low birth weight for gestational age. No statistically significant relationship between coffee exposure and pre-term birth ( $<37$ weeks) was found (Table 53). Trends of increasing risk with increased coffee consumption were consistent for low birth weight $(\leq 2500 \mathrm{~g})$ and low birth weight for gestational age (bottom 5\%). As only average consumption across trimesters was reported, no separation of results in relation to each trimester was possible. Like most other studies reported in this section, gestational age was generally determined from the last menstrual period only.

In a large cross sectional retrospective study from Boston, United States, Williams et al. (1992) studied the relationships of maternal cigarette smoking and coffee consumption to both premature rupture of membranes (one of the most common underlying causes of pre-term delivery) and to spontaneous pre-term labour ( $<37$ weeks) not complicated by premature rupture of the membranes. No specific information on the determinati- 
on of gestational age was given. The 307 pre-term deliveries due to premature rupture of membranes and the 488 pre-term deliveries due to other reasons were compared with 2252 randomly selected women who delivered at term at the same hospital. After delivering the women were asked how many cups of coffee they had consumed during the first trimester of pregnancy.

Tea consumption influenced neither pre-term delivery due to a premature rupture of membranes nor pre-term labour not complicated by a premature rupture of membranes (Table 53). However, women consuming three or more cups of coffee per day during the first trimester had an unadjusted 2.2-fold higher risk of pre-term premature rupture of membranes than women consuming two or fewer cups (Table 53). The occurrence of pre-term labour not complicated by premature rupture of membranes was less strongly associated with the consumption of three or more cups of coffee per day (borderline for significance). The study has been criticized for not adequately controlling for confounders (Pastore and Savitz, 1995).

In the United States it is known that pregnant women may choose to replace caffeinated with decaffeinated coffee because of concern about the potential adverse effects of consuming caffeinated beverages. Eskenazi et al. (1999) therefore designed a population-based study in order to examine the relationship between maternal decaffeinated and caffeinated coffee consumption during pregnancy and foetal growth and gestational duration. The following endpoints were investigated: pre-term delivery ( $<37$ weeks), low birth weight $(<2500 \mathrm{~g})$, small for gestational age $\left(<10^{\text {th }}\right.$ percentile percentile of weight for each completed gestational week between 22 and 44 weeks), mean birth weight; and gestational age (determined from the last menstrual cycle). The study comprised 7855 live births in California. At the time of completing the birth certificate, mothers answered a questionnaire in the hospital that among other things asked for coffee consumption during the middle (fourth to fifth month) of pregnancy. There was no increased risk for any of the studied endpoints due to coffee consumption in women who only used decaffeinated or caffeinated coffee as their source of coffee when compared to women who drank neither decaffeinated or caffeinated coffee. Interestingly, participants who consumed both caffeinated and decaffeinated coffee had an increased risk for pre-term delivery (Table 53). Possibly the retrospective collection of information on coffee consumption during a limited time period of pregnancy might have introduced a recall bias. 
Table 53. Pre term delivery in relation to intake of caffeine containing beverages

\begin{tabular}{|c|c|c|c|c|c|}
\hline $\begin{array}{l}\text { Reference and } \\
\text { location of study }\end{array}$ & Sample size and selection & $\begin{array}{l}\begin{array}{l}\text { Exposure period consi- } \\
\text { dered }\end{array} \\
\text { Sources of caffeine }\end{array}$ & $\begin{array}{l}\text { End-point(s) } \\
\text { Definition }\end{array}$ & $\begin{array}{l}\text { Results } \\
\text { Risk estimate: adjusted odd ratios, } \\
\text { including } 95 \% \text { confidence interval }\end{array}$ & Comments \\
\hline $\begin{array}{l}\text { Mau and Netter, } 1974 \\
\text { Prospective } \\
\text { cohort study } \\
\text { Germany }\end{array}$ & 5200 pregnant women & $\begin{array}{l}1^{\text {st }} \text { trimester } \\
\text { Coffee }\end{array}$ & $\begin{array}{l}\text { Pre term delivery } \\
\text { defined as }<260 \text { days } \\
\text { of gestational age, } \\
\text { and low birth weight } \\
\text { defined as } \\
\leq 2500 \mathrm{~g} \text {, or a birth } \\
\text { weight below the } 10^{\text {th }} \\
\text { percentile }\end{array}$ & $\begin{array}{l}\text { No association between caffeine intake (quantified as "never", "sel- } \\
\text { dom" and "often") and pre term delivery. }\end{array}$ & $\begin{array}{l}\text { Unacceptable poor quantification of caffeine } \\
\text { intake. Only consumption during the } 1^{\text {st }} \text { tri- } \\
\text { mester known. Confounding factors controlled } \\
\text { for one at a time. Smoking not quantified. }\end{array}$ \\
\hline $\begin{array}{l}\text { Van den Berg et al., } \\
1977 \\
\text { Prospective } \\
\text { cohort study } \\
\text { USA }\end{array}$ & $\begin{array}{l}\text { Around } 15000 \text { pregnant } \\
\text { women, members of } \\
\text { prepaid medical plan } \\
\text { (Kaiser Health Plan) }\end{array}$ & $\begin{array}{l}\text { During pregnancy } \\
\text { (not specified) } \\
\text { Only source: } \\
\text { Coffee }\end{array}$ & $\begin{array}{l}\text { Gestational age }<37 \\
\text { weeks, and/or birth } \\
\text { weight } \leq 2500 \mathrm{~g} \text {. }\end{array}$ & $\begin{array}{l}\leq 1 \text { cup coffee/day vs } \\
2-6, \geq 7 \text { cups/day (all) } \\
\geq 7 \text { cups/day, smoker } \\
\geq 7 \text { cups/day, non-smoker }\end{array}$ & $\begin{array}{l}\text { Poor definition of study base, exposure period } \\
\text { not well characterised, and non-optimal } \\
\text { control of confounders. }\end{array}$ \\
\hline $\begin{array}{l}\text { Berkowitz } \\
\text { et al., } 1982 \\
\text { Case-control } \\
\text { USA }\end{array}$ & $\begin{array}{l}166 \text { women delivering } \\
\text { pre term and } 299 \text { women } \\
\text { delivering post term. }\end{array}$ & $\begin{array}{l}\text { All three trimesters } \\
\text { were considered } \\
\text { separately. } \\
\text { Coffee and tea } \\
\text { (including iced tea and } \\
\text { coffee). }\end{array}$ & $\begin{array}{l}\text { Pre term defined as } \\
\text { live birth before } 37 \\
\text { weeks of gestation. }\end{array}$ & $\begin{array}{l}\text { Coffee }-1^{\text {st }}, 2^{\text {nd }} \text { and } 3^{\text {rd }} \text { trimester } \\
0 \text { cups vs } \\
1,2,3 \text {, or } \geq 4 \text { cups } \\
\text { Tea }-1^{\text {st }}, 2^{\text {nd }} \text { and } 3^{\text {rd }} \text { trimester } \\
0 \text { cups vs } \\
1,2,3, \text { or } \geq 4 \text { cups }\end{array}$ & $\begin{array}{l}\text { This is a small study but it has the power of } \\
0.8 \text { to reveal a relative risk of } 2.5 \text {. }\end{array}$ \\
\hline $\begin{array}{l}\text { Linn et al., } 1982 \\
\text { Retrospective cohort } \\
\text { study } \\
\text { USA }\end{array}$ & $\begin{array}{l}12205 \text { non-diabetic non- } \\
\text { asthmatic women who } \\
\text { had delivered a single } \\
\text { child }\end{array}$ & $\begin{array}{l}1^{\text {st trimester of preg- }} \\
\text { nancy. } \\
\text { Coffee }\end{array}$ & $\begin{array}{l}\text { Short gestation (not } \\
\text { clearly defined), and } \\
\text { premature rupture of } \\
\text { membranes. }\end{array}$ & $\begin{array}{l}\frac{\text { Short gestation }}{0 \text { vs } \geq 4 \text { cups of coffee }} \\
\text { Premature rupture of membranes: } \\
0 \text { vs } \geq 4 \text { cups of coffee }\end{array}$ & $\begin{array}{l}\text { Only coffee and tea consumption during } 1^{\text {st }} \\
\text { trimester considered. The confounder smoking } \\
\text { was not quantified. Retrospective design-bias } \\
\text { may be possible. Insufficient measurement of } \\
\text { consumption of caffeine-containing bever- } \\
\text { ages. }\end{array}$ \\
\hline $\begin{array}{l}\text { Furuhashi et al., } 1985 \\
\text { Prospective study } \\
\text { Japan }\end{array}$ & $\begin{array}{l}9921 \text { healthy pregnant } \\
\text { women } \\
\text { after } 24 \text { weeks gesta- } \\
\text { tional age }\end{array}$ & $\begin{array}{l}\text { During pregnancy } \\
\text { Coffee and green tea }\end{array}$ & \begin{tabular}{|l|} 
Pre term labour \\
(poorly defined).
\end{tabular} & $\begin{array}{l}\text { There was a significantly high incidence of impending abortion and } \\
\text { premature labour in women consuming at least } 5 \text { cups of coffee/day. }\end{array}$ & $\begin{array}{l}\text { No control for confounding factors (smoking } \\
\text { and others). Few women with a heavy coffee } \\
\text { consumption. No information available on how } \\
\text { gestational age was determined. }\end{array}$ \\
\hline $\begin{array}{l}\text { Olsen et al., } 1991 \\
\text { Restrospective cohort } \\
\text { study } \\
\text { Denmark }\end{array}$ & 11858 pregnant women & $\begin{array}{l}\text { Before pregnancy and } \\
\text { during } 1^{\text {st }} \text { and } 2^{\text {nd }} \\
\text { trimester } \\
\text { Coffee and tea }\end{array}$ & $\begin{array}{l}\text { Pre term delivery } \\
\text { defined as }<37 \text { weeks. }\end{array}$ & $\begin{array}{l}\text { Coffee } \\
0-3 \text { cups/day vs } \\
4-7, \geq 8 \text { cups/day } \\
\text { Tea } \\
0-3 \text { cups/day vs } \\
4-7, \geq 8 \text { cups/day }\end{array}$ & $\begin{array}{l}\text { Only average consumption across trimesters } \\
\text { was presented. Gestational age was some- } \\
\text { times determined from last menstrual period } \\
\text { and sometimes by ultrasound examinations. }\end{array}$ \\
\hline
\end{tabular}




\begin{tabular}{|c|c|c|c|c|c|}
\hline $\begin{array}{l}\text { Reference and } \\
\text { location of study }\end{array}$ & Sample size and selection & $\begin{array}{l}\begin{array}{l}\text { Exposure period consi- } \\
\text { dered }\end{array} \\
\text { Sources of caffeine }\end{array}$ & $\begin{array}{l}\text { End-point(s) } \\
\text { Definition }\end{array}$ & \begin{tabular}{|l|} 
Results \\
Risk estimate: adjusted odd ratios, \\
including $95 \%$ confidence interval
\end{tabular} & Comments \\
\hline $\begin{array}{l}\text { Mc Donald et al., 1992a } \\
\text { Retrospective cross- } \\
\text { sectional study } \\
\text { Canada }\end{array}$ & 40445 pregnant women & $\begin{array}{l}\text { Average consumption } \\
\text { across trimesters. } \\
\text { Coffee }\end{array}$ & $\begin{array}{l}\text { Pre term delivery } \\
\text { defined as }<37 \text { weeks. }\end{array}$ & $\begin{array}{l}0 \text { cups coffe/day vs } \\
1-2,3-4,5-9, \geq 10 \text { cups/day }\end{array}$ & $\begin{array}{l}\text { Only average consumption across trimesters } \\
\text { reported. }\end{array}$ \\
\hline $\begin{array}{l}\text { Williams et al.,1992 } \\
\text { Retrospective nested } \\
\text { case-control study } \\
\text { USA }\end{array}$ & $\begin{array}{l}\text { Cases with preterm } \\
\text { delivery were } 307 \\
\text { women with premature } \\
\text { rupture of membranes } \\
\text { (PROM) and } 488 \text { without } \\
\text { PROM, whereas controls } \\
\text { were } \\
2252 \text { women delivering } \\
\text { at term. }\end{array}$ & $\begin{array}{l}1^{\text {st }} \text { trimester } \\
\text { Coffee and tea }\end{array}$ & $\begin{array}{l}\text { Preterm delivery }(<37 \\
\text { weeks gestational } \\
\text { age) with or without } \\
\text { premature rupture of } \\
\text { membranes }\end{array}$ & 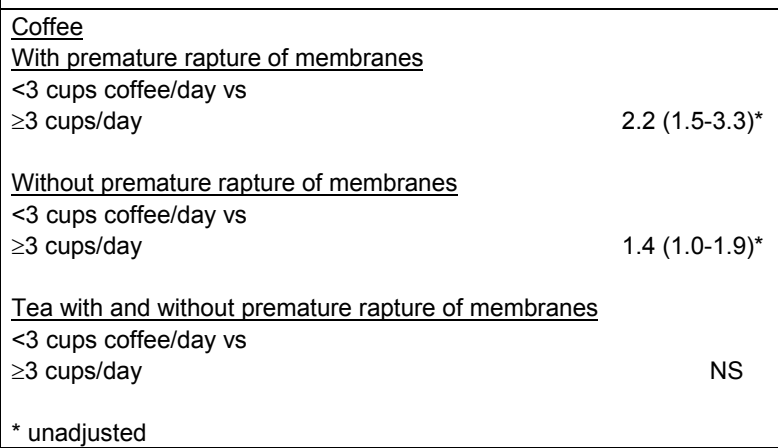 & $\begin{array}{l}\text { Consumption referred only to } 1^{\text {st }} \text { trimester of } \\
\text { pregnancy, and (various) factors influencing } \\
\text { pre term delivery may vary over the entire } \\
\text { gestational period. The confounder smoking } \\
\text { was not quantified. Recall bias possible. }\end{array}$ \\
\hline $\begin{array}{l}\text { Pastore and Savitz, } \\
1995 \\
\text { Case-control study } \\
\text { USA }\end{array}$ & $\begin{array}{l}408 \text { women with pre } \\
\text { term delivery and } 490 \\
\text { delivering at term.. }\end{array}$ & $\begin{array}{l}\text { All trimester } \\
\text { Coffee, tea, cola soft } \\
\text { drinks, and non-cola } \\
\text { caffeinated soft drinks. }\end{array}$ & $\begin{array}{l}\text { Pre term delivery } \\
\text { defined as }<37 \text { weeks } \\
\text { of gestation. }\end{array}$ & 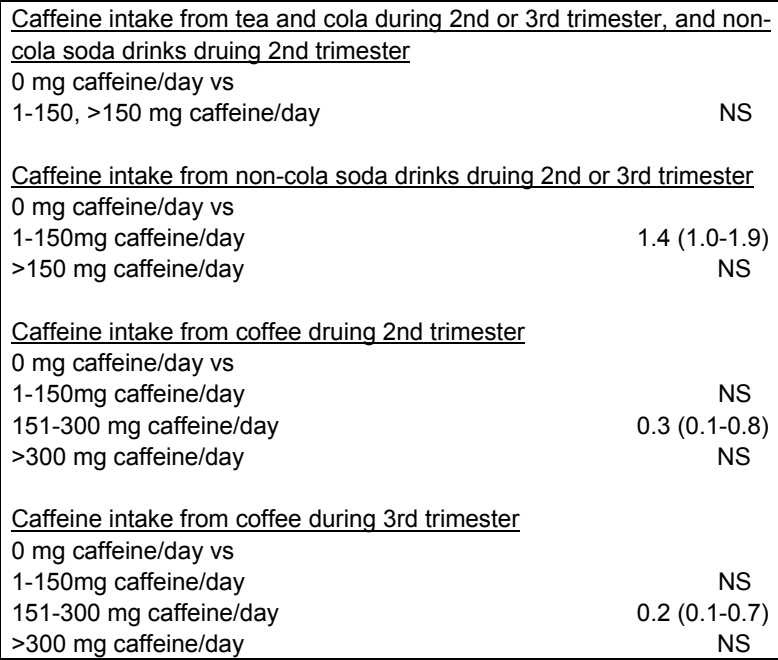 & $\begin{array}{l}\text { In absence of a dose-response relationship } \\
\text { the investigators concluded they found no } \\
\text { support for an association of consumption of } \\
\text { caffeine-containing beverages and pre term } \\
\text { delivery. The study had a relatively high drop } \\
\text { out rate. Interviews were quick for some } \\
\text { participants. The study gave no information on } \\
\text { how the gestational age was determined. }\end{array}$ \\
\hline
\end{tabular}




\begin{tabular}{|c|c|c|c|c|c|}
\hline $\begin{array}{l}\text { Reference and } \\
\text { location of study }\end{array}$ & Sample size and selection & \begin{tabular}{|l} 
Exposure period consi- \\
dered
\end{tabular} & $\begin{array}{l}\text { End-point(s) } \\
\text { Definition }\end{array}$ & \begin{tabular}{|l} 
Results \\
Risk estimate: adjusted odd ratios, \\
including $95 \%$ confidence interval
\end{tabular} & Comments \\
\hline $\begin{array}{l}\text { Eskenazi et al., } 1999 \\
\text { Retrospective cohort } \\
\text { study } \\
\text { USA }\end{array}$ & 7855 live births & $\begin{array}{l}\text { During the } 4^{\text {th }} \text { to } 5^{\text {th }} \\
\text { months of pregnancy } \\
\text { Coffee, decaffeinated } \\
\text { coffee, tea and cola }\end{array}$ & $\begin{array}{l}\text { Pre term delivery } \\
\text { defined as }<37 \text { weeks } \\
\text { of gestation. }\end{array}$ & 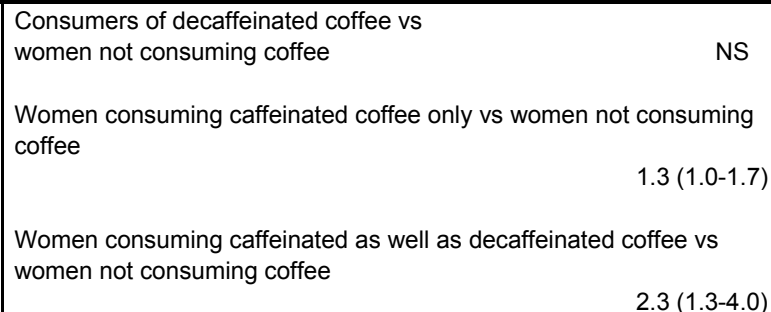 & $\begin{array}{l}\text { Exposure period limited to one month of } \\
\text { pregnancy (4-5 months), recall bias probable }\end{array}$ \\
\hline
\end{tabular}




\section{3. Summary of caffeine and pre-term delivery}

Pre-term delivery/pre-term birth has been defined as a gestational age of less than 37 completed weeks of pregnancy in all studies reviewed in this chapter. Some authors have also included birth weight of less than 2500 grams in the definition of pre-term births. The close agreement regarding definition makes it much easier to draw conclusions from the study results. Low socio-economic status, history of adverse pregnancy outcome, and antepartum haemorrhage have consistently been reported as risk factors associated with pre-term delivery (Williams et al 1992), and must, therefore, be controlled for in studies on this endpoint of pregnancy. It should be kept in mind, though, that pre-term delivery is a heterogenous condition caused, for example, by premature rupture of membranes, premature onset of labour, vaginal bleeding including placenta previa and abruptio placentae, and maternal illness (most often preeclampsia).

Since the end of the 1970s twenty epidemiological studies, predominantly of American and Canadian origin, have investigated the relationship between caffeine intake and pre-term delivery, but there are also five European studies, one Japanese study, and one Brazilian study. Although the studies have used a common definition of the biological endpoint studied, they have quantified the caffeine intake differently. Caffeine intake may come from various sources, but most studies have neglected one or more of them. All studies have considered caffeine intake from coffee, many have also considered the intake from tea and caffeine-containing soft drinks, primarily cola drinks, but very few studies have considered caffeine from cocoa, chocolate, and medicinal drugs.

The majority of the studies have a retrospective design, which could have introduced bias due to faulty recall of consumption. However, eight studies had a prospective design (Mau and Netter, 1974; Van den Berg, 1977; Tebbutt et al., 1984; Furuhashi et al., 1985; Martin and Bracken, 1987; Godel et al., 1992; Peacock et al., 1995; Wisborg et al., 1998) and should not be burdened by recall bias as much as the retrospective studies.

A drawback with many studies is the fact that consumption of caffeine-containing foods and beverages has not been considered trimester-bytrimester. Consumption in the third trimester is especially important, which ought to have been registered in all studies of this type. However, it is not unusual to find that only average consumption or first trimester consumption has been reported.

Many factors have the potential to confound a relationship between caffeine intake and pre-term delivery. One of the most important confounders, which should not be neglected in this context, is smoking. A high consumption of coffee has consistently been linked to smoking. 
Unfortunately, not all investigators have controlled for confounding factors, simply because of missing information.

Nine of the twenty studies conclude that there is no association between caffeine intake and pre-term delivery (Tebutt et al., 1984; Watkinson and Fried, 1985; Martin and Bracken, 1987; Fenster et al., 1991a; Godel et al., 1992; Fortier et al., 1993; Pastore and Savitz, 1995; Peacock et al., 1995 and Santos et al., 1998), and another five that there was no association between consumption of caffeine-containing beverages (mainly coffee and tea) and pre-term delivery (Mau and Netter, 1974; van den Berg, 1977; Berkowitz et al., 1982; Olsen et al., 1991 and Mc Donald et al, 1992a). Linn et al. (1982), however, found a relationship between coffee consumption and premature rupture of membranes. No definite conclusions could be drawn from the study by Weathersbee et al. (1997).

One study (Wisborg et al., 1998) reported a positive association between caffeine intake and pre-term delivery, and four (Linn et al., 1982; Furuhashi et al., 1985; Williams et al., 1992; Eskenazi et al., 1999) reported a positive association between consumption of caffeinecontainingn beverages and pre-term delivery. It should be noted, though, that the participants in the study by Williams et al. (1992) were derived from the study by Linn et al. (1982) and the positive response was confined to a significant relation between intake of coffee and premature rupture of membranes.

The studies by Weathersbee et al. (1977) and Furuhashi et al. (1985) suffer from many severe limitations; the most remarkable being the lack of adjustment for important confounding factors such as smoking. The study of Williams et al. (1992) showed that a high coffee consumption (3 or more cups per day) resulted in a doubled risk for pre-term labour due to premature rupture of membranes, whereas the risk for pre-term labour not complicated by premature rupture was only marginally increased. Wisborg and co-workers (1998) found that at caffeine intakes below 400 mg per day there was no difference in the risk of pre-term birth between smokers and non-smokers. At higher caffeine intakes, however, the risk of pre-term birth was increased almost threefold among smokers compared to non-smokers. Finally, the retrospective study of Eskenazi et al. (1999) came to the surprising conclusion that a high total consumption of regular caffeine-containing coffee and decaffeinated coffee during mid pregnancy increased the risk of pre-term delivery more significantly (OR 2.3) than did a high consumption of regular coffee alone (OR 1.3).

In conclusion, these data indicate that a relationship between caffeine intake and pre-term delivery is unlikely. 



\section{Caffeine and foetal growth retardation}

Who should be regarded as growth retarded? This question is not an easy one to answer, because foetal growth retardation may be defined in many ways, and at present there is no internationally accepted definition. Common parameters used as endpoints in the epidemiological studies presented in this chapter to assess foetal growth retardation are low birth weight (LBW), intrauterine growth retardation (IUGR), small for gestational age (SGA), and ponderal index. In addition, significantly reduced mean birth weight (BW) has sometimes been used - especially in older studies. Other parameters used as outcome variables in epidemiological studies on growth retardation are head circumference (HC), crown-rumplength (CRL), the weight of the placenta (PWT), and Agpar scores. Few studies have motivated their choice of endpoint. The most frequently used definitions of the most common parameters are presented in Table 54.

It appears as though low birth weight, intrauterine growth retardation and small for gestational age have been used as synonyms in many studies. This is clearly not correct (Bakketeig, 1998). For example, low birth weight (LBW) may be caused by foetal growth retardation but also by pre-term delivery and by genetic factors resulting in babies in the lower normal weight range ("just a small baby"), as well as maternal diseases. Birth weight is a complex parameter to study, as it is likely to be affected by a huge array of factors (see below). Whatever outcome used, it is imperative that gestational age is controlled for.

Birth weight obviously depends on the duration of gestation as well as on intrauterine growth rate. Low birth weight is thus a result of a short gestational period, retarded intrauterine growth, or a combination of both.

Table 54. Definition of some parameters used in the assessment of low birth weight.

\begin{tabular}{|l|l|}
\hline Parameter & Proposed definitions \\
\hline $\begin{array}{l}\text { Low birth weight } \\
\text { (LBW) }\end{array}$ & $\begin{array}{l}\text { - a birth weight below the } 10^{\text {th }} \text { percentile (related to growth standard } \\
\text { curves); } \\
-\leq 2500 \mathrm{~g}\end{array}$ \\
\hline $\begin{array}{l}\text { Intrauterine growth retardation } \\
\text { (IUGR) }\end{array}$ & $\begin{array}{l}- \text { a birth weight below the } 25^{\text {th }}, 10^{\text {th }}, 5^{\text {th }} \text { or } 3^{\text {rd }} \text { percentiles; } \\
- \text { more than } 2 \text { standard deviation below the mean birth weight (related } \\
\text { to growth standard curves) }\end{array}$ \\
\hline $\begin{array}{l}\text { Small for gestational age } \\
(\text { SGA }\end{array}$ & $\begin{array}{l}\text { often (incorrectly) used as a synonym for IUGR (thus the same defini- } \\
\text { tions have been proposed) }\end{array}$ \\
\hline $\begin{array}{l}\text { Low Ponderal index } \\
\text { the ratio Birth weight/(Birth length }{ }^{2} \text { ) is below the } 10^{\text {th }} \text { percentile }\end{array}$ \\
${ }^{*}$ The most commonly used criteria \\
${ }^{*}$ The term: "Low birth weight for gestational age " (LBWGA) is sometimes used as a synonym.
\end{tabular}


For this reason, it has been proposed that low birth weight infants should be classified as pre-term (before 37 weeks gestational age) with appropriate weight for gestational age, pre-term with growth retardation, or term with growth retardation (Pollack and Divon, 1992).

As the main question in this chapter is whether a low birth weight (LBW) or a statistically significant reduction in mean birth weight of the new-born can be the result of an intrauterine growth retardation (IUGR) caused by the mothers intake of caffeine and/or caffeine-containing beverages, it is apparent that a number of (confounding) factors which may influence birth weight have to be controlled for in the statistical analysis.

In an extensive methodological assessment based on epidemiological studies published 1970-1984, Kramer (1987) suggested that the following factors are important for intrauterine growth:

(i) Genetic and constitutional factors (infant sex, chromosomal aberrations, racial/ethnic origin, maternal height, pre-pregnancy weight, paternal weight, and height and maternal birth weight);

(ii) Demographic and psychosocial factors (maternal age, at least very young age, and socio-economic status);

(iii) Exposure to toxic compounds (cigarette smoking, tobacco chewing, and alcohol consumption being the most important);

(iv) Obstetric factors, nutritional status and maternal morbidity (parity, history of prior low birth weight infants, low gestational weight gain, caloric intake, general morbidity, and episodic illness).

A meta-analysis was carried out in order to identify the major causal determinants of intrauterine growth retardation. Within developing countries these were found to be black or Indian racial origins, poor gestational nutrition, low pre pregnancy weight, short maternal stature and malaria. In developed countries the most important single causal factor of intrauterine growth retardation by far was found to be cigarette smoking followed by poor gestational nutrition and low pre-pregnancy weight (Kramer, 1987). For more details, interested readers should consult Kramer (1987). In this context a Scandinavian prospective multi-centre study of 1945 women by Bakketeig et al. (1993) may be briefly mentioned. This study identified the following pre-pregnancy risk factors for smallfor-gestational age: smoking, previous low birth weight, and low maternal pre-pregnancy weight $(<50 \mathrm{~kg})$.

As a pathological decrease in foetal growth rate is known to be associated with neonatal mortality and morbidity, early identification of intrauterine growth retardation is of vital importance (Kramer, 1987; Golding, 1991). In this context, neonatal morbidity has been suggested to include asphyxia, meconium aspiration, pulmonary haemorrhage, hyperviscosity syndrome, and hypoglycemia (Wennergren, 1985; Pollack and Divon, 1992; Wollmann, 1998). According to Maruoka et al. (1998), children with a birth weight of less than 2500 grams have lower school perform- 
ance and intelligence test scores as teenagers than children with a normal birth weight. Thus, studies of factors influencing intrauterine growth retardation are important not only for foetal growth retardation but also in considering the development and the morbidity of older children and adults.

At least two mechanisms have been suggested for caffeine exposure having an effect on birth weight through intrauterine growth retardation. Caffeine is structurally similar to adenine and guanine and may interfere with cell division and metabolism. In addition, caffeine has a vasoconstrictive effect on placental intervillous blood flow that may contribute to the potential risk of intrauterine growth retardation (Kirkinen et al., 1983).

The following text (chapter 15) reviews studies devoted to a relationship between either caffeine intake (section 15.1) or consumption of caffeine-containing beverages (section 15.2) in fertile women and the occurrence of foetal growth retardation. Readers who wish to get a quick review of the contents of chapter 15 should proceed to sections 15.4 (Results), 15.5 (Discussions), and 15.6 (Conclusions).

\subsection{Foetal growth retardation in relation to intake of caffeine}

In order to facilitate reading, the studies are reviewed in chronological order. It should be noted that in the description of the studies only information of relevance for the assessment of the relationship between caffeine intake and foetal growth retardation would be presented.

The first study exploring a possible relationship between caffeine intake of mothers and birth weight of infants was a prospective cohort study carried out in Southern California 1974-1978 on slightly more than 5000 maternal-infant pairs (Kuzma and Sokol, 1982). The aim of the study was to evaluate the relative importance of volume, frequency, and beverage source of alcohol as determinants of infant birth weight (adjusted for gestational age), while adjusting for other known determinants using multivariate techniques. In total, 44 potential determinants of intrauterine growth were evaluated. Caffeine intake during the entire pregnancy and smoking were two of the eleven determinants influencing birth weight (Table 55). A synergistic interaction of caffeine intake and smoking was observed. Included in the analysis of caffeine were 4895 pairs of mother-infants. The selection of the study base was not clearly defined, and a rather high drop out rate seems possible (Kuzma and Kissinger, 1981). The authors concluded that their results appear to confirm a previous suggestion that heavy beer drinking during pregnancy is related to decreased intrauterine growth. Caffeine intake may also influence the mean birth weight. The results should, however, be interpreted cautiously 
since there are several alternative explanations for the finding. Furthermore, the study had several limitations. No specific information about the determination of gestational age is given in the study. No information was given on the sources of caffeine and the way the intake was quantified. It was not a primary aim to investigate the relationship between caffeine and birth weight.

All women participating in the Ottawa Prenatal Prospective study in Canada and whose offspring was at least one year old were asked to participate in a study of maternal use of caffeine before, during and after pregnancy and the effects upon offspring (Watkinson and Fried, 1985). 284 mothers and their 286 children (two twin pairs) were included in the study after they had returned questionnaires with adequately answered questions regarding their consumption of coffee, tea, caffeinated soft drinks, chocolate bars, chocolate drinks, and caffeine-containing medications. Data were requested in terms of frequency of use, portion size, method of preparation, and beverage strength. Seven consumption periods consisting of the third, second and first years before pregnancy, the first, second and third trimesters, and the year after pregnancy were covered. Upon becoming pregnant $62 \%$ of the women reduced only their intake of coffee, without reducing other sources of caffeine. Only twelve women consumed an average of more than $300 \mathrm{mg}$ caffeine per day during pregnancy. No significant relationships were found between the studied parameters (birth length, head circumference, ponderal index, gestational age, length of labour, and Apgar score) and pre pregnancy or pregnancy maternal caffeine use when caffeine was considered a continuous variable. When caffeine was considered a categorical variable, no significant associations were found for caffeine use before pregnancy. However, maternal intake of more than $300 \mathrm{mg}$ daily during pregnancy was associated with lowered birth weight (difference between groups: 352 grams) and smaller head circumference (difference between groups: $1.1 \mathrm{~cm}$ ) when smoking had been controlled for (Table 55). Moreover, the average ponderal index was lower in the heavy caffeine group but did not reach statistical significance. No association was apparent between heavy caffeine use and pregnancy weight gain, gestation age, Apgar, length of labour, or birth length of infant. The conclusions that can be drawn from this study are limited by the few number of women having a high caffeine intake (only 12), and by controlling for only one confounder at a time in the statistical analysis of the data. In addition, no information regarding the determination of gestational age was provided. It is also not clear whether birth weight was adjusted for gestational age. 


\begin{tabular}{|c|c|c|c|c|c|}
\hline $\begin{array}{l}\text { Reference } \\
\text { Type and location of study }\end{array}$ & Sample size and selection & $\begin{array}{l}\text { Exposure period consi- } \\
\text { dered } \\
\text { Sources of caffeine }\end{array}$ & \begin{tabular}{|l|} 
End-point(s) \\
Definitions
\end{tabular} & $\begin{array}{l}\text { Results } \\
\text { Risk estimate: adjusted odd ratios, } \\
\text { including } 95 \% \text { confidence interval } \\
\text { (NS = non significant) }\end{array}$ & Comments \\
\hline $\begin{array}{l}\text { Kuzma and Sokol,1982 } \\
\text { Prospective cohort study } \\
\text { USA }\end{array}$ & 4895 mother infant pairs & $\begin{array}{l}\text { During pregnancy } \\
\text { Sources of caffeine: } \\
\text { no information. }\end{array}$ & $\begin{array}{l}\text { Birth weight adju- } \\
\text { sted for gestational } \\
\text { age } \\
44 \text { potential deter- } \\
\text { minants of foetal } \\
\text { growth studied }\end{array}$ & $\begin{array}{l}\text { Consumption of caffeine-containing beverages contributes } \\
\text { significantly to the variance in birth weight. A synergistic inte- } \\
\text { raction of caffeine and smoking was observed }(p<0.03) \text {. }\end{array}$ & $\begin{array}{l}\text { It was not a primary aim to study caffeine. No } \\
\text { information regarding sources of caffeine and } \\
\text { caffeine consumption given. }\end{array}$ \\
\hline $\begin{array}{l}\text { Watkinson and Fried, } 1985 \\
\text { Retrospective nested case- } \\
\text { control Study } \\
\text { Canada }\end{array}$ & $\begin{array}{l}284 \text { women participating } \\
\text { in the Ottawa Prenatal } \\
\text { Study }\end{array}$ & $\begin{array}{l}3^{\text {rd }}, 2^{\text {nd }}, 1^{\text {st }} \text { year before } \\
\text { pregnancy and during } \\
1^{\text {st }}, 2^{\text {nd }}, 3^{\text {rd }} \text { trimesters } \\
\text { and } 1 \text { year after birth. } \\
\text { Coffee, tea, soft } \\
\text { drinks, chocolate } \\
\text { drinks and bars, } \\
\text { caffeine-cont. drugs }\end{array}$ & \begin{tabular}{|l} 
Birth weight, \\
birth length, \\
head circum- \\
ference, \\
ponderal index \\
gestational age
\end{tabular} & 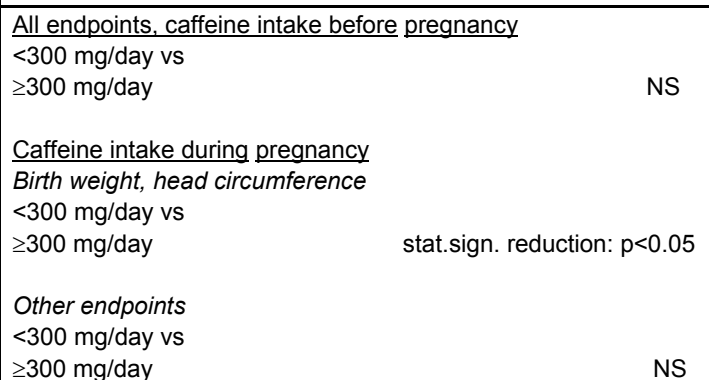 & $\begin{array}{l}\text { Very few "heavy" consumers }(n=12) \text {. Confounders } \\
\text { only controlled for one at a time. It is not clear } \\
\text { whether birth weight was adjusted for gestational } \\
\text { age. }\end{array}$ \\
\hline $\begin{array}{l}\text { Beaulac-Baillargeon and } \\
\text { Desrosiers, } 1987 \\
\text { Retrospective cohort study } \\
\text { Canada }\end{array}$ & 913 newborn infants & $\begin{array}{l}\text { "During pregnancy" } \\
\text { Coffee, tea, cola and } \\
\text { chocolate }\end{array}$ & \begin{tabular}{|l|} 
Birth weight, birth \\
length, \\
head circum- \\
ference, and placen- \\
tal weight \\
adjusted for gesta- \\
tional age and sex \\
of baby
\end{tabular} & $\begin{array}{l}\text { Birth weight } \\
0,1-14 \text { cigarettes/day } \\
<300 \mathrm{mg} \text { caffeine } / \text { day vs } \\
\geq 300 \mathrm{mg} / \text { day } \\
\geq 15 \text { cigarettes/day } \\
<300 \mathrm{mg} \text { caffeine/day vs } \\
\geq 300 \mathrm{mg} / \text { day } \\
\text { Birth length and head curcumference } \\
\text { Both dose levels } \\
<300 \mathrm{mg} \text { caffeine } / \text { day vs } \\
\geq 300 \mathrm{mg} / \text { day } \\
\text { Placental weight } \\
<300 \mathrm{mg} / \text { day and } \\
\geq 15 \mathrm{cig} . / \text { day } \\
\geq 300 \mathrm{mg} / \text { day and } \\
\geq 15 \mathrm{cig} \text { /day }\end{array}$ & $\begin{array}{l}\text { Not all participants were interviewed regarding } \\
\text { caffeine consumption. Time periods for consump- } \\
\text { tion was not specified, and consumption parameter } \\
\text { dichotomized. Recall bias may be possible. No } \\
\text { information about determination of gestational age. }\end{array}$ \\
\hline
\end{tabular}




\begin{tabular}{|c|c|c|c|c|c|c|}
\hline $\begin{array}{l}\text { Reference } \\
\text { Type and location of study }\end{array}$ & Sample size and selection & $\begin{array}{l}\text { Exposure period consi- } \\
\text { dered } \\
\text { Sources of caffeine }\end{array}$ & $\begin{array}{l}\text { End-point(s) } \\
\text { Definitions }\end{array}$ & \begin{tabular}{|l|} 
Results \\
Risk estimate: adjusted odd ratios, \\
including $95 \%$ confidence interval \\
(NS = non significant)
\end{tabular} & & Comments \\
\hline $\begin{array}{l}\text { Fried and O'Conell, } 1987 \\
\text { Cohort (The Ottawa prenatal) } \\
\text { study } \\
\text { Canada }\end{array}$ & $\begin{array}{l}\text { Original follow-up: } \\
667 \text { women } \\
\\
\text { Follow-up at } 12 \text { and } 24 \\
\text { months after delivery: } \\
123 \text { women }\end{array}$ & $\begin{array}{l}\text { Pre pregnancy } 1^{\text {st }} \\
\text { trimester } \\
3^{\text {rd }} \text { trimester } \\
\text { "average use" } \\
\text { Coffee, tea, cola and } \\
\text { "other dietary sources } \\
\text { of caffeine" } \\
\end{array}$ & $\begin{array}{l}\text { Birth weight, body } \\
\text { length, head circum- } \\
\text { ference at } 39-39.9 \\
\text { weeks of gestation }\end{array}$ & $\begin{array}{l}\text { All parameters studied } \\
<300 \mathrm{mg} \text { caffeine/day vs } \\
\geq 300 \mathrm{mg} \text { caffeine /day }\end{array}$ & NS & $\begin{array}{l}\text { A selected study base with few "heavy" consumers. } \\
\text { Not all subjects were interviewed regarding caffeine } \\
\text { consumption. }\end{array}$ \\
\hline $\begin{array}{l}\text { Brooke et al., } 1989 \\
\text { Prospective population- } \\
\text { based cohort study } \\
\text { Great Britain }\end{array}$ & 1513 white women & $\begin{array}{l}27^{\text {th }} \text { and } 35^{\text {th }} \\
\text { week of gestation. } \\
\text { Coffee, tea, cola and } \\
\text { cocoa }\end{array}$ & $\begin{array}{l}\text { Birth weight adju- } \\
\text { sted for gestational } \\
\text { age and maternal } \\
\text { height, parity and } \\
\text { baby's sex }\end{array}$ & \begin{tabular}{|l} 
Birth weight \\
$0 \mathrm{mg} /$ day vs \\
$1-200,201-400$, and \\
$>401 \mathrm{mg} / \mathrm{day}^{*}$ \\
\\
* recalculated from study
\end{tabular} & NS & Adequate measurement of gestational age. \\
\hline $\begin{array}{l}\text { Martin and Bracken, } 1987 \\
\text { Prospective Cohort study } \\
\text { USA }\end{array}$ & 3891 antenatal patients & $\begin{array}{l}\text { "During pregnancy" = } \\
1^{\text {st }} \text { trimester } \\
\text { Coffee, tea, colas, and } \\
\text { drugs }\end{array}$ & $\begin{array}{l}\text { Birth weight adju- } \\
\text { sted for gestational } \\
\text { age, low birth weight } \\
<2500 \mathrm{~g} \text { ) at term } \\
\text { deliveries, and rate } \\
\text { of low birth weight in } \\
\text { term deliveries } \\
\text { (IUGR) }\end{array}$ & $\begin{array}{l}\text { Birth weight } \\
0 \mathrm{mg} / \text { day vs } \\
<300 \mathrm{mg} / \mathrm{day} \\
>300 \mathrm{mg} / \mathrm{day} \\
\\
\text { Low birth weight } \\
0 \mathrm{mg} / \mathrm{day} \text { vs } \\
1-150 \mathrm{mg} \text { caffeine/day } \\
151-300 \mathrm{mg} \text { caffeine/day } \\
\geq 300 \mathrm{mg} \text { caffeine/day } \\
\\
\text { Mean gestational age } \\
\\
\text { Intrauterine growth retardation } \\
0 \mathrm{mg} / \mathrm{day} \text { vs } \\
1-150 \mathrm{mg} \text { caffeine/day } \\
151-300 \mathrm{mg} \text { caffeine/day } \\
\geq 300 \mathrm{mg} \text { caffeine/day } \\
\end{array}$ & $\begin{array}{c}\mathrm{NS} \\
\mathrm{p}<0.001 \\
\\
\mathrm{NS} \\
2.3(1.1-5.2) \\
4.6(2.0-10.5) \\
\mathrm{NS} \\
\\
\mathrm{NS} \\
\mathrm{NS} \\
4.0(1.9-8.6)\end{array}$ & 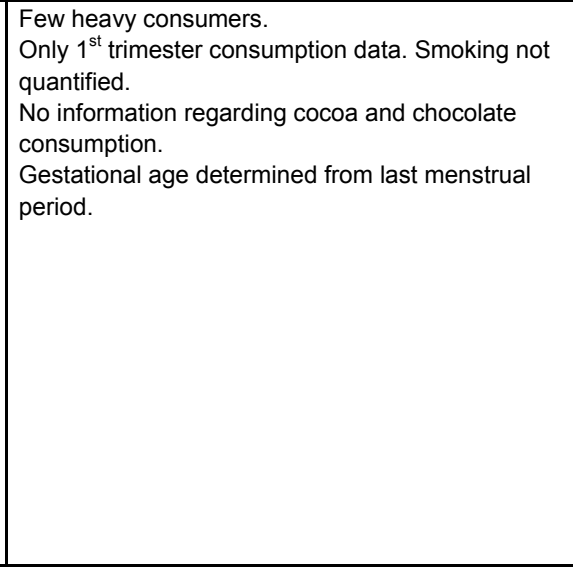 \\
\hline $\begin{array}{l}\text { Caan and Goldhaber, } 1989 \\
\text { Case control study } \\
\text { USA }\end{array}$ & $\begin{array}{l}131 \text { cases and } 136 \\
\text { controls }\end{array}$ & $\begin{array}{l}1^{\text {st }} \text { trimester } \\
\text { Coffee, tea, cola and } \\
\text { combination of cof- } \\
\text { fee+cola }\end{array}$ & $\begin{array}{l}\text { Low birth weight } \\
\text { defined as } 2 \text { stan- } \\
\text { dard deviations < } \\
\text { mean birth weight } \\
(\mathrm{n}=97) \text { or as birth } \\
\text { weight } \leq 2500 \mathrm{~g} \\
(\mathrm{n}=34)\end{array}$ & $\begin{array}{l}\text { Low birth weight } \\
\text { Caffeine from all sources } \\
0 \mathrm{mg} \text { caffeine/day vs } \\
<300,>300 \mathrm{mg} / \mathrm{day} \\
\text { Caffeine from coffee and cola drinks only } \\
0 \mathrm{mg} \text { caffeine/day vs } \\
<300 \mathrm{mg} / \mathrm{day} \\
>300 \mathrm{mg} / \mathrm{day}\end{array}$ & $\begin{array}{c}\text { NS } \\
\\
\text { NS } \\
3.53(1.05-11.81)\end{array}$ & $\begin{array}{l}\text { Inclusion criteria for cases/controls not given. } \\
\text { Small study with imprecise estimates and non- } \\
\text { optimal quantification of smoking. } \\
\text { Recall bias possible. Gestational age determined } \\
\text { only from last menstrual period. }\end{array}$ \\
\hline
\end{tabular}




\begin{tabular}{|c|c|c|c|c|c|}
\hline $\begin{array}{l}\text { Reference } \\
\text { Type and location of study }\end{array}$ & Sample size and selection & $\begin{array}{l}\text { Exposure period consi- } \\
\text { dered } \\
\text { Sources of caffeine }\end{array}$ & $\begin{array}{l}\text { End-point(s) } \\
\text { Definitions }\end{array}$ & $\begin{array}{l}\text { Results } \\
\text { Risk estimate: adjusted odd ratios, } \\
\text { including } 95 \% \text { confidence interval } \\
\text { (NS = non significant) }\end{array}$ & Comments \\
\hline $\begin{array}{l}\text { Peacock et al., } 1991 \\
\text { (data from Brooke et al 1989) } \\
\text { Prospective population- } \\
\text { based study } \\
\text { Great Britain }\end{array}$ & $\begin{array}{l}414 \text { smoking pregnant } \\
\text { women }\end{array}$ & $\begin{array}{l}\text { Caffeine intake recor- } \\
\text { ded at booking, and at } \\
28 \text { and } 36 \text { weeks of } \\
\text { gestation } \\
\text { Coffee, tea cocoa and } \\
\text { cola }\end{array}$ & $\begin{array}{l}\text { Birth weight ratio } \\
\text { adjusted for gesta- } \\
\text { tional age, maternal } \\
\text { height, sex of infant } \\
\text { and parity }\end{array}$ & $\begin{array}{l}\text { Birth weight } \\
0-200 \mathrm{mg} \text { caffeine/day vs } \\
201-400 \mathrm{mg} / \text { day } \\
>401 \mathrm{mg} / \text { day } \\
\text { - Caffeine consumption at booking } \\
\text { - Caffeine consumption at } 28 \text { weeks } \\
\text { - Caffeine consumption at } 36 \text { weeks }\end{array}$ & Adequate measurement of gestational age. \\
\hline $\begin{array}{l}\text { Fenster et al., 1991b } \\
\text { Case control study } \\
\text { USA }\end{array}$ & $\begin{array}{l}1230 \text { women with } \\
\text { singleton live births }\end{array}$ & $\begin{array}{l}1^{\text {st }} \text { trimester } \\
\text { Coffee, tea and soft } \\
\text { drinks }\end{array}$ & $\begin{array}{l}\text { Intrauterine growth } \\
\text { retardation }(\text { IUGR) }= \\
<10^{\text {th }} \text { percentile. } \\
\text { Low birth weight } \\
(\text { LBW })= \\
<2500 \mathrm{~g} .\end{array}$ & 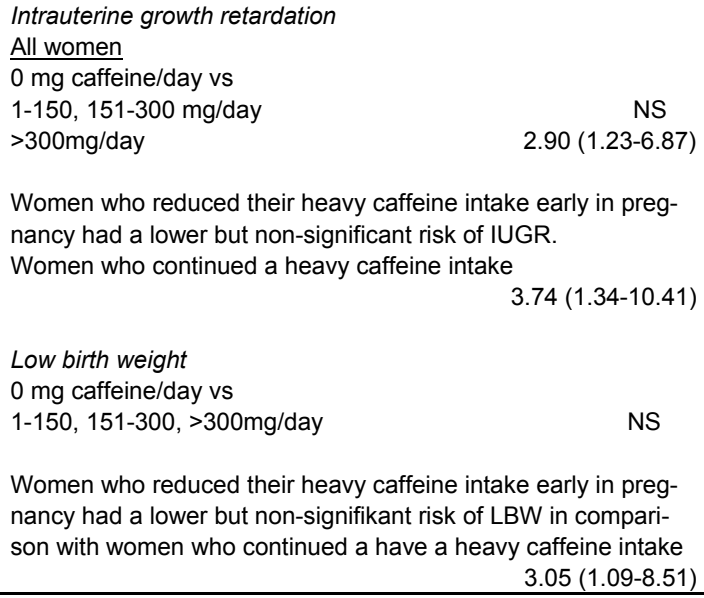 & $\begin{array}{l}\text { No information regarding caffeinated drugs, choco- } \\
\text { late and cocoa. Adjustment for smoking and alcohol } \\
\text { consumption was not optimal. Stratification of data } \\
\text { may not be adequate. Only } 1^{\text {st }} \text { tri-mester consump- } \\
\text { tion studied. } \\
\text { Inconsistency of the results for low birth weight and } \\
\text { intrauterine growth retardation. }\end{array}$ \\
\hline $\begin{array}{l}\text { Godel et al., } 1992 \\
\text { Prospective cohort study } \\
\text { Canada }\end{array}$ & 162 women & $\begin{array}{l}\text { "Caffeine intake in the } \\
\text { last } 24 \text { hours prenatal- } \\
\text { ly and at delivery" } \\
\text { Coffee, tea and cola }\end{array}$ & $\begin{array}{l}\text { Birth weight, } \\
\text { body length, } \\
\text { head circum-ference }\end{array}$ & $\begin{array}{l}\text { Birth weight } \\
\leq 300 \mathrm{mg} \text { caffeine/day vs } \\
>300 \mathrm{mg} / \text { day } \\
\\
\text { Body length } \\
\leq 300 \mathrm{mg} \text { caffeine/day vs } \\
>300 \mathrm{mg} / \text { day } \\
\\
\text { Head circumference } \\
\leq 300 \mathrm{mg} \text { caffeine/day vs } \\
>300 \mathrm{mg} / \text { day }\end{array}$ & $\begin{array}{l}\text { A small study with selected population and low } \\
\text { power. Data concerning each dose level not given. } \\
\text { No information about determination of gestational } \\
\text { age given. }\end{array}$ \\
\hline
\end{tabular}




\begin{tabular}{|c|c|c|c|c|c|}
\hline $\begin{array}{l}\text { Reference } \\
\text { Type and location of study }\end{array}$ & Sample size and selection & $\begin{array}{l}\text { Exposure period consi- } \\
\text { dered } \\
\text { Sources of caffeine }\end{array}$ & $\begin{array}{l}\text { End-point(s) } \\
\text { Definitions }\end{array}$ & $\begin{array}{l}\text { Results } \\
\text { Risk estimate: adjusted odd ratios, } \\
\text { including 95\% confidence interval } \\
\text { (NS = non significant) }\end{array}$ & Comments \\
\hline $\begin{array}{l}\text { Fortier et al., } 1993 \\
\text { Retrospective cohort study } \\
\text { Canada }\end{array}$ & 7025 women & $\begin{array}{l}\text { First } 16 \text { weeks and the } \\
\text { rest of the pregnancy } \\
\text { Coffee, tea, chocolate, } \\
\text { and colas }\end{array}$ & $\begin{array}{l}\text { Intrauterine growth } \\
\text { retardation }=10^{\text {th }} \\
\text { percentile adjusted } \\
\text { for sex and ges- } \\
\text { tational age. } \\
\text { Low birth weiht }= \\
<2500 \mathrm{~g}\end{array}$ & $\begin{array}{l}\text { Intrauterine growth retardation } \\
0-10 \mathrm{mg} \text { caffeine/day vs } \\
11-150 \mathrm{mg} / \mathrm{day} \\
151-300 \mathrm{mg} / \mathrm{day} \\
>300 \mathrm{mg} / \mathrm{day} \\
\\
\text { Low birth weight } \\
0-10 \mathrm{mg} \text { caffeine/day vs } \\
11-150,151-300,>300 \mathrm{mg} / \text { day }\end{array}$ & $\begin{array}{l}\text { Inconsistent results for low birth weight and intraute } \\
\text { rine growth retardation. It was few "heavy" consu- } \\
\text { mers. }\end{array}$ \\
\hline $\begin{array}{l}\text { Larroque et al., } 1993 \\
\text { Prospective cohort study } \\
\text { France }\end{array}$ & 628 women & $\begin{array}{l}1^{\text {st }} \text { trimester } \\
\text { Coffee, tea, cocoa and } \\
\text { cola }\end{array}$ & $\begin{array}{l}\text { Birth weight (mean } \\
\text { difference) adjusted } \\
\text { for gestational age } \\
\text { and infant sex }\end{array}$ & $\begin{array}{l}\text { Birth weight } \\
\leq 400 \mathrm{mg} \text { caffeine/day vs } \\
401-800 \mathrm{mg} / \mathrm{day},>800 \mathrm{mg} / \mathrm{day} \\
\text { Linear trend: } \\
\text { (borderline significance for non-smoking women) }\end{array}$ & $\begin{array}{l}\text { Definition of control group questionable. Only } 1^{\text {st }} \\
\text { trimester consumption for some women, and only } \\
\text { third trimester consumption for others. }\end{array}$ \\
\hline $\begin{array}{l}\text { Mills et al., } 1993 \\
\text { Prospective multi centre } \\
\text { cohort study } \\
\text { USA }\end{array}$ & $\begin{array}{l}431 \text { pregnant women } \\
\text { enrolled either before or } \\
\text { within } 21 \text { days of con- } \\
\text { ception }\end{array}$ & $\begin{array}{l}\text { During pregnancy at } 5 \text {, } \\
6,8,10 \text {, and } 12 \text { weeks } \\
\text { of gestation } \\
\text { Coffee (regular or } \\
\text { decaffeinated)tea, } \\
\text { cocoa, cola drinks, } \\
\text { drugs }\end{array}$ & $\begin{array}{l}\text { Intrauterine growth } \\
\text { retardation, head } \\
\text { circumference, and } \\
\text { crown-rump length } \\
\text { (ultrasonographic } \\
\text { indicator of early } \\
\text { foetal growth) }\end{array}$ & $\begin{array}{l}\text { Intrauterine growth retardation } \\
0 \mathrm{mg} \text { caffeine/day vs } \\
1-99,100-199,200-299, \\
\geq 300 \mathrm{mg} \text { caffeine/day } \\
\\
\text { Head circumference } \\
0 \mathrm{mg} \text { caffeine/day vs } \\
1-99,100-199,200-299, \\
\geq 300 \mathrm{mg} \text { caffeine/day } \\
\\
\text { Crown-rump length } \\
0 \mathrm{mg} \text { caffeine/day vs } \\
1-99,100-199,200-299 \\
\geq 300 \mathrm{mg} \text { caffeine/day } \\
\end{array}$ & $\begin{array}{l}\text { Very low caffeine exposure among studied women. } \\
\text { The studied population was not representative for } \\
\text { the general population. Gestational age was ade- } \\
\text { quately measured, but the study has inadequate } \\
\text { power to detect significant effects on studied para- } \\
\text { meters. }\end{array}$ \\
\hline $\begin{array}{l}\text { Shu et al., } 1995 \\
\text { Prospective Study } \\
\text { USA }\end{array}$ & 712 pregnancies & $\begin{array}{l}\text { All three trimesters } \\
\text { Coffee, tea and caffei- } \\
\text { nated soft drinks }\end{array}$ & $\begin{array}{l}\text { Mean birth weight } \\
\text { adjusted for gesta- } \\
\text { tional age (analysed } \\
\text { by each trimester) }\end{array}$ & $\begin{array}{l}\text { Mean birth weight }\left(1^{\text {st }}, 2^{\text {nd }} \text { or } 3^{\text {rd }} \text { trimester }\right) \\
0 \mathrm{mg} \text { caffeine/day vs } \\
1-49,50-199,200-299, \geq 300 \mathrm{mg} / \text { day }\end{array}$ & $\begin{array}{l}\text { Very few patients in higher exposure groups. } \\
\text { Smoking not treated as a continuos variable. }\end{array}$ \\
\hline $\begin{array}{l}\text { Cook et al., } 1996 \\
\text { (data from Brooke et al., } \\
\text { 1989) } \\
\text { Prospective population- } \\
\text { based study } \\
\text { Great Britain }\end{array}$ & $\begin{array}{l}640 \\
\text { women booking for } \\
\text { delivery 1982-84 }\end{array}$ & $\begin{array}{l}\text { At booking, and at } 27^{\text {th }} \\
\text { and } 35^{\text {th }} \text { week of } \\
\text { gestation } \\
\text { Coffee, tea, cola and } \\
\text { cocoa }\end{array}$ & $\begin{array}{l}\text { Birth weight adju- } \\
\text { sted for gestational } \\
\text { age, infant sex, } \\
\text { parity, maternal } \\
\text { height. } \\
\text { Blood con- } \\
\text { centration of } \\
\text { caffeine }\end{array}$ & $\begin{array}{l}\text { Birth weight } \\
\text { Increase of caffeine intake with } 1000 \mathrm{mg} / \text { week: } 1.3 \% \text { reduction } \\
\text { in birth weight (confidence interval } 95 \% \text { 0.5-2.1\%). The effect } \\
\text { being most apparent in smokers. } \\
\text { Blood caffeine concentrations } \\
\text { Unrelated to birth weight }\end{array}$ & Gestational age adequately determined. \\
\hline
\end{tabular}




\begin{tabular}{|c|c|c|c|c|c|c|}
\hline $\begin{array}{l}\text { Reference } \\
\text { Type and location of study }\end{array}$ & \begin{tabular}{|l} 
Sample size and selection \\
\end{tabular} & $\begin{array}{l}\text { Exposure period consi- } \\
\text { dered } \\
\text { Sources of caffeine }\end{array}$ & $\begin{array}{l}\text { End-point(s) } \\
\text { Definitions }\end{array}$ & \begin{tabular}{|l|} 
Results \\
Risk estimate: adjusted odd ratios, \\
including 95\% confidence interval \\
(NS = non significant)
\end{tabular} & & Comments \\
\hline $\begin{array}{l}\text { Vlajinac et al., } 1997 \\
\text { Retrospective study } \\
\text { Yugoslavia }\end{array}$ & 1011 women & $\begin{array}{l}\text { All trimesters (but only } \\
\text { results from } 3^{\text {rd }} \text { tri- } \\
\text { mester are presented) } \\
\text { Coffee, tea and cola }\end{array}$ & $\begin{array}{l}\text { Birth weight adju- } \\
\text { sted for gestational } \\
\text { age, infant sex, } \\
\text { parity, maternal } \\
\text { height and } \\
\text { length }\end{array}$ & $\begin{array}{l}\text { Birth weight } \\
\text { Non smoking mothers only } \\
0-10 \mathrm{mg} \text { caffeine/day vs } \\
11-70,71-140, \geq 141 \mathrm{mg} / \text { day } \\
\text { Across groups: } \\
\text { Linear trend: } \\
\\
\text { All women or smoking mothers only } \\
0-10 \mathrm{mg} \text { caffeine/day vs } \\
11-70,71-140, \geq 141 \mathrm{mg} / \text { day } \\
\text { Across groups: } \\
\text { Linear trend: }\end{array}$ & $\begin{array}{l}p=0.035 \\
p=0.006\end{array}$ & $\begin{array}{l}\text { No information about caffeine intake from chocola- } \\
\text { te, cocoa and drugs available. Very low consump- } \\
\text { tion levels of caffeine compared with other studies. } \\
\text { Potential confounders are not clearly presented. }\end{array}$ \\
\hline $\begin{array}{l}\text { Santos et al., 1998a } \\
\text { Multi centre case-control } \\
\text { study } \\
\text { Brazil }\end{array}$ & $\begin{array}{l}401 \text { cases (children with } \\
\text { birth weight }<2500 \mathrm{~g} \\
\text { and gestational age } \geq 28 \\
\text { weeks) and } 804 \text { controls }\end{array}$ & $\begin{array}{l}\text { During each trimester } \\
\text { Coffee, mate, } \\
\text { tea, chocolate, soft } \\
\text { drinks, } \\
\text { and medicines }\end{array}$ & $\begin{array}{l}\text { Intrauterine growth } \\
\text { retardation = birth } \\
\text { weight }<2500 \mathrm{~g} \\
\text { (low birth weight) } \\
\text { and gestation age } \\
<37 \text { weeks }\end{array}$ & $\begin{array}{l}\text { Low birth weight } \\
<100 \mathrm{mg} \text { caffeine/day } \\
100-299, \geq 300 \mathrm{mg} / \text { day } \\
\\
\text { Intrauterine growth retardation } \\
<100 \mathrm{mg} \text { caffeine/day } \\
100-299, \geq 300 \mathrm{mg} / \text { day }\end{array}$ & $\begin{array}{l}\text { NS } \\
\text { NS }\end{array}$ & $\begin{array}{l}\text { Same patients used more than once in the study. } \\
\text { Selection of controls could be questioned. Con- } \\
\text { sumption of caffeinated beverages poorly reported. } \\
\text { Mean caffeine intake very low. Quantity of smoking } \\
\text { not reported. Gestational age determined by the } \\
\text { method of Capurro (1978). Still births } \leq 28 \text { weeks } \\
\text { included. }\end{array}$ \\
\hline $\begin{array}{l}\text { Grosso et al, } 2001 \\
\text { Cohort study } \\
\text { USA }\end{array}$ & $\begin{array}{l}2714 \text { women delivering } \\
\text { a live born infant }\end{array}$ & $\begin{array}{l}\text { Exposure data from } 1^{\text {st }} \\
\text { and } 3^{\text {rd }} \text { trimesters } \\
\text { collected after delivery } \\
\text { Coffee, tea, soda } \\
\text { drinks }\end{array}$ & $\begin{array}{l}\text { Intrauterine growth } \\
\text { retardation = } \\
\leq 10^{\text {th }} \text { percentile for } \\
\text { gestational age at } \\
\text { birth }\end{array}$ & $\begin{array}{l}\text { Intrauterine growth retardation } \\
0 \mathrm{mg} \text { caffeine/day vs } \\
1-150,151-300,>300 \mathrm{mg} / \text { day }\end{array}$ & NS & $\begin{array}{l}\text { Mean intake of caffeine was very low, many women } \\
\text { had none. Selection bias of study base possible. } \\
\text { Gestational age determined by the method of } \\
\text { Ballard et al. (1979). }\end{array}$ \\
\hline $\begin{array}{l}\text { Clausson et al, } 2002 \\
\text { Prospective cohort study } \\
\text { Sweden }\end{array}$ & $\begin{array}{l}873 \text { women delivering a } \\
\text { live born infant }\end{array}$ & \begin{tabular}{|l|} 
Exposure from 4 \\
weeks before until 34 \\
weeks after pregnancy \\
Coffee, tea, chocolate, \\
soft drinks and medi- \\
cines
\end{tabular} & \begin{tabular}{|l|} 
Birth weight, \\
gestational age at \\
delivery, birth weight \\
standardized for \\
gestational age \\
(birth weight ratio) \\
\end{tabular} & $\begin{array}{l}\text { Birth weight } \\
0-99 \mathrm{mg} \text { caffeine/day vs } \\
100-299,300-499,>500 \mathrm{mg} / \mathrm{day} \\
\\
\text { Gestational age and birth weight ratio } \\
0-99 \mathrm{mg} \text { caffeine/day vs } \\
100-299,300-499,>500 \mathrm{mg} / \text { day } \\
\end{array}$ & NS & $\begin{array}{l}\text { Well performed study in which gestational age was } \\
\text { determined by ultrasound scan. }\end{array}$ \\
\hline
\end{tabular}


The influence of caffeine intake and cigarette use during pregnancy on foetal growth (birth weight, head circumference, birth length and placental weight) was explored in another Canadian study (Beaulac-Baillargeon and Desrosiers, 1987). This was a cohort study based on 913 newborn Canadian infants. Sources used for calculation of total caffeine consumption were coffee, tea, cola, and chocolate. A significant relationship between the mother's caffeine intake and cigarette smoking and birth weight (after adjusting for gestational length and sex) was found. The birth weight was $206 \mathrm{gm}$ ( $\pm 57.7 \mathrm{gm}$ ) lower for babies whose mothers consumed at least $300 \mathrm{mg}$ caffeine per day and smoked at least 15 cigarettes per day (Table 55). The caffeine intake was also found to affect placental weight, which increased with cigarette consumption among women who consumed less than $300 \mathrm{mg}$ of caffeine daily, but not among women with a higher caffeine intake. Head circumference and length at birth were affected only by cigarette smoking. The authors concluded that concomitant exposure to caffeine and cigarette smoke influence birth and placental weights. When interpreting the results of this study it should be noted that the "heavy" consumers were relatively few $(14.8 \%$ of the study sample), and that not all subjects were interviewed regarding caffeine consumption. Furthermore, caffeine consumption was dichotomised (cut off point $300 \mathrm{mg}$ ) and the time period of registering caffeine intake was not specified. The statistical analysis was not adjusted for factors such as pre pregnancy weight and maternal age, which could contribute to confounding the studied association. In addition, no information regarding the determination of gestational age has been provided.

Data from the Ottawa prenatal study, mentioned above, has been used by Fried and O'Connell (1987) in order to study the relationship between maternal usage of cigarettes, alcohol, cannabis, and caffeine during specified time periods of pregnancy (before pregnancy, first trimester, third trimester, and average use over pregnancy) and defined growth parameters (birth weight, birth length, head circumference, length of gestation etc) of the offspring. The sample group assessed at birth were selected and consisted of 667 infants and their mothers. 123 mothers and their offspring were followed up at 12 and 24 months of age. Average daily consumption of caffeine was calculated according to the number and size of servings of coffee, tea, cola beverages, and intake of unspecified dietary sources of caffeine during pregnancy. The average daily intake of caffeine (mg) during pregnancy was $107 \pm 131 \mathrm{mg}$ in the original sample and $148 \pm 213 \mathrm{mg}$ in the follow-up group. No significant negative influence was noted on any of the growth parameter studied (Table 55). Since the number of mother/offspring pairs studied was not high enough, the number of women having a high caffeine intake was low. It should be noted that not all subjects were asked about their consumption of caffeine. The study also failed to control for a previous history of complicated 
pregnancy. Finally, no information about the determination of gestational age is given in the study.

Martin and Bracken (1987) carried out a prospective study on 3891 antenatal patients at Yale-New Haven Hospital between 1980 and 1982. Average daily exposure of caffeine during the first trimester of pregnancy was estimated from information on consumption of coffee, tea, and caffeine-containing colas and drugs obtained in interviews with each participant at her first prenatal visit to the doctor. Caffeine contents per serving for coffee, tea, and colas were estimated to 107,34 , and $47 \mathrm{mg}$, respectively. The relationships between caffeine intake $(0,0-150,151-300$, or $>300 \mathrm{mg}$ /day) and mean birth weight, mean gestational age, rates of low birth weight $(<2500 \mathrm{~g})$, pre-term delivery ( $<37$ weeks of gestation), and intrauterine growth retardation were investigated in the study. Intrauterine growth retardation was examined using the rate of low birth weight in term deliveries.

About one fourth of the participants had no caffeine intake, whereas 8 $\%$ of the population ingested more than $300 \mathrm{mg}$ of caffeine daily. Most participants consumed small amounts of caffeine. Caffeine increased in a dose-dependent manner the risk for delivering a singleton new born with a low birth weight (less than 2,500 g) (Table 55). This association was observed in deliveries after 36 weeks gestational age only. At the highest intake level, over $300 \mathrm{mg}$ caffeine per day, the relative risk was $4.6(95 \%$ CI 2.0-10.5) after adjusting for confounding factors. Infants born to these women had an adjusted mean decrease in birth weigh of $105 \mathrm{~g}$. The other endpoints studied (mean gestational age, intrauterine growth retardation, and pre-term delivery) were unrelated to caffeine intake. The caffeine intake from chocolate and cocoa was missing. It should also be noted that only caffeine intake during the first trimester was investigated in this study, and that no information was obtained on the quantity of cigarettes smoked. Smoking was adjusted for only on the information smoking/nonsmoking. It should also be stressed that intrauterine growth retardation was limited to term deliveries. In addition, gestational age was determined from the last menstrual period, although ultrasonographic examination is regarded to be a much more reliable method.

The effect of various parameters on birth weight has also been investigated by a British prospective population study from inner London (Brooke et al., 1989). The recruited participants were 1513 of 1860 white women booking for delivery. The rest refused to participate or failed to complete the study for other reasons. Information on caffeine intake was obtained in interviews on consumption of coffee, tea, cocoa, and cola drinks at the 28th and 36 week of gestation, and was related to the week before interview. Total caffeine consumption per week was estimated on the basis that a cup of coffee contained $85 \mathrm{mg}$, a cup of tea $50 \mathrm{mg}$, a cup of cocoa $5 \mathrm{mg}$, and a drink of cola $40 \mathrm{mg}$. Gestational age was determined from the last menstrual period and by ultrasonographic exami- 
nation. After adjusting for gestational age and controlling for maternal height, parity, maternal smoking, and the sex of the baby, the total intake of caffeine from coffee, tea, and cola showed no association with birth weight (Table 55). The authors concluded that the main environmental cause of birth weight variation in this population was smoking.

The data of Brook et al. (1989) related to smoking women has subsequently been used in a prospective London-based study investigating the influence of alcohol and caffeine exposure at three stages of pregnancy on the birth weight of infants to smoking women (Peacock et al., 1991). Included in the study were 414 women who smoked and who completed all pregnancy interviews. The number and brand of cigarettes smoked, and the quantity of alcohol and caffeine ingested, were obtained by interview at booking, and at 28 and 36 weeks of gestation. Regarding caffeine, the intake of coffee, tea, cocoa and cola was recorded for the previous week at these points in pregnancy, and the intake calculated using the methods of Brook et al. (1989). The authors concluded that the results of the study indicate that heavy smoking in combination with heavy drinking and high intakes of caffeine could enhance the risk of poor foetal growth even more than heavy smoking alone. The amount smoked in terms of quantity and brand could not explain the effect of alcohol consumption on birth weight (corrected for gestational age and adjusted for maternal height, sex of infant and parity). The effect of caffeine was also independent of smoking. When alcohol, caffeine, and smoking were analysed together, alcohol and caffeine were both associated with more pronounced reductions in birth weight. Caffeine was associated with a reduction of up to $6.5 \%$ after adjusting for tobacco and alcohol intake. Heavy smoking ( $>13$ cigarettes/day) and heavy drinking ( $\geq 100 \mathrm{~g}$ alcohol/week) in combination with a high caffeine intake ( $\geq 400 \mathrm{mg} /$ day) resulted in a predicted reduction in mean birth weight of $18 \%$. These effects were strongest when consumption early in pregnancy was considered, and weakest for consumption just before delivery. It might be difficult to entangle to what extent the information on alcohol and caffeine consumption leads to a quantitative diversification of smoking within the three smoking categories used, thereby producing an apparent reduction in birth weight.

Data from the prospective study of Brooke et al. (1989) have been used by Cook and co-workers (1996) to examine the correlation between foetal growth and either caffeine intake or plasma levels of caffeine in women during pregnancy. Stored plasma from the study of Brooke et al. (1989) was available for 1500 women who had provided a blood sample on at least one occasion, and for 640 women who had provided a sample on all three occasions (at booking, 28 weeks, and 36 weeks). The final analysis included 640 women, of whom 500 were non-smokers and 140 smokers. Blood levels of caffeine and cotinine (a biomarker for cigarette smoking) were analysed by a sensitive gas chromatographic technique in 
1994. Blood levels of caffeine rose by $75 \%$ during pregnancy, though caffeine intake showed no changes during the same period. The caffeine intake increased steadily with increasing cotinine concentration above 15 $\mathrm{ng} / \mathrm{ml}$. Nonetheless, the blood caffeine concentrations fell. It was concluded that smokers consume more caffeine than non-smokers, but their caffeine metabolism is faster, resulting in lower blood concentrations. Blood caffeine concentrations during pregnancy were not related to foetal growth, whereas the caffeine intake was negatively associated with birth weight, but only in smokers (Table 55). The effect remained of borderline significance after adjustment for other factors (gestational age, maternal height, parity, and sex of infant). According to the authors, prudent advice for pregnant women would be to reduce caffeine intake in conjunction with stopping smoking. By limiting the chemical analysis to measurements of only caffeine (and no metabolites of caffeine), the time period between last consuming caffeine-containing beverages and the time of blood collection will heavily influence the biomarker used to approximate caffeine exposure.

From a large Californian cohort of 9564 women in the Kaiser Permanent Medical Care Program (a cohort originally recruited to investigate the potential adverse pregnancy outcome of aerial malathion) 131 cases and 136 controls were selected to participate in a case-control study investigating the influence of maternal caffeine exposure in the first trimester of pregnancy on birth weight of infants (Caan and Goldhaber, 1989). Cases were defined as women who had given birth either to babies weighing less than two standard deviations lower than the mean birth weight due to intrauterine growth retardation $(n=97)$, or women having babies weighing 2500 grams or less but without growth retardation $(n=34)$. Caffeine intake was calculated from retrospective information on daily consumption of coffee, tea, and soft drinks during the first trimester. The interviews were performed after completed pregnancy. There was no significant association between high caffeine intakes ( $>300 \mathrm{mg} /$ day) or heavy consumption (greater than 3 servings/day) of coffee or tea or cola drinks and an increased risk of giving birth to a child with low birth weight, although a non-significant trend could be recognised (Table 55). The authors conclude that their data support previous findings of a modest, though not statistically significant effect of caffeine consumption on foetal growth. The study contains a number of weaknesses: no description of how cases and controls were selected; a small study base; a design making recall bias possible; investigating caffeine intake only during first trimester; and no accurate quantification of the confounding factor of smoking. It should also be noted that gestational age was determined from the last menstrual period.

A case control study was carried out on 1230 women giving birth to singleton live infants in California, USA, during the period 1986-1987, in order to examine the association between maternal caffeine intake and 
low birth weight $(<2500 \mathrm{~g})$, intrauterine growth retardation $\left(<10^{\text {th }}\right.$ percentile of mean weight at each gestational week using Californian standard), and prematurity (Fenster et al., 1991). The participants were interviewed on average nine months after birth regarding their consumption of coffee, tea, and soft drinks during the month before pregnancy, if it changed during pregnancy, and if so, when and to what extent. This information was used to calculate each participant's average caffeine intake during the first trimester. The calculation of caffeine intake was based on the assumptions that a cup of coffee contained $107 \mathrm{mg}$ caffeine, a cup of tea $34 \mathrm{mg}$ caffeine, and soft drinks $47 \mathrm{mg}$ caffeine/can. The adjusted odds ratio for low birth weight at heavy maternal caffeine consumption was elevated but not statistically significantly so (Table 55). On the other hand, the adjusted odds ratio for intrauterine growth retardation in infants of women reporting heavy caffeine consumption was significantly increased. Furthermore, the increase was dose-dependent. Women who reduced their caffeine intake from greater than $300 \mathrm{mg} /$ day to less than that early in pregnancy had no increased risk of giving birth to infants with intrauterine growth retardation or low birth weight compared to women who continued to consume that amount. The main drawback in this inconsistent study (IUGR affected but not LBW) was that only caffeine intake during the first trimester was investigated. It should also be noted that gestational age was determined from the last menstrual period.

Smoking prevalence and intake of caffeine and alcohol during pregnancy, as well as the relation of these factors to birth weight, length, and head circumference, was investigated in a Canadian prospective cohort study (Godel et al, 1992). The selected participants were 162 women (56 Inuit, 38 Indian, 37 white and 31 of mixed race) who sought prenatal care in their community and gave birth between September 1987 and January 1990. The women's caffeine intake was estimated from answers to questionnaires, and assumed one serving of coffee to contain $120 \mathrm{mg}$ caffeine, one serving of tea $65 \mathrm{mg}$ caffeine, and one serving of cola 35 $\mathrm{mg}$ caffeine. Of the investigated women, 64\% (101/159) smoked, 57\% (88/154) ingested more than $300 \mathrm{mg}$ of caffeine daily, and 34\% (50/145) drank alcohol during their pregnancy. Smoking, caffeine intake, and binge drinking were reported most frequently by the Inuit and Indian mothers. Although no data was given on specific consumption categories and the number of women in each category of consumption, a decreased birth weight and birth length (both poorly defined) was reported to be significantly associated with smoking. Alcohol intake, especially binge drinking, was significantly related to decreased head circumference. In contrast, caffeine intake was not related to any of the outcome variables after smoking was controlled for (Table 55). Because of its poor quality, this study has a negligible impact on the assessment of a potential relationship between foetal growth retardation and intake of caffeine. 
A Canadian retrospective study carried out in 1989 aimed at assessing the relationship between caffeine intake during pregnancy and intrauterine growth retardation (birth weight lower than the $10^{\text {th }}$ percentile of the sex-specific and gestational age-specific distribution of birth weight according to Canadian standards), pre-term birth (birth before 37 completed weeks of pregnancy), and low birth weight $(<2500 \mathrm{~g})$. The study also evaluated the interaction of smoking with the studied outcomes (Fortier et al., 1993). 7025 women who lived in and around Quebec City and who had given birth to a singleton live born neonate were included in the study. Gestational age was determined from the last menstrual period and by ultrasonographic examinations. Caffeine intake from coffee, tea, chocolate, and colas was registered during two periods of pregnancy: the first 16 weeks and the rest of the pregnancy. These and other data were obtained by telephone interviews a few weeks after delivery. Caffeine consumption was associated with an increased risk of intrauterine growth retardation. For participants whose average daily caffeine intake was $0-10,11$ $150,151-300$, or $>300 \mathrm{mg}$, the adjusted odds ratios for giving birth to an infant with growth retardation increased in a dose dependent manner (Table 55). An interaction between caffeine exposure and smoking was noted. Drinking only decaffeinated coffee was not related to intrauterine growth retardation, which might indicate that the association with intrauterine growth retardation does not reflect an effect of coffee per se. There was no relationship between caffeine intake and low birth weight or preterm delivery. Shiono and Klebanoff (1993) have pointed out that the methodology of retrospectively collecting data could lead to inaccurate recall of caffeine consumption. Very few consumers in this study (around 4\%) ingested more than $300 \mathrm{mg}$ caffeine a day. Furthermore, the results were inconsistent, as the intrauterine growth retardation was influenced by high caffeine intakes by women, yet did not result in low birth weight.

Larroque et al. (1993) carried out a study on 628 women in order to investigate the influence of women's alcohol and caffeine consumption during pregnancy on the birth weight (adjusted for gestational age) of their infants. The interaction of smoking with the studied endpoints was also studied. The women were interviewed at their first visit to the maternity hospital in Roubaix, France, and included many heavy consumers of alcohol and caffeine, and both smokers and non-smokers. Gestational age was determined from the last menstrual period and by ultrasonographic examinations. Information on the intake of coffee, tea, cocoa, and cola drinks usually during the first trimester were converted to $\mathrm{mg}$ caffeine, assuming one cup or glass of the beverage to contain 110, 40, 5, and 40 $\mathrm{mg}$ caffeine, respectively. Some of the women, however, were asked about their beverage consumption during the third trimester. The total caffeine intake of women was classified as $\leq 400,401-800$ and $>800 \mathrm{mg}$. After adjustment for cigarette smoking, gestational age, infant sex, maternal age, parity, level of education and maternal height and weight, no 
relationship was noted between high caffeine intakes and lower birth weight. A decreasing but non-significant trend in birth weight was observed in deliveries of non-smoking women who had a high intake of caffeine. Shiono and Klebanoff (1993) have pointed out that very few women consumed no caffeine (6\%) and that 457 of the 628 women studied ingested less than $400 \mathrm{mg}$ caffeine per day. Since this was the lowest category of caffeine intake, it was used as the reference group when calculating the relative risk of low birth weight. Another categorisation of the exposure parameter might have given rise to another result. An obvious problem with the exposure parameter was that it differed in time between the women (first and third trimester, respectively).

Mills and co-workers (1993) studied the relationship between caffeine intake during pregnancy and the occurrence of spontaneous abortion and intrauterine growth retardation in a highly educated cohort of 431 women. The women originally participated as the non-diabetic control population in an American Diabetes study (a multicentre collaborative study conducted between 1980 and 1985), and were enrolled in the study either before pregnancy or within 21 days of conception. They were followed throughout pregnancy to determine: (1) caffeine exposure, (2) exposure to other risk factors, (3) foetal growth as assessed by ultrasonography, and (4) pregnancy outcome (spontaneous abortion, birth weight percentiles (BW) as a mean to assess intrauterine growth rate (defined as falling into a lower birth weight percentile specific for sex, race and gestational age in the United States), head circumference (HC, defined according to Swedish standards adjusted for gestational age and sex), and crown-rump length (CRL, assessed according to Robinson standard to measure early foetal growth)). The information used to calculate current caffeine intake from regular coffee, decaffeinated coffee, hot tea, cocoa, iced tea, regular cola drinks, diet cola drinks, or other diet drinks during the first-trimester was ascertained at the time of pregnancy diagnosis five weeks after the last menstrual period, as well as later during pregnancy (at 5, 6, 8, 10, and 12 weeks after the last menstrual period). For the calculation of caffeine intake, coffee was assigned a caffeine level of $100 \mathrm{mg}$; tea, $40 \mathrm{mg}$; decaffeinated coffee, $1.5 \mathrm{mg}$; cocoa, $13 \mathrm{mg}$, and cola, $40 \mathrm{mg}$. The major source of caffeine in the studied population was coffee $(59.5 \%)$, followed by tea $(20.5 \%)$, cola $(19.1 \%)$, cocoa $(0.5 \%)$, and decaffeinated coffee $(0.3 \%)$.

High intakes of caffeine $(>300 \mathrm{mg} /$ day) affected neither early foetal growth, assessed by crown-rump length on ultrasonographic examination, nor the proportion of babies with birth weights and head circumferences below the 10th percentile after other risk factors (notably smoking) were controlled for (Table 55). It should be noted that very few women $(n=13)$ consumed more than $300 \mathrm{mg}$ caffeine daily, and not many $(\mathrm{n}=30) 200$ $299 \mathrm{mg}$ caffeine daily, making it difficult or even impossible to draw conclusions about the higher intake levels. In fact, the majority was consuming less than $100 \mathrm{mg}$ daily. Measurements of crown-rump length 
during the first trimester of pregnancy as a marker for intrauterine growth have been questioned, as most of the growth occurs during the second trimester. The statistical calculations were not adjusted for nausea during pregnancy.

Shu et al. (1995) investigated the association between maternal smoking, alcohol, and caffeine consumption and foetal growth in a prospective study comprising 712 pregnancies. To obtain required information, for example information needed to calculate the exposure to caffeine (from coffee, tea and caffeinated soft drinks) during the first trimester of pregnancy, patients were interviewed by telephone upon entering pre-natal care (on average around 13 weeks into pregnancy). Gestational age was determined from the last menstrual period or by ultrasonographic investigation. Information was updated for later trimesters by mailed questionnaires at 28 weeks and 36 weeks of gestation. To perform the calculation of exposure from information on consumption, the investigator assigned a caffeine level of $100 \mathrm{mg}$ for a cup of coffee and $45 \mathrm{mg}$ for a cup of tea or a 12-ounce can of caffeinated soft drink. After adjusting for confounders, there was no correlation between caffeine intake and foetal growth. Nor were any of the sources of caffeine (coffee, tea or soft drinks) substantially related to birth weight or foetal growth (Table 55). As in many of the other epidemiological studies mentioned in this report, the group with a high caffeine exposure ( $\geq 300 \mathrm{mg} /$ day) was very small (4 women throughout pregnancy).

A study performed in Belgrade, in former Yugoslavia, examined the effect of women's caffeine consumption (and its possible interaction with smoking) during pregnancy on the birth weight of the newborn (Vlajinac et al., 1997). The participating 1011 women were interviewed during their first 3 days after delivery. The mothers were asked to estimate the frequency and amount of intake of coffee, tea, and cola drinks during each trimester of pregnancy. A cup of coffee and tea and a glass of a cola drink was considered to contain $70 \mathrm{mg}, 61 \mathrm{mg}$ and $26 \mathrm{mg}$ caffeine, respectively. Only results on data based on the third trimester were presented. Of the 1011 women participating in the study, 137 reported no caffeine intake during pregnancy. The mean intake in the other 874 women was low, only $133 \mathrm{mg}$. After adjustment for gestational age (adequately determined), infant sex, parity, and maternal height and weight, an average caffeine intake of as little as $\geq 71 \mathrm{mg}$ was associated with a significant reduction in birth weight (on average $116 \mathrm{~g}$ ) in non-smoking mothers (Table 55). The reduction in birth weight was dose dependent, being 153 $\mathrm{g}$ at an intake of $\geq 140 \mathrm{mg}$ caffeine. In comparison to other studies, the caffeine intake was very low in this study. No information about caffeine intake from chocolate, cocoa, and medicinal drugs was available. The reduction in birth weight was not statistically significant when both smoking and non-smoking women were included in the analysis. The presentation of potential confounders and how these have been controlled for in 
the statistical treatment of the data is not very clear in this publication. Such information is also required given the background of the chaotic conditions present in this part of Balkan during the period of the investigation.

A multicentre study with matched case-control design was conducted in Southern Brazil in order to investigate the effects of caffeine intake during pregnancy on the birth weight (Santos et al., 1998). Within the first 24 hours after delivery, the 1205 mothers (401 cases (with children with birth weight $<2,500 \mathrm{~g}$ and gestational age $\geq 28$ weeks) and 804 controls) were interviewed and their newborn children examined to assess birth weight and gestational age. The interview included questions on caffeine intake during each trimester of pregnancy. To assess caffeine intake, $10 \%$ of the mothers were re-interviewed at home, and samples of beverages (drip coffee and mate) collected and sent to the laboratory for caffeine determination by liquid chromatography. The analyses revealed that a cup of coffee contained between 19.8 and $45 \mathrm{mg}$ caffeine and a gourd of maté $10 \mathrm{mg}$ of caffeine. Exposure to caffeine from tea, chocolate, soft drinks, and medicinal drugs was estimated from a reference table. Conversion figures used were as follows: tea (depending on strength) 34$54 \mathrm{mg} / 180 \mathrm{ml}$ serving, drinking chocolate $4 \mathrm{mg} / 200 \mathrm{ml}$ serving, chocolate bars $20 \mathrm{mg} / 30 \mathrm{~g}$, and soft drinks $20 \mathrm{mg} / 200 \mathrm{ml}$ serving. Analyses were performed by conditional logistic regression. Cases on average ingested $148 \mathrm{mg}$ caffeine, and controls $146 \mathrm{mg}$. The statistical analysis showed that intake of caffeine had no effect on birth weight, pre-term births or intrauterine growth retardation (Table 55). The study has several limitations. The selection of controls could be questioned. The quantity of caffeine-containing beverages was poorly reported, and data from some individuals seems to have been used more than once in the study. Information concerning the quantification of smoking has not been reported. Finally, it may be noted that gestational age was determined by the method of Capurro et al (1978), which utilises a scoring system based on somatic and neurological signs.

Grosso et al (2001) investigated the effect of maternal caffeine consumption throughout pregnancy on foetal growth. The study comprised 2 714 women from the Yale Health in Pregnancy study who gave birth to a live born infant between 1988 and 1991. The study collected detailed information after delivering regarding coffee, tea, and soda drinking during the first and third trimesters of pregnancy. The authors estimated caffeine intake by assigning $107 \mathrm{mg}$ caffeine $/ 5 \mathrm{oz}$ cup of coffee, $34 \mathrm{mg}$ caffeine $/ 5 \mathrm{oz}$ cup of tea, and $47 \mathrm{mg}$ caffeine/ $12 \mathrm{oz}$ serving of soft drink. The total monthly caffeine consumption was calculated from these sources. The contribution of chocolate foods and drinks to the total caffeine consumption was negligible during the two months studied (month 1 and 7 of pregnancy). The outcome measured was intrauterine growth retardation, which was defined as $\leq 10^{\text {th }}$ percentile of birth weight for gestational 
age at birth. Gestational age was determined according to Ballard et al (1979), which is a simplified clinical scoring system for determining the maturation of newly born infants.

The study population comprised primarily non-smoking married white women. $40 \%$ of the participants abstained from coffee, tea, and soft drinks, while $45 \%$ of the participants consumed 1-150 mg caffeine per day. Coffee was the largest source of caffeine. Average caffeine intake during month 1 of pregnancy was higher than during month 7 (72.4 vs $54.0 \mathrm{mg}$ per day). Neither the consumption of $>300 \mathrm{mg}$ caffeine per day during the first month of pregnancy, nor that during month 7 was associated with intrauterine growth retardation. There was little evidence for any effect modification due to cigarette smoking on the caffeine associations. The authors concluded that their study provides evidence that prenatal caffeine consumption has no adverse effect on foetal growth. The most severe limitation of this study is that few women consumed more than $300 \mathrm{mg}$ caffeine daily, and that a considerable part of the study base did not drink the investigated caffeine beverages at all. Thus the study participants seem to be a very special group of women. Therefore, it may be difficult to use this study in order to draw general conclusions.

The latest study in this field investigated the effect of caffeine exposure during pregnancy on birth weight and gestational age in Swedish women (Clausson et al., 2002). The investigation was carried out as a prospective cohort study. The study participants were also recruited as controls in a case-control study of the relationship between early spontaneous abortion and caffeine consumption (Cnattingius et al., 2000). The study base was reviewed in chapter 12. Included in this study were 873 women delivering live born singleton infants. Information on caffeine consumption was obtained from in-person interviews performed on a week-by-week basis in the first trimester and biweekly in the second and third trimesters. Analysis of variance was used to estimate the effect of caffeine on birth weight, gestational age (determined by ultrasonographic examinations in the second trimester) at delivery, and birth weight standardized for gestational age (birth weight ratio). The calculations accounted for the effects of other co-variates such as maternal sociodemographic characteristics, plasma cotinine, and pregnancy symptoms. No associations were found between caffeine consumption $(0-\geq 500 \mathrm{mg} /$ day $)$ and birth weight, gestational age, and birth weight ratio (Table 55). The results did not change when caffeine exposure was averaged from conception to the 32nd to 34th gestational weeks, or when caffeine exposure was stratified by trimesters of pregnancy. The authors concluded that the results did not support an association between moderate (not defined) caffeine consumption and reduced birth weight, gestational age, or foetal growth.

The level of caffeine present in body fluids is dependent on the amount of caffeine consumed as well as on the caffeine elimination from 
the body. Caffeine is primarily metabolised by CYP1 2A to paraxanthine. Klebanoff et al. (2002) analysed the association between the thirdtrimester maternal serum concentration of paraxanthine and the delivery of a small-for-gestational age infant in 2515 women of the 2816 pregnancies enrolled in the Collaborative Perinatal Project from 1959 to 1966. In contrast to the serum concentration of caffeine, which exhibits a wide short-term fluctuation during the day depending on recent intake, the primary metabolite of caffeine, paraxanthine, fluctuates less. Small-forgestational age, defined as less than the tenth percentile for maternal ethnicity and infant gender. Among the 2515 studied pregnancies, 222 (8.8\%) children were small-for-gestational age and 2293 not small-forgestational age. Small-for-gestational age infants were more commonly born to women who smoked, women with fewer years of education, those with first births, and those who were younger, shorter, and lighter. The mean paraxanthine concentration in serum specimen drawn after 182 days gestation (a period of fast growth) was significantly higher among women who gave birth to small-for-gestational age infants compared with those who gave birth to infants that were not small-for-gestational age. When the serum paraxanthine level was categorized by level a statistically significant trend was observed among smokers but not among nonsmokers. The increased risk of delivery of a small-for-gestational age infant at high serum paraxanthine was confined to women who smoke, and adjustment for the actual number of cigarettes smoked per day did not change the results substantially.

As the study of Klebanoff et al. (2002) was planned quite a bit after the original Collaborative Perinatal Project cohort, it is understandable that several caveats can be pointed out. One is that the biological samples had been stored at $-20^{\circ} \mathrm{C}$ for 30 years, and the stability of paraxanthine during this time period at these conditions is not well known. Being the primary metabolite of caffeine in humans, the serum paraxanthine level was used as a biomarker for biological dose of caffeine, because the level fluctuates less throughout the day than does the serum level of caffeine. Therefore, it is possible that some of the women would have been allocated to other exposure groups if caffeine had been analysed instead of paraxanthine. Although very little is known about the stability of paraxanthine over 30 years in frozen serum, there are no strong indication that paraxanthine has deteriorated. As non-smokers metabolise caffeine less rapidly than do smokers, the serum paraxanthine concentration is higher among non-smokers than among smokers. Whereas the interaction between intake of caffeine and smoking is well established, the interaction between smoking and serum paraxanthine might differ. The mechanism for a caffeine-tobacco interaction is however unclear. An obvious weakness with the study is the fact that only one measurement of serum paraxanthine was available from each participating women, and this sample might not be representative for the general caffeine exposure, as the 
single measurement of paraxanthine is a marker of short-term caffeine intake.

\subsection{Foetal growth retardation in relation to intake of caffeine-containing beverages}

The studies are reviewed in a chronological order in order to facilitate reading. If a study has been previously presented in section 15.1, only additional information of importance will be given here. It should be noted that in the description of the studies, parameters other than those primarily related to foetal growth retardation would not be referred to in this section.

One of the earliest published studies dealing with the relationship between caffeinated beverages and low birth weight (defined as $\leq 2500$ grams or $<10^{\text {th }}$ percentile) was the prospective cohort study by Mau and Netter (1974). Their study base consisted of 5200 pregnant women having attended 20 German clinics for gynecology and pediatrics. The women were interviewed regarding intake of coffee and alcohol during the first trimester of their pregnancy. However, no quantitative data (cups/day) were collected. Instead the frequency of consumption was described as "never", "seldom", or "often". The results of the study were as follows (Table 56). Pregnant women who often consumed large amounts of coffee delivered infants with a low birth weight, according to both definitions of low birth weight. For various reasons (coffee consumption and smoking poorly quantified, data only from first trimester, non-adequate control for confounding factors) this study has very little value for the assessment of a potential relationship between coffee intake and foetal growth retardation.

Data from the Child Health and Development Studies performed in Oakland, California 1960-1967 were used by van den Berg (1977) to investigate the relationship between birth weight, length of gestation, and coffee consumption. Among the 15000 interviewed gravidas, $67 \%$ were white, 23\% black, 3\% Mexican-American, 4\% Oriental and another 3\% were of other ethnic backgrounds. A simple and practical classification of prematurity according to birth weight and gestation was proposed, utilising as points of separation 2500 grams and 37 weeks (Yerushalmy, 1967). Newborn infants were thus divided into four groups: 1) premature by both criteria, 2) premature by birth weight, but mature by length of gestation, 3) mature by birth weight but premature by gestation, and 4) mature by both criteria. There were a large proportion of smokers (65\%) among the heavy coffee drinkers, defined as those drinking at least 7 cups/day. The combination of heavy coffee consumption and smoking resulted in 9\% infants weighing 2500 grams or less, whereas this percentage was 4.4 among non-smoking heavy coffee consumers. Excessive 
consumption of coffee appeared to be associated with increased rates of prematurity in all subclasses. However, when smoking was controlled for, the effect of coffee on prematurity disappeared (Table 56). Nevertheless, it can be questioned whether confounders were adequately controlled for in this study. For example, no attempt to quantify smoking was made, and the period of coffee consumption was not specified. In a recent reanalysis of these data, Hogue (1981) demonstrated a significantly increased risk of low birth weight among consumers of seven or more cups of coffee daily after adjusting for smoking.

In a large American study based on 12205 non-diabetic, nonasthmatic women from the area around Boston, Linn and co-workers (1982) studied the effect of coffee consumption during the first trimester on the adverse outcome of pregnancies. Only women pregnant with a single child were included in the study. About one third of those interviewed reported drinking no coffee or tea during the first trimester, and $56.6 \%$ reported drinking no coffee. Only 5\% of the population reported drinking four or more cups of coffee per day (defined as "heavy" coffee drinkers). Higher coffee consumption was related to older maternal age, white ethnicity, and Catholicism, but not to marital status, college education, or socio-economic status. The heavy coffee drinkers also had a higher alcohol intake and smoked more frequently than those with a lower coffee intake. Low birth weight $(<2500$ g) was more common among the offspring of heavy coffee drinkers ( $\geq 4$ cups/day). Controlling for smoking revealed, however, that coffee drinking was unrelated to low birth weight (Table 56). In fact, the coffee intake also had no effect on bleeding during pregnancy, toxemica and eclampsia, preadmissions for false and premature labour, abnormal presentation, shorter gestation, or malformations. When interpreting the results of this study, it is important to remember that only first trimester consumption was considered, and that no information concerning the determination of gestational age was given. In addition, it cannot be excluded that the non-coffee or teadrinking group may have been exposed to caffeine from other sources. Furthermore, smoking was not adequately quantified. Finally, it can be noted that the retrospective design of the study could have introduced recall bias. 
Table 56. Foetal growth retardation in relation to intake of caffeine containing beverages

\begin{tabular}{|c|c|c|c|c|c|}
\hline $\begin{array}{l}\text { Reference and } \\
\text { location of study }\end{array}$ & $\begin{array}{l}\text { Sample size and } \\
\text { selection }\end{array}$ & $\begin{array}{l}\text { Exposure period considered } \\
\text { Sources of caffeine }\end{array}$ & \begin{tabular}{|l} 
End-point(s) \\
Definition
\end{tabular} & \begin{tabular}{|l} 
Results \\
Risk estimate adjusted odd ratios, \\
including $95 \%$ confidence interval
\end{tabular} & Comments \\
\hline $\begin{array}{l}\text { Mau and Netter, } 1974 \\
\text { Cohort study } \\
\text { Germany }\end{array}$ & $\begin{array}{l}5200 \text { pregnant } \\
\text { women }\end{array}$ & $\begin{array}{l}1^{\text {st }} \text { trimester of pregnancy } \\
\text { Coffee }\end{array}$ & $\begin{array}{l}\text { Low birth weight } \\
\text { defined as } \\
\leq 2500 \mathrm{~g} \text {, or }<10^{\text {th }} \\
\text { percentile }\end{array}$ & $\begin{array}{l}\text { Quantities consumed only specified as "never", "seldom" and "often" } \\
\text { Women who "often" consumed coffee more often delivered low birth } \\
\text { weight infants. }\end{array}$ & $\begin{array}{l}\text { Unacceptable poor quantification of caffeine intake. } \\
\text { Only consumption during the } 1^{\text {st }} \text { trimester known. } \\
\text { Confounding factors controlled for one at a time. } \\
\text { Smoking not quantified. } \\
\text { No information about determination of gestational } \\
\text { age. }\end{array}$ \\
\hline $\begin{array}{l}\text { van den Berg et al., } \\
1977 \\
\text { Cohort study } \\
\text { USA }\end{array}$ & $\begin{array}{l}8514 \text { pregnant } \\
\text { women in the } \\
\text { Kaiser Health Plan }\end{array}$ & $\begin{array}{l}\text { During pregnancy } \\
\text { (not specified) } \\
\text { Coffee }\end{array}$ & $\begin{array}{l}\text { Birth weight } \\
\leq 2500 \mathrm{~g} .\end{array}$ & $\begin{array}{|ll|}\text { Birth weight } \leq 2500 \mathrm{~g} \text { at }<37 \text { weeks gestational age } & \\
\geq 7 \text { cups/day smoker } & 5.1 \% \text { of women } \\
\geq 7 \text { cups/day non-smoker } & 2.6 \% \text { of women } \\
& \\
\text { Birth weight } \leq 2500 \mathrm{~g} \text { at } \geq 37 \text { weeks gestational age } & \\
\geq 7 \text { cups/day smoker } & 3.9 \% \text { of women } \\
\geq 7 \text { cups/day non-smoker } & 1.8 \% \text { of women }\end{array}$ & $\begin{array}{l}\text { Poor definition of study base, quantification of } \\
\text { exposure and period of exposure not well characte- } \\
\text { rised, and non-optimal control of confounders. }\end{array}$ \\
\hline $\begin{array}{l}\text { Linn et al., } 1982 \\
\text { Retrospective cohort } \\
\text { study } \\
\text { USA }\end{array}$ & $\begin{array}{l}12205 \text { non } \\
\text { diabetic women } \\
\text { who delivered a } \\
\text { single child }\end{array}$ & $\begin{array}{l}1^{\text {st }} \text { trimester of pregnancy. } \\
\text { Coffee }\end{array}$ & $\begin{array}{l}\text { Low birth weight } \\
\text { defined as } \\
<2500 \mathrm{~g} \text {. }\end{array}$ & $\begin{array}{l}\text { Low birth weight } \\
0 \text { cups of coffee vs } \\
\geq 4 \text { cups of coffee }\end{array}$ & $\begin{array}{l}\text { Only coffee and tea consumption during } 1^{\text {st }} \text { trimester } \\
\text { considered. The confounder smoking was not } \\
\text { quantified. Retrospective design-bias may be pos- } \\
\text { sible. Insufficient measurement of consumption of } \\
\text { caffeine-containing beverages. }\end{array}$ \\
\hline $\begin{array}{l}\text { Furuhashi et al., } 1985 \\
\text { Prospective study } \\
\text { Japan }\end{array}$ & \begin{tabular}{|l|}
9921 healthy \\
pregnant women \\
with gestational \\
age $>24$ weeks
\end{tabular} & $\begin{array}{l}\text { "During pregnancy" } \\
\text { Coffee and green tea }\end{array}$ & $\begin{array}{l}\text { Mean birth } \\
\text { weight//ntra-uterine } \\
\text { growth retardation } \\
\text { was not defined. }\end{array}$ & $\begin{array}{l}\text { Small foetus for gestation age } \\
<5 \text { cups coffee/day vs } \\
\geq 5 \text { cups coffee/day }\end{array}$ & $\begin{array}{l}\text { No control for confounding factors (smoking and } \\
\text { others). Few women with a heavy coffee consump- } \\
\text { tion. No information available on how gestational } \\
\text { age was determined. }\end{array}$ \\
\hline $\begin{array}{l}\text { Munoz et al., } 1988 \\
\text { Prospective study } \\
\text { Costa Rica }\end{array}$ & \begin{tabular}{|l|}
48 pregnant \\
women; \\
26 coffee drinkers \\
and 22 non coffee \\
drinkers \\
\end{tabular} & $\begin{array}{l}\text { Last trimester and early } \\
\text { lactation period } \\
\text { Coffee }\end{array}$ & \begin{tabular}{|l} 
Birth weight (no \\
definition)
\end{tabular} & $\begin{array}{l}\text { Birth weight } \\
0 \text { cup coffee/day vs } \\
\geq 3 \text { cups/day }\end{array}$ & $\begin{array}{l}\text { Very small study having a low power. Only one level } \\
\text { of coffee consumption studied. Drop outs had higher } \\
\text { parity. Gestational age was determined by method } \\
\text { of Dubowitz (1970). }\end{array}$ \\
\hline $\begin{array}{l}\text { Brooke et al., } 1989 \\
\text { Prospective population } \\
\text { study } \\
\text { Great Britain }\end{array}$ & $\begin{array}{l}1513 \text { white wo- } \\
\text { men }\end{array}$ & $\begin{array}{l}27^{\text {th }} \text { and } 35^{\text {th }} \\
\text { week } \\
\text { Coffee, tea, cola and } \\
\text { cocoa }\end{array}$ & $\begin{array}{l}\text { Birth weight adjusted } \\
\text { for gestational age } \\
\text { and maternal height, } \\
\text { parity and baby's sex }\end{array}$ & $\begin{array}{l}\text { Birth weight } \\
\text { Coffee consumption } \\
0 \text { cups coffee/week vs } \\
1-7,15-28, \geq 29 \text { cups/week } \\
\\
\text { Tea consumption } \\
0 \text { cups coffee/week vs } \\
1-7,15-42, \geq 43 \text { cups/week }\end{array}$ & $\begin{array}{l}\text { Measurement of gestational age adequately perfor- } \\
\text { med. }\end{array}$ \\
\hline
\end{tabular}




\begin{tabular}{|c|c|c|c|c|c|c|}
\hline $\begin{array}{l}\text { Reference and } \\
\text { location of study }\end{array}$ & $\begin{array}{l}\text { Sample size and } \\
\text { selection }\end{array}$ & $\begin{array}{l}\text { Exposure period considered } \\
\text { Sources of caffeine }\end{array}$ & $\begin{array}{l}\text { End-point(s) } \\
\text { Definition }\end{array}$ & \begin{tabular}{|l|} 
Results \\
Risk estimate adjusted odd ratios, \\
including $95 \%$ confidence interval
\end{tabular} & & Comments \\
\hline $\begin{array}{l}\text { Caan and Goldhaber, } \\
1989 \\
\text { Case control study } \\
\text { USA }\end{array}$ & $\begin{array}{l}131 \text { cases and } 136 \\
\text { controls }\end{array}$ & $\begin{array}{l}1^{\text {st }} \text { trimester of pregnancy } \\
\text { Coffee, tea and cola }\end{array}$ & $\begin{array}{l}\text { Low birth weight } \\
\text { defined as } 2 \text { SD }< \\
\text { mean birth weight } \\
(n=97) \\
\text { or as } \geq 2500 \mathrm{~g} \\
(n=34)\end{array}$ & $\begin{array}{l}\text { Low birth weight } \\
\text { Coffee, tea and cola drinks } \\
\text { none vs } \\
\text { light/moderate, heavy intake } \\
\\
\text { Total intake of coffee and cola } \\
\text { none vs } \\
\text { light/moderate/heavy intake3.53 (1.05-11.81) }\end{array}$ & NS & $\begin{array}{l}\text { Inclusion criteria for study base not described. Small } \\
\text { study, leading to imprecise risk estimates. Recall } \\
\text { bias possible. } \\
\text { Dichotomization of smoking. } \\
\text { (smoking not quantified) } \\
\text { Gestational age was determined only from last } \\
\text { menstrual period. }\end{array}$ \\
\hline $\begin{array}{l}\text { Olsen et al., } 1991 \\
\text { Retrospective cohort } \\
\text { study } \\
\text { Denmark }\end{array}$ & $\begin{array}{l}11858 \text { pregnant } \\
\text { women }\end{array}$ & $\begin{array}{l}\text { Before and at } 1^{\text {st }} \text { and } 2^{\text {nd }} \\
\text { trimester of pregnancy } \\
\text { Coffee and tea }\end{array}$ & $\begin{array}{l}\text { Birth weight and low } \\
\text { birth weight defined as } \\
<2500 \mathrm{~g}\end{array}$ & $\begin{array}{l}\text { Low birth weight } \\
\text { Coffee consumption } \\
0-3 \text { cups coffee/day vs } \\
4-7 \text { cups/day } \\
\geq 8 \text { cups/day } \\
\\
\text { Tea consumption } \\
0-3 \text { cups tea/day vs } \\
4-7 \text { cups/day } \\
\geq 8 \text { cups/day }\end{array}$ & $\begin{array}{c}1.4(1.1-1.7) \\
\mathrm{NS} \\
\\
1.3\left(\begin{array}{c}1.0-1.7) \\
\mathrm{NS}\end{array}\right.\end{array}$ & $\begin{array}{l}\text { Only average consumption across trimesters repor- } \\
\text { ted } \\
\text { Measurements of gestational age adequately per- } \\
\text { formed. }\end{array}$ \\
\hline $\begin{array}{l}\text { Mc Donald et al, 1992a } \\
\text { Retrospective cross- } \\
\text { sectional study } \\
\text { Canada }\end{array}$ & $\begin{array}{l}40445 \text { women } \\
\text { with just completed } \\
\text { pregnancies }\end{array}$ & $\begin{array}{l}\text { Average consumption } \\
\text { Coffee }\end{array}$ & $\begin{array}{l}\text { Low birth weight } \\
\text { defined as } \\
\leq 2500 \mathrm{~g} \text {, and low birth } \\
\text { weight for gestational } \\
\text { age as } \leq 2500 \mathrm{~g} \text { at }<37 \\
\text { weeks of gestation }\end{array}$ & \begin{tabular}{|l} 
Low birth weight \\
0 cups coffee/day vs \\
$1-2,3-4,5-9$ cups/day \\
$\geq 10$ cups/day \\
\\
Low birth weight for gestational age \\
0 cups coffee/day vs \\
$1-2,3-4$ cups/day \\
$5-9$ cups/day \\
$\geq 10$ cups/day
\end{tabular} & $\begin{array}{c}\mathrm{NS} \\
1.43(1.02-2.02) \\
\\
\mathrm{NS} \\
1.34(1.10-1.65) \\
\mathrm{NS}\end{array}$ & $\begin{array}{l}\text { Only average consumption during pregnancy repor- } \\
\text { ted. }\end{array}$ \\
\hline $\begin{array}{l}\text { Fortier et al., } 1993 \\
\text { Retrospective cohort } \\
\text { study } \\
\text { Canada }\end{array}$ & 7025 women & $\begin{array}{l}\text { During two periods of } \\
\text { pregnancy: } \\
\text { the first } 16 \text { weeks and } \\
\text { the rest } \\
\text { Coffee, tea, chocolate, } \\
\text { and } \\
\text { Cola }\end{array}$ & $\begin{array}{l}\text { Low birth weight was } \\
\text { defined as } \\
<2500 \mathrm{~g} \text {, and intrau- } \\
\text { terine growth retarda- } \\
\text { tion as } \\
<10^{\text {th }} \text { percentile }\end{array}$ & $\begin{array}{l}\text { Intrauterine growth retardation } \\
\text { Coffee consumption } \\
0 \text { cup coffee/day vs } \\
<1 \text { cup coffee/day } \\
\geq 1 \text { cup coffee/day } \\
\text { Tea, colas and chocolate consumption } \\
\begin{array}{l}\text { No consumption vs } \\
\text { Consumption }\end{array}\end{array}$ & $\begin{array}{c}\text { NS } \\
1.35(1.12-1.63) \\
\text { NS }\end{array}$ & $\begin{array}{l}\text { Inconsistent results for low birth weight and intraute- } \\
\text { rine growth retardation. There were few "heavy" } \\
\text { consumers. Gestational age was determined by last } \\
\text { menstrual period only. }\end{array}$ \\
\hline
\end{tabular}




\begin{tabular}{|c|c|c|c|c|c|}
\hline $\begin{array}{l}\text { Reference and } \\
\text { location of study }\end{array}$ & $\begin{array}{l}\text { Sample size and } \\
\text { selection }\end{array}$ & $\begin{array}{l}\text { Exposure period considered } \\
\text { Sources of caffeine }\end{array}$ & $\begin{array}{l}\text { End-point(s) } \\
\text { Definition }\end{array}$ & \begin{tabular}{|l|} 
Results \\
Risk estimate adjusted odd ratios, \\
including $95 \%$ confidence interval
\end{tabular} & Comments \\
\hline $\begin{array}{l}\text { Spinillo et al., } 1994 \\
\text { Prospective case } \\
\text { control study } \\
\text { Italy }\end{array}$ & $\begin{array}{l}347 \text { cases with } \\
\text { foetal growth } \\
\text { retardation and } \\
694 \text { controls }\end{array}$ & $\begin{array}{l}\text { Data obtained at prenatal } \\
\text { visits and at delivery } \\
\text { Coffee }\end{array}$ & $\begin{array}{l}\text { Intrauterine growth } \\
\text { retardation defined as } \\
\text { a birth weight }<\text { sex } \\
\text { specific } 10^{\text {th }} \text { percentile } \\
\text { of Italian standard } \\
\text { curves }\end{array}$ & $\begin{array}{l}\text { Intrauterine growth retardation } \\
0-1 \text { cup coffee/day vs } \\
1-4 \text { cups/day } \\
>4 \text { cups/day }\end{array}$ & $\begin{array}{l}\text { How consumption data were obtained was not } \\
\text { reported. Few high consumers of coffee. } \\
\text { Measurement of gestational age adequately perfor- } \\
\text { med. }\end{array}$ \\
\hline $\begin{array}{l}\text { Shu et al., } 1995 \\
\text { Prospective study } \\
\text { USA }\end{array}$ & 712 pregnancies & $\begin{array}{l}\text { All three trimesters } \\
\text { Coffee, tea and caffeina- } \\
\text { ted soft drinks }\end{array}$ & $\begin{array}{l}\text { Mean birth weight } \\
\text { adjusted for gestatio- } \\
\text { nal age }\end{array}$ & $\begin{array}{l}\text { Birth weight } \\
\frac{\text { Coffee }}{\geq 3 \text { cups/day }} \\
\text { Tea and soft drinks } \\
\geq 1 / \text { week }\end{array}$ & $\begin{array}{l}\text { Very few patients in higher exposure groups. Smo- } \\
\text { king not treated as a continuous variable. }\end{array}$ \\
\hline $\begin{array}{l}\text { Rondo, } 1996 \\
\text { Case-control study } \\
\text { (unmatched) } \\
\text { Brazil }\end{array}$ & $\begin{array}{l}356 \text { mother- baby } \\
\text { pairs with intraute- } \\
\text { rine growth retar- } \\
\text { dation, and } 356 \\
\text { mother-baby pairs } \\
\text { with normal gesta- } \\
\text { tional age }\end{array}$ & $\begin{array}{l}\text { No information on exposu- } \\
\text { re period } \\
\text { Coffee }\end{array}$ & $\begin{array}{l}\text { Intrauterine growth } \\
\text { retardation defined as } \\
\text { a birth weight less } \\
\text { than the } 10^{\text {th }} \text { percenti- } \\
\text { le according to Lub- } \\
\text { chenco et al. (1963) }\end{array}$ & 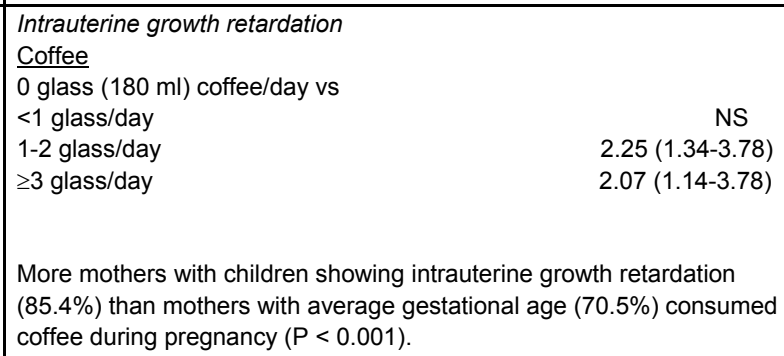 & $\begin{array}{l}\text { It has been questioned whether the study opulation } \\
\text { was representative. Exposure period not defined. } \\
\text { Gestational age determined by the method of Capur- } \\
\text { ro (1978). }\end{array}$ \\
\hline $\begin{array}{l}\text { Maruoka et al., } 1998 \\
\text { Retrospective cohort } \\
\text { study } \\
\text { Japan }\end{array}$ & $\begin{array}{l}23132 \text { infants } \\
1 \text { month old } \\
\text { at check up }\end{array}$ & $\begin{array}{l}\text { Exposure time not defined } \\
\text { Coffee }\end{array}$ & $\begin{array}{l}\text { Low birth weight } \\
\text { defined as a birth } \\
\text { weight }<2500 \mathrm{~g}\end{array}$ & $\begin{array}{l}\text { Low birth weight } \\
\text { Coffee } \\
<1 \text { cup coffee/day vs } \\
\geq 1 \text { cup of coffee }\end{array}$ & $\begin{array}{l}\text { Coffee consumption not specified in time. Some low } \\
\text { birth weight infants may have been missed if they } \\
\text { remained in hospital for care. No information given } \\
\text { about determination of gestational age. }\end{array}$ \\
\hline $\begin{array}{l}\text { Santos, } 1998 \\
\text { Multi centre case- } \\
\text { control study } \\
\text { Brazil }\end{array}$ & $\begin{array}{l}401 \text { cases } \\
\text { (children with birth } \\
\text { weight }<2500 \mathrm{~g} \\
\text { and gestational } \\
\text { age } \geq 28 \text { weeks) } \\
\text { and } 804 \text { controls }\end{array}$ & $\begin{array}{l}\text { During each trimester } \\
\text { Coffee, mate, tea, choco- } \\
\text { late, soft drinks, and } \\
\text { medicines }\end{array}$ & $\begin{array}{l}\text { Low birth weight } \\
\text { defined as } \\
<2500 \mathrm{~g} \text {, and intrau- } \\
\text { terine growth retarda- } \\
\text { tion defined as low } \\
\text { birth weight at }<37 \\
\text { weeks of gestation }\end{array}$ & $\begin{array}{l}\text { Low birth weight and intrauterine growth retardation } \\
\text { Coffee: } 0 \mathrm{mg} \text { vs } \geq 100 \mathrm{mg} \\
\text { Instant coffee: } 0 \mathrm{mg} \text { vs } \geq 100 \mathrm{mg} \\
\text { Maté: } 0 \mathrm{mg} \text { vs } \geq 100 \mathrm{mg} \\
\text { Black tea: } 0 \mathrm{mg} \text { vs } \geq 40 \mathrm{mg} \\
\text { Chocolate bars: } 0 \mathrm{mg} \text { vs } \geq 40 \mathrm{mg} \\
\text { Chocolate drinks: } 0 \mathrm{mg} \text { vs } 1-50 \mathrm{mg} \\
\text { Soft drinks: } 0 \mathrm{mg} \text { vs } \geq 40 \mathrm{mg} \\
\text { All sources }\end{array}$ & $\begin{array}{l}\text { Some women were used more than once in the } \\
\text { study. Selection of controls could be questioned. } \\
\text { Consumption of caffeinated beverages poorly } \\
\text { reported. Mean caffeine intake very low. Qantity of } \\
\text { smoking not reported. Gestation age determined by } \\
\text { the method of Capurro (1978). Still births } \leq 28 \text { weeks } \\
\text { included. }\end{array}$ \\
\hline
\end{tabular}




\begin{tabular}{|c|c|c|c|c|c|c|}
\hline $\begin{array}{l}\text { Reference and } \\
\text { location of study }\end{array}$ & $\begin{array}{l}\text { Sample size and } \\
\text { selection }\end{array}$ & $\begin{array}{l}\text { Exposure period considered } \\
\text { Sources of caffeine }\end{array}$ & \begin{tabular}{|l} 
End-point(s) \\
Definition
\end{tabular} & $\begin{array}{l}\text { Results } \\
\text { Risk estimate adjusted odd ratios, } \\
\text { including } 95 \% \text { confidence interval }\end{array}$ & & Comments \\
\hline $\begin{array}{l}\text { Eskenazi et al., } 1999 \\
\text { Retrospective cohort } \\
\text { study } \\
\text { USA }\end{array}$ & 7855 live births & $\begin{array}{l}\text { During } 4^{\text {th }}-5^{\text {th }} \text { months of } \\
\text { pregnancy, collected after } \\
\text { delivery } \\
\text { Coffee, decaffeinated } \\
\text { coffee, tea and cola }\end{array}$ & $\begin{array}{l}\text { Birth weight, low birth } \\
\text { weight, small for } \\
\text { gestational age }\end{array}$ & $\begin{array}{l}\text { Birth weight } \\
\text { Caffeinated coffee } \\
\text { A statistically significant reduction of } \\
-3.0 \mathrm{gm} / \text { cup}_{\text {week* }}{ }^{*} \text { was observed } \\
\text { Decaffeinated coffee, tea and cola } \\
\\
\text { Low birth weight, small for gestational age } \\
\text { All beverages } \\
\text { * refers to exposure period considered }\end{array}$ & $\begin{array}{l}\text { NS } \\
\text { NS }\end{array}$ & $\begin{array}{l}\text { Exposure period limited to one month of pregnancy } \\
\text { (4-5 months). Recall bias is probable. } \\
\text { Gestational age determined only by last menstrual } \\
\text { period. }\end{array}$ \\
\hline $\begin{array}{l}\text { Grosso et al., } 2001 \\
\text { Cohort study } \\
\text { USA }\end{array}$ & $\begin{array}{l}2714 \text { women } \\
\text { delivering a live } \\
\text { born infant at } \\
\text { Yale-New Haven } \\
\text { 1988-1991 }\end{array}$ & $\begin{array}{l}\text { Exposure data regarding } \\
1^{\text {tt }} \text { trimester collected } \\
\text { before } 16^{\text {th }} \text { week of } \\
\text { gestation and } 3^{\text {d }} \text { tri- } \\
\text { mesters collected after } \\
\text { delivery } \\
\text { Coffee, tea, soda drinks }\end{array}$ & $\begin{array}{l}\text { Intrauterine growth } \\
\text { retardation defined as } \\
<10^{\text {th }} \text { percentile }\end{array}$ & $\begin{array}{l}\text { Intrauterine growth retardation } \\
\text { Coffee, tea and soda drinks }\end{array}$ & NS & $\begin{array}{l}\text { Many women did not drink caffeinated beverages at } \\
\text { all. Selection bias may be possible. Few women hac } \\
\text { the high coffee intake. Gestational age determined } \\
\text { by the method of Ballard et al (1979). }\end{array}$ \\
\hline
\end{tabular}


In the Japanese study carried out by Furuhashi and co-workers (1985), 9 921 healthy pregnant women with a gestational age of 24 weeks were interviewed about caffeine ingestion during pregnancy. The women were divided into five categories: those consuming less than 5 cups of coffee per day during pregnancy ( $\mathrm{n}=3815)$, those consuming more than 5 cups of coffee per day $(\mathrm{n}=53)$, those consuming both coffee and green tea $(n=473)$, those consuming only green tea $(n=348)$, and those neither consuming coffee nor green tea (controls) $(n=5$ 232). Subsequently, the intake was correlated to pregnancy outcome: mean birth weight (definition not stated), length of labour, mean amount of intrapartum haemorrhage and incidence of intrauterine growth retardation (definition not stated), spontaneous abortion, premature labour, and foetal abnormality. Women who consumed more than 5 cups of coffee per day gave birth to babies small for gestational age, but the condition was not defined and no information was given about how it was determined (Table 56). There was no control for confounding factors. The authors, however, concluded that socio-economic variables might be more important than any direct effect of coffee for this outcome. It may also be noted that the study included very few heavy coffee drinkers. More than one category of coffee consumption should have been used. Consequently, dose response could not be assessed.

In a small study from Costa Rica, Munoz et al. (1988) investigated the influence of consumption of coffee on haematologic and trace element status in pregnant women. Two groups of pregnant low-income women were studied: 22 coffee drinkers (consuming $\geq 3$ cups of coffee daily) and 26 women who consumed no coffee at all. Women who drank 1-2 cups of coffee/day were excluded $(n=188)$, as were women who did not drink coffee but only tea $(n=3)$. The birth weight was significantly lower for infants whose mothers consumed coffee (mean: $3189 \pm 300$ grams) than for those whose mothers abstained from coffee consumption (mean: 3 $310 \pm 343$ grams) (Table 56). It should, however, be noted that gestational age was determined according to Dubowitz et al (1970) - a scoring system based on somatic and neurological signs. As this study is small and has a very low statistical power, the results should be interpreted with great caution. Drop outs $(n=62)$ had higher parity, which has been suggested to be a contributing factor to higher birth weight. Since only one category of coffee-consuming women were included in the study, it was not possible to study birth weight in relation to coffee dose.

The British prospective population study of Brooke et al. (1989) presented in the previous section also investigated the effect of coffee, tea, cola drinks and cocoa consumption on birth weight. At the $28^{\text {th }}$ and $36^{\text {th }}$ week of gestation interviewers obtained information on consumption of coffee, tea, cocoa, and cola during the week before the interview. After controlling for smoking, the intake of coffee and tea was unrelated to birth weight (Table 56). Smoking was the most important single factor 
influencing birth weight. The authors concluded that social and psychological factors such as the consumption of caffeine-containing beverages have little or no direct effect on birth weight corrected for gestational age (foetal growth).

The retrospective case-control study of Caan and Goldhaber (1989), presented in more detail in section 15.1, studied the relative risk for low birth weight in relation to daily consumption $(0,>0-<3, \geq 3$ servings) of caffeinated coffee, tea, and soft drinks during the first trimester of pregnancy. No association was found between risk of low birth weight and consumption of coffee, tea, or cola drinks. Heavy total consumption of coffee and cola drinks was associated with a marginally increased risk of low birth weight (Table 56). The authors conclude that their data support previous findings of a modest effect of caffeine consumption on foetal growth. The selection of cases and controls could be questioned in this small study. The estimation of risk could also be regarded as imprecise. Recall bias is probable, and smoking was not adequately quantified.

In a Danish study, Olsen et al. (1991) investigated the influence of women's coffee consumption on birth weight, pre-term births, and congenital malformations. It was a case control study comprising 11858 pregnant women recruited from two Danish cities between 1985 and 1987. The participants responded to a mailed questionnaire on eating and drinking habits during pregnancy. Among other things, the women were asked how many cups of coffee and tea they consumed daily during the period before becoming pregnant. The questions were repeated for the first two trimesters of pregnancy. Data on the intake of caffeinated soft drinks were not recorded in this study, as it has been found that the intake by adults in Denmark is low. Thirty-five percent of the women in the study drank four cups of coffee or more per day and seven percent 8 or more cups. It was found that high coffee consumption was associated with habitual alcohol consumption as well as smoking. Maternal consumption of at least four cups of coffee a day or more was associated with a moderate decrease in birth weight, especially among smokers (Table 56). No obvious dose response effect was observed. Low birth weight was defined as $<2500$ grams. A drawback with this study is that only average consumption across trimesters was reported. Thus, no separation of results in relation to each trimester was possible. Gestational age was adequately determined.

A Canadian retrospective cross-sectional study carried out by McDonald et al (1992a) assessed the effects of smoking and alcohol and coffee consumption on pregnancy outcome. Of the 51512 pregnancies, 11067 were excluded for different reasons, mainly because of factors known to affect length of gestation (determined from last menstrual period) and birth weight, leaving 40445 pregnancies for analysis. Birth weights were studied in connection with prematurity. Prematurity was defined in three ways: low birth weight $(\leq 2500 \mathrm{~g})$, pre-term birth ( $<37$ weeks), and low 
birth weight for gestational age (bottom 5\%). Trends of increasing risk with increased coffee consumption were observed for low birth weight and low birth weight for gestational age (Table 56). The risk of low birth weight for gestational age increased by a factor of 1.04 per cup of coffee and day. A drawback with this study is that only average consumption across trimesters was reported. Thus, no separation of results in relation to each trimester was possible.

Another Canadian study with retrospective design was performed by Fortier and co-workers (1993) using 7025 women living in Quebec City as the study base. The aim of this study, which was presented in detail in the previous section, was to assess the relationship between caffeine intake during pregnancy and intrauterine growth retardation (IUGR), preterm birth and low birth weight, and to evaluate the interaction of caffeine and smoking on these outcomes. The adjusted odds ratios for delivering a newborn with growth retardation was significantly increased in women whose average daily coffee consumption was $\geq 1$ cup/day (Table 56). No statistically significant relationships were found between intake of tea, cola drinks, or chocolate and growth retardation. The intakes of these beverages were, however, not quantified (yes or no).

In order to estimate the risk of foetal growth retardation resulting from the interaction between maternal smoking during pregnancy and other recognised risk factors, a case-control study of prospectively collected data was performed at the University of Pavia, Italy (Spinillo et al, 1994). Included in the study were 347 pregnancies with diagnosis of foetal growth retardation (a sex specific birth weight $\leq 10^{\text {th }}$ percentile of Italian standard curves, confirmed by sonographic diagnosis of IUGR) and 694 control pregnancies with foetuses of appropriate size. Excluded were cases with foetal malformations and women who had stopped smoking during pregnancy. The following parameters were studied: maternal age, unmarried/married, nulliparity, pre pregnancy weight, weight gain, previous low birth weight, foetal sex, first trimester haemorrhage, hypertension, maternal education, social class, alcohol consumption, and coffee consumption. It was concluded that several factors could affect the risk of foetal growth retardation in smoking women. The combined effect of smoking and coffee consumption on the risk of foetal growth retardation was found to be additive rather than multiplicative. Coffee consumption was also found to be an independent predictor of intrauterine growth retardation - there was a significant positive trend relating the number of cups of coffee consumed during pregnancy (Table 56). No information was given about how information on coffee consumption was obtained in this study. Very few of the women $(n=3)$ consumed $>4$ cups of coffee/day, leading to a very imprecise estimation of the risk of high coffee consumption.

The prospective study of Shu et al. (1995) on 712 pregnancies in Pennsylvania and New York was presented in the previous section. The 
aim of the study was to investigate the association between maternal smoking, alcohol consumption, and caffeine intake. The frequency and amount of coffee, tea, and caffeinated soft drinks consumed during each trimester of pregnancy were obtained in interviews. The authors concluded that none of the sources of caffeine (that is, coffee, tea and soft drinks) were substantially related to birth weight (adjusted for gestational age) or foetal growth. The study was handicapped by the fact that only 4 women reported consumption of $\geq 3$ cups of coffee/day.

In Sao Paulo, Brazil, Rondo and co-workers (1996) examined the association between coffee consumption during pregnancy and foetal growth in an unmatched case-control study. Included in the study were mother/baby pairs showing intrauterine growth retardation (IUGR, defined as a birth-weight $<10^{\text {th }}$ percentile according to Lubchenco et al., 1963 ) and 356 mother/baby pairs who showed appropriate growth for gestational age (AGA). Gestational age was determined by the method of Capurro et al (1978), which utilises a scoring system based on somatic and neurological signs. During pregnancy, coffee was consumed by $85.4 \%$ of the women delivering a growth retarded child, whereas $70.5 \%$ of women delivering children of appropriate growth for gestational age consumed coffee. The proportion of women who gave birth to intrauterine growth-retarded babies increased as the average consumption of coffee increased (Table 56). The tendency for heavy coffee drinkers of delivering babies with intrauterine growth retardation remained after controlling for alcohol intake and cigarette smoking. Of eight independent risk factors for intrauterine growth retardation, coffee consumption attributed $28 \%$ of the risk in this Brazilian population. Important questions when assessing this study are whether the population investigated is representative, and whether the methodology is suitable. Finally, it should be noted that no information on when the women were interviewed, or on the actual period of exposure, was provided. The investigators also did not fully control for identified potential confounders.

Maruoka et al. (1998) recently carried out a study in order to identify risk factors for low birth weight $(<2500 \mathrm{~g})$ in Japanese infants. The data were collected from questionnaires completed by the parents of 23132 infants who underwent a standardised baby check-up for 1-month-old infants conducted by the Fukuoka City Medical Association between 1987 and 1995. Coffee consumption was reported to not contribute significantly to low birth weight in this population (Table 56). However, the period of coffee consumption was not stated, and the data poorly presented.

In the previous section, a Southern Brazil case-control study investigating the effects of consumption of coffee, tea, maté, chocolate, caffeinated soft drinks, and medicinal drugs during each trimester of pregnancy on the birth weight of infants was presented (Santos et al., 1998). The 401 mothers of children having a birth weight $<2500 \mathrm{~g}$ and gestational age $\geq$ 
28 weeks (cases), and 804 mothers of children with a normal birth weight (controls) were interviewed within 24 hours after delivery. The cases and controls were recruited from four maternity hospitals in Pelotas, and were matched for time of birth and hospital of delivery. The mean intake of the various caffeine-containing beverages was similar among cases and controls. No association was found between consumption of the beverages and intrauterine growth retardation or low birth weight (Table 56). As reported in the previous section, the study has many limitations.

In order to examine the relationship between maternal consumption of decaffeinated and caffeinated coffee during pregnancy and foetal growth and gestational duration, Eskenazi et al. (1999) performed a populationbased study comprising 7855 live-births in California, United States. At the time of completing the birth certificate, mothers answered a questionnaire in the hospital. The questionnaire contained questions about consumption of decaffeinated as well as normal coffee, tea, and cola during the fourth and fifth month of pregnancy. The following endpoints were investigated in the study: pre-term delivery (gestation of less than 37 weeks length), low birth weight ( $<2500$ gram), small for gestational age $\left(<10^{\text {th }}\right.$ percentile of weight for each completed gestation week between week 22 and 44), mean birth weight and gestational age. Women who consumed coffee only in decaffeinated form did not have an increased risk for delivering a child with low birth weight or for being small for gestational age at birth. Women who always consumed coffee as regular coffee, however, had an increased risk of giving birth to babies with a reduced birth weight. When considered as a continuous variable, regular coffee was found to be associated with a $3.0 \mathrm{~g} / \mathrm{cup} /$ week reduction (in the studied time period) in adjusted mean birth weight (Table 56). When interpreting this study, it is important to consider that the exposure period investigated was limited to a one-month period in the middle of the pregnancy (4-5 months). Furthermore, recall bias cannot be excluded, as consumption was registered a considerable time after the exposure period. It should be noted that gestational age was determined from the last menstrual period, which is not regarded as being as reliable as ultrasonographic examination.

The study by Grosso et al. (2001), extensively presented in section 15.1, also analysed the association between consumption of the different caffeine-containing beverages and foetal growth. No statistically significant association was found between these parameters (Table 56). As mentioned in the previous section, the study base seems to have been a special group of women with a very low intake of caffeine-containing beverages. 


\subsection{Meta-analysis of foetal growth retardation in relation to intake of caffeine/caffeine-containing beverages.}

As varying results have been found in the referred publications regarding intake of caffeine/caffeine-containing beverages and foetal growth retardation, two meta-analyses have been performed in order to clarify if a relationship exists between the studied parameters or not.

The former of these meta-analysis was performed by Santos et al. (1998b). Epidemiological studies published between 1966 and 1995 and devoted to the relationship between intake of caffeine and the birth weight or duration of pregnancy (pre-term delivery) was identified by searches performed on Medline. Twenty-six studies were located. A scoring system specific for each type of epidemiological study was used in order to rank the overall quality of each paper in an objective manner. Each study was treated as the stratification variable and its weight, in the weighed average, was proportional to the inverse of its variance. Among the twenty-two studies on birth weight, eleven were on mean birth weight, nine on low birth weight $(<2500$ gram), and four on intrauterine growth retardation (birth weight under the $10^{\text {th }}$ percentile for gestational age). Only thirteen of these twenty-two studies could be used for pooled estimation, as the remaining nine studies did not provide adequate statistical information.

Combined analysis of the three approved studies on mean birth weight showed a significant decrease in birth weight of nearly $43 \mathrm{~g}$ among newborns of the heavier caffeine-consuming mothers in comparison with mothers who consumed lower amounts or no caffeine at all. The homogeneity test (estimating the variability in treatment effect) was not significant $(p>0.05)$. Concerning the nine studies reporting on low birth weight, the pooled estimate suggested an increased risk for low birth weight of $33 \%$ among consumers having a high intake of caffeine compared to those having a low or no caffeine intake at all. Intrauterine growth retardation was the outcome assessed in three studies. The pooled estimate of these studies indicated an increased risk for intrauterine growth retardation of $24 \%$ among women with a high caffeine intake, compared to those exposed to a low or no caffeine intake at all. Homogeneity tests were, however, significant $(\mathrm{p}<0.001)$ for both low birth weight and intrauterine growth retardation, indicating that the studies were highly heterogenous for both parameters, and thus should not be summarised in single estimates. The high heterogeneity of the available epidemiological literature on the relationship between caffeine intake and birth weight adjusted to gestational age prevents a reliable pooled estimate to be obtained though meta-analysis. According to the scoring system, the reported studies were not highly discrepant in quality, but problems in exposure measurements and/or bias induced by exclusion of some studies (lacking statistical information) were suggested as possible explanations for the inconsistency. 
Another meta-analysis (Fernandes et al., 1998), was performed in order to determine the association of moderate to heavy caffeine exposure during pregnancy to spontaneous abortions or birth weight. In this analysis, the criteria for including the studies in the meta-analysis were: articles written in the English language, case-control or cohort design, caffeine exposure during pregnancy, documented caffeine consumption, control group with low or no consumption of caffeine $(0-150 \mathrm{mg} / \mathrm{day})$, and documented data regarding birth weight. The necessarily strict inclusion criteria resulted in only a part of the studies reviewed in section 15.1 and 15.2 being included in the meta-analysis. The following seven studies dealing with caffeine exposure and birth weight met inclusion criteria: Caan and Goldhaber, 1989; Fenster et al., 1991b; Fortier et al., 1993; Linn et al., 1982; Martin and Bracken, 1987; McDonald et al., 1992; and Mills et al., 1993. The group of women with the highest caffeine exposure and the control group were compared using Mantel-Haenszel pooling.

The authors concluded that the overall risk ratio for low birth weight was 1.51 among the 64268 pregnancies. The 95\% confidence interval was 1.39-1.63. This means that there is a small but statistically significant increased risk of women who have a "high" ( $>150 \mathrm{mg}$ caffeine/day) intake of caffeine giving birth to a baby with low birth weight. The risk ratio was shown to increase with increasing daily caffeine consumption. Data from two studies (Caan and Goldhaber, 1989 and Fenster et al., 1991b) also analysing intrauterine growth retardation supported this conclusion. However, controlling for confounders like maternal age, smoking, and consumption of alcohol was not possible in the meta-analysis, which obviously diminishes the value of the exercise considerably.

\subsection{Summary of results of studies devoted to the relationship between exposure to caffeine/caffeine- containing beverages and foetal growth retardation}

Since 1974, thirty epidemiological studies concerning the relationship between foetal growth retardation and intake of caffeine and/or caffeinecontaining beverages have been published. These have predominantly been of American or Canadian origin. There are, however, also two studies from Brazil, one from Costa Rica, and two from Japan and nine from Europe. The main outcome parameters studied were low birth weight, reduction in birth weight in comparison with a referent group (birth weight observed as a continuous variable), and intrauterine growth retardation. Low birth weight has been defined as a birth weight of $<2500 \mathrm{~g}$ or a birth weight below the 10th percentile of national growth standard curves. Intrauterine growth retardation has been defined as a birth weight below a specific percentile of growth standard curves. Both low birth weight and intrauterine growth retardation have been observed as non- 
continuous variables. Approximately fifty percent of the studies had a prospective design, the majority being fairly large to very large cohort studies, having a study base of some hundreds to several thousands of women. The majority of the retrospective studies were cohort studies, while some were performed with a case-control design. Of the thirty studies, nineteen have assessed the relationship between foetal growth retardation and consumption of caffeine (Table 55). Seventeen studies have assessed the relationship between foetal growth retardation and consumption of caffeine-containing beverages (Table 56). Thus in six studies, the exposure variable were amount of caffeine as well as amount of caffeinecontaining beverages.

\subsubsection{Caffeine}

In nine out of the nineteen studies investigating a relationship between caffeine exposure and foetal growth retardation, no statistically significant relationship between exposure and studied endpoint(s) was observed. It should be noted that the majority of these negative studies had a prospective design.

Eight out of the nineteen studies designed to investigate a potential relationship between caffeine exposure and foetal growth retardation observed a statistically significant relationship between the exposure and the studied endpoint (Kuzma and Sokol, 1982; Watkinson and Fried, 1984; Beaulac-Baillargeon and Desrosiers, 1987; Martin and Bracken, 1987; Peacock et al., 1991; Fenster et al., 1991b; Fortier et al., 1993; Vlajinac et al., 1997). In four of these studies (Martin and Bracken, 1987; Fenster et al., 1991b; Fortier et al., 1993; Vlajinac et al., 1997) a dose response relationship was observed. In some studies, the effect was confined to subgroups of the studied population. Thus, Beaulac-Baillargeon and Desrosier (1987) and Peacock et al. (1991) observed a foetal growth retardation at high caffeine intakes only in smokers, while Vlajinac et al. (1997) found an association only in non-smokers. In two retrospective studies (Fenster et al., 1991; Fortier et al., 1993) a significant effect could be seen only on intrauterine growth retardation, whereas low birth weight, which was also measured, was unaffected. This inconsistency has not yet been explained, and the results should, therefore, be interpreted with care. In addition, it may be noted that two studies (Larroque et al., 1994; Cook et al., 1996) found a borderline association between caffeine intake and foetal growth retardation in non-smokers and smokers, respectively. The lowest dose of caffeine, which resulted in a statistically significant reduction in birth weight in the reviewed studies, was $11-150 \mathrm{mg} /$ day and $70-$ $140 \mathrm{mg} /$ day (Fortier et al., 1993; Vlajinac et al., 1997). In most of the other studies $\geq 300-400 \mathrm{mg}$ caffeine/day was required before a statistically significant effect was induced. 
It may be possible that the same women have been included in several of the studies. This could be the case in the studies by Cook et al. (1996), Brooke et al. (1989), and Peacock et al. (1991), and also in Watkinson and Fried (1985) and Fried and O'Conell (1987), respectively.

\subsubsection{Caffeine-containing beverages}

Eleven of the seventeen studies exploring a relationship between consumption of caffeine-containing beverages and foetal growth retardation observed a statistically significant relationship between these parameters. A dose-response relationship was found in five studies (Mau and Netter, 1974; van den Berg, 1977; McDonald et al., 1992; Rondo et al., 1996; Eskenazi et al., 1999). In half of the studies, "caffeine-containing beverages" was equivalent to coffee consumption. In the remaining studies, the consumption referred to tea, and sometimes to cocoa and cola drinks. The lowest amount of caffeine-containing beverage(s), which resulted in a statistically significant reduction in birth weight/intrauterine growth retardation, was $\geq 1$ cup of coffee daily (Fortier et al., 1993; Eskenazi et al., 1999). In most of the other studies, higher exposure levels were required in order to produce a statistically significant effect - usually $\geq 4-9$ cups of coffee daily (or $\geq 6$ cups of tea). In two of the eleven positive studies, a significant synergistic relationship was found between consumption of caffeine-containing beverages and smoking (Olsen et al., 1991 and Spinillo et al., 1994).

\subsection{Discussion}

The studies assessed and discussed in this chapter are diverse in many aspects. They differ with respect to design, selection and number of participants, choice of outcome variable, quality of intake data, controlling for confounding factors, and statistical power.

Most studies that have presented data on the association between caffeine intake or consumption of caffeine-containing beverages and foetal growth retardation have originally not been designed for this purpose. Many studies have explored a potential relationship between intake of caffeine/caffeine-containing beverages and other end-points of pregnancy, or collected information on caffeine exposure as necessary information in order to adjust other statistical calculations for confounding factors. This obviously may result in the inappropriate design of studies specifically focusing on the association between caffeine intake or consumption of caffeine-containing beverages and foetal growth retardation.

The aim of most epidemiological studies is to draw conclusions for the general population. In some of the reviewed studies, it may be questioned as to whether the investigated sample could be considered as 
being representative for the general population of pregnant women. This is particularly obvious in the studies by Fried and O'Conell (1987) who recruited women consuming cannabis, alcohol, and tobacco, and Godel et al. (1992) who investigated a sample with a very special racial distribution. Some women are likely to have been studied in more than one investigation.

Many outcome variables have been used in the assessed studies in order to investigate foetal growth retardation. Most common have been mean birth weight (birth weight observed as a continuous variable) in comparison with a referent group, low birth weight, and intrauterine growth retardation. In the reviewed studies, low birth weight and intrauterine growth retardation have been defined as a birth weight less than 2 $500 \mathrm{~g}$, or a birth weight less than the $10^{\text {th }}$ percentile of all birth weights of the regional population, or alternatively, as a birth weight more than two standard deviations lower than the mean birth weight. Thus, both low birth weight and intrauterine growth retardation have been treated as noncontinuous variables.

In addition to the outcome parameters mentioned above, birth length, crown-rump length, head circumference, placental weight and ponderal index have been utilised as indicators of foetal growth retardation in some studies. In all studies it is important that gestational age of the foetus/child has been measured and controlled for. This has fortunately been done in almost all studies. In this context, it should, however, be noted that in many studies there is no specific information about the method used to determine gestational age. Furthermore, it is evident that in many of the older studies gestational age was determined by recording the last menstrual period, which is not regarded to be as reliable as using ultrasonographic methods. Obviously the method used is an important factor in the assessment of foetal growth retardation.

From what has been stated above, it should be clear that comparing results of different studies on the relationship between caffeine/beverage exposure and foetal growth retardation is complicated by the use of different outcomes. The general problems related to the consumption data have been discussed in chapter seven. However, it should be stressed that a general problem with the retrospective design is the possibility of introducing a recall bias in the assessment of consumption, as the time period between actual consumption and reporting this consumption may be lengthy. Another drawback in many studies is that consumption by trimester has not been considered. Consumption in the third trimester is especially important, which should have been registered in all studies of this type, as foetal growth is particularly intense during the later periods of pregnancy. In many studies, however, only average consumption or first trimester consumption has been reported, and this is a severe limitation of the study. All studies, except the study of Cook et al. (1996), rely on self-reporting. It is important to remember that the validity of self- 
reporting is dependent on the understanding and co-operation of the participants in the study. Educational levels could thus influence the reliability of consumption data. Information regarding sources of caffeine intake varies between studies. In most cases consumption of coffee has been reported. In addition, some studies have also registered consumption of tea and caffeinated soft drinks. In rare studies, the use of cocoa, chocolate and medicinal drugs containing caffeine have also been investigated. Because of individual taste and the cultural consumption pattern in the country where the study was performed, the importance of obtaining data from the various sources contributing to the total caffeine exposure differs. For example, the contribution of caffeinated soft drinks to the total caffeine consumption among adults in Denmark is of minor importance (Olsen et al., 1991), whereas this caffeine source obviously should not be neglected in studies performed in North America.

The intake of caffeine in most of the studies reviewed in this section (except for the studies of Olsen et al. (1991), Peacock et al. (1991), and Larroque et al. (1993)) could be characterised as fairly low in comparison to the mean consumption in the Nordic countries. Accordingly, a general problem in the majority of the studies is that the number of participants consuming $\geq 300 \mathrm{mg}$ of caffeine daily is small or in some studies even very small, which reduces the ability to predict the outcome (at this consumption level) with statistical precision.

Controlling for confounding factors is of course very important. Accordingly, most investigators have assessed the relevance of potential confounding factors in a stepwise multiple regression model. Certain confounding factors have almost consistently been shown to be of importance in studies on foetal growth retardation. Among these confounding factors are: smoking, duration of pregnancy (e.g. gestational age), prepregnancy weight, weight gain during pregnancy, ethnicity, parity, and use of alcohol (Kuzma and Sokol, 1982).

Smoking, being perhaps the most important confounder, should never be neglected in this context. In most epidemiological studies that have studied coffee consumption, an association between caffeine intake and cigarette smoking has been observed. It is also known that caffeine is eliminated much faster in smokers than in non-smokers, because the cigarette smoke induces enzymes that degrade components of the cigarette smoke. The same enzymes also metabolise caffeine. As smoking is known to affect birth weight in a dose-dependent manner, adjusting for smoking means that the number of cigarettes smoked must be accounted for. This has, however, not been considered in all studies - the only information available in some studies was if the women was a smoker or not. Inadequate control of confounding factors, including smoking (not assessed at all), characterises, for example, the studies of Furuhashi et al. (1985) and Mau and Netter (1974). 


\subsection{Conclusion}

A statistically significant relationship between caffeine exposure and foetal growth retardation was found in nearly half of the reviewed epidemiological studies, although the adjusted odd ratios did not much exceed 1.00. A dose response was demonstrated in some of the studies. Borderline significance was obtained in two additional studies.

It should, however, be emphasised that many studies showing a significant decrease in foetal growth at high caffeine intakes have used a retrospective design, suffer from severe limitations (see below), and have observed the effect only in specific subgroups such as smokers or nonsmokers. In the majority of studies carried out with a prospective design, no statistically significant relationship between caffeine exposure and foetal growth retardation was observed.

When referring to consumption of caffeine-containing beverages, a statistically significant relationship between intake of at least some caffeine-containing beverages and foetal growth retardation was found in eleven of seventeen published studies. In half of these studies, "caffeinecontaining beverages" was equivalent to coffee. The lowest amount of caffeine/caffeine-containing beverages, which could be attributed to a statistically significant reduction in foetal growth, was estimated to be 11$150 \mathrm{mg}$ or $\geq 0.5-1.5$ cup of coffee daily. In most studies, however, a much higher exposure was required in order to produce a significant reduction in foetal growth retardation: $\geq 300-400 \mathrm{mg}$ or $\geq 4$ cups of coffee daily.

Methodological problems in many of the studies make it difficult to perform an overall assessment. The methodological problems may be connected with the study base (selection of studied sample and to few individuals), recall bias, non-optimal control of confounding factors, and statistical considerations. Furthermore, an undefined lifestyle associated with high intakes of caffeine may contribute to confounding. In this context not reporting - or not adequately reporting - personal habits such as smoking or drinking alcohol may play a significant role.

In summary, the resilient quality of most assessed studies does not enable reliable conclusions to be drawn. Although it may not be prudent to rule out a possible relationship between the intake of caffeine or caffeinecontaining beverages and reduced mean birth weight based on the results of the reviewed investigations, it should be kept in mind that in most modern prospective studies no significant association has been observed. 


\section{Caffeine intake and effects on foetuses in utero}

Only a few studies have dealt with the possible relationship between caffeine exposure of the foetus and effects on the foetus in utero. In general, these are clinical investigations rather than epidemiological studies. These and three in vitro studies are summarised in this chapter.

\subsection{In vitro studies on caffeine exposure of foetal organs/tissues}

Resch and co-workers have performed two in vitro studies on the effects of caffeine on foetal heart muscles removed micro-surgically from induced abortions and cultured in nutrient solution. The first of these studies showed that foetal hearts cultured in vitro were increasingly more sensitive to the inotrophic effect of caffeine with gestational age from 6 to 17 weeks (Resch et al., 1985). Furthermore, the effect was dose dependent at all developmental stages, and the agreement between dose, gestational age and effect was excellent (Table 57). The lowest concentration tested $(1.94 \mu \mathrm{g} / \mathrm{ml})$ did not deviate much from the blood levels found in one of the groups of foetuses studied by Devoe et al. (1993), see section 16.2.

In the second study, the same investigators studied the contractility of twenty-five heart muscles 6 to 20 weeks old by incubating the tissues in nutrient solutions containing $0,0.01,0.1$ and $1 \mathrm{mM}$ caffeine $(1 \mathrm{mM}$ caffeine corresponds to $194 \mu \mathrm{g} / \mathrm{ml})$. Caffeine induced an age- and concentration-dependent change in contractility of the hearts (Table 57). The greatest changes were observed in the oldest hearts at the two highest caffeine concentrations.

The caffeine concentrations used in the in vitro experiment were similar to those reached in the plasma of pregnant women who had ingested $2-5$ cups of coffee $(3.2-30 \mu \mathrm{g} / \mathrm{ml})$, as well as in the tissues of foetuses of coffee-drinking mothers $(1.9-9.9 \mu \mathrm{g} / \mathrm{ml})$. The authors concluded that pregnant women should be advised to be cautious regarding caffeinecontaining medical preparations and coffee consumption, as caffeine might exert harmful effects on the foetus. The experiments were well designed. However, the relevance of these results for the in vivo situation is not clear.

In order to investigate whether caffeine-induced alterations in placental vascular tone might produce adverse effects on the foetus, Ramirez et al. (1998) performed a well-designed in vitro study on isolated human 
placental arteries and veins. The tissues were kept at resting tone in the presence and absence of endothelium exposed to cumulative doses of caffeine $(0.1 \mathrm{nM}-0.1 \mathrm{mM})$. Prior to caffeine exposure, some of the vessels were sub-maximally pre-contracted with U44619 (a tromboxane mimethic). Dose-response curves for the reaction to serotonin, $\mathrm{KCl}$, U46619, and prostaglandin F2 $\alpha$ on contractility were also obtained. At resting tone, caffeine did not alter vascular tone in human placental arteries and veins (Table 57). Caffeine also failed to alter the efficiency of other contractile agents. Addition of the drug to pre-contracted placental blood vessels resulted in modest relaxation (15-30\% of maximal tone). Thus, caffeine does not appear to alter human placental vascular tone in vitro. The relevance of these results for an in vivo situation is not clear.

\subsection{Clinical studies on the effect of maternal caffeine intake on foetuses in utero.}

Common study parameters in the in vivo studies of the effect of maternal caffeine intake on foetuses in utero have been foetal breathing, body movement, and effects on the foetal cardiovascular system. Four of the six studies (McGowan et al., 1987; Salvador and Koos, 1989; Devoe et al., 1993; Miller et al., 1994) were performed in the United States.

In a Finnish study, Kirkinen and co-workers (1983) investigated the effects of maternal ingestion of two cups of coffee on placental blood flow within the last trimester of 20 pregnancies. Maternal serum levels of caffeine and epinephrine at 30 minutes after ingestion of the coffee were significantly elevated in comparison with the fasting values. The average caffeine level was as high as $8.4 \mu \mathrm{g} / \mathrm{ml}$. Although the level of noradrenaline remained unchanged, the level of adrenaline increased significantly. The maternal pulse rate and blood pressure remained unchanged. The intervillous placental blood flow decreased, but the foetal umbilical vein blood flow was unchanged (Table 58). Patients with hypertension during pregnancy initially showed a reduced intervillous blood flow, which did not change after maternal caffeine intake. The authors concluded that confirmatory studies on caffeine effects in human pregnancy are needed, as decreased placental blood supply and increased maternal serum epinephrine levels associated with maternal coffee ingestion may constitute a potential perinatologic risk.

However, as the study base was heterogenous and small, no conclusions can be drawn from this investigation.

McGowan and colleagues (1987) studied the effects of short- and long-term maternal ingestion of caffeine in 14 uncomplicated pregnancies on the breathing and body movements of third-trimester foetuses. The participants had been selected from a larger sample of pregnant women based on their dietary intake of caffeine. They were divided into two 
equally large groups: high consumers of caffeine ( $>500 \mathrm{mg} /$ day) and "low" consumers $(<250 \mathrm{mg} /$ day $)$. All mothers followed a standard study protocol and underwent overnight fasting. Studies began with a 30minute control period, followed by oral administration of $200 \mathrm{mg}$ caffeine, and a 180-minute observation period with continued maternal fasting. Blood samples for the analysis of glucose and caffeine levels were collected every 30 minutes, and continuous recording of foetal breathing and body movements were entered on a microcomputer for off-line analysis.

The two groups were similar for all obstetric outcome features. Plasma glucose levels were similar and constant in both groups. The baseline caffeine level was higher in the group of women having a high coffee intake, but the caffeine levels increased significantly at 60 minutes after caffeine administration in both groups. Foetal breathing rates and body movement incidences were similar in both groups before and after caffeine administration (Table 58). Foetal breathing movement incidence decreased significantly in foetuses of women with a low caffeine intake, but was sustained at baseline levels in women with a high caffeine intake throughout the study. It was concluded that short-term administration of $200 \mathrm{mg}$ caffeine does not appear to have a significant physiological impact on the studied activities. However, long-term ingestion of high levels of caffeine during pregnancy is associated with higher maternal plasma caffeine levels and foetal breathing activity when compared with low caffeine ingestion. This paper can be considered a prelude to a more important study performed at the same research institute (Devoe et al, 1993).

The results of McGowan et al. (1987) were partly confirmed by Devoe et al. (1993). These researchers investigated whether the level of longterm maternal caffeine ingestion influenced foetal behaviour in 20 healthy third-trimester pregnancies. The study participants were selected from answers in a dietary questionnaire that identified each women to either have a high ( $>500 \mathrm{mg} /$ day) or a low ( $>200 \mathrm{mg} /$ day) caffeine intake, 10 women for each group. Between the 30th and 40th week of gestation, biweekly 2-hour continuous ultrasonographic observations of foetal heart rate, breathing activity, and eye, trunk, and extremity movements were conducted. Maternal serum levels of caffeine were determined at each session, and were found to always be significantly higher in the high caffeine intake group than in the low caffeine intake group.

When compared with low exposed foetuses, the foetuses exposed to high caffeine levels spent similar mean time in quiet sleep, less mean time in active sleep, and much greater mean time in arousal (Table 58). The authors concluded that this is the first study to demonstrate that longterm maternal caffeine consumption may affect foetal behaviour. The authors pointed out that there is no established "safe" threshold for maternal caffeine consumption, but that a daily intake of less than $200 \mathrm{mg}$ did not seem to influence foetal behaviour (Devoe et al., 1993). It should 
be noted that the birth weight of infants and parity of the mothers in the group of women/foetuses exposed to high caffeine concentrations was significantly lower than the birth weight of infants from the group of women/foetuses exposed to low caffeine concentrations. It is not known whether the fact that women in the group exposed to low amounts of caffeine were older than women in the higher exposure group had any influence on the results. No obviously abnormal behaviours were noted in infants during the first two days of life.

With exception for the poor matching of groups in other respects than caffeine intake, and not controlling for use of drugs such as ethanol and benzodiazepines, the study was well performed.

Using a single-blind crossover design, the effects of maternal consumption of regular or decaffeinated coffee on the foetus were studied in eight non-smoking pregnant women during weeks 32 to 36 weeks of gestation (Salvador and Koos, 1989). Before initiation of the study, women had abstained from caffeine-containing drugs or beverages for at least one week. After an overnight fast, the women drank 2 cups of coffee (regular or decaffeinated), and were followed during the subsequent 4 hours. The following parameters were studied: maternal blood pressure and heart rate, serum concentrations of caffeine, catecholamines and glucose, foetal breathing, and foetal heart rate. This procedure was repeated 1 week later, when the woman drank the type of coffee she had not consumed the week before.

According to the authors, the 2 cups of coffee contained $454 \mathrm{mg}$ caffeine, which is a considerable amount for two cups of coffee, whereas the equivalent volume of decaffeinated coffee contained only $12 \mathrm{mg}$ caffeine. Maternal consumption of regular coffee resulted in maximum average caffeine concentration $(5.7 \mu \mathrm{g} / \mathrm{ml}) 30$ minutes after the women began drinking the coffee, and was associated with a doubling in the incidence of foetal breathing activity and a significant fall in foetal heart rate that remained for some hours (Table 58). Since consumption of decaffeinated coffee also increased the incidence of foetal breathing activity significantly (during the second experimental hour), and produced a slight but nonsignificant reduction in foetal heart rate, it is possible that the observed effects may be attributed to other ingredients in coffee than caffeine. It seems mandatory to study the effects of decaffeinated coffee further under controlled conditions. The significance of these results should also be weighted against the low number of women studied. The strength of the investigation was its design, but the actual caffeine exposure from coffee could be questioned. 
Table 57. In vitro studies on caffeine exposure of foetal organs/tissues.

\begin{tabular}{|c|c|c|c|c|c|}
\hline $\begin{array}{l}\text { Reference } \\
\text { Type of study }\end{array}$ & Sample size and selection & $\begin{array}{l}\text { Exposure period considered } \\
\text { Sources and dosage of } \\
\text { caffeine }\end{array}$ & End-point(s) & Results & Comments \\
\hline $\begin{array}{l}\text { Resch et al., } 1985 \\
\text { In vitro study }\end{array}$ & $\begin{array}{l}\text { Twenty-five foetal hearts } \\
\text { from terminated pregnan- } \\
\text { cies }\end{array}$ & $\begin{array}{l}\text { Age: } 6-17 \text { weeks of gesta- } \\
\text { tion } \\
0,1.94,19.4 \text { and } 194 \mu \mathrm{g} \\
\text { caffeine/ml }\end{array}$ & $\begin{array}{l}\text { Changes (\%) in heart rate in } \\
\text { comparison with control } \\
\text { hearts }\end{array}$ & $\begin{array}{l}\text { A significant age- and concentration- dependent increase } \\
\text { in foetal heart rate was observed. }\end{array}$ & $\begin{array}{l}\text { Relevance of the results for an in vivo situation is not } \\
\text { clear. }\end{array}$ \\
\hline $\begin{array}{l}\text { Resch et al., } 1987 \\
\text { In vitro study }\end{array}$ & $\begin{array}{l}\text { Twenty-five foetal hearts } \\
\text { from terminated pregnan- } \\
\text { cies }\end{array}$ & $\begin{array}{l}\text { Age: } 6-20 \text { weeks of gesta- } \\
\text { tion } \\
0,1.94,19.4 \text { and } 194 \mu \mathrm{g} \\
\text { caffeine/ml }\end{array}$ & $\begin{array}{l}\text { Changes (\%) in contractility } \\
\text { in comparison with control } \\
\text { hearts }\end{array}$ & $\begin{array}{l}\text { A significant age- and concentration- dependent increase } \\
\text { in contractility was observed. }\end{array}$ & $\begin{array}{l}\text { Relevance of the results for an in vivo situation is not } \\
\text { clear. }\end{array}$ \\
\hline $\begin{array}{l}\text { Ramirez et al., } 1998 \\
\text { In vitro study }\end{array}$ & $\begin{array}{l}\text { Placentas, arteries and } \\
\text { veins }(n=10) \text { isolated from } \\
\text { uncomplicated term } \\
\text { pregnancies: at least } 38 \\
\text { weeks of gestation }\end{array}$ & $\begin{array}{l}\text { Caffeine concentration in } \\
\text { solution: } \\
0.1 \mathrm{nM}-0.1 \mathrm{mM}\end{array}$ & $\begin{array}{l}\text { Placental vascular tone } \\
\text { alterations }\end{array}$ & $\begin{array}{l}\text { Vascular tone in human placental arteries and veins } \\
\text { No change with caffeine at resting tone. } \\
\text { Addition of the drug to precontracted placental blood } \\
\text { vessels } \\
\text { Modest relaxations (15-30\% of maximal tone) were } \\
\text { observed. }\end{array}$ & $\begin{array}{l}\text { Caffeine does not appear to alter human placental } \\
\text { vascular tone in vitro. } \\
\text { Relevance of the results for an in vivo situation is not } \\
\text { clear. }\end{array}$ \\
\hline
\end{tabular}


The most recent of the American in vivo studies aimed at assessing the acute cardiovascular effects of caffeine ingestion in pregnant subjects and their foetuses (Miller et al., 1994). Seven caffeine-naive gravidas at the 24-28 and 34-38 weeks of gestation were examined for a large number of parameters. These were maternal pulse and blood pressure, and foetal heart rate, uterine artery, foetal aorta, and umbilical artery flow velocity waveforms before and after ingestion of a $100 \mathrm{mg}$ caffeine citrate solution per $\mathrm{m}^{2}$ body surface area. The dosage was roughly equivalent to one brewed cup of coffee. The caffeine exposure influenced maternal pulse (a reduction), diastolic blood pressure (an increase), mean arterial blood pressure (an increase), uterine artery systolic-to-diastolic (S/D) ratio (an increase), foetal heart rate (a reduction), and foetal heart rate acceleration (an increase) (Table 58). The gestational age did not influence the effect. The caffeine administration did not influence foetal aortic and umbilical artery S/D ratios. However, foetal aortic peak velocities increased upon caffeine exposure, and the increase was augmented with advancing gestational age. Thus, modest amounts of caffeine citrate in caffeine-naive subjects affected both the foetal and the maternal cardiovascular systems in this study. However, it was performed with a very limited number of pregnant women. It should also be noted that only five of the seven participants were truly caffeine-naive. A serious problem with this study is the lack of analyses of caffeine in maternal blood. The experimental design might thus have introduced unknown bias, apart from the fact that the experiments were not carried out with a single or double blind design.

A very small Dutch study aimed at evaluating the effect of caffeine in women with twin pregnancies who volunteered to take part in the investigation (Huisman et al., 1997). Five women were investigated before and after drinking coffee for the following parameters: maternal haemodynamics, umbilical blood flow, foetal heart rate and twin behaviour (longitudinally documented during a 30-minute session from 8 to 16 gestational weeks). There was a significant mean increase in maternal heart rate ( 8 beats per minute) after drinking coffee. Also the pulsatility index of the umbilical artery showed significant increase after intake of coffee. Two of five behavioural parameters (swallowing and breathing) of the twin foetuses demonstrated significant changes after the mother's consumption of coffee (Table 58). This study on only 5 women was poorly presented. However, it demonstrated significant effects of caffeine consumption on maternal and foetal haemodynamics, and indicates that it seems worthwhile to study the influences of coffee consumption on early twin behaviour in larger samples of pregnant women. 
Table 58. Clinical studies on caffeine exposure in utero

\begin{tabular}{|c|c|c|c|c|c|}
\hline $\begin{array}{l}\text { Reference } \\
\text { Study type and location }\end{array}$ & Sample size and selection & $\begin{array}{l}\text { Exposure period, Sources } \\
\text { Dosage of caffeine }\end{array}$ & End-point(s) & Results & Comments \\
\hline $\begin{array}{l}\text { Kirkinen et al., } 1983 \\
\text { Clinical trial } \\
\text { Finland }\end{array}$ & 20 pregnancies & $\begin{array}{l}3^{\text {rd }} \text { trimester } \\
\text { Coffee } 2 \text { cups }\end{array}$ & $\begin{array}{l}\text { Caffeine and epinephrine } \\
\text { concentrations in maternal } \\
\text { serum } \\
\text { Placental blood flow }\end{array}$ & $\begin{array}{l}\text { Caffeine and epinephrine conc. in maternal serum } \\
\text { Sign. increase }(p<0.01) \\
\text { Placental blood flow } \\
\text { Sign decrease }(p<0.05) \text {. } \\
\text { In pregnancies associated with hypertension } \\
\text { intervillous blood flow was reduced initially, and } \\
\text { did not change after caffeine intake. }\end{array}$ & Small and heterogeneous study base. \\
\hline $\begin{array}{l}\text { McGowan et al., } 1987 \\
\text { Clinical trial } \\
\text { USA }\end{array}$ & $\begin{array}{l}14 \text { patients, divided into } \\
\text { high consumers } \\
\text { ( }>500 \mathrm{mg} / \text { day) and } \\
\text { low consumers } \\
\text { ( }<250 \mathrm{mg} / \text { day) of caffeine }\end{array}$ & $\begin{array}{l}\text { 36-39 weeks of pregnancy } \\
\text { Both groups were admi- } \\
\text { nistrated } \\
200 \mathrm{mg} \text { caffeine orally; the } \\
\text { foetus was observed for } \\
180 \text { minutes thereafter }\end{array}$ & $\begin{array}{l}\text { Maternal plasma caffeine and } \\
\text { blood glucose concentrations } \\
\text { (every } 30 \text { minutes), } \\
\text { foetal breathing and body } \\
\text { movements (continuous) }\end{array}$ & $\begin{array}{l}\text { Mean maternal plasma caffeine concentrations } \\
\text { Significantly higher in the high consumers compa- } \\
\text { red with low consumers at all intervals. } \\
\text { Maternal blood glucose concentrations } \\
\text { No difference between groups. } \\
\text { Foetal breathing rates and body movements } \\
\text { Similar in both groups before and after caffeine } \\
\text { administration. } \\
\text { Foetal breathing movement Incidence decreased } \\
\text { significantly in low consumers, whereas no } \\
\text { deviation from baseline was observed among } \\
\text { high consumers }\end{array}$ & $\begin{array}{l}\text { The results of this paper were partly confirmed in Devoe et } \\
\text { al, 1993, but birth weight was the same in both groups in } \\
\text { this paper. } \\
\text { For American conditions the exposure seems high. }\end{array}$ \\
\hline $\begin{array}{l}\text { Salvador and Koos, } \\
1989 \\
\text { Single-blind clinical } \\
\text { crossover study } \\
\text { USA }\end{array}$ & $\begin{array}{l}8 \text { pregnant women } \\
\text { Non smokers }\end{array}$ & $\begin{array}{l}32-36 \text { weeks } \\
\text { pregnant } \\
\text { Coffee } 2 \text { cups (regular or } \\
\text { decaffeinated); } \\
\text { procedure was repeated } \\
\text { one week later }\end{array}$ & $\begin{array}{l}\text { Foetal heart rate and } \\
\text { breathing activity. } \\
\text { Concentrations of caffeine, } \\
\text { cate-cholamines, glucose in } \\
\text { serum. }\end{array}$ & $\begin{array}{l}\text { Foetal heart rate } \\
\text { Intake of regular coffee was associated with a } \\
\text { significant fall. } \\
\text { Decaffeinated coffee also produced a slight but } \\
\text { NS, reduction. } \\
\text { Foetal breathing activity } \\
\text { Intake of regular coffee was associated with a } \\
\text { sign. increase. Decaffeinated coffee also increa- } \\
\text { sed foetal breathing activity (sign during } 2^{\text {nd }} \text { exp. } \\
\text { hour) }\end{array}$ & $\begin{array}{l}\text { Limited number of participants. } \\
\text { Advantages of this study: the cross over procedure and } \\
\text { the single blind design. } \\
\text { The effects of decaffeinated coffee should be studied } \\
\text { under controlled conditions. }\end{array}$ \\
\hline
\end{tabular}




\begin{tabular}{|c|c|c|c|c|c|}
\hline $\begin{array}{l}\text { Reference } \\
\text { Study type and location }\end{array}$ & Sample size and selection & $\begin{array}{l}\text { Exposure period, Sources } \\
\text { Dosage of caffeine }\end{array}$ & End-point(s) & Results & Comments \\
\hline $\begin{array}{l}\text { Devoe et al., } 1993 \\
\text { Clinical trial } \\
\text { USA. }\end{array}$ & $\begin{array}{l}20 \text { normal pregnancies } \\
\text { divided in two groups: } \\
\text { "High" caffeine consumers } \\
\text { (> } 500 \mathrm{mg} / \text { day) } \\
\text { "Low" caffeine consumers } \\
(<200 \mathrm{mg} / \text { day })\end{array}$ & $\begin{array}{l}\text { Normal consumption of } \\
\text { caffeine-containing beve- } \\
\text { rages and foods }\end{array}$ & \begin{tabular}{|l|}
$\begin{array}{l}\text { Maternal caffeine levels and } \\
\text { foetal behavioural states. }\end{array}$ \\
Examinations at $30-40$ weeks \\
of pregnancy biweekly.
\end{tabular} & $\begin{array}{l}\text { Mean maternal serum caffeine levels } \\
\text { Significantly higher in "high" caffeine consumers } \\
\text { compared with "low" caffeine consumers } \\
\text { Foetal behaviour states } \\
\text { Foetuses exposed to "high" caffeine levels spent } \\
\text { in comparison with foetuses exposed to "low" } \\
\text { caffeine levels: } \\
\text { - similar mean time in quiet sleep } \\
\text { - less mean time in active sleep } \\
\text { - and much greater mean time in arousal }\end{array}$ & $\begin{array}{l}\text { The study was well performed, but no analyses of com- } \\
\text { monly used drugs like ethanol or benzodiazepines were } \\
\text { performed. } \\
\text { Birth weight and parity groups exposed to "high" caffeine } \\
\text { levels were at term significantly lower than birth weights of } \\
\text { infants exposed to "low" caffeine levels in utero. Mothers } \\
\text { with low caffeine intake were older than mothers having } \\
\text { "high" caffeine intake. No withdrawal symptoms were } \\
\text { observed. }\end{array}$ \\
\hline $\begin{array}{l}\text { Miller et al., } 1994 \\
\text { Clinical trial } \\
\text { USA }\end{array}$ & 7 pregnant women & $\begin{array}{l}\frac{1^{\text {st }} \text { investigation: }}{\text { at } 24-28 \text { weeks pregnancy }} \\
\frac{2^{\text {nd }} \text { investigation: }}{\text { at } 34-38 \text { weeks pregnancy }} \\
\text { Caffeine citrate solution: } \\
\frac{1^{\text {st }} \text { invest: } 178 \pm 14.3 \mathrm{mg}}{2^{\text {nd }} \text { invest: }} \\
\frac{185 \pm 16.1}{\mathrm{mg}}\end{array}$ & \begin{tabular}{|l|} 
Maternal pulse and blood \\
pressure (diastolic and \\
arterial). \\
Foetal heart rate, and accele- \\
rations \\
Uterine artery, foetal aorta, \\
umbilical artery flow velocity
\end{tabular} & $\begin{array}{l}\text { Significant differences after caffeine administrati- } \\
\text { on } \\
\text { Maternal pulse } \downarrow \text {, diastolic blood pressure } \uparrow \text {, } \\
\text { mean arterial blood pressure } \uparrow \text {, uterine artery } \\
\text { systolic - to-diastolic (S/D) ratio } \uparrow \text {. Foetal heart } \\
\text { rate } \downarrow \text {, foetal heart rate accelerations } \uparrow \text {, foetal } \\
\text { aortic peak velocities } \uparrow \text {. } \\
\text { No sign. differences after caffeine administration } \\
\text { Foetal aorta, umbilical artery (S/D) ratios. }\end{array}$ & $\begin{array}{l}\text { Limited number of participants. Two of seven participants } \\
\text { were not caffeine-naive. Analyses of caffeine in maternal } \\
\text { blood are lacking. The experiments were neither carried } \\
\text { out with a single or double blind design. }\end{array}$ \\
\hline $\begin{array}{l}\text { Huisman et al., } 1997 \\
\text { Clinical pilot study } \\
\text { The Netherlands }\end{array}$ & $\begin{array}{l}5 \text { women with twin preg- } \\
\text { nancies were investigated } \\
\text { before and after drinking } \\
\text { coffee. }\end{array}$ & \begin{tabular}{|l|} 
Early pregnancy \\
( 8 weeks) \\
\\
2 cups of strong coffee \\
(total exposure approxi- \\
mately $500 \mathrm{mg}$ of caffeine) \\
at weekly intervals
\end{tabular} & \begin{tabular}{|l|} 
Maternal hemodynamics, \\
umbilical blood flow, foetal \\
heart rate and twin behaviour \\
assessed weekly -from 8 to \\
16 gestational weeks. \\
\end{tabular} & $\begin{array}{l}\text { Maternal heart rate } \\
\text { Mean increase was } 8 \text { bpm ( } p<0.01) \text { after coffee } \\
\text { intake. } \\
\text { Pulsatility index of the umbilical artery } \\
\text { Significant increase after coffee intake }(p<0.05) \text {. } \\
\text { Behaviour } \\
\text { Swallowing and breathing showed significant } \\
\text { changes after intake of coffee }(p<0.001) \text {. }\end{array}$ & $\begin{array}{l}\text { Low number of participants }(n=5) \text {. Results were poorly } \\
\text { presented. }\end{array}$ \\
\hline
\end{tabular}




\subsection{Summary of caffeine intake and effects on foetuses.}

Three studies differed markedly from the rest, since they were performed in vitro. One of these studies investigated the rate of foetal hearts (Resch et al., 1985), and another the contractility of foetal hearts in caffeine solutions (Resch et al., 1987). In both studies, a significant age- and concentration-dependent increase was registered. In the third study, vascular tone alterations were examined in human placental arteries and veins (Ramirez et al., 1998). The latter study indicated that micromolar concentrations of caffeine could bring about a modest relaxation (15-30\% of maximal tone) of pre-contracted placental blood vessels.

The six clinical investigations presented in this section were all very small, and focused on the effects of maternal caffeine exposure on foetal breathing (foetal breathing rate and foetal breathing movements), foetal body movements (foetal eye, trunk and extremity movements), and effects on the foetal cardiovascular system (foetal heart rate, foetal heart acceleration, foetal blood pressure; uterine artery, foetal aorta, and umbilical artery flow velocity waveforms). The following parameters were simultaneously studied in the mother: blood pressure (diastolic and systolic), heart rate, serum concentration of caffeine, glucose and catecholamines (epinephrine, norepinephrine and dopamine). The studied parameters varied between studies. McGowan et al. (1987), Devoe et al. (1993), and Salvador et al. (1989) concentrated on the effects of caffeine on breathing and body movements of the foetus, whereas Kirkinen et al (1983), Miller et al. (1994), and Huisman et al. (1997) paid more attention to how this compound influenced haemodynamic parameters.

With the exception of one of the studies, which investigated the influence of caffeine on early twin pregnancies (Huisman et al., 1997), all other clinical studies were carried out on women in the third trimester of pregnancy. The administration of caffeine differed between studies. In two studies (McGowan et al., 1987; Miller et al., 1994) the pregnant women ingested purified caffeine, whereas in the studies by Kirkinen et al (1983), Salvador and Koos (1989) and Huisman et al. (1997) the women drank 2 cups of coffee. Caffeine is likely to be more quickly absorbed when administered as a pure compound. The sixth study (Devoe et al., 1993) investigated the effects of a natural (unsupplemented) long-term exposure to caffeine from coffee.

The study results are contradictory. For example, high caffeine intakes of pregnant women increased the foetal heart rate in two studies (Devoe et al., 1993; Huisman et al., 1997), whereas the rate was reduced in two other studies (Salvador and Koos, 1989; Miller et al., 1994). Similarly, two studies found high caffeine exposures to increase the foetal breathing rate (Salvador and Koos, 1989; Devoe et al., 1993), whereas another 
found high caffeine exposures to have no effect on the foetal breathing rate (McGowan et al., 1987). It is possible that some of the discrepancies could be explained by the fact that the background intake of caffeine from foods was poorly controlled for. Furthermore, administered dosage and form (tablets, solutions or as coffee), and the genetic constitution of the pregnant women, varied considerably between studies.

In conclusion, the available data on foetuses exposed to caffeine in utero reviewed in this chapter are so divergent that it is difficult to predict what effects are likely to appear upon exposure of pregnant women to caffeine, and to what extent the effects could be defined as adverse. An interesting finding by Salvador and Koos (1989) should be noted, namely the observation that decaffeinated coffee (like regular coffee) also increased the incidence of foetal breathing activity and produced a slight reduction in foetal heart rate. This observation raises the question as to whether constituents of coffee other than caffeine may have pharmacological effects on foetuses in utero and influence their behaviour. 


\section{Maternal intake of caffeine and effects on neonates, infants and older children.}

The definitions used for neonates and infants in this report are the definitions suggested by Dorland (1985). A neonate is a child younger than 4 weeks, while an infant is a child younger than 24 months. The chapter reviews data from case reports, clinical investigations and epidemiological studies carried out in order to study the effects of maternal intake of caffeine on neonates, infants and older children. In most studies, the effects of caffeine exposure in utero have been investigated, while in a few of the studies caffeine exposure via breast milk has also been included.

As thoroughly described in chapter 8, the half-life of caffeine is doubled or tripled during pregnancy due to hormonal influences. As a result, the elimination of caffeine is much slower in pregnant women than in non-pregnant women, especially during the third trimester. Elimination is also delayed in the neonate. The greatly increased half-life of caffeine during pregnancy is expected to cause a significant increase of tissue concentrations of caffeine, as long as the pregnant women do not reduce their caffeine intake.

After birth the neonate/infant may be exposed to caffeine via breast milk. It has been shown that the time courses for caffeine and its primary degradation products in milk parallel their respective serum profiles (Stavchansky et al., 1988, Oo et al., 1995). Tyrala and Dodson (1979) reported that peak concentrations of caffeine in serum and milk were attained 60 minutes after oral intake of caffeine, but the levels were lower in milk than in serum. Breast milk collected during the first hour after the mother's dose (one cup of coffee with $150 \mathrm{mg}$ caffeine) contained approximately $1.5 \mu \mathrm{g} / \mathrm{ml}$ caffeine, that is a fraction of the amount ingested by the mother. These observations were confirmed by Berlin et al. (1984), who studied fifteen lactating women and nursing infants between 2 weeks and 9 months of age, who ingested various but known amounts of a caffeinated beverage. On average, the elimination half-life of caffeine was $6.1 \pm 4.4 \mathrm{~h}$ for milk. Oo et al. (1995) reported a $5.5 \pm 1.8 \mathrm{~h}$ half-life for caffeine in breast milk 6-28 weeks post partum. The corresponding half-lives of paraxanthine, theobromine, and theophylline were $6.7 \pm 2.8 \mathrm{~h}, 12 \pm 2.5 \mathrm{~h}$, and 8.2 $\pm 3.7 \mathrm{~h}$, respectively (Oo et al., 1995).

Using the data of Oo et al. (1995) on the pharmacokinetics of methylxanthines in breast milk, and assuming neonatal milk consumption at 150 $\mathrm{ml} / \mathrm{kg} /$ day, the newborn would ingest an equivalent of $18 \%$ of the mater- 
nal caffeine dose (on a body weight basis). Approximately $7 \%$ of this $18 \%$ would be caffeine. Although caffeine is excreted to a limited extent in breast milk, and the dose of caffeine presented to the infant is generally regarded as small (i.e. $<5 \%$ of maternal dose), clinical concern continues to focus on the inability of the neonate to metabolise caffeine (for more details, see chapter 8). It is known that the enzymes of the metabolic system needed for caffeine metabolism are not completely developed until the child is six months old. Consequently, caffeine is to a larger extent eliminated in an unchanged form in the newborn (and in particular the premature newborn), which is at greater risk for accumulating caffeine. The amount of caffeine accumulated by the baby depends on the average caffeine concentration in the mothers' serum and breast milk during nursing, as well as the amount of milk ingested by the baby, the absorption of caffeine by the infant, and the baby's rate of caffeine elimination. The caffeine elimination rate varies from one infant to another, and is very slow in the premature or full-term newborn human infant (Tyrala and Dodson, 1979; Le Guennec and Billon, 1987; Parsons and Neims, 1981).

Adequate possibilities of metabolising and eliminating caffeine are lacking in the foetus. In the case of a high maternal consumption of caffeine-containing foods during pregnancy, the resulting enhanced exposure of the foetus to caffeine could therefore be potentially dangerous. (For more details, see chapter 8.3). Investigations concerning the effects of caffeine/theophylline in the treatment of apnoea, which is a fairly oftenreported condition of prematurity, have not been reviewed in this chapter, except for the study done by Toubas et al. (1986). The reason for this is that doses and administration (intravenous) are not relevant when considering an exposure via food (Nehlig and Debry, 1994a, 1994b).

\subsection{Effects of chronic caffeine consumption by the mother on neonates, infants and older children}

The effects of maternal exposure to alcohol, nicotine, and caffeine during pregnancy on the mental and motor development of infants at eight months of age were studied by Streissguth and colleagues (1980). As the same workers have subsequently have made follow-up studies of the same cohort the resulting observations will be discussed in connection with the original study. The studied subjects were 462 infants who's primarily white, married, and well-educated mothers were interviewed during the fifth month of pregnancy. They were selected from a larger sample of 1529 mothers (part of the Seattle longitudinal study 1974-75) to maximise the number of offspring of heavily drinking and smoking women in this sample. Caffeine intake during early and mid-pregnancy was estimated from the reported consumption of coffee, tea, cola beverages, and cocoa. Of the 462 women, $20 \%$ consumed $\geq 444 \mathrm{mg}$ caffeine/day, a 
relatively high amount for American women (Barr et al., 1984). Caffeine intake was higher among women consuming $\geq 1$ oz alcohol per day (32\%) than in women having a lower alcohol consumption (16\%). The mother's caffeine intake did not influence the mental and motor development of infants at 8 months of age as assessed using the Bayley Scales of Infant Mental and Motor Development (Table 59). It should be noted that the main interest of the investigators of this publication was the effect of maternal consumption of alcohol. No specific hypothesis regarding any expected effects of caffeine has been presented, which makes it difficult to know what kind of behavioural tests it would be optimal to use. This is also apparent in the follow-up studies of the cohort. Furthermore, the interpretation of the study is complicated by the fact that no data on the level of caffeine consumed by the mother in relationship to the studied outcome in the infant was reported.

The same cohort was also used in order to explore the relationship between maternal caffeine intake during pregnancy and infant size at 8 months of age. The 453 infants were examined at birth and again at their 8-month birthday. As shown in Table 59, there was no correlation between maternal caffeine intake during pregnancy and the studied parameters of infant size (length, weight, and head circumference) at birth or 8 months of age (Barr et al., 1984).

The cohort was followed up again at an age of 4 years and 3 months (Barr et al., 1990). This examination focused on the effects of prenatal caffeine exposure on fine and gross motor performance in the children. In some of the fine motor performance tests, statistically significant relationships were observed. The authors, however, considered the findings inconsistent, and thus difficult to interpret.

When the children were 7 years old the cohort was studied again, this time to evaluate the influence of prenatal caffeine on offspring development (Barr and Streissguth, 1991). The developmental parameters studied were height, weight, and head circumference, and results from individually administered IQ and attention tests. After appropriate statistical adjustment for relevant co-variates (cigarette smoking, alcohol, maternal size, demographics, etc.) prenatal caffeine exposure was found to be unrelated to most newborn and infant outcome measures at 7 years of age. A significant association was found only between prenatal caffeine exposure and breech presentation (Table 59). No biological mechanism for the observed influence on breech presentation was given. Since this study involved a secondary analysis of data collected for other purposes, specifically designed studies are required to determine the validity of the indicated association between caffeine exposure and breech presentation. The general conclusion was that the long-term consequences of prenatal caffeine exposure are absent in this cohort (Barr and Stressguth, 1991).

In a clinical investigation published as a letter to Lancet, Van't Hoff (1982) reported on the caffeine plasma concentrations in the umbilical 
cord in 52 healthy pregnant women giving birth to 55 full-term healthy neonates. No information was given on how the women were selected. Thirty-eight of the babies had plasma caffeine levels below $15 \mu \mathrm{mol} / \mathrm{l}$. Seven of the babies with higher plasma levels had been treated for recurrent apnoea. The mean intake of caffeine (from coffee, tea, cola drinks and cocoa) during pregnancy (average) was estimated to $290 \pm 230 \mathrm{mg}$. The caffeine exposure did not influence either the pregnancy or the baby, as judged by the records of the labour, Apgar scores, and clinical examination. However, no statistical evaluation was presented (Table 59).

The effects of prenatal exposure to smoking, caffeine, and alcohol on the neonate were studied in 173 infants whose mothers consumed little or no alcohol during pregnancy (Jacobson et al., 1984). The data were originally collected in order to study the effects of prenatal exposure to PCBs (in most cases via contaminated fish). However, intakes of caffeine and alcohol, as well as smoking habits before and during pregnancy, were registered in maternal interviews administered in the hospitals 2-3 days after delivery. Over $85 \%$ of the women consumed caffeine during pregnancy, with the mean daily consumption being $121.44 \mathrm{mg} /$ day or 1.45 cups of coffee. Less than $3 \%$ of the women drank quantities characteristic of "heavy consumers" in this study, e.g. equivalent to more than $591 \mathrm{mg}$ caffeine per day. A significant $32 \%$ reduction in caffeine intake was registered during pregnancy. The following outcomes were studied in relation to caffeine intake: birth weight (BW), crown-heel length (CHL), gestational age (GA), neonatal behavioural (according to Brazleton, 1973) including reflexes, orientation, arousal, and irritability. Twentyeight of the forty-eight potential confounders could be controlled for. Interestingly, the study found a high caffeine intake prior to pregnancy to be associated with poorer orientation, greater arousal on range of state and general irritability. During pregnancy, a high caffeine intake was associated with shorter gestation and a higher incidence of abnormal reflexes (Table 59). It should be noted that the behavioural effects reported were limited to the immediate post partum period and that no measurements of caffeine concentrations in infants' blood were carried out. The number of participants in the study was quite limited in relation to the large number of confounders being controlled for. 
Table 59. Maternal intake of caffeine during pregnancy/lactation period and effects on neonates, infants and older children

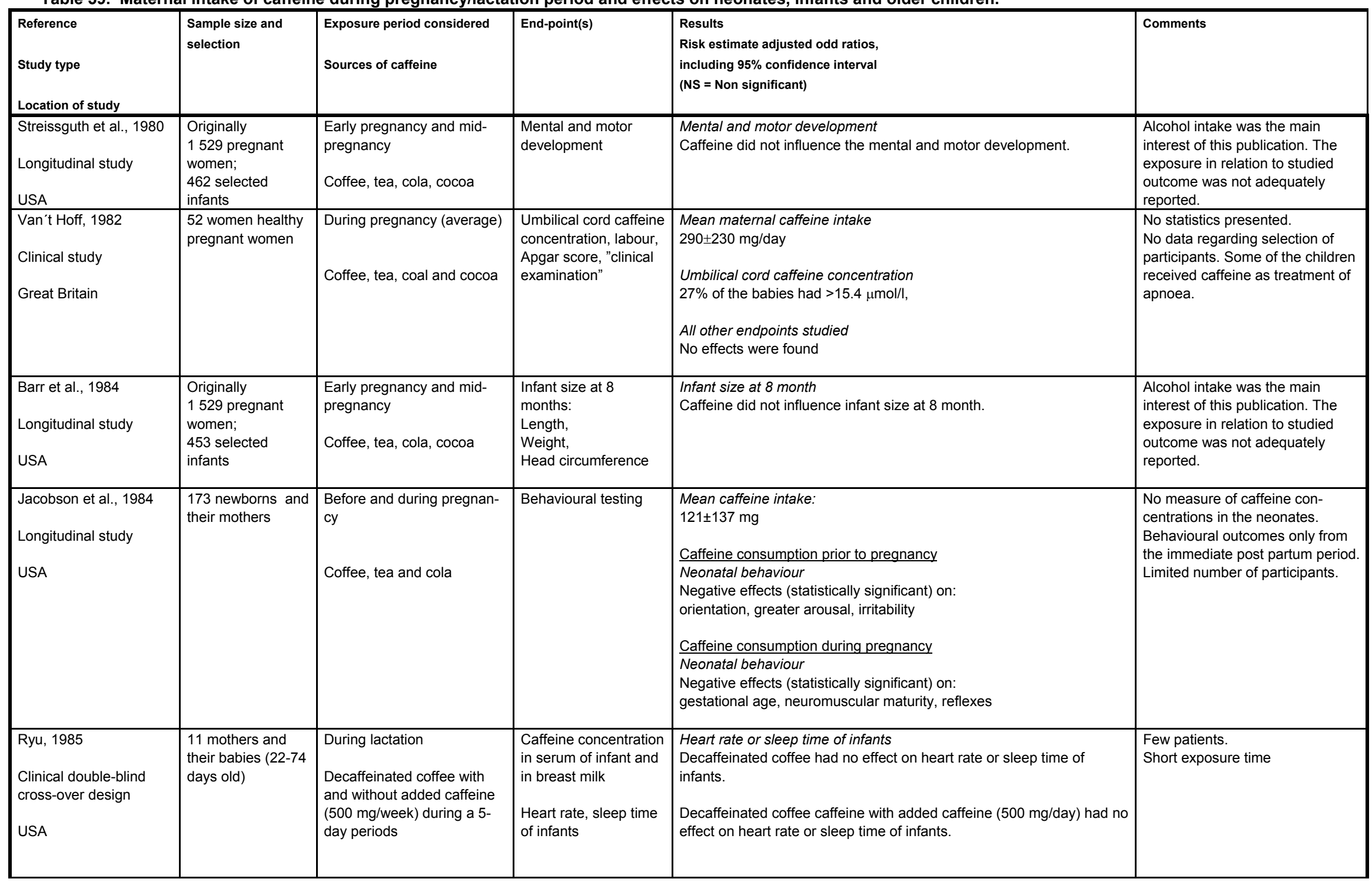




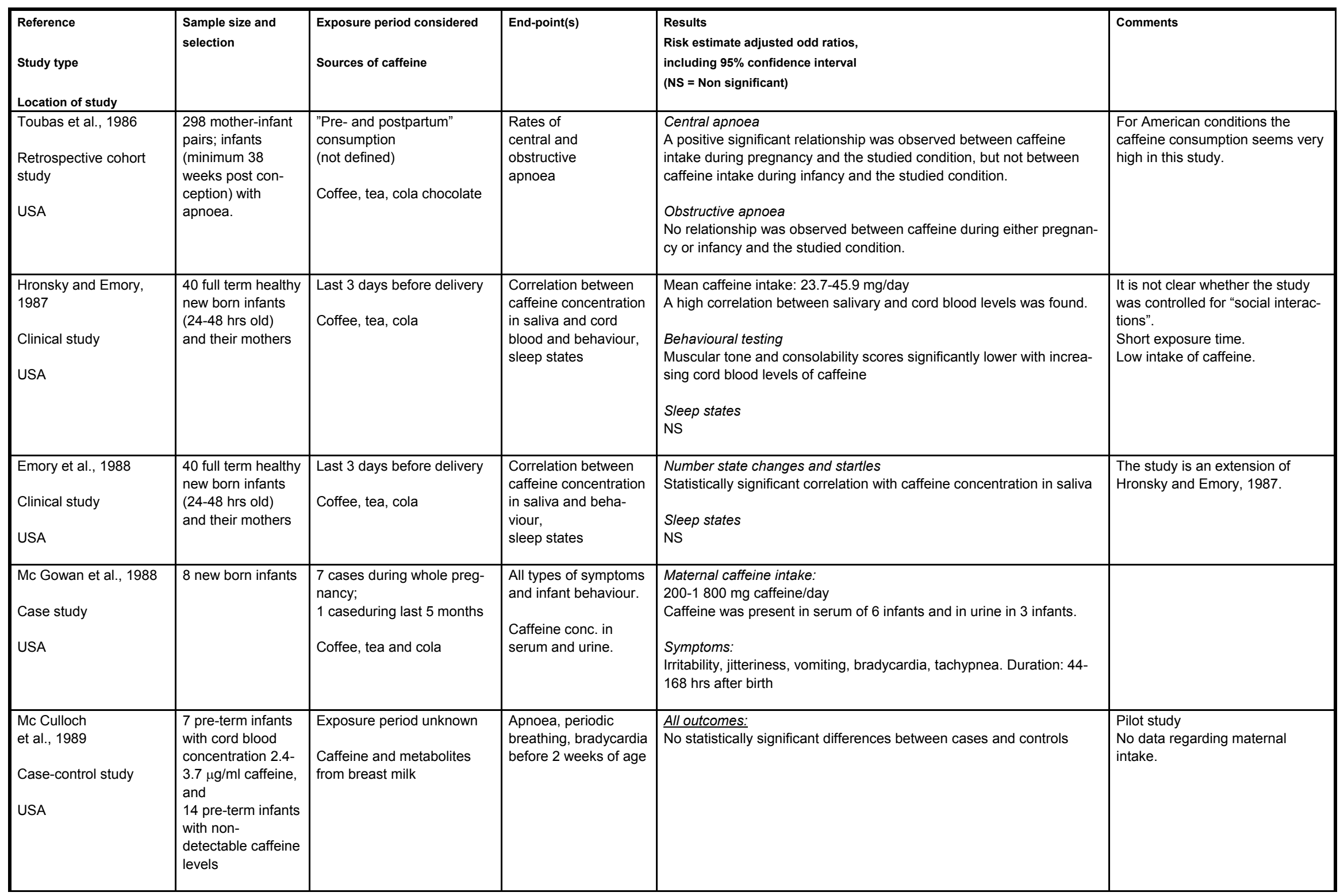




\begin{tabular}{|c|c|c|c|c|c|}
\hline $\begin{array}{l}\text { Reference } \\
\text { Study type } \\
\text { Location of study }\end{array}$ & $\begin{array}{l}\text { Sample size and } \\
\text { selection }\end{array}$ & $\begin{array}{l}\text { Exposure period considered } \\
\text { Sources of caffeine }\end{array}$ & End-point(s) & $\begin{array}{l}\text { Results } \\
\text { Risk estimate adjusted odd ratios, } \\
\text { including } 95 \% \text { confidence interval } \\
\text { (NS = Non significant) }\end{array}$ & Comments \\
\hline $\begin{array}{l}\text { Barr and Streissguth, } \\
1990 \\
\text { Longitudinal study } \\
\text { USA }\end{array}$ & $\begin{array}{l}\text { Originally } \\
1529 \text { pregnant } \\
\text { women; } \\
449 \text { selected } \\
\text { infants }\end{array}$ & $\begin{array}{l}\text { Early pregnancy and mid- } \\
\text { pregnancy } \\
\text { Coffee, tea, cola, cocoa }\end{array}$ & \begin{tabular}{|l|} 
Effects on fine and \\
gross motor perfor- \\
mance $\quad$ at 4 \\
years
\end{tabular} & $\begin{array}{l}\text { Fine motor performance tests } \\
\text { Statistically significant relationships with caffeine consumption for } \\
\text { some parameters }\end{array}$ & $\begin{array}{l}\text { The exposure in relation to stu- } \\
\text { died outcome was not adequately } \\
\text { reported } \\
\text { The results of the tests were } \\
\text { inconsistent and thus difficult to } \\
\text { interpret. }\end{array}$ \\
\hline $\begin{array}{l}\text { Barr and Streissguth, } \\
1991\end{array}$ & $\begin{array}{l}\text { Originally } \\
1529 \text { pregnant } \\
\text { women } \\
\text { From their } \\
\text { offspring } 482 \\
\text { infants were } \\
\text { analysed } \\
\end{array}$ & $\begin{array}{l}\text { Early pregnancy and mid- } \\
\text { pregnancy } \\
\text { Coffee, tea, cola, cocoa }\end{array}$ & $\begin{array}{l}\text { Neurobehavioural } \\
\text { outcomes at } \\
7 \text { years }\end{array}$ & $\begin{array}{l}\text { Breech presentation } \\
\text { Statistically significant increase at } \geq 296 \mathrm{mg} / \mathrm{day} \text { (linear threshold) } \\
\text { (the only parameter affected by caffeine consumption in the study) } \\
\text { General conclusion } \\
\text { No long term effects of caffeine }\end{array}$ & $\begin{array}{l}\text { It may be questioned whether the } \\
\text { used tests are relevant. A mecha- } \\
\text { nism for influence on breech was } \\
\text { not presented. }\end{array}$ \\
\hline $\begin{array}{l}\text { Hadeed and Siegel, } \\
1993 \\
\text { Case-control study } \\
\text { USA }\end{array}$ & $\begin{array}{l}16 \text { case infants } \\
\text { excreting caffeine } \\
\text { in urine, and } 56 \\
\text { control infants with } \\
\text { no excretion of } \\
\text { caffeine in urine }\end{array}$ & $\begin{array}{l}\text { Exposure period unknown } \\
\text { Coffee, tea, chocolate and } \\
\text { cola }\end{array}$ & $\begin{array}{l}\text { Tachy-arrhytmias, } \\
\text { premature atrial } \\
\text { contraction, } \\
\text { fine tremours, } \\
\text { tachypnea }\end{array}$ & $\begin{array}{l}\text { Maternal consumption } \\
\text { Cases: }>500 \mathrm{mg} / \mathrm{day} \\
\text { Controls: }<250 \mathrm{mg} / \mathrm{day} \\
\\
\text { All endpoints studied: } \\
\text { Statistically significant increased frequencies in cases compared with } \\
\text { controls. All symptoms disappeared by } 3 \text { days of age. }\end{array}$ & $\begin{array}{l}\text { Selection of patients was not } \\
\text { described. } \\
\text { Exposure period not clearly } \\
\text { stated. } \\
\text { Few patients in the caffeine group }\end{array}$ \\
\hline $\begin{array}{l}\text { Ford et al., } 1998 \\
\text { Case-control study } \\
\text { New Zealand }\end{array}$ & $\begin{array}{l}393 \text { sudden infant } \\
\text { death syndrome } \\
\text { cases, and } \\
1592 \text { matched } \\
\text { infant controls }\end{array}$ & $\begin{array}{l}1^{\text {st }} \text { and } 3^{\text {rd }} \text { trimester } \\
\text { Coffee, tea and cola }\end{array}$ & \begin{tabular}{|l|} 
Caffeine intake in \\
relation to sudden \\
infant death syndrome
\end{tabular} & $\begin{array}{ll}1^{15 t} \text { trimester } & \\
0-399 \mathrm{mg} \text { caffeine /day vs } & \\
\geq 400 \mathrm{mg} / \text { day } & \\
& \\
3^{\text {rd }} \text { trimester } & \\
0-399 \mathrm{mg} \text { caffeine/day vs } & \\
\geq 400 \mathrm{mg} / \text { day } & 1.46(1.05-2.05) \\
& \\
\text { All pregnancy } & \\
0-399 \mathrm{mg} \text { caffeine/day vs } & \\
\geq 400 \mathrm{mg} / \text { day } & 1.65(1.15-2.36)\end{array}$ & $\begin{array}{l}\text { No dose response } \\
\text { Threshold effect }\end{array}$ \\
\hline $\begin{array}{l}\text { Alm et al., } 1999 \\
\text { Case-control study } \\
\text { Scandinavia }\end{array}$ & $\begin{array}{l}244 \text { sudden infant } \\
\text { death syndrome } \\
\text { cases, and } \\
869 \text { matched infant } \\
\text { controls }\end{array}$ & $\begin{array}{l}\text { Mean intake during preg- } \\
\text { nancy } \\
\text { Coffee, tea }\end{array}$ & $\begin{array}{l}\text { Caffeine and alcohol } \\
\text { consumption } \\
\text { in relation to sudden } \\
\text { infant death syndrome }\end{array}$ & $\begin{array}{l}0 \mathrm{mg} \text { caffeine/day vs } \\
1-400,401-800,>800 \mathrm{mg} / \text { day }\end{array}$ & \\
\hline
\end{tabular}


In order to determine the effect of maternal caffeine ingestion (500 $\mathrm{mg}$ /day) on the heart rate and sleeping patterns of their breast-fed infants, 11 mother-infant pairs were entered into a small study with a balanced crossover design (Ryu, 1985). Infants were 22-74 days old at the onset of the study. The mothers ingested 5 cups of decaffeinated coffee daily during one 5-day period, and 5 cups of decaffeinated coffee with added caffeine $(100 \mathrm{mg} / \mathrm{cup})$ during another 5-day period. Concentrations of caffeine in breast milk on the last day of the caffeine period ranged from 1.6 to $6.2 \mu \mathrm{g} / \mathrm{ml}$, and the intake of caffeine by the infants was estimated to be $0.3-1.0 \mathrm{mg} / \mathrm{kg}$ body weight/day. Infant serum did not contain detectable amounts of caffeine on the last day of either experimental period. There was no difference in the 24-hour heart rate and sleeping patterns during the two conditions of exposure (Table 59). Due to the low number of mother-infant pairs included in the study, these results should only be considered as preliminary.

In order to explore the relationship of prenatal maternal smoking and caffeine intake to the occurrence of apnoea in their offspring, rates for central and obstructive apnoea were analysed in a cohort of 298 motherinfant pairs (Toubas et al., 1986). Central apnoea was defined as the simultaneous cessation of both breathing effort and airflow, and obstructive apnoea as the cessation of air flow with continued thoraic breathing efforts. The age of the infants ranged from 26 to 58 weeks when the study began and their gestational age at birth ranged from 26 to 46 weeks. All studies were performed at a post-conceptional age of at least 38 weeks. Caffeine intake was calculated based on dietary information concerning the mother's coffee, tea, chocolate, and cola drink consumption, and expressed as mg caffeine consumed per day. Rates of central and obstructive apnoea of 6 to 10 seconds in duration were calculated. After controlling for smoking, there was no correlation between caffeine intake and obstructive apnoeas during pregnancy or infancy (Table 59). However, for central apnoea rates, there was a positive significant relationship for caffeine intake during pregnancy.

Hronsky and Emory (1987) measured the caffeine concentrations in cord blood and saliva from 40 vaginally delivered breast-fed infants (2448 hours old) and their healthy non-smoking mothers, and studied the behavioural effects of caffeine on the infant. The caffeine intake from coffee, tea and cola drinks during the last three days before delivery was quantified from information given in a food frequency questionnaire administered shortly after delivery, and controlled by measuring the caffeine level in blood and saliva from both mothers and infants. Maternal caffeine intake was correlated with caffeine levels in cord blood, but this correlation was not as strong as that seen in infants' salivary and cord blood levels of caffeine. The average caffeine intake on the day of testing was as low as $46 \mathrm{mg}$ in studied women. Infant behaviour was assessed using the BNBAC method (Brazelton 1973), which included the study of 
13 specified behaviours, none of which were very well characterised. In addition, sleep-state observations of infants were made. Increased exposure to caffeine significantly influenced certain interactive behaviours (muscular tone and consolability scores) in response to stimulation (Table 59), but had little or no effect upon spontaneous sleep states (Honsky and Emory, 1987). Infant salivary caffeine levels were significantly correlated with the number of state changes and startle reactions observed during the administration of the Brazelton Neonatal Behavior Assessment Scale (Emory et al., 1988). It is not clear whether social interactions between the mother and her infant were controlled for in this study.

In a case report describing a few patients, Mc Gowan et al. (1988) reported a withdrawal syndrome in 8 infants born to mothers who had chronically ingested average to large doses of caffeine (200-1 $800 \mathrm{mg}$ ) daily during pregnancy. Seven of the mothers had maintained this consumption during the entire pregnancy, while one mother reported "heavy consumption" only during the last 5 months of gestation. The infants exhibited unusual behaviour in the immediate newborn period - predominant irritability, jitteriness, and vomiting (Table 59). Two infants also had bradycardia and tachypnea. No other causes for the symptoms other than caffeine were identified. The age at onset ranged from 11 to 42 hours. Caffeine was present in the serum of seven of the infants, and three of the six infants had caffeine in their urine. The duration of symptoms ranged from 44 to 168 hours, and then resolved spontaneously. At 9 to 18 months of age, the infants were judged to be developing normally.

In a pilot study, McCulloch and co-workers (1989) investigated the influence of transplacentally acquired caffeine on the occurrence of apnoea, bradycardia, and periodic breathing in pre-term infants. Cases and controls were selected among 79 pre-term infants who had the cord blood caffeine concentrations measured at the time of delivery. No information on the mothers' intake of caffeine-containing beverages was available. Eleven infants $(14 \%)$ had detectable caffeine concentrations, ranging from 1.1 to $3.7 \mu \mathrm{g} / \mathrm{ml}$. Seven infants with detectable caffeine had impedance pneumograms recorded before 2 weeks of age. Each of these seven infants was matched with two infants without detectable caffeine by birth weight, gestational age, and chronological age at pneumogram recording, to yield a control group of 14 infants. Comparison of quantitative measures of apnoea, bradycardia, and periodic breathing (obtained from pneumogram analysis), as well as the incidence of monitor alarms on bedside nursing records between the infant groups during the first two weeks of life, revealed no significant differences between the groups (Table 59). It should be stressed that differential exposure to caffeine related to the time period of delivery and the studies on behavioural effects to the first two weeks of life.

Out of a study sample originally consisting of 154 full-term infants born at a medical centre in Los Angeles between 1985 and 1987, new- 
born infants with urine tests that were positive $(n=16)$ or negative for caffeine $(n=56)$, and negative for drugs and/or alcohol, were identified. The infants were assessed for caffeine effects on the central nervous system (Hadeed and Siegel, 1993). In the relatively small caffeine group, the mothers had an intake of more than $500 \mathrm{mg}$ of caffeine daily, while mothers in the control group consumed less than $250 \mathrm{mg} / \mathrm{day}$. The time period that defined the maternal caffeine exposure was not clearly stated. The predominant sources of caffeine were, however, coffee, tea, and cola drinks. During the first 12 hours of life, newborn infants from the caffeine group showed increased frequency of cardiac arrhythmias, premature atrial contraction, fine tremors, and tachypnea in comparison to the control group (Table 59). These symptoms usually disappeared by 3 days of age, and could, according to the author, be characterised as withdrawal symptoms.

A multicentre case-control study on the association between maternal caffeine consumption during pregnancy and the risk of sudden infant death syndrome (SIDS) was performed in New Zealand by surveying parents of 393 SIDS victims and parents of 1592 control infants (Ford et al., 1998). The mothers' caffeine exposure from tea, coffee, and cola drinks, in each of the first and third trimesters was estimated by questionnaire, assuming one cup of coffee to contain $100 \mathrm{mg}$ caffeine, one cup of tea $40 \mathrm{mg}$ caffeine, and one glass of cola drink $40 \mathrm{mg}$. Women with a daily caffeine intake of at least $400 \mathrm{mg}$ during the first and third trimesters of pregnancy had an increased risk of giving birth to infants that experienced SIDS (Table 59). After adjusting for confounding factors, the increased odds ratio was significant only for caffeine consumption during the third trimester. No dose response was evident. Reducing heavy caffeine intake during pregnancy could, according to the authors, be a way of lessening the risk of SIDS, but this needs confirmation in new investigations. The adjustment for smoking was not optimal, as it only took into account whether the mother had smoked (yes/no) in the last two weeks before delivering a dead child.

The influence of maternal caffeine exposure on sudden infant death syndrome (SIDS) has also been investigated by the Nordic epidemiological SIDS study, a case control study in which all parents of SIDS victims in the Nordic countries from September 1992 to August 1995 were invited to participate (Alm et al., 1999). Of the 294 families of SIDS victims, 244 agreed to participate in the study (82\%), whereas only 869 of the 1 207 matched control families (72\%) agreed to participate. The crude odds ratios for consumption of more than $800 \mathrm{mg}$ caffeine per day during pregnancy and after pregnancy were significantly raised, 3.9 and 3.1, respectively. However, after adjustment for maternal smoking in the first trimester, maternal age, education and parity, no significant effect of caffeine during or after pregnancy remained (Table 59). Thus, in this study, 
high caffeine exposure during or after pregnancy was not found to be an independent risk factor for sudden infant death syndrome.

\subsection{Effects of chronic consumption of caffeine- containing beverages by the mother on neonates, infants, and older children}

In 1984, Khanna and Somani reported a case of a premature infant with unusually high concentrations of transplacentally acquired caffeine. The mother drank 24 cups of coffee per day during pregnancy. The infant developed apnoea, and as the treating medicinal staff did not know about the mother's extraordinary consumption of coffee, the infant was given caffeine therapy. Serum caffeine concentration was found to be 40.3 micrograms $/ \mathrm{ml}$ prior to caffeine administration on the fifth day of age (Table 60). Caffeine concentration at birth was estimated (based on the pharmacokinetic extrapolation - caffeine half-life of 100 hours) to have been much higher. The authors suggested that the manifestation of apnoea in this infant might have been related to caffeine withdrawal.

Munoz et al. (1988) investigated the influence of the consumption of coffee on haematological and trace element status in non-smoking pregnant women in Costa Rica (see also section 14.3). Two groups of pregnant low-income women were studied: 22 coffee drinkers ingesting at least $450 \mathrm{ml}$ coffee per day, and 26 women who did not drink coffee. Women who drank 1-2 cups of coffee/day $(n=188)$ and women who consumed only tea $(n=3)$ were excluded from the study. The following parameters were studied in the coffee-drinking and coffee-abstaining groups: maternal haemoglobin $(\mathrm{Hb})$ and haematocrit $(\mathrm{Hct})$ at 8 months of gestation, cord blood $\mathrm{Hb}$ and $\mathrm{Hct}$, infant birth weight (no specific definition) and $\mathrm{Hb}$ and $\mathrm{Hct}$ at 1 months of age, and breast-milk Fe concentration. The birth weight was significantly lower for infants whose mothers consumed coffee ( $3189 \pm 300$ grams) than for infants whose mothers did not consume coffee (3 $310 \pm 343$ grams) (Table 60). Maternal haemoglobin $\mathrm{Hb}$ and haematocrit (Hct) at 8 months of gestation, cord blood $\mathrm{Hb}$ and $\mathrm{Hct}$, infant birth weight and $\mathrm{Hb}$ and Hct at 1 months of age, and breastmilk Fe concentration were significantly lower in the coffee group than in the non-coffee group (Table 60). The association between the mothers' coffee consumption and the infants $\mathrm{Hb}$ and Hct was independent of maternal $\mathrm{Fe}$ status and birth weight. These results are consistent with previously reported data in rats, and indicate that maternal coffee intake may contribute to maternal and infant anaemia. As the study was small, and, therefore, had a low statistical power, the results should be interpreted with great caution. It could also be questioned whether the method of selecting the two groups of women could have confounded the studied 
result. The 62 women who dropped out of the study had a higher parity, and parity has been suggested to contribute to a higher birth weight.

In a letter to the editor of the Medical Journal of Australia, Thomas (1988) reported five cases assumed to have caffeine abstinence syndrome (Table 60). The symptoms observed were excessive crying, irritability, and poor sleeping patterns, feeding difficulties and vomiting. In three of the infants caffeine was detected in the urine. (The urine from two other infants was not analysed.) The mothers of these infants had ingested up to 15 cups of percolated coffee and/or 2 litres of Coca-Cola daily. The author concluded that the failure to consider this and other non-narcotic abstinence syndromes could lead to many unnecessary investigations and delay in treatment.

Oei and colleagues (1989) reported foetal arrhythmia caused by the excessive intake of caffeine by three pregnant women. The mothers had ingested extreme amounts of caffeine-containing beverages: 1.5 litre of cola drinks or 10 cups of coffee daily, respectively. The infants (two cases) and the foetus (one case) had irregular heart rhythms, which were restored to normal several days after birth, or when the pregnant mother stopped drinking cola (Table 60). The authors concluded that excessive intake of caffeine can cause tachycardia, extrasystoles, and arrhythmia.

In 1990, epidemiologists at the National Health Institute in Helsinki, Finland, performed a regression analysis of the association of the coffee consumption in different countries $(\mathrm{kg} /$ person/year) and the annual incidence of diabetes mellitus. Countries with the highest per capita consumption of coffee also had the highest incidence of insulin dependent diabetes (Tuomilethto, et al., 1990). However, the investigators pointed out that the results must be interpreted with caution. As could be expected, their publication was criticised by other researchers who questioned the scientific evidence of their conclusion. The results inspired Virtanen and co-workers (1994) to perform a further study in order to determine whether coffee or tea consumption by the child before diagnosis of diabetes, or consumption by parents at the time of the child's conception or during pregnancy, was associated with the risk for childhood type 1 diabetes. 600 newly diagnosed diabetic children younger than 15 years and 536 randomly selected population-based children and their parents took part in this nation-wide study. Data on coffee consumption during pregnancy (which could have been a long period back in time) were available from only 366 case-control pairs. This could of course have introduced a bias. After adjustment for the mother's education, child's age and child's sex, the risk for type 1 diabetes increased significantly in children who consumed at least 2 cups of coffee or at least 1 cup of tea per day (Table 60 ). It is not clear whether sugar intake, which could be a possible confounder, was controlled for. 
Table 60. Intake of caffeine containing beverages and effects on neonates, infants and older children

\begin{tabular}{|c|c|c|c|c|c|}
\hline $\begin{array}{l}\text { Reference } \\
\text { Study type } \\
\text { Locationn of study }\end{array}$ & Sample size and selection & $\begin{array}{l}\text { Exposure period consi- } \\
\text { dered } \\
\text { Sources of caffeine }\end{array}$ & $\begin{array}{l}\text { End-point(s) } \\
\text { Definitions }\end{array}$ & $\begin{array}{l}\text { Results } \\
\text { Risk estimate; adjusted odd ratios, } \\
\text { including } 95 \% \text { confidence interval }\end{array}$ & Comments \\
\hline $\begin{array}{l}\text { Khanna and Somani, } \\
1984 \\
\text { Case report } \\
\text { USA }\end{array}$ & $\begin{array}{l}1 \text { mother/infant pair } \\
\text { (premature) }\end{array}$ & $\begin{array}{l}\text { During pregnancy } \\
\text { Coffee }\end{array}$ & & $\begin{array}{l}\text { Maternal intake: } 24 \text { cups of coffee/day } \\
\text { Caffeine concentration in infants serum: } \\
40.3 \mu \mathrm{g} / \mathrm{ml} \text { at an age of } 5 \text { days } \\
\text { Symptoms: } \\
\text { Apnoea }\end{array}$ & $\begin{array}{l}\text { Symptoms probably related to } \\
\text { caffeine withdrawal }\end{array}$ \\
\hline $\begin{array}{l}\text { Munoz et al., } 1988 \\
\text { Prospective longitudinal } \\
\text { study } \\
\text { Costa Rica }\end{array}$ & $\begin{array}{l}8 \text { pregnant } \\
\text { women } \\
\text { ( } 26 \text { coffee drinkers and } \\
22 \text { non coffee drinkers) }\end{array}$ & $\begin{array}{l}\text { Last trimester and } \\
\text { early lactation period } \\
\text { Coffee }\end{array}$ & $\begin{array}{l}\text { Hb (mother, cord, } \\
\text { infant) } \\
\text { Hct (mother, cord, } \\
\text { infant) } \\
\text { Fe-concentration in } \\
\text { breast milk }\end{array}$ & $\begin{array}{l}\text { Coffee consumption } \\
\text { Non coffee group }(0 \mathrm{ml} / \text { day }) \text { vs } \\
\text { Coffee group }(\leq 450 \mathrm{ml} / \text { day }): \\
\text { all endpoints statistically significantly lower in the coffee group }\end{array}$ & $\begin{array}{l}\text { Very small group -very low } \\
\text { power. } \\
\text { Only one level of coffee consump- } \\
\text { tion. } \\
\text { Drop outs had higher parity. }\end{array}$ \\
\hline $\begin{array}{l}\text { Thomas, } 1988 \\
\text { Case report } \\
\text { Australia }\end{array}$ & 5 neonates & $\begin{array}{l}\text { Exposure period not } \\
\text { stated } \\
\text { Coffee, Coca-Cola }\end{array}$ & & $\begin{array}{l}\text { Maternal daily intake: } \\
15 \text { cups of coffee or } 2 \text { litre of Coca-Cola } \\
\\
\text { Symptoms: } \\
\text { Neonatal abstinence syndrome }\end{array}$ & $\begin{array}{l}\text { Letter to the editor. } \\
\text { Specific data lacking }\end{array}$ \\
\hline $\begin{array}{l}\text { Oei et al., } 1989 \\
\text { Case report } \\
\text { The Netherland }\end{array}$ & $\begin{array}{l}\text { women: } \\
2 \text { neonates } \\
1 \text { foetus ( } 23 \text { weeks } \\
\text { gestation) }\end{array}$ & $\begin{array}{l}\text { Last hours-weeks of } \\
\text { pregnancy } \\
\text { Coffee, cola }\end{array}$ & & $\begin{array}{l}\text { Maternal intake: } \\
10 \text { cups of coffee or } 1.5 \mathrm{~L} \text { of cola; } \\
\text { Symptoms: Arrhythmias, tachycardia, extrasystoles, which ceased } \\
\text { when the mothers stopped intake of coffee or cola }\end{array}$ & \\
\hline $\begin{array}{l}\text { Virtanen et al., } 1994 \\
\text { Case-control study } \\
\text { Finland }\end{array}$ & $\begin{array}{l}600 \text { cases and } 536 \\
\text { controls } \\
\text { All diabetic children less } \\
\text { than } 15 \text { years } 1986-1989\end{array}$ & $\begin{array}{l}\text { Current use of cof- } \\
\text { fee/tea by mothers } \\
\text { and fathers (= indica- } \\
\text { tor of the consumption } \\
\text { at the time of concep- } \\
\text { tion). Coffee use } \\
\text { during pregnancy } \\
\text { (time not specified). } \\
\text { Coffee, tea }\end{array}$ & Type 1 diabetes & $\begin{array}{l}\text { Current use (=use at the time of conception) } \\
\text { Fathers } \\
0 \text { cups vs } \\
1-8 \text { cups } \\
>9 \text { cups } \\
\\
\text { Mothers; or Fathers and mothers } \\
0 \text { cups vs } \\
\text { All dose levels } \\
\\
\text { Use during pregnancy } \\
\text { Mothers use of coffee } \\
0 \text { cups vs } \\
\text { All doses }\end{array}$ & $\begin{array}{l}\text { Recall bias is likely. Control for } \\
\text { sugar consumption was not } \\
\text { carried out. It is possible that } \\
\text { heavy consumption of coffee by } \\
\text { the fathers may be associated } \\
\text { with other life-style factors, which } \\
\text { may explain the observed effects. }\end{array}$ \\
\hline $\begin{array}{l}\text { Engle et al., } 1999 \\
\text { Randomized trial } \\
\text { Guatemala }\end{array}$ & $\begin{array}{l}132 \text { infants } 12-24 \\
\text { months old, split into an } \\
\text { anemic and a non- } \\
\text { anemic sub-group }\end{array}$ & $\begin{array}{l}\text { Each trimester during } \\
\text { pregnancy and during } \\
\text { childhood } \\
\text { Coffee }\end{array}$ & $\begin{array}{l}\text { Behaviour and sleep- } \\
\text { ing time }\end{array}$ & $\begin{array}{l}\text { During pregnancy (median intake } 3 \text { cups/day) } \\
\text { Statistically significant negative association with behaviour } \\
\\
\text { During childhood: } \\
\text { Statistically significant longer sleeping time }\end{array}$ & \\
\hline
\end{tabular}




\begin{tabular}{|c|c|c|c|c|c|}
\hline $\begin{array}{l}\text { Reference } \\
\text { Study type } \\
\text { Locationn of study }\end{array}$ & Sample size and selection & $\begin{array}{l}\text { Exposure period consi- } \\
\text { dered } \\
\text { Sources of caffeine }\end{array}$ & $\begin{array}{l}\text { End-point(s) } \\
\text { Definitions }\end{array}$ & $\begin{array}{l}\text { Results } \\
\text { Risk estimate; adjusted odd ratios, } \\
\text { including } 95 \% \text { confidence interval }\end{array}$ & Comments \\
\hline $\begin{array}{l}\text { Schüz et al., } 2001 \\
\text { Case-control study } \\
\text { Germany }\end{array}$ & $\begin{array}{l}177 \text { cases } \\
\text { (children < } 10 \text { years old) } \\
2006 \text { control children }\end{array}$ & $\begin{array}{l}\text { During pregnancy } \\
\text { Coffee (regular and } \\
\text { decaffeinated), tea }\end{array}$ & $\begin{array}{l}\text { Wilms tumour } \\
\text { (nephro-blastoma) }\end{array}$ & $\begin{array}{l}\text { All studied sources of caffeine } \\
0 \text { cups coffee/day vs } \\
1-3,4+\text { cups/day }\end{array}$ & $\begin{array}{l}\text { Selection and recall bias can not } \\
\text { be excluded } \\
\text { Few persons in the } 4+\text { group. } \\
\text { Hereditary factor in the cases was } \\
\text { unknown. }\end{array}$ \\
\hline
\end{tabular}


Parental consumption of coffee or tea during the conception period of the child and maternal coffee consumption during pregnancy did not affect the risk of diabetes in the children. Strangely enough, heavy coffee ( $\geq 9$ cups/day) use by the fathers (post-natally) was found to be associated with a greater risk for diabetes type 1 .

Coffee is commonly given daily to toddlers in Guatemala. Possible negative effects of coffee ingestion on cognitive development and sleep patterns were assessed in 132 children 12-24 months of age who had received coffee for $>2$ months and were iron deficient as judged by at least one indicator (Engle et al., 1999). Children were stratified by initial haemoglobin as anaemic $(\mathrm{Hgb}<10.5 \mathrm{~g} / \mathrm{dl})$ or non-anaemic $(\mathrm{Hgb} \geq 10.5$ $\mathrm{g} / \mathrm{dl}$ ) and were randomly assigned to an experimental group receiving a coffee substitute consisting of sugar and colouring, and a control group continuing with coffee. Of the 72 toddlers in the experimental group, 53 were non-anaemic and 19 anaemic. The corresponding figures in the control group were 42 non-anaemic and 18 anaemic. Anaemic children were provided Fe supplements for 2-3 months, and compliance was assessed every second week. The children were evaluated for their cognitive development and sleep after 5 months supplementation by test personal that was not aware of either the treatment group or the anaemic condition. The evaluation was performed with the Bayley Scales of Infant Development II. Scores were the Mental Development Index (MDI), the Psychomotor Development Index (PDI), and scales from the Behaviour Rating Scale (BRS). The child's sleep during the previous $24 \mathrm{~h}$ was assessed with a set of standardised sleep questions to the caregiver on the first visit and every 2 weeks thereafter.

No significant effects of treatment on cognitive development as indicated by test scores or BRS ratings were found (Table 60). However, an effect of postnatal coffee ingestion was observed for sleep duration. At the final visit to the tester, children in the substitute group slept more during the night and overall (night plus naps during a recent $24 \mathrm{~h}$ period) than children in the coffee group, a difference not seen at the first visit. No differences were found in sleep difficulty or number of waking times during the night. Women's reported coffee intake per day during pregnancy was associated with lower BRS ratings, even after controlling for socio-economic status and child age. The authors concluded that prenatal coffee ingestion was negatively associated with Behaviour Rating Scales, and that this should be investigated further.

Schüz et al. (2001) analysed pooled data from two population-based case-control studies on Wilms tumour (a nephroblastoma) carried out by the German Childhood Cancer Register. Included in the studies were a total of 177 children under the age of 10 years with Wilms tumour diagnosed between 1988 and 1994, and 2006 control children sampled from population registration files in western Germany. The parents of the children gave information on potential risk factors via questionnaires and 
by subsequent telephone interviews. Information was collected on maternal exposure to alcohol, coffee, and tea during pregnancy. Regarding the intake of coffee (regular and decaffeinated), the following categories were used: none, 1-3 cups, and 4 or more cups daily. Two models were used for the statistical analysis. One was based on pooled data from the two studies, the other on separate analysis of the studies. But the investigator chose to present the results from the pooled analyses only, as the most stable risk estimates were obtained with this model. The investigators failed to confirm an association between maternal coffee and tea consumption during pregnancy and the occurrence of Wilms tumour (Table 60). The authors concluded that high birth weight may play a role in the aetiology of Wilms tumour in these studies, but many risk factors previously suggested are of lesser importance. The strength of this study is its size. However, it is also burdened by drawbacks. Recall bias regarding the actual consumption of caffeine-containing beverages cannot be excluded. The number of "heavy" coffee drinkers was low, making it difficult to draw conclusions from the highest levels of exposure. Finally, and probably the most serious disadvantage in this investigation, it was not controlled for as to whether cases had a hereditary predisposition for Wilms tumour.

\subsection{Results of studies regarding caffeine/caffeine- containing beverages and effects on children including neonates and infants.}

Twenty-two reports, predominantly of American origin, concerning the relationship between maternal intake of caffeine and/or caffeinecontaining beverages and effects on infants, neonates and young children have been published since 1980. Fifteen reports have assessed the relationship between consumption of caffeine and the effects on studied children, while seven reports have been devoted to the relationship between consumption of caffeine-containing beverages and effects on the studied children.

The publications are of varying quality. It should be noted that many of the studies suffer from methodological problems. One example is the lack of hypotheses to be studied, which of course makes it difficult to know whether the used methods are appropriate and optimal for the purpose, even if the used tests of mental and motor development are considered to be well working and valid. Another common limitation is the size of the study base. Four publications can be characterised as case reports and two as pilot studies, with one having a randomised design. The remaining investigations are epidemiological studies. Nine have been performed with a retrospective design (usually case-control studies), and five 
with a prospective design. The results of the studies are summarised in Tables 59 and 60.

\subsubsection{Caffeine}

A number of studies discussed in this section found no relationship between the caffeine intake of mothers during pregnancy and the studied effects on neonates, infants and older children (V'ant Hoff, 1982; Ryu, 1985; Mc Culloch et al., 1989; Streissguth et al., 1980; Barr et al., 1984; Barr and Streissguth, 1991; Alm et al., 1999). A few of these studies should be categorised as small pilot studies with a low chance of finding any significant effects (Ryu (1985; Mc Culloch et al., 1989), and the study of V'ant Hoff (1982) did not verify the absence of effect by proper statistical treatment of the data. A series of reports (Streissguth et al., 1980; Barr et al., 1984; Barr et al., 1990; Barr and Stressguth, 1991) came out of the Seattle long-term study, which followed a cohort of newborn infants for seven years. Unfortunately, the cohort was not established specifically for the purpose of investigating potential risks related to caffeine exposure of foetuses in utero or new-borns in utero via breast milk. The study was initially designed to investigate the effect of social drinking on the health and development of offspring. The Seattle long-term study, however, found no effects in new-born children at 8 months of age regarding mental and motor development or size of infants: length, weight, and head circumference. In the follow-up study at 4 years (Barr et al., 1990), a relationship between caffeine and certain parameters in the fine motor tests was observed. The results were, however, inconsistent and difficult to interpret. At 7 years, caffeine did not affect height, weight, head circumference, or motor ability. These results were obtained by individually administered IQ and attention tests (Barr and Streissguth, 1991).

The eight remaining studies found that a high caffeine intake influenced one or more of the studied parameters. Thus, neurobehavioural effects were observed in the studies of Honsky and Emory (1987), Jacobson et al. (1984), and Emory et al. (1988) (the same cohort was studied in the two latter investigations). In these studies, negative effects on reflexes, neuromuscular maturity, muscular tone, numbers of state changes, and startle reactions were associated with a high caffeine intake during pregnancy. Caffeine exposure before pregnancy was associated with a decrease in orientation capacity, increased alertness, and irritability. Many of the studies, however, suffer from methodological weaknesses, as indicated above.

Symptoms like irritability, vomiting, unusual behaviour, arrhythmia, bradycardia, and effects on respiration resulting in tachypnea or apnoea 
have been associated with a phenomenon usually referred to as withdrawal symptoms, and have been observed in some reports (see also section 17.3.2). An association between caffeine consumption and apnoea is not unlikely, according to the study of Toubas et al. (1986). Abstinence symptoms have generally appeared when pregnant women have consumed very large amounts of caffeine-containing beverages. The symptoms seen in the neonate that seem to be biologically plausible have often resolved spontaneously several days after birth, and no long-term effects have been reported.

A relationship between caffeine consumption and sudden infant death syndrome (SIDS) has been found in one multi-centre study from New Zealand not adequately controlled for smoking (Ford et al, 1998). A Scandinavian study that was unable to confirm this finding (Alm et al, 1999) actually indicated that the relation to sudden infant death syndrome could have been a result of poor adjustment for confounders.

\subsubsection{Caffeine-containing beverages}

Seven reports have been published regarding the effects of maternal consumption of caffeine-containing beverages and effects on neonates and older children. Three case reports (Khanna and Somani, 1984; Thomas, 1988; Oei et al., 1989) showed an association between high coffee or cola consumption and the development of apnoea and arrhythmia, that is, a neonatal abstinence syndrome (see above). Other investigations noted in a single study and requiring confirmation, indicate that maternal coffee intake may contribute to maternal and infant anaemia, and that coffee and tea consumption by the studied children during childhood was associated with an increased risk for type 1 diabetes. In a randomised study on infants 12-24 months old from Guatemala, children who were given coffee had significantly longer sleeping times than children who were given a substitute, but the behaviour of the coffee-exposed children was not negatively influenced by increased maternal coffee consumption during pregnancy.

\subsubsection{Conclusions}

Most studies carried out in order to investigate the possible effects of maternal exposure to caffeine/caffeine-containing beverages on children in utero have been performed on neonates and infants younger than 6-12 months. Studies concerning long-term effects on older children are scarce. In addition, several studies have also assessed the possible effects of caffeine via breast milk on children.

Withdrawal (abstinence) symptoms in infants whose mothers have consumed large amounts of caffeine-containing beverages during pregnancy have been described in several case reports and pilot studies. In 
general, no abnormalities have been detected in subsequent clinical follow-ups of the studied children. A suggested association between sudden infant death syndrome and maternal caffeine intake or coffee consumption, however, seems to disappear when smoking is adequately controlled for. It is much too early to speculate on any possible association between diabetes type 1 and maternal consumption of caffeine-containing beverages.

It is possible that consumption of caffeine/caffeine-containing beverages during pregnancy (and in early childhood) may be associated with effects on infants' behaviour. But as the data available are inconsistent, and often of questionable quality, such associations cannot be verified or excluded. 



\section{Summary of the results in epidemiological studies on the relationship between caffeine intake, or intake of caffeine- containing beverages and foods, and adverse effects on the pregnancy or the foetus}

It is highly unlikely that a consumer in the Nordic countries is not exposed to caffeine and other methylxanthines through either the diet, medicinal products and/or skin care products. These compounds occur naturally in a number of beverages such as cocoa, coffee, guarana, maté, tea, yaupon, and yoco as well as in cola nuts and food products containing cocoa and chocolate (mainly candy and bakery products). Caffeine is also added to foods, typically to various types of drinks, notably cola drinks, energy drinks, smart drinks, and certain other soft drinks. In medicinal products, caffeine is often a part of analgesic, antipyretic, antihistaminic, and central stimulating products, as well as an ingredient of drugs used for migraine and fatigue. Caffeine also occurs in tonics and vitamin B supplements. A minor part of the exposure may come from dermal application of skin care products.

As the exposure to the other trimethylxanthines, theobromine and theophylline, is quantitatively less important, the rest of the discussion will focus on caffeine. Exposure to theobromine mainly occurs though products containing cocoa or chocolate, and exposure of theophylline occurs mainly through tea and specific medicinal products.

Although most people are exposed to caffeine as well as the other methylxanthines, the quantity they are exposed to varies greatly from person to person. Most estimates on caffeine exposure have been done on adults at the population level. Thus, there are data available on the average daily intake of caffeine (per capita figures or data on a small group of individuals) in consumers from Australia, Canada, the USA, Brazil, the United Kingdom, Denmark, and Sweden. These data show that the average caffeine intake is lower in Australia, Brazil, and the North American countries than in the European countries, in particular, lower than in Finland and the Scandinavian countries. Whereas the average intake of caffeine in 
North America has been estimated to be between 186 and $240 \mathrm{mg}$ per day, it has been estimated to be between 425 and $490 \mathrm{mg}$ per day in Finland and the Scandinavian countries. The average caffeine intake in the United Kingdom has been estimated to between 280 and $444 \mathrm{mg}$ per day. The main reason for the Nordic countries having the highest intake of caffeine is that coffee consumption is higher in these countries than elsewhere, and coffee is, in most countries, the main contributor to caffeine intake. In countries where tea consumption is high, as for example in Ireland and the United Kingdom (and possibly other countries such as Russia and India), tea provides the main contribution to the total intake of caffeine. The limited data available on total caffeine intake in individual consumers indicates a very large interindividual variation from low values to significantly over $1000 \mathrm{mg}$ per day.

Re-calculated into average daily exposure per $\mathrm{kg}$ body weight, the Nordic data mentioned above results in $6-7 \mathrm{mg} / \mathrm{kg}$ body weight for an adult person of $70 \mathrm{~kg}$. This figure could be compared to the limited amount of data available on the caffeine intake of children and teenagers. Data from the Nordic countries indicate that caffeine exposure in teenagers starts to resemble the intake of adults, whereas data from the United States show that in younger children the highest exposures occur in the age group of 2-3 years. On a per kilogram body weight basis, the exposure of these young children is 2 to 4 times higher than the exposure of adults.

Available information shows that the average caffeine intake in women is reduced during pregnancy. However, the magnitude of the reduction varies from person to person. The reduction is mainly due to a transient reduced consumption of coffee occurring within the first and second trimester of the pregnancy. One factor contributing to this reduction is the nausea experienced by many women early in pregnancy. As a result, the average daily caffeine intake among Danish women is estimated to be reduced from around $490 \mathrm{mg}$ before or after pregnancy to around $375 \mathrm{mg}$ during pregnancy.

In adult humans, caffeine and other methylxanthines are rapidly and essentially completely absorbed from the gastrointestinal tract and distributed into body tissues in approximate proportion to their water content. Caffeine crosses the placenta, enters gonadal tissue, uterine secretion, and blastocysts, and is secreted into milk. Caffeine, and to a lesser extent theophylline, also diffuses though the blood/brain barrier. There is no accumulation of caffeine in any tissue or organ.

The peak plasma level of caffeine is reached within $30 \mathrm{~min}$ after consumption of the pure compound, and somewhat later (after 1 1 $1 / 2-2$ hours) after consumption of foods or beverages containing caffeine. The half-life of caffeine in the blood plasma of adult humans is normally about 3-6 $\mathrm{h}$ (corresponding values for theophylline and theobromine are $4.9 \mathrm{~h}$ and 10 $\mathrm{h}$, respectively), due mainly to metabolism and lesser to excretion. A 
"normal" concentration of caffeine in tissues of consumers of caffeinecontaining beverages is in the range $0.2-2 \mu \mathrm{g} / \mathrm{ml}$. A complication for the interpretation of experimental data is the finding by Denaro et al. (1990) and Cheng et al. (1990) that caffeine may exhibit dose-dependent kinetics, such that the rate of caffeine metabolism may decrease with increasing doses of caffeine. Denaro et al. (1990) observed a decline in clearance capacity of $22 \%$ after an increase in caffeine dose from $4.2 \mathrm{mg} / \mathrm{kg}$ body weight per day to $12 \mathrm{mg} / \mathrm{kg}$ body weight per day, and Cheng et al. (1990) reported a similar decline of $29 \%$ after escalating single oral doses of caffeine from 70 to $300 \mathrm{mg}$. If high caffeine intake does dampen CYP1 A2 activity, this may increase overall exposure to caffeine but might also work to counteract any potential detrimental effects of caffeine metabolites, making the assessment of any cause-effect relationship between caffeine and spontaneous abortion very complex (Signorello et al., 2001). Another reason for the rather wide variation in half-life of caffeine in humans is the fact that metabolism is dose-dependent, being a little slower at higher caffeine intakes. The first and most important step in the biotransformation of caffeine in humans, is the removal of the 3-methyl group by the enzyme CYP1A2 to yield 1,7-dimethylxanthine or paraxanthine. This pathway represents almost $80 \%$ of the primary caffeine metabolism. Paraxanthine is then further oxidized and demethylated. Hydroxylation produces water-soluble uric acids. Less than $2 \%$ of the ingested caffeine is excreted unchanged in the urine.

Caffeine metabolism is, however, dependent on a number of other factors such as age, hormonal status, and presence of other chemical compounds or drugs. In the foetus and newborn, which are defective in the liver enzymes that metabolise the compound (mainly CYP1A2), caffeine has a much longer half-life than in the adult human. In the newborn it is close to 4 days. Many chemical compounds alter caffeine metabolism. Cigarette smoking, exposure to polychlorinated biphenyls, or to rifampicin drugs has been shown to increase caffeine metabolism, thereby reducing its half-life. Since they all induce CYP enzymes in man, the mechanism for the increased caffeine metabolism is increased amounts of CYP1A1 and CYP1A2 in the liver. The former is usually nearly absent in liver. Of course, diseases that damage the liver may decrease caffeine metabolism. This has been reported to be the case with liver cirrhosis, viral hepatitis, and alcohol-induced fatty liver. Pregnancy and use of oral contraceptives are known to increase the half-life of caffeine in plasma to around $10 \mathrm{~h}$ due to decreased expression/activity of CYP1A2 in the liver. The prolonged half-life results in the accumulation of caffeine in the body, unless the consumption is reduced appropriately. Caffeine elimination is essentially unchanged during the first trimester of pregnancy, which is the period of greatest risk for the development of morphologic anomalies. The rate then slows progressively to one-half and one-third that in the non-pregnant state during the second and third trimesters, respectively. In 
contrast, the plasma half-life of caffeine is shorter than the "normal' 3-6 $\mathrm{h}$ in older infants and young children (Figure 5), in normally ovulating women, and in adult smokers (in comparison to non-smokers). The reason for these variations are probably immature, inhibited, or induced biotransformation systems.

It should not be forgotten that the main enzyme involved in the metabolism of caffeine, CYP1 A2 also is involved in the metabolic activation of numerous chemical carcinogens, such as heterocyclic and aromatic amines and nitroaromatic compounds, as well as in the biotransformation of many xenobiotics. Therefore, the result of some of the studies referred to in the present document may reflect an inter-play of various unmeasured factors that are possibly related to the biological endipecaususudiedhylxanthines readily cross the placenta, the exposure of the foetus to methylxanthines is dependent on the consumption habit of the pregnant woman. Thus, a few $\mu \mathrm{g} / \mathrm{ml}$ is a normal concentration in the foetus as well. Although individuals vary greatly in their sensitivity to heavy doses of caffeine, toxic symptoms, such as severe restlessness and muscular tension and twiching, do not begin to appear until concentrations higher than $30 \mu \mathrm{g} / \mathrm{ml}$ are reached. The short-term lethal dose of caffeine in adult humans appears to be about 5 to $10 \mathrm{~g}$ in a normal sized person. One cup of coffee contains approximately $0.1 \mathrm{~g}$ caffeine.

The newborn may be exposed to caffeine though breast milk; the milk concentration parallels the concentration profile in serum. The half-life of caffeine in breast milk is not much longer than in serum. Assuming a neonatal milk consumption of $150 \mathrm{mg} / \mathrm{kg} /$ day and the pharmacokinetic data on methylxanthines by Oo et al. (1995), the newborn would ingest an equivalent of $18 \%$ of the maternal caffeine dose (on a body weight basis). Around $7 \%$ of this $18 \%$ would be caffeine, with the rest being caffeine metabolites.

Analytical data show that methylxanthines can be detected in the serum of the breast fed infant only if the mother ingested a relatively large quantity of the compounds. Usually the amount of caffeine ingested is considered too small to induce measurable clinical effects. Yet irritability and insomnia are observed in some breast-fed babies when their mothers have ingested coffee, beverages, and/or medication with high caffeine contents. By analysing the urine of breast-fed infants it has been established that the adult metabolite pattern of partially demethylated xanthines and ureates was attained at an age of 7 to 9 months. The data indicate that the approximately 4 days long half-life of caffeine characteristic of the newborn depends in large part on slow urinary excretion of unchanged caffeine, since there is little or no metabolism.

Based on what is stated above, it seems clear that the foetus is at risk of being exposed to high concentrations of caffeine if the mother has a high consumption of caffeine-containing beverages, foods, or drugs. The 
caffeine exposure of the newborn child is usually less than that of the foetus.

Over 140 epidemiological studies have investigated the relationship between women's caffeine intake or intake of caffeine-containing beverages (and thereby foetal exposure) and adverse effects on the pregnancy and the foetus and newborn child. The endpoints studied in relation to the given intake parameters have included fertility, spontaneous abortion, pre-term delivery, foetal growth retardation, congenital malformations of the foetus, foetal behaviour, and effects on neonates, infants and older children.

The rationale for performing these studies comes from experimental mechanistic studies and epidemiological research. Several plausible biological mechanisms for a relationship between caffeine exposure and the studied parameters have been proposed, and these have been presented in brief in chapter 11-16.

This report aims at critically assessing the available epidemiological literature to be able to identify any adverse condition during pregnancy, on the foetus, and in young children that could be related to a high intake of caffeine. The following sections summarise the impression received from the critical assessment of the published studies, and present the conclusions drawn by the Nordic expert group based on these epidemiological studies.

\subsection{Summary of the critical assessment of epidemiological studies and their results}

In a substantial number of the epidemiological studies discussed in chapters 11-16 the criteria for including participants in the study and the methodology to estimate caffeine exposure can both be called in question. A probable reason for the weakness in this area is that many of the studies originally were planned to investigate other hypotheses than the one explored in the assessed articles. Monitoring of exposure is crucial, and estimating individual intakes from food frequency questionnaires are known to have severe limitations (chapter 10), in particular when questions refer to consumption that took place much earlier.

When assessing epidemiological studies of the type reviewed in this report, in which most of the caffeine exposure of the studied subjects is derived from beverages enjoyed in a social context, it must be born in mind that the beverages contain a large number of other compounds than the ones investigated, complicating the task to identify the causal factor for the established relationship. There is always a risk that another component in a food is responsible for an observed effect than the compound actually studied. Regarding coffee, which is the main contributor to the caffeine intake in the Nordic countries, Viani (1993) has reviewed the 
chemical composition and Arnaud (1993) the metabolism of many of these components.

\subsubsection{Conclusion on intake of caffeine or caffeine-containing beverages and fertility}

The fertility parameters studied were time to pregnancy/time to conception, fecundability (the probability of becoming clinically pregnant in each menstrual cycle), pregnancy rate, success of in vitro fertilisation and embryo transfer, and effects on sperm quality. Most studies were devoted to time to pregnancy/time to conception, and this time span was defined as the time between stopping contraception and clinically diagnosed pregnancy.

In epidemiological studies related to fertility it is very important to consider what time period of exposure the study actually refers to. The appropriate period should be the time when attempts to get pregnant were made, that is, the time directly before conception, not during pregnancy, as it has been shown that many women tend to reduce their caffeine intake early in pregnancy. Thus, investigating caffeine intake during pregnancy retrospectively, as has been done in many studies, may result in an underestimation of the actual exposure during the period prior to conception. Consequently, information in epidemiological studies that have related daily levels of caffeine intake during various parts of the pregnancy to delayed conception/reduced fecundability must be interpreted with great care.

Five retrospective studies investigated the relationship between time to pregnancy and caffeine exposure, and eight studies investigated the relationship to the number of cups/cans of caffeinated beverages consumed daily. As the published results are contradictory, available data only gives marginal support for high caffeine intakes being related to time to pregnancy/conception. These studies give no indication of a relationship between consumption of tea, caffeinated soft drinks, or decaffeinated coffee and time to pregnancy. Studies on the relationship between coffee consumption and time to pregnancy give a less clear picture. However, considering the limitations of the studies, the results of most of them indicate that high coffee consumption is not strongly correlated with an increased time to pregnancy.

In eight studies, the probability of becoming clinically pregnant in each menstrual cycle (fecundability) was explored in relation to caffeine exposure, and in five studies this probability was explored in relation to the number of cups/cans of caffeinated beverages consumed each day. These studies give even less support of a relationship between the studied parameters than do the studies related to time to pregnancy/time to conception. 
To what extent the male partner may influence reduced fertility, besides influencing the frequency of intercourse and having semen of nonoptimal quality, has usually not been explored in the epidemiological studies, and therefore is not controlled for. In vitro incubation of human semen with caffeine, as well as with other methylxanthines, appears to increase the motility of fresh and previously frozen human spermatozoa. Thus, there are some in vitro data available that could be interpreted that the quantity of caffeine ingested by the male partner of the studied women could influence fertility. Whether this is also the case in vivo is a hypothesis open for testing.

It can be concluded that the results obtained in epidemiological studies concerning a possible relationship between caffeine or caffeinecontaining beverages and fertility are contradictory and difficult to interpret. The data of many studies have limitations due to the experimental design. A relationship between caffeine intake and time to pregnancy/time to conception/fecundability cannot be ruled out, but at present the evidence for such a relationship must be considered weak. The reason for this conclusion is that there is no consistency in results between studies, and that accurate data regarding caffeine exposure during the time period shortly before pregnancy seldom has been available in the epidemiological studies. Furthermore, there are only a few studies that have related caffeine exposure to effects on spermatozoa in vivo.

\subsubsection{Conclusion on intake of caffeine or caffeine-containing beverages and spontaneous abortion}

Spontaneous abortion is one of the most common complications of pregnancy. The definition of spontaneous abortion varies over the world. According to one accepted definition, a spontaneous abortion is a pregnancy that ends before 22 completed weeks of gestation, or results in a birth weight of 500 grams or less, and does not end in a live birth. In Sweden the definition is a pregnancy that ends before 28 complete weeks. Miscarriages not recognised by the mothers are of course unlikely to be registered. Therefore, the frequency of early (pre-clinical) loss is not very well known, mainly because of the difficulties in recognising the condition.

One complication in the assessment of studies concerning spontaneous abortion is that there obviously are many causes of this pregnancy outcome. Spontaneous abortions may thus be regarded as a heterogenous group of disorders. Besides chromosomal abnormalities, which are responsible for about $60 \%$ of clinically recognised spontaneous abortions during the first three months of pregnancy, and uterine/cervical causes, the factors most consistently associated with recognised spontaneous abortion risk are prior spontaneous abortion and older maternal age. Previous reproductive events of other types, exposure to exogenous factors such as tobacco, alcohol, and chemicals in the occupational setting, and 
psychological factors have all given conflicting results when studied epidemiologically. One of the exogenous factors suggested to influence spontaneous abortion rate is caffeine intake. Potential effects of caffeine on foetal development may follow prolonged accumulation of caffeine in pregnant women and passage to the foetus, which lacks the enzymes necessary for the metabolism of caffeine until several days after birth.

Because many factors have been postulated to influence the rate of spontaneous abortion, the problem of confounding factors pushing a nonexistent relationship into looking like a significant relationship, or, on the contrary, reducing an existing relationship into non-significance, has to be addressed in all epidemiological studies. Not all investigators have adequately controlled for such confounding factors. A very important confounding factor that can never be neglected in this context is smoking. In several prospective and retrospective studies, an increased rate of spontaneous abortion has been reported in smokers with the relative risks being in the range 1.2 to 1.8 . It might not be enough to adjust only qualitatively for smoking (yes/no), as the amount smoked might govern, for example, how much the caffeine metabolism is influenced.

Maternal illness during pregnancy, such as nausea and gastrointestinal and cardiovascular problems, might also be a confounding factor. Nausea coupled to pregnancy typically begins at 4-6 weeks of gestation, and peaks in incidence and severity by 8-12 weeks (Deuchar, 1995; Furneaux et al., 2001). It has been anticipated that women with a viable pregnancy are more likely to experience nausea, and reduce their intake of caffeine (and other compounds), than women who have a non-viable pregnancy and experience nausea less frequently. Nausea has been controlled for in the studies by Cnattingius et al. (2000) and Wen et al. (2001), which at present seem to be the most accurate investigations of the relationship between caffeine/coffee consumption and early spontaneous abortion. Mothers who have gastrointestinal or cardiovascular problems that may predispose them to spontaneously abort might be advised to avoid or limit caffeine consumption. In both cases, the bias introduced would spuriously reduce the risk estimates for caffeine.

A difficult circumstance to control for is the non-equal influence of environmental factors on different foetuses. The fraction of foetuses carrying chromosomal abnormalities that are non-compatible with survival differs during pregnancy. It is very high in early pregnancy, drops during the late first trimester, and becomes comparatively low at the end of pregnancy. As exposure to environmental factors such as caffeine might have potential to influence healthy foetuses but not foetuses already bound to be aborted, carefully controlling for the karyotype of the foetus might be required but be very difficult. It is particularly important to control for the karyotype during early pregnancy when the fraction of chromosomally abnormal foetuses is higher, as the rate of abnormal foetuses drops quickly with the gestational age of the woman. 
Eighteen epidemiological studies have explored the relationship between caffeine/coffee consumption and spontaneous abortion. The definition of spontaneous abortion or miscarriage differed between studies. As the risk factors and cause of spontaneous abortion may vary during the pregnancy, it is very important that the condition is accurately defined. Seven research groups limited their study base to patients with early foetal loss (before 12 weeks of gestation) and two studies were devoted to miscarriages only in late pregnancy. The rest of the studies included both fairly early and late abortions.

It can be concluded that the results of more than half of the described epidemiological studies concerning intake of caffeine/caffeine-containing beverages and spontaneous abortions indicate a positive relationship. However, as repeatedly pointed out throughout the report, most studies have weaknesses in their adjustment of potential confounding factors and in the selection of the study base. Thus, the results are far from easy to interpret. However, taking all information into account, we have come to the conclusion that high intake of caffeine during pregnancy, at least during early pregnancy, might increase the risk for spontaneous abortions. Although the epidemiological studies have been criticised for problems in design, six of them have been used in a meta-analysis, which arrived at the same conclusion as presented above. The combined odds ratio in the meta-analysis was 1.36 with a $95 \%$ confidence interval of 1.29-1.45. One particular note of caution should be given, and that is that the potential confounders identified in the separate studies were not adjusted for in the meta-analysis because they were too poorly presented in some of the individual studies.

Three studies have been devoted to a possible relationship between caffeine metabolism and spontaneous abortion. These studies made use of biomarkers of caffeine metabolism in blood and urine, as well as information on acetylator genotypes (slow or fast). The profile of caffeine and caffeine metabolites in the body fluids portrays caffeine metabolic activity, reflecting the capacity for caffeine clearance and hence the ultimate caffeine load on the body. The speed of caffeine metabolism will also determine the exposure to caffeine metabolites, mainly paraxanthine. Whereas Fenster et al. (1998) observed no interaction between caffeine intake and enzyme activities, Signorello et al. (2001) found women with high CYP1A2 activity to have an increased risk of normal karyotype spontaneous abortion. The data of the latter study could be interpreted as indicating that the metabolites of caffeine play a role in the ethiology of spontaneous abortions. At present there are no experimental data to confirm this theory. However, the third study found that women with the highest quintile of serum paraxanthine had an increased risk for both early and late spontaneous abortion (Klebanoff et al., (1999). As two of these studies have been criticised for substantial shortcomings in design and performance, a possible relationship between caffeine metabolism 
and spontaneous abortion needs further investigation. It should be stressed that the main enzyme metabolising caffeine, CYP1A2, is also involved in the metabolic activation of numerous chemical carcinogens, and therefore data of this kind may reflect the interplay of various unmeasured factors that are possibly related to spontaneous abortion.

\subsubsection{Conclusion on caffeine intake and congenital malformations}

Although exposure of laboratory animals to a single high dose of caffeine during gestation results in an increased risk for the development of facial clefts and limb anomalies, both apportioning the total dose in animals studied to several administrations with lower doses, and the results of epidemiological studies on humans, reveal no obvious relationship between maternal caffeine intake and foetal facial clefts, skeletal malformations, or any other infant birth defects. Nor has any relationship between the intake of caffeine-containing beverages and congenital malformations been established.

The finding of a relationship between late testicular descent into the scrotum and intake of cola drinks in low quantities is very puzzling and may be a study artefact. In addition, heavy coffee consumption ( $\geq 4$ cups/day) in one study appeared to be associated with a reduced incidence of Down syndrome. This phenomenon could, however, be explained by the fact that high coffee consumption (possibly caffeine intake) is more likely to reduce the viability of a Down syndrome conceptus than that of a normal conceptus.

Because of the huge variation in quality of the epidemiological data available (see chapter 12), the question of whether caffeine is teratogenic or not in humans cannot be considered completely settled. However, at present, there is no evidence from epidemiological studies that high caffeine exposures cause congenital malformations in humans.

\subsubsection{Conclusion on caffeine intake and pre-term delivery}

Pre-term delivery/pre-term birth within all twenty studies reviewed in this report has been defined as a gestational age of less than 37 completed weeks of pregnancy. Some authors have also considered a birth weight of less than 2500 grams as part of the definition of pre-term births. The close agreement on definition makes it much easier to draw conclusions from the study results. Low socio-economic status, a history of adverse pregnancy outcome, and antepartum haemorrhage have consistently been reported as risk factors associated with pre-term delivery, and must, therefore, be controlled for in studies on this endpoint of pregnancy. This is, however, not as easy as it seems, as pre-term delivery is a heterogenous condition caused by, for example, premature rupture of membranes, pre- 
mature onset of labour, vaginal bleeding (including placenta previa and abruptio placentae), and maternal illness (most often preeclampsia).

The majority of the studies devoted to this condition have a retrospective design, which could have introduced exposure bias due to faulty recall of consumption. The eight studies with a prospective design should be less burdened by recall bias compared to the retrospective studies. Although the studies have used a common definition of the studied biological endpoint, they have quantified caffeine intake differently. A drawback with many studies is the fact that the consumption of caffeinecontaining foods and beverages has not been dichotomised by trimester. Especially important is consumption in the third trimester, which ought to have been registered in all studies of this type. However, it is not unusual to find that only consumption during the first trimester or average consumption during pregnancy has been reported.

Fourteen of the twenty studies conclude that there is no association between caffeine intake or intake of caffeine-containing beverages and pre-term delivery. One study reported a positive association between caffeine intake and pre-term delivery, and four reported an association between the consumption of caffeine-containing beverages and pre-term delivery. However, as many of the positive studies suffer from severe limitations such as not controlling for smoking, these positive correlations may be explained by other factors. It can be concluded, therefore, that a relationship between caffeine intake and pre-term delivery is unlikely, at least for most causes of pre-term delivery.

\subsubsection{Conclusion on caffeine intake and foetal growth retardation}

Thirty epidemiological studies concerning the relationship between foetal growth retardation and intake of caffeine and/or caffeine-containing beverages have been published. The main outcome parameters studied were low birth weight, reduction in birth weight in comparison with a referent group (birth weight observed as a continuous variable), and intrauterine growth retardation. Low birth weight has been defined as a birth weight of $<2500 \mathrm{~g}$ or a birth weight below the $10^{\text {th }}$ percentile of national growth standard curves. Intrauterine growth retardation has been defined as a birth weight below a specific percentile of growth standard curves. In addition to these outcome parameters, birth length, crown-rump length, head circumference, placental weight, and ponderal index have been utilised as indicators of foetal growth retardation in some studies.

It is important that the gestational age of the foetus (child) has been controlled for. Fortunately, this has been done in almost all studies, although far from all studies have specified the method used to determine gestational age. The ultrasonographic method, which is considered to be more accurate, is preferred to methods based on determinations from the last menstrual cycle. Particularly important for the exposure parameter is 
knowledge about consumption during the third trimester of pregnancy, which should have been assessed in all studies of this type, as foetal growth is particularly intense during the later stages of pregnancy. In many studies, however, only average consumption or consumption during the first trimester has been reported. This drawback severely limits the conclusions that can be drawn from these studies.

Controlling for confounding factors is, as always, important. Some confounding factors have nearly consistently been shown to be of importance in studies on foetal growth retardation. Among these confounding factors are: smoking, duration of pregnancy (e.g. gestational age), pre pregnancy weight, weight gain during pregnancy, ethnicity, parity, and use of alcohol. The importance of accurately controlling for smoking should be stressed, as an association between caffeine intake and cigarette smoking is commonly observed. It is known that caffeine is eliminated much faster in smokers than in non-smokers, because the cigarette smoke induces enzymes that degrade components of the cigarette smoke. The same enzymes also metabolise caffeine. As smoking is known to affect birth weight in a dose dependent manner, adjusting for smoking means that the number of cigarettes smoked must be accounted for. This has, however, not been considered in all studies - the only information available in some studies was if the women was a smoker or not.

Approximately fifty percent of the thirty reviewed studies had a prospective design. The majority were fairly large to very large cohort studies. Of the studies, nineteen had assessed the relationship between foetal growth retardation and consumption of caffeine, whereas seventeen studies assessed the relationship between foetal growth retardation and consumption of caffeine-containing beverages. Thus, in six studies, the exposure variable was the amount of caffeine as well as the amount of caffeine-containing beverages.

A statistically significant relationship between caffeine exposure and foetal growth retardation was found in about half of the reviewed epidemiological studies, although the adjusted odd ratios did not much exceed 1.00. A dose response was demonstrated in some of the studies. Borderline significance was obtained in two additional studies. It should, however, be emphasised that many studies showing a significant decrease in foetal growth at high caffeine intakes had a retrospective design, and observed the effect only in specific subgroups such as smokers or nonsmokers. Many of these studies had weaknesses in experimental design, often due to the study originally being designed for investigating other relationships. This would lead to methodological problems connected with the study base, recall bias, and non-optimal control of confounding factors in the statistical analysis. In two retrospective studies, a significant effect could be seen only on intrauterine growth retardation, whereas low birth weight, which was also measured, was unaffected. This inconsistency has not yet been explained, and these results should, therefore, 
be interpreted with care. The majority of studies carried out with a prospective design showed no statistically significant relationship between caffeine exposure and foetal growth retardation.

In most of the studies reviewed in this section, the intake of caffeine could be characterised as fairly low in comparison to the mean consumption in the Nordic countries. Accordingly, a general problem in the majority of the studies is that the number of participants consuming $\geq 300 \mathrm{mg}$ of caffeine daily is small or in some studies even very small, which reduces the ability to predict the outcome (at this consumption level) with statistical precision. The lowest dose of caffeine, resulting in a statistically significant reduction in birth weight in one of the reviewed studies, was $70-140 \mathrm{mg} /$ day, which approximately corresponds to the amount of caffeine in a large cup of coffee. In most other studies $\geq 300-400 \mathrm{mg}$ caffeine/day ( $\geq 4$ normal cups of coffee) was required before a statistically significant effect was induced.

Eleven of the seventeen studies exploring a relationship between consumption of caffeine-containing beverages and foetal growth retardation observed a statistically significant relationship between these parameters. A dose-response relationship was found in five studies. In half of the studies "caffeine-containing beverages" was equivalent to coffee. In the remaining studies, the consumption referred to tea, and sometimes to cocoa and cola drinks. The lowest amount of caffeine-containing beverage(s) resulting in a statistically significant reduction in birth weight/intrauterine growth retardation was $\geq 1$ large cup of coffee daily. In most other studies higher exposure levels were required in order to produce a statistically significant effect - usually $\geq 4-9$ cups of coffee daily (or $\geq 6$ cups of tea). In two of the eleven positive studies, a significant synergistic relationship was found between the consumption of caffeine-containing beverages and smoking.

In summary, the resilient quality of most assessed studies does not enable definitive conclusions to be drawn. Although it is definitely not prudent to rule out a possible relationship between the intake of caffeine or caffeine-containing beverages and reduced mean birth weight based on the results of the reviewed investigations, it should be kept in mind that in most modern prospective studies no significant association has been observed. However, the two meta-analyses that have been devoted to the relationship between intake of caffeine and the birth weight of infants or duration of pregnancy revealed significant growth retardation at high intakes of caffeine. On the other hand, confounders could not adequately be controlled for in these meta-analyses. Specifically designed and controlled studies are required to establish whether a high intake of caffeine may result in intrauterine growth retardation. 


\subsubsection{Conclusion on caffeine intake and effects on foetuses}

Whether maternal caffeine exposure can affect foetal behaviour has been investigated in in vitro studies of human tissue and six clinical studies of the mother and foetus using the ultrasonographic techniques. As all clinical investigations were very small and focused on different behaviour/effect parameters in the foetus (foetal breathing, foetal body movements, and effects on the foetus cardiovascular system) it is not surprising that it is difficult to draw general conclusions.

The in vitro studies showed that caffeine had a significant effect on the foetal heart rate and contractility, as well as on the vascular tone of human placental arteries and veins at exposures of biologically relevant doses of caffeine. This is not unexpected, as caffeine has pronounced pharmacological effects in adults (see chapter 9), and the methylxanthine readily crosses the placenta. Possible effects of caffeine on the foetus in vivo are much less clear, partly because the studied parameters varied between studies, partly because caffeine was administered differently (as pure caffeine, as coffee, or in normal food) in the various studies (caffeine is likely to be more quickly absorbed when administered as pure compound). The different study designs make it more difficult to confirm or contradict earlier observations.

With the exception of one of the studies, which investigated the influence of caffeine on early twin pregnancies, the five other clinical studies were carried out on women in the third trimester of pregnancy. The study results have been contradictory. For example, high caffeine intake of pregnant women increased the foetal heart rate in two studies, whereas it was reduced in two other studies. Similarly, two studies found high caffeine exposures to increase foetal breathing rate, whereas another found high caffeine exposures to have no effect on foetal breathing rate. It is possible that some of the discrepancies could be explained by the fact that the background intake of caffeine from foods was poorly controlled for. Furthermore, administered dosage and form (tablets, solutions, or as coffee), and the genetic constitution of the pregnant women varied considerably between studies.

In conclusion, it seems probable that maternal consumption of caffeine or coffee influences foetal behaviour. The reviewed study results on foetuses exposed to caffeine in utero are, however, so divergent that it is difficult to predict what effects are likely to appear upon the exposure of pregnant women to caffeine, and, particularly, to what extent the effects could be defined as adverse. Larger and accurately designed studies are needed to explore whether this relationship exists. An interesting finding by Salvador and Koos (1989) should be noted, namely, the observation that decaffeinated coffee (like regular coffee) also increased the incidence of foetal breathing activity and produced a slight reduction in foetal heart rate. This observation raises the question as to whether constituents of 
coffee other than caffeine may have pharmacological effects on foetuses in utero and influence their behaviour.

18.1.7. Conclusion on maternal caffeine exposure and effects on neonates, infants, and older children

The extent of research on possible effects in children of exposure to caffeine/caffeine-containing beverages in utero is limited and often of questionable quality, and have mainly been performed on neonates and infants younger than 6-12 months. Studies concerning long-term effects on older children are scarce. The lack of well-designed epidemiological studies to address the question limits the conclusions that can be drawn.

Although withdrawal (abstinence) symptoms in infants whose mothers have consumed large amounts of caffeine-containing beverages during pregnancy have been described in several case reports and pilot studies, no persistent abnormalities have been confirmed in a subsequent clinical follow-up of the studied children. As available data is limited and the results are inconsistent, an association between the consumption of caffeine/caffeine-containing beverages during pregnancy (and in early childhood) and infants' behaviour can at present be neither verified nor excluded. 



\section{Concluding discussion}

In 1980 the American Food and Drug Administration (FDA) issued recommendations to women to limit their intake of caffeine-containing beverages during pregnancy. This recommendation was based on results from studies on experimental animals, which had shown teratogenic effects of caffeine at very high doses. Since then, many epidemiological studies have been conducted in order to investigate whether intake of caffeine could affect pregnancy outcome. These studies have predominantly been performed in the US and Canada, but there are also some Europeans studies. The cultural affiliation is important, as the average caffeine intake in North America is substantially lower than in Europe, in particular lower than in the Nordic countries.

As the mean consumption of caffeine is especially high in the Nordic countries, the Working Group on Food Toxicology and Risk Evaluation (NNT) within the Nordic Council of Ministers, commissioned an expert group of Nordic food toxicologists to evaluate available epidemiological data concerning the relationship between maternal exposure to caffeine and other methylxanthines and adverse effects on the pregnancy, the foetus and young children. The adverse effects analysed in the epidemiological studies included: fertility/delayed conception, spontaneous abortions, congenital malformations, pre-term delivery, foetal growth retardation, effects on foetuses, and, finally, effects on neonates, infants and older children. The expert group has reached the following conclusions:

\section{Fertility:}

It cannot be ruled out that an association exists between caffeine exposure and fertility (delayed conception), but the evidence for such an association must at present be considered weak. One important reason contributing to the uncertainty in this respect is the lack of reliable data on caffeine exposure during the time before pregnancy.

\section{Spontaneous abortion:}

It seems probable that at least relatively high intakes of caffeine may adversely affect the risk of having a spontaneous abortion, especially early in pregnancy. Although the results of the available epidemiological studies in this field partly are contradictory and not easy to interpret, depending mainly on problems with confounding, the possible association is currently supported by some modern studies, which can be considered well designed and performed. 


\section{Congenital malformations:}

The available epidemiological data give no evidence that high caffeine exposure of women during pregnancy cause congenital malformations. However, the number of epidemiological studies is limited and their quality sometimes of questionable standard.

Pre-term delivery:

No relationship between caffeine exposure and pre-term delivery has been demonstrated in most acceptable epidemiological studies exploring this relationship. A few studies have found a positive association, but this may be explained by other factors that were not well controlled. Hence the expert group concludes that an association between prenatal caffeine exposure and pre-term delivery is unlikely at the exposure levels documented in the studies.

\section{Foetal growth retardation:}

As the overall result of the studies on a possible relationship between caffeine exposure and foetal growth retardation (mainly studies on birth weight) is contradictory, it is not possible to exclude a relationship between high intake of caffeine and reduced mean birth weight. It should, however, be kept in mind that in most modern prospective studies no significant effects have been observed. If a relationship between foetal growth retardation and caffeine intake exists, the resulting reduction in birth weight would probably be small and, thus, in most cases of minor importance clinically.

\section{Effects on the foetus:}

As only a few studies with a limited number of participants and a diverging design, have been carried out, it is very difficult to predict what effects will appear upon high exposure of pregnant women to caffeine. It seems probable that consumption of caffeine-containing foods, beverages and drugs could influence foetal behaviour but it is much less clear to what extent the effects could be considered adverse. Consequently, new and better-designed studies are warranted to be able to conclude on this relationship.

\section{Effects on neonates, infants and older children:}

The available studies on prenatal caffeine exposure via the placenta and postnatal via the breast milk have shown no consistent behavioural or cognitive effects on infants. It should, however, be pointed out that most of the assessed studies in this field are of questionable quality. Therefore, an association between prenatal caffeine exposure and behavioural or cognitive effects in infants can neither be verified nor excluded.

Health authorities in many countries have advised and are still advising women to limit their consumption of caffeine during pregnancy. Rec- 
ommendations of this type are probably based on many of the epidemiological studies assessed in this report. However, there is still considerable lack of data of high quality in relation to effects on reproduction. Understandably, this has resulted in uncertainties in the risk assessment of caffeine. To improve on the situation, a large number of investigators and authorities during the last two decades have reviewed the potential reproductive toxicity of caffeine or coffee (e.g. FDA, 1980b; Dlugosz and Bracken, 1992; Leviton, 1993; Nehlig and Debry, 1994c; Golding, 1995; Hinds et al., 1996; SCF, 1999) with the aim of establishing the safety of consuming foods and beverages containing caffeine. The following discussion is, however, limited to the results of two recent assessments.

The EU Scientific Committee on Food (SCF) performed the first of these safety assessments. The Committee launched a statement on the safety of consuming caffeine in pregnancy as part of an assessment of energy drinks January 21, 1999. The SCF states: "contradictory results have been noted in human studies on the effects of prenatal caffeine intake on birth weight and on incidence of spontaneous abortions. Some reviews attribute apparent effects of caffeine on birth weight to the confounding effect of smoking. No clear association has been established between caffeine intake in early pregnancy and spontaneous abortion or delayed conception. Similarly there are no consistent associations between prenatal caffeine exposure and pre-term delivery or congenital malformation. In many of the human studies reviewed, caffeine consumers have been subdivided into low, moderate and high consumers for analysis of data. In those studies indicating effects on pregnancy outcome, the association with caffeine was confined to high consumers. Studies on prenatal caffeine exposure have shown no consistent behavioural or cognitive effects on children either at pre-school or school age. A long-term follow-up study in children whose mothers were exposed to 150-200 mg caffeine/day during pregnancy found no clear effects on mental development, psychomotor functions or behaviour up to 7 years of age." The SCF concluded: "In general, maternal consumption during pregnancy does not appear to have any measurable adverse consequences for the human foetus at intakes up to $300 \mathrm{mg} /$ day" (SCF, 1999).

In another recently published assessment on the safety of caffeine in pregnancy, Leviton and Cowan (2002) presented the following conclusions: "(a) An association between caffeine consumption and a reproductive hazard is more likely to be seen in lower-quality studies than in studies that come closer to approximating the ideal. This is especially evident for "lower" birth weight and congenital anomalies. (b) The association between caffeine consumption and spontaneous abortion may well reflect the Stein-Susser epiphenomenon (women with prominent nausea tend to reduce caffeine consumption and nausea appears to be a marker of good implantation, perhaps reflecting a favorable balance of hormones produced by a healthy placenta). (c) The claim that caffeine 
consumption by women delays conception has not been followed by convincing support. (d) Reproductive hazards associated with cigarette smoking tend to be associated with caffeine/coffee consumption. Sometimes this appears to be a consequence of residual confounding associated with inadequate adjustment for cigarette smoking, which is over-represented among those who drink the most coffee/caffeine. Sometimes this reflects the tendency of women to underreport socially undesirable behaviors (e.g. smoking) while accurately reporting socially neutral behaviors (e.g. coffee and caffeine consumption). Thus, it seems reasonable to conclude that no convincing evidence has been presented to show that caffeine consumption increases the risk of any reproductive adversity."

The expert group under the Nordic Working Group on Food Toxicology (NNT) agrees with many of the conclusions expressed by the EU Scientific Committee on Food (SCF) in their Opinion published January 21,1999 . Some differences in opinion should, however, be noted. A couple of new well-designed studies on caffeine intake and spontaneous abortion have appeared since the statement of the Committee was made. The results of these studies allow the expert group to conclude that there is a probable association between caffeine intake and spontaneous abortion instead of "no clear association" as claimed by the SCF, at least at relatively high intakes of caffeine. In the case of delayed conception, the NNT group doubts that there is an association to caffeine exposure, but on the other hand, it cannot be entirely ruled out at present. Furthermore, though no consistent association has been found in the studies of congenital malformations, the fact that studies in this field are comparatively few and suffer from many limitations, a new well-designed study to close the subject would be welcome. Like the SCF, the NNT group has come to the conclusion that contradictory results have been obtained in human studies on the effects of maternal caffeine intake during pregnancy on birth weight. The NNT group takes the position that if high intakes of caffeine reduce birth weight, which is at present uncertain, this effect is likely to be small.

The NNT group also shares some of the conclusions expressed by Leviton and Cowan (2002) in their recently published assessment on the safety of caffeine in pregnancy. In agreement with Leviton and Gowan (2002), the NNT group has identified many methodological problems that limit the conclusions that can be drawn from the results of these epidemiological studies. The problem caused with nausea occurring in pregnant women during the first and second trimester of pregnancy as a confounding factor when analysing an association between caffeine consumption and spontaneous abortion has also been pointed out by the NNT group. The possibility of residual confounding associated with inadequate adjustment for cigarette smoking (which is over-represented among women who consume large amounts of coffee) has also been addressed by the NNT group. The overall conclusion by Leviton and Cowan (2002) is 
that it seems reasonable that no convincing evidence has been presented to show that caffeine consumption increases the risk of any reproductive adversity. The NNT group has more confidence in the recently published well-designed studies. Furthermore, as the epidemiological results are split between studies that give significant and non-significant effects, it can be claimed that there is no convincing evidence that caffeine does not increase the risk of reproductive adversity.

The possibility that caffeine, especially at high doses, could affect pregnancy in a negative way should be communicated in a non-traumatic way to women in childbearing age having a high caffeine intake from caffeine-containing beverages, foods, and drugs. For these women, a reduction in caffeine intake from all sources is warranted. As a doseeffect response has been found in many of the reviewed human studies, the NNT group, like the SCF and the FDA, finds it appropriate to continue the current discussion on limiting the caffeine intake during pregnancy. In the absence of sufficient studies of good scientific quality regarding many of the parameters dealt with in this report, the NNT group would like to recommend concentrating available resources in the future to only perform precise and well designed studies that are able to control for the majority of the many factors that may confound a relationship between intake of methylxanthines by women of childbearing age and adverse effects on herself, her foetus and young children. 



\section{References}

Abbott, P.J. (1986) Caffeine: a toxicological overview. The Medical Journal of Australia 17: 518-521.

A.C.S.H. (1981) The health effects of caffeine. Am. Council on Science and Health, New York, 102 pp.

Ahlsten, G. (1988) Bäst för fostret/det nyfödda barnet om kvinnan inte röker under graviditeten. Läkartidningen 85:849-852.

Aitken, R.J., Best, F., Richardson, D.W., Schats, R. and Simm, G. (1983) Influence of caffeine on movement characteristics, fertilizing activity and ability to penetrate cervical mucus of human spermatozoa. J. Reprod. Fert., 67:19-27.

Alderete, E., Eskenazi, B. and Sholtz, R. (1995) Effect of cigarette smoking and coffee drinking on time on conception. Epidemil., 6:403-408.

Aldridge, A., Parsons, W.D. and Neims, A.H. (1977) Stimulation of caffeine metabolism in the rat by 3 methylcholanthene. Life Sci., 21:967974.

Aldridge, A., Aranda, J.V. and Niems, A.H. (1979) Caffeine metabolism in the newborn. Clin. Pharmacol. Ther., 25:447-453.

Aldridge, A. and Neims, A.H. (1980) Relationship between the clearance of caffeine and its 7-N-demethylation in developing beagle puppies. Biochem. Pharmacol., 29:1909-1914.

Aldridge, A., Bailey, J. and Neims, A.H. (1981) The disposition of caffeine during and after pregnancy. Semin. Perinatol., 5:310-314.

Alikaridis, F. (1987) Natural constituents of Ilex species. J. Ethnopharmacol., 20:121-144.
Alm, B., Wennergren, G., Norvenius, G., Skjaerven, R., Öjen, N., Helweg- Larsen, H., Lagercrantz, H. and Irgens L.M. (1999) Caffeine and alcohol as risk factors for sudden infant death syndrome. Arch. Dis. Child., 81:107-111.

Anderson, L. and Gibbs, M. (1962) The biosynthesis of caffeine in the coffee plant. J. Biol. Chem. 237, 1941-1944.

Aranda, J.V., Sitar, D.S., Parsons, W.D., Laughnan, P.M. and Neims, A.H. (1976) Pharmacokinetic aspects of theophylline premature newborns. New Engl. J. Med., 295:413-416.

Aranda, J.V., Gorman, W., Bergsteinsson, H. and Gunn, T. (1977) Efficacy of caffeine in treatment of apnea in the lowbirth-weight infant. J. Pediatr., 90:467472.

Aranda, J.V., Collinge, J.M., Zinman, R. and Watters, G. (1979a) Maturation of caffeine elimination in infancy. Arch. Dis. Childhood 54:946-949.

Aranda, J.V., Louridas, A.T., Vitullo, B.B., Thom, P., Aldridge, A. and Haber, R. (1979b) Metabolism of theophylline to caffeine in human fetal liver. Science 206:1319-1321.

Arbeit, M.L., Nicklas, T.A., Frank, G.C., Webber, L.S., Miner, M.H. and Berenson, G.S. (1988) Current caffeine intake of young children: Amount and sources. J. Am. Diet. Assoc., 88:466-471.

Armstrong, B.G., McDonald, A.D. and Sloan, M. (1992) Cigarette, alcohol, and coffee consumption and spontaneous abortion. Am. J. Publ. Health 82:85-87.

Arnaud, M.J. (1976a) Indentification, kinetic and quantitative study of $\left[2-{ }^{14} \mathrm{C}\right]$ and $\left[1-\mathrm{Me}-{ }^{14} \mathrm{C}\right]$ caffeine metabolites in 
rat's urine by chromatographic separations. Biochem. Med., 16:67-76.

Arnaud, M.J. (1976b) Metabolism of 1,3,7-trimethyldihydrouric acid in the rat: new metabolic pathway of caffeine. Experientia 32:1238-1240.

Arnaud, M.J. (1984) Products of metabolism of caffeine. In: P.B. Dews (Ed.), Caffeine. Perspectives from Recent Research, Springer-Verlag, Berlin, pp. 338.

Arnaud, M.J. (1985) Comparative metabolic disposition of $\left[1-\mathrm{Me}^{14} \mathrm{C}\right]$ caffeine in rats, mice and chinese hamsters. Drug Met. Dispos., 13:471-478.

Arnaud, M.J. (1987) The pharmacology of caffeine. Prog. Drug Res., 31:273-313, 1987.

Arnaud, M.J. (1993) Metabolism of caffeine and other components of coffee. In: Caffeine, Coffee and Health, S- Garattini (Ed.), Raven Press, Ltd., New York, p. 43-95.

Arnaud, M.J. and Welsch, C. (1979a) Metabolic pathway of theobromine in the rat and identification of two new metabolites in human urine. J. Agric. Food Chem., 27:524-527.

Arnaud, M.J. and Welsch, C. (1979b) Metabolism of $\left[1-\mathrm{Me}^{-14} \mathrm{C}\right]$ paraxanthine in the rat: identification of a new metabolite. Experientia 35:34.

Arnaud, M.J. and Welsch, C. (1980) Caffeine metabolism in human subjects. 9th Symposium of the Association Scientifique Internationale du Cafe, ASIC Colloq., London, pp. 385-396.

Arnaud M.J., Ben-Zvi, Z., Yaari, A. and Gorodischer, R. (1986) Res. Comm. Chem. Path. Pharmac., 52:407-410.

Ashihara, H. and Crozier, A. (1999) Biosynthesis and metabolism of caffeine and related purine alkaloids in plants. Advances in Botanical Research 30:117205.

Ashihara, H., Monteiro, A.M., Gillies, F.M. and Crozier, A. (1996a) Biosynthe- sis of caffeine in leaves of coffee. Plant Physiol., 111:747-753.

Ashihara, H., Monteiro, A.M., Moritz, T., Gillies, F.M. and Crozier, A. (1996b) Catabolism of caffeine and related purine alkaloids in leaves of Coffea arabica L. Planta 198:334-339.

Ashihara, H., Gillies, F.M. and Crozier, A (1997) Metabolism of caffeine and related purine alkaloids in leaves of tea (Camellia sinensis L.). Plant Cell Physiol., 38:413-419.

Astill, C., Birch, M.R., Dacombe, C., Humphrey, P.G. and Martin, P.T. (2001) Factors affecting the caffeine and polyphenol contents of black and green tea infusions. J. Agric. Food Chem., 49:5340-5347.

Attfield, J. (1865) On the food-value of the cola-nut- a new source of thein. Pharm.J. $6,457-460$.

Axelrod, J. and Reichenthal, J. (1953) The fate of caffeine in man and a method for its estimation in biological material. J. Pharmacol. Exp. Ther., 107:519-523.

Axelsson, G., Rylander, R. and Molin, I. (1989) Outcome of pregnancy in relation to irregular and invonvenient work schedules. Br. J. Indust. Med., 46:393-398.

Bada, H.S., Khanna, N.N., Somani, S.M. and Tin, A.A. (1979) Interconversion of theophylline and caffeine in newborn infants. J. Pediat., 94:993-995.

Bailey, D.N., Weiber, R.T. and Naylor, A.J. (1982) A study of salicylate and caffeine excretion in the breast milk of two nursing mothers. J. Anal. Toxicol., 6:64-68.

Bakketeig, L.S. (1998) Current growth standards, definitions, diagnosis and classification of fetal growth retardation. Eur. J. Clin. Nutr., 52:S1:S1-S4.

Bakketeig, L.S., Jacobsen, G., Hoffman, H.J., Lindmark, G., Bergsjø, P., Molne, K. and Rødsten, J. (1993) Pre-pregnancy risk factors of small-for-gestational age births among parous women in Scandi- 
navia. Acta Obstet. Gynecol. Scand., 72:273-279.

Baltassat, F., Darbour, N. and Ferry, S. (1985) Étude du contenu purique de drogues a caféine: II. Le guarana, Paullinia sorbilis Mart. Plantes médicinales et phytothérapie 19:68-74.

Baranowsi, J., Pochopie'n, G. and Baranowska, I. (1998) Determination of nicotine, cotinine and caffeine in meconium using high-performance liquid chromatography. J. Chomatogr., 707:317-321.

Barkay, J. and Zuckerman, H. (1978) Further developed devise for human sperm freezing by the twenty minute method. Fertil. Steril., 29:304-308.

Barkay, J. and Zuckerman, H. (1980) Aid and sperm bank development in Israel. In: Human artificial insemination and semen preservation, G. David, W.S. Price (eds.), New York: Plenum Press, pp. 45-50.

Barkay, J., Zuckermann, H., Sklan, D. and Gordon, S. (1977) Effect of caffeine on increasing the motility of frozen human sperm. Fertil. Steril., 28:175-177.

Barkay, J., Bartoov, B., Ben-Ezra, S., Langsam, J., Feldman, E., Gordon, S. and Zuckerman, H. (1984) The influence of in vitro caffeine treatment on human sperm morphology and fertilizing capacity. Fertil. Steril., 41:913-918.

Barone, J.J. and Roberts, H. (1983) History and use. Fd. Tech.,September, 32-39.

Barone, J.J. and Roberts, H. (1984) Human consumption of caffeine. In: Caffeine. Perspectives from Recent Research. Springer-Verlag, Berlin, pp. 59-73.

Barone, J.J. and Roberts, H.R. (1993) Caffeine consumption. Seventh International Caffeine Workshop, Santorini, Greece, June, 13-17.

Barone, J.J. and Roberts, H.R. (1996) Caffeine consumption. Fd. Chem. Toxic. 34(1), 119-129.

Barr, H.M., Streissguth, A.P., Marchtin, D.C. and Herman, C.S. (1984) Infant size at 8 months of age: relationship to maternal use of alcohol, nicotine, and caffeine during pregnancy. Pediatrics 74 : 336-41.

Barr, H.M. and Streissguth A.P. (1991) Caffeine use during pregnancy and child outcome: a 7-year prospective study. Neurotoxicol Teratol., 13:441-8.

Barton, C.R., Adams, T.L. and Zarowitz, M.A. (1991) Stable transformation of foreign DNA into Coffea arabica plants. ASIC 14 Colloq. Sci. Int. Cafe, 1991, San Francisco, USA, 1:460-464.

Bartsch, A. (1998) Mate. "Stimulans nicht nur für Gauchos". Ernähungs-Umschau 45:273-276.

Bättig, K. and Welzl, H. (1993) Psychopharmacological profile of caffeine. In: Caffeine, Coffee and Health, S- Garattini (Ed.), Raven Press, Ltd., New York, p. 213-253.

Baumann, T.W. (1996) Coffein. Bot. Helv., 106:127-158.

Baumann, T.W. and Wanner, H. (1972) Untersuchungen über den Transport von Kaffein in der Kaffeepflanze (Coffea arabica). Planta 108:11-20.

Baumann, T.W., Schulthess, B.H. and Hänni, K. (1995) Guaraná (Paullinia cupana) rewards seed dispersers without intoxicating them by caffeine. Phytochemistry 39:1063-1070.

Beach, C.A., Kianchine, J.R. and Gerber, N. (1984) The excretion of caffeine in the semen of men: pharmacokinetics and comparison of the concentrations in blood and semen. J. Clin. Pharmacol., 24:120-126.

Beaulac-Baillargeon, L. and Desrosiers, C. (1987) Caffeine-cigarette interaction on fetal growth. Am.J. Obstet. Gynecol., 157:1236-1240.

Belliardo, F., Martelli, A. and Valle, M.G. (1985) HPLC determination of caffeine and theophylline in Paullinia cupana Kunth (Guarana) and Cola spp. samples. Z. Lebensm. Unters. Forsch., 180:398401. 
Bempong, D.K., Houghton, P.J. and Steadman, K. (1993) The xanthine content of guarana and its preparations. Int. J. Pharmacog., 31:175-181.

Benowitz, N.L. (1990) Clinical pharmacology of caffeine. Annu. Rev.Med., $41: 277-88$

van den Berg, B. (1977). Epidemiologic observations of prematurity: effects of tobacco, coffee, and alcohol. In: The Epidemiology of Prematurity, M.D.Reeds and F.J Stanley (Eds.), Urban and Schwarzenberg, Baltimore, pp. 157-176.

Berger, A. (1988) Effects of caffeine consumption on pregnancy outcome. A review. J. Reproduct. Med., 33:945-956.

Berkowitz, G.S. and Lapinski, R.H. (1996) Risk factors for cryptorchidism: a nested case-control study. Paediatr. Perinat. Epidemiol., 10:39-51.

Berkowitz, G.S., Holford, T.R. and Berkowitz, R.L.(1982) Effects of cigarette smoking, alcohol, coffee and tea consumption on pre-term delivery. Early Hum. Dev., 7:239-50.

Berlin, C.M. Jr. (1981) Excretion of the methylxanthines in human milk. Sem. Perinatology 5:389-394.

Berlin, C.M., Denson, H.M., Daniel, C.H. and Ward, R.M. (1984) Disposition of dietary caffeine in milk, saliva, and plasma of lactating women. Pediatrics 73:59-63.

Berthemot and Dechastelus (1840) Chemische Untersuchung des Guarana. Liebig's Ann. Chem. 36, 90-93.

Berthou, F., Ratanasavanh, D., Alix, D., Carlhant, D., Riche, C. and Guillouzo, A. (1988) Caffeine and theophylline metabolism in newborn and adult human hepatocytes: A comparison with adult rat hepatocytes. Biochem. Pharmacol., 37:3691-3700.

Berthou, F., Flinois, J.-P., Ratanasavanh, D., Beaune, P., Riche, C., and Guillouzo, A. (1991) Evidence for the involvement of several cytochomes P-450 in the first steps of caffeine metabolism by human microsomes. Drug Met. Disp., 19:561567.

Blanchard, J. and Sawers, S.J.A. (1983) Comparative pharmacokinetics of caffeine in young and elderly men. J. Pharmacokinet. Biopharmaceut., 11:109-126.

Blanchard, J., Weber, C.W. and Shearer, L.E. (1992) Methylxanthine levels in breast milk of lactating women of different ethnic and socioeconomic classes. Biopharm. Drug Dispos., 13:187-196.

Blauch, J.L. and Tarka, S.M.Jr. (1983) HPLC determination of caffeine and theobromine in coffee, tea, and instant hot cocoa mixes. J. Food Sci., 48:745$747+750$.

Bolúmar, F., Olsen J., Rebagliato, M., Bisanti, L. and the European Study Group on Infertility and Subfecundity. (1997) Caffeine intake and delayed conception: a European multicenter study on intertility and subfecundity. Am. J. Epidemiol., 145:324-334.

Bonati, M., Latini, R., Marra, G., Assael, B.M. and Parini, R. (1981) Theophylline metabolism during the first month of life and development. Pediatr. Res., 15:304308.

Bonati, M., Latini, R., Tognoni, G., Young, J.F. and Garattini, S. (1984-85) Interspecies comparison of in vivo caffeine pharmacokinetics in man, monkey, rabbit rat, and mouse. Drug Metabol. Rev., 15:1355-1383.

Bonoli, M., Colabufalo, P., Pelillo, M., Toschi, T.G. and Lercker G. (2003) Fast determination of catechins and xanthines in tea beverages by micellar electrokinetic chromatography. J. Agric. Food Chem., 51:1141-1147.

Borlée, I., Lechat, M.F., Bouckaert, A. and Misson, C. (1978) Le café, facteur de risque pendant la grossesse? Louvain Med., 97:279-284.

Bory, C., Baltassat, P., Porthault, M., Bethenod, M., Frederich, A. and Aranda, J.V. (1978) Biotransformation of 
theophylline to caffeine in premature newborn. Lancet ii (No. 8101):12041205.

Bory, C., Baltassat, P., Porthault, M., Bethenod, M., Frederich, A. and Aranda, J.V. (1979) Metabolism of theophylline to caffeine in premature newborn infants. J. Pediat., 94:988-993.

Boutroy, M.-J., Vert, P., Monin, P., Royer, R.J. and Royer-Morrot, M.-J. (1979a) Methylation of theophylline to caffeine in premature infants. Lancet i (No. 8120):830.

Boutroy, M.-J., Vert, P., Royer, R.J., Monin, P. and Royer-Morrot, M.-J. (1979b) Caffeine, a metabolite of theophylline during the treatment of apnea in the premature infant. J. Pediat. 94:996-998.

Branfman, A.R., McComish, M.F., Bruni, R.J., Callahan, M.M., Robertson, R. and Yesair, D.W. (1983) Characterization of diaminouracil metabolites of caffeine in human urine. Drug Metabol. Disp., 11:206-210.

Brasche, S., Winkler, G. And Heinrich, J. (1998) Dietary intake and smoking Results from a dietary survey in Erfurt in 1991/92. Z. Ernähungswiss., 37:211214.

Brazelton, T.B. (1973) Neonatal behavioural assessment scale. Philadelphia: Lippincott.

Brazier, J.L., Ritter, J., Berland, M., Khenfer, D. and Faucon, G. (1983) Pharmacokinetics of caffeine during and after pregnancy. Dev. Pharmacol. Ther., 6:315-322.

Bresler, H.W. (1904) Über die Bestimmung der Nucleinbasen in Safte von Beta vulgaris. Hoppe-Seyler's Z. Physicol. Chem. 41, 535-541.

Brooke, O.G., Anderson, H.R., Bland, J.M., Peacock, J.L. and Stewart C.M. (1989) Effects on birth weight of smoking, alcohol, caffeine, socioeconomic factors, and psychosocial stress. Br. Med. J., 298:795-801.
Brune, H., Deutsch-Wenzel, R.P., Habs, M., Ivankovic, S. and Schmähl, D. (1981) Investigation of the tumorigenic response to benzo(a)pyrene in aqueous caffeine solution applied orally to Sprague-Dawley rats. J. Cancer Res. Clin. Oncol., 102:153-157.

Bruce, B. and Cpiller, G.A. (1998) Caffeine, calcium and bone health. In: Caffeine, G.A. Spiller (Ed.), CRC Press, New York, pp. 345-356.

Buck, G.M., Sever, L.E., Batt, R.E. and Mendola, P. (1997) Life-style factors and female infertility. Epidemiol., 8:435441.

Bunker, M.L. and Mc Williams; M. (1979) Caffeine content of common beverages. J. Am. Dietetic. Assoc., 74:28-32.

Burg, A.W. (1975) Physiological disposition of caffeine. Drug Metab. Rev., 4:199-228.

Burg, A.W. and Stein, M.E. (1972) Urinary excretion of caffeine and its metabolites in the mouse. Biochem. Pharmacol., 21:909-922.

Burg, A.W. and Werner, E. (1972) Tissue distribution of caffeine and its metabolites in the mouse. Biochem. Pharmacol., 21:923-936.

Burg, A.W., Burrows, R. and Kensler, C.J. (1974) Unusual metabolism of caffeine in the squirrel monkey. Toxicol. Appl. Pharmacol., 28:162-166.

Buters, J.T.M., Tang, B.-K., Pineau, T. Gelboin, H., Kimura, S., and Gonzalez, F.J. (1996) Role of CYP1A2 in caffeine pharmacokinetics and metabolism: studies using mice deficient in CYP1A2. Pharmacogenetics 6:291-296.

Butler, M.A., Iwasaki., M., Guengerich, F.P., and Kadlubar, F. (1989) Human cytochrome P-450PA (P-450IA2), the phenacetin $\mathrm{O}$-deethylase, is primarily responsible for the hepatic 3demethylation of caffeine and $\mathrm{N}$ oxidation of carcinogenic arylamines. Proc. Natl. Acad. Sci., 86, 7696-7700. 
Caan, B. and Goldhaber, M.K. (1989) Caffeinated beverages and low birth weight a case-control study. Am J Public Health 79:1299-300.

Caan, B. And Coates, A. (1994) Association of delayed conseption with caffeine consumption. Comments, Am. J. Epidemiol., 140:663-664.

Caan, B., Charles, P., Quesenberry, Jr. and Ashley, O. (1998) Differences in fertility associated with caffeinated beverage consumption. Am. J. Publ. Health 88:270-274.

Cai, X. And Marik, J.J. (1989) Improving penetrating capacity of spermatozoa with poor motility by addition of caffeine at coincubation with zona-free hamster ova. Fert. Steril., 51:719-721.

Callahan, M.M., Robertson, R.S., Arnaud, M.J., Branfman, A.R., McComish, M.F., and Yesair D.W. (1982) Human metabolism of [1-methyl-14C]- and [2$14 \mathrm{C}]$ caffeine after oral administration. Drug Met. Disp., 10: 417-423.

Callahan, M.M., Robertson, R.S., Branfman, A.R., McComish, M.F. and Yesair, D.W. (1983) Comparison of caffeine metabolism in three nonsmoking populations after oral administration of radiolabeled caffeine. Drug Metabol. Disp., 11:211-217.

Camargo, M.C.R. and Toledo, M.C.F. (1999) HPLC determination of caffeine in tea, chocolate products and carbonated beverages. J. Sci. Food Agric., 79:1861-1864.

Camargo, M.C.R., Toledo, M.C.F. and Farah, H.G. (1999) Caffeine daily intake from dietary sources in Brazil. Food Addit. Cont., 16:79-87.

Capurro, H., Konichezky, S., Fonseca, D. et al. (1978) A simplified method for diagnosis of gestational age in the newborn infant. J. Pediatr., 93:120-122.

Carlson, M. and Thompson, R.D. (1998) Liquid chomatographic determination of methylxanthines and catechins in herbal preparations containing guaraná. J. AOAC Internat., 81:691-701.
Carneiro, M. F. (1999) Advances in coffee biotechnology. AgBiotechNet, 1:1-7.

Carrier, O., Pons, G., Rey, E., Richard, M.-O., Moran, C., Badoual, J. and Olive, G. (1988) Maturation of caffeine metabolic pathways in infancy. Clin. Pharmacol. Ther., 44:145-151.

Casas, M., Ferrer, S., Calaf, J., RodriguezEspinosa, J., Jane, F., Herrera-Marschitz, M. and Ungerstedt, U. (1989) Dopaminergic mechanism for caffeine-induced decrease in fertility? Lancet $i: 731$.

Cazeneuve, C., Pons, G., Rey, E., Treluyer, J.-M., Cresteil, T., Thiroux, G., D'Athis, P. and Olive, G. (1994) Biotransformation of caffeine in human liver microsomes form foetuses, neonates, infants and adults. Br. J. Clin. Pharmac., 37:405-412.

Chistianson, R.E., Oechsli, F.W. and van den Berg, B.J. (1989) Caffeinated beverages and decreased fertility. Lancet $335: 378$.

Cheney, R.H. (1947) The biology and economics of beverage industry. Econ. Bot. 1, 243-275.

Cheng, W.S., Murphy, T.L., Smith, M.T., Cooksley, W.G., Halliday, J.W. and Powell, L.W. (1990) Dose-dependent pharmacolokinetics of caffeine in humans: Relevance as a test of quantitative liver function. Clin. Pharmacol. Thery., 47:516-524.

Chevalley, J. (1976) Theobromine and caffeine content of cocoa beans from different botanical and geographical origins.

Chou, T. (1992) Wake up and smell the coffee. Caffeine, coffee, and the medical consequences. West J. Med., 157:544553.

Chou, T.M. and Benowitz, N.L. (1994) Caffeine and coffee: effects on health and cardiovascular disease. Comp. Biochem. Physiolo., 109:173-189.

Chistensen, H.D. and Whitsett, T.L. (1979) Measurements of xanthines and their 
metabolites by means of high pressure liquid chromatography. Chomatographic Sci., 10:507-537.

Chistensen, H.D. and Neims, A.H. (1984) Measurement of caffeine and its metabolites in biological fluids. In: Caffeine. Perspectives from Recent Research, P.B. Dews (Ed.), Springer-Verlag, Berlin, pp. 39-47.

Chung, W.-G., and Cha Y.-N. (1997) Oxidation of caffeine to theobromine and theophylline is catalyzed primarily by flavin-containing monooxygenase in liver microsomes. Biochem. Biophys. Res. Commun., 235:685-688.

Claireaux, A.E. (1975) The effect of oxygen on the lung. J. Clin. Pathol. Suppl. 1975:75-80.

Clark, C.H. and Shankel, D.M. (1975) Antimutagenesis in microbiol systems. Bacteriol. Rev., 39:33-53.

Clausson, B., Granath, F., Ekbom, A., Lundgren, S., Nordmark, A., Signorello, L.B. and Cnattingius, S. (2002) Effect of caffeine exposure during pregnancy on birth weight and gestational age. Am. J. Epidemiol., 155:429-436.

Clifford, M.N. and Ramirez-Martinez, J.R. (1990) Chlorogenic acids and purine alkaloid contents of maté (Ilex paraguariensis) leaf and beverage. Food Chem., 35:13-21.

Cloughley, J.B. (1981) Factors influencing the caffeine content of black tea: Part 1The effect of field variables. Fd. Chem. 9, 269-276.

Cnattingius, S., Signorello, L.B., Annerén, G., Clausson, B., Ekbom, A., Ljunger, E., Blot, W.J., McLaughlin, J.K., Petersson, G., Rane, A. and Granath, F. (2000) Caffeine intake and the risk of firsttrimester spontaneous abortion. New Engl. J. Med., 343:1839-1845.

Collins, T.F.X. (1981) Update to review caffeine studies. FDA By-Lines 11:19-.

Collins, T. F. X., Welsh, J. J., Black, T. N., and Ruggles, D. I. (1981). A study of the teratogenic potential of caffeine given by oral intubation to rats. Regul. Toxic. Pharmacol., 1:355-.

Collins, T. F. X., Welsh, J. J., Black, T. N., and Ruggles, D. I. (1983). A study of the teratogenic potential of caffeine ingested in drinking water. Fd. Chem. Toxic., 21:763-777.

Consumers Europe (1996) Euromonitor International Inc. P. 194-196.

Cornish, H.H. and Chistman, A.A. (1957) A study of the metabolism of theobromine, theophylline, and caffeine in man. J. Biol. Chem., 228:315-323.

Cook, D.G., Peacock, J.L., Feyerabend, C., Carey, I.M., Jarvis, M.J., Anderson, H.R. and Bland, J.M. (1996) Relation of caffeine intake and blood caffeine concentrations during pregnancy to foetal growth: prospective population based study. Br. Med. J., 313:1358-1362.

Cooling, D. (1993) Theophylline toxicity. J: Emerg. Med., 11:415-425.

Correa, A., Stolley, A. and Liu, Y. (2000) Prenatal tea consumption and risks of anencephaly and spina bifida. Ann. Epidemiol., 10:476-477.

Cramer, D.W. (1990) Caffeine and infertility. Lancet 335:792-793.

Craig, W.J. and Nguyen, T.T. (1984) Caffeine and theobromine levels in cocoa and carob products. J. Food Science 49:302-305.

Cunningham, H.M. (1970) Biological halflife of caffein in pigs. Can. J. Anim. Sci., 50:49-54.

Curatolo, P.W. and Robertson, D. (1983) The health consequences of caffeine. Ann. Intern. Med., 98:641-653.

Curtis, K., Savitz, D. and Arbuckle, T. (1997) Effects of cigarette smoking, caffeine consumption, and alcohol intake on fecundability. Am. J. Epidemiol., 146:32-41.

Czok, G., Schmidt, B. and Lang, K. (1969) Verteilung von $8-{ }^{14} \mathrm{C}$-Coffein im Orga- 
nismus der Ratte. Z. Ernaehungswiss., 9:109-117.

Daly, J.W. (1993) Mechanism of action of caffeine. In: Caffeine, Coffee and Health, S. Garattini (Ed.), Raven Press, Ltd., New York, p. 97-150.

D'Ambrosio, S.M. (1994) Evaluation of the genotoxicity data on caffeine. Reg. Toxicol. Pharmacol., 19:243-281.

D'Amicis, A. and Viani, R. (1993) The consumption of coffee. In: Caffeine, Coffee and Health, S. Garattini (Ed.), Raven Press Ltd., New York, pp. 1-16.

Danielle, W.F. (1865) On the cola-nut of tropical West Africa (The guru.nut of Soudan). Pharm. J. 6, 450-457.

Darragh, A., Lambe, R.F., Hallinan, D. and O'Kelly, D.A. (1979) Caffeine in soft drinks. Lancet i:1196.

Dasta, J.F. (1979) Placental transfer of pheophylline. J. Am. Med. Assoc., 242:323-x.

Debry, G. (1994) Coffee and health. John Libbey Eurotext, Paris, p. 10.

Defilippi, A., Piancone, G. and Tibaldi, G.P. (1995) La qualità dei mieli - Metodica HPLC per la determinazione della caffeina nei mieli d'aramcop. Industrie Alimentari 34:6-8.

Dempsey, D.A., Partridge, J.C., Jones, R.T. and Rowbotham, M.C. 1998) Cocaine, nicotine, caffeine, and metabolite plasma concentrations in neonates. J. Anal. Toxicol., 22:220-224.

Denaro, C.P., Brown, C.R., Wilson, M., Jacob III, P. and Benowitz, N.L. (1990) Dose-dependency of caffeine metabolism with repeated dosing. Clin. Pharmacol. Ther., 48:277-285.

Deuchar, N. (1995) Nausea and vomiting in pregnancy: a review of the problem with particular regard to psychological and social aspects. Br. J. Obstet. Gynaecol., 102:6-8.

Devoe, L.D., Murray, C., Youssif, A. and Arnaud, M. (1993) Maternal caffeine consumption and foetal behaviour in normal third-trimester pregancy. Am. J. Obstet. Gynecol., 168:1105-1111.

De Vries, J.W., Johnson, K.D. and Heroff, J.C. (1981) HPLC Determination of caffeine and theobromine content of various natural and red dutched cocoas. J. Food Sci., 46:1968-1969.

Dews (1982) Caffeine. Ann. Rev. Nutr. 2:323-41.

Dictionnaire des termes de médecine, chirurgie, art vétérinaire, pharmacie, histoire, naturelle, botanique, physique, chimie, etc.; (1823) Paris, p. 109.

Dlugosz, L. and Bracken, M.B. (1992) Reproductive effects of caffeine: A review and theoretical analysis. Epidemiol. Rev., 14:83-100.

Dlugosz, L., Belanger, K., Hellenbrand, K., Holford, T.R., Leaderer, B. and Bracken, M.B. (1996) Maternal caffeine consumption and spontaneous abortion: a prospective cohort study. Epidemiology $7: 250-255$.

Dominguez-Rojas, V., de Juanes-Pardo, J.R., Astasio-Arbiza, P., Ortega-Molina, P. and Gordillo-Florencio, E. (1994) Spontaneous abortion in a hospital population: are tobacco and coffee intake risk factors? Eur. J. Epidemiol., 10:665-668.

Dorland, W.A.N. (1985) Dorland's Illustrated medical dictionary, 26th edition, W.B. Saunders Company, Philadelphia.

Drouillard, D.D., Vesell, E.S. and Dvorchik, B.H. (1978) Studies on theobromine disposition in normal subjects. Clin. Pharmacol. Ther., 23:296-302.

Dubowitz, L.M.S., Dubowitz, V. and Goldberg, C. (1970) Clinical assessment of gestational age in the newborn infant. J. Pediat., 77:1-10.

Dulout, F. N., Larramendy, M. L. and Olivero, O. A. (1981). Effect of caffeine on the frequency of chromosome aberrations induced in vivo by triethylenemelamine (TEM) and adriamycin (ADR) in mice. Mutation Res., 82:295-304. 
Dumas, M., Gouyon, J.B., Tenenbaum, D., Michiels, Y., Escousse, A. and Alison, M. (1982) Systemic determination of caffeine plasma concentrations at birth in preterm and full-term infants. Dev. Pharmacol. Ther., 4S:182-186.

ECF (1990) European Coffee Federation. European Coffee report 1989. Hans-G. Müller-Henniges. Bernhard Rothfos $\mathrm{GmbH}$, May.

Eijk, J.L. v. (1952) Phytochemical investigation of Erodium cicutarium. Pharm. Weekbl. 87, 425-432.

Elintarvikeliitto (1998) Elintarvikeliitto (Finland), Panimo- ja virvoitusjuomateollisuusliitto Ry.

Ellis, E.F., Koysooko, R. and Levy, G. (1976) Pharmacokinetics of theophylline in children with asthma. Pediatrics 58:542-547.

Ellison, R.C., Singer, M.R., Moore, L.L., Nguyen, U.-S., Marmor, J.K. and Pawlik, E.J. (1993) Current caffeine intake in typical American children: Reported intake and salivary levels. (A preliminary report). Seventh International Caffeine Workshop, Santorini, Greece, June 1317, 1993, pp. 10.

Ellison, R.C., Singer, M.R., Moore, L.L., Nguyen, U.-S., Garrahie, E.J. and Marmor, J (1995) Current caffeine intake of young children: Amount and sources. J. Am. Diet. Assoc., 95:802-804.

Elmazar, M. M. A., McElhatton, P. R. and Sullivan, F. M. (1982). Studies on the teratogenic effects of different oral preparations of caffeine in mice. Toxicology 23:57-71.

Emory, EK., Konopka, S., Honsky, S, Tuggey, R. and Dave R. (1988) Salivary caffeine and neonatal behavior: assay modification and functional significance. Psychopharmacol., 94:64-8.

Engle, P.L., VasDias, T., Howard, I., Romero-Abal, M.E., Quan de Serrano, J., Bulux, J., Solomons, N.W., and Dewey, K.G. (1999) Effects of discontinuing coffee intake on iron deficient
Guatemalan toddlers' cognitive development and sleep. Early Hum. Dev., 53:251-69.

Erickson, H.T., Corrēa, M.P.F. and Escobar, J.R. (1984) Guarani (Paullinia cupana) as a commercial crop in Brazilian Amazonia. Economic Botany 38:273286.

Eskenazi, B. (1993) Caffeine during pregnancy: grounds for concern? J. Am. Med. Assoc., 270:2973-2974.

Eskenazi, B., Stapleton, A.L., Kharrazi, M.and Chee, W.Y. (1999) Associations between maternal decaffeinated and caffeinated coffee consumption and fetal growth and gestational duration. Epidemiology 10:242-249.

Esmelindro, A.A., Dos Santos Girardi, J., Mossi, A., Jacques, A. and Dariva, C. (2004) Influence of agronomic variables on the composition of mate lea leaves (Ilex paraguariensis) extracts obtained from $\mathrm{CO} 2$ extraction at $30 \mathrm{oC}$ and 175 bar. J. Agric. Food Chem., 52:19901995.

Eteng, M.U.,Eyong, E.U., Akpanyung, E.O., Agiang, M.A. and Aremu, C.Y. (1997) Recent advances in caffeine and theobromine toxicities: a review. Plant Foods Hum. Nutr., 51:231-43.

Etherton, G.M. and Kochar, M.S. (1993) Coffee: Facts and Controversies. Clinical Review. Arch. Fam. Med., 2:317-323.

Fabro, S. and Sieber, S.M. (1969) Caffeine and nicotine penetrate the preimplantation blastocyst. Nature 223:410411.

FAO (1996a) Yearbook. Production 1996. FAO, Rome, Table 78, p. 172.

FAO (1996b) Yearbook. Production 1996. FAO, Rome, Table 79, p. 173.

FAO (1996c) Yearbook. Production 1996. FAO, Rome, Table 80, p. 174.

FDA (1980) US Food and Drug Administration. Statement by Jere E. Govan. Commissioner of Food \& Drugs. HHS News; Sept. 5, 1980. Washington: US 
Department of Health and Human Services (no. p.80-36).

FDA (1980b) FDA:deletion of GRAS status, proposed declaration that no prior sanction exists, and use on an interim basis pending additional study. Federal Register 45/205, 69817-69838.

Fechner, M.G.T. (1826) Repertorium der organischen Chemie, (Leipzig).

Feldman, E.B. (1998) Death by chocolate. Nutrition Today 33:106-112.

Feng, Q., Yang, M., Zheng, X., Zhen, X., Pan, N. and Chen, Z. (1992) Agrobacterium mediated transformation of coffee (Chinese). Chin. J. Biotechnol., 8:255260.

Fenster, L., Eskenazi, B., Windham, G.C. and Swan, S.H. (1991a) Caffeine consumption during pregnancy and spontaneous abortion. Epidemiology 2:168174.

Fenster, L., Eskenazi, B., Windham, G.C. and Swan, S.H. (1991b) Caffeine consumption during pregnancy and fetal growth. Am J Public Health 81:458-461.

Fenster, L., Hubbard, A.E., Swan, S.H., Windham, G.C., Waller, K., Hiatt, R.A. and Benowitz, N. (1997) Caffeinated beverages, decaffeinated coffee and spontaneous abortion. Epidemiology 8:515-523.

Fenster, L., Quale, C., Hiatt, R.A., Wilson, M., Windham, G.C. and Benowitz, N.L. (1998) Rate of caffeine metabolism and risk of spontaneous abortion. Am. J. Epidemiol., 147:503-510.

Fenster, L., Quale, C., Waller, K., Windham, G.C., Elkin, E.P., Benowitz, N. and Swan, S.H. (1999) Caffeine consumption and menstrual function. Am. J. Epidemiol., 149:550-557.

Fernandes, O., Sabharwal, M., Smiley, T., Pastuszak, A., Koren, G. And Einarson, T. (1998) Moderate to heavy caffeine consumption during pregnancy and relationship to spontaneous abortion and abnormal foetal growth: a meta-analysis. Reprod. Toxicol., 12:435-444.
Fernández, P.L., Martín, M.J., González, A.G. and Pablos, F. (2000) HPLC determination of catechins and caffeine in tea. Differentiation of green, black and instant teas. Analyst 125:421-425.

Fernández, P.L., Pablos, F., Martín, M.J. and Gonzáles, A.G. (2002) Study of catechin and xanthine tea profiles as geopgraphical tracers. J. Agric. Food Chem., 50:1833-1839.

Fincke, A., Lange, H. and Kleinert, H. (1965) Handbook of the cacao products. Springer, Berlin., p. 377-378.

Fincke, A. (1989) Analytische und technologische Entwicklungen auf dem Gebiet der Kakaoerzeugnisse. Lebensmittelchem. Gerichtl. Chem., 43:49-55.

Fischer, E. (1882) Ueber Caffei'ns, Theobromin, Xantin und Guanin. Liebig's Ann. Chem. 215, 253-320.

Fischer, E. (1897a) Ueber die Consitution des Caffei'ns, Xanthins, Hypoxanthines und verwandter Basen. Ber. Dtsch. Chem. Ges. 30, 549-559.

Fischer, E. (1907) Untersuchung in der Puringruppe. (1882-1906) (Springer Verlag, Berlin) 608pp.

Florack, E., Zielhius, G. and Rolland R. (1994) Cigarette smoking, alcohol consumption, and caffeine intake and fecundability. Prev. Med., 23:175-180.

Ford, R.P., Schluter, PJ., Mitchell, EA., Taylor, B.J., Scragg, R.and Stewart A.W. (1998) Heavy caffeine intake in pregnancy and sudden infant death syndrome. New Zealand Cot Death Study Group. Arch. Dis. Child., 78:9-13.

Fortier, I., Marchcoux, S. and BeaulacBaillargeon, L. (1993) Relation of caffeine intake during pregnancy to intrauterine growth retardation and pre-term birth. Am. J. Epidemiol., 137:931-40.

Franzke, C., Grunert, S., Hildebrandt, U. and Griehl, H. (1967) Über das Vorkommen von Theophylline in Kaffee. Hoppe-Seyler's Z. Physiol. Chem. 348, 1725-1726. 
Fredericks, A.B., Benowitz, N.L and Savanapridi, C.Y. (1981) The cardiovascular and autonomic effects of repeated administration of delta-9tetrahydroxannabinol to rhesus monkeys. J. Pharmacol. Exp. Ther., 216:247-253.

Fredholm, B.B. (1980) Are methylxanthine effects due to antagonism of endogenous adenosine? Trends Pharmacol. Sci., $1: 129-132$

Fredholm, B. (1984) Cardiovascular and renal actions of methylxanthines. Prog Clin Biol Res., 158:303-30.

Fredholm, B. (1995) Adenosine, Adenosine Receptors and Actions of Caffeine. Pharmacol. Toxicol., 76:93-101.

Fredholm, B., Bättig, K., Holmén, J., Nehlig, A. and Zvartau, E.E. (1999) Actions of Caffeine in the Brain with Special Reference to Factors that Contribute to its Widespread Use. Pharmacol. Rev., 51:83-133.

Frei, J.V. and Venitt, S. (1975) Chromosome damage in the bone marrow of mice treated with the methylating agents methyl methanesulphonate and $\mathrm{N}$ methyl-N-nitrosourea in the presence or absence of caffeine, and its relationship with thymoma induction. Mutation Res., 29:89-96.

Freire, A.V., Lightfoot, D.A. and Preece, J.E. (1994) Genetic transformation of coffee (Coffea arabica L.) by agrobacterium spp. HortScience 29:454.

Fried, PA. and O'Conell, C.M. (1987) A comparison of the effects of prenatal exposure to tobacco, alcohol, cannabis and caffeine on birth size and subsequent growth. Neurotoxicol Teratol., 9:79-85.

Friedman, J. and Waller, G.R. (1983) Caffeine haxards and their prevention in germinating seeds of coffee (Coffea arabica L.). J. Chem. Ecol., 9:1099-1106.

Fuh, U., Doehmer, J., Battula, N., Wölfel, C., Kudla, C., Keita, Y., and Staib, A.H. (1992) Biotranformation of caffeine and theophylline in mammalian cell lines genetically engineered for expression of single cytochome P450 isoforms. Biochem. Pharm., 43:225-235

Fujii, T. and Nishimura, H. (1972). Adverse effects of prolonged administration of caffeine on rat fetus. Toxic. Appl. Pharmacol., 22:449-457.

Fujimori, N. and Ashihara, H. (1993) Biosynthesis of caffeine in flower buds of Camellia sinensis. Annals of Botany 71:279-284.

Furneaux, E.C., Langley-Evans, A:J., Langley-Evans, S.C. (2001) Nausea and vomiting of pregnancy: endocrine basis and contribution to pregnancy outcome. Obstet. Gynecolog. Survey 12:775-782.

Furuhashi, N., Sato, S., Suzuki, M., Hiruta, M., Tanaka, M. and Takahashi, T. (1985) Effects of caffeine ingestion during pregnancy. Gynecol. Obstet. Invest., 19:187-191.

Galasko, G.T.F., Furman, K.I. and Alberts. E. (1989) The caffeine contents of nonalcoholic beverages. Fd. Chem. Toxic., 27:49-51.

Galli, C., Spano, P.F. and Szyskzka, K. (1975) Accumulation of caffeine and its metabolities in rat fetal brain and liver. Pharmacol. Res. Commun., 7:217-221.

Garrett, B.E. and Griffiths, R.R. (1997) The role of dopamine one the Behavioral effects of caffeine in Animals and Humans. Pharmacol. Biochem. Behav., 57:533-547.

George, J., Murphy, T., Roberts, R., Cooksley, W.G.E., Halliday, J.W. and Powell, L.W. (1986) Influence of alcohol and caffeine consumption on caffeine elimination. Clin. Exp. Pharmacol. Physiol., 13:731-736.

Giese, F.v. (1820) Vermischte Notizen . 1. Kaffestoff und Salzgehalt des Quassia Extrakts. Allg. Nord. Ann. Chem. Freunde Naturkd. Arzneiwiss. 4, 240241.

Giese, F.v. (1821) Verschiedene Beobachtungen. J. Chem. Phys. 31, 203-209. 
Gilbert, R.M. (1984) Caffeine consumption. The Methylxanthine beverages and foods: Chemistry, consumption, and health effects. 185-213. Alan R. Liss. Inc., 150 Fifth Avenue, New York, NY 10011.

Gilbert, R.M. (1976) Caffeine as a drug of abuse. Res. Adv. Alcohol Drug Probl., 3:49-176.

Gilbert, S. G. and Rice, D. C. (1991). Somatic development of the infant monkey following in utero exposure to caffeine. Fund. Appl. Toxicol., 17:454-465.

Gilbert, R.M., Marshman, J.A., Scwieder, M. and Berg, R. (1976) Caffeine content of beverages as consumed. Can. Med. Assoc. J. 114, 205-208.

Gilbert, S.G., Rice, D.C., Reuhl, K.R: and Stavric, B. (1988) Adverse pregnancy outcome in the monkey (Macaca fascicularis ) after chronic caffeine exposure. J. Pharmacol. Exp. Ther., 245:1048-1053.

Godel, J.C., Pabst, H.F., Hodges, P.E., Johnson, K.E., Froese, G.J. and Joffres M.R. (1992) Smoking and caffeine and alcohol intake during pregnancy in a northern population: effect on foetal growth. Can. Med. Assoc. J., 147:181188

Golding, J. (1991) The epidemiology of perinatal death. In: Reproductive and Perinatal Epidemiology, M. Kiely (Ed.), CDC Press Inc., Boca Raton.

Golding, J. (1995). Reproduction and caffeine consumption-a literature review. Early Human Devel., 43:1-14.

Goldstein, A. and Wallace, M.E. (1997) Caffeine dependence in schoolchildren? Exp. Clin. Psychopharmac. 5(4), 388392.

Goldstein, A. and Warren, R. (1962) Passage of caffeine into human gonadal and fetal tissue. Biochem. Pharmacol., 11:166-168.

Gorodishcer, R., Zmora, E., Ben-Zvi, Z., Warszwaski, D. Yaari, A., Sofer, S. and Arnaud, M.J. (1986) Urinary metabolites of caffeine in the premature infant. Eur. J. Pharmacol., 31:497-499.

Goth, R. and Cleaver, J.E. (1976) Metabolism of caffeine to nucleic acid precursors in mammalian cells. Mutation Res., 105-114.

Graham, D.G. (1978) Caffeine - its identity, dietary sources, intake and biological effects. Nutrit. Rev., 36:97-102.

Grant, D.M., Tang, B.K., and Kalow, W. (1983) Variability in caffeine metabolism. Clin. Pharmac. Ther., 33:591-602.

Grant, D.M., Blum, M., Beer, M., and Meyer, U.A. (1991) Monomorphic and polymorphic human arylamine $\mathrm{N}$ acetyltransferases: a comparison of liver isozymes and expressed products of two cloned genes. Mol. Pharmac. 39., 184191.

Gregory, J., Foster, K., Hazel, T. and Wiseman, M. (1990) The dietary and nutritional survey of British adults. Social Survey Division, p. 43,44,46,76. HMSO BOOKS (PC 13A), Publication Center, PO Box 267, London SW8 5DT.

Grèzees, J., Thomasset, B. and Thomas, D. (1993) Coffea arabica protoplast culture: transformation assays. ASIC 15 Colloq. Sci. Int. Cafe, 1992, Montpellier, France. p. 745-747.

Grèzees, J., Thomas, D. and Thomasset, B. (1994) Factors influencing protoplast isolation from Coffea arabica cells. Plant Cell, Tissue and Organ Culture 36:9197.

Grodstein, F., Goldman, M., Ryan, L. and Cramer, D. (1993) Relation of female infertility to consumption of caffeinated beverages. Am. J. Epidemiol., 137:13531360.

Grosso, L.M., Rosenberg, K.D., Belanger, K., Saftlas, A.F., Leaderer, B. and Bracken, M.B. (2001) Maternal caffeine intake and intrauterine growth retardation. Epidemiology 11:447-455.

Gu, L., Gonzalez, F.J., Kalow, W. and Tang, B.K. (1992) Biotransformation of caffeine, paraxanthine, theobromine amd 
theophylline by cDNA-expressed human CYP1A2 and CYP2E1. Pharmacogenetics 2:73-77.

Ha, H.R., Chen, J., Krähenbühl, S. and Follath, F. (1996) Biotransformation of caffeine by cDNA-expressed human cytochomes P-450. Eur. J. Clin. Pharmacol., 49:309-315.

Hadeed, A. and Siegel, S. (1993) Newborn cardiac arrhythmias associated with maternal caffeine use during pregnancy. Clin. Pediatr., 32:45-47.

Hadorn, H. (1980) Theobromine-, caffeine- and total alkaloid contents of cocoa mass. CCB 5:26-28.

Hakim, R.B., Gray, R.H. and Zacur, H. (1998) Alcohol and caffeine consumption and decreased fertility. Fertil. Steril., 70:632-637.

Haley, T.J. (1983) Metabolism and pharmacokinetics of theophylline in human neonates, children, and adults. Drug Metabol. Rev., 14:295-335.

Hammerstone Jr. J.F., Romanczyk Jr, L.J. and Aitken, W.M. (1994) Purine alkaloids distribution within Herrania and Theobroma. Phytochemistry 35:12371240.

Hansson, K. (1978). Caffeine enhancement of chromosomal aberrations induced by thiotepa in bone marrow cells of mice. Hereditas 89:129-131.

Hardman, J.G., Limbird, L.E., Molinoff, P.B., Ruddon, R.W. and Goodman Gilman, A. (1996) Goodman Gilman's The Pharmacological Basis of Therapeutics. Ninth Edition. McGraw-Hill, New York.

Hardy, B.G., Lemieux, C., Walker, S.E. and Bartle, W.R. (1988) Interindividual and intraindividual variability in acetylation: Characterization with caffeine. Clin. Pharmacol. Ther., 44:152-157.

Harrison, R.F. (1978) Insemination of husband's semen with and without the addition of caffeine. Fertil. Steril., 29:532-534.
Harrison, R.F., Sheppard, B.L. and Kaliszer, M. (1980) Observations on the motility, ultrastructure and elemental composition of human spermatozoa incubated with caffeine. Andrologia 12:3442.

Hatanaka, T., Choi, Y.E., Kusano, T. and Sano, H. (1999) Transgenic plants of coffee Coffea canephora from embryogenic callus via Agrobacterium tumefaciens-mediated transformation. Plant Cell Reports 19:106-110.

Hatch, E.E. and Bracken, M.B. (1993) Association of Delayed Conception with Caffeine Consumption. Am. J. Epidemiol., 138:1082-1092.

Heinonen, O.P., Slone, D., Shapiro, S., Gaetano, L.F., Hartz, S.C., Mitchell, A.A., Monson, R.R., Rosenberg, L., Siskind, V. And Kaufman, D.W. (1977) Birth defects and drugs in pregnancy. Publ. Sci. Group, Inc., Littleton

Helakorpi, S., Uutela, A., Prättälä, R., Berg, M.-A. and Puska, P. (1997) Suomalaisen aikuisväestön terveyskäyttäytyminen. Kevät 1997. Publications of the National Public Health Institute B10/1997.

Haley, T.J., (1983) Metabolism and pharmacokinetics of theophylline in human neonates, children, and adults. Drug Metabol. Rev., 14:295-335.

Hemminiki, E., Rahkonen, O., Rimpela, A and Rimpela M. (1988) Coffee drinking among Finnish youth. Soc. Sci. Med. 26(2), 259-264.

Hill, R.M., Craig, J.P., Chaney, M.D., Tennyson, L.M. and McCulley, L.B. (1977) Utilization of over-the-counter drugs during pregnancy. Clin. Obstet. Gynecol., 20:381-394.

Hinds, T.S., West, W.L., Knight, E.M. and Harland, B.F. (1996) The effect of caffeine on pregnancy outcome variables. Nutr. Rev., 54:203-207.

Hirsh, K. (1984) Central nervous system pharmacology of the dietary methylxanthines. Prog. Clin. Biol. Res., 158:235-301. 
Hodgson, J.M., Proudfoot, J.M., Croft, K.D: et al. (1999) Comparison of the effects of black and green tea on in vitro lipoprotein oxidation in human serum. J. Sci. Food Agric., 79:561-566.

Hogue, C.J. (1981) Coffee in pregnancy. Lancet i (No. 8219):554.

Holmgren, P., Nordén-Pettersson, L. and Ahlner, J. (2004) Caffeine fatalities four case reports. For. Sci. Int., 139:7173.

Honsky, S.L. and Emory, E.K. (1987) Neurobehavioral effects of caffeine on the neonate. Infant Behav. Dev., 10:6180 .

Hook, E.B. (1978) Dietary cravings and aversions during pregnancy. Am. J. Clin. Nutr., 31:1355-1362.

Hughes, H., E. and Goldstein, D., A. (1988). Birth defects following maternal exposure to ergotamine, beta blockers, and caffeine. J. Med. Genet., 25:396399.

Hughes, J.R. and Oliveto, A.H. (1997) A systematic survey of caffeine intake in Vermont. Exp. Clin. Psychopharmac., 5:393-398.

Hughes, E.G., YoungLai E.V. and Ward, S.M. (1992) Cigarette smoking and outcomes of in-vitro fertilization and embryo transfer: a prospective cohort study. Human Reproduct, 7:358-361.

Huisman, M., Risseeuw, B., van Eyck, J. and Arabin, B. (1997) Nicotine and caffeine. Influence on Prenatal Hemodynamics and Behaviour in Early Twin Pregnancy. J. Reprod. Med., 42:731-734.

Hurst, W.J., Martin, R.A. and Tarka, S.M. Jr. (1984) Analytical methods for quantification of methylxanthines. In: The Methylxanthine Beverages and Foods: Chemistry, Consumption, and Health Effects, Alan R. Liss, Inc., New York, pp. 17-28.

IARC (1991) International Agency for Research on Cancer (IARC) Monograph on the Evaluation of Carcinogenic Risks to Humans. Vol 51 Coffee, tea, mate, methylxanthines and methylglyoxal, IARC, Lyon, pp. 513.

Ikeda, G., J., Sapienza, P. P., McGinnis, M. L., Bragg, L., E., Walsh, J. J. and Collins, T. F. X. (1982). Bloodlevels of caffeine and results of fetal examination after oral administration of caffeine to pregnant rats. J. Appl. Toxicol., 2:307314.

Infante-Rivard, C., Fernández, A., Gauthier, R., David, M. and Rivard, G.E. (1993) Fetal loss associated with caffeine intake before and during pregnancy. J. Am. Med. Assoc., 270:2940-2943.

Infante-Rivard, C. and Fernández, A. (1994) Fetal loss and caffeine intake. J. Am. Med. Assoc., 272:28-29.

Inoue, T. and Adachi, F. (1962) Studies on biogenesis of tea components. III. The orgin of the methyl groups in caffeine. Chem. Pharm. Bull. 10, 1212-1214.

Institute of Food Technologists' Expert Panel on Food Safety \& Nutrition. (1983). Caffeine. Food Tech., April, 8791.

International Coffee Organisation (1981) Robusta Coffee: Study of world production ans consumption. London: International Coffee organisation 1860(E).

Iscovich, J.M., Iscovich, R.B., Howe, G., Shiboski, S and Kaldor, J.M. (1989) A case-control study of diet and breast cancer in Argentina. Int. J. Cancer 44:770-776.

Jacobson, S.W., Fein, G.G., Jacobson, J.L., Schwartz, P.M. and Dowler, J.K. (1984) Nenatal Correlates of prenatal exposure to smoking, caffeine and alcohol. Infant behavior and development 7:253-265.

James, J. E. (1991). Caffeine and Health. Galliards Ltd. Great Yarmouth, Norfolk.

James, J.E. and Paull, I. (1985) Caffeine adn human reproduction. Rev. Environ. Health 5:151. 
James, J.E., Bruce, M.H. and Scott, N.R. (1989) Self-report reliability and symptomatology of habitual caffeine consumption. Br. J. Clin. Pharmac. 27; 507514.

Jarvis, M.J. (1993) Does caffeine intake enhance absolute levels of cognitive performence? Psychpharm. 110, 45-52.

Jenne, J.W., Nagasawa, H.T. and Thompson, R.D. (1976) Relationship of urinary metabolites of theophylline to serum theophylline levels. Clin. Pharmacol. Ther., 19:375-381.

Jensen, O.M., Wahendorf, J., Knuden, J.B. and Sørensen, B.L. (1986) The Copenhagen case-control study of bladder cancer. II. Effect of coffee and other beverages. Int. J. Cancer 37:651-657.

Jensen, T.K., Henriksen, T.B., Hjollund, N.H.I., Scheike, T., Kolstad, H., Giwercman, A., Ernst, E., Bonde, J.P., Skakkebaek, N.E. and Olsen, J. (1998a) Caffeine intake and fecundability: a follow-up study among 430 Danish couples planning their first pregnancy. Reproduct. Toxicol., 12:289-295.

Jensen, T.K., Hjollund, N.H.I., Henriksen, T.B., Scheike, T., Kolstad, H., Giwercman, A., Ernst, E., Bonde, J.P., Skakkebaek, N.E. and Olsen, J. (1998b) Does moderate alcohol consumption affect fertility? Follow up study among couples planning first pregnancy. Br. Med. J., 317:505-510.

Jiang, C.S., Kilfeather, S.A., Pearson, R.M. and Turner, P. (1984) The simulatory effects of caffeine, theophylline, lysine-theophylline and 3-isobutyl-1methylxanthine on human sperm motility. Br. J. clin. Pharmacol., 18:258-262.

Jobst, C. (1838a) Thein identisch mit Caffein. Ann. Chem. Pharm. 25, 63-66.

Jobst, C. (1838b) Analyse des Theins. Arch. Pharm. 65, 85-86.

Joesoef, M.R., Beral, V., Rolfs, R.T., Aral, S.O. and Cramer, E.W. (1990) Are caffeinated beverages risk factors for delayed conception? Lancet 335:136-137.
Johansson, S.L. (1981) Carcinogenicity of analgesics: long-term treatment of Sprague-Dawley rats with phenacetin, phenazone, caffeine and paracetamol (acetamidophen). Int. J. Cancer 27:521-529.

Johansson, L. And Solvoll, K. (1999) Norkost 1993-94 og 1997. Statens råd for ernæring og fysisk aktivitet, Oslo, p. $38-46$.

Kadlec, G.J., Thanh Ha, L., Jarboe, C.H., Richards, D. and Karibo, J.M. (1978) Theophylline half-life in infants and young children. Ann. Allergy 40:303310.

Kalberer, P. (1965) Breakdown of caffeine in the leaves of Coffea arabica L. Nature 205, 597-598.

Kamei, K., Matsuda, M. and Momose, A. (1975) New sulfur-xontaining metabolites of caffeine. Chem. Åjar,. Bull., 23:683-685.

Kalow, W. (1985) Variablity of Caffeine Metabolism in Humans. Arzneim.Forsch./Drug Res., 35:319-324.

Kalow; W. (1993) Caffeine intake levels in children. Seventh International Caffeine Workshop, Santorini, Greece, June, 1317.

Kaplan, E., Holmes, J.H. and Sapeika, N. (1974) Caffeine content of tea and coffee. S. Afr. Med. J., 48:510-511.

Kaplan, G.B., Greenblatt, D.J., Ehenberg, B.L., Goddard, J.E., Cotreau, M.M., Harmatz, J.S. and Shader, R.I. (1997) Dose-dependent pharmacokinetics and psychomotor effects of caffeine in humans. J. Clin. Pharmacol., 37:693-703.

Karlsson, J.-A., Heintz, L. And Persson, C.G.A. (1985) Behavioural actions of xanthines related to tissue distribution and adenosine antagonism. In: Andersson, K.E. and Persson, C.G.A: (Eds.), Anti-asthma Xanthines and Adenosine, Amsterdam. Excerpta Medica, pp. 459461.

Kato, M., Kanehara, T., Shimizu, H., Suzuki, T., Gillies, F.M., Crozier, A. and Ashihara, H. (1996) Caffeine biosynthe- 
sis in young leaves of Camellia sinensis: In vitro studies on $\mathrm{N}$-methyltransferase activity involved in the conversion of xanthosine to caffeine. Physiol. Plantarum 98:629-636.

Kato, A., Crozier, A. and Ashihara, H. (1998) Subcellular localization of the N3 methyltransferase involved in caffeine biosynthesis in tea. Phytochem., 48:777779 .

Kato, M., Mizuno, K., Crozier, A., Fujimura, T. and Ashihara, H. (2000) Caffeine synthase gene from tea leaves. Nature 406:956-957.

Kennedy, J.S., von Moltke, L.L., Harmatz, J.S., Engelhardt, N. and Greenblatt, D.J. (1991) Validity of self reports of caffeine use. J. Clin. Pharmac. 31, 677-680.

Khanna, N.N. and Somani, S.M. (1984) Maternal coffee drinking and unusually high concentrations of caffeine in the newborn. Clin. Toxicol., 22:473-483.

Khokhar, S. and Magnusdottir, S.G.M. (2002) Total phenol, catechin, and caffeine contents of teas commonly consumed in the United Kingdom. J. Agric. Food Chem., 50:565-570.

Kihlman, B.A. (1977) Caffeine and Chromosomes. Elsevier Sci. Publ. Comp., Amsterdam, pp. 504.

Kihlman, B. and Andersson, H., C. (1987). Effects of caffeine on chromosomes in cells of higher eukaryotic organisms. Rev. Env. Health 7:279-382.

Kinizig-Schippes, M., Fuh, U., Zaigler, M., Dammaeyer, J., Labedzki, A., Bulitta, J. and Sorgel, F. (1999) Interaction of pefloxacin and enoxacin with the human cytochome P450 enzyme CYP1A2. Clin. Pharmacol. Ther., 65:262-274.

Kirkinen, P., Jouppila, P., Koivula, A., Vuori, J. and Puukka, M. (1983) The effect of caffeine on placental and fetal blood flow in human pregnancy. Am. J. Obstet. Gynecol,, 147:939-942.

Kitada, M., Kamataki, T., Itahashi, K., Rikihisa, T. and Kanakubo, Y. (1987) P$450 \mathrm{HFLa}$, a form of cytochomoe P-450 purified from human fetal livers, is the 16 alpha-hydroxylase of dehydroepiandosterone 3-sulfate. J. Biol. Chem., 262:13534-13537.

Kiyohara, C., Kono, S., Honjo, S., Todoroki, I., Sakurai, Y., Nishiwaki, M., Hamada, H., Nishikawa, H., Koga, H., Ogawa, S. and Nakagawa, K. (1999) Inverse association between coffee drinking and serum uric acid concentrations in middle-aged Japanese males. Br. J. Nutr., 82:125-130.

Klebanoff, M.A., Levine, R.J., Clemens, J.D. and Wilkins, D.G. (2002) Maternal serum caffeine metabolites and smallfor-gestational age birth. Am. J. Epidemiol., 155:32-37.

Klebanoff, M.A., Levine, R.J., DerSimonian, R., Clemens, J.D. and Wilkins, D.G.

Klesges, R.C., Ray, J.W. and Klesges, L.M. (1994) Caffeinated coffee and tea intake and its relationship to cigarette smoking: an analysis of the second national health and nutrition examination survey. (NHANES II). Journal of substance abuse, 6, 407-418.

Kline, J., Stein, Z. and Susser, M. (1989) Conception to Birth: Epidemiology of Prenatal Development. New York, Oxford University Press.

Kline, J., Levin, B., Silverman, J., Kinney, A., Stein, Z., Susser, M. and Warburton, D. (1991) Caffeine and spontaneous abortion of known karyotype. Epidemio$\log$ 2:409-417.

Kline, J., Levin, B., Kinney, A., Stein, Z., Susser, M. and Warburton, D. (1994) Fetal loss and caffeine intake. J. Am. Med. Assoc., 272:27-28.

Knutti, R., Rothweiler, H. And Schlatter, C. (1982) The effect of pregnancy on the pharmacokinetics of caffeine. Arch. Toxicol. Suppl. 5:187-192.

Konwar, B.K., Das, S.C., Bodoloi, B.J. and Dutta, R. K. (1998) Hairy root development in tea though Agrobacterium rhizogenes-mediated genetic transformation. Two and a Bud 45:19-20. 
Kossel, A. (1888) Ueber eine neue Base aus dem Pflanxenreich. Ber. Dtsch. Chem. Ges., 21:2164-2167.

Kraft Freia Marabou, Sweden (1998)

Kramer, M.S. (1987) Determinants of low birth weight. Methodological assessment and meta-analysis. Bull. WHO 65:663737.

Kraus, D.M., Fischer, J.H., Reitz, S.J., Kecskes, S.A., Tsu, F., McCulloch, K.M., Tung, E.C. and Cwik, M.J. (1993) Alteration in theophylline metabolism during the first year of life. Clin. Pharmacol. Ther., 54:351-359.

Kretschmar, J.A. and Baumann, T.W. (1999) Caffeine in Citrus flowers. Phytochemistry 52:19-23.

Kurppa, K., Holmberg, P., C., Kuosma, E. and Saxén, L. (1983). Coffee consumption during pregnancy and selected congenital malformations: A nation-wide case-control study. Am. J. Public Health 73:1397-1399.

Kuzma, J.W. and Kissinger, D.G. (1981) Patterns of alcohol and cigarette use in pregnancy. Neurobehav. Toxicol. Teratol., 3:211-221.

Kuzma, J.W. and Sokol, R.J. (1982) Maternal drinking behaviour and decreased uterine growth. Alcohol Clin. Exp. Res., 6:396-402.

Lakenbrink, C., Lapczynski, S., Maiwald, B. and Engelhardt, U.H. (2000) Flavonoids and other polyphenols in consumer brews of tea and other caffeinated beverages. J. Agric. Food Chem., 48:28482852.

Lambert, G.H., Schoeller, D.A., Kotake, A.N., Flores, C. and Hay, D. (1986) The effect of age, gender, and sexual maturation on the caffeine breath test. Dev. Pharmacol. Ther., 9:375-388.

Larkin, F.A., Basiotis, P.P., Riddick, H.A., Stjes, K.E. and Pao, E.M. (1990) Dietary pattern of women smokers and nonsmokers. J. Am. Diet. Assoc., 90:230237.
Larroque, B., Kaminski, M., Lelong, N., Subtil, D. and Dehaene, P. (1993) Effects of birth weight of alcohol and caffeine consumption during pregnancy. Am. J. Epidemiol., 137:941-950.

Lauritsen, J.G. (1977) Genetic aspects of spontaneous abortion. Dan. Med. Bull., 24:169-189.

Lawrence, R.A. (1989) Drugs in breast milk and the effect on the infant. In Lawrence, R.A: (Ed.): Breast-Feeding: A Guide for the Medical Profession, 3rd ed. St. Louis, C.V. Mosby, pp.518-595.

Le, G.J.C. and Billon, B. (1987) Delay in caffeine elimination in breast-fed infants. Pediatrics 79:264-268.

Legator, M.S. and Zimmering, S. (1979) Review of the genetic effects of caffeine. J. Environ. Sci. Health C13:135-188.

Le Guennec, J.-C. and Billon, B. (1987) Delay in caffeine elimination in breastfed infants. Pediatrics 79:264-268.

Lelo, A., Miners, J.O., Robson, R. and Birkett, D.J. (1985) Assessement of caffeine exposure: Caffeine content of beverages, caffeine intake, and plasma concentrations of methylxanthines. Clin. Pharmacol. Ther. 39(1), 54-59.

Leonard, T., Watson, R.R. and Mohs, M.E. (1987) The effects of caffeine on various body systems: A review. J. Am. Diet. Assoc., 87:1048-1053.

Leroy, T., Royer, M., Paillard, M., Berthouly, M., Spiral, J., Tesserieau, S., Legavre, T. and Altosaar, I. (1997) Introduction de gènes d'intérêt agronomique dans l'espèce Coffea canephora Pierre par transformation avec Agrobacterium sp. ASIC 17 Colloq. Sci. Int. Cafe, 1997, Nairobi, p. 439-446.

Leroy, T., Philippe, R., Royer, M., Frutos, R., Duris, D., Dufour, M., Jourdan, I., Lacombe, C. and Fenouillet, C. (1999) Genetically modified coffee trees for resistance to Coffee leaf miner. Analysis of gene expression, resistance to insects and agronomic value. ASIC 18 Colloq. 
Sci. Int. Cafe, 1999, Helsinki, p. 332338 .

Leroy, T., Henry, A.-M., Royer, M., Altosaar, I., Frutos, R., Duris, D. and Philippe, R. (2000) Genetically modified coffee plants expressing the Bacillus thuringiensis cry $1 \mathrm{Ac}$ gene for resistance to leaf miner. Plant Cell Reports 19:382-389.

Levin, R.M., Greenberg, S.H. and Wein, A.J. (1981) Quantitative analysis of the effects of caffeine on sperm motility and cyclic adenosine 3',5'-monophosphate (AMP) phosphodiesterase. Fert. Steril., 36:798-802.

Leviton, A. (1993) Coffee, caffeine, and reproductive hazards in humans. In: Caffeine, Coffe and Health, S. Garattini (Ed.), Raven Press, New York, p. 343358 .

Leviton, A. (1998) Heavy caffeine consumption in pregnancy, smoking, and sudden infant death syndrome. Arch. Dis. Child., 79:291.

Leviton, A. and Cowan, L. (2002) A review of the literature relating caffeine consumption by women to their risk of reproductive hazards. Food Chem. Toxicol., 40:1271-1310.

Linn, S., Schoenbaum, S.C., Monson, R.R., Rosner, B., Stubblefield, P.G. and Ryan, K.J. (1982) No association between coffee consumption and adverse outcomes of pregnancy. New Engl. J. Med., 52:141-145.

Lin, J.-K., Lin, C.-L., Liang, Y.-C., Shiau, S.-Y. L. And Juan, I.-M. (1998) Survey of catechins, gallic acid, and methylxanthines in green, oolong, pu-erh, and black teas. J. Agric. Food Chem., 46:3635-3642.

Lindgren, G., Strandell, A. And Tanner, J.M. (1997) Nya referensvärden för barns utveckling, Läkartidningen 94(35), 2915-2918.

Little, R.E. and Weinberg, C.R. (1993) Risk factors for antepartum and intrapartum stillbirth. Am. J. Epidemiol., 137:1177-1189.
Lohmann, S.M. and Miech, R.P. (1976) Theophylline metabolism by the rat liver microsomal system. J. Pharmacol. Exp. Ther., 196:213-225.

London, S., Willett, W., Longcope, C. and McKinlay, S. (1991) Alcohol and other dietary factors in relation to serum hormone concentrations in women at climacteric. Am. J. Clin. Nutr., 53:166-171.

Looser, E., Baumann, T.W. and Wanner, H. (1974) The biosynthesis of caffeine in the coffee plant. Phytochemistry 13, 2515-2518.

Lubchenco, L.O., Hansman, C., Dressler, M. and Boyd, E. (1963) Interauterine growth as estimated from liveborn birth weight data at 24 to 42 weeks of gestation. Pediatrics 32:793-800.

Lubin, F. And Ron, E. (1990) Consumption of methylxanthine-containing beverages and the risk of breast cancer. Cancer Letters 53:81-90.

Lubin, F., Ron, E., Wax, Y., Funaro, M., Shitrit, A., Black, M. and Modan, B. (1984) Coffee and methylxanthine in benign and malignant breast diseases. In: MacMahon, B. and Sugimura, T. (Eds.), Coffee and Health (Banbury Report 17), Cold Spring Harbor, N.Y., CSH Press, pp. 177-187.

Lubin, F., Ron, E., Wax, Y. and Modan, B. (1985) Coffee and methylxanthines and breast cancer: a case-control study. J. Natl. Cancer Inst., 74:569-573.

Läkemedelsverket, Enheten för läkemedelsepidemiologi. (1998)

Madhava Naidu, M., Veluthambi, K., Srinivasan, C.S. and Naidu, R. (1998) Agrobacterium mediated transformation in Coffea canephora. Developments in Plantation Crops Res., 1998:46-50.

MAFF; Joint Food Safety and Standard Group. (1998) Survey of coffeine and other methylxanthines in energy drinks and other caffein-containing products (updated). Food Surveillance Information Sheet. March; 144 (No.103 revised). 
Makler, A., Makler, E., Itzkovitz, J. And Brandes, J.M. (1980) Factors affecting sperm motility. IV. Incubation of human semen with caffeine, kallikrein, and other metabolically active compounds. Fert. Steril., 33:624-630.

Marraccini, P., Deshayes, A., Pétiard, V. and Rogers, W.J. (1999) Molecular cloning of the complete $11 \mathrm{~S}$ seed storage protein gene of Coffea arabica and promoter analysis in transgenic tobacco plants. Plant Physiol. Biochem. 37:273282.

Marshburn, P.B., Sloan, C.S. and Hammond, M.G. (1989) Semen quality and association with coffee drinking, cigarette smoking, and ethanol consumption. Fertil. Steril., 52:162-165.

Martin, T.R. and Bracken, M.B. (1987) The association between low birth weight and caffeine consumption during pregnancy. Am. J. Epidemiol.,126:813821.

Martin, J.B., Annegers, J.F., Curb, J.D., Heyden, S., Howson, C., Lee, E.S. and Lee, M. (1988) Mortality patterns among hypertensives by reported level of caffeine consumption. Prev. Med., 17:310320 .

Martius, T. (1840) Ueber die Zusammensetzung des Guaranins. Ann. Chem. 36, 93-95.

Maruoka, K., Yagi, M., Akazawa, K., Kinukawa, N., Ueda, K. and Nose Y. (1998) Risk factors for low birthweight in Japanese infants. Acta Paediatr., 87:304-309.

Marx, F. and Maia, J.G. (1990) Analysis of guarana (Paullinia cupana var. sorbilis). III. Identification and determination of guarana beverages by HPLC analysis of caffeine and theophylline. Quimica Nova 13:285-286.

Matissek, R. (1997) Evaluation of xanthine derivatives in chocolate - nutritional and chemical aspects. Z. Lebensm. Unters. Forsch. A., 205:175-184.

Matissek, R. (1998) Methylxanthine im Kakao. Süsswaren 42:22-24 + 26 .
Matsouka, R., Uno, H., Tanaka, H., Kerr, C. S., Nakazawa, K. and Nadal-Ginard, B. (1987). Caffeine induces cardiac and other malformations in the rat. Am. J. Med. Gen. (Suppl.), 3:433-443.

Matsumoto, S. and Fukui, M. (1998) Agrobacterium tumefaciens-Mediated Gene Transfer to Tea Plant (Camellia sinensis) Cells. JARQ 32:287-291.

Mau, G. and Netter, P. (1974) Kaffee- und Alkoholkonsum - Risikofaktoren in der Schwangerschaft? Geburtshilfe und Frauenheilkunde 34:1018-1022.

Mazzafera, P. (1994) Caffeine, theobromine and theophylline distribution in Ilex paraguariensis. Revista Brasileira de Fisiologia Vegetal 6:149-151.

Mazzafera, P. (1997) Maté drinking: Caffeine and phenolic acid intake. Food Chem., 60:67-71.

Mazzafera, P. and Carvalho, A. (1992) Breeding for low seed caffeine content of coffee (Coffea L.) by interspecific hybridization. Euphytica 59:55-60.

Mazzafera, P., Crozier, A. And Magalhães, A.C. (1991) Caffeine metabolism in Coffea arabica and other species of Coffee. Phytochem., 30:3913-3916.

McCulloch, K.M., Braun, R.J., Simms, P.E., Evans, M.A. and Kelly, D.H. (1989) Transplacentally acquired caffeine and the occurrence of apnea, bradycardia, and periodic breathing in preterm infants: Preliminary Communication. Pediat. Pulmonol., 7:66-70.

McDonald, A.D., Armstrong, B.G. and Sloan M. (1992a) Cigarette, Alcohol, and Coffee Consumption and Prematurity. Am. J. Pub. Med., 82:87-90.

McDonald, A. D., Armstrong, B. G. and Sloan, M. (1992b). Cigarette, alcohol, and coffee consumption and congenital defects. Am. J. Public Health 82:91-93.

McGowan, J., Devoe, L.D., Searle, N. and Altman, R. (1987) The effects of longand short-term maternal caffeine ingestion on human foetal breathing and 
body movements in term gestations. Am. J. Obstet. Gynecol., 157:726-729.

McGowan, J.D, Altman, R.E. and Kanto, W.P. Jr. (1988) Neonatal Withdrawal Symptoms After Chronic Maternal Ingestion of Caffeine. South Med., J., 81:1092-1094.

Medicus, L. (1875) Zur Constitution der Harnsäuregruppe. Liebig's Ann. Chem., 175:230-251.

Mehr, C.B., Biswal, R.N., Collins, J.L. and Cochran, H.D. (1996) Supercritical carbon dioxide extraction of caffeine from guaraná. J. Supercrit. Fluids 9:185-191.

Menéndez-Yuffá, A. and de Garcia, E.G. (1996) Coffea species (Coffee). In Biotechnology in Agriculture and Forestry, Volume 35. Trees IV, Y.P.S. Bajaja (Ed.), Springer-Verlag, Berlin, pp.94119.

Meurer-Grimes, B., Berkov, A. And Beck, H. (1998) Theobromine, theophylline, and caffeine in 42 samples and products of guaraná (Paullinia cupana, Sapindaceae). Economic Botany 52:293-301.

Miller, R.C., Watson, W.J., Hackney, A.C. and Seeds, J.W. (1994) Acute maternal and foetal cardiovascular effects of caffeine ingestion. Am. J. Perinatol., 11:132-136.

Mills, J.L., Holmes, L.B., Aarons, J.H., Simpson, J.L., Brown, Z.A., JovanovicPeterson, L.G., Conley, M.R., Graubard, B.I., Knopp, R.H. and Metzger, B.E: (1993) Moderate caffeine use and the risk of spontaneous abortion and intrauterine growth retardation. J. Am. Med. Assoc., 269:593-597.

Miners, J.O., Attwood, J. And Birkett, D.J. (1982) Theobromine metabolism in man. Drug Metabol. Disposition 10:672-675.

Minton, J.P., Foecking, M., Webster, D. et al. (1979) Response of fibrocystic disease to caffeine withdrawal and correlation of cyclic nucleotides with breast disease. Am. J. Obstet. Gynecol., 135:157-158.

Moh, U., Althoff, J., Ketkar, M.B., Conradt, P. and Morgareidge, K. (1984) The influence of 'spontaneous' tumours in Wistar derived rats. Food Chem. Toxicol., 22:377-382.

Moksnes, M.T. (2001) Koffein i kosmetikk. Veternœrinstituttet, $10 \mathrm{p}$.

Mondal, T.K., Bhattacharya, A., Sood, A. and Ahuja, P.S. (1999) An efficient protocol for somatic embryogenesis and its use in developing transgenic tea (Camellia sinensis (L.) O. Kuntze) for field transfer. Current Plant Science and Biotechnology in Agriculture 36:181-184.

Monte, W.C. and Ashoor, S.H. (1985) Caffeine content of selected soft drinks. Journal App. Nutr. 37(1), 43-45.

Morgan, K.J., Stults, V.J. and Zabik, M.E. (1982) Amount and dietary sources of caffeine and saccharin intake by individuals ages 5 to 18 years. Reg. Toxic. Pharmacol. 2, 296-307.

Morabia, A. and Wynder, E.L. (1990) Dietary habits of smokers, people who never smoked, and ex-smokers. Am. J. Clin. Nutr., 52:933-937.

Moussa, M.M. (1983) Caffeine and sperm motility. Fertil. Steril., 39:845-.

Mulder, Ch. J. (1838) Chemische Untersuchung des chinesischen und des javanischen Threes. Arch. Pharm. 65, 68-84.

Mumford, G.K., Benowitz, N.L., Evans, S.M., Kaminski, B.J., Preston, K.L., Sannerud, C.A., Silverman, K. and Griffiths, R.R. (1996) Absorption rate of methylxanthines following capsules, cola and chocolate. Eur. J. Clin. Pharmacol., 51:319-325.

Munoz, L.M., Lonnerdal, B., Keen, C.L. and Dewey, K.G. (1988) Coffee consumption as a factor in iron deficiency anemia among pregnant women and their infants in Costa Rica. Am. J. Clin. Nutr., 48:645-651.

Nagata, T. and Sakai, S. (1984) Differences in caffeine, flavanols and amino acids contents in leaves of cultivated species of Camellia. Jap. J. Breeding 34:459-467. 
Nagata, T. and Sakai, S. (1985) Purine base patterns of Camellia irrawadiensis. Phytochemistry 24:2271-2272.

Nash, J. and Persaud, T.V.N. (1988) Reproductive and teratological risks of caffeine. Anat. Anz., 167:265-270.

National Food Agency of Denmark. (1989). Embryo-foetal damage and chemical substances. Working Party Report, May; p 68.

Natsume, N., Kawai, T., Ogi, N. and Yoshida, W. (2000) Maternal risk factors in cleft lip and palate: case control study. Br. J. Oral Maxillofac. Surg., 38:23-25.

Negishi, O., Ozawa, T. and Imagawa, H. (1985a) Conversion of xanthosine into caffeine in tea plants. Agric. Biol. Cgem. 49, 251-253.

Negishi, O., Ozawa, T. And Imagawa, H. (1985b) Methylation of xanthosine by tea-leaf extracts and caffeine biosynthesis. Agric. Biol. Chem., 49:887-890.

Negishi, O., Ozawa, T. And Imagawa, H. (1992) Biosynthesis of caffeine from purine nucleotides in tea plant. Biosci. Biotech. Biochem., 56:499-503.

Nehlig, A. (1999) Are we dependent upon coffee and caffeine? A review on human and animal data. Neurosci. Biobehav. Rev., 23:563-576.

Nehlig, A. and Debry, G. (1994a) Consequences on the newborn of chronic maternal consumption of coffee during gestation and lactation: a review. J. Am. Coll. Nutr., 13:6-21.

Nehlig, A. and Debry, G. (1994b). Potential teratogenic and neurodevelopmental consequences of coffee and caffeine exposure: A review on human and animal data. Neurotox. Teratol. 16:531-543.

Nehlig, A. and Debry, G. (1994c) Potential genotoxic, mutagenic and antimutagenic effects of coffee: a review. Mutation Res., 317:145-162.

Nehlig, A. and Debry, G. (1996) Coffee and cancer: A review of human and animal data. In: Metabolic Consequences of
Changing Dietary Patterns, A.P. Simopoulos (Ed.), World Rev. Nutr. Diet. (Basel) 79:185-221.

Nehlig, A., Daval, J.L. and Debry, G. (1992) Caffeine and the central nervous system: mechanisms of actions: biochemical, metabolic and psychostimulant effects. Brain Res. Rew., 17:139-170.

Nolen, G. A. (1981). The effect of brewed and instant coffee on reproduction and teratogenesis in the rat. Toxicol. Appl. Pharmacol. 58;171-183.

Nolen, G.A. (1988) The developmental toxicology of caffeine. In: Issues and Reviews in Teratology, Vol 4, H. Kalter (Ed.), Plenum Publ. Corp., pp. 305-350.

Nomura, T. (1983) Comparative inhibiting effects of methylxanthines on urethaninduced tumors, malformations, and presumed somatic mutations in mice. Cancer Res., 43:1342-1346.

Nousbaum, J.M., Berthou, F, Carlhant, D., Riche, C., Rabazkiewitcz, M., and Gouerou, H. (1994) Four-week treatment with omeprazole increases the metabolism of caffeine. Am. J. Gastroenterol., 89:371375 .

Nuttens, M.C., Romon, M., Ruidavets, J.B., Arveiler, D., Ducimetiere, P., Lecerf, J.M. med flera (1992) Relationship between smoking and diet: The MonicaFrance project. J. Internal Med., 231:349-356.

Obanda, M., Owuor, P.O. and Taylor, S.J. (1997) Flavanol composition and caffeine content of green leaf as quality potential indicatiors of Kenyan Black teas. J. Sci. Food Agric., 74:209-215.

O'Conell, F.D. (1969) Isolation of caffeine from Banisteriopsis inebrians (Malpighiaceae) Naturwissenschaften 56 , 139.

Oei, S.G., Vosters, R.P.L. and van der Hagen, N.L.J. (1989) Foetal arrhythmia caused by excessive intake of caffeine by pregnant women. Br. Med. J., 298:568-569. 
Oesterheld, J.R. (1998) A review of developmental aspects of cytochome P450. J. Child Adoles. Psychopharmacol., 8:161174.

Ogutuga, D.B.A. and Northcote, D.H. (1970a) Caffein information in tea callus tissue. J. Exp. Bot. 21, 258-273.

Ogilvie, R.I. (1978) Clinical pharmacokinetics of theophylline. Clin. Pharmacokinet., 3:267-x.

Ogutuga, D.B.A. and Northcote, D.H. (1970b) Biosynthesis of caffeine in tea callus tissue. Biochem. J. 117, 715-720.

Ocampo, C.A. and Manzanera, L.M. (1991) Advances in genetic manipulation of the coffee plant. ASIC 14 Colloq. Sci. Int. Cafe, 1991, San Francisco, USA, p. 378-382.

Olsen, J. (1991) Cigarette smoking, tea and coffee drinking, and subfecundity. Am. J. Epidemiol., 133:734-739.

Olsen, J., Overvad, K. and Frische, G. (1991). Coffee consumption, birth weight, and reproductive failures. Epidemiology 2:370-374.

Oo, C.Y., Burgio, D.E., Kuhn, R.C., Desai, N. and McNamara, P.J. (1995) Pharmacokinetics of caffeine and its demethylated metabolites in lactation: predictions of milk to serum concentration ratios. Pharmaceut. Res., 12:313-316.

Ohsako, S. and Deguchi, T. (1990) Cloning and expresion of cDNAs for polymorphic and monomorphic arylamine Nacetyltransferases from human liver. J. Biol. Chem., 265:4630-4634.

Oudry, V. (1827) Thein, eine organische Salzbase im Three (Thea chinesis). Mag. Pharm. 19, 49-50.

Palm, P. E., Arnold., E. P., Rachwall, P. C., Leyczek, J. C., Teague, K. W. and Kensler, C. J. (1978). Evaluation of the teratogenic potential of fresh-brewed coffee and caffeine in the rat. Toxicol. Appl. Pharmacol. 44;1-16.

Parazzini, F., Bocciolone, L., Fedele, L., Negri, E., La Vecchia, C. and Acaia, B.
(1991) Risk factors for spontaneous abortion. Int. J. Epidemiol., 20:157-161.

Parazzini, F., Tozzi, L., Chatenoud, L., Restelli, S., Luchini, L. and La Vecchia, C. (1994) Alcohol and risk of spontaneous abortion. Human Reprod., 9:19501953.

Parazzini, F., Chatenoud, L., Benzi, G., Di Cintio, E., Dal Pino, D., L. Tozzi, L., and Fedele, L. (1996) Coffee and alcohol intake, smoking and risk of multiple pregnancy. Human Reprod., 11:23062309.

Parazzini, F., Chatenoud, L., Di Cintio, E., Mezzopane, R., Surace, M., Zanconato, G., Fedele, L. and Benzi, G. (1998) Coffee consumption and risk of hospitalized miscarriage before 12 weeks of gestation. Human Reproduct., 13:2286-2291.

Parkinson, A. (1996) Biotransformation of xenobiotics. In Casarett and Doull's Toxicology: The Basic Science of Poisons. ed. Klaassen, C.D., MacMillan, 5th edition, New York, 113-186.

Parsons, W.D. and Neims, A.H. (1981) Prolonged half-life of caffeine in healthy term newborn infants. J. Pediatr., 98:640-641.

Pastore, L.M. and Savitz D.A. (1995) Case-control study of caffeinated beverages and pre-term delivery. Am. J. Epidemiol., 141:61-69.

Peacock, J.L., Bland, J.M. and Anderson, H.R. (1991) Effects on birth weight of alcohol and caffeine consumption in smoking women. J. Epidemiol. Commun. Health 45:159-163.

Peacock, J.L., Bland, J.M. and Anderson, H.R. (1995) Preterm delivery: effects of socioeconomic factors, psychological stress, smoking, alcohol, and caffeine. Br. Med. J., 311:531-535.

Pelletier, M.J. (1826) Note sur la caféine. J. Pharm. 12, 229-233.

Petridou, E., Katsouyanni, K., Spanos, E., Skalkidis, Y., Panagiotopoulou, K. and Trichopoulos, D. (1992) Pregnancy 
estrogens in relation to coffee and alcohol intake. Ann. Epidemiol., 2:241-247.

Pharmaca Fennica (1997)

Phelps, H.M. and Phelps, C.E. (1988) Caffeine ingestion and breast cancer. A negative correlation. Cancer 61:10511054.

Pollack, R. and Divon, M. (1992) Intrauterine Growth Retardation: Definition, Classification, and Aetiology. Clin. Obstet. Gynecol., 35:99-107.

Pons, G., Carrier, O., Richard, M.-O., Rey, E., d'Athis, P., Moran, C., Cadoual, J. and Olive, G. (1988) Developmental changes of caffeine elimination in infancy. Dev. Pharmacol. Ther., 11:258-264.

Pozner, J., Papatestas, A.E., Fagerstrom, R., Schwartz, I., Saevitz, J., Feinberg, M. and Aufses, A.H. Jr. (1986) Association of tumor differentiation with caffeine and coffee intake in women with breast cancer. Surgery 100:482-488.

Prins, G.S. and Ross, L.S. (1985) Properties of human epididymal sperm obtained from an alloplastic spematocele: motility assessment and penetration of zona-free hamster oocytes in the presence and absence of caffeine. Fert. Steril., 44:401-405.

Purves, D. and Sullivan, F. M. (1993). Reproductive effects of caffeine. Experimental studies in animals. In: Caffeine, coffee, and health, Garattini, S., (Ed.), Raven Press, New York, pp. 325-333.

Rafter, J.J. and Nilsson, L. (1981) Involvement of the intestinal microflora in the formation of sulphur-containing metabolites of caffeine. Xenobiotica 11:771778.

Rall, T.W. (1980) Central nervous system stimulants. The xanthines. In: A.G. Gilman et al. (Eds.) The Pharmacological Basis of Therapeutics, 6th ed., Macmillan, London, pp. 592-607.

Ramirez, R.J., Kalenic, J., Einzig, S. and OMarch, H.A. (1998) Caffeine and Nicotine: Effects on Human Placental
Vascular Tone In Vitro. J. Matern.-FetInvest., 8:39-45.

Rao, G.S., Khanna, K.L. and Cornish, H.H. (1973) Identification of two new metabolites of caffeine in the rat urine. Experientia 29:953-955.

Ratanasavanh, D., Beaune, P., Morel, F., Flinois, J.-P., Guengerich, F-P. and Guillouzo, A. (1991) Intralobular distribution and quantitation of cytochome P-450 enxymes in human liver as a function of age. Hepatol., 13:1142-1151.

Resch, B.A., Papp, J.G., Gyöngyösi, J. and Széll, S.J. (1985) Die Wirkung des Koffeins auf die fetale Herzfrequenz und die Koffeinkonsum-Gewohnheiten der Schwangeren. Z. Gynäkol. 107:12491253.

Resch, B.A., Papp, J.G. and Gyöngyösi, J. (1987) Die Wirkung des Koffeins auf die Kontraktilität des foetalen Herzmuskels. Z. Gynäkol. 109:945-951.

Ritchie, J.M. (1970) Central nervous system stimulants. The xanthines. In: L.S. Goodman and A. Gilman (Eds.) The Pharmacological Basis of Therapeutics, 4th Ed., Macmillan, London, pp. 358370 .

Rivera-Calimlin, L. (1977) Drugs in breast milk. Drug Ther., 7:59-63.

Roberts, M.F. and Waller, G.R. (1979) NMethyltransferases and 7-methyl-N9nucleoside hydrolase activity in Coffea arabica and the biosynthesis of caffeine. Phytochem., 18:451-455.

Robbins, W.A., Vine, M.F., Truong, K.Y. and Everson, R.B. (1997) Use of fluorescence in situ hybridization (FISH) to assess effects of smoking, caffeine, and alcohol on aneuploidy load in sperm of healthy men. Environ. Mol. Mutagen., 30:175-183.

Roberts, C.J. and Lowe, C.R. (1975) Where have all the conceptions gone? Lancet i:498-499.

Roberts, E.A., Furuya, K.N., Tang, B.K. and Kalow, W. (1994) Caffeine biotransformation in human hepatocyte lines de- 
rived from normal liver tissue. Biochem. Biophys. Res. Commun., 201:559-566.

Robiquet (1823) Café. In: Dictionnarie technologique, Vol.4, (Thomine et Fortic, Paris).

Rochleder (1850a) Jahresber. Chem. 434437.

Rochleder (1850b) Notiz über einige Zersetzungsproducte des Caffei'ns. Liebig's Ann. Chem. 73, 56-58.

Rodopoulos, N., Hojvall, L. and Norman, A. (1996) Elimination of theobromine metabolites in healthy adults. Scand. J. Clin. Lab. Invest., 56:373-383.

Rogers, B.J. (1981) Factors affecting mammalian in Vitro fertilization. In: Bioregulators of Reproduction, G. Jagiello and H.J. Vogel (Eds.), Academic Press, New York, pp. 459-486.

Rohan, T.E. and McMichael, A.J. (1988) Methylxanthines and breast cancer. Int. J. Cancer 41:390-393.

Rondo, P.H., Rodrigues, L.C. and Tomkins, A.M. (1996) Coffee consumption and intrauterine growth retardation in Brazil. Eur. J. Clin. Nutr., 50:705-709.

Rosenberg, L., Mitchell, A. A., Shapiro, S and Slone, D. (1982). Selected birth defects in relation to caffeine-containing beverages. J. Am. Med. Assoc., 247;1429-1432.

Rosenkranz, H.S. and Ennever, F.K. (1987) Evaluation of the genotoxicity of theobromine and caffeine. Fodd Chem. Toxicol., 25:247-251.

Rossignol, A.M. (1985) Caffeinecontaining beverages and premenstrual syndrome in young women. Am. J. Publ. Health 75:1335-1337.

Roue, J. and Roue, A. (1968) Chromosome aberrations in human spontaneous abortions. Mammalian Chromosome Newsletter 9:246-248.

Rubes, J., Lowe, X., Moore, D., Perreault, S., Slott, V., Evenson, D., Selevan, S.G. and Wyrobek, A.J. (1998) Smoking ci- garettes is associated with increased sperm disomy in teenage men, Fertil. Steril., 70:715-723.

Runge, F. (1820) Phytochemische Entdeckungen, (Berlin) 204 pp.

Russel, T.A. (1955) The kola of Nigeria and the Cameroons. Trop. Agric. (Trinidad) $32,210-240$.

Ruzich, J.V., Gill, H. And Wein, A.J. (1987) Objective assessment of the effect of caffeine on sperm motility and velocity. Fertil. Steril., 48:891-893.

Ryu, J.E. (1985a) Effect of maternal caffeine consumption on heart rate and sleep time of breast-fed infants. Dev. Pharmacol. Ther., 8:355-363.

Ryu, J.E. (1985b) Caffeine in human milk and in serum of breast-fed infants. Dev. Pharmacol. Ther., 329-337.

Ryu, J.E. (1985) Effect of maternal caffeine consumption on heart rate and sleep time of breast-fed infants. Dev. Pharmacol. Ther., 8:355-363.

Röhborn, G. and Buckel, U. (1976). Investigations in bone marrow cells of Chinese hamsters after simultaneous application of caffeine and cyclophosphamide. Hum. Genet. 33;113-119.

Saldaňa, M.D.A., Zetzl, C., Mohamed, R.S., Baer, M.G. and Mazzafera, P. (1999) Extraction of purine alkaloids from maté (Ilex paraguariensis) using supercritical CO2. J. Agric. Food Chem., 47:3804-3808.

Saldaňa, M.D.A., Zetzl, C., Mohamed, R.S. and Brunner, G. (2002) Extraction of methylxanthines from guaraná seeds, mate leaves, and cocoa beans using supercritical carbon dioxide and ethanol. J. Agric. Food Chem., 50:4820-4826.

Salvador, H.S. and Koos, B.J. (1989) Effects of regular and decaffeinated coffee on foetal breathing and heart rate. Am. J. Obstet. Gynecol., 160:1043-1047.

Santos, Victoria, Huttly and Carvalhal. (1998a) Caffeine intake and low birth 
weight - a population-based case control study. Am. J. Epidemiol., 147:620-627.

Santos I.S., Victoria C.G., Huttly S. and Morris S. (1998b) Caffeine intake and pregnancy outcomes: a meta-analytic review. Cad. Saude Publica, 14: 523530.

Sawynok, J. and Yaksh, T.L. (1993) Caffeine as an Analgesic Adjuvant: A Review of Pharmacology and Mechanisms of Action. Pharmacol. Rev., 45:43-85.

Sawynok, J. (1995) Pharmacological Rationale for the Clinical Use of Caffeine. Drugs 49:37-50.

SBU (2000) Behandling av astma and KOL. En systematisk kunskapsöversikt. SBU-rapport 151, Stockholm.

SCB (1998) Statistical Yearbook of Sweden. 84, 446. Norstedts Stockholm.

Schairer, C., Brinton, L.A. and Hoover, R.N. (1987) Methylxanthines and breast cancer. Int. J. Cancer 40:469-473.

Schill, W.-B. (1975) Caffeine- and kallikrein-induced stimulation of human sperm motility: a comparative study. Andrologia 7:229-236.

Schill, W.-B., Pritsch, W. And Preissler, G. (1979) Effect of caffeine and kallikrein on cryo-preserved human spermatozoa. Int. J. Fertil., 24:27-32.

Schoenfeld, C., Amelar, R.D. and Dubin, L. (1975) Stimulation of ejaculated human spermatozoa by caffeine. Fertil. Steril., 26:158-161.

Scheiber, G.B., Maffeo, C.E., Robins, M., Masters, M.N. and Bond, A.P. (1988) Measurement of coffee and caffeine intake: Implications for epidemilogic research. Prev.Med. 17, 280-294.

Schultes, R.E. (1942) Plantae Colombianae II Yoco: a stimulant of southern Colombia. Bot. Mus. Leaflets, Harvard University, (Cambridge, Mass.) 10, 301324.

Schulthess, B.H., Morath, P., and Baumann, T.W. (1996) Caffeine biosynthe- sis starts with the metabolically channelled formation of 7-methyl-xmp-a new hypothesis. Phytochemistry 41, 169-175.

Schüz, J., Kaletsch, U., Mainert, R., Kaatasch, P. And Michaelis, J. (2001) High birth weight and other risk factors for Wilms tumour: results of a populationbased case-control study. Eur. J. Pediatr., 160:333-338.

Scott, M. J. (1983). Caffeine induced limb malformations: Description of malformations and quantification of placental transfer. Teratology 28;427-435.

Scott, N.R., Chakraborty, J. and Marks, V. (1986) Urinary metabolites of caffeine in pregnant women. Br. J. clin. Pharmac., 22:475-478.

Scott, N.R., Chakraborty, J. and Marks, V. (1989) Caffeine consumption in the United kingdom: A retrospective survey. Fd. Sci. Nutr. 42F, 183-191.

Senanayake, U.M. and Wijesekera, R.O.B. (1971) Theobromine and caffeine content of the cocoa bean during its growth. J. Sci. Food Agric., 22:262-263.

Shiono, P.H. and Klebanoff, M.A. (1993) Invited commentary: caffeine and birth outcomes. Am. J. Epidemiol., 137:951954.

Shirlow, M.J. (1983) Patterns of caffeine consumption. Hum. Nutr: App. Nutr.37A, 307-313.

Shively, M.J. (1984) Methylxanthine composition and consumption patterns of cocoa and chocolate products. The Methylxanthine Beverages and Foods: Chemistry, consumption, and health effects; 185-213. Alan R. Liss. Inc., 150 Fifth Avenue, New York, NY 10011

Shively, M.J. and Tarka, S.M. Jr. (1984) Methylxanthine composition and consumption patterns of cocoa and chocolate products. The Methylxanthine Beverages and Foods: Chemistry, consumption, and health effects, Alan R. Liss. Inc., New York, NY, p. 149-178.

Shively, C.A., Tarka, S.M.Jr., Arnaud, M.J., Dvorchik, B.H., Passananti, G.T. 
and Vesell, E.S. (1985) High levels of methylxanthines in chocolate do not alter theobromine disposition. Clin. Pharmacol. Ther., 37:415-424.

Shu, X.O., Hatch, M.C., Mills, J., Clemens, J. and Susser, M. (1995) Maternal smoking, alcohol drinking, caffeine consumption, and fetal growth: results from a prospective study. Epidemiology 6:115-120.

Signorello, L.B., Nordmark, A., Franath, F., Blot, W.J., McLaughlin, J.K., Annerén, G., Lundgren, S., Ekbom, A., Rane, A. and Cnattingius, S. (2001) Caffeine metabolism and the risk of spontaneous abortion of normal karyotype fetuses. Obstet. Gynecol., 98:1059-1066.

Silverman, K., Evans, S.M., Strain, E.C. and Griffith, R.R. (1992) Withdrawal syndrome after the double blind cessation of caffeine consumption. New Engl. J. Med., 327:1109-1114.

Sivak, A. (1994) Coteratogenic effects of caffeine. Reg. Toxicol. Pharmacol., 19:1-13.

Slattery, M.L. and West, D.W. (1993) Smoking, alcohol, coffee, tea, caffeine, and theobromine: risk of prostate cancer in Utah (United States). Cancer Causes Control 4:559-563.

Smith, S. E., McElhatton, P. R. and Sullivan, F. M. (1987). Effects of administering caffeine to pregnant rats either as a single daily dose or as divided doses four times a day. Fd. Chem. Toxic. 25:125133.

Solvoll, K., Selmer, R., Loken, E.B., Foss, O.P. and Trygg, K. (1989) Coffee, dietary habits, and serum cholesterol among men and women 35-49 years of age. Am. J. Epidemiol. 129:1277-1288.

Somorin, O. (1974) Caffeine distribution in C. acuminata, T. cacao, C. Arabica. J. Fd. Science 39:1055-1056.

Somani, S.M., Khanna, N.N. and Bada, H.S. (1980) Caffeine and theophylline: Serum/CSF correlation in premature infants. J. Pediatr., 96:1091.
Sonnier, M. and Cresteil, T. (1998) Delayed ontogenesis of CYP1A2 in the human liver. Eur. J. Biochem., 251:893897.

Soyka, L.F. (1979) Effects of methylxanthines on the fetus. Clin. Perinatol., $6: 37-51$.

Söndahl, M.R. (1989) The potential impact of biotechnology in coffee. ASIC 13 Colloq. Sci. Int. Cafe 407-419.

Söndahl, M.R. (1990) Coffee and Cocoa. Agricultural Biotechnology 262-272.

Spinillo, A., Capuzzo, E., Nicola, S.E, Colonna, L., Egbe, T.O. and Zara C. (1994) Factors potentiating the smokingrelated risk of fetal growth retardation. J. Obstet. Gynaecol., 101:954-958.

Spiral, J. and Pétiard, V. (1991) Protoplat culture and regeneration in Coffea species. ASIC 14 Colloq. Sci. Int. Cafe, 1991, San Francisco, USA, p. 383-391.

Spiral, J. and Pétiard, V. (1993) Dévelopment d'une méthode de transformation appliquée à différentes espèces de caféier et régénération de plantules transgéniques. ASIC 15 Colloq. Sci. Int. Cafe, 1993, Montpellier, France, 1:115122.

Spiral, J., Thierry, C., Paillard, M. and Petiard, V. (1993) Obtention de plantules de Coffea canephora Pierre (Robusta) transformées par Agrobacterium rhizogenes. C.R. Acad. Sci. Paris, 316:Ser. III:1-6.

Sreenath, H.L. and Naveen, K.S: (1999) Development of Agrobacterium tumefaciens mediated genetic transformation techniques for Indian coffee selections why and how? Indian Coffee 63:3-7.

Srisuphan, W. and Bracken, M.B. (1986) Caffeine consumption during pregnancy and association with late spontaneous abortion. Am. J. Obstet. Gynecol., 154:14-20.

Stanton, C.K. and Gray, R.H. (1995) Effects of caffeine consumtion on delayed conception, Am. J. Epidemiol., 142:1322-1329. 
Staritsky, G. (1970) Ambryoid formation in callus tissues of coffee. Acta Bot. Neerl., 19:509-514.

Statens Jordbruksverk (1997) Livsmedelskonsumtionen 1993-1996. 15, 38, 47.

Statistics Sweden (2001) Yearbook of agricultural statistics 2001. Including food statistics. Official Statistics of Sweden, Statistics Sweden, Halmstad.

Stavchansky, S., Combs, A., Sagraves, R., Delgado, M. and Joshi, A. (1988) Pharmacokinetics of caffeine in breast milk and plasma after single oral administration of caffeine to lactating mothers. Biopharmaceut. Drug Disp., 9:285-299.

Stavric, B., Klassen, R., Watkinson, B., Karpinski, K., Stapley, R. and Fried, P. (1988) Variability in caffeine consumption from coffee and tea: Possible significance for epidemilogical studies. Fd. Chem. Toxic. 26(2), 111-118.

Stenhouse, J. (1843a) Ueber Thein und seine Dartstellung. Liebig's Ann. Chem. 45, 366-372.

Stenhouse, J. (1843b) Nachträgliches über das Thein. Lieglig's Ann. Chem. 46, 227-230.

Stein, Z. And Susser, M. (1991) Miscarriage, caffeine, and the epiphenomena of pregnancy: the causal model. Epidemiology 2:163-167.

Stewart, I. (1985) Identification of caffeine in citrus flowers and leaves. J. Agric. Food Chem., 33:1163-1165.

Streissguth, A.P., Barr, H.M., Marchtin, D.C. and Herman C.S. (1980) The effects of maternal alcohol, nicotine, and caffeine use during pregnancy on infant mental and motor development at eight months. Alcohol Clin. Exp. Res., 4:152164.

Stubblefield, P.G., Monson, R.R., Schoenbaum, S.C., Wolfson, C.E., Cookson, D.J. and Ryan, K.J. (1984) Fertility after induced abortion: a prospective followup study. Obstet. Gynecol., 63:186-193.
Sugiyama, M., Matsuoka, C and Takagi, T. (1995) Transformation of coffee with Agrobacterium Rhizogenes. ASIC 16 Colloq. Sci. Int. Cafe 2:853-859.

Suzuki, T. (1972) The parcitipation of Sadenosylmethionine in the biosynthesis of caffeine in the tea plant. FEBS Lett. $24,18-20$.

Suzuki, T. (1973) Methabolism of methylamine in the tea plant. Biochem. J. 132, 753-763.

Suzuki, T. and Takahashi, F. (1975a) Biosynthesis of caffeine by tea-leaf extracts. Enzymic formation of theobromine from 7-methylxanthine and of caffeine from theobromine. Biochem. J. 146, $87-96$.

Suzuki, T. And Takahashi, F. (1976a)

Caffeine biosynthesis in Camellia sinensis. Phytochem., 15:1235-1239.

Suzuki, T. And Waller, G.R. (1984a)

Biosynthesis and biodegradation of caffeine, theobromine, and theophylline in Coffea arabica L. Fruits. J. Agric. Food Chem., 32:845-848.

Suzuki, T. And Waller, G.R. (1984b) Biodegradation of caffeine: formation of theophylline and theobromine from caffeine in mature Coffea arabica fruits. J. Sci. Food Agric., 35:66-70.

Suzuki, T., Ashihara, H. and Waller, G.R. (1992) Purine and purine alkaloid metabolism in Camellia and Coffea plants. Phytochem., 31:2575-2584.

Sved, S., Hossie, R.D. and McGilveray, I.J. (1976) The human metabolism of caffeine to theophylline. Res. Commun. Chem. Pathol. Pharmacol., 13:185-192.

Svensk Kaffe Information (1993) KaffeHistorien om en sägenomspunnen handelsvara. Svensk Kaffe Information, Box 4049, 10261 Stockholm.

Takayama, S., Nagao, M., Suwa, Y. and Sugimura, T. (1984) Long-term carcinogenicity studies on caffeine, instant coffee, and methylglyoxal in rats. In: B. MacMahon \& T. Sugimura (Eds.), Ban- 
bury Report 17: Coffee and health, New York, Cold Spring Harbor Laboratory, pp. 99-104.

Takeda, Y. (1994) Differences in caffeine and tannin contents between tea cultivars, and application to tea breeding. Jap. Agric. Res. Quart., 28:117-123.

Takizawa, K. and Mattison, D.R. (1983I Female reproduction. Am. J. Ind. Med., 4:17-30.

Tang, B.K., Grant, D.M. and Kalow, W. (1983) Isolation and identification of 5acetylamino-6-formylamino-3methyluracil as a major metabolite of caffeine in man. Drug Metabolism and Disposition 11:218-220.

Tang-Liu, D.-S. And Riegelman, S. (1981) Metabolism of theophylline to caffeine in adults. Res. Commun. Chem. Pathol. Pharmacol., 34:371-379.

Tarka, S.M. Jr. (1982) The toxicology of cocoa and methylxanthines: a review of the literature. Crit. Rev. Toxicol., 9:275312

Taslimi, M.M. and Herrick, C.N. (1986) Caffeine consumption during pregnancy and association with late spontaneous abortion. Am. J. Obstet. Gynecol., 155:1146-1147.

Tassaneeyakul, W., Birkett, D.J., McManus, M.E., Tassaneeyakul, W., Veronese, M.E.; Anderson, T., Tukey, R.H. and Miners, J.O. (1994) Caffeine metabolism by human hepatic cytochomes $\mathrm{P} 450$ : contributions of $1 \mathrm{~A} 2,2 \mathrm{E} 1$ and $3 \mathrm{~A}$ isoforms. Biochem. Pharm., 47:1767-1776.

Tebbutt, I.H., Teare, A.J., Meek, J.H., Mallett, K.A. and Hawkins, D.F. (1984) Caffeine, theophylline and theobromine in pregnancy. Biol. Res. Pregn. Perinatol., 5:174-176.

Tennes, K. and Blackard, C. (1980). Maternal alcohol consumption, birth weight, and minor physical anomalies. Am. J. Obstet. Gynecol. 138:774.

Terada, H- and Sakabe, Y. (1984) Highperformance liquid chomatographic determination of theobromine, theophylline and caffeine in food products. J. Chromatography 291:453-459.

Tesařik, J., Kopený, V. And Dvoák, M. (1984) Selective binding of human cumulus cell-secreted glycoproteins to human spermatozoa during capacitation in vitro. Fertil. Steril., 41:919-925.

Thomas, D.B. (1988) Neonatal abstinence syndrome. Med. J. Aust., 148:598.

Thuvander, A., Paulsen, J.E., Azberg, K., Johansson, N., Vidnes, A., EnghardtBarbieri, H., Trygg, K., Lund-Larsen, K., Jahl, S., Widenfalk, A., Bosnes, V., Alexander, J., Hult, K. and Olsen, M. (2001) Levels of ochatoxin A in blood from Norwegian and Swedish blood donors and their possible correlation with food consumption. Food Chem. Toxicol., 39:1145-1151.

Tikkanen, J. and Heinonen, O. P. (1991). Maternal exposure to chemical and physical factors during pregnancy and cardiovascular malformations in the offspring. Teratology 43;591-600.

Timson, J. (1972) Effects of theobromine, theophylline and caffeine on the mitosis of human lymphocytes. Mutation Res., 15:197-201.

Timson, J. (1975) Theobromine and theophylline. Mutation Res., 47:1-52.

Tobias, D.Y. (1982) Current methods of caffeine determination: Review of the literature, 1975-1980. FDA By-Lines No. 3, pp. 129-156.

Torfs, C.P. and Christianson, R.E. (2000) Effect of maternal smoking and coffee consumption on the risk of having a recognized Down syndrome pregnancy. Am. J. Epidemiol., 152:1185-1191.

Toubas, P.L., Duke, J.C., McCaffree, M.A., Mattice, C.D., Bendell, D. and Orr, W.C. (1986) Effects of maternal smoking and caffeine habits on infantile apnea: a retrospective study. Pediatrics 78:159-63.

Traub, A.I., Earnshaw, J.C., Brannigan, P.D. and Thompson, W. (1982) A critical assessment of the response to caffei- 
ne of human sperm motility. Fertil. Steril., 37:436-437.

Troger, U. And Meyer, F.P. (1995) Influence of endogenous and exogenous effectors on the pharmacokinetics of theophylline: Focus on biotransformation. Clin. Pharmacokinet., 28:287-314.

Trova, C., Cossa, G. And Gandolfo, G. (1994) Indagine sulla presenza di caffeina nel miele. Industrie Alimentari 33:403-405.

Trygg, K., Lund-Larsen, K., Sandstad, B., Hoffman, H.J., Jacobsen, G. and Bakketeig, L.S. (1995) Do pregnant smokers eat differently from pregnant nonsmokers? Pediat. Perinat. Epidemiol., 9:307-319.

Tserng, K.-Y., King, K.C. and Takieddine, F.N. (1981) Theophylline metabolism in premature infants. Clin. Pharmacol. Ther., 29:594-600.

Tsutsumi, K., Kotegawa, T., Matsuki, S., Tanaka, Y., Ishii, Y., Kodama, Y., Kuranari, M., Miyakawa, I. and Nakano, S. (2001) The effect of pregnancy on cytochome P4501A2, xanthine oxidase, and $\mathrm{N}$-acetyltransferase activities in humans. Clin. Pharmacol. Ther., 70:121-125.

Tuomilehto, J., Tuomilehto-Wolf, E., Virtala, E. and LaPorte, R. (1990) Coffee consumption as trigger for insulin dependent diabetes mellitus in childhood. Br. Med. J., 300:642-643.

Tyrala, E.E. and Dodson, W.E. (1979) Caffeine secretion into breast milk. Arch. Dis. Childhood 54:787-789.

Vacca, V. and Fenu, P. (1996) Indagine sul contenuto di caffeina in alcuni mieli sardi del commercio. Industrie Alimentari 35:568-571.

Vacca, V., Agabbio, M. and Fenu, P. (1997) La caffeina nei fiori del genere Citrus. Relazioni con la presenza dell'Alcaloide riscontrata nei mieli di agrumi. Industrie Alimentari 36:611-613

Van Boxtel, J., Berthouly, M., Carasco, C., Dufour, M. and Eskes, A. (1995) Transient expression of $\beta$-glucuronidase follo- wing biolistic delivery of foreign DNA into coffee tissues. Plant Cell Reports 14:748-752.

Van den Berg, B.J., Chistianson, R.E., and Oechsli, F.W. (1988) The California child health and development studies of the School of Public Health, University of California at Berkeley. Pediatr. Perinat. Epidemiol., 2:265-282.

Van't Hoff, W. (1982) Caffeine in pregnancy. Lancet I:1020.

Vartianinen, E., Jousilahti, P., Juolevi, A., Sundvall, J., Alfthan, G., Salminen, I. and Puska, P. (1998) Finriski 1997. Tutkimus kroonisten kansantautien riskitekijöistä, niihin liittyvistä elintavoista, oiresta ja terveyspalvelujen käytöstä. National Public Health Institute 81/1998, Helsinki, Finland.

Vergnes, M.F. and Alary, J. (1986) Dosage des xanthiques naturels par CLHP. Talanta 33:997-1000.

Verheijen, F.R. (1999) Caffeine content of common beverages in the Icelandic diet. Department of Pharmaceutical Analysis and Human Toxicology, University of Utrecht, pp 34.

Viani, R. (1993) The composition of coffee. In: Caffeine, Coffee and Health, SGarattini (Ed.), Raven Press, Ltd., New York, p. 17-41.

Viell, B., Grabner, L., Fruchel, G. and Boczek, P. (1996) New caffeinated beverages. A pilot survey of familiarity and consumption by adolescents in NorthRhine Westphalia and Berlin and considerations of consumer protection. Z. Ernahungswiss (Dec. 35(4), 378-386.

Virtanen, S.M., Rasanen, L., Aro, A., Ylonen, K., Lounamaa, R., Akerblom, H.K. and Tuomilehto, J. (1994) Is children's or parents' coffee or tea consumption associated with the risk for type 1 diabetes mellitus in children? Childhood Diabetes in Finland Study Group. Eur. J. Clin. Nutr., 48:279-85.

Viscoli, C.M., Lachs, M.S. and Horwitz, R.I. (1993) Bladder cancer and coffee 
drinking: a summary of case-control research. Lancet 341:1432-1437.

Vlajinac, H.D., Petrovic, R.R., Marchinkovic, J.M., Sipetic, S.B. and Adanja, B.J. (1997) Effect of caffeine intake during pregnancy on birth weight. Am. J. Epidemiol., 145:335-338

von Borstel, R. (1983) Biological effects of caffeine. Metabolism. Food Technol., $37: 40-43+46$.

Wadelius, M., Stjernberg, E., Wikholm, B.E. and Rane, A. (2000) Polymorphisms of NAT2 in relation to sulphasalazine-induced agranulocytosis. Pharmacogenetics 10:35-41.

Wanner, H., Pésáková, M., Baumann, T.W., Charubala, R., Guggisberg, A., Hesse, M. and Schmid, H. (1975) $0(2), 1,9$-trimethyluric acid and 1,3,7,9tetramethyluric acid in leaves of different Coffee species. Phytochemistry 14, 747-750.

Warburton, D. and Fraser, F.C. (1964) Spontaneous abortion risks in man. Am. J. Hum. Genet., 16:1-15.

Warren, R.N. (1969) Metabolism of xanthine alkaloids in man. J. Chomatogr., 40:468-469.

Warszawski, D., Ben-Zvi, Z.and Gorodischer, R. (1981) Caffeine metabolism in liver slices during postnatal development in the rat. Biochem. Pharmacol., 30:3145-3150.

Watkinson, B. and Fried, P.A. (1985) Maternal caffeine use before, during and after pregnancy and effects upon offspring. Neurobeh. Toxic. Teratol, 7, 9-17.

Weathersbee, P.S., Olsen, L.K. and Lodge, J.R. (1977) Caffeine and pregnancy. Postgraduate Med., 62:64-69.

Wei, M. (1994) Fetal loss and caffeine intake. J. Am. Med. Assoc., 272:27.

Weigel, M.M. and Weigel, R.M. (1989) Nausea and vomiting of early pregnancy and pregnancy outcome. An epidemiolo- gical study. Br. J. Obstet. Gynecol., 96:1304-1311.

Weinberg, C.R. and Wilcox, A.J. (1990)

Caffeine and fertility. Lancet 335:792.

Weinstein, D., Mauer, I. and Solomin, H.M. (1972) The effect of caffeine on chromosomes of human lymphocytes. In vivo and in vitro studies. Mutation Res., 16:391-399.

Wellmann, F.L. (1961) Coffee. Botany. Cultivation abd Utilization, (Leonard Hill (Books) Ltd., London; Interscience Publ. Inc., New York) 488pp.

Welsch, C.W. (1994) Caffeine and the development of the normal and neoplastic mammary gland. Proceed. Soc. Exp. Biol. Med., 207:1-12.

Wen, W., Shu, X.O., Jacobs, D.R. Jr. and Brown, J.E. (2001) The association of maternal caffeine consumption and nausea with spontaneous abortion. Epidemiol., 12:38-42.

Wennergren, M. (1985) Perinatal risk factors with special reference to intrauterine growth retardation and neonatal adaption. Department of Obstetrics and Gynecology, Sahlgrenska sjukhuset Göteborg, Sweden Dissertation.

Willaman, J.J. and Schubert, B.G. (1961) Alkaloid-bearing plants and their contained alkaloids. Agric. Res. Serv., U.S. Dept. Agric., Tech. Bull. 1234, pp. 1287.

Wilcox, A. Weinberg, C. and Baird, D. (1988a) Caffeinated beverages and decreased fertility, Lancet ii:1453-1456.

Wilcox, A.J., Weinberg, C.R., O'Connor, J.G. etc. (1988b) Incidence of early loss of pregnancy. N. Engl. J. Med., 319:189194.

Wilcox, A.J. and Weinberg, C.R. (1991) Tea and fertility. Lancet 337:1159-1160.

Wilcox, A.J., Weinberg, C.R: and Baird, D.D. (1990) Risk factors for early pregnancy loss. Epidemiology 1:382-385. 
Willetts, P., Buxton, P., Chapman, S., Brereton, P. and Wood, R. (1994) Studies of the properties and xanthine composition of the herbal supplement guarana. In: Bioactive Substances in Food of Plant Origin. Proc. Int. Euro Food Tox IV Conf., H. Kozłowska, J. Fornal, Z. Zdu'nczyk, Eds.), Polish Acad. Sci., Olsztyn, pp. 443-447.

Williams, M.A., Monson, R.R., Goldman, M.B., Mittendorf, R. and Ryan, K.J. (1990) Coffee and delayed conception. Lancet 335:1603.

Williams, M.A., Goldman, M.B., Mittendorf, R. and Monson, R.R. (1991) Subfertility and the risk of low birth weight. Fertil. Steril., 56:668-671.

Williams, M.A., Mittendorf, R., Stubblefield, P.G., Lieberman, E.; Schoen, S.C. and Monson, R.R. (1992) Cigarettes, coffee, and pre-term premature rupture of the membranes. Am. J. Epidemiol., 135:895-903.

Wilson, J. G. and Scott, W. J. (1984). Caffeine. Perspectives from Recent Research, Ed. Dews, P., B. SpringerVerlag, pp. 165-200.

Willson, K. (1999) Coffee, Cocoa and Tea. Crop Production Science and Horticulture 8, CABI Publ., Wallingford, UK, 300 pp.

Windham, G.C., Von Behen, J., Fenster, L., Schaefer, C. and Swan, S.H. (1997) Moderate maternal alcohol consumption and risk of spontaneous abortion. Epidemiology 8:509-514.

Wink, M. (1997a) Compartmentation of secondary metabolites and xenobiotics in plant vacuoles. Adv. Bot. Res., 25:141169.

Wisborg, K., Henriksen, T.B., Hadegaard, M. and Secher, N.J. (1998) Rygning under graviditet og præterm fødsel. Ugeskr. Læger., 160:1033-1037

Wolfrom, D. and Welsch, C.W: (1990) Caffeine and the development of normal, benign, and carcinomatous human breast tissues: a relationship? J. Med.,
Wollmann, H.A. (1998) Intrauterine growth restriction: definition and aetiology. Horm. Res., 49 (Suppl 2):1-6.

Woskresensky, A. (1842) Ueber das Theobromin. Liebig's Ann. Chem. 41, 125-127.

Wright, E.V. (1976) Chromosomes and human fetal development. In: Roberts, D.F.. Thomson, A.M., eds. The biology of human fetal growth. London: Taylor and Francis Ltd, pp. 237-252.

Würzner, H.-P., Lindström, E., Vuataz, L. and Luginbühl, H. (1977a) A 2-year feeding study of instant coffees in rats. II. Incidence and types of neoplasms. Food Cosmet. Toxicol., 15:289-296.

Xi, B., Liu, Z.S., Liang, Y.R., Liu, Z.S. and Ziang, Y.R. (1997) J. Tea Sci., 17:155-156.

Yamagami, T., Handa, H., Takeuchi, J., Munemitsu, H., Aoki, M. and Kato, Y. (1983) Rat pituitary adenoma and hyperplasia induced by caffeine administration. Surg. Neurol., 20:323-331.

Yerushalmy, J. (1967) The classification of newborn infants by birth weight and gestational age. J. Pediat., 71:164-172.

Yurchak, A.M. and Jusko, W.J. (1978) Theophylline secretion into breast milk. Pediatrics 57:518-525.

Yesair, D.W., Branfman, A.R. and Callahan, M.M. (1984) Human disposition and some biochemical aspects of methylxanthines. In: The methylxanthine beverages and foods, G.A. Spiller (Ed.), A.R. Liss, Inc., New York, pp. 215-233

Yurchak, A.M. and Jusko, W.J. (1976) Theophylline secretion into breast milk. Clin. Pharmacol. Ther., 57:518-525.

Zaadstra, B.M., Looman, C.W.N., Velde, E.R., Habbema, J.D.F. and Karbaat, J. (1994) Moderate drinking: no impact on female fecundity. Fert. Steril., 62:948954.

Zaigler, M., Rietbrock, S., Szymanski, J., Dericks-Tan, J.S.E., Staib, A.H. and Fuh, U. (2000) Variation of CYP1A2- 
dependent caffeine metabolism during menstural cycle in healthy women. Int. J. Clin. Pharmacol. Therapeut., 38:235244.

Zajdela, F. and Latarjet, R. (1973) Inhibitory effect of caffeine on the induction of skin cancers by UV light in the mouse (Fr.). C.R. Acad. Sci. (Paris), 277:10731076.

Zajdela, F. and Latarjet, R. (1975) The inhibitory effect of caffeine on the induction of cutaneous tumors in mice by ultraviolet rays. In: Bucalossi, P., Veronesi, U. And Cascinelli, N. (Eds.), Proc. XI Int. Cancer Congr., Florence, 20-26 October 1974, Vol. 3, Amsterdam, Excerpta Medica, pp. 120-123
Zajdela, F. snd Latarjet, R. (1978a) Ultraviolet light induction of skin carcinoma in the mouse; influence of cAMP modifying agents. Bull. Cancer 65:305-314.

Zajdela, F. and Latarjet, R. (1978b) Inhibition of skin carcinogenesis in vivo by caffeine and other agents. Natl. Cancer Inst. Monogr., 50:133-140.

Zevin, S. and Benowitz, N.L. (1999) Drug Interactions with tobacco smoke. Clin Pharmacokin., 36:425-438.

Zoumas, B.L., Wesley, R.K. and Martin, R.A. (1980) Theobromine and caffeine content of chocolate products. J. Fd. Science 45, 314-316. 


\section{Abbreviations used in this report}

adj

AGA

Ah-receptor

AMP

BL

BIBRA

BRS

bw

BW

CA

CAMP

CAS-number

CHO cells

CI

Cig

CIS

CNS

CRL

CYP 1A1

CYP 1A2

CYP3A4

CYP3A7

CYP2D6

CYP2D met

CYP2E1

DNA

EPA

EU

FAO

FDA

G2 phase

GA

GABA

GC

GLP

GMP
Adjusted for

Appropriate for gestational age

Aryl hydrocarbon receptor

Adenosine monophosphate

Birth length

The British Industrial Biological Research Association

Behaviour Rating Scale

Body weight

Birth weight

Chromosome Aberration (test)

Cyclic adenosine monophosphate

Chemical Abstract Service Registry Number

Chinese Hamster Ovary cells

Confidence Interval

Cigarette(s)

Commonwealth of Independent States: Russia, Belarus,

Kazakhstan, Kyrgyzstan, Tajikistan and Armenia

Central Nervous System

Crown-rump length

Cytochrome P450 isoenzym

Cytochrome P450 isoenzym

Cytochrome P450 isoenzym

Cytochrome $\mathrm{P} 450$ isoenzym

Cytochrome P450 isoenzym

Cytochrome P450 isoenzym

Cytochrome P450 isoenzym

Deoxyribonucleic acid

Environmental Protection Agency (USA)

European Union

Food and Agriculture Organization (United Nations)

Food and Drug Administration (USA)

Phase in the mitotic cell division cycle

Gestational age

Gamma-aminobutyric acid

Gas chromatography

Good Laboratory Practice

Guanosine monophosphate 


\begin{tabular}{|c|c|}
\hline $\mathrm{Hb}$ & Hemoglobin \\
\hline $\mathrm{HC}$ & Head circumference \\
\hline Het & Hematocrit \\
\hline $\mathrm{HCG}$ & Human chorionic gonadotropin \\
\hline HPLC & High Pressure Liquid Chromatography \\
\hline IARC & International Agency for Research on Cancer \\
\hline $\operatorname{Im}$ & Intramuscularly \\
\hline IMP & Inosinic acid (inosine $5^{\prime}$-monophosphate) \\
\hline In vitro & Experiments in cell cultures and bacteria \\
\hline In vivo & Experiments in intact animals \\
\hline Ip & Intra-peritoneally \\
\hline IPCS & International Programme on Chemical Safety (WHO) \\
\hline IUGR & Intrauterine growth retardation \\
\hline IUPAC & International Union of Pure and Applied Chemistry \\
\hline Iv & Intravenously \\
\hline JECFA & Joint FAO/WHO Expert Committee on Food Additives \\
\hline JMPR & Joint FAO/WHO Meeting on Pesticide Residues \\
\hline LBW & Low birth weight \\
\hline LBWGA & Low birth weight for gestational age \\
\hline $\mathrm{LD}_{50}$ & $\begin{array}{l}\text { Lethal Dose, median. The dosage of chemical needed to } \\
\text { produce death in } 50 \% \text { of the treated animals. }\end{array}$ \\
\hline LMP & Last menstrual period \\
\hline $\mathrm{LO}(\mathrm{A}) \mathrm{EL}$ & Lowest Observed (Adverse) Effect Level \\
\hline MAFF & Ministry of Agriculture and Fishing, Great Britain \\
\hline MDI & Mental Development Index \\
\hline MTD & Maximum Tolerated Dose \\
\hline NCI & National Cancer Institute (USA) \\
\hline NOEL & No Effect Level \\
\hline NNT & $\begin{array}{l}\text { Nordic Working Group on Food Toxicology and Risk As- } \\
\text { sessment }\end{array}$ \\
\hline $\mathrm{NO}(\mathrm{A}) \mathrm{EL}$ & No Observable (Adverse) Effect Level \\
\hline $\mathrm{NOC}$ & N-nitroso compounds. \\
\hline NTP & National Toxicology Programme (USA) \\
\hline NS & Not statistically significant \\
\hline OECD & Organisation for Economic Co-operation and Development \\
\hline OR & Odds ratio \\
\hline PDI & Psychomotor Development Index \\
\hline PI & Ponderal index; the ratio (birth weight/ birth length) \\
\hline PMTDI & $\begin{array}{l}\text { Provisional Maximum Tolerable Daily Intake. Term used } \\
\text { like TDI. }\end{array}$ \\
\hline Po & Per os (by mouth) \\
\hline Ppm & Parts per million \\
\hline PT & Preterm birth \\
\hline PX & Paraxanthine \\
\hline PW & Placental weight \\
\hline
\end{tabular}




$\begin{array}{ll}\text { RNA } & \text { Ribonucleic acid } \\ \text { RTCS } & \text { Registry of Toxic Chemical Substances } \\ \text { SA } & \text { Spontaneous abortion, misscarriage } \\ \text { SAM } & \text { S-adenosyl-L-methionine } \\ \text { sc } & \text { Subcutaneous } \\ \text { SCE } & \text { Sister chromatide exchange } \\ \text { SGA } & \text { Small for gestational age } \\ \text { SCF } & \text { Scientific Committee on Food (previously for food) } \\ \text { SGOT } & \text { Serum glutamate-oxalatetransaminase } \\ \text { SGPT } & \text { Serum Glutamate PyruvateTransaminase } \\ \text { SIDS } & \text { Sudden Infant Death Syndrome } \\ \text { sign } & \text { Significant } \\ \text { SOS chromotest } & \text { DNA repair test } \\ \text { US } & \text { Ultrasonographic examinations } \\ \text { UV } & \text { Ultraviolet light } \\ \text { WHO } & \text { World Health Organization (United Nations) } \\ \text { XMP } & \text { Xanthosine monophosphate } \\ \text { XO } & \text { Xanthin oxidase }\end{array}$

